MARIA MAGDALENA GRZELAK

\title{
Innowacyjność \\ przemysłu spożywczego w Polsce
}

OCENA. UWARUNKOWANIA. ROZWÓJ

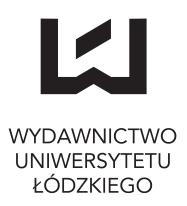

ŁÓDŹ 2011 
RECENZENT

Wiesław Pluta

REDAKTOR WYDAWNICTWA UŁ

Elżbieta Marciszewska-Kowalczyk

SKŁAD I ŁAMANIE

ESUS - Maciej Torz

PROJEKT OKŁADKI

Barbara Grzejszczak

(C) Copyright by Uniwersytet Łódzki - Wydawnictwo Uniwersytetu Łódzkiego 2012

Wydawnictwo Uniwersytetu Łódzkiego

90-131 Łódź, ul. Lindleya 8

Wydanie I. Nakład 140 egz. Ark. druk. 17,25.

Zam. 4998/2012. Cena zł 34,-- VAT

ISBN 978-83-7525-709-0 


\section{Spis treści}

Wstęp . . . . . . . . . . . . . . . . . . . . . . . . 5

1. Procesy innowacyjne w gospodarce - wybrane aspekty teoretyczne . . . . 11

Wprowadzenie. . . . . . . . . . . . . . . . . . 11

1.1. Zmiany a innowacje . . . . . . . . . . . . . . 11

1.2. Definicje innowacji . . . . . . . . . . . . . . . . . . 14

1.3. Systematyka innowacji. . . . . . . . . . . . . . . . 21

1.4. Modele innowacji . . . . . . . . . . . . . . . . . . 31

1.5. Innowacje w teorii ekonomii. . . . . . . . . . . . . . . . . 36

1.6. Paradygmat gospodarki opartej na wiedzy. . . . . . . . . . . . . 39

1.7. Innowacje a konkurencja i konkurencyjność . . . . . . . . . . . . 44

Podsumowanie . . . . . . . . . . . . . . . . . . . . 49

2. Innowacyjność polskiej gospodarki w świetle badań statystycznych. . . . 51

Wprowadzenie. . . . . . . . . . . . . . . . . 51

2.1. Pojęcie i istota Narodowych Systemów Innowacji . . . . . . . . . . . 51

2.1.1. Narodowe Systemy Innowacji w wybranych krajach europejskich $\quad 57$

2.1.2. Specyfika Narodowego Systemu Innowacji w Polsce . . . . . . 60

2.1.3. Nakłady, zatrudnienie w działalności B+R krajów Unii Europejskiej 65

2.2. Teoria i praktyka statystyczna badań nad innowacyjnością . . . . . . . 69

2.2.1 Metodologia OECD . . . . . . . . . . . . . . . . . . 69

2.2.2. Metodologia Unii Europejskiej . . . . . . . . . . . . . . . . 77

2.2.3. Metodologia badań GUS . . . . . . . . . . . . . . 80

2.3. Ranking innowacyjności krajów UE według sumarycznego wskaźnika

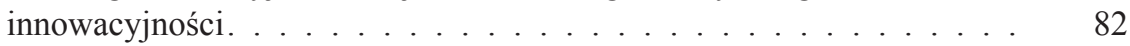

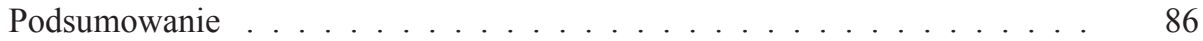

3. Analiza produkcyjno-ekonomicznej sytuacji przemysłu spożywczego

w Polsce . . . . . . . . . . . . . . . . . . . . . . . . . . . . . 87

Wprowadzenie. . . . . . . . . . . . . . . . . . 87

3.1. Miejsce przemysłu spożywczego w polskiej gospodarce . . . . . . . 87

3.2. Tendencje rozwojowe przemysłu spożywczego w latach 1999-2008 . . . 93

3.2.1. Rozwój i przemiany struktury produkcji przemysłu spożywczego . 93

3.2.2. Bezpośrednie inwestycje zagraniczne. . . . . . . . . . . . . . 98

3.2.3. Produktywność przemysłu spożywczego . . . . . . . . . . . 101

3.2.4. Wyniki ekonomiczno-finansowe przemysłu spożywczego . . . . . 109

3.3. Ocena konkurencyjności branż przemysłu spożywczego w latach $2002-2008 \ldots \ldots$. . . . . . . . . . . . . . . . . 113

Podsumowanie . . . . . . . . . . . . . . . . . . . . . . 124

4. Analiza innowacyjności przedsiębiorstw przemysłu spożywczego w Polsce 127

Wprowadzenie. . . . . . . . . . . . . . . . . . . . 127

4.1. Działalność innowacyjna przedsiębiorstw przemysłu spożywczego w Polsce w latach 1999-2008 . . . . . . . . . . . . . . . . . . . 127

4.1.1. Nakłady na działalność innowacyjną . . . . . . . . . . . . . . 129 
4.1.2. Efekty działalności innowacyjnej . . . . . . . . . . . . . . . . 134

4.1.3. Współpraca w zakresie działalności innowacyjnej . . . . . . . . . 142

4.1.4. Bariery rozwoju innowacji . . . . . . . . . . . . . . . . . 144

4.2. Miejsce przemysłu spożywczego w przetwórstwie przemysłowym

- analiza innowacyjności według głównych składowych . . . . . . . . . 145

4.2.1. Metodologia głównych składowych . . . . . . . . . . . . . . 146

4.2.2. Ranking działów przetwórstwa przemysłowego według innowacyjności . . . . . . . . . . . . . . 151

Podsumowanie . . . . . . . . . . . . . . . . . . 158

5. Ocena innowacyjności przedsiębiorstw w poszczególnych branżach przemysłu spożywczego - próba budowy i empirycznej weryfikacji syntetycznego miernika . . . . . . . . . . . . . . . . . . . . . . . . 161

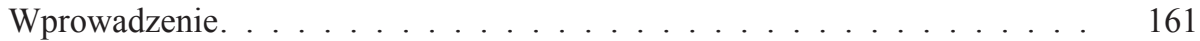

5.1. Wskaźniki innowacyjności przedsiębiorstw przemysłowych . . . . . . . 161

5.2. Procedura porządkowania liniowego . . . . . . . . . . . . 163

5.3. Wybrane zagadnienia metod analizy skupień . . . . . . . . . . . . . . 171

5.4. Wstępna analiza danych - dobór wskaźników diagnostycznych . . . . . 179

5.5. Syntetyczna ocena innowacyjności branż przemysłu spożywczego

w latach 2004-2008 . . . . . . . . . . . . . . . . . . . . . . . 186

6. Ekonometryczna analiza efektów innowacyjności w przemyśle

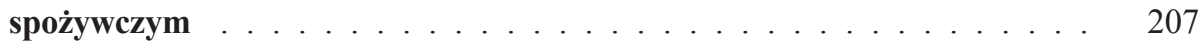

Wprowadzenie. . . . . . . . . . . . . . . . 207

6.1. Przegląd ekonomicznych modeli wzrostu gospodarczego. . . . . . . . . 207

6.2. Ocena wpływu innowacjności na konkurencyjność przedsiębiorstw

funkcjonujących w przemyśle spożywczym . . . . . . . . . . . . . . 213

6.2.1. Przemysł spożywczy ogółem . . . . . . . . . . . . . . . 215

6.2.1.1. Model produkcji sprzedanej . . . . . . . . . . . 215

6.2.1.2. Model wydajności pracy . . . . . . . . . . . . . . . . 218

6.2.1.3. Model wartości dodanej brutto. . . . . . . . . . . . 220

6.2.1.4. Model łącznej produktywności czynników produkcji (TFP) 221

6.2.2. Branże przemysłu spożywczego . . . . . . . . . . . . . . . . 224

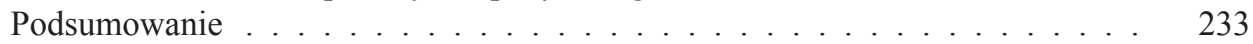

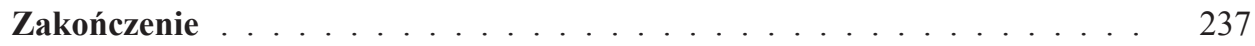

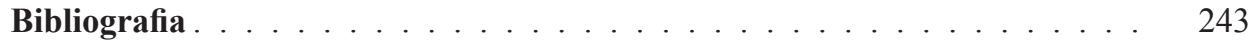

Spis rysunków . . . . . . . . . . . . . . . . . . . 255

Spis tabel . . . . . . . . . . . . . . . . . . . . . . 257

Innovativeness of the Food Industry in Poland (summary). . . . . . . . . . 259

Od redakcji. . . . . . . . . . . . . . . . . . . . . 263 


\section{Wstęp}

W dobie gospodarki opartej na wiedzy nauka, technika i innowacje są istotnym elementem kształtującym przewagi konkurencyjne gospodarek narodowych, sekcji, działów i podmiotów gospodarczych. Znajduje to również potwierdzenie w dokumentach strategicznych UE, a zwłaszcza w przyjętej przez Radę Europejską w 2000 r. strategii lizbońskiej oraz w jej znowelizowanej wersji, zaakceptowanej przez Radę Europejską w 2005 r. Jednak niepowodzenia związane z realizacją strategii lizbońskiej (w wersji pierwotnej i znowelizowanej) przyczyniły się do powstania nowego programu rozwoju gospodarek krajów UE, sformułowanego w marcu 2010 r. w Europa 2020. Strategia na rzecz inteligentnego i zrównoważonego rozwoju sprzyjającemu włączeniu społecznemu [Europa 2020. Strategia..., 2010]. W dokumentach tych podkreśla się fundamentalne znaczenie edukacji, działalności badawczo-rozwojowej $(\mathrm{B}+\mathrm{R})$ i innowacji jako czynników warunkujących trwały wzrost gospodarczy. Zgodnie z programem gospodarczym UE przedsiębiorstwa innowacyjne stanowią podstawę innowacyjności kraju.

Innowacje, jako przedmiot zainteresowania teoretyków ekonomii czy praktyków gospodarczych, cieszą się rosnącym zainteresowaniem i coraz większą dociekliwością badaczy. Wynika to przede wszystkim z nowego ich postrzegania jako czynnika determinującego wzrost efektywności gospodarowania. Innowacje stały się kolejnym - obok kapitału rzeczowego i siły roboczej - czynnikiem produkcji.

Innowacyjność nie jest sama w sobie celem, ale jest narzędziem służącym do osiągania przewagi konkurencyjnej przez poszczególne firmy, sekcje gospodarki narodowej, regiony, państwa czy grupy państw. Podobnie konkurencyjność nie jest traktowana jako ostateczny cel gospodarujących podmiotów. $Z$ jednej strony, w ujęciu mikroekonomicznym, jest środkiem do utrzymania lub umacniania pozycji na rynku oraz osiągania pozytywnych wyników ekonomicznych przez przedsiębiorstwa, z drugiej zaś, w wymiarze makroekonomicznym, do podnoszenia poziomu życia obywateli poprzez zwiększanie konsumpcji różnych dóbr i poprawę jakości środowiska przyrodniczego [Świtalski 2005, s. 165].

Procesy innowacyjne stały się przedmiotem intensywnych badań i dociekań naukowych na przełomie lat 60. i 70. ubiegłego wieku. Zagadnieniami związanymi z konkurencyjnością przedsiębiorstw i gospodarek ekonomiści zajęli się znacznie później, bo w latach 90 . ubiegłego stulecia. Ten nurt badań zainicjowany został przez Michaela E. Portera [1990, 1998].

Literatura przedmiotu, dość liczna jeśli idzie o badania dotyczące innowacyjności gospodarki, najczęściej koncentruje się na ocenie stopnia tego zjawiska w skali makroekonomicznej, rzadziej dotyczy ona sektorów gospodarki, rozumianych jako działy, grupy czy klasy (zgodnie z Europejską Klasyfikacją Działalności). Jeszcze mniejszą uwagę przywiązuje się do oceny wpływu innowacyjności na rozwój specyficznych kierunków działalności wytwórczej. 
Przemysł spożywczy, do którego zalicza się produkcję artykułów spożywczych, napojów i wyrobów tytoniowych (działy 15 i 16 PKD), jest jednym z ważniejszych obszarów działalności przemysłowej w Polsce. Świadczy o tym jego udział w produkcji globalnej (6\%), wartości dodanej brutto $(2,8 \%)$, zatrudnieniu $(4,4 \%)$ czy eksporcie $(6,2 \%)$. Obecnie należy on do najszybciej rozwijających się dziedzin polskiej gospodarki.

Mało jest w naszym kraju kierunków działalności gospodarczej konkurencyjnych na krajowym i międzynarodowym rynku, którymi możemy „podbić świat”. Istnieje opinia, że produkcja żywności może stać się naszą narodową specjalnością. Jeśli tak, to polityka państwa, nauka oraz praktyka gospodarcza powinny wspierać rozwój tego działu gospodarki.

Zmiany dokonujące się w gospodarce światowej coraz silniej wpływają na funkcjonowanie sektora żywnościowego w Polsce. Przyszłość przemysłu spożywczego pozostaje $\mathrm{w}$ silnym związku $\mathrm{z}$ jego efektywnością i konkurencyjnością. Te aspekty są ważne chociażby z dwóch powodów. Po pierwsze, nowe systemy produkcji żywności mogą być rozwijane pod warunkiem konieczności poprawy efektywności ekonomicznej prowadzonej działalności. Po drugie, kwestie związane ze standardami unijnymi, ochroną środowiska i ograniczonymi zasobami naturalnymi, a zwłaszcza dostępnością wody, wymagają uwzględnienia tych warunków w systemach produkcji. Sprostanie im możliwe jest między innymi dzięki, stosowaniu innowacyjnych metod produkcji, zarządzania, organizacji pracy oraz wprowadzaniu nowoczesnych form dystrybucji towarów. W realiach współczesnej gospodarki nieustanne tworzenie, przyswajanie i adaptowanie wiedzy oraz poszukiwanie rozwiązań innowacyjnych staje się podstawowym warunkiem konkurencyjności.

Integracja z UE oraz procesy globalizacyjne, a tym samym coraz większe otwarcie Polski na kontakty ze światem gospodarczym, nasilają walkę konkurencyjną między przedsiębiorstwami na rynku krajowym i zagranicznym. Aby utrzymać pozycję rynkową, firmy muszą nieustannie się rozwijać, muszą być innowacyjne. Innowacyjność warunkuje więc rozwój przemysłu spożywczego w Polsce, co wydaje się implikować oczywistą potrzebę analizy problemów z tej dziedziny.

W literaturze ekonomicznej sporo jest prac poświęconych problematyce prywatyzacji, restrukturyzacji, integracji z UE czy analiz efektywności ekonomicznej przedsiębiorstw przemysłu spożywczego [por. np. Drożdż 2008; Firlej 2008; Duczkowska-Małysz, Szymecka 2009; Urban 2010]. Nieco mniej pisze się na temat innowacyjności, jeśli już, to głównie na poziomie całego przemysłu lub wybranego kierunku przetwórstwa spożywczego, a jeszcze mniej jest analiz poświęconych zależnościom pomiędzy innowacyjnością a rozwojem i konkurencyjnością poszczególnych branż wchodzących w skład przemysłu spożywczego. Brakuje szerszego ,spojrzenia” na cały przemysł spożywczy w aspekcie innowacyjności i jej związków z konkurencyjnością.

W niniejszej pracy podjęta została próba wypełnienia luki w zakresie analiz innowacyjności w przemyśle spożywczym, a przede wszystkim poszczególnych 
jego branż (na poziomie klas PKD) w kontekście rozwoju i konkurencyjności. $\mathrm{W}$ dotychczas stosowanych ujęciach brak jest tego typu analiz. W pracy na tle teoretycznych rozważań ekonomicznych stawiane są tezy weryfikowane z zastosowaniem metod ilościowych, w tym zwłaszcza statystyki wielowymiarowej oraz regresji panelowej. Co istotne, w niniejszych badaniach podjęto próbę budowy i empirycznej weryfikacji syntetycznego miernika innowacyjności zarówno na szczeblu przemysłu spożywczego ogółem, jak i niższych szczeblach agregacji (na poziomie klas lub grup klas PKD). Analiza ma charakter mezoekonomiczny, gdyż branże przemysłu spożywczego uznano za mezosystemy gospodarcze w odniesieniu do całego przemysłu.

Celem głównym autorki pracy jest dokonanie oceny stopnia innowacyjności przemysłu spożywczego w Polsce oraz określenie wpływu tej innowacyjności na rozwój i konkurencyjność całego kierunku tej działalności wytwórczej, jak i jego klas lub grup klas.

W osiągnięciu tego celu ma pomóc usystematyzowanie wiedzy ekonomicznej pozwalającej na zrozumienie uwarunkowań złożoności procesów i zjawisk o charakterze innowacyjnym i konkurencyjnym dotyczących przedsiębiorstw przemysłu spożywczego.

Realizacji celu głównego podporządkowano następujące cele szczegółowe:

- ukazanie istoty, wielowymiarowości, źródeł i celów działalności innowacyjnej,

- ocena jakości i dostępności danych statystycznych dotyczących innowacyjności przedsiębiorstw na różnych szczeblach agregacji,

- diagnoza produkcyjno-ekonomicznej sytuacji przemysłu spożywczego w Polsce,

- budowa syntetycznych mierników innowacyjności dla przemysłu spożywczego na różnych poziomach $\mathrm{PKD}$,

- empiryczna weryfikacja syntetycznego miernika oceny innowacyjności branż (klas i grup klas) przemysłu spożywczego,

- identyfikacja i klasyfikacja branż przemysłu spożywczego, w których działalność innowacyjna przyniosła relatywnie najlepsze efekty ekonomiczne,

- budowa i empiryczna weryfikacja modeli konkurencyjności przemysłu spożywczego na różnych poziomach PKD.

Analizę przemysłu spożywczego ogółem przeprowadzono dla lat 1999-2008, a więc uwzględniono pięć lat poprzedzających akcesję Polski do UE i pięć lat członkostwa Polski w strukturach Wspólnoty. Tam, gdzie było to możliwe, analizę rozszerzono o rok 2009. Podobna ocena, na poziomie poszczególnych klas lub grup klas przemysłu spożywczego, dotyczyła okresu 2002(4) -2008, w zależności od dostępności informacji statystycznych.

W badaniach postawiono następujące hipotezy badawcze:

H1. Przemysł spożywczy charakteryzuje się niskim stopniem innowacyjności w porównaniu z innymi działami przetwórstwa przemysłowego. 
H2. Innowacyjność przedsiębiorstw funkcjonujących w dziale przemysłu spożywczego jest zróżnicowana branżowo.

H3. Innowacyjność przemysłu spożywczego wpływa na jego konkurencyjność. klas).

H4. Efekty innowacyjności są zróżnicowane branżowo (klasy lub grupy

H5. Liderzy przemysłu spożywczego (branże) charakteryzują się wysoką innowacyjnością.

Konstrukcja rozprawy uwarunkowana jest celem głównym oraz merytorycznym przedmiotem badań. Analiza ma charakter teoretyczno-empiryczny, a weryfikację hipotez badawczych przeprowadzono z wykorzystaniem narzędzi statystycznych i ekonometrycznych.

Praca składa się z sześciu rozdziałów. Pierwszy ma charakter teoretyczny, przybliżający problematykę innowacji w możliwie pełnej złożoności. Zawiera prezentację, omówienie znaczenia i szczegółowe rozwinięcie problematyki innowacji w przedsiębiorstwach i gospodarce. Zwraca uwagę na pojęcia - zmiana i innowacja, wskazując $m$. in. na problemy i trudności w definiowaniu innowacji i jej klasyfikacji. Analiza ekonomicznych wymiarów problematyki innowacji kończy rozważania pierwszego rozdziału.

Rozdział drugi jest poświęcony podkreśleniu znaczenia Narodowych Systemów Innowacji (NSI), charakterystyce tego systemu w Polsce oraz próbie oceny szans zwiększenia jego efektywności. Istnieje bowiem przekonanie, że innowacyjność gospodarki uwarunkowana jest charakterem Narodowego Systemu Innowacji, a polityka innowacyjna państw opiera się właśnie na tym systemie [Okoń-Horodyńska 2000, s. 120]. Współcześnie sukcesy odnoszą te gospodarki, które opanowały umiejętność szybkiej i efektywnej transformacji osiągnięć nauki w nowe lub udoskonalone produkty, technologie i rozwiązania w zakresie organizacji i zarządzania. $\mathrm{W}$ tej części pracy przedstawiono również metodologię statystycznych badań innowacyjności OECD, Unii Europejskiej i GUS oraz zaprezentowano ranking innowacyjności krajów UE, opublikowany przez Komisję Europejską, a będący efektem projektu European Innovation Scoreboard (2009).

W rozdziale trzecim przeanalizowano pozycję przemysłu spożywczego w polskim agrobiznesie, opisano klasyfikację tego przemysłu według PKD oraz scharakteryzowano jego tendencje rozwojowe w latach 1999-2008(9). W szczególności akcent został położony na produkcję sprzedaną, eksport, inwestycje, napływ BIZ, wydajność pracy i produktywność czynników produkcji. Podjęto również próbę ilościowej oceny konkurencyjności branż przemysłu spożywczego w badanym okresie.

Kolejny rozdział poświęcony został wyłącznie ocenie działalności innowacyjnej przedsiębiorstw przemysłu spożywczego na tle przetwórstwa przemysłowego i przemysłu ogółem. Postępowanie badawcze oparto na wynikach badań działalności innowacyjnej przedsiębiorstw zrealizowanych przez GUS zgodnie 
z międzynarodową metodologią Oslo. Końcową cześć tego rozdziału stanowi empiryczna weryfikacja pozycji przemysłu spożywczego w rankingu innowacyjności działów przetwórstwa przemysłowego w Polsce, przeprowadzona z zastosowaniem metody głównych składowych.

W piątym rozdziale pracy analizą objęto niższe szczeble agregacji przemysłu spożywczego (klasy lub grupy klas), przy wykorzystaniu podstawowych wskaźników innowacyjności przedsiębiorstw przemysłowych. Wkładem własnym jest syntetyczna ocena innowacyjności badanych branż w latach 2004-2008, przeprowadzona na podstawie statystycznych metod porządkowania liniowego obiektów i analizy skupień

Przeprowadzone w rozdziale czwartym i piątym oceny implikują zagadnienie wpływu innowacji na pozycję konkurencyjną przedsiębiorstw przemysłu spożywczego. W tej sytuacji wciąż otwarte pozostaje pytanie, w jaki sposób badać relacje i powiązania między innowacjami a konkurencyjnością w przemyśle spożywczym?

Próbę odpowiedzi na tak postawione pytanie znajdziemy w ostatnim rozdziale pracy. W pierwszej kolejności akcent położono na teoretyczne podstawy badania relacji między postępem technicznym a wzrostem gospodarczym, wskazując m. in. na trudności w identyfikacji i pomiarze zmiennych mogących mieć wpływ na badane zjawiska. Biorąc pod uwagę powyższe uwarunkowania przeprowadzono empiryczną weryfikację różnych wariantów modeli konkurencyjności przedsiębiorstw przemysłu spożywczego na różnych poziomach jego agregacji.

W pracy wykorzystano szeroki wachlarz metod przetwarzania, prezentacji $\mathrm{i}$ interpretacji zgromadzonych danych, tj. metodę opisową, metodę porównawczą oraz narzędzia statystyczne i ekonometryczne. Do oceny innowacyjności przemysłu spożywczego i analiz na różnych jego szczeblach agregacji użyto metod wielowymiarowej analizy statystycznej, w tym metody głównych składowych, porządkowania liniowego i analizy skupień. Modele ekonometryczne (w tym panelowe) wykorzystano do analizy przyczynowo-skutkowych związków innowacyjności i konkurencyjności przedsiębiorstw przemysłu spożywczego.

Podstawowym źródłem informacji o innowacyjności przemysłu spożywczego ogółem są dane statystyczne zawarte w Statystyce nauki i techniki $(\mathrm{N}+\mathrm{T})$, Działalności innowacyjnej przedsiębiorstw i Rocznikach statystycznych przemystu opracowanych przez GUS na podstawie międzynarodowych zaleceń metodologicznych OECD i Eurostatu, opublikowane w serii podręczników Frascati Family Manuale. Informacje dotyczące innowacyjności poszczególnych branż (klas lub grup klas) przemysłu spożywczego pochodzą z niepublikowanych źródeł GUS. Z kolei charakterystyki liczbowe dotyczące podmiotów gospodarczych, produkcji, sprzedaży, zatrudnienia, wydajności pracy, rentowności, nakładów inwestycyjnych, środków trwałych i handlu zagranicznego przemysłu spożywczego ogółem (dział 15 i 16 PKD) oraz grup i klas tego przemysłu, zostały opracowane na podstawie publikowanych i niepublikowanych źródeł GUS. 
W pracy oparto się również na materiałach Instytutu Ekonomiki Rolnictwa i Gospodarki Żywnościowej, dotyczących zwłaszcza handlu zagranicznego i sytuacji ekonomiczno-finansowej przedsiębiorstw poszczególnych klas przemysłu spożywczego.

Innymi ważnymi źródłami danych były: niepublikowane informacje NBP o napływie i zasobach BIZ, informacje PAIiIZ o inwestycjach zagranicznych, dostępne raporty i opracowania tematyczne, zarówno krajowe, jak i zagraniczne (np. European Innovation Scoreboard (EIS), Inwestycje zagraniczne w Polsce, Polski sektor żywnościowy w pierwszych latach czlonkostwa).

Prezentowane $\mathrm{w}$ niniejszej pracy metody badań nad przemysłem spożywczym będą, zdaniem autorki, stanowić punkt wyjścia do podobnych analiz przestrzenno-czasowych podejmowanych dla innych działów i klas przemysłu, a rezultaty mogą zostać wykorzystane przez środowisko naukowe zajmujące się tą problematyką, jak również przez instytucje odpowiedzialne za kreowanie polityki innowacyjnej w Polsce.

Należy zaznaczyć, iż przeprowadzone badania nie wyczerpują wszystkich kwestii, jakie można by sformułować w odniesieniu do złożonego i wielowątkowego zagadnienia innowacyjności i jej związków z konkurencyjnością. Na wiele wyłaniających się pytań nie ma jednoznacznych odpowiedzi. Należy je traktować jako kwestie do dalszych rozważań i pogłębionych analiz.

W tym miejscu pragnę podziękować recenzentowi prof. zw. dr hab. Wiesławowi Plucie za cenne uwagi i sugestie, które pozwoliły przygotować końcową wersję tekstu. 


\section{Procesy innowacyjne w gospodarce \\ - wybrane aspekty teoretyczne}

\section{Wprowadzenie}

Pojęcie ,innowacja” jest współcześnie przedmiotem ogromnego zainteresowania przede wszystkim nauk społecznych i ekonomicznych. Wynika to z roli, jaką przypisuje się innowacjom w rozwoju społeczno-gospodarczym kraju. Jednak termin ,innowacja” jest stosowany w wielu rozmaitych sytuacjach i znaczeniach. Rozbieżności w formułowaniu tego pojęcia wynikają z różnego pojmowania innowacji. W literaturze poglądy na innowacje nie są jednolite, a w analizach ekonomicznych zwraca się coraz częściej uwagę na problem nakładów i efektów działalności innowacyjnej.

Przedmiotem niniejszego rozdziału pracy jest przybliżenie istoty innowacji. Zawiera on prezentację, omówienie znaczenia i szczegółowe rozwinięcie problematyki innowacji w przedsiębiorstwach i gospodarce. Na tym tle wprowadza się rozróżnienie pojęć - zmiana i innowacja. W tej części pracy wskazuje się także na problemy i trudności w definiowaniu innowacji. Stosując różne kryteria, dokonano klasyfikacji innowacji oraz modeli procesu innowacyjnego. Celem tego rozdziału jest również próba teoretycznej refleksji nad złożoną problematyką innowacji i jej wpływem na konkurencyjność przedsiębiorstw i gospodarek. W rozważaniach zawartych w nim wykazano, że w warunkach globalnej konkurencji innowacje są głównym instrumentem zapewniającym wzrost konkurencyjności.

\subsection{Zmiany a innowacje}

Przed poszczególnymi gospodarkami, przedsiębiorstwami, instytucjami stoją ciągle nowe wyzwania. Wynikają one $\mathrm{z}$ faktu, że podmioty funkcjonują w otoczeniu, które nieustannie się zmienia, co wymusza potrzebę ciągłego dostosowywania się do zmian w nim zachodzących. Zmieniają się sposoby działania konkurencji, przedsiębiorstw kooperujących (dostawców surowców, odbiorców), przepisy prawa (w tym wymagania związane z ochroną środowiska naturalnego), a przede wszystkim upodobania konsumentów.

Narastająca globalizacja prowadzi do nieustannych zmian w wielkości oraz strukturze popytu i podaży. Każdy podmiot, chcąc utrzymać się na rynku, powinien ciągle dokonywać modyfikacji w swojej strategii działania, szybko reagując na zmiany rynku lub najlepiej powinien te zmiany wyprzedzać [Janasz 2009, s. 19]. 
Potrzeba ciągłego rozwoju, zarówno społecznego, jak i gospodarczego, związana jest nierozerwalnie z koniecznością wprowadzania zmian, zwłaszcza tych prowadzących do poprawy warunków życia poprzez możliwie najefektywniejsze zastosowania $\mathrm{w}$ różnych dziedzinach istniejącej wiedzy. Można zatem powiedzieć, że zmiany to immanentna cecha życia społecznego i gospodarczego, gdyż są powszechne i nieuchronne. W ostatnim czasie wprowadza się coraz więcej zmian, co jest powodowane dynamicznym rozwojem informatyki i procesami globalizacji gospodarek. Postrzegając współczesne zmiany uważa się, że jedyną stałą rzeczą w gospodarowaniu jest stała zmiana [Drucker 1995, s. 66-67].

Źródła zmian są wewnętrzne, zewnętrzne, ekonomiczne i pozaekonomiczne, różnorodny jest ich charakter i wpływ na funkcjonowanie wprowadzających je podmiotów oraz na otoczenie. Na ogół dokonanie zmiany wiąże się z powstaniem czegoś innego, nowego i nieznanego wcześniej. To pierwsze zastosowanie nowego rozwiązania. Zmiany mogą dotyczyć poziomu mikro (ich efekty są odczuwalne przez wprowadzający je podmiot i co najwyżej najbliższe otoczenie), mezo (wprowadzone zostają w wybranych segmentach gospodarki), makro (efekty są odczuwalne przez gospodarkę narodową) oraz mega (odczuwalne w skali świata).

Najwięcej możliwości do wprowadzania zmian istnieje w przedsiębiorstwach, gdyż działają one w otoczeniu, którego zmienność wymusza działania dostosowawcze i weryfikacyjne. Analizując zmiany w kontekście widzenia stopnia antycypacji zakresu, można wyróżnić [Białasiewicz 2004, s. 15]:

- zmiany przez dostosowanie (adaptację),

- zmiany przez doskonalenie,

- zmiany przez przeprojektowanie,

- zmiany przez przeobrażenia.

Najszerszym zakresem czynności charakteryzuje się ostatnia zmiana, która obejmuje przeobrażenia całościowe i strategiczne, w rezultacie których powstają nowe produkty, usługi, nowe struktury i procesy.

Zmiany, które osiągają wymiar makro w skali gospodarek światowych i mega w skali świata, mogą powstawać w dwojaki sposób. Po pierwsze, zmiany wprowadzone w przedsiębiorstwie na poziomie mikro uzyskują status zmian makro i mega dzięki procesom upowszechniania: dyfuzji przez imitację, patentom, obrotowi nośnikami wiedzy technologicznej, bezpośrednim inwestycjom zagranicznym itp. Natomiast drugim sposobem prowadzącym do zmian w skali makro i mega są inicjatywy reform instytucji narodowych, ugrupowań politycznogospodarczych krajów oraz instytucji międzynarodowych. Źródłem nie są tutaj przedsiębiorstwa, a zmiany nie przenikają stopniowo do innych podmiotów, lecz od razu mają wymiar makro (instytucje krajowe) lub mega (instytucje międzynarodowe) [Świtalski 2005, s. 68].

Jednak nie każda zmiana jest innowacją. Aby właściwie zdefiniować kategorię innowacji, konieczne jest bardziej precyzyjne określenie zmian, które są jej treścią, tzn. trzeba powiedzieć, jakie zmiany zasługują na miano innowacji. 
W literaturze przedmiotu wymienia się różne warunki, które powinny towarzyszyć zmianie, aby można było ją uznać za innowację.

Według Petera F. Druckera, zmiana wprowadzona przez podmiot staje się innowacją w określonym wymiarze dopiero wówczas, gdy zostanie zaakceptowana przez interesariuszy podmiotów (klientów, dostawców, gospodarkę, społeczeństwo) i utrwalona w postaci nowych standardowych praktyk, procedur i produktów. Drucker pisał: ,innowacja jest skutkiem wywołanym w gospodarce i społeczeństwie [...] albo jest zmianą w procesie, to znaczy w sposobie, w jaki ludzie pracują i coś wytwarzają" [Drucker 1992, s. 153].

Władysław Świtalski uważa, że zmiana, aby mogła być traktowana jako innowacja, powinna charakteryzować się określonymi cechami. Okoliczności, które sprzyjają przekształceniu się zmiany w innowację są następujące [Świtalski 2005, s. 68]:

a) zmiana modyfikująca lub wprowadzająca nowe elementy do sposobu lub wyników funkcjonowania podmiotu jest innowacją,

b) zmiana, uważana przez dany podmiot za innowację, powinna być wprowadzona w sposób świadomy, celowy i trwały,

c) innowacja jest taką zmianą, która powoduje bardziej efektywne funkcjonowanie podmiotu (niższe koszty, krótszy czas reakcji podmiotu na zewnętrzne bodźce itp.) lub podwyższenie użyteczności wyników funkcjonowania podmiotu (np. wyższa użytkowa lub techniczna jakość produktów materialnych lub usług w warunkach, gdy koszt uzyskania produktu nie uległ zwiększeniu lub nastąpiła obniżka kosztów wytwarzania produktu w warunkach niepogarszania jego jakości użytkowej i technicznej),

d) zmiana powinna mieć zdolność do upowszechniania się wśród innych podmiotów, które dotychczas nie wprowadziły zmian o podobnej charakterystyce.

Jeśli spełnione są wszystkie lub co najmniej większość warunków, to mamy do czynienia $\mathrm{z}$ sukcesem odniesionym przez podmiot wprowadzający zmianę i innowacją sensu stricto. Można powiedzieć, że innowacje przyczyniają się do postępu w określonej dziedzinie. Zbiór innowacji tworzy postęp i tak np. gdy wprowadza się innowacje dotyczące techniki mówi się o postępie technicznym [Bojewska 2009, s. 155].

Zdolność do wdrażania innowacji jest określana mianem innowacyjności. Precyzując można powiedzieć, że innowacyjność oznacza zdolność, motywację, a także postawy podmiotów gospodarczych do działań o charakterze naukowym, badawczym, technicznym, organizacyjnym, finansowym i handlowym, mających na celu opracowanie i wdrożenie nowych lub istotnie ulepszonych materiałów, wyrobów, urządzeń, usług, procesów lub metod przeznaczonych na rynek albo innego zastosowania w praktyce.

Bywa jednak i tak, że nie wszystkie zmiany i zamierzenia innowacyjne kończą się sukcesem. Nie wszystkie innowacje można uznać za postęp ze względu na skutki. Przed każdym innowatorem pojawia się obawa, niepewność co do 
efektów podjętych działań innowacyjnych. Złożoność procesów wiodących od pomysłu na innowację do jej końcowego efektu zależy od wielu, często niezależnych od siebie, zdarzeń. Niektóre innowacje mogą stanowić regres, powodować straty gospodarcze czy obniżać stopień zorganizowania przedsiębiorstwa. Mogą nie przynosić żadnych korzyści ani innowatorowi, ani jego otoczeniu. Ostateczny efekt wprowadzonych innowacji zależy od wyników uzyskanych przez innowatora (koszty wytwarzania produktów, poziom jakości użytkowej), od sposobu dotarcia do nabywcy (reklama, promocja, dystrybucja, obsługa posprzedażna) oraz od reakcji odbiorców, na które wpływają potrzeby, moda, różne gusty, poziom dochodów i niekiedy chęć pokazania wyszukanych wzorców konsumpcji. Zatem charakter efektów - pozytywny lub negatywny - określa się dopiero po wprowadzeniu określonej innowacji. Te same zmiany realizowane w różnych warunkach nie zawsze przynoszą takie same efekty [Bojewska 2009, s. 157]. Decyzje o wprowadzeniu bądź zaniechaniu innowacji są bardzo trudne, obarczone ryzykiem, mimo że współcześnie procesy globalizacji ułatwiają dostęp do informacji o możliwościach zrealizowania zmian, i mimo że warunki konkurencji rynkowej sprzyjają preferowaniu innowacyjności. Jednak procesy wprowadzania innowacji są na ogół kosztowne i ryzykowne, cechują się niepowtarzalnością, trudnością w przewidywaniu ostatecznych wyników, relatywnie długim okresem zamrożenia. Zaangażowanie znacznych zasobów firmy w przedsięwzięcia innowacyjne, które mogą zakończyć się niepowodzeniem, może przyczynić się nawet do upadku firmy. Pojawia się zatem konieczność podjęcia próby identyfikacji tych elementów procesu innowacyjnego, które determinują skuteczność prac związanych $\mathrm{z}$ wdrażaniem innowacji.

W ostatnich latach obserwuje się znaczne zróżnicowanie innowacyjności pomiędzy firmami czy też gospodarkami narodowymi. Przyczyn tego zjawiska jest wiele. Do najczęściej wymienianych w literaturze przedmiotu zalicza się: stopień i sposoby finansowania badań podstawowych i stosowanych $(B+R)$, zróżnicowany poziom rozwoju działalności naukowo-badawczej, uwarunkowania wynikające $\mathrm{z}$ tradycji cywilizacyjnych różnych krajów, a także różnice w kulturach korporacji i stosowanych strategiach rozwoju przedsiębiorstw.

\subsection{Definicje innowacji}

W literaturze przedmiotu duże znaczenie przypisuje się innowacjom jako czynnikowi determinującemu wzrost gospodarczy oraz poszukiwaniom metod oceniających ten wpływ. Jednoznaczne określenie siły omawianych relacji nie jest jednak łatwe, zarówno z powodu problemów definicyjnych, jak i trudności związanych ze sposobami kwantyfikacji danych. Pomimo ukazania się wielu prac, artykułów i monografii na temat innowacji, nadal brak jest jednoznacznej definicji, która nadawałaby się do adaptacji i konwersji na materiał statystyczny, 
porównywalny w ujęciu sektorowym i międzynarodowym. W publikacjach poświęconych problematyce innowacji bardzo często pomija się złożoność procesów innowacyjnych (informacyjnych, materialnych i finansowych), które towarzyszą przejściu od pomysłu do wprowadzenia innowacji, będącej realizacją pomysłu w praktyce. Komplikacje definicyjne wynikają również z faktu, że innowacje w rzeczywistości są złożonym procesem łączącym trzy sfery: naukę, technikę i produkcję [Mujżel 1977, s. 45-46]. Brak uniwersalnych definicji innowacji, na podstawie których ustala się klasyfikację, miejsce powstawania, zasięg i znaczenie zmian w gospodarce, są powodem powstawania zniekształceń w statystykach, a zatem i diagnoz mających na celu z jednej strony oceny i porównania poziomu innowacyjności podmiotów i gospodarek, a z drugiej wskazywanie kierunków i sposobów oddziaływania polityki innowacyjnej na rozwój działalności badawczo-rozwojowej i innowacyjnej danego kraju. Właściwe definiowanie i rozumienie problematyki innowacji zwiększyłoby zapewne skuteczność polityki proinnowacyjnej, poprzez odpowiednie jej planowanie i dostosowywanie do panujących warunków [Świtalski 2005, s. 79].

Innowacje są jednym z najbardziej złożonych i niejednoznacznie zdefiniowanych pojęć w teorii ekonomii. Dyskusja, czym faktycznie są innowacje trwa do dzisiaj. Pierwsze skojarzenie ze słowem ,innowacja” wiąże się z czymś nowym, czymś, czego jeszcze do tej pory nie było. Pytanie tylko, czy innowacją jest już sama myśl, pomysł, projekt, koncepcja czy może dopiero ich wdrożona w życie realizacja?

W literaturze przedmiotu prezentuje się ogromną liczbę definicji innowacji. Definiują je ekonomiści, badacze nauk ścisłych i społecznych. Oprócz innowacji technicznych, wyróżnia się te o charakterze organizacyjnym, kulturowym, marketingowym, psychologicznym. Termin ,innowacja” jest szeroko rozumiany i odnosi się do wszystkich sfer życia gospodarczego, społecznego i kulturalnego. „Innowacja” pochodzi od łacińskiego słowa innovatio - odnowienie.

Pojęcie innowacji do nauk ekonomicznych wprowadził w 1912 r. Joseph Schumpeter, który traktuje innowacje jako czynnik rozwoju gospodarczego. Rozwój ten charakteryzuje się nowymi kombinacjami środków produkcji powstałymi w sposób nieciągły, będącymi właśnie innowacjami [Schumpeter 1960, s. 103-104]. Jego ujęcie jest już traktowane jako klasyczne. Według Schumpetera pojęcie ,innowacje” obejmuje następujące przypadki [Schumpeter 1960, s. 104] :

- wprowadzenie nowego produktu (funkcje produktu, konstrukcje, materiały),

- zastosowanie nowej, dotychczas niewykorzystanej, metody wytwarzania produktów,

- wejście na nowy rynek,

- zdobycie nowego źródła surowców i materiałów lub maszyn i urządzeń,

- stworzenie nowego przedsiębiorstwa, którego struktura majątkowa, sposób finansowania lub system zarządzania są lepiej zharmonizowane z typem nowego lub dotychczasowego produktu lub procesu,

- wprowadzenie nowej organizacji jakiegoś przemysłu. 
Definicja ta jest punktem wyjścia rozważań o znaczeniu innowacji w gospodarce. W ujęciu Schumpetera innowacja oznacza wprowadzenie do praktyki nowego rozwiązania, przy czym przedmiotem tych badań były przede wszystkim innowacje technologiczne (produktowe i procesowe) i ich oddziaływanie na gospodarkę.

Rozumienie innowacji Schumpeter ograniczył do komercjalizacji nowego produktu lub wdrożenia nowego procesu przez przedsiębiorcę warunkowanego motywem zysku. Twórca ten za główną siłę rozwoju uważał ducha przedsiębiorczości, tj. wprowadzanie do produkcji i handlu różnych innowacji przynoszących zysk.

Innowacje to najważniejsza siła napędowa rozwoju gospodarki, bowiem są one specyficznym narzędziem przedsiębiorczości, która wyrażając się w ciągłym poszukiwaniu nowych kombinacji czynników wytwórczych, jest motorem postępu gospodarczego [Nowak 2000, s. 17]. Tak rozumianą innowację poprzedza fakt zaistnienia wynalazku, a w efekcie dalszych działań przedsiębiorczych, innowacje są stopniowo rozpowszechniane i wdrażane przez kolejne podmioty gospodarcze. Stałe kreowanie i upowszechnianie wszelkiego rodzaju innowacji uważa się dzisiaj za normę zdrowej gospodarki rynkowej i stymulator jej rozwoju.

Schumpeter w swoich rozważaniach doceniał znaczenie wiedzy, ale nie zajmował się powiązaniami między wiedzą a innowacjami. Według tego autora wszelkie upowszechnianie innowacji to odrębny rodzaj zmian, określany mianem imitacji. W pracach tych zwraca się również uwagę na zależności i wpływ procesów innowacyjnych zachodzących w skali mikro (przedsiębiorstw) na procesy makroekonomiczne, a mianowicie na finanse, poziom ogólnej aktywności gospodarczej i poziom bezrobocia. Zmian powodowanych innowacjami nie da się opisać rachunkiem różniczkowym nawet wówczas, gdy próbuje się je uśredniać na poziomie działu przemysłu lub całej gospodarki - ,innowacje powodują zasadniczą nieciągłość" [Schumpeter 1928, s. 391]. Warto podkreślić, że Schumpeter wskazał właściwy kierunek zależności przyczynowo-skutkowych stwierdzając, że to innowacje są przyczyną ożywienia gospodarczego, a nie odwrotnie.

Pierwsza teoria innowacji, sformułowana przez Schumpetera, dotyczyła gospodarki kapitalistycznej z początku XX w., w której głównymi czynnikami produkcji były ziemia, praca i kapitał, zdecydowanie mniejszą rolę odgrywały wiedza i informacja. W ostatnich latach relacje miedzy czynnikami produkcji zostały odwrócone i obecnie uważa się, że podstawowe znaczenie ma właśnie wiedza $\mathrm{i}$ informacja, które determinują wprowadzenie innowacji.

Nim zaprezentowane zostaną wybrane definicje innowacji, dla potrzeb wyjaśnienia trudności terminologicznych oraz istoty innowacji, warto prześledzić ten skomplikowany proces, od powstania innowacji do zastąpienia jej nowym rozwiązaniem. Jego złożoność przedstawiono na rys. 1.1.

Za pierwszą fazę powstania wynalazku w układzie: badania $\rightarrow$ prace rozwojowe $\rightarrow$ wdrożenie $\rightarrow$ produkcja powszechnie uważa się badania. Efektem badań 
podstawowych jest inwencja, a badań stosowanych - innowacja. W wielu przypadkach badania podstawowe oraz badania stosowane winny być poprzedzone badaniem rynku, które oceniają zapotrzebowanie na dany produkt [Kasperkiewicz 1989, s. 24-26]. Można również przytoczyć wiele przykładów powstania nowego produktu, który sam przez swoją podaż tworzył popyt.

Innowacje utożsamiane są zarówno $\mathrm{z}$ pewną ideą, nowatorskim pomysłem, jak i z ich rzeczowym efektem i konkretną zmianą w działalności gospodarczej lub też z procesem o charakterze zależności przyczynowo-skutkowych, mających na celu przygotowanie i wprowadzenie do praktyki nowatorskiego rozwiązania. W ujęciu klasycznym proces innowacji obejmuje pięć faz: badania podstawowe, badania stosowane, prace rozwojowe, wdrożenie innowacji, upowszechnienie innowacji - dyfuzja.

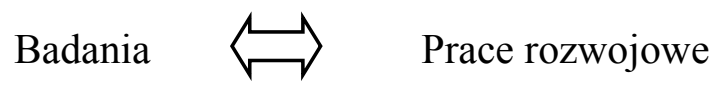

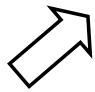

Zapotrzebowanie

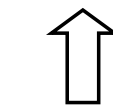

Dyfuzja

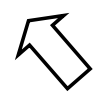

Produkcja

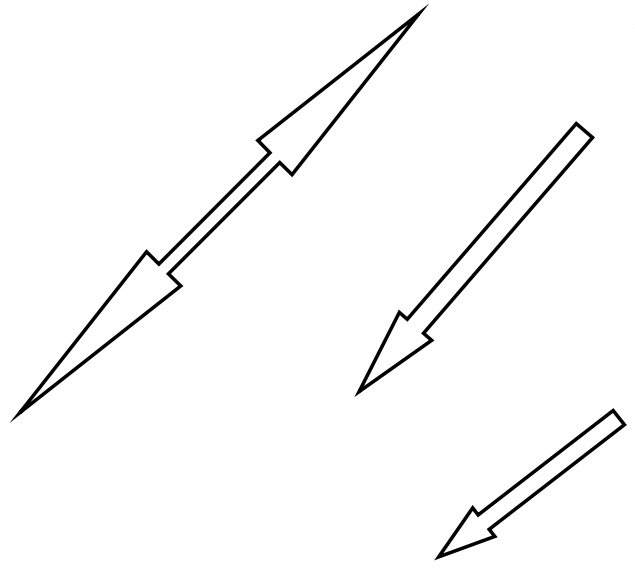

$\sqrt{2}$

Wdrożenie<smiles>C1CCCCC1</smiles>

Wynalazek<smiles>C1=CCC1</smiles>

Patent

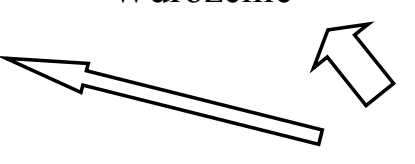

Licencja

Rysunek 1.1. Schemat procesu innowacji

Źródło: M. S z aj t, Aktywność innowacyjna a wzrost gospodarczy Polski. Analiza statystyczno-ekonometryczna, Wyd. Politechniki Częstochowskiej, Częstochowa 2008, s. 9. 
Jedną z definicji innowacji zaproponował S. Kuznets [1959, s. 30]. Według niego, w momencie pojawienia się pożądanych wyników badań rozpoczynają się prace rozwojowe, mające na celu nadanie im charakteru użytkowego. Definiuje on innowacje jako nowe zastosowanie starej lub nowej wiedzy do procesu produkcji, inicjujące zastosowanie wynalazku.

Ch. Freeman stwierdził: „nie wprowadzać innowacji, to znaczy umierać”. Jako innowacje traktował on pierwsze handlowe wprowadzenie nowego produktu, procesu, systemu lub urządzenia [Freeman 1982, s. 25-27]. Podobne stanowisko reprezentował E. Mansfield, nazywając innowacją pierwsze zastosowanie wynalazku [Mansfield 1968, s. 1-2]. Mansfield nie rozróżniał wynalazku od innowacji, a takie rozróżnienie pojawiło się u Schumpetera, który uważał, że kreowanie wiedzy, czyli wynalazek, jest zupełnie odmienne od innowacji, tj. wprowadzania wiedzy do produkcji. Cześć wynalazków nigdy nie znajduje zastosowania i tym samym nie prowadzi do innowacji, a z kolei wiele innowacji nie wymaga wynalazku. Zdaniem Schumpetera to nie sama obecność jakiegoś wynalazku, ale gotowość do zmiany w produkcji decyduje o tym, czy innowacje będą wdrożone, czy nie.

A. Pomykalski definiuje innowacje jako proces obejmujący wszystkie działania związane $\mathrm{z}$ kreowaniem pomysłu, powstaniem wynalazku, a następnie jego wdrożeniem w postaci produktu lub procesu [Pomykalski 2001, s. 26]. Czas od momentu powstania wynalazku do jego wykorzystania jako innowacji jest różny, ale na ogół okres ten ulega skróceniu wraz z rozwojem gospodarczym.

Różnice definicyjne są m.in. efektem dwóch odmiennych podejść: pierwsze, traktujące jako innowację tylko pierwsze zastosowanie wynalazku oraz drugie, uznające za innowację każde kolejne zastosowanie wynalazku [Poznański 1979, s. 26-41]. Schumpeter był zwolennikiem i twórcą pierwszego podejścia. Wyróżniał, jak już wcześniej wspomniano, dwa pojęcia: innowacja i imitacja. Cytowani badacze - S. Kuznets, Ch. Freeman, E. Mansfield - zawężali zakres innowacji do pierwszego zastosowania. Jednak większość ekonomistów opowiada się za drugim podejściem.

Ogromne znaczenie i rolę innowacji w działalności gospodarczej podmiotów podkreślał Drucker [2004, s. 161], który uznaje ją za podstawową siłę sprawczą przedsiębiorczości, nadającą przez zorganizowaną i racjonalną pracę z pozoru bezproduktywnym zasobom nowe możliwości tworzenia bogactwa. Innowacja w pewnym sensie tworzy zasoby, ponieważ zasób nie istnieje, dopóki człowiek nie znajdzie dla niego zastosowania. Ten sam autor twierdzi także, że:

- innowacja to praca, która wymaga wiedzy, często wielkiej pomysłowości, odpowiednich predyspozycji, jednak przede wszystkim oznacza ciężką celową pracę,

- aby odnieść sukces, innowatorzy muszą wykorzystywać swoje mocne strony, muszą patrzeć na możliwości w szerokim zakresie,

- innowacja jest skutkiem procesów w gospodarce i społeczeństwie, zmianą w zachowaniach ludzi, w tym jak pracują, jak produkują. 
S. M. Kot [1993, s. 27] innowacje rozumie jako relatywnie nowe, produkcyjne zastosowanie informacji naukowych lub technicznych. Przytoczona definicja jest bardzo krótka, ale jednocześnie czytelna i dość zbliżona do innych ostatnio formułowanych pojęć.

„Innowacja oznacza nowy, nieznany dotychczas sposób zaspokojenia nowych potrzeb. Innowacje jako synonim nowych sposobów realizowania określonych potrzeb, odnosić można do wszystkich aspektów działalności ludzkiej, mówi się w związku z tym o innowacjach technicznych, ekonomicznych itd." [Kasprzyk 1980, s. 26-27].

„Innowacja wiąże się z każdym dobrem, usługą lub ideą, które są postrzegane przez kogokolwiek jako nowe. Idea może mieć długą historię, lecz dla ludzi staje się innowacją wówczas, gdy widzą ją jako nową" [Kotler 1991, s. 342].

Współcześnie innowację rozumie się jako „twórczy i interakcyjny proces wplątujący rynek i instytucje pozarynkowe. Innowacja składa się z twórczego użytku różnych form wiedzy, który odpowiada rynkowemu popytowi i wymaganiom wyznaczanym przez społeczeństwo innowacyjne" [Simonetti 1995, s. 77-89]. Powyższa definicja w sposób wyraźny podkreśla trzy aspekty pojęcia innowacji: dynamiczny (innowacja stanowi proces), techniczny (dotyczy wynalazku) i technologiczny (dotyczy jego wykorzystania). Zatem technologia oznacza organizację wiedzy służącej celom praktycznym, wiedza dotyczy technicznego zastosowania wynalazku, a efekt ekonomiczny uzyskuje się poprzez realizację procesu.

W literaturze przedmiotu innowacje pojmowane są $\mathrm{w}$ aspekcie szerokim i wąskim. W szeroko rozumianym ujęciu chodzi o zmiany dokonujące się w gospodarce i w systemach społecznych. W wąsko pojmowanym aspekcie innowacje ogranicza się do nowości, która została wprowadzona pierwszy raz na rynek, a więc są to przede wszystkim innowacje techniczne, mające wpływ na procesy produkcyjne.

W Polsce głównym źródłem informacji z zakresu działalności innowacyjnej gospodarki narodowej, jej sekcji i działów jest GUS. Zatem w pracach badawczych podejmujących próby oceny innowacyjności polskiej gospodarki niezbędna jest znajomość i właściwe rozumienie definicji stosowanych przez GUS.

Definicje i określenia związane z działalnością innowacyjną wykorzystywane przez Główny Urząd Statystyczny obowiązują w całym procesie gromadzenia, przetwarzania, publikowania i wykorzystania danych zbieranych przez urząd. System prowadzonych przez GUS badań statystycznych działalności innowacyjnej przedsiębiorstw oparty jest na międzynarodowej metodologii standardowej zwanej metodologią lub systemem Oslo (od nazwy podręcznika metodycznego badań statystycznych innowacji opracowanego przez OECD i Eurostat - Oslo Manual). W rozumieniu GUS: „Innowacja technologiczna (TPP innovation) ma miejsce wtedy, gdy nowy lub ulepszony produkt zostaje wprowadzony na rynek, albo gdy nowy lub ulepszony proces zostaje zastosowany w produkcji, przy czym 
ów produkt i proces są nowe przynajmniej z punktu widzenia wprowadzającego je przedsiębiorstwa. [...] Innowacje technologiczne powstają w wyniku działalności innowacyjnej obejmującej szereg działań o charakterze badawczym (naukowym), technicznym, organizacyjnym, finansowym i handlowym. Innowacja technologiczna oznacza obiektywne udoskonalenie właściwości produktu lub procesu, bądź systemu dostaw w stosunku do produktów i procesów dotychczas istniejących. Mniejsze techniczne lub estetyczne modyfikacje produktów i procesów, nie wpływające na osiągi, właściwości, koszty lub też zużycie materiałów, energii i komponentów nie są traktowane jako innowacje technologiczne" [Nauka i technika w 2009 roku, s. 125-126].

Powyższa definicja, zdaniem wielu ekonomistów, posiada dwie zasadnicze wady. Po pierwsze, niepotrzebnie ogranicza innowacje do wymiaru komercyjnego, a po drugie, nie uwzględnia istotnego aspektu innowacji, a mianowicie redukcji pracochłonności i tym samym wpływu innowacji na wielkość i strukturę zatrudnienia [OECD 1996].

Warto zauważyć, że co się tyczy przydatności stosowanych w oficjalnych publikacjach zasad rozróżniania innowacji w obecnych warunkach gospodarowania, to pojawia się pewne rozczarowanie, że w wiedzy o innowacjach nie dokonał się znaczący postęp od czasów J. A. Schumpetera, który, jak już wspomniano, uważany jest za ojca definicji innowacji. Schumpeter już na początku XX w. pojmował innowacje jako „nieciągłe przeprowadzanie nowych kombinacji w pięciu następujących przypadkach: wprowadzanie nowego towaru (lub jego gatunku, z jakim konsumenci się jeszcze nie spotkali), wprowadzenie nowej metody produkcji, otwarcie nowego rynku, zdobycie nowego źródła surowców lub przeprowadzenie nowej organizacji jakiegoś przemysłu”. Najczęściej stosowaną ogólną definicją innowacji jest ciągle definicja Schumpetera, który w procesie wprowadzania innowacji wyróżniał trzy następujące kolejno po sobie etapy określane jako: wynalazek (invention), innowacja (innovation) i rozpowszechnianie (diffusion). Definicja ta wprowadza rozróżnienie pomiędzy działalnością wynalazczą a innowacją, która w tym ujęciu ograniczona jest do procesu komercjalizacji nowego produktu (commercialisation of new product) lub wdrożenia nowego procesu (implementation of new process). Zaletą tej definicji jest to, że wymaga ona, by nowe produkty i procesy miały wartość ekonomiczną, na co wskazuje ich komercjalizacja.

Od czasów Schumpetera rozumienie innowacji ulegało zmianie [Rothwell 1994]. Współcześnie pojęcie to traktowane jest bardzo szeroko i jak dotąd nie ma jednej uniwersalnej definicji. Istnieje jednak pewna zgodność wśród teoretyków i praktyków zajmujących się tą tematyką, iż nie da się zmierzyć i opisać innowacyjności przedsiębiorstwa (wybranego sektora lub gospodarki) za pomocą jednego lub kilku wskaźników. Już nie wystarczy porównać w skali międzynarodowej wielkości wydatków na $\mathrm{B}+\mathrm{R}$ czy udziału wysoko zaawansowanych wyrobów technologicznych w produkcji, aby ocenić poziom ich innowacyjności. 
Jedną z prób kompleksowego pomiaru innowacyjności na poziomie makroekonomicznym jest powstający corocznie, począwszy od 2000 r., z inicjatywy Komisji Europejskiej, raport European Innovation Scoreboard (EIS). Celem tego raportu jest ocena poziomu innowacyjności krajów członkowskich UE oraz innych wybranych krajów w kontekście celów określonych w strategii lizbońskiej. Szerzej na ten temat napisano w rozdziale drugim (podrozdz. 2.2 i 2.3 ).

Zaprezentowane definicje innowacji, zarówno polskich, jak i zagranicznych autorów określają je jako postęp, pozytywną zmianę. Autorem odmiennego podejścia do innowacji jest Z. Madej, który za innowacje uznaje coś nowego, czyli zmiany w stosunku do istniejącego stanu, ale mogą być to zmiany o charakterze postępowym, neutralnym lub regresywnym [Madej 1970, s. 13]. Jest to jednak teoria odosobniona.

Przedstawione definicje innowacji nie wyczerpują tej problematyki, ale wskazują na złożoność procesu innowacji, który wymaga dalszych badań i opracowań. Podsumowując można stwierdzić, iż innowacje charakteryzują się tym, że [Świtalski 2005, s. 106]:

- pojawiają się jako efekt pozytywnej zmiany,

- są nimi zainteresowane podmioty liczące na korzyści z wprowadzenia innowacji lub obawiające się strat z powodu zagrożenia, jakie stwarza innowacyjny konkurent,

- mają trudną do zdefiniowania naturę wyrażającą się miedzy innymi w tym, że nie są obserwowalne wszystkie aspekty trwałej zmiany,

- amorficzność innowacji i ograniczony krąg bezpośrednich interesariuszy (beneficjentów i narażonych na poniesienie strat) powoduje, iż badania procesów powstawania i rozprzestrzeniania się innowacji są prowadzone fragmentarycznie,

- wyróżniają się swoistą dynamiką (własność przyrostowości, nieodłączność występowania aspektów produktowych i procesowych),

- starzeją się i ulegają zanikowi tym szybciej, im większy odnoszą sukces,

- sukces innowacji nie zależy jedynie od natury samej innowacji i podmiotu innowatora, ale również od wpływu czynników całkowicie niesterowalnych i bardzo często mających silny wpływ na badane zjawisko.

\subsection{Systematyka innowacji}

Systematyka (rozumiana jako klasyfikacja rodzajowa) innowacji nie należy do łatwych zadań. Wynika to stąd, że skoro nie ma zgody co do definicji innowacji, nie może być również jednej płaszczyzny podziału poszczególnych jej rodzajów. Za wynik procesów innowacyjnych mogą być uważane choćby nowe produkty, usługi, technologie, określona pozycja na rynku czy zmiany organizacyjne przedsiębiorstwa [Nowak-Far 2000, s. 28]. Szerokie rozumienie innowacji pozwala 
wyodrębnić wiele jej typów na podstawie różnorodnych kryteriów. Poszczególne typy są ze sobą powiązane i często te same należą do kilku grup klasyfikacyjnych. Poznanie rodzajów innowacji pozwala uporządkować sposób myślenia na ich temat i ułatwia zrozumienie istoty innowacji. Klasyfikacje innowacji dobrze obrazują rzeczywisty zakres tego pojęcia.

W literaturze przedmiotu najczęściej spotyka się dychotomiczny podział innowacji na produktowe i procesowe. Jednak przedsięwzięcia innowacyjne obejmują swym zasięgiem nie tylko produkty i procesy, ale również inne obszary działalności człowieka. Klasyfikacja innowacji zaprezentowana w podręcznikach Oslo Manual (2005) wskazuje odrębność działań o charakterze technologicznym (produkty i procesy) i organizacyjnym czy marketingowym (rys. 1.2). Innowacje nietechnologiczne obejmują swym zasięgiem wdrażanie zaawansowanych technik zarządzania, wprowadzanie istotnie zmienionych struktur organizacyjnych czy wdrażanie nowych lub istotnie zmienionych strategii działania przedsiębiorstwa, a także innowacje marketingowe, takie jak istotna zmiana strategii marketingowej przedsiębiorstwa, istotne zmiany o charakterze estetycznym lub inne twórcze modyfikacje produktów przedsiębiorstwa, niebędące innowacjami technicznymi [Działania innowacyjne..., s. 133-134].

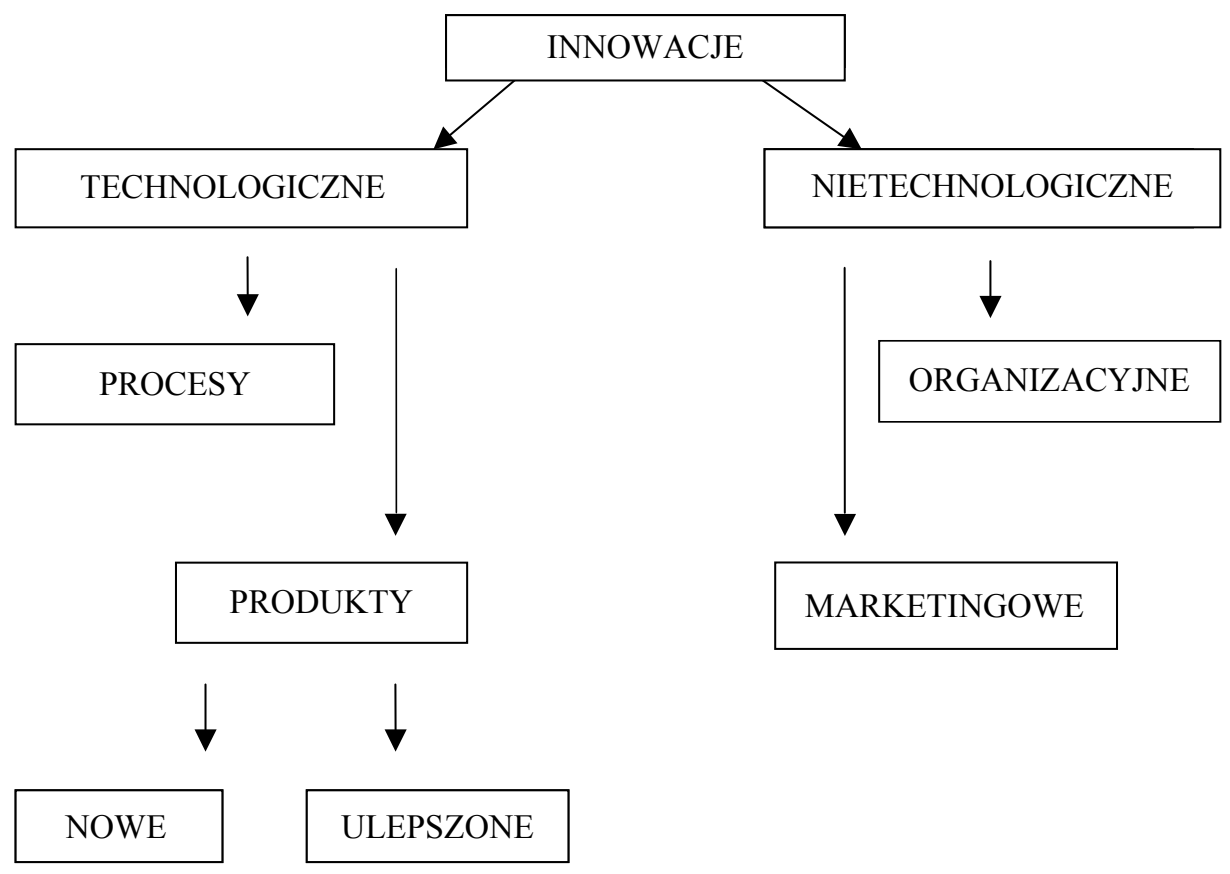

Rysunek 1.2. Typologia innowacji

Źródło: opracowanie własne. 
Klasyfikacja innowacji jest coraz bogatsza, gdyż pojawiają się nowe warunki i kryteria podziału. Procesy innowacji występują w różnych podmiotach realizujących działalności ujęte w Europejskiej Klasyfikacji Działalności niezależnie od ich form prawnych, funkcji i celów. Z punktu widzenia kryterium motywu lub celu prowadzenia działalności można wyróżnić [Świtalski 2005, s. 87-88]:

- obszar biznesu obejmujący wszystkie podmioty, których celem funkcjonowania jest zysk; są to jednostki gospodarcze prowadzące działalność regulowaną w Polsce przez kodeks spółek handlowych, niezależnie od liczby właścicieli i form organizacji; tutaj jednostki takie nazywamy przedsiębiorstwami lub firmami,

- obszary jednostek będących formalnie przedsiębiorstwami, ale których działalność nie jest nastawiona na zysk, w Polsce takimi przedsiębiorstwami są Polskie Koleje Państwowe jako centralna jednostka odpowiedzialna za obsługę potrzeb transportowych; w strukturze PKP mogą występować spółki podporządkowane, których celem jest tworzenie zysku,

- obszar jednostek zaspokajających potrzeby społeczne (zdrowie, edukacja, bezpieczeństwo obywateli i przestrzeganie prawa, opieka socjalna, certyfikacja zgodności z normami, ochrona środowiska itp.),

- obszar administracji publicznej, obrony narodowej, więziennictwa,

- obszar działalności stowarzyszeń (społecznych, naukowych, zawodowych, regionalnych itp.),

- obszar pozostałej działalności usługowej, komunalnej, socjalnej i indywidualnej.

W powyższych podmiotach, podzielonych na sześć obszarów, może być prowadzona działalność innowacyjna, ale warto podkreślić, że tylko w pierwszym obszarze - przedsiębiorstw nastawionych na zysk - możliwa jest identyfikacja innowacji i jednocześnie ocena ich efektów. Taką ocenę umożliwiają sprawozdania finansowe. Należy jednak zauważyć, że wprowadzone innowacje $\mathrm{w}$ jednostkach innych niż przedsiębiorstwa, szczególnie w instytucjach obsługi potrzeb społecznych, administracji publicznej i obrony narodowej mogą mieć duży wpływ na innowacyjność sektora przedsiębiorstw oraz generować zmiany w innych jednostkach i tym samym zwiększać innowacyjność gospodarki. Sprawność instytucji funkcjonujących w otoczeniu przedsiębiorstw ma w obecnych realiach gospodarczych coraz większe znaczenie. W Polsce, w warunkach integracji europejskiej, to od sprawności funkcjonowania administracji publicznej w dużym stopniu zależy pozyskanie i wykorzystanie funduszy strukturalnych, które mogą być przeznaczone na modernizację procesów wytwórczych w przedsiębiorstwach.

Innowacje mogą się więc pojawiać w rożnych podmiotach, niezależnie od celu ich funkcjonowania, ale oprócz miejsca ich wprowadzenia należy zwrócić uwagę również na inne kryteria. Dla potrzeb wyróżnienia, klasyfikacji głównych rodzajów innowacji wykorzystamy cztery kryteria, którymi są [Świtalski 2005, s. 88-106]: 
1) nośnik lub przedmiot innowacji, w ramach tego kryterium wyróżnia się innowacje: produktowe, procesowe oraz organizacyjne,

2) znaczenie lub doniosłość innowacji, wyróżnia się tu innowacje przełomowe, podstawowe oraz przyrostowe (uzupełniające),

3) pierwszeństwo lub oryginalność innowacji - wyróżnia się tu innowacje oryginalne (absolutne) oraz wtórne (naśladowcze),

4) źródło przedsięwzięcia innowacyjnego, wyróżnia się tu innowacje powstałe w wyniku zastosowania rezultatów badań i prac rozwojowych prowadzonych na zewnątrz jednostki, innowacje będące efektem badań rynku i preferencji nabywców, innowacje powstałe na skutek własnych prac innowatora, innowacje wprowadzone w wyniku nieoczekiwanych zdarzeń oraz innowacje będące kopiami innowacji zastosowanych przez inne jednostki.

Ze względu na przedmiot pracy najważniejszy jest pierwszy z przedstawionych powyżej, podział innowacji na produktowe, procesowe i organizacyjne. Taka klasyfikacja jest bardzo popularna i często spotykana w analizach ekonomicznych. Innowacja produktowa ma miejsce wówczas, gdy wprowadza się na rynek nowe produkty, służące zaspokajaniu nowych potrzeb lub udoskonala się wyroby już wytwarzane. Zatem innowacje produktowe to zmiany fizycznej charakterystyki lub osiągów istniejących wyrobów i usług, albo tworzenie całkowicie nowych wyrobów i usług. Tego typu innowacje są ,uprzedmiotowione” w wyrobach bądź usługach bezpośrednio sprzedawanych konsumentom. Przejawiają się więc we wprowadzaniu na rynek produktów, które dostarczają konsumentom nową lub ulepszoną użyteczność. Innowacje produktowe można podzielić na innowacje w [Niedzielski i Rychlik 2006, s. 31]:

- środkach produkcji,

- przedmiotach konsumpcji.

Innowacja procesowa polega na wdrożeniu nowego lub udoskonaleniu dotychczasowego procesu produkcji wyrobu lub usługi oraz na nowym prowadzeniu usług czy dystrybucji produktów. Innowacje o charakterze procesowym są „uprzedmiotowione" w procesach produkcji. Związane są przede wszystkim ze zmianami technologii wytwarzania w przedsiębiorstwach i metodach pracy, a także z kombinacją takich zmian. Innowacją procesową jest np. zastosowanie robotów.

Często granica między innowacjami produktowymi i procesowymi zaciera się, bowiem nowy produkt wymaga nowego procesu, natomiast nowy proces stwarza możliwość wprowadzenia innowacji produktowych. Nowy składnik procesu wytwórczego np. nowa maszyna jest warunkiem powodzenia innowacji procesowej.

Innowacja organizacyjna to zmiany w funkcjonowaniu organizacji, wprowadzone w celu zwiększenia sprawności działania. Przyjmuje się, że aby zmiany organizacyjne mogły być uznane za innowacje, muszą przynieść wymierne 
korzyści w wyniku ich wprowadzenia, np. wzrost wydajności pracy czy obrotów. W metodologii Oslo wskazuje się, że innowacje organizacyjne obejmują takie obszary firmy, jak [Podręcznik Oslo,1997, s. 58]:

- wprowadzanie istotnych modyfikacji w strukturach organizacyjnych,

- wdrażanie nowych technik zarządzania na zaawansowanym poziomie,

- wprowadzanie nowych lub znacznie zmodyfikowanych strategii.

Innowacja przelomowa (radykalna) to innowacja, która w radykalny sposób doprowadza do powstania nowych produktów i nowych procesów. Innowacje procesowe o przełomowej doniosłości cechują się zastosowaniem zupełnie nowych technologii, które wymagają nowych: urządzeń, specjalności zawodowych i surowców. Tego typu innowacje wywołują rewolucje technologiczne i powodują zastąpienie dotychczas wytwarzanych produktów lub stosowanych procesów nowymi. Stare produkty, o ile są dalej wytwarzane, przestają pełnić dotychczasowe funkcje i stają się obiektami kolekcjonerskimi. Z. Madej tego typu innowacje nazywa twórczymi (kreatywnymi) i uważa, że istotą tych innowacji jest zdobywanie terra incognita, torowanie głównych szlaków cywilizacji technicznej oraz wciskanie się w luki rozwoju, czyli opanowanie dziedzin nieodkrytych [Madej 1970]. W przedsiębiorstwie innowacje radykalne wywołują zmianę przełomową, tak zwaną nieciągłą, i polegają na całkowitym przekształceniu sposobu funkcjonowania organizacji [Tushman, Newman, Romanelli 1988, s. 29-44]. Innowacje przełomowe powodują zasadnicze zmiany na rynku w popycie lub podaży, a tym samym w konkurencji. Często przykładowo wymienianymi innowacjami przełomowymi w zakresie produktów są: lokomotywa parowa, samochód osobowy z napędem spalinowym, tranzystor i układ scalony oraz komputer, a w zakresie procesów: pasteryzacja żywności, łączność za pomocą sztucznych satelitów, chemioterapia i radioterapia w leczeniu nowotworów.

Innowacja podstawowa posiada główne cechy innowacji przełomowej, ma podobną zdolność upowszechniania się przez dyfuzję, lecz z mniejszą intensywnością wpływa na zmiany sposobu pracy, wytwarzania produktów i ich konsumpcji. Ważną cechą różniącą innowacje podstawowe od przełomowych jest to, że dyfuzja innowacji podstawowych odbywa się tylko w obrębie tych działalności, w których powstały ich pierwowzory, tzn. w tych samych gałęziach przemysłu lub zaspokajające te same potrzeby. Oto kilka przykładów podstawowych innowacji produktowych: kolorowy monitor o płaskim ekranie, tworzywa syntetyczne (poliamid, poliester, poliuretan), karta płatnicza oraz przykłady innowacji procesowych; kopiowanie dokumentów metodą kserograficzną, laparoskopowe operacje, proces zgrzewania punktowego wyrobów metalowych.

Innowacje przyrostowe polegają na udoskonaleniu tego, co jest wykonywane dobrze (tzw. dostrajanie) lub wprowadzaniu modyfikacji jako reakcji na stopniowe zmiany zachodzące w otoczeniu (tzw. przyrostowe dostosowywanie) [Niedzielski i Rychlik 2006, s. 36]. Właściwością innowacji przyrostowych jest to, że przyczyniają się one do ulepszeń procesu lub produktu, które wcześniej 
mogły być wynikiem innowacji przełomowej lub podstawowej. Są realizowane, w przeciwieństwie do innowacji przełomowych i podstawowych, w dłuższym czasie. W wielu sytuacjach przejęcie innowacji w wyniku zakupu patentu, procesu lub wskutek imitacji praktyk oryginalnego innowatora, czyli bez opłaty licencyjnej, skutkuje innowacjami przyrostowymi, których nie jest w stanie zrealizować początkowy innowator. Innowacje przyrostowe polegają więc na modyfikacji istniejących produktów, usług i technologii, zatem mają ograniczony wpływ na konkurencyjność na rynku. Przykłady produktowych innowacji przyrostowych to: kolejne udoskonalenia wybranej marki samochodu, udoskonalenia opakowania np. do herbaty, ulepszenia aparatu fotograficznego w telefonie komórkowym. Przykładem procesowych innowacji przyrostowych z kolei może być: uruchomianie tanich linii lotniczych, drukowanie tekstów i ilustracji w procesie offsetowym, kserograficznym i atramentowym.

W tym miejscu warto zwrócić uwagę, że podział ogółu innowacji na przełomowe, podstawowe i przyrostowe jest wysoce subiektywny. Zatem w bardziej szczegółowych analizach typologii innowacji należy dokładniej sprecyzować kryteria podziału.

Innowacja oryginalna to innowacja wprowadzona po raz pierwszy w skali świata, która może oczywiście dotyczyć produktu lub procesu. Istotą innowacji oryginalnej jest to, że w określonym czasie, spośród wielu ofert innowacyjnych, została uznana za najlepszą i staje się powszechnie przyjętym wzorcem nowości. Oryginalny innowator dysponuje przewagą nad konkurentami, która polega na wyprzedzeniu innych w zdobyciu użytecznej wiedzy co do sposobu wytwarzania nowego produktu lub stosowania nowego procesu. Uzyskane przewagi są chronione utrzymywaniem tajemnic przemysłowych, rejestracjami patentów, marek i praw do wzorów użytkowych. Szybkość rozchodzenia się oryginalnej innowacji wśród podmiotów mogących ją zastosować uzależniona jest od dostępu do informacji o innowacjach, skłonności podmiotów do wprowadzania zmian, istnienia bodźców sprzyjających innowacyjności społeczeństw, gospodarek, regionów i podmiotów. Mówiąc o bodźcach uwzględnia się przede wszystkim ich istnienie w tzw. miękkiej części instytucji, czyli chodzi nie tyle o samo ustanowienie i funkcjonowanie instytucji zajmujących się innowacyjnością, ale przede wszystkim o zachęty finansowe (np. odpisy kosztów przygotowania i realizacji innowacji w ciężar kosztów) i prawne do wprowadzania innowacji [Świtalski 2005, s. 99-100]. Dlatego we współczesnych badaniach nad innowacyjnością coraz większy nacisk kładzie się właśnie na tworzenie systemów wspierających innowacyjność przedsiębiorstw, regionów, gospodarek narodowych i ich ugrupowań [Okoń-Horodyńska 1999].

Natomiast innowacje wtórne, określane również mianem odtwórczych lub naśladowczych, to pewne kopie innowacji oryginalnych, które powstają dzięki dyfuzji, imitacji i adaptacji innowacji oryginalnych do nowych warunków. Innowacje wtórne uznaje się po pierwsze za „nowości zapożyczone”, a więc 
stosowane już gdzieś indziej, przejęte od jego oryginalnego twórcy i już wcześniej wykorzystywane w określony sposób. Po drugie, zalicza się do nich kreatywne wykorzystanie wcześniej stosowanych w inny sposób i w innym obszarze metod działania [Penc 1999, s. 144-145]. Innowacje tego rodzaju odgrywają szczególną rolę w rozwoju przedsiębiorstw i powinny być promowane na szczeblu organizacyjnym. Długość życia innowacji wtórnej jest silnie uzależniona od warunków zewnętrznych, a mianowicie od: typu i poziomu technologii dziedziny działalności, w której pojawia się innowacja; struktury podmiotów istniejących w przemysłach i działalnościach, które mogą być odbiorcami innowacji; natężenia konkurencji wśród podmiotów występujących w tych przemysłach i działalnościach, w których mogą być zastosowane rozpatrywane innowacje oraz od stopnia liberalizacji warunków prowadzenia działalności w danym kraju i w danej dziedzinie.

Każdej innowacji można przypisać źródło, czyli miejsce, w którym została zainicjowana, pomysł, który stał się inspiracją oraz przyczyny wywołujące określone zmiany. Według A. Pomykalskiego, źródłem innowacji jest wszystko to, co inspiruje człowieka do procesu zmian [Pomykalski 2001a, s. 25-27]. Uwzględniając kryterium źródła wyróżniamy, zgodnie z tym co przedstawiono wcześniej, pięć rodzajów innowacji. Pierwszym z nich są innowacje powstale w wyniku badań podstawowych i stosowanych oraz prac rozwojowych prowadzonych na zewnątrz podmiotu innowatora. Taka innowacja nosi miano innowacji opartej na wiedzy [Drucker 1992, s. 120]. Na ogół faza badań podstawowych (często zaspokajających ciekawość badaczy), a nawet faza badań stosowanych (kiedy badacz zastanawia się, jaki można zrobić użytek z uzyskanych wyników) nie prowadzi do komercjalizacji wyników (odkryć naukowych, wynalazków, modeli i nowych teorii). Do komercjalizacji rezultatów badań naukowych potrzebne są prace rozwojowe, które mogą być wykonane już w podmiotach innowatora, ale często czas, jaki upływa od pojawienia się wynalazku do powstania jego użytkowej wersji, jest bardzo długi.

Innowacje będące efektem badania rynku i preferencji konsumentów najczęściej dotyczą produktów i powodują dostosowanie produktu do oczekiwań klientów. Taka innowacja może być zrealizowana w podmiocie innowatora lub w przypadku istotniejszych zmian, może wymagać współpracy z zewnętrznymi ośrodkami badawczymi. W literaturze przedmiotu toczy się od wielu lat dyskusja, $\mathrm{w}$ jakim stopniu innowacje są efektem sygnałów pochodzących z rynku, a w jakim jest to wynik podaży pomysłów ze źródeł pozarynkowych [Schmookler 1966; Verspagen, Kleinknecht 1990].

Innowacje powstałe na skutek wlasnych prac innowatora są efektem spontanicznych działań pracowników przedsiębiorstwa lub instytucji, ale z uwzględnieniem oczekiwanych korzyści. Celem tego typu innowacji jest ulepszanie struktury i wartości użytkowej produktów lub procesów wytwarzania. Sukces tego rodzaju innowacji zależy przede wszystkim od kreatywnych pracowników, od ich determinacji, zdolności twórczego myślenia i umiejętności przekształcenia 
pomysłów w praktyczne rozwiązania. W kształtowaniu postaw innowacyjnych pracowników dużą rolę odgrywa kadra kierownicza przez odpowiednie motywowanie, nagradzanie i tworzenie klimatu innowacyjnego. Proinnowacyjna kultura organizacji sprzyja uzyskiwaniu przewag konkurencyjnych i tym samym przyczynia się do rozwoju firmy.

Innowacje wprowadzone w wyniku nieoczekiwanych zdarzeń są reakcją innowatora na takie zdarzenia zachodzące wewnątrz organizacji lub jej otoczeniu. Mogą one polegać na odkryciu przewag podmiotu wobec konkurentów, pojawieniu się w otoczeniu nowych szans na odniesienie sukcesu, ale też poniesieniu nieprzewidywalnych porażek lub na zupełnie nowych zagrożeniach. Konstruktywna reakcja podmiotu na nieoczekiwane zdarzenia powinna polegać na twórczym wykorzystaniu wniosków z analizy przyczyn porażek i powstałych zagrożeń. Sformułowanie postaw organizacji wobec nowych sytuacji jest sprawą zarówno strategii, jak i kultury organizacji.

Innowacje będące kopiami innowacji zastosowanych przez inne jednostki pochodzą ze zjawisk imitacji, dyfuzji i procesów międzynarodowego transferu innowacji. Jednym z głównych motywów kopiowania innowacji jest motyw opisany przez cytowanego wcześniej Josepha Schumpetera: „Za pierwotną zmianą, która odniosła sukces, podążają inne podmioty operujące w tym samym rodzaju działalności; coraz więcej przedsiębiorstw powtarza praktyki innowatorów, zarówno dlatego, że oczekują one korzyści, jak i dlatego, że obawiają się poniesienia strat" [Schumpeter 1928, s. 377]. Ogromne znaczenie procesów dyfuzji innowacji jest udokumentowane w badaniach, które wskazują, że ponad połowa zarejestrowanych w długich okresach przyrostów PKB w rozwiniętych gospodarkach świata powstaje dzięki transferowi wiedzy i generowaniu na jego podstawie innowacji produktowych i procesowych, będących wynikiem przestrzennej dyfuzji technologii i umiejętności wytwarzania doskonalszych produktów [Linsu 1997].

Po scharakteryzowaniu typów innowacji wyróżnionych na podstawie czterech kryteriów wskazanych przez W. Świtalskiego, poniżej przedstawiono jeszcze kilka innych klasyfikacji opracowanych przez wybranych autorów.

Autorem jednej z takich klasyfikacji jest J. Penc, który ze względu na dziedzinę wiedzy czy praktyki, jakiej dotyczą, wyodrębnia m.in.: innowacje techniczne, artystyczne, naukowe, technologiczne, społeczne, ekologiczne [Penc 1999, s. 144].

Zależnie od dziedziny działalności, której dotyczą, można podzielić innowacje na [Penc 1999, s. 144]:

- funkcyjne, zaspokajające nowe, dotychczas nieujawnione potrzeby społeczne, a więc służące nowym funkcjom (wynalezienie telefonu, Internetu, itp.),

- innowacje przedmiotowe, polegające na wprowadzeniu nowych przedmiotów (maszyn, przyrządów, wyrobów) w miejsce dotychczas użytkowanych, ale znacznie lepiej spełniających zadania, dla których zostały wytworzone (zastąpienie telefonu stacjonarnego sieciowym), 
- innowacje technologiczne polegające na wprowadzeniu nowych metod wytwarzania, usprawniających produkcję i czyniących ją lepszą bądź tańszą, czy też przynoszących poprawę warunków pracy i jej środowiska (zastępowanie nitowania spawaniem, oczyszczania mechanicznego biologicznym itp.),

- innowacje organizacyjne polepszające organizację pracy i produkcji, poprawiające stan bezpieczeństwa i higieny pracy, ułatwiające pracownikowi jej wykonanie (wprowadzenie technologii grupowej, elastycznych systemów produkcji, ruchomego czasu pracy itp.),

- innowacje ekologiczne zmniejszające lub eliminujące negatywne skutki działania firmy dla środowiska naturalnego (zamknięty cykl produkcyjny, recycling, wprowadzenie dodatkowych zabezpieczeń przed awariami itp.).

W zależności od intensywności technologicznej i kapitałowej wyróżnia się [Fengler 1991, s. 9]:

- innowacje „lekkie” o zaawansowanej technologii,

- innowacje „ciężkie” o zaawansowanej technologii,

- innowacje „lekkie” o prostej technologii,

- innowacje „ciężkie” o prostej technologii.

Ze względu na kryterium złożoności można wyodrębnić:

- innowacje niesprzężone - są one rezultatem zarówno działalności twórczej, jak i naśladowczej, wykonywanej przez pojedynczych racjonalizatorów, którzy sami je wprowadzają, wykorzystując jedynie własną wiedzę i własny kapitał,

- innowacje sprzężone - są one rezultatem wspólnego wysiłku i współdziałania wielu osób, zespołów, a nawet całych instytucji. Są one podstawą rozwoju współczesnej firmy. Wymóg sprzężenia działań w procesie innowacyjnym wynika ze złożoności techniki, jej coraz wyższego poziomu, podziału pracy, specjalizacji pracowników, wzajemnego przenikania się nauki, techniki i produkcji. Wyrazem sprzężenia pracy w tym zakresie jest funkcjonowanie i rozwój różnego rodzaju jednostek naukowo-badawczych i rozwojowych oraz powoływanie zespołów zadaniowych o zróżnicowanej strukturze.

Uwzględniając kryterium miejsca powstawania innowacji wyróżnia się [Penc 1999, s. 145]:

- innowacje krajowe - rozwiązania opracowane przez własny dział badawczo-rozwojowy, przez różne placówki naukowo-badawcze, uczelnie wyższe itp.,

- innowacje zagraniczne - rozwiązania przejmowane z zagranicy w postaci licencji, imitacji czy też przez tworzenie joint-ventures bądź korzystanie z franchisingu.

Ze względu na mechanizm pobudzania do innowacji dzieli się je na [Podstawy nauki o przedsiębiorstwie, 1997, s. 149]:

- innowacje podażowe: są one następstwem odkryć, wynalazków i pomysłów. Działanie mechanizmu pobudzania innowacji podażowych polega głównie na tym, że uczeni - twórcy nowej techniki - dokonują odkryć i wynalazków pod wpływem dociekliwości badawczej i predyspozycji twórczych, a także pod wpływem indywidualnej potrzeby osiągnięć (samorealizacji), 
- innowacje popytowe; są one stymulowane przez potrzeby ujawniające się na rynku lub poza nim (dotyczy to m.in. takich obszarów, jak zdrowie, ochrona środowiska itp.). Droga do innowacji prowadzi więc przez podejmowanie odpowiednich badań, dokonanie wynalazku, bądź też wyszukanie odpowiedniego rozwiązania, którego wdrożenie stanowi odpowiedź na istniejące zapotrzebowanie.

Według kryterium dziedziny gospodarki bądź wiedzy, z której się wywodzą, wyróżnia się następujące innowacje:

- ucieleśnione w materiale, tzw. innowacje twarde. Przykładem są nowe maszyny i urządzenia, pochodzące $\mathrm{z}$ dyscyplin technicznych i przyrodniczych,

- nieucieleśnione, tzw. miękkie. Mają one postać np. nowego systemu organizacji, usprawnienia w systemie szkolenia załogi. Dotyczą one głównie nauk organizacji i zarządzania, ekonomiki i nauk społecznych.

Z kolei B. Ileczko [1979] zaproponował podział innowacji na:

- antropocentryczne, dotyczące różnych przejawów życia jednostek ludzkich,

- społeczne, dotyczące organizacji stosunków międzyludzkich,

- techniczne, dotyczące zmian w technice i technologii.

Badacz podejmujący próbę oceny innowacyjności napotyka na wiele barier i trudności, w tym na te związane z różnego rodzaju klasyfikacjami dotyczącymi innowacji. Klasyfikacje, o których mowa, mają na ogół charakter subiektywny. I tak na przykład z perspektywy firmy jej nowe albo ulepszone produkty sprzedawane na rynku, są produktami innowacyjnymi. Jednak te same produkty nie są innowacyjne dla innych uczestników rynku, np. kupujący mogą je znać dzięki innym wytwórcom.

Kolejny podział innowacji zaczerpnięty z literatury to podział na innowacje ciągłe (polegają na ulepszeniach pewnych produktów) i innowacje nieciągłe (ich nośnikiem jest produkt wprowadzony na rynek po raz pierwszy, wywołujący radykalną zmianę w zachowaniu konsumenta) [Evans 1996, s. 70]. Generalnie innowacje mają charakter procesu kumulacyjnego, gdyż większość z nich stanowi uzupełnienie techniki istniejącej i przyczynia się do podniesienia efektywności starej techniki oraz poprawy jej jakości, a powstanie nowości uwarunkowane jest dostępem do istniejącej wcześniej wiedzy [Budzyński 1996, s. 15].

Prezentując różne klasyfikacje innowacji, należy pamiętać o ważnym kryterium korzyści. Ze względu na rodzaj uzyskiwanych przez społeczeństwo korzyści innowacje dzieli się na powodujące [Baruk 1992, s. 32-39]:

- obniżkę kosztów,

- poprawę jakości produktów,

- wzrost ilości produktów,

- poprawę warunków pracy i bezpieczeństwa,

- ochronę naturalnego środowiska człowieka. 
Przedstawiona próba typologii innowacji przy wykorzystaniu różnych kryteriów z pewnością nie wyczerpuje wszystkich sytuacji i okoliczności, w których powstają i upowszechniają się znaczące dla rozwoju gospodarczego i społecznego innowacje. Typologię innowacji można rozbudować stosując jeszcze inne kryteria: typ podmiotu innowatora (przedsiębiorstwo, instytucja itp.), cel (koszty, jakość, sprawność działania, wysokość nakładów koniecznych do jej zrealizowania), przewidywany wpływ innowacji na produktywność czynników.

Zaprezentowano różnorodny przegląd klasyfikacji innowacji, ale warto zauważyć, że sedno podziału sprowadza się do rozróżnienia innowacji produktowych i procesowych. Klasyfikacje innowacji mają na celu m.in. umożliwienie badań innowacyjności przedsiębiorstw i gospodarek. Standardem w międzynarodowych badaniach jest tzw. metodologia Oslo, która koncentruje się na innowacjach technologicznych (produktowych i procesowych). Informacje statystyczne gromadzone przez GUS i Eurostat umożliwiają, zwłaszcza w dłuższym okresie, identyfikację innowacji głównie produktowych i procesowych.

\subsection{Modele innowacji}

Innowacja jest efektem realizacji określonego procesu innowacyjnego. W podrozdziale 1.2 zwrócono uwagę na trudności w definiowaniu pojęcia innowacja, co wynika przede wszystkim ze złożoności procesu innowacyjnego. W literaturze przedmiotu często używa się zamiennie takich pojęć, jak proces innowacyjny, proces wynalazczy, działalność lub aktywność innowacyjna oraz model innowacyjny. Proces innowacyjny, co wynika już z samego określenia „proces”, składa się z faz, etapów, uporządkowanych chronologicznie, powiązanych ze sobą różnymi interakcjami. Na procesy innowacyjne można patrzeć z pozycji gospodarki, przedsiębiorstwa lub pojedynczej innowacji. Niezależnie od sposobu definiowania proces innowacyjny w najbardziej ogólnym ujęciu składa się z dwóch faz: fazy powstawania innowacji i jej upowszechniania. Ogromne zainteresowanie problematyką innowacji skutkuje doskonaleniem metod gromadzenia i klasyfikacji danych oraz rozwojem metod badawczych. Podejmowane są kolejne próby budowania modeli, których celem jest odwzorowanie zachowania przedsiębiorcy wobec możliwości realizowania lub finansowania badań i uzyskiwania szans wdrożenia opłacalnych innowacji. Modele procesów innowacyjnych podlegały różnym modyfikacjom: od czasów J. Schumpetera i podażowego modelu innowacyjnego do czasów współczesnych, z nowymi schematami procesów innowacyjnych, uwzględniającymi dynamiczne zmiany zachodzące $\mathrm{w}$ otoczeniu podmiotów gospodarczych, postęp techniczny i zjawisko globalizacji. 
Dla badaczy innowacji oraz polityki gospodarczej ważne jest poznanie siły oddziaływania dwóch bodźców powstawania innowacji: pchania technologicznego (możliwości technologiczne) oraz ciągnienia popytem (handlowa atrakcyjność). Znany brytyjski teoretyk zarządzania innowacjami, R. Rothwell, uważa, że do początku lat 90 . XX w. istniało pięć generacji modeli procesów innowacyjnych [Rothwell 1992]. Krótka charakterystyka tych generacji znajduje się w tab. 1.1.

Tabela 1.1. Pięć generacji modeli innowacji R. Rothwella

\begin{tabular}{|l|l|}
\hline \multicolumn{1}{|c|}{ Generacja } & \multicolumn{1}{c|}{ Podstawowe cechy } \\
\hline Pierwsza, druga & Prosty model liniowy - model podażowy, model popytowy. \\
\hline Trzecia & $\begin{array}{l}\text { Model powiązany, zakładający interakcję różnych elementów i sprzężenia } \\
\text { zwrotne informacji. }\end{array}$ \\
\hline Czwarta & $\begin{array}{l}\text { Model równoległy, integracja wewnątrz firmy oraz współpraca } \\
\text { z dostawcami i odbiorcami, akcent położony na powiązania i alianse. }\end{array}$ \\
\hline Piąta & $\begin{array}{l}\text { System zintegrowany, oparty na sieciowych powiązaniach: elastyczny, oparty } \\
\text { na systemie odpowiedzi powiązanej z konsumentem, innowacja ciągła. }\end{array}$ \\
\hline
\end{tabular}

Ź ró d ł o : R. Rothwell podane za K. K o z i o 1, Innowacyjność polskich przedsiębiorstw przemysłowych na tle doświadczeń Unii Europejskiej, „Rozprawy i Studia Uniwersytetu Szczecińskiego" 2007, t. 661, s. 46.

Wśród polskich badaczy podobną klasyfikację modeli innowacji zaproponowała E. Okoń-Horodyńska [1998].

Liniowy model procesu innowacyjnego opierał się na założeniu, że działalność badawczo-rozwojowa jest głównym bodźcem do powstania innowacji. Koncepcja ta dominowała w okresie od lat 50. do końca 80. XX w. Pierwszym stosowanym modelem liniowym był model podażowy, w którym głównym inicjatorem innowacji był ośrodek $\mathrm{B}+\mathrm{R}$, funkcjonujący w przedsiębiorstwie lub poza nim. Inna nazwa tego modelu to model innowacji ,pchany przez naukę”. $Z$ takim podejściem wiąże się podażowa teoria innowacji, według której istnieje twórca innowacji (sfera B+R) i przedsiębiorstwa, które należy skłonić do wdrożenia innowacji. Źródłem innowacji jest tu sfera badawczo-rozwojowa. W modelu tym wyróżnia się cztery fazy. Pierwsza to faza badań podstawowych, potem faza badań stosowanych, produkcja i marketing. W tym okresie potrzeby klientów nie były głównym przedmiotem zainteresowań, gdyż rynek był wówczas chłonny. Sukces przedsiębiorstwa uzależniony był zatem od sfery B+R i umiejętności korzystania z różnych odkryć naukowych. Model liniowy dobrze współgrał z podażową koncepcją źródeł innowacji. 


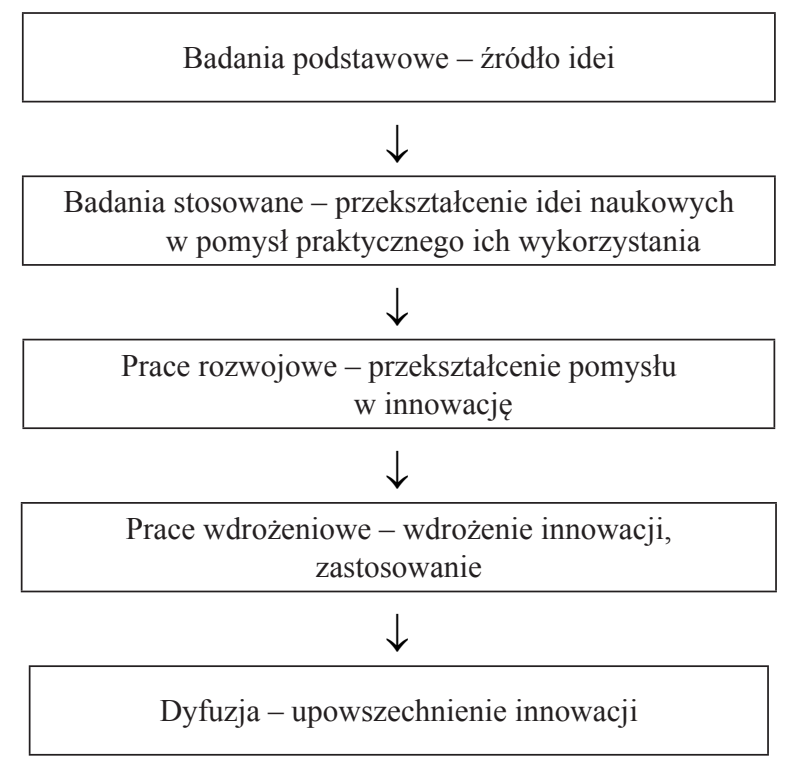

Rysunek 1.3. Podażowy liniowy model procesu innowacyjnego

Źródło: opracowanie własne.

Podstawowymi założeniami podażowego liniowego modelu procesu innowacyjnego są wiodąca rola nauki w procesie innowacyjnym oraz czasowa zależność kolejnych faz. Ten model ma liczne grono przeciwników, jak i zwolenników. Duże programy realizowane w przeszłości (Apollo, Manhattan) nie tylko opierały się na tym modelu, ale również wskazywały na jego przydatność w innych niż wojskowe przedsięwzięciach. Przykładem takiego zastosowania mogą być programy zwalczania choroby Heinego i Medina oraz walki z AIDS [Świtalski 2005, s. 124].

W popytowym liniowym modelu procesu innowacyjnego inspiracją dla procesów innowacyjnych są potrzeby rynkowe. Na konkurencyjnym rynku trudno sprzedać produkty nieakceptowane przez klientów. Zwrócenie szczególnej uwagi na potrzeby klientów zaowocowało opracowaniem modelu popytowego, zwanego inaczej modelem innowacji ciągnionej przez rynek. Model popytowy charakteryzuje się taką samą liczbą faz jak model podażowy, ale główną różnicą było umiejscowienie potrzeb rynkowych na pierwszym miejscu, jako impulsu do powstania innowacji.

Zastąpienie liniowego modelu podażowego przez popytowy nie świadczyło o negacji pierwszego z nich, ale o potrzebie równoległego występowania obu form procesów innowacyjnych. Według S. Gomułki, żeby innowacja mogła się pojawić i mieć powodzenie, muszą być spełnione zarówno warunki możliwości technologicznej, jak i handlowej atrakcyjności. Nie ma więc sensu pytać, jaki jest wkład każdego z tych czynników do sukcesu innowacji [Gomułka 1998, s. 43]. 
Model popytowo-podażowy zapewnia właściwą podaż innowacji kształtowaną przez występujący na nią popyt na rynku.

Jednak model popytowo-podażowy okazał się zbyt uproszczony, gdyż proces innowacyjny nie jest tylko pochodną zmian na rynku lub w zakresie wiedzy naukowo-technicznej. Proces innowacji powinien integrować potrzeby rynku z możliwościami jej realizacji i wdrożenia. Innowacje są wynikiem połączenia możliwości naukowych, produkcyjnych i popytu [Pomykalski 2001, s. 41-42]. Nowoczesne ujęcie procesu innowacyjnego traktuje go jako ciąg interakcji od powstania idei innowacji do jej komercjalizacji - wdrożenia i dyfuzji. Nastąpiło zatem przejście z prostego modelu liniowego do bardziej złożonych modeli interaktywnych.

Do najbardziej popularnych modeli interaktywnych należą model sprzężony i model związanego łańcucha. W literaturze modele te są także nazywane dynamicznymi modelami interakcyjnego procesu innowacyjnego. Model sprzężony opracowali R. Rothwell i W. Zegveld. Zwrócono w nim szczególną uwagę na projektowanie inżynierskie, sprzężenia zwrotne między rynkowymi i technologicznymi fazami innowacji, powiązania między sferą $\mathrm{B}+\mathrm{R}$, produkcją i marketingiem $\mathrm{w}$ firmie oraz między firmami i instytucjami [Rothwell 1992; Stawasz 1999, s. 24-32].

Model „związanego łańcucha” (łańcuchowych sprzężeń zwrotnych - chainlinked model) zaprezentowali w połowie lat 80 . XX w. S. Kline i N. Rosenberg [1986]. Jest to model wielofazowy, w którym szczególną role odgrywa zakumulowana wiedza i badania, wiążąc ze sobą poszczególne fazy realizacji innowacji [Świtalski, 2005, s. 134-138] Dotarcie do zakumulowanej wiedzy jest możliwe na etapie każdej fazy procesu innowacyjnego. Oznacza to, że można wprowadzać innowacje bez prowadzenia często długich i kosztownych badań naukowych. $\mathrm{W}$ modelach liniowych badania naukowe odgrywały największą rolę, natomiast w modelu związanego łańcucha nie są czynnikiem najważniejszym, ale koniecznym. Najważniejsza jest umiejętność korzystania z wiedzy, powstającej zarówno na zewnątrz firmy, jak i wewnątrz niej. Sukces rynkowy osiągają firmy, które poprzez ciągłe kształcenie są zdolne do zastosowania najbardziej aktualnej wiedzy. W tej sytuacji bardzo ważna jest informatyka, która przyśpiesza przepływ informacji. Ważne są także potencjalne potrzeby rynkowe, które oddziałują na cały proces.

Silne współdziałanie między $\mathrm{B}+\mathrm{R}$ i marketingiem jest konieczne do osiągnięcia pozytywnych wyników ekonomicznych. Zapotrzebowanie odbiorców jest często uznawane za czynnik w większym stopniu zwiększający efektywność innowacji niż potencjał techniczny.

W schemacie łańcuchowych sprzężeń zwrotnych i w objaśnieniach zasad działania jego składników [Kline 1985a, 1985b; Kline, Rosenberg 1986] brak jest bezpośrednich odniesień do motywacji przedsiębiorców, wymuszeń rynkowych lub oczekiwań nabywców. Model nie uwzględnia zależności typu finansowego i ograniczeń kosztowych. 


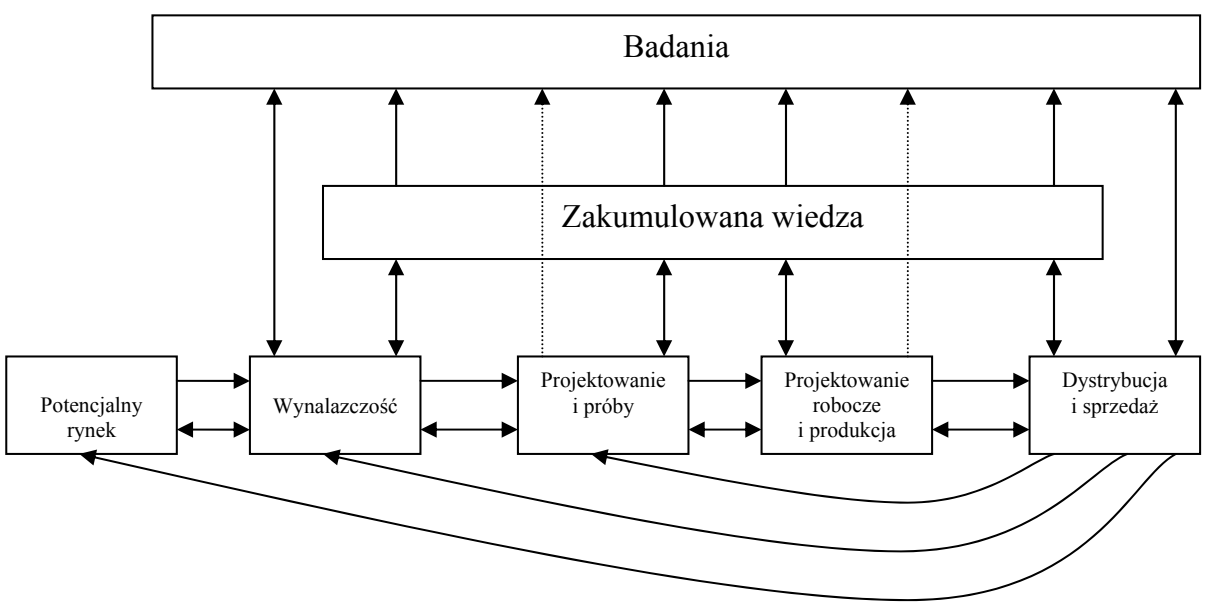

Rysunek 1.4. Model łańcuchowych sprzężeń zwrotnych według Kline’a i Rosenberga

Źr ódło: opracowanie własne na podstawie S. J. Kline, N. R o s e n b e rg, An Overview of Innovation, [w:] R. L a n d a u, N. R o s e n b e r g (eds), The Positive Sum Strategy. Harnessing Technology for Economic Growth, National Academy Press, Washington DC 1986, s. 17-18.

W następnych latach liczba zwolenników modeli nieliniowych rosła. Oprócz dwóch powyższych koncepcji dynamicznych modeli interakcyjnych pojawiały się kolejne, których autorami byli między innymi P. Drucker i D. Frey [Marciniak 2000, s. 38-39]. W niniejszej rozprawie uwzględniono tylko wybrane modele procesu innowacyjnego. Analiza poszczególnych modeli innowacji wykracza poza zakres niniejszego opracowania ${ }^{1}$. Nowe modele procesu innowacyjnego były doskonalone poprzez dodawanie następnych, ważnych elementów oraz rozbudowywanie sprzężeń zwrotnych. Postępująca globalizacja, rosnące wymagania klientów oraz dynamiczny rozwój informatyki sprawiły, że model innowacji zaczął przypominać sieć uwzględniającą pierwotne i wtórne sprzężenia między elementami modelu i zawierającą więcej czynników niż wcześniej omawiane modele. W literaturze modele te nazwano sieciowymi. Wśród badaczy innowacji panuje obecnie przekonanie, że innowacje powstają w sieciach łączących poszczególne organizacje. Silna konkurencja na rynku spowodowała wzrost roli takich czynników, jak szybkość i efektywność wprowadzania innowacji. Proces tworzenia rzeczy nowych wymaga współpracy wielu podmiotów, kierujących się często rożnymi interesami. Taki sieciowy charakter procesu innowacyjnego zaproponował R. Rotwell w modelu piątej generacji [Rothwell 1994, s. 7-31]. Wzrost szybkości i efektywności wdrażania innowacji osiągnięto dzięki wewnętrznym działaniom

${ }^{1}$ Prezentację modeli innowacji zawierają prace: Kwiatkowski 1990; Jasiński 1997; Gomułka 1997; Pomykalski 2001a. 
w organizacji, dostawcom i użytkownikom oraz wykorzystaniu możliwości informatyki, co pozwala na sprawne komunikowanie się.

Wad i niedoskonałości modelu liniowego zbudowanego na koncepcji szeregowego uporządkowania faz powstawania innowacji nie usuwa model nieliniowy. Ogromna złożoność i różnorodność procesów innowacji (różne źródła, rodzaje, miejsca powstania, dziedziny działalności, sposoby finansowania, warunki otoczenia) powodują, że nierealne są chyba oczekiwania co do powstania jednego uniwersalnego modelu innowacji.

Obecny model nieliniowy, niestety, nie może być używany jako narzędzie normatywne lub narzędzie prognozy. Brak w nim bowiem odpowiedzi na wiele szczegółowych pytań. Wynika to zapewne z trudności występujących zarówno po stronie wiedzy autorów modeli i teorii innowacji (dostępność danych, faktografia, rozumienie natury procesów badawczych, projektowych i komercjalizacyjnych), jak i po stronie metodologii procesu twórczego - narzędzia statystyczne, wzorce badań, stosowane paradygmaty [Świtalski 2005, s. 123].

Należy przypuszczać, że rozwój teorii innowacji, procesów innowacyjnych i metod badawczych będzie prowadzić do powstania bardziej złożonych i odpowiadających rzeczywistości modeli procesu innowacyjnego.

\subsection{Innowacje w teorii ekonomii}

Do lat 90. XX w., a więc do okresu poprzedzającego ogłoszenie paradygmatu gospodarki opartej na wiedzy, zainteresowanie teoretyków ekonomii problematyką innowacji było stosunkowo niewielkie. Wielcy ekonomiści, którzy tworzyli główne nurty nauk ekonomicznych, zauważali wprawdzie istnienie zjawiska innowacji, ale nie dostrzegali wpływu innowacji na rozwój gospodarczy.

Za prekursora badań nad innowacjami uważany jest powszechnie Joseph Schumpeter, nazywany twórcą teorii innowacji. W $1912 \mathrm{r}$. Schumpeter po raz pierwszy $\mathrm{w}$ teorii ekonomii sformułował pięć przypadków pojawiania się nowych kombinacji różnych materialnych elementów i produkcyjnej siły człowieka, które nazwał później innowacjami [Mikosik 1993, s. 68]. Jako pierwszy zauważył, że nowe kombinacje (pomysły) powstałe w sposób nieciągły są innowacjami. Innowacja stanowi każdorazowo niepowtarzalny czyn. Zmiany o charakterze inwencyjnym lub imitacyjnym mają ciągły przebieg, natomiast innowacje to zmiany o typowo nieciągłym charakterze, stąd ich wyjątkowość. Rozwojowi innowacji, w wyniku jej dyfuzji, towarzyszy wzrost gospodarczy i trwa do momentu wyczerpania możliwości ekspansji. Joseph Schumpeter jest twórcą podstaw ekonomicznej teorii innowacji, który jako pierwszy włączył opis mechanizmu generującego innowacje do teorii ekonomii [Schumpeter 1928, 1995]. Jednak nowatorskie teorie Schumpetera przez dziesięciolecia nie stały się przedmiotem dalszych i bardziej wnikliwych badań nad istotą innowacji i ich wpływem na rozwój przedsiębiorstwa, działów przemysłu i gospodarek narodowych. 
Za główną przyczynę braku rozwoju teorii Schumpetera uważa się odejście od analizy czynników i procesów długookresowego wzrostu i skupienie się na mechanizmach krótkookresowych zmian w gospodarce, a zwłaszcza na zapobieganiu odchyleniom od stanu równowagi [Tobin 1997]. Zatem głównym obszarem badań była wówczas równowaga, a nie analiza długookresowego wzrostu gospodarek narodowych. Wprawdzie w drugiej połowie XX w. powstawały liczne prace poświęcone procesom innowacji, w szczególności faktografii innowacji [Griliches 1957; Schmookler 1966; Goldhar 1974; Rosenberg 1974 i wielu innych], modelom innowacji [Utterback, Abernathy 1975] oraz poszukiwaniu teorii innowacji [Nelson, Winter 1977], to jednak nie spotkały się one z należytym zainteresowaniem twórców syntez i nowych ujęć oraz teoretyków makroekonomii.

Problematyka innowacji, wywołujących zmiany w gospodarce, nie znalazła odzwierciedlenia ani w teorii ekonomii ani w polityce gospodarczej. Rządzący nie widzieli związku miedzy wzrostem gospodarczym a badaniami naukowymi i innowacjami.

Ogromnym krokiem naprzód w rozwoju teorii innowacji był zapoczątkowany w 1988 r. międzynarodowy program OECD (Technology/Economy Programme $T E P)$. Jego efektem były publikacje wskazujące na konieczność poszukiwania przez politykę gospodarczą, naukową i innowacyjną źródeł postępu technicznego oraz nowe opracowanie metodyki pomiaru wyników badań naukowych i zastosowań technologii (Oslo Manual), które stało się standardowym podręcznikiem stosowanym przez urzędy statystyczne oraz badaczy [Stan nauki i techniki w Polsce, 1999]. W publikacjach i raportach, będących efektem realizacji programu TEP, coraz częściej zwracano uwagę na istotny wpływ działalności badawczej i innowacji na gospodarkę i społeczeństwo.

Pojawiły się kolejne, ważne opracowania monograficzne, które porządkowały wiedzę w obszarze nauka - technologia - innowacje - gospodarka (OECD 1996a, 1996b, 1996c). Zbiegło to się w czasie z postulatami budowy gospodarek opartych na wiedzy, a konkurencyjność gospodarek zaczęto oceniać już nie tylko przez pryzmat bilansu obrotów handlowych. Podkreślano również, że ceny i koszty nie przesądzają o konkurencyjności poszczególnych firm. Ekonomiści coraz częściej sięgają do wskaźników charakteryzujących wiedzę oraz innowacyjność, które zaczęli traktować jako predykatory przyszłego rozwoju gospodarczego i pozycji kraju na globalnym rynku, ujawniając ukryty potencjał gospodarek, na razie niewidoczny w typowych zestawieniach makroekonomicznych. W kolejnych publikacjach OECD (1997) zwracano uwagę na rolę rządów w kształtowaniu konkurencyjności poszczególnych przedsiębiorstw, sektorów działalności gospodarczej i całych gospodarek narodowych. Teoria ekonomii i polityka gospodarcza uzyskały, dzięki programowi TEP, pomoc w rozwijaniu nowych badań nad innowacyjnością wraz z jej źródłami i czynnikami, nad konkurencyjnością w warunkach gospodarki globalnej, a także nad formułowaniem strategii rozwoju gospodarczego. 
Jednak do końca XX w. trudno szukać w światowej literaturze opracowań przełomowych, wyjaśniających związki przyczynowo-skutkowe między innowacjami a wzrostem gospodarczym. Nie powstały teorie wyjaśniające mikroekonomiczne przyczyny zmian.

Również w polskiej literaturze pojawiły się opracowania, których autorzy dostrzegali doniosłość problematyki innowacji. W Polsce autorem jednej z pierwszych publikacji, która przybliża problematykę innowacji jest K. Poznański. W latach 70. prowadził on badania dotyczące miejsca i roli innowacji w warunkach gospodarki centralnie planowanej w porównaniu z gospodarką kapitalistyczną. Zwracał szczególną uwagę na innowacyjność przedsiębiorstw produkcyjnych i utożsamiał ją z ,częstotliwością podejmowania zmian technicznych w produkcji”. Wskazywał na trudności badawcze wynikające m.in. z braku porównywalności danych w ujęciu międzynarodowym [Poznański 1981, s. 10].

Z kolei B. Fiedor wykazał się nowatorskim spojrzeniem na mechanizm powstawania postępu naukowo-technicznego. Sygnalizował potrzebę nowego spojrzenia na źródła tego postępu. Jego zdaniem postęp techniczny ma charakter endogeniczny, a nie egzogeniczny, jak zakładała dominująca wtedy teoria neoklasyczna. Postęp techniczny zależy między innymi od aktywnej działalności przedsiębiorców [Fiedor 1979, s. 37-41]. Fiedor zdawał sobie jednak sprawę z trudności zbudowania modelu, który by uwzględniał endogeniczność związku między nauką, technologią i gospodarką oraz innowacyjne produkty i procesy. Uważał, że budowa takiego modelu nie może opierać się na powszechnie stosowanej funkcji produkcji Cobba-Douglasa, która, jego zdaniem, nie odzwierciedla skokowego charakteru procesów innowacyjnych.

W literaturze polskiej warto również zwrócić uwagę na książkę S. Gomułki Teoria innowacji $i$ wzrostu gospodarczego, wydaną w 1998 r., w której badacz analizuje i próbuje łączyć teorię wzrostu z teorią innowacji.

Istotny wkład w rozwój teorii wpływu innowacji na wzrost gospodarczy miały poglądy P. M. Romera. Uważał on, że ,główną siłą napędową wzrostu gospodarczego jest postęp techniczny, czyli udoskonalanie wiedzy o sposobach przetwarzania nakładów w produkty” [Romer 1990] oraz że „postęp techniczny ma charakter endogeniczny, czyli jest efektem zamierzonych działań podmiotów gospodarczych" [Snowdon, Vane 2003, s. 115]. Romer zaproponował teorię wzrostu endogenicznego ${ }^{2}$, która jest oparta na innowacjach wprowadzonych przez podmioty działające wewnątrz gospodarki, a wprowadzana zmiana jest analizowana pod względem wykonalności i opłacalności. Każda innowacja obarczona jest ryzykiem, której źródłem jest przede wszystkim brak informacji o procesach zachodzących w otoczeniu i przyszłych warunkach gospodarowania. Romer podkreślał, że skumulowana $\mathrm{w}$ pojedynczym podmiocie wiedza ma w założeniu właściwości dóbr publicznych, co powoduje, że inne podmioty zyskują również dostęp

\footnotetext{
${ }^{2}$ Bliższe omówienie ekonomicznych modeli wzrostu gospodarczego znajduje się w podrozdz. 6.1.
} 
do innowacji. Powstałe w ten sposób „korzyści zewnętrzne” prowadzą w konsekwencji do wzrostu całej gospodarki.

Badania innowacji oraz dane na ten temat stanowią obecnie obszerną dziedzinę wiedzy. Wzrost znaczenia i złożoność problematyki innowacji wyraża się między innymi tym, że badaniem i analizą przedsięwzięć innowacyjnych zajmują się przedstawiciele różnych dyscyplin naukowych. Mimo ogromnej liczby publikacji z zakresu innowacji i innowacyjności, które zostały opublikowane w drugiej połowie XX i na początku XXI w. - trudno znaleźć pozycje zawierające chociaż próby systematyzacji dostępnej już wiedzy, uporządkowania pola badawczego czy też wskazania dróg syntezy. Lukę w tej dziedzinie próbują wypełnić, z różnym skutkiem, kolejne publikacje OECD z serii podręcznikowej poświęconej gromadzeniu i interpretacji danych o innowacjach. Są one nastawione głównie na ujednolicenie metod gromadzenia, aktualizacji i analizowania danych na potrzeby statystyki, nauki, techniki i innowacji i tym samym nie przyczyniają się do poznania uwarunkowań wdrożeń wyników badań i rozprzestrzeniania się innowacji.

Badania nad innowacyjnością koncentrują się przede wszystkim na innowacjach produktowych i procesowych, co owocuje niepełnym obrazem innowacyjności przedsiębiorstw. Nadal słabo jest rozpoznana natura innowacji nietechnologicznych, które często przesądzają o sukcesie innowacyjnym firmy. Brakuje także opracowań oceniających innowacyjność innych ważnych instytucji i podmiotów, takich jak np. administracja państwowa, ochrona zdrowia, edukacja, bezpieczeństwo publiczne, ubezpieczenia emerytalne.

W ostatnich latach pojawiły się publikacje nawiązujące do dokonań Schumpetera, ale nie zaowocowało to powstaniem ekonomicznej teorii innowacji, co zauważył Peter Drucker [Drucker 1992, s. 43]. Brak teorii jest dotkliwie odczuwany przez nauki ekonomiczne od czasu opublikowania przez Roberta M. Solowa publikacji poświęconej postępowi technicznemu i agregatowej funkcji produkcji [Solow 1957]. Problem „nierozliczonej reszty” ciągle istnieje.

\subsection{Paradygmat gospodarki opartej na wiedzy}

Twórcy teorii makroekonomii doszli do wniosku, iż pogląd, że wzrost gospodarczy można wyjaśnić zwiększeniem się majątku trwałego na zatrudnionego, nie znajduje potwierdzenia w danych empirycznych. Fakt ten zainspirował do łączenia procesów rozwoju i wzrostu z gospodarką opartą na wiedzy.

Koncepcja gospodarki opartej na wiedzy (knowledge based economy) powstała w celu zwrócenia uwagi na specyficzne właściwości współczesnej gospodarki, korzystającej w coraz większym stopniu ze zgromadzonego kapitału wiedzy. Koncepcja ta wskazuje na różnice w stosunku do wcześniej panującej 
gospodarki przemysłowej, która również korzystała z wiedzy, ale jej rozwój był oparty przede wszystkim na wzroście kapitału rzeczowego i wzroście siły roboczej [Welfe W. 2007, s. 7].

Pojęcie gospodarki opartej na wiedzy (GOW) pojawiło się na początku lat 90. ubiegłego wieku. Początkowo używano go w odniesieniu do Stanów Zjednoczonych, a potem do wszystkich wysoko rozwiniętych gospodarek świata. Zazwyczaj termin ten kojarzony jest $\mathrm{z}$ technologiami informatyczno-komunikacyjnymi, postępem technicznym i innowacyjnością. Istotne jest również rosnące znaczenie globalizacji, a także nauki i wiedzy, będącej podstawą współczesnych przemian, gdyż wzrasta zapotrzebowanie na nią i na wykwalifikowanych pracowników umysłowych. Coraz większa konkurencja polegająca na tworzeniu i wprowadzaniu na rynek innowacji wymaga ciągłego podnoszenia swoich kompetencji i tworzenia oraz przyswajania nowej wiedzy. Państwo, zmuszone do umożliwiania swoim obywatelom zdobywania nowej wiedzy, musi ponosić wydatki na edukację, badania i rozwój oraz tworzyć elastyczne uwarunkowania dotyczące rynku pracy.

Choć pojęcie GOW pojawiło się w literaturze światowej stosunkowo niedawno, to obecnie poświęca mu się coraz więcej uwagi. Często jest stosowane zamiennie z takimi terminami, jak gospodarka informacyjna, cyfrowa, sieciowa, gospodarka nasycona czy napędzana wiedzą i wreszcie nowa ekonomia.

W literaturze przedmiotu występuje wiele definicji ,gospodarki opartej na wiedzy" (GOW). Najczęściej akcentuje się w nich następujące cechy gospodarki [Kudrycka 2003, s. 16]:

- niski udział w zatrudnieniu i PKB rolnictwa i przemysłu, a bardzo wysoki udział usług,

- wysoki udział w inwestycjach inwestycji w wiedzę i „software”,

- wysoki udział nowoczesnych technik i technologii w sferze produkcji.

Z kolei w definicji opracowanej przez OECD i znajdującej się w publikacji The Future of Global Economy zwraca się uwagę na wzrost zatrudnienia w sektorach wiedzochłonnych i powszechną świadomość, że do „pracy w wiedzy” niezbędne jest lepsze wykształcenie, i że jest ona lepiej opłacalna [Woroniecki 2001, s. 47-48].

W definicjach tych podkreśla się znaczenie wiedzy jako istotnego zasobu ekonomicznego gospodarki i przedsiębiorstwa. Takie określenie gospodarki opartej na wiedzy nie jest precyzyjne, gdyż wiedza również w przeszłości odgrywała istotną rolę w procesach wzrostu gospodarczego. Zatem bardziej adekwatne wydaje się zdefiniowanie gospodarki opartej na wiedzy jako takiej, w której wiedza we wszystkich jej formach odgrywa kluczową rolę w stymulowaniu rozwoju społeczno-gospodarczego i staje się ważniejszym od nakładów na środki trwałe czynnikiem determinującym poziom i tempo rozwoju gospodarczego.

Definicję gospodarki opartej na wiedzy można rozważać:

- z punktu widzenia makroekonomii - definicja ta została sformułowana w raporcie opracowanym przez OECD i Bank Światowy - określa ona, że jest 
to gospodarka, w której wiedza jest tworzona, przyswajana, przekazywana i wykorzystywana bardziej efektywnie przez przedsiębiorstwa, organizacje, osoby fizyczne i społeczności, sprzyjając szybkiemu rozwojowi gospodarki i społeczeństwa,

- z punktu widzenia mikroekonomii - jest to definicja prof. A. Koźmińskiego, zgodniez którą jest to gospodarka, z działającymi wieloma przedsiębiorstwami, które o wiedzę opierają swoją przewagę konkurencyjną.

Społeczeństwa państw wysoko rozwiniętych budują w ostatnich latach gospodarkę opartą na wiedzy, w której wiedza i kwalifikacje są jedynym źródłem długookresowej przewagi konkurencyjnej.

Warto zauważyć, że proces tworzenia nowej jakościowo gospodarki nie jest samoistny, wymaga on bowiem pewnego sterowania, co wynika z faktu, że sprawne funkcjonowanie gospodarki opartej na wiedzy jest zdeterminowane wykorzystaniem wiedzy, intelektu i kompetencji człowieka. Pierwszym krokiem powinno więc być budowanie społeczeństwa informacyjnego. W tym natomiast procesie szczególną rolę przypisuje się szeroko rozumianej edukacji. Jest oczywiste, że inwestycje w kapitał ludzki są przede wszystkim wynikiem indywidualnych decyzji jednostek i ich realizacji. Wykonanie owych decyzji wymaga natomiast określonych warunków, które powinny być tworzone przez władze państwowe, samorządowe i ugrupowania integracyjne.

Podejmując problematykę roli wiedzy w rozwoju społeczno-gospodarczym należy uwzględnić co najmniej czteroelementowy układ odniesienia [Świtalski 2005, s. 139-140]:

1) społeczeństwo z właściwymi mu tradycjami, poziomem kultury i postawami jednostek,

2) państwo z jego instytucjami, deklarowanymi celami i stosowaną polityką edukacyjną, naukową i gospodarczą oraz polityką innowacyjną,

3) podmioty gospodarujące i łączące się z nimi strategie rozwoju, sposoby wykorzystania wiedzy, potrzeby w przyswajaniu nowej wiedzy, zdolności absorpcji wiedzy, potencjał i pozycja rynkowa,

4) sektor wiedzy składający się z systemu edukacji, systemu badań (podstawowych i stosowanych) oraz systemu utrzymania i popularyzacji zasobów wiedzy.

Paradygmatem gospodarki opartej na wiedzy jest z jednej strony przekonanie o dominującej roli wiedzy w tworzeniu dobrobytu i stymulacji rozwoju, z drugiej zaś traktowanie wiedzy w kategoriach produktu, którym można handlować tak, jak tradycyjnymi dobrami materialnymi. Wiedza jest zarówno produktem, jak i czynnikiem napędzającym wzrost gospodarczy. Filarami gospodarki opartej na wiedzy są edukacja, nauka oraz rozwój społeczeństwa informacyjnego. Te obszary gospodarki powinny rozwijać się równomiernie i zyskiwać na dynamice, zapewniając dopływ wykwalifikowanych kadr oraz nowoczesnych rozwiązań technologicznych. 
Rozważając paradygmat gospodarki opartej na wiedzy należy podkreślić istotny wpływ twórczego stosowania zasobów wiedzy na prestiż i polityczny potencjał państwa, poziom życia społeczeństwa (wielkość konsumpcji, zapewnienie obywatelom szans rozwoju intelektualnego i awansu) oraz sferę mikroekonomiczną, która dzięki technologicznemu i finansowemu metabolizmowi przedsiębiorstw pozwala przenosić efekty stosowania wiedzy przez podmioty gospodarujące na społeczeństwo i państwo. Wiąże się to z polityczną pozycją państwa w skali światowej lub w skali ugrupowania czy regionu. Analiza przemian zachodzących w światowej gospodarce wskazuje, że największe korzyści z globalizacji przypadają zasobnym w wiedzę krajom wysoko rozwiniętym, dysponującym wykwalifikowaną, kreatywną siłą roboczą. Pozostałe kraje są zmuszone dostosowywać się do gwałtownych zmian, jakie niesie ze sobą globalizacja, bowiem w przeciwnym wypadku grozi im postępująca marginalizacja. Dysproporcje w rozwoju gospodarczym można zatem niwelować poprzez rozwój gospodarki opartej na wiedzy.

Literatura poświęcona problematyce związanej z gospodarką opartą na wiedzy jest już obszerna nie tylko na świecie, ale także w Polsce 3 . Jednak spory definicyjne nadal istnieją, a problemy badawcze nie są w pełni zidentyfikowane. Badania obejmujące paradygmat tego rodzaju gospodarki znajdują się na dość wczesnym etapie poszukiwań. Gromadzony jest materiał empiryczny i właściwe instrumentarium opisowo-badawcze (terminologia, metody obserwacji, mierniki, metody identyfikacji zależności przyczynowo-skutkowych, modele struktur i dynamiki procesów).

Paradygmat gospodarki i społeczeństwa opartego na wiedzy będzie można uznać za nową dyscyplinę nauki dopiero wtedy, gdy jednolicie uporządkowany materiał empiryczny będzie wystarczająco bogaty, a warsztat badawczy na tyle elastyczny i uniwersalny, aby można było [Rodrigues 2003]:

- ocenić stopień nasycenia wiedzą poszczególnych społeczeństw i gospodarek,

- ustalać rzeczywisty poziom finansowania sektora wiedzy przez źródła publiczne i prywatne,

- porównywać poziom rozwoju gospodarek z punktu widzenia wkładu sektora wiedzy w ten rozwój,

- identyfikować i klasyfikować te składowe sektora wiedzy, które dzięki stymulowaniu innowacji najbardziej przyczyniają się do uzyskania wyższej jakości życia społeczeństw,

- prowadzić badania nad formułowaniem polityki mającej na celu przyspieszenie wzrostu gospodarczego lub polepszenie jakości życia w wyniku zastosowania narzędzi właściwych dla gospodarki korzystającej z wiedzy.

${ }^{3}$ Por. Kukliński (red.) 2002 i 2003; Zienkowski (red.) 2003; Zienkowski 2004; OkońHorodyńska (red.) 2004. 
Często opisy gospodarki opartej na wiedzy i stosowane metody badawcze są realizacjami okazjonalnych zamówień. Jeżeli jednak chcemy dojść do obiektywnych ocen wpływu szeroko pojmowanej wiedzy na rozwój i wzrost gospodarczy, to powinna powstać użyteczna teoria tworzenia i zastosowania wiedzy w gospodarkach i ich podmiotach.

Osiąganie przez gospodarkę narodową statusu gospodarki i społeczeństwa opartego na wiedzy zależy przede wszystkim od aktywności i postaw głównych podmiotów tej gospodarki, czyli przedsiębiorstw. W nich bowiem dokonują się innowacje wykorzystujące wiedzę, niezależnie z jakiego źródła ta wiedza pochodzi. Nie ma większego znaczenia czy są to wyniki badań podstawowych, stosowanych, sektora nauki i wiedzy danej gospodarki narodowej, czy import patentów i wiedzy z innych gospodarek [Woroniecki 2003, s. 95]. Wiele gospodarek narodowych (Japonia, Korea Południowa, Tajwan) swój sukces gospodarczy zawdzięcza importowi wiedzy. Warto zauważyć, że sektor wiedzy i nauki w żadnym z krajów, nawet najbogatszych, nie jest w stanie prowadzić we wszystkich dziedzinach badań naukowych na światowym poziomie. W tym kontekście warto zwrócić uwagę na czynniki przyczyniające się do wytworzenia środowiska sprzyjającego praktycznej absorpcji wiedzy przez przedsiębiorstwa, organizacje publiczne pełniące funkcje obsługi społeczeństwa (zdrowie, publiczne bezpieczeństwo, rozwój infrastruktury technicznej itp.) oraz organy państwa kształtujące politykę społecznogospodarczą i innowacyjną. Zatem samo zwiększanie nakładów budżetu na sektor nauki i wiedzy nie jest warunkiem wystarczającym do rozwoju gospodarki opartej na wiedzy, zasadniczą sprawą jest wytwarzanie klimatu proinnowacyjnego w gospodarujących podmiotach i ich otoczeniu. Efekty rozwojowe można uzyskać wykorzystując już istniejące zasoby wiedzy.

Podejmując próbę oceny gospodarki opartej na wiedzy należy wziąć pod uwagę podstawowe mierniki oceny rozwoju nauki i techniki, w tym przede wszystkim udział wydatków na działalność badawczo-rozwojową w PKB, strukturę nakładów na $\mathrm{B}+\mathrm{R}$ w podziale na badania podstawowe, stosowane i prace rozwojowe oraz dyscypliny naukowe, jak również strukturę finansowania tych wydatków według źródeł, potencjał naukowy per capita i wskaźnik innowacyjności.

Osiągnięcie przez Polskę statusu gospodarki i społeczeństwa opartych na wiedzy wymaga rzeczywistych działań, a nie tylko głoszenia haseł i propagowania pozytywnych osiągnięć w tej dziedzinie innych krajów. Można odnieść wrażenie, że - w ocenie władz - sytuacja społeczno-gospodarcza będzie nadal niezła bez specjalnego wysiłku, a wyzwania dotyczące przyszłości same się pozytywnie rozwiążą.

Ważnym czynnikiem do osiągnięcia statusu gospodarki opartej na wiedzy jest dążenie do opracowania teorii wpływu wiedzy na wzrost gospodarczy, czyli powstanie nowej teorii ekonomicznej. Jest to jednak zadanie bardzo trudne, a dotychczasowe próby nie przynoszą zadowalających efektów. 


\subsection{Innowacje a konkurencja i konkurencyjność}

Dynamicznie rozwijający się rynek oraz wszechobecna konkurencja znajdują swoje odzwierciedlenie w procesach innowacyjnych. Podmioty gospodarcze muszą dostosowywać się do zmian zachodzących w ich otoczeniu, co wymaga wdrażania innowacji i bycia innowacyjnym. Innowacje i innowacyjność przedsiębiorstw i gospodarek nie są celami samymi w sobie. To czynniki poprawiające sprawność gospodarowania i przyczyniające się do uzyskiwania korzyści ekonomicznych przez przedsiębiorstwa, branże, gospodarki narodowe i społeczeństwa. Wyrazem osiągania korzyści z wprowadzonych innowacji jest konkurencyjność.

Innowator poprzez wzrost jakości produktu lub obniżenie kosztu wytwarzania poprawia swoją pozycję konkurencyjną, czego wyrazem może być wzrost popytu na jego produkty, a to z kolei może zwiększać przychody ze sprzedaży, udział w rynku oraz wzrost rentowności. Poprawa konkurencyjności innowatora może być efektem innowacji produktowej, procesowej lub organizacyjnej. Podwyższona konkurencyjność firm przynosi pozytywne efekty na rynkach krajowych i zagranicznych (wyższe wpływy z eksportu). Poprawiają się wyniki nie tylko innowatora, ale i budżetu państwa, np. poprzez zwiększenie przychodów z tytułu podatku dochodowego czy wzrostu zasobów zagranicznych środków płatniczych. Jeżeli w wyniku innowacji następuje stały wzrost sprzedaży, rośnie zapotrzebowanie na pracę oraz lokalne surowce i materiały, tym samym poprawia się poziom życia miejscowej społeczności.

Związek między konkurencyjnością a konkurencją oparty jest na założeniu, że konkurencyjność nie może być osiągnięta w oderwaniu od konkurencji. Im silniejsza konkurencja, tym większe szanse poprawy konkurencyjności, w przeciwnym wypadku grozi wycofanie się z danej produkcji lub rynku [Ziemiecki, Żukrowska 2004, s. 15].

Konkurencja jest $\mathrm{z}$ jednej strony kategorią powszechnie znaną, zrozumiałą a drugiej strony wieloznaczną i trudną do zdefiniowania. Philip Taylor uważa, że: „konkurencja to stan na rynku, na którym występuje nieprzeliczalna ilość nabywców i sprzedawców, starających się maksymalizować zysk lub zadowolenie, cena na tym rynku bierze się tylko z oddziaływania podaży i popytu. Taki stan rynku, którego nie może zmienić żaden pojedynczy kontrahent, jest nazywany wolną konkurencją aproksymującą konkurencję doskonałą" [Taylor 1969, s. 43].

Zmiany zachodzące $\mathrm{w}$ życiu gospodarczym, społecznym i politycznym zmieniają sposób patrzenia na istotę konkurencji, jej przesłanki i mechanizmy rywalizacji. Wpływają tym samym na sposób definiowania konkurencji. Przedstawiciele ekonomii neoklasycznej koncentrowali się na konkurencji cenowej. Z czasem ekonomiści zaczęli dostrzegać istotną rolę przedsiębiorcy i doniosłość konkurencji w zakresie kosztów i jakości. W warunkach nowej ekonomii ważne stało się łączenie konkurencji z paradygmatem gospodarki opartej na wiedzy i tym samym z innowacjami. 
W ostatnim trzydziestoleciu obserwowano ogromne i rosnące zainteresowanie problematyką konkurencji. Efektem tego zainteresowania jest duża liczba publikacji, w których autorzy zwracają uwagę na nowe wymiary rywalizacji $^{4}$. Badacze akcentują dynamiczny charakter procesów konkurencji i potrzebę łączenia wzrostu gospodarczego, będącego wynikiem konkurencji, generowania innowacji oraz przejmowania pomysłów innowacyjnych w drodze dyfuzji i imitacji [Aghion i in. 2001]. Ogromny wkład w rozwój teorii konkurencji, zwłaszcza z punktu widzenia przedmiotu niniejszej pracy, miały publikacje M. E. Portera [1980, 1985, 1990, 2001]. Przedmiotem jego badań były praktyki konkurencyjne stosowane przez realne przedsiębiorstwa w zakresie strategii konkurencji, źródeł powstawania i sposobów utrzymania bezwzględnych przewag konkurencyjnych w najlepszych przedsiębiorstwach [Porter 1998]. Porter analizował również istotę, przejawy i skutki występowania bezwzględnych przewag konkurencyjnych gospodarek narodowych jako całości [Porter 1990].

Wyrazem zmian zachodzących w postrzeganiu zjawiska konkurencji jest definicja pochodząca z roku 2000: „Konkurencja to stała walka między przedsiębiorstwami o uzyskanie względnej przewagi w dysponowanych zasobach, które umożliwiają zajęcie pozycji rynkowej przewagi konkurencyjnej w pewnych segmentach rynku, a tym samym uzyskanie lepszej przychodowości finansowej. Teoria konkurencji opartej na przewadze zasobowej uwzględnia fakt, że powoduje wytrącanie rynku z równowagi oraz zakłada, iż innowacje, uczenie się i zdobywanie wiedzy organizacyjnej mają endogeniczny charakter" [Hunt 2000, s. 135].

Przedsiębiorstwa, instytucje i gospodarki, rywalizując między sobą, dążą do osiągnięcia przewag konkurencyjnych, chcą osiągnąć konkurencyjność. Pojecie konkurencyjności zostało wprowadzone po raz pierwszy w 1985 i miało wymiar makroekonomiczny, dotyczyło bowiem konkurencyjności gospodarki Stanów Zjednoczonych [Świtalski 2005, s. 165].

Ogólnie konkurencyjność to zdolność do konkurowania, co w rzeczywistości oznacza zdolność do zwiększania udziału w rynku lub utrzymanie dotychczasowej pozycji. Konkurencyjność może dotyczyć produktu, przedsiębiorstwa, branży, technologii, gospodarki. Jednak nie każdy badacz konkurencyjności tak ją rozumie. Ekonomiści, którzy stosowali pojęcie konkurencyjności do całej gospodarki zostali skrytykowani przez P. Krugmana. Jego zdaniem pojęcie konkurencyjność należy stosować tylko do poziomu mikro [Krugman 1994]. Konkurencyjność jako kategoria ekonomiczna jest trudna do jednoznacznego zdefiniowania. W literaturze przedmiotu nie ma jednej uniwersalnej definicji tego pojęcia.

Według P. Jonesa i D. Teece'a: „Konkurencyjność nie jest sama w sobie celem, ale stanowi środek do osiągania celu. Jest ona miarą ekonomicznych zdolności i potencjału kraju na tle gospodarki światowej. Kraje konkurencyjne są w stanie w pełni przechwycić korzyści biorące się z liberalizacji stosunków

\footnotetext{
${ }^{4}$ Zob.: Blaug 1995; Hunt 2000; Singer 2000; Connor 2003, Porter 1980, 1985, 1990, 2001.
} 
międzynarodowych. Kraje te mogą również kształtować międzynarodowy porządek gospodarczy, a zarazem osiągnąć własne cele społeczne i ekonomiczne. Kraje, które kiedyś były konkurencyjne w skali międzynarodowej, ale utraciły tę pozycję, stoją przed trudnymi problemami dostosowań w sferze gospodarczej, społecznej i politycznej [Jones, Teece 1988, s. 109].

Kolejna definicja konkurencyjności dotyczy wymiaru mikroekonomicznego. „Konkurencyjność w odniesieniu do pojedynczej firmy oznacza zdolność do wytworzenia właściwych dóbr lub usług o właściwej jakości, po właściwej cenie i we właściwym czasie. Konkurencyjność sprowadza się do zaspokojenia potrzeb nabywcy w bardziej wydajny sposób i bardziej sprawnie niż inne firmy" [Competitiveness Forging..., 1995].

W polskiej literaturze nowatorską definicję konkurencyjności zaproponował S. Flejterski. Zwrócił w niej bowiem uwagę, jako jeden z pierwszych, że źródeł konkurencyjności należy upatrywać we wszystkich etapach projektowania, planowania, ulepszania projektów i realizacji przedsięwzięć mających na celu wprowadzenie konkurencyjnych produktów i racjonalnych metod ich wytwarzania. Według Flejterskiego; „Przez konkurencyjność rozumie się, najogólniej rzecz biorąc, zdolność do projektowania, wytwarzania i sprzedawania towarów, których ceny, jakość i inne walory są bardziej atrakcyjne od odpowiednich cech towarów oferowanych przez konkurentów [Flejterski 1984, s. 391].

Za stosowaniem pojęcia konkurencyjności w ujęciu makro, czyli w odniesieniu do gospodarki narodowej przemawia fakt, że jedne gospodarki są bardziej konkurencyjne niż inne w przyciąganiu bezpośrednich inwestycji zagranicznych ukierunkowanych na tworzenie nowych zdolności wytwórczych (green field projects). Przewagi konkurencyjne krajowych przedsiębiorstw tylko w niewielkim stopniu przyciągają bezpośrednie inwestycje zagraniczne. Ważniejszymi czynnikami są rozwiązania systemowe funkcjonujące w gospodarkach narodowych. Duży wpływ na decyzję o lokowaniu kapitału w danym kraju, oprócz taniej siły roboczej, rozsądnych stawek podatku, wielkości miejscowego rynku, wywiera dostępność wykwalifikowanych kadr, poziom infrastruktury technicznej, procedura rejestracji działalności i uzyskiwania stosownych zezwoleń oraz środowisko sprzyjające zagranicznym inwestycjom. Uważa się, że w przyciąganiu ważniejszych inwestorów w Polsce istotną rolę odgrywały instytucje i stopień ich innowacyjności. Najważniejsze w przypadku konkurencyjności gospodarek jest wytwarzanie i podtrzymywanie w dłuższym okresie środowiska sprzyjającego innowacyjności i wprowadzeniom samych innowacji. Giovanni Dosi [2000] zauważył, że na tempo wzrostu wpływają ,głębsze czynniki” niż kapitał i praca. W swej publikacji wyraźnie zaznaczył wagę wpływu czynników instytucjonalnych i organizacyjnych oraz innowacji adaptacyjnych w państwach na poprawę konkurencyjności gospodarki.

$\mathrm{O}$ istnieniu $\mathrm{w}$ praktyce konkurencyjności gospodarek świadczą również opracowywane od wielu lat rankingi konkurencyjności poszczególnych krajów. 
Cieszą się one dużą popularnością, zwłaszcza w kontekście porównań międzynarodowych.

Wyrazem sukcesu danego kraju jest kategoria konkurencyjności, a więc względnej, rejestrowanej w rankingach World Economic Forum (WEF) czy International Management Development (IMD) pozycji kraju albo bezwzględnej pozycji mierzonej za pomocą różnych wskaźników (udział w światowym handlu różnych grup towarów, tempo wzrostu gospodarczego, rentowność sprzedaży, majątku itp.).

$I M D$ i $W E F$ publikują roczne raporty o międzynarodowej pozycji konkurencyjnej każdego z badanych krajów. Obie instytucje odmiennie definiują konkurencyjność, ale wyniki rankingów są podobne. Obecne definicje konkurencyjności, a także metodologia i zakres badań różnią się od tradycyjnego jej wyjaśniania kosztami komparatywnymi, produktywnością czy rywalizacją między firmami.

W opracowaniach IMD przyjmuje się, że „konkurencyjność krajów zależy od ich umiejętności w budowaniu i utrzymywaniu takiego środowiska, w którym firmy są w stanie wytwarzać więcej wartości, a także zwiększać poziom zasobności obywateli" [IMD 2009, s. 479]. IMD ocenia konkurencyjność w oparciu o dane statystyczne i opinie menedżerów zebrane przy pomocy ankiet. Zebrane dane są analizowane przy zastosowaniu tzw. modelu „diamentu” opracowanego przez M. E. Portera [1990].

Z kolei, $W E F$ definiuje konkurencyjność jako połączenie polityki, instytucji i czynników, które określają poziom produktywności danego kraju [WEF 2009, s. 4]. Według twórców Raportu $W E F$, gospodarka konkurencyjna osiąga wysoką produktywność i dzięki temu umożliwia osiąganie wysokich dochodów, wysokiego poziomu życia obywateli i wysokich stóp zwrotu z inwestycji. W badaniu konkurencyjności $W E F$, przyjmuje się, że tworzą ją następujące czynniki konkurencyjności danego kraju: instytucje, infrastruktura, stabilność makroekonomiczna, służba zdrowia i podstawowe wykształcenie, wykształcenie wyższe i doskonalenie zawodowe, sprawność rynku towarów i rynku pracy, zaawansowany rynek finansowy, poziom rozwoju technicznego, rozmiary rynku wewnętrznego, przedsiębiorczość i innowacyjność gospodarki. Powyższe czynniki służą do obliczenia indeksu konkurencyjności i określeni miejsca danego kraju w międzynarodowym rankingu [Radomski 2010, s. 240].

Definicje stosowane przez IMD i WEF są przez ekonomistów akceptowane, bowiem właściwie określają istotę współczesnej konkurencyjności. Natomiast rankingi konkurencyjności opracowane przez te instytuty, podobnie jak wiele innych rankingów, budzą pewne zastrzeżenia z powodu subiektywnego charakteru wielu kryteriów, np. opinii menedżerów. Niestety, Polska w rankingach konkurencyjności obu instytucji zajmuje odległe miejsca, mimo wysokiego, w porównaniu z innymi krajami UE, wzrostu PKB. Zatem instytucjonalna infrastruktura polskiej gospodarki nie tworzy przyjaznych warunków dla rozwoju przedsiębiorczości, innowacyjności i konkurencyjności. 
Z badania przeprowadzonego przez M. A. Weresę i R. Rapackiego, którego celem była syntetyczna ocena konkurencyjności polskiej gospodarki wynika, że w Polsce zachodzą, wprawdzie niewielkie, ale pozytywne zmiany. W przeszłości o pozycji konkurencyjnej Polski decydowały przede wszystkim niskie ceny zasobów. Obecnie konkurencyjność polskiej gospodarki powoli zaczyna być kształtowana przez innowacje. W Polsce, w oparciu m.in. o fundusze strukturalne UE, realizowane są programy wspierające innowacje. W rezultacie tych działań poprawiają się wskaźniki innowacyjności gospodarki (rośnie produkcja dóbr i usług innowacyjnych, wzrasta liczba zgłoszeń patentowych). Jednak w Polsce porównaniu z innymi krajami UE wpływ innowacji na konkurencyjność gospodarki jest dość ograniczony [Weresa, Rapacki 2010, s. 252].

Konkurencyjność gospodarek jest nie tylko przedmiotem rozważań teoretycznych, ale również obszarem problemowym, wobec którego formułowane są zalecenia i wskazania kierowane do rządów poszczególnych krajów zarówno rozwijających się, jaki i rozwiniętych. Współcześnie konkurencyjność gospodarek, jak wcześniej wykazano, jest analizowana nie tylko przez pryzmat obrotów handlowych czy kosztowych przewag komparatywnych [Porter 1990]. Mierniki charakteryzujące wiedzę i innowacje są określane jako predykatory przyszłej konkurencyjności, które na ogół nie są widoczne w typowych i bieżących zestawieniach makroekonomicznych. Warto zauważyć, że badacze oceniając konkurencyjność gospodarek coraz częściej sięgają do informacji o liczbie rejestrowanych patentów i liczbie publikacji naukowych, które z kolei są efektami wcześniej podjętych działań naukowych i innowacyjnych.

Należy jednak pamiętać, że zarówno innowacyjność, jak i konkurencyjność nie są ostatecznym celem przedsiębiorstw i gospodarek. Bezwzględna konkurencyjność jest jedynie środkiem do osiągania wyższych dochodów, wyższej konsumpcji obywateli oraz zapewnienia szans rozwoju społecznego w przyszłości. Rysunek 1.5. potwierdza podejście M. E. Portera do konkurencyjności, której celem jest dobrobyt społeczeństwa, a źródłem innowacyjność.

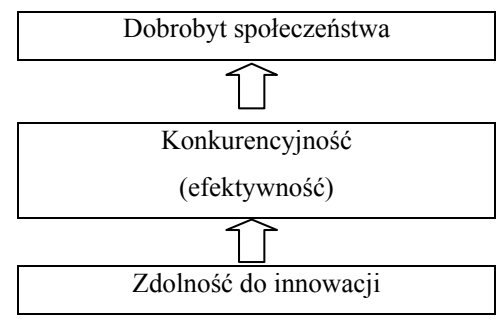

Rysunek 1.5. Cele działalności innowacyjnej

Źródło: M. E. P o r te r, Innovations and Competitiveness: Findings on the Netherlands, Organizing Innovation Based Economy, The Hague, The Netherlands, 2001, s. 3. 
Bogactwa narodów nie ocenia się dziś jedynie po właściwie kształtowanych parametrach makroekonomicznych. Jak twierdzi M. E. Porter, przewagi konkurencyjnej należy upatrywać przede wszystkim w zdolności do bycia innowacyjnym, do ciągłego podnoszenia jej poziomu i uzyskiwania dzięki temu odpowiedniej efektywności [Porter 2001, s. 192]. Rośnie znaczenie innowacji przyczyniających się w sposób pośredni (a więc w średnich i długich okresach) do zapewnienia konkurencyjności gospodarek, a są to innowacje w systemie edukacji oraz $\mathrm{w}$ organizacji i finansowaniu badań podstawowych i stosowanych. Wydaje się, że innowacje w systemie edukacji w Polsce powinny zmierzać w kierunku podwyższenia kwalifikacji przedsiębiorczych społeczeństwa. Innowacje w instytucjach również przyczyniają się do wzrostu konkurencyjności gospodarki w skali międzynarodowej. Jednak innowacje instytucjonalne stanowią oddzielną kategorię innowacji, wymagają dalszych badań, bowiem na razie są słabo rozpoznane.

$\mathrm{Na}$ gruncie teorii udowodniono, że osiągnięcie przewagi konkurencyjnej jest możliwe tylko poprzez działania innowacyjne, a zdolność przedsiębiorstw do innowacji i do podnoszenia poziomu technologicznego decyduje o konkurencyjności przedsiębiorstw, branż i całej gospodarki [Porter 1990]. Jak zatem można badać powiązania między innowacjami w przedsiębiorstwach, np. przemysłu spożywczego a ich konkurencyjnością? Służą temu różnorodne modele wykorzystujące mierniki konkurencyjności. Wybór mierników, za pomocą których można dokonać oceny efektów występowania badanego zjawiska, nie należy do najłatwiejszych zadań, ponieważ musi uwzględniać istniejące ograniczenia oraz brak kompletności i porównywalności danych statystycznych.

W podrozdziale 3.3 podjęto próbę oceny konkurencyjności branż przemysłu spożywczego w latach 2002-2008. Natomiast empiryczna weryfikacja wpływu innowacji na konkurencyjność przedsiębiorstw przemysłu spożywczego jest przedmiotem rozważań szóstego rozdziału pracy.

\section{Podsumowanie}

Narastające tempo procesu globalizacji wywołuje dynamiczne zmiany we wszystkich sferach życia społeczno-gospodarczego. Każdy podmiot, aby utrzymać się na rynku, powinien ciągle dokonywać zmian oraz szybko reagować na te zachodzące $w$ jego otoczeniu. Jednak oprócz zmian polegających na dostosowywaniu się do nowych warunków panujących w otoczeniu mamy do czynienia ze zmianami endogenicznymi, inicjowanymi przez przedsiębiorcę. Dla rozwoju gospodarczego istotne są zmiany, które są innowacjami. W rozdziale pierwszym podjęto próbę opisania istoty innowacji, a to wymagało prześledzenia całego procesu innowacyjnego. 
Wydaje się, że wysiłek podjęty w celu bliższego rozpoznania znaczeń poszczególnych terminów i pojęć z zakresu procesu innowacyjnego przyczyni się do uporządkowania terminologii oraz wpłynie na sposoby identyfikacji innowacji i innowacyjności przedsiębiorstw i gospodarek narodowych.

$\mathrm{Z}$ rozważań teoretycznych zawartych $\mathrm{w}$ tym rozdziale wynika, że innowacje i innowacyjność należy postrzegać jako złożony zestaw środków służących do poprawy konkurencyjności przedsiębiorstw, branż i gospodarek narodowych. Konkurencyjność umożliwia osiąganie coraz wyższych poziomów konsumpcji i dobrobytu społeczeństw.

Wnikliwa analiza procesów innowacyjnych, poparta wnioskami ze studiów literaturowych, prowadzi do konkluzji, że osiąganie przewagi konkurencyjnej opartej na wiedzy i innowacjach stanowi gwarancję trwałego rozwoju. Sukces odnoszą te gospodarki, które potrafią wyzwolić w sobie zdolność do trwałego generowania innowacji. 


\section{Innowacyjność polskiej gospodarki w świetle badań statystycznych}

\section{Wprowadzenie}

Obecnie jednym z największych wyzwań, z jakimi powinna się zmierzyć nie tylko Polska, ale cała zjednoczona Europa, jest wskazanie kierunków i sposobów zwiększenia innowacyjności gospodarek i funkcjonujących w nich podmiotów gospodarczych. Droga do zwiększenia konkurencyjności na globalnym rynku wiedzie poprzez gospodarkę opartą na wiedzy, a w tym przede wszystkim przez wzrost innowacyjności.

Istnieje przekonanie, że innowacyjność gospodarki uwarunkowana jest charakterem Narodowego Systemu Innowacji, a polityka innowacyjna współczesnych państw opiera się właśnie na tym systemie.

Wzrost znaczenia innowacyjności powoduje zwiększone zapotrzebowanie na dane statystyczne z tego zakresu. Analizy systemów innowacji będą służyć politykom, przedsiębiorcom i innym uczestnikom tych systemów tylko wtedy, gdy będą obiektywne i będą wskazywać ich pozytywne strony i niedociągnięcia. Unia Europejska dostrzega ogromne znaczenia badań statystycznych w promowaniu, wspieraniu i poszukiwaniu źródeł innowacyjności i dlatego finansuje specjalne projekty badawcze mające na celu doskonalenie metodologii badań statystycznych innowacji.

Pierwszą część niniejszego rozdziału poświęcono przybliżeniu problematyki Narodowego Systemu Innowacji, wyjaśnieniu jego istoty, charakterystyce tego systemu w Polsce oraz próbie oceny szans zwiększenia jego efektywności.

W drugiej części rozdziału przedstawiono metodologię badań innowacyjności krajów i działalności innowacyjnej przedsiębiorstw w Unii Europejskiej. Scharakteryzowano metodologię: OECD, Eurostatu i badań w Głównym Urzędzie Statystycznym. Na koniec zaprezentowano miejsce Polski w rankingu innowacyjności krajów Unii Europejskiej opracowanym przez Komisję Europejską, a będącym wynikiem projektu European Innovation Scoreboard 2009.

\subsection{Pojęcie i istota Narodowych Systemów Innowacji}

W końcu lat 80 . XX w. w krajach OECD dostrzeżono znaczenie wpływu procesów innowacyjnych na przebieg procesów gospodarczych i wykreowano pojecie narodowych (krajowych) systemów innowacji. Powstanie koncepcji NSI wiąże 
się z poglądem głoszonym przez wielu wybitnych ekonomistów (Ch. Freemana, R. Nelsona, M. Portera, N. Rosenberga, K. Pavitta i B.A. Lundvalla), że szeroko rozumianą innowacyjność czy też zdolność innowacyjną gospodarki należy analizować w kontekście specyficznych dla danej gospodarki narodowej uwarunkowań ekonomicznych, instytucjonalnych i kulturowych. Innowacje w większym stopniu niż sądzono wcześniej odzwierciedlają pewne unikalne uwarunkowania i specyficzne obszary kompetencji właściwe dla danej gospodarki narodowej, w której opracowano nowatorskie rozwiązania.

Samo pojęcie Narodowego Systemu Innowacji wymaga precyzyjnego wyjaśnienia, aby nie kojarzyć tego systemu (modelu) z istnieniem centralnej instytucji kształtującej optymalny system funkcjonowania procesów innowacyjnych.

Zatem NSI nie stanowią odrębnych instytucji czy organizacji, ale dzięki licznym sprzężeniom zwrotnym, które występują między instytucjami możliwe jest sprawne projektowanie, tworzenie, selekcjonowanie, absorpcja i dystrybucja innowacji. NSI tworzą efektywne powiązania pomiędzy tymi, którzy generują nową wiedzę oraz tymi, którzy mogą ją z pożytkiem wykorzystywać. W takim rozumieniu Narodowe Systemy Innowacji są w stanie w sposób bardzo czytelny kreować politykę innowacyjną państwa.

W bogatej literaturze tematu NSI rozwijanego w krajach OECD w latach 90. przedstawiono różne definicje krajowych systemów innowacji. Jedną z najczęściej cytowanych jest definicja B. A. Lundvalla, który Narodowy System Innowacji określa jako układ podsystemów produkcyjnych, naukowo-technicznych, rozwiązań instytucjonalnych i zależności między nimi, które wpływają na poziom innowacyjności gospodarki [Lundvall 1992, s. 12-15]. Tak zdefiniowany NSI można analizować w wąskim i szerokim ujęciu. W wąskim obejmuje on ogół instytucji należących do sfery badawczo-rozwojowej, takich jak: szkoły wyższe, instytuty badawcze (prywatne i publiczne) i jednostki badawczo-rozwojowe przedsiębiorstw. Natomiast w szerokim ujęciu do NSI zalicza się różnorodnych uczestników reprezentujących poszczególne podsystemy struktury ekonomicznej danej gospodarki, w tym przede wszystkim: szkoły wyższe, instytucje badawczorozwojowe, przedsiębiorstwa przemysłowe, instytucje finansowe i marketingowe, instytucje publiczne itp. [Archiebugi, Howells, Mitchie 2001, s. 5]. Znaczenie owych podsystemów w oddziaływaniu na procesy innowacyjne jest uwarunkowane czynnikami instytucjonalnymi i historycznymi, które wpływają na NSI.

Według R. R. Nelsona i N. Rosenberga Narodowy System Innowacji jest zespołem instytucji, których wzajemne oddziaływania determinują innowacyjność przedsiębiorstw. Najważniejszymi instytucjami tego systemu są: szkoły wyższe, agendy rządowe, wspomagające działalność badawczo-rozwojową i przedsiębiorstwa, które odgrywają wiodącą rolę w danej branży [Nelson, Rosenberg 1993, s. $4,5,15]$. Podstawowym celem, jaki powinien realizować Narodowy System Innowacji, jest maksymalizacja korzyści technologicznych gospodarki, które są wynikiem interakcji między instytucjami tworzącymi ten system. 
W Polsce tematykę NSI podjęli A. Kukliński i B. Kacprzyński, zwracając uwagę na jego znaczenie dla konkurencyjności polskiej gospodarki. Koncepcja NSI została rozwinięta w pracach E. Okoń-Horodynskiej, A. Jasińskiego i wielu innych badaczy [Okoń-Horodyńska 1998; Jasiński 2006].

E. Okoń-Horodyńska NSI określa jako zespół różnych instytucji, które łącznie i indywidualnie biorą udział w rozwoju i dyfuzji nowych technologii oraz jako konstrukcję instytucjonalną, w której rządy i stosowane przez nie formy polityki wspierają proces innowacji. Innymi słowy NSI oznacza całokształt powiązanych ze sobą instytucjonalnych i strukturalnych czynników w gospodarce narodowej i społeczeństwie, które generują, selekcjonują i wchłaniają innowacje technologiczne wyzwalając proces uczenia się [Okoń-Horodyńska 2000, s. 120].

P. Patel i K. Pavitt rozróżniają w ramach NSI cztery kategorie instytucji, które aktywnie uczestniczą w procesie tworzenia i wdrażania innowacji. Są to [Patel, Pavitt 1994, s. 79-80]:

- uniwersytety i mniejsze jednostki badawcze, które prowadzą badania naukowe podstawowe i stosowane,

- przedsiębiorstwa stosujące ofensywną strategię innowacyjną,

- publiczne i prywatne instytucje działające w sferze edukacji i szkoleń zawodowych,

- agendy rządowe zajmujące się głównie finansowaniem i organizowaniem działalności badawczo-rozwojowej.

Instytucjonalne podejście do NSI prezentuje definicja Metcalfa przyjęta w oficjalnych publikacjach OECD. Według niego NSI to: kompleks wyodrębnionych instytucji, które wspólnie i indywidualnie wnoszą wkład do rozwoju i rozprzestrzeniania się (dyfuzji) nowych technologii, i które tworzą zrąb, w ramach którego rządy formułują i realizują politykę mającą za zadanie oddziaływanie na procesy innowacyjne. Jest to więc system wzajemnie powiązanych instytucji umiejących tworzyć, przechowywać i przekazywać wiedzę i umiejętności leżące u podstaw nowych technologii [Metcalfe 1995, s. 490-512]. W tym ujęciu poziom innowacyjności gospodarek zależy nie tylko od funkcjonowania poszczególnych instytucji NSI (przedsiębiorstw, wyższych uczelni, instytutów badawczych itp.), lecz przede wszystkim od tego, jak owe instytucje współpracują i wzajemnie na siebie oddziałują oraz współdziałają ze społecznymi instytucjami, uwzględniając wartości niematerialne, normy i zasady prawne.

R. R. Nelson i B. Lundvall wyodrębniają następujące filary Narodowego Systemu Innowacji [Molina, Kinder 2000, s. 16-17]:

- firmy, relacje między firmami i relacje między firmami i uniwersytetami,

- narodowy system edukacji wraz z narodowym systemem badań,

- otoczenie ekonomiczne, infrastruktura publiczna, prawo, instytucje finansowe,

- polityka makroekonomiczna, edukacyjna i innowacyjna. 
Kolejna, a zarazem kończąca ten przegląd definicja została sformułowana na podstawie określeń NSI, pojawiających się w różnych definicjach. Można przyjąć, że Narodowy System Innowacji jest konstrukcją obejmującą całokształt powiązanych ze sobą publicznych i prywatnych instytucji, które zgłaszają popyt na projekty innowacyjne, realizują owe projekty, przekształcają wyniki prac badawczo-rozwojowych w komercyjne innowacje i oddziałują na dyfuzję innowacji [Okoń-Horodyńska 2002, s. 155, 1998; 2004, s. 13; Weresa 2003, s. 99-100]. Narodowy System Innowacji tworzą nie tylko podmioty bezpośrednio działające $\mathrm{w}$ sferze $\mathrm{B}+\mathrm{R}$, ale również agendy rządowe i przedsiębiorstwa, które decydują o poziomie innowacyjności gospodarki.

Przyjęcie zasady, że zadaniem NSI jest usprawnienie procesów innowacyjnych, nie narzuca określonego modelu NSI. Jak pokazują doświadczenia różnych krajów może on mieć różną strukturę oraz odmienne metody oddziaływania poszczególnych elementów systemu [Kowalak 2006, s. 59-58].

Zatem nie można zbudować jednego uniwersalnego NSI odpowiedniego dla wszystkich gospodarek narodowych, albowiem poszczególne modele powinny uwzględniać specyficzne cechy, właściwe dla danej gospodarki. Są to np. poziom rozwoju ekonomicznego, warunki geopolityczne, sytuacja demograficzna, wielkość sektora produkującego wiedzę, jego produktywność, jakość kapitału ludzkiego, sprawność działania instytucji rządowych, kultura organizacji, poziom prywatnych i publicznych inwestycji, wewnętrzny popyt na innowacje technologiczne, jak również różnice w strukturze systemów produkcyjnych i instytucjonalnych poszczególnych gospodarek.

W literaturze przedmiotu, mimo wyraźnych różnic między systemami, podejmowane są próby budowy schematów obrazujących poszczególne koncepcje NSI. Schematy (modele) te określają w sposób mniej lub bardziej precyzyjny uczestników omawianych systemów. Na NSI w gospodarce składa się wiele podmiotów tradycyjnie klasyfikowanych do sfery nauki, produkcji oraz administracji państwowej, które działają w otoczeniu krajowym i międzynarodowym. Najważniejszymi uczestnikami są ośrodki naukowo-badawcze, instytucje rządowe i pozarządowe wspierające działalność badawczą i naukową, przedsiębiorstwa, organizacje zrzeszające uczestników systemu, w tym przede wszystkim sieci innowacyjne i klastry. W schematach tych pokazane są również wielorakie powiązania i sprzężenia informacyjne oraz decyzyjne pomiędzy uczestnikami systemu [Szajt 2008, s. 34-35].

Poniżej zaprezentowano jeden $\mathrm{z}$ wielu, istniejących w literaturze, modeli NSI. Uwydatnia on relacje zachodzące między poszczególnymi uczestnikami owego systemu na poziomie mikro-, mezo- i makroekonomicznym. W centrum systemu znajduje się innowacyjna firma (poziom mikro), która prowadzi prace badawczo-rozwojowe, dokonuje zakupów projektów $\mathrm{B}+\mathrm{R}$, przeznacza wysokie nakłady finansowe na działalność badawczą, współpracuje z jednostkami naukowymi. Firma ta stanowi istotny element Regionalnego Systemu Innowacji, może być również aktywnym uczestnikiem klastra (poziom mezo). Kontekst makroekonomiczny tworzy natomiast system instytucjonalno-regulacyjny gospodarki, 
w tym porządek prawny, organizacje, układ podmiotowy, struktura własności, sposób koordynacji działalności gospodarczej podmiotów, jakość infrastruktury rynkowej [Dworak 2008, s. 15].

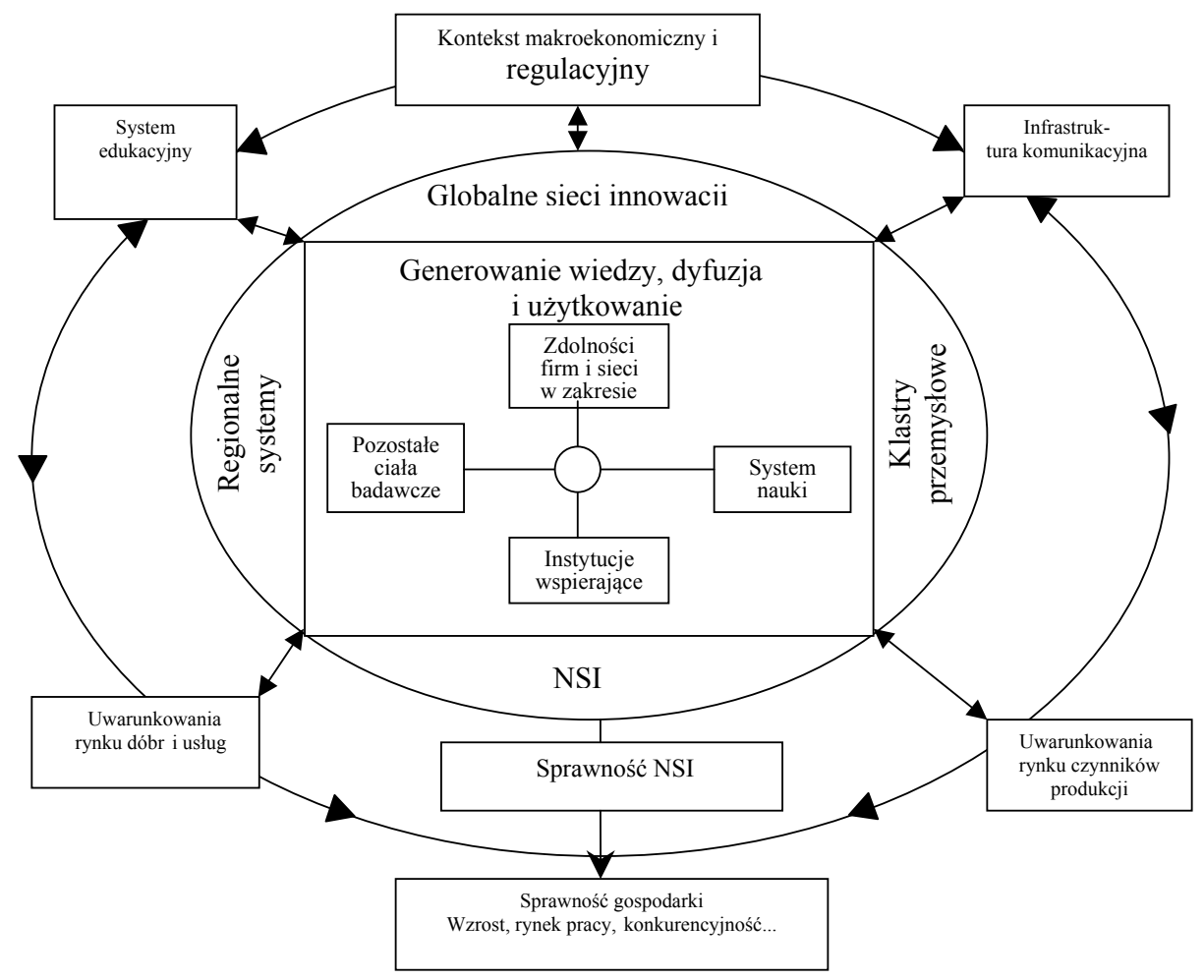

Rysunek 2.1. Schemat NSI

Źr ó d ło: Technologia, produktywność i tworzenie nowych miejsc pracy, OECD, 1998; E. O k oń H o r o d y ń s k a, Narodowy System Innowacji w Polsce, Akademia Ekonomiczna im. K. Adamieckiego, Katowice 1998, s. 133.

Z przedstawionego na rys. 2.1. schematu wynika, że nadzór nad NSI sprawuje państwo, rozumiane jako system instytucji o charakterze wspierającym innowacyjność. Dzięki finansowaniu ze strony państwa oraz innego rodzaju bodźcom ekonomicznym, a także wsparciu natury organizacyjnej, uaktywnieni zostają kolejni uczestnicy w systemie. Uczestnikami tymi są zarówno twórcy (pomysłodawcy, wynalazcy itp.), jak i wykonawcy (podmioty wdrażające i rozpowszechniający innowacje), lecz ostatecznym odbiorcą innowacji jest rynek.

W tym systemie państwo odgrywa ważną rolę jako podmiot biorący udział w finansowaniu $\mathrm{B}+\mathrm{R}$ jako twórca polityki fiskalnej (tym samym wpływający 
W sposób znaczący na zachowanie rynku) oraz jako twórca polityki budżetowej (oddziałujący na wzrost liczby osób związanych z działalnością badawczo-rozwojową i zwiększenie potencjału naukowo-badawczego państwa). Właściwie realizowana polityka proinnowacyjna umożliwia rozwój badań podstawowych i stosowanych. Duże znaczenia ma również polityka państwa w dziedzinie edukacji, która przesądza o kwalifikacjach kadry pracującej.

Istotnymi podmiotami $\mathrm{w}$ prezentowanym systemie są uczelnie wyższe. Stanowią one, obok prywatnych instytutów badawczych, główne źródło innowacji, gdyż dysponują zapleczem technicznym i zasobem wiedzy, która wykorzystana we właściwy sposób dzięki konkretnym bodźcom, prowadzi do wzrostu aktywności innowacyjnej.

Sektor przedsiębiorstw to kolejna bardzo ważna grupa podmiotów decydujących o innowacyjności gospodarki narodowej. Możemy w nim wyróżnić przedsiębiorstwa: duże (na ogół posiadające własne zaplecze badawcze), małe i średnie oraz zagraniczne (w tym międzynarodowe korporacje i spółki-córki światowych potentatów, których zaplecze badawcze często jest zlokalizowane w innych państwach). Przedsiębiorstwa pełnią więc rolę producenta, twórcy innowacji oraz zamawiającego $\mathrm{w}$ przypadku niedostatecznie rozwiniętego własnego zaplecza badawczego lub jego braku.

W NSI instytucjami wiążącymi poszczególnych uczestników systemu są różnego rodzaju organizacje o zasięgu krajowym, regionalnym czy międzynarodowym. Przedsiębiorstwa poprzez kooperację handlową, produkcyjną i współpracę badawczą tworzą klastry przemysłowe. Firmy funkcjonujące w ramach klastrów dzięki ścisłej współpracy z jednostkami badawczymi szybko otrzymują informacje dotyczące rozwiązań wielu problemów technologicznych i mają jednocześnie wpływ na kształt innowacji powstających w procesie badawczym. Dobrze funkcjonujący NSI powinien tworzyć efektywne powiązania pomiędzy tymi, którzy generują nową wiedzę oraz tymi, którzy mogą ją z pożytkiem wykorzystywać. W takim rozumieniu NSI jest w stanie w sposób czytelny kreować politykę innowacyjną państwa. Dzięki silnym powiązaniom głównych uczestników Narodowych Systemów Innowacji dąży się do osiągnięcia jak najlepszych wyników w dziedzinie innowacyjności prowadzącej do rozwoju gospodarczego.

Mówiąc o NSI należy przypomnieć o braku uniwersalnego wzorca, gdyż każdy kraj charakteryzuje się odmiennymi uwarunkowaniami społeczno-gospodarczymi. Trudno zatem zbudować system odpowiadający wszystkim krajom. Wielu badaczy polityki innowacyjnej podejmuje jednak próby klasyfikacji i uogólniania NSI.

Poniżej przedstawiamy jedną z wielu klasyfikacji modeli NSI [Weresa 2002, s. 58-60]:

A. Pierwszą grupę tworzą systemy zwane rynkowymi; występują głównie w gospodarkach krajów anglosaskich (USA, Wielka Brytania, Kanada, Australia). Rysem charakterystycznym tych gospodarek jest istotne znaczenie systemu edukacji, w którym szczególny nacisk kładzie się na rozwój nauk o życiu (głównie medycyny, 
biologii, biochemii), elastyczny rynek pracy, specjalizację przemysłu, polegającą na wspieraniu dziedzin wysokich technologii (przemysł farmaceutyczny, kosmiczny, nauki biologiczne), sprawnie działający sektor finansowy, aktywnie uczestniczący w budowaniu narodowego systemu innowacji, i przedsiębiorstwa zorientowane na skupianiu swojej działalności innowacyjnej wewnątrz własnej organizacji;

B. Druga grupa systemów innowacji to „systemy europejskiej integracji”. Systemy te koncentrują się na rozwoju nauk ścisłych; są zorientowane na wspieranie przemysłu chemicznego i maszynowego. Istotną rolę w ich rozwoju odgrywa system edukacji i działalność badawczo-rozwojowa, oparte głównie na sektorze publicznym, jak również synchronizacja następujących działań: promowanie wzrostu gospodarczego, aktywne metody przeciwdziałania bezrobociu, dbałość o dobrobyt społeczny i intensywna polityka innowacyjna. Model europejskiej integracji występuje we Francji, Niemczech, w Holandii i we Włoszech;

C. Trzecia grupa Narodowych Systemów Innowacji obejmuje kraje skandynawskie (Finlandia, Szwecja, Norwegia). Szczególną rolę odgrywa w nich internacjonalizacja działalności badawczo-rozwojowej, technologiczna specjalizacja w rozwoju przemysłów opartych na intensywnej eksploatacji surowców, działalność $\mathrm{B}+\mathrm{R}$ finansowana przede wszystkim ze środków prywatnych, implementacja nowoczesnych metod produkcji, realizacja wysokich standardów kształcenia, wspieranego istotnymi wydatkami, zwłaszcza z budżetu państwa, bardzo duże znaczenie edukacji na poziomie uniwersyteckim;

D. Czwartą grupę systemów tworzy japoński system innowacji, zwany społeczno-demokratycznym lub mezokorporacyjnym (mezzo-corporative), z uwagi na wysoki stopień specjalizacji sektorowej. System ten charakteryzuje się dynamicznym zarządzaniem technologiami, elastycznym i mobilnym rynkiem pracy, koncentracją wysiłków badawczych na poziomie badań stosowanych, przede wszystkim w sferze nauk inżynieryjnych, dużą efektywnością badań stosowanych, znaczną specjalizacją branżową, silnym powiązaniem z Narodowymi Systemami Innowacji innych krajów poprzez handel zagraniczny;

E. Piątą grupę stanowią systemy innowacji tworzone w gospodarkach znajdujących się w procesie transformacji systemowej, zwane „zmutowanymi” lub zmieniającymi się (mutant). Gospodarki te muszą sprostać istotnemu wyzwaniu, jakim jest stworzenie instytucji, które umożliwią kreowanie międzynarodowej współpracy w korzystnych dla podmiotów krajowych warunkach.

\subsubsection{Narodowe Systemy Innowacji w wybranych krajach europejskich}

Nim podjęta została próba scharakteryzowania i oceny Narodowego Systemu Innowacji funkcjonującego $\mathrm{w}$ Polsce, skoncentrowano się na najważniejszych aspektach systemów innowacji wybranych, wysoko rozwiniętych krajów Unii 
Europejskiej. Poznanie specyfiki tych systemów wymaga zwrócenia uwagi na strukturę ich finansowania i organizację.

W państwach UE duże znaczenie mają, zarówno w finansowaniu, jak i prowadzeniu działalności B+R trzy grupy podmiotów: instytucje rządowe, przedsiębiorstwa prywatne, szkoły wyższe. W większości państw istnieją mechanizmy koordynujące wydatki na działalność badawczo-rozwojową oraz doradcze instytucje, które pomagają $\mathrm{w}$ formułowaniu polityki w zakresie nauki i technologii.

Gospodarka niemiecka uważana jest za jedną z najsilniejszych w Europie. Teoretycy i praktycy problematyki innowacyjności wysoko oceniają również niemiecki NSI. System ten finansowany jest prawie w połowie przez rząd federalny i w połowie przez władze regionalne. Poszczególne landy mają duży udział w finansowanie działalności B+R. W niemieckim NSI mamy do czynienia z systemem, w którym, z jednej strony funkcjonują przedsiębiorstwa, z drugiej - władze państwowe $\mathrm{z}$ wyraźnym podziałem zadań federalnych i regionalnych. Zatem strukturę systemu wspomagającego innowacyjność niemieckiej gospodarki tworzą rząd federalny oraz władze krajów związkowych. Na szczeblu federalnym w zarządzaniu innowacjami bierze udział kilka federalnych ministerstw wraz z urzędem kanclerza. Głównymi kreatorami polityki na szczeblu federalnym są federalne Ministerstwo Edukacji i Nauki oraz federalne Ministerstwo Gospodarki i Technologii. W 2005 r. rząd A. Merkel przeniósł odpowiedzialność za główne działania koncentrujące się na firmach $\mathrm{z}$ ministerstwa związanego $\mathrm{z}$ edukacją do gospodarki. Ta zmiana podkreśla rangę działań wspierających innowacje. Jednoznaczny podział kompetencji, wraz z dużą przejrzystością celów strategicznych określonych dla poszczególnych uczestników, decyduje o sukcesie. W zasadzie wszystkie środki finansowe dystrybuowane są przez funkcjonujące $\mathrm{w}$ tym celu fundacje $\mathrm{i}$ organizacje wspierające i promujące działalność B+R. Należą do nich [por. Spielkamp, Vopel 1997]:

- Max - Planck Gesellschaft (MPG) - instytucja sponsorska wspierana przez rząd federalny i władze regionalne, zaangażowana głównie w badania podstawowe w wybranych obszarach nauki i sztuki;

- Fraunhofer Gesellschaft (FG) - instytucja sponsorska typu non-profit wspierana prze rząd federalny i władze regionalne, działająca na terenie Niemiec i poza nimi. Zajmuje się komercjalizacją wyników badan - partneruje w zawieraniu kontraktów pomiędzy przedsiębiorstwami i instytucjami publicznymi;

- German Research Council, Deutsche Forschungsgemeinschaft (DFG) główna organizacja promująca działalność $B+R$ w Niemczech oferująca wsparcie finansowe dla projektów badawczych, głównie dla młodych pracowników. Wspiera politykę proinnowacyjną i kontakty międzynarodowe;

- Arbeitgemeinschaft Industrieller Forschungsvereinigungen (ALF) - instytucja zrzeszająca ponad sto organizacji przemysłowych i badawczych zajmująca się promowaniem wyników badań, które mogą być komercjalizowane głównie w małych i średnich przedsiębiorstwach. Finansowo jest wspierana przez Ministerstwo Ekonomii i Przemysłu; 
- Instytucje z Blue list zajmujące się działaniami na rzecz badań i rozwoju, instytuty badawcze i rozwojowe działające w oparciu o dodatkowe wsparcie, także niepubliczne.

Niemiecki NSI przez dziesięciolecia był uważany za wzorcowy, dzięki „kaskadowemu" systemowi transferu technologii pomiędzy instytucjami badawczymi i przedsiębiorstwami, łączącemu w ustalonych proporcjach środki budżetów centralnych i lokalnych, subwencje dla konkretnych projektów i inwestycje własne przedsiębiorstw i fundacji naukowych. Okazało się jednak, że ten system jest mniej skuteczny w przypadku nowych technologii, głównie informatyki i biotechnologii, które wymagają elastyczności, bardzo szybkiej reakcji na zmiany w otoczeniu, skłonności do podejmowania ryzyka i integracji procesów innowacji, od badań podstawowych aż po komercjalizację [za: Klincewicz 2008, s. 42]. Zatem słabością tego systemu jest stopień jego skomplikowania, który wynika przede wszystkim z ustroju politycznego. Na szczeblu federalnym i związkowym muszą istnieć instytucje, których zadaniem jest koordynowanie działań [European Trend..., 2006, s. 1-2].

Z kolei w Szwecji NSI składa się z sześciu platform współpracujących ze sobą. Pierwsza zajmuje się ogólnie polityką innowacyjną, a stanowią ją władze państwowe, parlament, ministerstwa współpracujące z władzami unijnymi. Druga to instytucje związane $\mathrm{z}$ wprowadzaniem i koncesjonowaniem działalności $\mathrm{B}+\mathrm{R}$. Trzecią stanowią najważniejsze grupy podmiotów w działalności $\mathrm{B}+\mathrm{R}-$ przedsiębiorstwa, samodzielne laboratoria i instytuty, uczelnie i inni wykonawcy badań. Czwarta platforma zajmuje się propagowaniem innowacji poprzez różnego rodzaje programy badawcze i działalność instytucji, takich jak parki technologiczne. Piąty element systemu stanowią prywatne i publiczne instytucje finansujące działalność innowacyjną. Szósta platforma zawiera w sobie instytucje zajmujące się regulacjami własności i gromadzeniem informacji, takie jak The Swedish Patent and Registration Office i The Swedish Inventors' Association. Wysoka innowacyjność Szwecji jest efektem długoletniej polityki zachęcania przedsiębiorstw do inwestowania $\mathrm{w}$ działalność $\mathrm{B}+\mathrm{R}$. W latach 90. prace $\mathrm{B}+\mathrm{R}$ w 80\% koncentrowały się na elektronice, transporcie i środkach farmaceutycznych. W tym czasie były to najbardziej zaawansowane technologicznie i innowacyjnie gałęzie gospodarki, a Szwecja zajmowała wysoką pozycję w światowych rankingach innowacyjności. Państwo wzięło na siebie zadania związane z badaniami podstawowymi i wsparciem dużych podmiotów, zwłaszcza liczących się eksporterów. Natomiast działające na terenie Szwecji przedsiębiorstwa zajmują się pracami rozwojowymi i bezpośrednim opracowaniem użytecznych technologii. Wysoka innowacyjność Szwecji świadczy o efektywności krajowego systemu innowacji. Warto przypomnieć, że Szwecja uznawana jest, obok Finlandii, za najbardziej innowacyjne państwo w Europie [Szajt 2009, s. 62-64].

Odmiennym od wcześniej prezentowanych systemów jest Narodowy System Innowacji Hiszpanii. Jego cechą charakterystyczną jest silna pozycja 
i rola poszczególnych ministerstw - począwszy od Ministerstwa Obrony poprzez Edukacji i Nauki, a na Kultury kończąc. Ministerstwa te współpracują z Międzyministerialną Komisją do spraw Nauki i Technologii, która jest instytucją koordynującą prace wszystkich uczestników systemu. Komisję wspierają dodatkowo rady doradcze oraz główny sekretariat sprawujący kontrolę nad harmonogramem realizacji założonych planów w zakresie $\mathrm{B}+\mathrm{R}$. W podstawowych założeniach nie wyróżnia się przedsiębiorstw i sektora szkół wyższych. Przekłada się to niewątpliwie na jakość funkcjonowania systemu innowacyjności. Spośród krajów tzw. „starej Unii” Hiszpania zajmuje jedno z ostatnich miejsc w rankingach innowacyjności gospodarki [Krupowicz 2010]. Podobne w swej strukturze do rozwiązań hiszpańskich są systemy innowacyjne państw bałtyckich.

\subsubsection{Specyfika Narodowego Systemu Innowacji w Polsce}

Wzrost innowacyjności jest wyzwaniem dla Polski, zwłaszcza w warunkach integracji europejskiej i globalizacji gospodarki światowej. Koncepcja systemu innowacji zakłada, że źródeł innowacyjności w gospodarkach należy poszukiwać w sieciach zależności między przedsiębiorstwami, sektorem publicznym, uczelniami wyższymi i innymi instytucjami wspierającymi, a każdy z uczestników tego systemu może mieć znaczący wpływ na wzrost innowacyjności. W tym kontekście ważne są odpowiedzi na pytania: jaką rolę w systemie innowacji powinien odgrywać rząd; czy należy zwiększać wydatki rządowe na badania; jak stymulować aktywność innowacyjną sektora prywatnego itp. Warto zauważyć, że budowanie Narodowego Systemu Innowacji w Polsce nie powinno opierać się wyłącznie na doświadczeniach krajów wysoko rozwiniętych, ze względu na różnice regionalne, dystans ekonomiczny i obciążenie myślenia i działania części społeczeństwa gospodarką centralnie planowaną.

Instytucjonalną strukturę polskiego Narodowego Systemu Innowacji tworzą trzy poziomy: rządowy (legislacyjny), na którym tworzona jest narodowa polityka innowacyjna, wykonawczy oraz skupiający podmioty prowadzące działalność edukacyjną i badawczo-rozwojową. Przyjęcie koncepcji instytucjonalnego charakteru NSI oznacza, że jest on traktowany jako system należący do szeroko pojętego otoczenia biznesu (przedsiębiorstwa).

Pierwszy poziom (Sejm, Premier, Rada Ministrów, UKIE) określa ogólne cele polityki innowacyjnej z uwzględnieniem wymogów integracji w ramach Unii Europejskiej i proponuje alokację budżetu. Sejm zatwierdza propozycje ustaw, ustala budżet i podatki. Parlament decyduje o poziomie i podziale budżetu na badania, co ma ogromne znaczenie dla działalności instytucji badawczych finansowanych centralnie oraz prywatnej działalności innowacyjnej, która jest wrażliwa na zmiany podatkowe. 
Drugi poziom, zwany wykonawczym, tworzą podmioty odpowiedzialne za przygotowanie konkretnych programów operacyjnych, uwzględniających założenia przyjętej polityki innowacyjnej. Należą do niego następujące instytucje: Ministerstwo Gospodarki, Ministerstwo Pracy i Polityki Społecznej, Ministerstwo Nauki i Szkolnictwa Wyższego, Ministerstwo Edukacji Narodowej, Urząd Patentowy i Główny Urząd Statystyczny. Główna odpowiedzialność wykonawcza za zgłaszanie propozycji i zarządzanie ramami instytucjonalnymi narodowej polityki innowacyjnej skoncentrowana jest w Ministerstwie Gospodarki, które jest zorientowane na komercyjne aspekty polityki innowacyjnej, takie jak wdrażanie innowacji w przedsiębiorstwach, rozwój nowych produktów itp. oraz w Ministerstwie Nauki i Szkolnictwa Wyższego, które kontroluje budżetowe finansowanie badań [Gomułka 2006a, s. 161].

$\mathrm{Na}$ trzecim poziomie natomiast znajdują się instytucje prowadzące działalność edukacyjną i badawczo-rozwojową, które stanowią podstawę dla rozwoju produktów i usług innowacyjnych. Do tego poziomu zalicza się placówki naukowe PAN, szkoły wyższe oraz JBR-y. Instytucje te stanowią w Polsce tzw. zasób nauki, badań i rozwojus.

Obok wymienionych podmiotów do instytucji Narodowego Systemu Innowacji należą instytucje pomostowe, takie jak: urzędy pracy; Polska Agencja Rozwoju Przedsiębiorczości; Polska Agencja Informacji i Inwestycji Zagranicznych; Agencja Restrukturyzacji i Modernizacji Rolnictwa; Agencja Rozwoju Przemysłu; Fundacja ds. Innowacji, Restrukturyzacji i Przedsiębiorczości; krajowe i międzynarodowe punkty kontaktowe obsługujące konkretne programy narodowe lub międzynarodowe (np. unijne); organizacje związane z kreowaniem innowacji w gospodarce: finansowe (np. Fundacja na Rzecz Nauki Polskiej, Regionalne Instytucje Finansowe, Bank Światowy, UNIDO), konsultacyjne i informacyjne (Europejskie Centrum Informacji, Ośrodek Przetwarzania Informacji), ubezpieczeniowe i prawne; parki naukowo-technologiczne; inkubatory przedsiębiorczości [Okoń-Horodyńska 2004, s. 16]. Bardzo ważną instytucją pomostową NSI w Polsce jest Polska Agencja Rozwoju Przedsiębiorczości. Prowadzi ona działalność informacyjną, doradczą, szkoleniową oraz pełni funkcję instytucji finansującej rozwój innowacji w Polsce, z wykorzystaniem funduszy unijnych. Jej celem jest aktywizacja działań innowacyjnych w samorządach, szkołach wyższych, inkubatorach przedsiębiorczości, centrach transferu technologii oraz parkach naukowo-technologicznych.

Syntetyczną klasyfikację instytucji Narodowego Systemu Innowacji w Polsce proponuje S. Pangsy-Kania, która dzieli je następująco (tab. 2.1) ${ }^{6}$ :

\footnotetext{
${ }^{5} \mathrm{~W}$ nomenklaturze GUS wyodrębnia się także jednostki rozwojowe i pozostałe jednostki [por. Nauka i technika w 2007 r., s. 31].

${ }^{6}$ Są to zarazem instytucje kreujące polską politykę innowacyjną [por. Pangsy-Kania 2007, s. 256]
} 
Tabela 2.1. Wybrane instytucje NSI w Polsce

\begin{tabular}{|c|c|c|}
\hline $\begin{array}{l}\text { Instytucie kształtujące polską } \\
\text { politykę innowacyjną }\end{array}$ & $\begin{array}{l}\text { Instytucje wdrażające rządową } \\
\text { politykę innowacyjną }\end{array}$ & $\begin{array}{l}\text { Instytucje pozarządowe } \\
\text { działające na rzecz wzrostu } \\
\text { innowacyjności }\end{array}$ \\
\hline $\begin{array}{l}\text { Sejm (parlament), } \\
\text { Ministerstwo Gospodarki } \\
\text { (Departament } \\
\text { Innowacyjności), } \\
\text { Ministerstwo Edukacji } \\
\text { Narodowej, } \\
\text { Fundacja na Rzecz Nauki } \\
\text { Polskiej, } \\
\text { Urząd Patentowy RP }\end{array}$ & $\begin{array}{l}\text { Polska Akademia Nauk, } \\
\text { uczelnie wyższe, } \\
\text { jednostki badawczo-rozwojowe, } \\
\text { Polska Agencja Rozwoju } \\
\text { Przedsiębiorczości, } \\
\text { Polska Agencja Informacji } \\
\text { i Inwestycji Zagranicznych, } \\
\text { innowacyjny biznes }\end{array}$ & $\begin{array}{l}\text { parki naukowe } \\
\text { i technologiczne, } \\
\text { inkubatory przedsiębiorczości, } \\
\text { centra transferu technologii, } \\
\text { instytucje pomostowe, } \\
\text { akceleratory technologii, } \\
\text { krajowe punkty kontaktowe }\end{array}$ \\
\hline
\end{tabular}

Źródło: opracowanie własne na podstawie: S. Pang s y-Kania, Polityka innowacyjna państwa a narodowa strategia konkurencyjnego rozwoju, Wydawnictwo Uniwersytetu Gdańskiego, Gdańsk 2007, s. 256.

W tabeli 2.2 zaprezentowano podstawowe informacje o liczbie jednostek prowadzących w Polsce działalność badawczo-rozwojową w ostatnich kilkunastu latach. Jednostki sfery $B+R$ to ogół instytucji i osób zajmujących się pracami twórczymi, podejmowanymi dla zwiększenia zasobu wiedzy, jak również dla znalezienia nowych zastosowań tej wiedzy [Nauka i technika w 2009 roku, s. 30].

W tym miejscu warto nadmienić, że działalność badawczo-rozwojowa $(\mathrm{B}+\mathrm{R})$ obejmuje [Hage, Hollingsworth 2000, s. 972]:

- badania podstawowe - skoncentrowane na tworzeniu wiedzy w ramach określonej dyscypliny naukowej, bez odnoszenia się do jej zastosowań,

- badania stosowane - zdobywanie wiedzy przydatnej w sytuacjach praktycznych, m.in. w rozwoju technologii, która może podlegać ochronie patentowej,

- prace rozwojowe - odnoszące się do tworzenia konkretnych produktów, opartych o osiągnięcia badań stosowanych,

- badania związane z procesami produkcyjnymi i kontrolą jakości,

- badania zawiązane z komercjalizacją i marketingiem produktów.

Informacje dotyczące działalności badawczej i rozwojowej w Polsce obejmują następujące grupy jednostek prowadzących tę działalność [Rocznik statystyczny RP 2010, s. 452-453; Nauka i technika w 2009 roku, s. 30-31]:

1) Jednostki naukowe i badawczo-rozwojowe, tj. jednostki, których podstawowym rodzajem działalności jest prowadzenie prac badawczo-rozwojowych:

- placówki naukowe Polskiej Akademii Nauk (państwowe jednostki organizacyjne), obejmują instytuty, zakłady, centra, stacje badawcze, ogrody botaniczne oraz inne jednostki naukowe prowadzące badania naukowe lub prace badawczorozwojowe. Działają na podstawie ustawy z dnia 25.04.1997 r. o Polskiej Akademii Nauk. Podstawową placówką naukową PAN jest instytut posiadający osobowość 
prawną. Do zadań instytutu należy w szczególności prowadzenie badań, kształcenie pracowników naukowych oraz specjalistów o szczególnych kwalifikacjach w określonych dyscyplinach. Nadzór nad PAN w zakresie zgodności działania jej organów z przepisami ustawowymi i statutem Akademii sprawuje Rada Ministrów,

- jednostki badawczo-rozwojowe (jednostki państwowe działające na podstawie ustawy z dnia 25.07.1985 r. o jednostkach badawczo-rozwojowych). Tworzone w celu prowadzenia prac badawczych i rozwojowych, których wyniki powinny znaleźć zastosowanie w określonych dziedzinach gospodarki narodowej i życia społecznego. Posiadają osobowość prawną, ich organem nadzorującym jest minister właściwy dla zakresu działania jednostki, przy czym Rada Ministrów może tworzyć jednostki badawczo-rozwojowe mające międzyresortowy zakres działania. Jednostkami badawczo-rozwojowymi są instytuty naukowo-badawcze, w tym jednostki posiadające status państwowego instytutu badawczego, ośrodki badawczo-rozwojowe i centralne laboratoria,

- inne, tj. jednostki prywatne, zaklasyfikowane według PKD 2007 do działu 72 „Badania naukowe i prace rozwojowe”;

2) Jednostki obsługi nauki - obejmują jednostki, które do swoich podstawowych zadań zaliczają działalność informacyjną, upowszechnianie wiedzy i popularyzację osiągnięć nauki i techniki, rozwój kultury oraz inne funkcje wspomagające związane z rozwojem nauki i techniki. Są to biblioteki, archiwa naukowe, muzea, stowarzyszenia naukowe i inne jednostki obsługi nauki;

3) Jednostki rozwojowe - podmioty gospodarcze, przede wszystkim przedsiębiorstwa przemysłowe posiadające własne zaplecze badawczo-rozwojowe (laboratoria, biura konstrukcyjne, zakłady rozwoju techniki itp.) prowadzące działalność badawczą i rozwojową głównie o charakterze prac rozwojowych, obok swojej podstawowej działalności;

4) Szkoły wyższe publiczne i niepubliczne;

5) Pozostałe jednostki - obejmują państwowe i samorządowe jednostki organizacyjne, w których prowadzenie prac badawczo-rozwojowych ma znaczenie marginalne. Zaliczane są tu m.in. szpitale (prowadzące prace badawczo-rozwojowe obok swojej podstawowej działalności z wyjątkiem klinik akademii medycznych i uniwersytetów oraz Centrum Medycznego Kształcenia Podyplomowego ujętych w kategorii „szkoły wyższe” oraz szpitali posiadających status instytutów naukowo-badawczych ujętych w kategorii ,jednostki badawczo-rozwojowe"), ogrody botaniczne i parki narodowe, agencje i instytucje rządowe, jak również organy władzy. Podmioty te są często zleceniodawcami badań, stąd rejestruje się u nich zazwyczaj nakłady zewnętrzne na prace $\mathrm{B}+\mathrm{R}$.

Jak wynika z przedstawionych danych (tab. 2.2), ogólna liczba jednostek, które w 2009 r. prowadziły działalność badawczo-rozwojową w Polsce wynosiła 1298 i była największa w całym badanym okresie. Wzrost w stosunku do roku 1995 wyniósł aż 560 jednostek. Natomiast w strukturze jednostek B+R nastąpiły różnokierunkowe zmiany. W roku 2009 w porównaniu z 1995 zmniejszyła się liczba 
jednostek naukowych i badawczo-rozwojowych (z 334 do 270), w tym placówek naukowych PAN o 5, jednostek badawczo-rozwojowych o 89. Jednostki badawczo-rozwojowe działające w 2009 r. podlegały różnym ministerstwom, w tym Ministerstwu: Gospodarki - 58 jednostek, Infrastruktury - 12, Rolnictwa i Rozwoju Wsi - 16, Środowiska - 5 oraz Zdrowia - 17. Wyraźnie wzrosła liczba jednostek obsługi nauki - z 4 do 37. Wysoką dynamikę wzrostu obserwujemy w przypadku jednostek rozwojowych, których liczba wzrosła ponad dwukrotnie (z 296 w 1995 r. do 767 w 2008) oraz szkół wyższych, gdzie wzrost wyniósł 87\% (z 104 do 194).

Tabela 2.2. Liczebność jednostek prowadzących działalność badawczo-rozwojową (B+R) w Polsce w wybranych latach okresu 1995-2009

\begin{tabular}{|l|c|c|c|c|c|c|c|c|c|}
\hline \multicolumn{1}{|c|}{ Wyszczególnienie } & 1995 & 2000 & 2002 & 2003 & 2004 & 2005 & 2007 & 2008 & 2009 \\
\hline Ogółem & $\mathbf{7 3 8}$ & $\mathbf{8 6 0}$ & $\mathbf{8 3 8}$ & $\mathbf{9 2 5}$ & $\mathbf{9 5 7}$ & $\mathbf{1 0 9 7}$ & $\mathbf{1 1 4 4}$ & $\mathbf{1 1 5 7}$ & $\mathbf{1 2 9 8}$ \\
\hline $\begin{array}{l}\text { Jednostki naukowe i badawczo- } \\
\text { rozwojowe }\end{array}$ & $\mathbf{3 3 4}$ & $\mathbf{3 2 1}$ & $\mathbf{3 3 8}$ & $\mathbf{3 1 4}$ & $\mathbf{3 0 0}$ & $\mathbf{2 9 6}$ & $\mathbf{2 8 0}$ & $\mathbf{2 6 9}$ & $\mathbf{2 7 0}$ \\
\hline Placówki naukowe PAN & 81 & 81 & 81 & 80 & 78 & 76 & 75 & 73 & 76 \\
\hline Jednostki badawczo-rozwojowe & 218 & 222 & 211 & 201 & 197 & 194 & 180 & 150 & 129 \\
\hline Inne & 35 & 18 & 46 & 33 & 25 & 26 & 25 & 46 & 65 \\
\hline Jednostki obsługi nauki & $\mathbf{4}$ & $\mathbf{1 8}$ & $\mathbf{2 9}$ & $\mathbf{3 1}$ & $\mathbf{3 0}$ & $\mathbf{3 4}$ & $\mathbf{2 6}$ & $\mathbf{3 1}$ & $\mathbf{3 7}$ \\
\hline Jednostki rozwojowe & $\mathbf{2 9 6}$ & $\mathbf{4 0 2}$ & $\mathbf{3 4 5}$ & $\mathbf{4 4 6}$ & $\mathbf{4 8 0}$ & $\mathbf{6 0 3}$ & $\mathbf{6 7 0}$ & $\mathbf{6 4 0}$ & $\mathbf{7 6 7}$ \\
\hline Szkoły wyższe & $\mathbf{1 0 4}$ & $\mathbf{1 1 4}$ & $\mathbf{1 1 9}$ & $\mathbf{1 2 8}$ & $\mathbf{1 2 8}$ & $\mathbf{1 4 3}$ & $\mathbf{1 5 0}$ & $\mathbf{1 9 5}$ & $\mathbf{1 9 4}$ \\
\hline Pozostałe jednostki & - & $\mathbf{5}$ & $\mathbf{7}$ & $\mathbf{6}$ & $\mathbf{1 9}$ & $\mathbf{2 1}$ & $\mathbf{1 8}$ & $\mathbf{2 2}$ & $\mathbf{3 0}$ \\
\hline
\end{tabular}

Źródło: Nauka i technika w 2007 roku, GUS, Warszawa 2009, s. 31; Nauka i technika w 2008 roku, GUS, Warszawa 2010, s. 32; Rocznik statystyczny RP 2010, Warszawa 2010, s. 458.

W ostatnich latach wzrasta rola i znaczenie regionów w gospodarce i tym samym regionalnych systemów innowacji. Jest to następstwem sukcesów odnoszonych przez wiele obszarów przemysłowych w Ameryce Północnej, Europie i Azji. Obszary te pod wpływem innowacji przekształcały się z terenów rolniczych w nowoczesne centra przemysłowe, co było związane $\mathrm{z}$ dostępem do najnowszej wiedzy oraz kapitału finansowego i ludzkiego. $Z$ rozwojem regionalnego systemu innowacji ściśle powiązane jest pojęcie klastra. Jest to grupa firm współpracujących ze sobą w sieci na danym terenie. Sukces gospodarczy tych firm jest przede wszystkim efektem interakcji zachodzących między nimi, które są ułatwione przez gospodarczą i geograficzną bliskość. Klastry często obejmują alianse strategiczne przedsiębiorstw z uczelniami, instytucjami $\mathrm{B}+\mathrm{R}$ oraz klientami. Są one ważnym elementem NSI.

Liczba klastrów w Polsce systematycznie się zwiększa. Inicjatywy klastrowe napotykają na różne bariery, takie jak np. bariery regulacyjno-administracyjne i legislacyjne, techniczne i kulturowe. Jednak największą barierę stanowi niska skłonność do współpracy polskich przedsiębiorstw i placówek 
naukowych [Kładź, Kowalski 2010, s. 267-268]. Polityka wspierania klastrów jest $\mathrm{w}$ Polsce prowadzona od niedawna i traktuje się ją jako element polityki innowacyjnej ${ }^{\top}$.

Z dotychczasowych rozważań wynika, że Narodowy System Innowacji w Polsce tworzą podmioty zróżnicowane z punktu widzenia celów i rodzaju działalności, które podlegają różnym ministerstwom, przede wszystkim o charakterze gospodarczym. Wydaje się, że działalność wielu jednostek nie jest podporządkowana realizacji potrzeb przedsiębiorstw czy celów publicznych, jest ona natomiast kierowana przez naukowców i badaczy.

A. Wilmańska, zastępca Prezesa Polskiej Agencji Rozwoju Przedsiębiorczości, ekspert OECD, współredagująca Strategię Innowacyjności OECD, zauważa w „Polish Market” (2010, nr 6), że na obecnym etapie rozwoju polskiej gospodarki istnieje potrzeba zmodyfikowanego podejścia do zagadnienia innowacji.

Wyzwania, przed którymi dzisiaj stoimy wymagają innego podejścia do innowacji. Potrzebujemy nie tyle polityki innowacyjnej co polityki na rzecz innowacji. Kluczowe jest spojrzenie na innowacje w sposób całościowy, kompleksowy, horyzontalny a nie z punktu widzenia poszczególnych sektorów. To podejście powinno być znacznie szersze niż tylko przez pryzmat high-tech. Trzeba tutaj dostrzegać i nową wiedzę, umiejętności, aktywa niematerialne związane z własnością intelektualną. Tylko w taki sposób znajdziemy bardziej efektywne instrumenty pozwalające rozwiązywać problemy współczesnej gospodarki. Takie podejście wymaga ścisłej współpracy aktorów zarówno lokalnych, jak i międzynarodowych systemów innowacji. Tworzenie dobrych warunków dla rozwoju innowacyjności nie może być tylko domeną Ministerstwa Gospodarki. Potrzebna jest aktywność także innych resortów, np. Ministerstwa Infrastruktury, Kultury, Nauki i Szkolnictwa Wyższego. To szersze podejście jest charakterystyczne dla nowej Strategii Innowacyjności przygotowanej przez OECD [Krupowicz 2010].

\subsubsection{Nakłady, zatrudnienie w działalności $B+R$ krajów Unii Europejskiej}

Oceniając skuteczność NSI należy zwrócić uwagę przede wszystkim na kategorie, które przez ekonomistów są traktowane jako determinanty innowacyjności. Kategoriami tymi są nakłady na badania i rozwój $(\mathrm{B}+\mathrm{R}) \mathrm{w} \% \mathrm{PKB}$, struktura tych nakładów oraz zatrudnienie w działalności badawczo-rozwojowej. Tocząca się dyskusja na temat nakładów na $\mathrm{B}+\mathrm{R}$ pokazuje $-\mathrm{z}$ jednej strony - zróżnicowanie poziomu tych nakładów między krajami, najczęściej w relacji

\footnotetext{
${ }^{7}$ Konieczność wspierania klastrów w Polsce wskazano w dokumencie strategicznym pt. Kierunki zwiększenia innowacyjności gospodarki na lata 2007-2013, który został przyjęty przez rząd w dniu 4.09.2006 r.
} 
do PKB, ale - z drugiej - próbuje wskazać możliwości zwiększenia tychże nakładów. Dyskutuje się również na temat docelowego i optymalnego poziomu nakładów na $\mathrm{B}+\mathrm{R}$ w relacji do $\mathrm{PKB}$ oraz wynikających $\mathrm{z}$ tego tytułu korzyści dla gospodarek narodowych. Udział nakładów na B+R w PKB jest uznawany za jeden z najbardziej syntetycznych mierników działalności badawczo-rozwojowej każdego kraju.

Na rysunku 2.2 przedstawiony został udział nakładów na B+R w PKB w poszczególnych krajach UE w roku 2007.

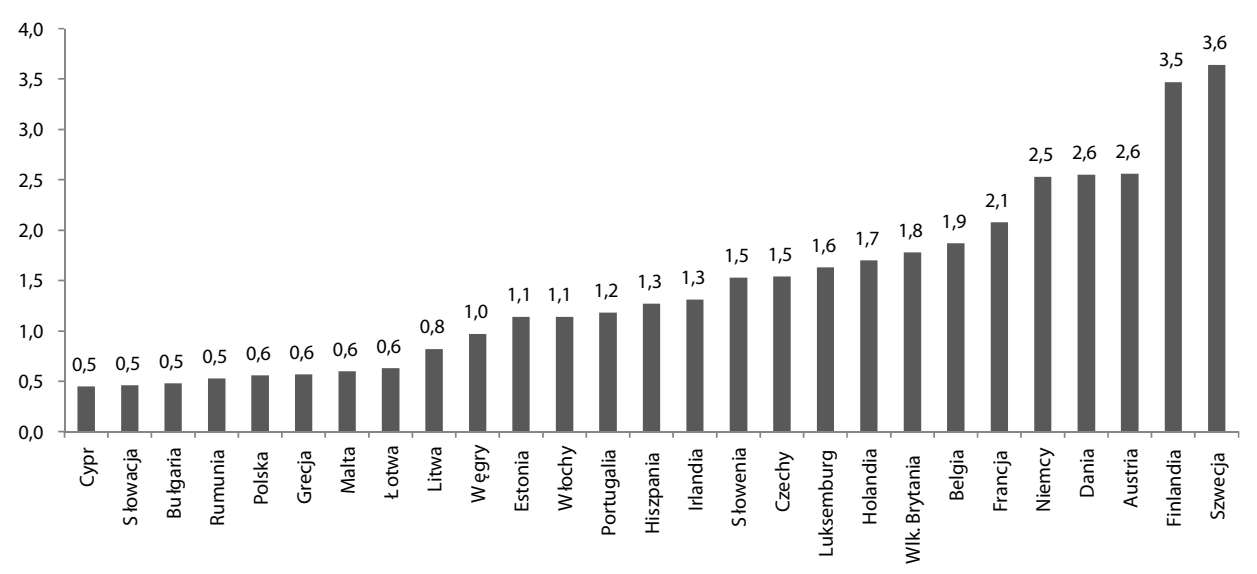

Rysunek 2.2. Relacja nakładów na B+R do PKB w krajach UE w 2007 r.

Źródło: opracowanie własne na podstawie danych Eurostatu i GUS.

Jak wynika $\mathrm{z}$ informacji przedstawionych na rys. 2.2, w roku 2007 w Szwecji i Finlandii nakłady na działalność B+R w relacji do PKB wyraźnie dominowały nad nakładami w pozostałych krajach UE (odpowiednio 3,64 i 3,47$)$. W Austrii, która zajęła trzecie miejsce, nakłady były również wysokie, bowiem stanowiły $2,56 \%$ PKB, ale w porównaniu ze Szwecją i Finlandią były zdecydowanie niższe (odpowiednio o 1,08 i 1,01 pkt. proc.). Podobny do Austrii poziom nakładów na $\mathrm{B}+\mathrm{R}$ miał miejsce w Danii $(2,55 \%)$ i Niemczech $(2,53 \%)$. W krajach „starej Unii” nakłady były wyższe niż w pozostałych krajach członkowskich UE, wyjątek stanowią jedynie Czechy i Słowenia. Zatem w grupie krajów Europy Środkowo-Wschodniej, należących do Unii Europejskiej, najwyższą pozycję z punktu widzenia relacji nakładów na działalność $\mathrm{B}+\mathrm{R}$ do $\mathrm{PKB}$ zajmują Czechy $(1,54 \%)$ i Słowenia $(1,53 \%)$, które wyprzedzają pod względem nakładów nawet takie kraje jak: Irlandia $(1,31 \%)$, Hiszpania $(1,27 \%)$, Portugalia $(1,18 \%)$ i Włochy $(1,14 \%)$. Stosunkowo niski poziom nakładów na $\mathrm{B}+\mathrm{R}$ w Hiszpanii, która zajmuje pod tym względem 14 miejsce w UE, 
obciąża efektywność NSI w tym kraju. Natomiast, omówione również wcześniej, NSI Niemiec i Szwecji charakteryzują się bardzo wysokim udziałem nakładów na $\mathrm{B}+\mathrm{R}$ w $\mathrm{PKB}$, co zapewne sprzyja aktywności innowacyjnej w tych państwach.

Polska pod względem nakładów na $\mathrm{B}+\mathrm{R}$ jest na szarym końcu krajów UE, zajmuje bowiem dopiero 23. miejsce $\mathrm{z}$ nakładami na poziomie zaledwie $0,56 \%$ PKB. Tak niski poziom badanego wskaźnika uniemożliwia sprawne funkcjonowanie NSI w Polsce i tym samym wzrost innowacyjności gospodarki. Strategia lizbońska, której głównym celem było osiągnięcie wysokiego stopnia konkurencyjności UE w zakresie badawczym, a w szczególności uzyskanie przez wszystkie kraje członkowskie wskaźnika wydatków na $\mathrm{B}+\mathrm{R}$ w relacji do PKB w wysokości 3\%, jak wynika z powyższej analizy, nie zostanie zrealizowana. Wśród krajów UE tylko Szwecja i Finlandia osiągnęły, zakładany w strategii lizbońskiej, poziom tego wskaźnika, natomiast Austria, Dania i Niemcy są najbliżej jego spełnienia. Niestety, większość państw (15) nie osiągnęła nawet połowy tego progu.

Analizując poziom nakładów na $\mathrm{B}+\mathrm{R}$ w kontekście funkcjonowania NSI w krajach UE nie możemy poprzestać na ich udziale w PKB, gdyż bardzo ważny jest nie tylko poziom, ale również struktura finansowania tychże nakładów. Niestety jest ona niekorzystna dla Polski. W roku 2007 tylko 33,1\% (a w 2009 r. 28,5\%) środków pochodziło z sektora przedsiębiorstw, pozostała cześć z sektora publicznego, głównie ze strony państwa. Spośród nowych krajów członkowskich UE niższy udział finansowania nakładów na $\mathrm{B}+\mathrm{R}$ przez sektor przedsiębiorstw odnotowano na Litwie $(24,5 \%)$, w Rumunii $(26,9 \%)$ i Bułgarii $(30,6 \%)$. Tymczasem w najbardziej innowacyjnych gospodarkach europejskich struktura finansowania nakładów na $\mathrm{B}+\mathrm{R}$ przez państwo i przedsiębiorstwa jest dokładnie odwrotna. W Niemczech sektor przedsiębiorstw finansuje nakłady na $\mathrm{B}+\mathrm{R}$ w 68,1\%, w Szwecji 65,8\%, w Finlandii 68,2\%.

Struktura finansowania nakładów na $\mathrm{B}+\mathrm{R}$ przedstawia się w Polsce w zasadzie dokładnie odwrotnie niż struktura uznawana aktualnie przez ekspertów zachodnich jako optymalna z punktu widzenia efektywności badań naukowych, tzn. ich przydatności do gospodarki. Zgodnie z najnowszymi ustaleniami optymalna proporcja funduszy określanych jako „prywatne” i ,publiczne” przedstawia się 65: 35. Zdaniem wspomnianych ekspertów, jeśli udział środków określanych jako prywatne, czyli pochodzące spoza budżetu państwa, w nakładach ogółem na działalność $\mathrm{B}+\mathrm{R}$ jest niższy niż $65 \%$, to tzw. globalna efektywność tych nakładów jest wyraźnie mniejsza.

Kolejnym ważnym elementem oceny NSI są zasoby ludzkie. Porównując zasoby ludzkie dla nauki i techniki (Human Resources for Science and Technology) w poszczególnych krajach UE zauważamy, iż w roku 2007 najlepsze wyniki w tym zakresie osiągnęła Finlandia, gdzie zasoby HRST stanowiły 50,1\% siły roboczej. Kolejne miejsca pod tym względem zajęły: Holandia (49,8\%), Dania 
(48,8\%), Szwecja (48,7\%), Belgia (46,1\%) Estonia (44,4\%), Niemcy (43,6\%). W Hiszpanii zasoby HRST stanowiły $39,7 \%$ siły roboczej i wynik ten oscyluje wokół średniej unijnej. Natomiast w Polsce wskaźnik ten był jeszcze niższy wyniósł $32,5 \%$, co zapewne jest odbiciem starych postaw proinnowacyjnych w naszym kraju.

W porównaniach NSI bardzo ważnym wskaźnikiem jest liczba wniosków patentowych zgłoszonych do EPO (European Patent Office - Europejski Urząd Patentowy). Wskaźnik ten jest miarą oceniającą rezultaty, efektywność nakładów i zatrudnienia w działalności badawczo-rozwojowej poszczególnych krajów UE.

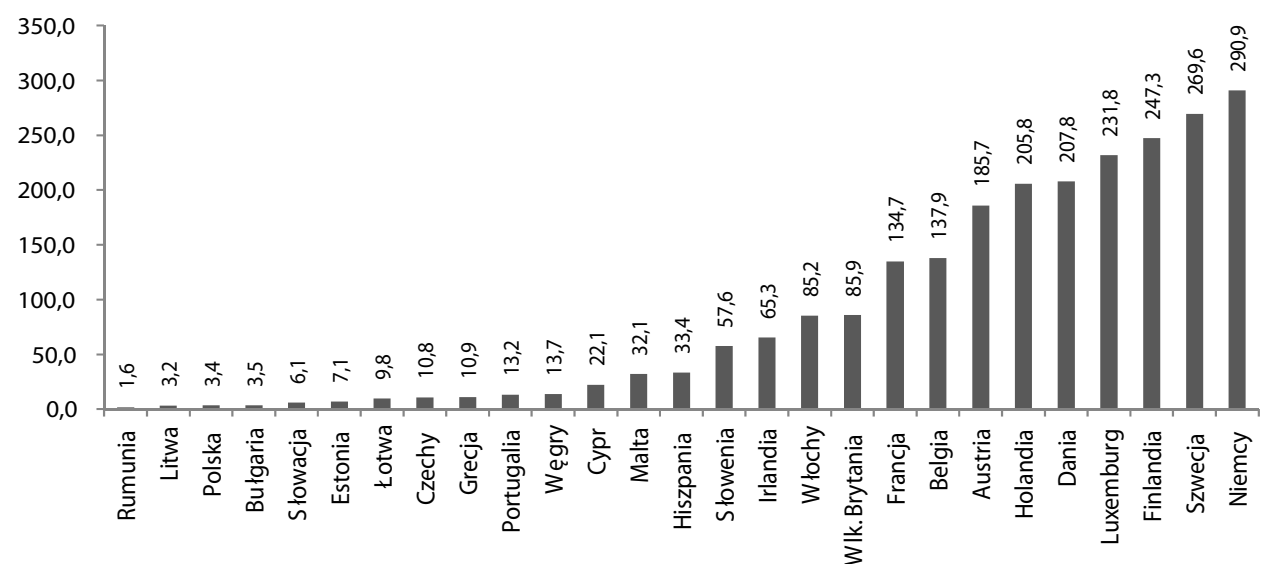

Rysunek 2.3. Liczba wniosków patentowych zgłoszonych do EPO w przeliczeniu na 1 mln mieszkańców w 2006 r.

Ź ródło: opracowanie własne na podstawie danych Eurostatu.

Obserwujemy ogromne zróżnicowanie krajów UE pod względem liczby wniosków patentowych złożonych do EPO w przeliczeniu na 1 milion mieszkańców w 2006 r.. Możemy mówić wręcz o przepaści dzielącej nowe kraje członkowskie UE od najbardziej innowacyjnych gospodarek europejskich. Z prezentowanych na rys. 2.3. informacji wynika, że najwyższą aktywnością patentową w Europie charakteryzuje się gospodarka niemiecka (290). Wynik ten potwierdza, że NSI w Niemczech działa sprawnie, a nakłady poniesione na działalność badawczo-rozwojową dają pozytywne efekty w postaci nowych rozwiązań naukowo-technicznych. Bardzo wysoko należy również ocenić NSI Szwecji, bowiem z wynikiem 270 wniosków patentowych zajmuje ona drugie miejsce w Europie. NSI w tych dwóch krajach wyróżnia właściwa organizacja, wsparcie pośrednie 
i bezpośrednie podstawowych podmiotów systemu oraz zaangażowanie władz regionalnych w kształtowanie postaw proinnowacyjnych. Zdecydowanie gorzej na tym tle przedstawia się NSI Hiszpanii. W analizowanym roku Hiszpania złożyła zaledwie 33 wnioski patentowe i jest to wynik wyraźnie gorszy od średniej unijnej, która wyniosła 88 wniosków. Wyniki dla Polski $(3,4)$, która zajęła trzecie miejsce od końca i wyprzedziła tylko Litwę i Rumunię, są tragiczne. Zatem NSI w Polsce i w większości krajów Europy Środkowo-Wschodniej nie odpowiadają standardom europejskim - ich efektywność, jak wynika z dotychczasowej analizy, nie wskazuje na możliwości rozwoju.

\subsection{Teoria i praktyka statystyczna badań nad innowacyjnością}

Pobudzanie działalności innowacyjnej w różnych dziedzinach gospodarki jest na przestrzeni ostatnich kilku lat jednym z głównych celów polityki gospodarczej nie tylko w krajach UE, ale także w pozostałych krajach OECD ${ }^{8}$. Realizacja tego celu wymaga regularnych badań statystycznych, dostarczających wiarygodnych danych obrazujących działalność innowacyjną na różnych poziomach (mikro, mezo i makro) i w różnych sektorach/działach gospodarki [Działalność innowacyjna przedsiębiorstw w latach 2004-2006, s. 1]. Intensywne promowanie działalności innowacyjnej, zwłaszcza w przedsiębiorstwach, wymusiło powstanie międzynarodowych systemów jej monitorowania. Pierwsze próby opracowania metodologii badania innowacyjności przedsiębiorstw sięgają początku lat 60. poprzedniego wieku. Metodologia badań innowacyjności jest cały czas rozwijana i doskonalona, ale nadal daleka od ideału. Poniżej opisano metodologie statystycznych badań innowacji prowadzonych w krajach OECD i krajach Unii Europejskiej, w tym również w Polsce.

\subsubsection{Metodologia OECD}

W ostatnich latach nauka, technika i innowacje uznawane są za główne czynniki determinujące poprawę konkurencyjności gospodarek. W związku z tym zaobserwować można systematyczny wzrost zainteresowania wskaźnikami naukowo-technicznymi oraz zapotrzebowania na nie. Badania w tym zakresie są prowadzone na szczeblu międzynarodowym (OECD, ONZ, UE) i krajowym (organizacje rządowe i pozarządowe).

\footnotetext{
${ }^{8}$ OECD to międzynarodowa organizacja skupiająca 30 wysoko rozwiniętychi demokratycznych państw, powstała w 1961 r.. Jest sukcesorką Organizacji Europejskiej Współpracy Gospodarczej, powołanej w 1948 r. dla integrowania odbudowujących się ze zniszczeń wojennych gospodarek krajów europejskich, które korzystały z planu Marshalla.
} 
Największy wkład w opracowanie metodologii i rozwój badań innowacyjności ma Organizacja Współpracy Gospodarczej i Rozwoju (OECD). Opracowywane przez OECD raporty, studia, analizy i prognozy obejmują różne dziedziny życia społeczno-ekonomicznego. Obecnie kluczową dziedziną badań jest statystyka nauki i techniki (w skrócie $\mathrm{N}+\mathrm{T}$ ), która zajmuje się ilościowym opisem zjawisk związanych z funkcjonowaniem tzw. systemów nauki i techniki (Science and Technology Systems - STS). Statystyka nauki i techniki obejmuje [Kozioł 2009, s. 130]:

- statystykę działalności badawczej i rozwojowej (B+R),

- statystykę innowacji (działalności innowacyjnej),

- statystykę patentów (ochrona własności przemysłowej),

- bilans płatniczy w dziedzinie techniki $(T B P)$,

- wysoką technikę (produkcja, zatrudnienie i handel zagraniczny) i usługi oparte na wiedzy $(H T \& K I S)$,

- wskaźniki dotyczące tzw. zasobów ludzkich dla nauki i techniki (HRST),

- bibliometrię (naukometria).

Uzyskane w wyniku badań dane służą do konstruowania wskaźników naukowo-technicznych. Zgodnie z definicją stosowaną przez OECD wskaźniki naukowo-techniczne są to ,szeregi danych zaprojektowane i zbierane w celu znalezienia odpowiedzi na pytania dotyczące systemu nauki i techniki, jego wewnętrznej struktury oraz związków z gospodarką, środowiskiem naturalnym i społeczeństwem, a także stopnia, w jakim realizuje on cele stawiane przez tych, którzy nim zarządzają, pracują w jego obrębie lub znajdują się w obszarze jego oddziaływania". Wyznaczone w oparciu o standardową metodologię wskaźniki z zakresu $\mathrm{N}+\mathrm{T}$ umożliwiają międzynarodowe porównania i ocenę poziomu nauki, techniki i innowacyjności w wybranych krajach.

Badania nad miernikami N+T rozpoczęto w latach 60. XX w. W $1963 \mathrm{r}$. we włoskim miasteczku Frascati powstała pierwsza wersja Proposed Standard Practice for Surveys of Research and Development, znana jako Frascati Manual.

Do tej pory ukazało się sześć wersji przewodnika. Ostatnia, obowiązująca obecnie wersja podręcznika pochodzi z 2002 r. Od piątej edycji wydanej w 1994 r. koncentrowano się na badaniach i rozwoju $(B+R)$ oraz innowacyjności, jako najważniejszych elementach gospodarki opartej na wiedzy (GOW). Wersja szósta kładzie nacisk na statystykę $\mathrm{B}+\mathrm{R}$ w sektorze usług oraz zasoby ludzkie dla sfery badawczo-rozwojowej. Współpraca OECD z innymi międzynarodowymi i regionalnymi organizacjami i ugrupowaniami, w tym z UE, spowodowała, że

${ }^{9}$ Zob. Science and Technology Indicators for Policy Making, Workshop III, Introductory Document, prepared by The Scientific, Technological and Industrial Indicators Division (OECD) under the supervision of Dr. G. Sirilli (National Research Council, Italy), Vienna - Bratislava Conference, „Economies in Transition - Science, Technology and Innovation Policies”, 4-6 March 1991. 
metodologia Frascati Manual stała się standardem na świecie [Frascati Manual 2002]. Ta współpraca odbywa się w ramach grupy NESTI (National Experts on Science and Technology Indicators). Jej ekspertami mogą być producenci, użytkownicy danych, delegaci krajowi. Ze strony polskiej w pracach NESTI uczestniczy GUS oraz KBN jako przedstawiciel użytkowników danych. Efektem współpracy jest przede wszystkim opracowanie kompleksowej metodologii badań, która jest opisana w serii podręczników metodologicznych zwanych potocznie Frascati Family. Seria ta obejmuje podręczniki dotyczące [Kozioł 2009, s.130]:

- metodologii badań nad działalnością B+R (Frascati Manual),

- metodologii badań nad innowacjami (Oslo Manual),

- innowacji w krajach rozwijających się (Bogota Manual),

- zasobów ludzkich (Canberra Manual),

- bilansu płatniczego w dziedzinie techniki (TBP Manual),

- statystyki patentowej (Patent Manual).

Pod patronatem i przy współpracy NESTI organizowane są również specjalistyczne konferencje i seminaria poświęcone wybranym zagadnieniom z dziedziny statystyki nauki i techniki. Grupa NESTI wskazuje na ciągłą potrzebę doskonalenia metod badawczych i podejmuje prace nad opracowaniem nowej generacji wskaźników dla tzw. gospodarki opartej na wiedzy.

Podstawowym wskaźnikiem wykorzystywanym przez Podręcznik Frascati do analizy działalności badawczo-rozwojowej jest tzw. wskaźnik GERD mierzący krajowe nakłady brutto na działalność $\mathrm{B}+\mathrm{R}$ (niezależnie od źródła pochodzenia środków). Relacja GERD/PKB jest jednym z najważniejszych wskaźników międzynarodowej statystyki porównawczej.

Najważniejszym podręcznikiem z rodziny Frascati dotyczącym badań statystycznych działalności innowacyjnej jest Oslo Manual: Proposed guidelines for collecting and interpreting technological innovation data (Podręcznik Oslo. Zasady gromadzenia i interpretacji danych dotyczacych innowacji ). Pierwsze wydanie tego podręcznika ukazało się w 1992 r. i zostało opracowane przez OECD i Nordycki Fundusz Przemysłu. Podręcznik dotyczył innowacji wprowadzanych w przemyśle. Wydanie drugie pochodzi z 1997 r. i jest efektem współpracy OECD i Eurostatu. W wydaniu tym uaktualniono definicje i metodologię na podstawie doświadczeń badawczych, co miało służyć lepszemu zrozumieniu procesu innowacyjnego oraz uwzględnieniu szerszego spektrum rodzajów działalności, w tym przede wszystkim objęciu badaniem działalności innowacyjnej w sektorze usług. Zwrócono również uwagę na problemy związane ze stosowaniem wskaźników innowacji w polityce publicznej [Nauka i technika w 2008 roku, s. 139]. Polska wersja drugiego wydania Podręcznika Oslo opublikowana została przez Komitet Badań Naukowych w 1999 r.

Aktualnie obowiązuje trzecia wersja podręcznika Oslo Manual 2005, która ukazała się pod koniec 2005 r. Pełna nazwa najnowszej trzeciej edycji podręcznika brzmi: Oslo Manual: Proposed guidelines for collecting and interpreting 
technological innovation data (Podręcznik Oslo. Zasady gromadzenia i interpretacji danych dotyczacych innowacji). W tym wydaniu podręcznika dokonano poszerzenia systemu pomiaru innowacji. Po pierwsze, wskazano ważną rolę, jaką w działalności innowacyjnej przedsiębiorstw odgrywają powiązania z innymi firmami i instytucjami. W podręczniku wymieniono czynniki stymulujące procesy innowacyjne na poziomie firmy i jej otoczenia. Po drugie, zwrócono uwagę na ogromne znaczenie innowacji wprowadzanych w sektorach, gdzie skala działalności $\mathrm{B}+\mathrm{R}$ jest niewielka, np. w sektorze usług czy w produkcji o niskim udziale czynnika technologicznego. Po trzecie, definicję innowacji rozszerzono o dwa dodatkowe rodzaje: innowacje organizacyjne i innowacje marketingowe [Oslo Manual 2005, s. 28-32]. Polska wersja tego podręcznika została opublikowana przez Ministerstwo Nauki i Szkolnictwa Wyższego w roku 2008.

Metodologia zawarta w podręczniku, określana metodologią Oslo, stanowi obecnie powszechnie przyjęty międzynarodowy standard metodologiczny stosowany we wszystkich krajach prowadzących badania statystyczne innowacji. Opracowana w oparciu o nowoczesne, interakcyjne modele działalności innowacyjnej obejmuje zestaw definicji i zaleceń metodycznych dotyczących statystycznych badań innowacji.

W odróżnieniu od badań statystycznych działalności B+R czy wynalazczej (statystyka patentów) dotyczących aktywności związanej z tworzeniem wartości nowych na skalę światową, przedmiotem badań innowacji opartej na metodologii Oslo jest cała gama nowości. Są to zarówno nowości na skalę światową (innowacje absolutne), nowości wyłącznie z punktu widzenia danego przedsiębiorstwa (innowacje imitacyjne), jak i innowacje kreacyjne (innovation as creative effort) będące wynikiem twórczej, wynalazczej aktywności badanych przedsiębiorstw, a także innowacje będące wynikiem procesów dyfuzji (innovation as diffusion), których wprowadzenie wymaga ze strony wdrażających je przedsiębiorstw wynalazczej aktywności [Działalność innowacyjna..., 2008, s. 2].

W metodologii Oslo wyróżnia się dwa podejścia do pomiaru innowacyjności firm:

- metoda podmiotowa (subject approach),

- metoda przedmiotowa (object approach).

W metodzie podmiotowej badaniu podlega działalność innowacyjna i zachowania innowacyjne przedsiębiorstwa. Bada się czynniki kształtujące działalność innowacyjną na poziomie przedsiębiorstwa (cele innowacyjności, bariery, strategie) oraz zakres różnych aktywności innowacyjnych. Efektem zastosowania tej metody jest możliwość porównań innowacyjności przedsiębiorstw w danym przemyśle oraz między jego działami. Przykładem praktycznego zastosowania metody podmiotowej są badania działalności innowacyjnej przedsiębiorstw prowadzone w krajach UE i EFTA w ramach programu Community Innovation Survey, jak również badania statystyczne innowacji prowadzone przez GUS [Nauka i technika w 2009 roku, s. 121-122]. 
Metoda przedmiotowa polega na zliczaniu poszczególnych innowacji wprowadzonych na rynek. Została ona wdrożona w badaniu LBIO - Literature-Based Innovation Output Indicators, którego celem jest zbieranie informacji o poszczególnych wprowadzonych na rynek innowacjach na podstawie ogłoszeń zamieszczonych przez przedsiębiorstwa w prasie fachowej - technicznej i handlowej [Działalność innowacyjna ... 2008, s. 3]. W obowiązującej wersji Podręcznika Oslo Manual 2005 poszerzono, w stosunku do poprzedniego wydania, zakres badań. Zakres ten dotyczy nie tylko sektora przedsiębiorstw w przemyśle, ale również firm w sektorze usług rynkowych, co powoduje, że badaniem objęte są także tzw. innowacje nietechnologiczne (non-technological), a mianowicie innowacje organizacyjne i marketingowe. W Podręczniku Oslo innowacje nietechnologiczne definiuje się jako wszelką działalność innowacyjną przedsiębiorstw, która nie jest związana z opracowywaniem i wprowadzaniem na rynek nowych lub istotnie zmienionych wyrobów i usług albo wdrażaniem nowych lub istotnie zmienionych procesów. To przede wszystkim innowacje organizacyjne, menedżerskie i marketingowe, takie jak:

- wdrażanie zaawansowanych technik zarządzania, np. TQM (kompleksowe zarządzanie jakością) czy TQS (system zarządzania kontyngentami taryfowymi i nadzoru importu),

- wprowadzanie istotnie ulepszonych struktur organizacyjnych,

- wdrażanie nowych lub istotnie zmienionych strategii działania przedsiębiorstwa,

- istotna zmiana koncepcji/strategii marketingowej przedsiębiorstwa,

- istotna zmiana o charakterze estetycznym lub inne twórcze modyfikacje produktów przedsiębiorstwa, niebędące innowacjami technicznymi.

Zmiany o charakterze usługowym uznaje się za innowacje, wówczas gdy wywierają pozytywny, dający się zmierzyć wpływ na wyniki przedsiębiorstwa, np. wzrost sprzedaży.

Innowacje w sektorze usług różnią się od innowacji sektora przedsiębiorstw przede wszystkim niematerialnością oraz jednoczesnością procesu świadczenia i konsumpcji, a to zwiększa trudności badania i analizowania tego rodzaju usług [Oslo Manual 2005, s. 148-151].

Zgodnie z zaleceniami metodologicznymi Oslo innowacją technologiczną jest wprowadzenie na rynek nowego lub ulepszonego produktu, jak również zastosowanie w produkcji nowego lub ulepszonego procesu, przy czym ów produkt i proces są nowe przynajmniej z punktu widzenia wprowadzającego je przedsiębiorstwa. Innowacje technologiczne powstają w wyniku działalności innowacyjnej obejmującej szereg działań o charakterze badawczym, technicznym, organizacyjnym, finansowym i handlowym. Zatem innowacje technologiczne dotyczą produktów i procesów nowych lub ulepszonych. Innowacja technologiczna oznacza obiektywne udoskonalenie właściwości produktu lub procesu bądź systemu dostaw w stosunku do produktów i procesów dotychczas istniejących. Mniejsze 
techniczne lub estetyczne modyfikacje produktów i procesów, nie wpływające na osiągi, właściwości, koszty lub też na zużycie materiałów, energii i komponentów nie są traktowane jako innowacje technologiczne. Innowacje technologiczne mogą występować we wszystkich rodzajach działalności przedsiębiorstwa, tzn. zarówno w działalności podstawowej, jak i drugorzędnej i dalszych, a także działalności pomocniczej prowadzonej przez m.in. działy sprzedaży, rachunkowości, informatyczne, np. komputeryzacja działu sprzedaży lub działu finansowego przedsiębiorstwa może być uznana za innowację technologiczną [Nauka i technika w 2009 roku, s. 126].

Według metodologii Oslo działalność innowacyjna to szereg działań, których celem jest opracowanie i wdrożenie innowacji. Niektóre z tych działań są innowacyjne same w sobie, inne zaś mogą nie zawierać elementu nowości, lecz są niezbędne do opracowania i wprowadzenia innowacji. Działalność innowacyjna może być prowadzona przez samo przedsiębiorstwo na jego własnym terenie (wewnątrz firmy, tzw. in-house innovation) lub polegać na nabyciu dóbr, usług, w tym usług konsultingowych, bądź wiedzy ze źródeł zewnętrznych, co bywa określane jako nabycie technologii zewnętrznej w postaci materialnej lub niematerialnej [Nauka i technika w 2009 roku, s. 119].

Jednym z objawów innowacyjności gospodarki są dziedziny charakteryzujące się dużym nasyceniem $\mathrm{B}+\mathrm{R}$ ( $\mathrm{R} \& \mathrm{D}$ intensity), czyli tzw. wysoka technika. Metodologia dziedzin i produktów wysokiej techniki znajduje się w jednym z podręczników z rodziny Frascati: Revision of the High-Technology Sector and Product Classification. Podręcznik został opublikowany przez OECD w 1997 r. Pojęcie wysokiej techniki stosowane było pierwotnie przede wszystkim do analiz handlu zagranicznego, ale obecnie coraz częściej wskazuje się na przydatność wskaźników z tego zakresu również do analiz konkurencyjności gospodarek.

Oprócz wysokiej intensywności $\mathrm{B}+\mathrm{R}$ dziedziny zaliczane do wysokiej techniki charakteryzują się ponadto [Nauka i technika w 2009 roku, s. 186]:

- wysokim poziomem innowacyjności,

- krótkim cyklem życiowym wyrobów i procesów i szybką dyfuzją innowacji technologicznych,

- wzrastającym zapotrzebowaniem na wysoko kwalifikowany personel, szczególnie w zakresie nauk technicznych i przyrodniczych,

- dużymi nakładami kapitałowymi, wysokim ryzykiem inwestycyjnym i szybkim ,starzeniem się" inwestycji,

- ścisłą współpracą naukowo-techniczną, w obrębie poszczególnych krajów i na arenie międzynarodowej, pomiędzy przedsiębiorstwami i instytucjami badawczymi,

- wzmagającą się konkurencją w handlu międzynarodowym.

W szacunkach dotyczących intensywności $\mathrm{B}+\mathrm{R}$ stosowane są dwa podejścia: według dziedzin przemysłu (the industry approach) oraz według wyrobów (the product approach). OECD stosuje obecnie dwie klasyfikacje dziedzin przemysłu w oparciu o zawartość B+R [Nauka i technika w 2009 roku, s. 187]. 
Pierwsza, starsza klasyfikacja, zalecana dla lat 1970-1980, dzieli przemysł na trzy kategorie:

- wysoką technikę (high technology) - obejmującą dziedziny, w których nakłady na działalność B+R stanowią ponad 4\% wartości sprzedaży,

- średnią technikę (medium technology) - obejmującą dziedziny, w których nakłady na działalność B+R stanowią od 1\% do 4\% wartości sprzedaży,

- niską technikę (low technology) - obejmującą dziedziny, w których nakłady na działalność B+R stanowią 1\% lub mniej wartości sprzedaży.

Według tej klasyfikacji do wysokiej techniki zaliczono przemysł lotniczy, produkcję komputerów i maszyn biurowych, przemysł farmaceutyczny, przemysł elektroniczny, produkcję aparatury naukowo-badawczej oraz maszyn elektrycznych.

Z kolei druga lista przeznaczona dla lat 1980-1995, w odróżnieniu od pierwszej opracowana została w oparciu o obliczenia uwzględniające nie tylko bezpośrednią, ale i pośrednią zawartość B+R. Obejmuje ona 4 następujące kategorie:

- wysoką technikę (high-technology industries),

- średniowysoką technikę (medium-high-technology industries),

- średnioniską technikę (medium-low-technology industries),

- niską technikę (low-technology industries).

Zgodnie z powyższą klasyfikacją wysoka technika nie obejmuje już produkcji aparatury naukowo-badawczej oraz produkcji maszyn elektrycznych, które przesunięte zostały do kategorii średniowysokiej techniki. Jeśli chodzi o różnice pomiędzy obiema listami, niektóre dziedziny, zaliczane dotąd do niskiej techniki, zmieniły nieco swoje położenie i w nowym ujęciu przesunięte zostały do kategorii średnioniskiej techniki (np. przemysł stoczniowy). Lista została opracowana dla kilkunastu najbardziej rozwiniętych krajów OECD: Stanów Zjednoczonych, Japonii, Niemiec, Francji, wielkiej Brytanii, Kanady, Włoch, Holandii, Australii i Danii [Nauka i technika w 2009 roku, s. 187].

Najnowsza lista dziedzin przemysłu według poziomów techniki została opublikowana przez OECD w 1997 r. i różni się przede wszystkim od poprzedniej zaklasyfikowaniem kilku dziedzin do wyższego niż dotychczas poziomu (np. przesunięcie działu 33 - Produkcja instrumentów medycznych, precyzyjnych i optycznych, zegarów i zegarków ze średniowysokiej techniki do wysokiej techniki (por. tab. 2. 3).

Metoda według dziedzin posiada jednak wady. Największą jest wysoki stopień agregacji danych. Kolejną jest to, że wiele produktów produkowanych przez firmy zaliczane do dziedziny wysokiej techniki reprezentuje w rzeczywistości średnią lub niską technikę i odwrotnie. Wynika to w głównej mierze z faktu, że całość nakładów na działalność $\mathrm{B}+\mathrm{R}$ w danym sektorze jest przypisywana do podstawowego rodzaju działalności firm składających się na ten sektor i w konsekwencji dochodzi do przeszacowań intensywności technologicznej w jednych sektorach kosztem jej niedoszacowania w innych. 
Tabela 2. 3. Klasyfikacja dziedzin przemysłu według poziomów techniki opracowana przez OECD w 1997 r.

\begin{tabular}{|c|c|}
\hline EKD & Opis \\
\hline \multicolumn{2}{|r|}{ Wysoka technika } \\
\hline 35.3 & Produkcja statków powietrznych i kosmicznych \\
\hline 24.4 & Produkcja wyrobów farmaceutycznych \\
\hline 30 & Produkcja maszyn biurowych i komputerów \\
\hline 32 & Produkcja sprzętu i urządzeń radiowych i telewizyjnych i komunikacyjnych \\
\hline 33 & $\begin{array}{l}\text { Produkcja instrumentów medycznych, precyzyjnych i optycznych, zegarów } \\
\text { i zegarków }\end{array}$ \\
\hline \multicolumn{2}{|r|}{ Średniowysoka technika } \\
\hline 31 & Produkcja maszyn i aparatury elektrycznej, gdzie indziej niesklasyfikowana \\
\hline 34 & Produkcja pojazdów samochodowych, przyczep i naczep \\
\hline 24 bez 24.4 & Produkcja wyrobów chemicznych, bez produkcji wyrobów farmaceutycznych \\
\hline $35.2,35.4,35.5$ & $\begin{array}{l}\text { Produkcja lokomotyw kolejowych i tramwajowych oraz taboru kolejowego } \\
\text { i tramwajowego; } \\
\text { Produkcja motocykli i rowerów } \\
\text { Produkcja pozostałego sprzętu transportowego }\end{array}$ \\
\hline 29 & Produkcja maszyn i urządzeń, gdzie indziej niesklasyfikowana \\
\hline \multicolumn{2}{|r|}{ Średnioniska technika } \\
\hline 35.1 & Produkcja i naprawa statków i łodzi \\
\hline 23 & Wytwarzanie koksu, produktów rafinacji ropy naftowej i paliw jądrowych \\
\hline 25 & Produkcja wyrobów gumowych i z tworzyw sztucznych \\
\hline 26 & Produkcja wyrobów z surowców niemetalicznych pozostałych \\
\hline 27 & Produkcja metali \\
\hline 28 & Produkcja metalowych wyrobów gotowych, z wyjątkiem maszyn i urządzeń \\
\hline \multicolumn{2}{|r|}{ Niska technika } \\
\hline $15-16$ & $\begin{array}{l}\text { Produkcja artykułów spożywczych i napojów } \\
\text { Produkcja wyrobów tytoniowych }\end{array}$ \\
\hline $17-19$ & $\begin{array}{l}\text { Włókiennictwo } \\
\text { Produkcja odzieży i wyrobów futrzarskich } \\
\text { Produkcja skór wyprawionych i wyrobów ze skór wyprawionych }\end{array}$ \\
\hline 20 & Produkcja drewna i wyrobów z drewna \\
\hline 21 & Produkcja masy celulozowej, papieru oraz wyrobów z papieru \\
\hline 22 & $\begin{array}{l}\text { Działalność wydawnicza; poligrafia i reprodukcja zapisanych nośników } \\
\text { informacji }\end{array}$ \\
\hline $36-37$ & $\begin{array}{l}\text { Produkcja mebli; działalność produkcyjna, gdzie indziej niesklasyfikowana; } \\
\text { Zagospodarowanie odpadów }\end{array}$ \\
\hline
\end{tabular}

Źródło: Nauka i technika w 2007 roku, GUS, Warszawa 2009, s. 200 za: Revision of the high-technology sector and product classification (1997), STI Working Papers 1972, no. 2, OECD. 
Wady metody „według dziedzin” niweluje w dużym stopniu metoda „produktowa", która została opracowana na podstawie szczegółowych danych dotyczących nakładów na działalność $\mathrm{B}+\mathrm{R}$ według grup wyrobów, jednak takie informacje są na razie dostępne dla sześciu krajów: Stanów Zjednoczonych, Niemiec, Włoch, Szwecji i Holandii.

OECD opracowało w 1995 r. listę wyrobów wysokiej techniki, która obejmuje 9 grup wyrobów [Nauka i technika w 2009 roku, s. 40-41, 352]:

- sprzęt lotniczy,

- komputery i maszyny biurowe,

- elektronika i telekomunikacja,

- farmaceutyki,

- chemia,

- aparatura naukowo-badawcza,

- maszyny elektryczne,

- maszyny nieelektryczne,

- uzbrojenie.

Lista ta jest w znacznym stopniu kompatybilna z najnowszą listą dziedzin wysokiej techniki. Słabą stroną metody produktowej są trudności z przygotowaniem dostatecznie szczegółowej listy wyrobów wyłącznie w oparciu o metodę ilościową oraz niemożności ustalenia hierarchii w wyodrębnionej grupie wyrobów, odzwierciedlającej ich techniczne zaawansowanie [Nauka i technika w 2009 roku, s. 189]. Warto także pamiętać, że przyjęta metoda szacowania intensywności B+R dyskryminuje te dziedziny i grupy wyrobów, w których w badanym okresie ma miejsce szybszy wzrost produkcji/sprzedaży niż wzrost nakładów na $\mathrm{B}+\mathrm{R}$, spowodowany wzrostem popytu lub/i dynamiczną polityką handlową w danej branży. Trwają prace nad rozwijaniem metody produktowej, uwzględniającej dynamiczne zmiany zachodzące w gospodarce. W grupie wyrobów zaliczanych do wysokiej techniki wyodrębniane są kolejne kategorie, np. ultrawysoką technikę oraz technikę wysokiego poziomu.

Handel wyrobami wysokiej techniki jest najbardziej rozpowszechnioną formą dyfuzji tzw. technologii materialnej, zawartej w dobrach i usługach. Na razie jedynie nieliczne kraje są twórcami wysokiej techniki na szerszą skalę. Pozostałe produkują wyroby wysokiej techniki w oparciu o zagraniczne licencje lub są zmuszone je importować.

OECD pracuje również nad przygotowaniem nowych, przyszłościowych tematów badań z zakresu statystyki nauki, techniki i innowacji, takich jak biotechnologia, nanotechnologia czy zarządzanie wiedzą w przedsiębiorstwie.

\subsubsection{Metodologia Unii Europejskiej}

Badanie innowacyjności w krajach Unii Europejskiej opiera się na metodologii opracowanej przez OECD i Eurostat, czyli na zaleceniach wynikających z podręczników Frascati Family, a przede wszystkim z Oslo Manual. Gromadzeniem, 
opracowaniem statystycznym i publikowaniem informacji dotyczących nauki, techniki i innowacji zajmuje się Europejski Urząd Statystyczny - Eurostat.

W Unii Europejskiej prowadzone są dwa podstawowe badania innowacyjności [Nauka i technika w 2009 roku, s.123]:

- CIS (Community Innovation Survey),

- EIS - European Innovation Scoreboard.

Community Innovation Survey to międzynarodowy program badań statystycznych innowacji zainicjowany na początku lat dziewięćdziesiątych XX wieku przez Komisję Europejską poprzez Eurostat i DG XIII (SPRINT Programme, European Innovation Monitoring System, EIMS). Do tej pory przeprowadzono sześć rund badań (CIS-1, CIS-2, CIS-3, CIS-4, CIS-2006 i CIS-2008), a ich głównym celem jest porównanie działalności innowacyjnej przedsiębiorstw europejskich [Działalność innowacyjna... 2008, s. 4-5]. Pierwsze dwie rundy badań obejmowały tylko kraje członkowskie UE i EFTA, a od CIS-3 badania były prowadzone również w krajach kandydujących do UE. Wykonawcami badań w poszczególnych krajach uczestniczących w CIS są krajowe urzędy statystyczne lub odpowiednie ministerstwa. W Polsce realizuje to badanie GUS.

CIS-1 dotyczyło innowacji technicznych wprowadzanych w latach 1990-1992 w przedsiębiorstwach przemysłowych (sekcja Manufacturing, przetwórstwo przemysłowe). Badanie obejmowało trzynaście krajów należących do tzw. Europejskiego Obszaru Gospodarczego, czyli UE i EFTA (Belgia, Dania, Francja, Grecja, Hiszpania, Niderlandy, Irlandia, Luksemburg, Niemcy, Norwegia, Portugalia, Wielka Brytania i Włochy) i było przeprowadzone w oparciu o wspólny kwestionariusz, tzw. zharmonizowany kwestionariusz OECD/UE, opracowany na podstawie zaleceń metodycznych Oslo Manual.

CIS -2, czyli druga runda programu została zrealizowana w 1998 r., a badaniem zostały objęte również przedsiębiorstwa należące do tzw. sektora usług rynkowych (market services) - handel hurtowy i komisowy, z wyjątkiem sprzedaży hurtowej realizowanej na zasadzie bezpośredniej płatności lub kontraktu; transport lądowy, wodny i powietrzny; telekomunikacja; pośrednictwo finansowe; informatyka i działalność pokrewna; działalność w zakresie architektury, inżynierii i pokrewne doradztwo techniczne. Badanie CIS-2 dotyczyło innowacji wprowadzonych w latach 1994-1996. Tylko w Hiszpanii badanie prowadzone w ramach drugiej rundy programu CIS obejmowało, podobnie jak w pierwszej rundzie, wyłącznie sekcję Przetwórstwo przemystowe.

CIS-3 przeprowadzone zostało na przełomie lat 2001 i $2002 \mathrm{w}$ oparciu o trzecią wersję zharmonizowanego kwestionariusza OECD/UE i dotyczyło okresu 1998-2000. Badania zostały poszerzone o dane dotyczące innowacji w dziedzinie organizacji i zarządzania.

CIS -4 , badania w ramach tej rundy prowadzone były w roku 2005 i dotyczyły lat 2002-2004. 
Badanie CIS-2006 przeprowadzono w roku 2007 i dotyczyło aktywności innowacyjnej przedsiębiorstw w latach 2004-2006, a pod względem zawartości tematycznej było ono w znacznej mierze powtórzeniem badania $C I S-4$.

W roku 2009 przeprowadzono badanie działalności innowacyjnej przedsiębiorstw w przemyśle oraz we sektorze usług w latach 2006-2008, opartych na kwestionariuszu CIS-2008.

Ze względu na różnice w treści zastosowanych formularzy wyniki kolejnych rund programu CIS nie są niestety w pełni porównywalne.

Zgodnie z nowymi aktami prawnymi UE ${ }^{10}$ dotyczącymi statystyki innowacji poszerzone badania innowacji typu CIS prowadzone będą co dwa lata. Pierwsze cztery odbywały się co cztery lata. W przyszłości planuje się prowadzenie tych badań w trybie corocznym. O znaczeniu, jakie przypisywane jest w UE badaniom statystycznym innowacji świadczy stwierdzenie, jakie padło podczas zorganizowanej w ramach realizacji programu CIS w maju 1996 r. w Luksemburgu międzynarodowej konferencji Innovation measurement and policies, że „badania statystyczne innowacji i inne sposoby pomiaru innowacji powinny być rozwijane tak, by w przyszłości osiągnęły status podobny do tego, jaki obecnie mają rachunki narodowe" [Nauka i technika w 2009 roku, s. 124].

Drugie, obok programu CIS, źródło informacji na temat działalności innowacyjnej przedsiębiorstw europejskich to European Innovation Scoreboard (Europejska tabela wyników w dziedzinie innowacji). Badanie to wykorzystuje w dużej części dane pochodzące z badania CIS. Dostarcza porównywalnych wyników na temat poziomu innowacyjności w poszczególnych krajach i pokazuje postęp na drodze do najbardziej konkurencyjnej gospodarki na świecie. Jest to także europejskie forum dla porównań (benchmarking) i wymiany doświadczeń między poszczególnymi krajami.

W ostatnich edycjach EIS uwzględniano od 25 do 29 wskaźników opisujących innowacyjność gospodarki. Opierając się na tych wskaźnikach, Komisja Europejska opracowuje Summary Innovation Index (złożony wskaźnik innowacyjności), służący do oceny efektywności innowacyjnej krajów UE.

Wskaźniki oceny innowacyjności gospodarki zostały ujęte w pięciu kategoriach (wymiarach) ${ }^{11}$ :

${ }^{10}$ Obecnie podstawę prawną badań statystycznych innowacji w krajach UE I EFTA stanowią: Decyzja Parlamentu Europejskiego i Rady nr 1608/2003/EC z dnia 22.07.2003 r. oraz Rozporządzenie Komisji Europejskiej nr 1450/2004 z dnia 13.08.2004 r. - Decision No 1608/2003/EC of the European Parliament and of the Council of 22 July 2003 concerning the production and development of Community Statistics on Science and Technology (OJ L 230, 16.9.2003, s. 1) oraz Commission Regulation (EC) No 1450/2004 of 13 August 2004 implementing Decision No 1608/2003/EC of the European Parliament and of the Council concerning the production and development of Community Statistics on Innovation.

11 Szczegółowe wykazy wskaźników zawierają poszczególne raporty EIS, np.: European Innovation Scoreboard 2009. Comparative Analysis of Innovation Performance, Pro Inno Europe. 
- czynniki sprzyjające innowacjom,

- tworzenie wiedzy (inwestycje w kapitał ludzki, działalność B+R),

- innowacyjność i przedsiębiorczość (pomiar innowacyjności na poziomie mikroekonomicznym),

- wdrażanie innowacji,

- własność intelektualna.

Z roku na rok metody badawcze innowacyjności w ramach EIS są doskonalone, zwiększa się także liczba państw objętych badaniem. W roku $2000 \mathrm{w}$ badaniu uwzględniono 17 państw, a w roku 2009 już 37, w tym wszystkie kraje członkowskie UE. Natomiast liczba wskaźników składających się na Summary Innovation Index wzrosła w tym czasie z 16 do 29, a kategorii innowacyjności z czterech do pięciu.

Unia Europejska w ramach tej samej metodologii prowadzi badania dotyczące poziomu innowacyjności przedsiębiorstw i regionów w skali mezo- i mikroekonomicznej. Przykładem takich badań może być innowacyjny indeks sektorowy (Innovation Sector Index), który składa się z 12 wskaźników (11 wskaźników pochodziło z badania $C I S-3$, jeden z badań OECD-STAN). Badaniem objęto 25 sektorów z przemysłu oraz wybranych usług [Kozioł 2009, s. 147].

Innowacyjność regionów unijnych bada The Regional Innovation Scoreboard. Pierwszy raport powstał w roku 2003 i stanowił załącznik do EIS. Najnowsza wersja Regional Innovation Scoreboard 2006 składa się z siedmiu wskaźników: zasoby ludzkie w nauce i technice; odsetek osób uczestniczących w dalszym kształceniu; krajowe wydatki na działalność $\mathrm{B}+\mathrm{R}$ jako \% PKB; wydatki na działalność $\mathrm{B}+\mathrm{R}$ w przedsiębiorstwach; zatrudnienie $\mathrm{w}$ przemysłach średnio-wysokiej i wysokiej technologii; zatrudnienie w usługach wysokich technologii; liczba zgłoszeń patentowych do EPO.

\subsubsection{Metodologia badań GUS}

Główny Urząd Statystyczny podpisał w roku 1990 deklarację o współpracy z Urzędem Statystycznym Wspólnoty Europejskiej - Eurostatem. Od tego czasu nastąpiła wzmożona współpraca obu instytucji. Polska, jako jeden z krajów członkowskich UE jest zobowiązana, nie tylko, do prowadzenia polityki społeczno-gospodarczej zgodnej z wytycznymi Wspólnoty, ale również do prowadzenia badań statystycznych według zasad unijnych.

Promowanie i wspieranie działalności innowacyjnej w różnych dziedzinach gospodarki jest jednym z głównych celów polityki gospodarczej w krajach UE. Właściwa realizacja tego celu nie byłaby możliwa bez regularnych badań statystycznych, dostarczających wiarygodnych danych obrazujących zakres oraz charakter działalności innowacyjnej na różnych poziomach i różnych sektorach gospodarki [Działalność innowacyjna... 2008, s. 1]. 
W Polsce badaniami statystycznymi innowacji zajmuje się Wydział Nauki i Techniki w Departamencie Statystyki Gospodarczej GUS. Badania są prowadzone zgodnie z metodologią Oslo. Przyjęcie wspólnej metodologii badań umożliwia międzynarodowe porównania w zakresie aktywności innowacyjnej poszczególnych gospodarek narodowych lub jej segmentów.

Badania innowacji prowadzone przez GUS obejmują przedsiębiorstwa przemysłowe oraz przedsiębiorstwa sektora usług i są ujęte w Programie Badań Statystycznych Statystyki Publicznej w tematach 1.43.02 - Innowacje w przemyśle (PNT-02) i 1.43 .13 - Innowacje w sektorze ustug (PNT-02/u). Co dwa lata dane na temat innowacji przekazywane są do Eurostatu [Działalność innowacyjna ... 2010, s. 6].

System prowadzonych przez GUS badań statystycznych działalności innowacyjnej przedsiębiorstw składa się aktualnie z dwóch rodzajów badań, a mianowicie [Nauka i technika w 2009 roku, s. 137-138]:

- skróconego badania rocznego obejmującego jednostki liczące powyżej 49 pracujących oraz

- poszerzonego badania cyklicznego dotyczącego różnorodnych aspektów działalności innowacyjnej przedsiębiorstw, opartego na tzw. zharmonizowanych kwestionariuszach opracowanych przez Eurostat w ramach kolejnych rund międzynarodowego programu badawczego Community Innovation Survey - CIS. Badanie te obejmują również jednostki mniejsze liczące od 10 do 49 pracujących. W przeszłości badania przeprowadzane były co cztery lata, obecnie co dwa lata. Cykliczność tych badań powoduje, że ważnymi informacjami dysponujemy nie dla kolejnych, ale tylko niektórych lat w badanym okresie.

Wyniki powyższych badań znajdują się w wielu publikacjach GUS. Warto jednak zwrócić uwagę na trzy charakteryzujące się największym zakresem, a są to: Działalność innowacyjna przedsiębiorstw, Nauka i technika oraz Roczniki statystyczne przemystu.

W przeszłości badania działalności innowacyjnej w przemyśle obejmowały przedsiębiorstwa w sekcjach: C - górnictwo, D - przetwórstwo przemysłowe oraz E - wytwarzanie i zaopatrywanie w energię elektryczną, gaz i wodę według PKD 2004, określanych w terminologii stosowanej w GUS ogólnym mianem ,przemysł".

W roku 2010 ukazała się publikacja z wynikami ostatnich badań z zakresu innowacyjności przedsiębiorstw Działalność innowacyjna przedsiębiorstw w latach 2006-2009, w której przedstawiono wyniki poszerzonego badania działalności innowacyjnej przedsiębiorstw w przemyśle oraz sektorze usług w latach 2006-2008, opartych na kwestionariuszu CIS 2008, jak również wyniki badania skróconego, obejmującego badanie działalności innowacyjnej przedsiębiorstw w przemyśle i sektorze usług w latach 2007-2009. Publikacja została przygotowana przez zespół pracowników Ośrodka Statystyki Nauki, Techniki, Innowacji i Społeczeństwa Informacyjnego w Urzędzie Statystycznym w Szczecinie. 
Otrzymane wyniki zaprezentowane zostały zgodnie z podziałem:

- lata 2006-2008 według PKD 2004;

- lata 2006-2008 według PKD 2007;

- lata 2007-2009 według PKD 2007.

Badania statystyczne prowadzane przez GUS dotyczą różnorodnych aspektów działalności innowacyjnej przedsiębiorstw, a w szczególności:

- udziału przedsiębiorstw innowacyjnych w ogólnej liczbie przedsiębiorstw,

- nakładów finansowych na działalność innowacyjną,

- celów działalności innowacyjnej,

- przychodów ze sprzedaży produktów innowacyjnych,

- źródel informacji dla innowacji,

- współpracy z innymi podmiotami w zakresie działalności innowacyjnej,

- publicznego wsparcia dla innowacji,

- barier utrudniających wdrażania innowacji,

- ochrony własności intelektualnej itd.

Należy jednak podkreślić, że GUS publikuje wyniki badań dotyczących działalności innowacyjnej przedsiębiorstw przemysłowych tylko na poziomie sekcji i działów (dwucyfrowy poziom agregacji według PKD 2004). Sytuacja ta utrudnia, a czasami nawet uniemożliwia, prowadzenie analiz innowacyjności na niższych szczeblach agregacji, tj. na poziomie grup i klas (trzy- i czterocyfrowy poziom agregacji według PKD 2004).

\subsection{Ranking innowacyjności krajów UE według sumarycznego wskaźnika innowacyjności}

Badanie European Innovation Scoreboard dostarcza porównywalnych wyników na temat poziomu innowacyjności w poszczególnych krajach i pokazuje postęp na drodze do najbardziej innowacyjnych gospodarek świata. The European Innovation Scoreboard (EIS) to raport publikowany corocznie przez Komisje Europejską począwszy od 2001 r. w ramach inicjatywy Dyrektoriatu Generalnego Przedsiębiorczości i Przemysłu (Directorate General of Enterprises and Industry) PRO INNO Europe, której celem jest zarówno badanie innowacyjności w krajach Unii Europejskiej, jak i jej promowanie i wspieranie.

Raport EIS za 2009 r. zawiera wyniki kompleksowego pomiaru innowacyjności 27 krajów członkowskich Unii Europejskiej i innych wybranych krajów (Chorwacji, Serbii, Turcji, Islandii, Norwegii i Szwajcarii). Prezentuje również porównanie krajów unijnych $\mathrm{w}$ kontekście luki innowacyjnej ze Stanami Zjednoczonymi i Japonią, a także w odniesieniu do Brazylii, Indii, Rosji i Chin.

Sumaryczny indeks innowacyjności (SII) jest obliczany jako wielkość złożona, na którą składają się wartości 29 wskaźników zgrupowanych w 7 kategoriach 
ujętych w 3 bloki odnoszące się do czynników ułatwiających innowacyjność, aktywności firm i wyników.

Do bloku 1 zaliczono główne czynniki stymulujące innowacje czyli zasoby ludzkie, finanse i wsparcie. Blok 2 przedstawia inwestycje firm, powiązania i przedsiębiorczość oraz własność intelektualną. Blok 3 prezentuje wyniki działalności firm o charakterze innowatorów i efekty ekonomiczne.

Wymienione czynniki tworzą jądro osiągnięć innowacyjnych danego kraju, ale ważne są także inne czynniki, które wpływają na innowacyjność, takie jak rola rządu, rynki, czynniki społeczne zapotrzebowanie i akceptacja innowacji. EIS korzysta z najbardziej aktualnych danych statystycznych Eurostatu i innych uznawanych w skali międzynarodowej źródeł dostępnych w czasie przeprowadzanych analiz w celu zwiększenia porównywalności między krajami.

Ranking dzieli badane państwa na cztery grupy (tab. 2.4). Grupę liderów (innovation leaders) tworzą Dania, Finlandia, Niemcy, Szwecja i Wielka Brytania. Ich osiągnięcia innowacyjne są znacznie powyżej średniej dla 27 krajów członkowskich UE. Spośród tych krajów Niemcy i Finlandia robią najszybsze postępy, a Dania i Wielka Brytania są w okresie stagnacji.

Do drugiej grupy naśladowców innowacji (innovation followers) należą Austria, Belgia, Cypr, Estonia, Francja, Irlandia, Luksemburg, Holandia i Słowenia. Ich wyniki są poniżej liderów innowacyjności, ale bliskie lub powyżej średniej dla UE-27 w 2009 r. Cypr, Estonia i Słowenia wykazały zdecydowaną poprawę i awansowały do tej grupy z grupy niższej.

Trzecia grupa - umiarkowani innowatorzy (moderate innovators) - to Czechy, Grecja, Węgry, Włochy, Litwa, Malta, Polska, Portugalia, Słowacja i Hiszpania. Osiągnięcia $\mathrm{w}$ zakresie innowacyjności w tej grupie krajów są poniżej średniej unijnej.

Czwartą grupę tworzą Bułgaria, Łotwa i Rumunia. Są to kraje o poziomie innowacyjności dużo poniżej średniej UE. Mają do odrobienia największy dystans, ale jednocześnie szybciej niż pozostałe go redukują.

W czołówce w rankingu ,innowacyjnych” krajów Unii znalazły się kraje skandynawskie. Do „pierwszej klasy światowej” zaliczono Szwecję, Finlandię, Danię i Niemcy, a także Szwajcarię. Polska jest na szarym końcu i Komisja Europejska zaliczyła nas do krajów „tracących grunt pod nogami”.

W rankingu innowacyjności EIS 2009 w porównaniu do poprzednich lat „nowe i stare” kraje członkowskie UE bardziej się przemieszały. Oczywiście nadal liderami innowacyjności są tradycyjnie kraje skandynawski oraz Niemcy i Wielka Brytania. Jednak w następnych grupach nastąpiły wyraźne przetasowania. W drugiej grupie znalazły się np. najlepsza wśród nowych krajów UE Estonia oraz Cypr i Słowenia. Z kolei w trzeciej grupie pierwsze miejsce zajmują Czechy wyprzedzając stare kraje UE: Portugalię, Hiszpanię, Włochy i Grecję. 
Tabela 2.4. Klasyfikacja państw członkowskich Unii Europejskiej według sumarycznego wskaźnika innowacyjności (SII) w 2009 r.

\begin{tabular}{|c|c|c|c|}
\hline \multirow[t]{2}{*}{ Grupa } & $\begin{array}{c}\text { Miejsce } \\
\text { w rankingu }\end{array}$ & Kraj & $\begin{array}{l}\text { Sumaryczny wskaźnik innowacyjności } \\
\text { (SII) }\end{array}$ \\
\hline & \multicolumn{2}{|c|}{ UE-27 } & 0,478 \\
\hline \multirow{5}{*}{$\begin{array}{l}\text { Liderzy } \\
\text { innowacyjności } \\
\text { (innovation leaders) }\end{array}$} & 1 & Szwecja & 0,636 \\
\hline & 2 & Finlandia & 0,622 \\
\hline & 3 & Niemcy & 0,596 \\
\hline & 4 & Wielka Brytania & 0,575 \\
\hline & 5 & Dania & 0,574 \\
\hline \multirow{9}{*}{$\begin{array}{l}\text { Naśladowcy } \\
\text { innowacji } \\
\text { (innovation } \\
\text { followers) }\end{array}$} & 6 & Austria & 0,536 \\
\hline & 7 & Luksemburg & 0,525 \\
\hline & 8 & Belgia & 0,516 \\
\hline & 9 & Irlandia & 0,515 \\
\hline & 10 & Francja & 0,501 \\
\hline & 11 & Holandia & 0,491 \\
\hline & 12 & Estonia & 0,481 \\
\hline & 13 & Cypr & 0,479 \\
\hline & 14 & Słowenia & 0,466 \\
\hline \multirow{10}{*}{$\begin{array}{l}\text { Umiarkowani } \\
\text { innowatorzy } \\
\text { (moderate } \\
\text { innovators) }\end{array}$} & 15 & Czechy & 0,415 \\
\hline & 16 & Portugalia & 0,401 \\
\hline & 17 & Hiszpania & 0,377 \\
\hline & 18 & Grecja & 0,37 \\
\hline & 19 & Włochy & 0,363 \\
\hline & 20 & Malta & 0,343 \\
\hline & 21 & Słowacja & 0,331 \\
\hline & 22 & Węgry & 0,328 \\
\hline & 23 & Polska & 0,317 \\
\hline & 24 & Litwa & 0,313 \\
\hline \multirow{3}{*}{$\begin{array}{l}\text { Niepozorni } \\
\text { Innowatorzy } \\
\text { (modest innovators) }\end{array}$} & 25 & Rumunia & 0,294 \\
\hline & 26 & Łotwa & 0,261 \\
\hline & 27 & Bułgaria & 0,231 \\
\hline
\end{tabular}

Źr ó d ło : European Innovation Scoreboard 2009. Comparative Analysis of Innovation Performance, Pro Inno Europe, s. 63.

Z omawianego raportu wynika, że z innowacyjnością w Unii Europejskiej jest źle i brak szans na dogonienie USA, a zwłaszcza przodującej w świecie Japonii. Tymczasem pojawiają się dwaj inni silni konkurenci: Indie i Chiny, które szybko stają się ośrodkami badań i rozwoju na światową skalę. 
Założenia Strategii Lizbońskiej nie są realizowane. Unijne inwestycje na badania są o jedną trzecią mniejsze niż w USA i eksperci twierdzą, że jeżeli nic się nie zmieni, to zbliżenie się do USA i Japonii pod względem poziomu innowacyjności nie będzie możliwe. Brak postępów Europy w pościgu za Stanami Zjednoczonymi i Japonią to nie tylko efekt relatywnie niskich nakładów na działalność badawczą i rozwojową, ale także słabszych powiązań pomiędzy sferą publiczną i prywatną, mniejszej liczby zgłaszanych patentów i niższego zatrudnienia w B+R.

W raporcie EIS 2009 zostały wyznaczone wskaźniki innowacyjności także dla Brazylii, Rosji, Indii i Chin. Porównując innowacyjność tych krajów z innowacyjnością unijną wynika, że UE zachowała przewagę na Brazylią, nieznacznie umocniła swoją pozycję wobec Rosji, traci ją natomiast w stosunku do Indii oraz w bardzo szybkim tempie do Chin.

Polska zajmuje odległe 23. miejsce w rankingu krajów UE. Komisja zwraca uwagę na niekorzystne warunki dla badań i rozwoju w Polsce i niewielkie środki przeznaczane na tę kluczową dla innowacyjności dziedzinę. Źle wygląda również współpraca firm z ośrodkami akademickimi i innymi jednostkami funkcjonującymi w otoczeniu firmy. Mierzalne efekty wdrażania innowacji, takie jak liczba patentów w relacji do liczby ludności, liczba zarejestrowanych wzorów użytkowych też prezentują się bardzo słabo na tle większości krajów UE. Niestety, również tempo w jakim nadrabiamy dystans, dzielący nas od najbardziej rozwiniętych krajów Europy, nie jest imponujące. W ciągu ostatnich pięciu lat, spośród krajów będących na podobnym poziomie jak Polska, wolniejszy rozwój był tylko na Węgrzech. Relatywnie silną stroną polskiej gospodarki jest kapitał ludzki, inwestycje firm oraz tzw. efekty ekonomiczne, które pokazują, jak działalność innowacyjna przekłada się na wzrost zatrudnienia, eksport oraz sprzedaż.

Polska, podobnie jak inne kraje, które stosunkowo niedawno przystąpiły do UE, korzysta z funduszy strukturalnych, których celem jest m.in. wspieranie i promowanie działalności innowacyjnej. Skoro inne państwa czynią większe postępy w rozwoju innowacyjności, to pojawia się pytanie czy fundusze strukturalne są w Polsce właściwie wykorzystywane? Może warto skorzystać z doświadczeń innych krajów.

Osiągnięcia Estonii i Czech w zakresie poprawy innowacyjności są imponujące. Wydaje się, że doświadczenia czeskie powinny być dla Polski pewnym drogowskazem. W Czechach obserwuje się silne wsparcie fiskalne badań i rozwoju. Stosowane się bodźce finansowe, skłaniające przedsiębiorstwa do inwestowania w wysokie technologie. Rezygnuje się z bezpośredniego wsparcia finansowego projektów badawczych poprzez dotacje i granty zastępując je ulgami finansowymi. Takie podejście wydaje się być właściwym rozwiązaniem, ponieważ z jednej strony dotacje są jednorazowym wsparciem, a z drugiej strony wiadomo, że środki strukturalne wspierające innowacyjności będą w przyszłości coraz mniejsze. Celem rozwiązań czeskich jest tworzenie postaw proinnowacyjnych w samym przedsiębiorstwie. Przedsiębiorstwa, poprzez system zachęt, są motywowane do kontynuowania projektów badawczych i rozwijania potencjału innowacyjnego. 


\section{Podsumowanie}

Z rozważań przeprowadzonych w tym rozdziale wynika, że trudno jest określić jeden, uniwersalny NSI odpowiadający wszystkim krajom. System powinien być dopasowany do specyficznych uwarunkowań każdego z państw.

Narodowy System Innowacji w Polsce różni się wyraźnie od systemów innowacji funkcjonujących w wysoko rozwiniętych krajach Unii Europejskiej. Przyczyną tego stanu są nie tylko problemy finansowe, ale również struktura organizacyjna i podział kompetencji.

Oceniając funkcjonowanie NSI w Polsce można zaproponować kilka wniosków :

- aktualny poziom wydatków na B+R w Polsce, bez względu na sposób funkcjonowania NSI, nie daje żadnych szans poprawy innowacyjności polskiej gospodarki,

- należy wprowadzić system zachęt finansowych - umożliwiający odpis kosztów $\mathrm{B}+\mathrm{R}$ od przychodów, jak również dodatkowe ulgi podatkowe,

- doskonalenie systemu szkolnictwa wyższego powodującego wzrost poziomu edukacji i jej ukierunkowania (poprawę HRST) w celu powiększania kapitału intelektualnego i popytu wewnętrznego na innowacje,

- promowanie współpracy między publicznymi instytucjami badawczymi i firmami w celu lepszego wykorzystania osiągnięć nauki,

- trzeba zwiększyć udział sektora przedsiębiorstw, a zmniejszyć sektora rządowego w finansowaniu innowacji,

- należy usprawnić działanie dotychczasowych podmiotów pomostowych i powołać nowe, które przyczynią się do sprawnego funkcjonowania całego systemu.

Promowanie i wspieranie działalności innowacyjnej nie jest możliwe bez regularnych badań statystycznych, dostarczających wiarygodnych danych opisujących działalność innowacyjną na różnych poziomach i w różnych sektorach gospodarki. Należy jednak pamiętać, że innowacyjność jest trudno mierzalnym zjawiskiem. W krajach Unii Europejskiej obowiązuje metodologia Oslo, która jest nieustannie modyfikowana i doskonalona. Obecnie eksperci zwracają uwagę na potrzebę opracowania nowej generacji wskaźników charakteryzujących innowacyjność krajów i przedsiębiorstw. Zmiany metodologii badań powodują, że w dłuższym horyzoncie czasu dane statystyczne nie są w pełni porównywalne. Kolejnym problemem dla badacza jest ograniczony stopień szczegółowości publikowanych danych.

Interesującym źródłem wiedzy o innowacyjności polskiej gospodarki w międzynarodowym ujęciu porównawczym są badania European Innovation Scoreboard. Z raportu EIS 2009 wynika, że Polska pod względem poziomu innowacyjności gospodarki pozostaje na końcu krajów UE. Odnotowaliśmy co prawda pewien postęp, ale jest on niestety niewielki i co gorsze, większość krajów naszego regionu nadrabia dystans dzielący od najbardziej innowacyjnych gospodarek szybciej od nas. 


\section{Analiza produkcyjno-ekonomicznej sytuacji przemysłu spożywczego w Polsce}

\section{Wprowadzenie}

Przemysł spożywczy jest ważnym działem gospodarki narodowej, gdyż wytwarza głównie dobra konsumpcyjne niezbędne do codziennego życia, a zapewnienie bezpieczeństwa żywnościowego społeczeństw jest nadrzędnym celem polityki społeczno-gospodarczej każdego z państw.

Celem niniejszego rozdziału pracy jest określenie roli i znaczenia przemysłu spożywczego w polskiej gospodarce i sektorze żywnościowym oraz zdiagnozowanie produkcyjno-ekonomicznej sytuacji tego przemysłu w ostatnim dziesięcioleciu.

Uznano, iż poszukiwanie odpowiedzi na pytanie odnośnie wpływu innowacji na konkurencyjność przedsiębiorstw przemysłu spożywczego winno być poprzedzone oceną wyników produkcyjno-ekonomicznych w badanym okresie, jak również analizą porównawczą wskaźników mierzących konkurencyjność poszczególnych branż przemysłu spożywczego.

\subsection{Miejsce przemysłu spożywczego w polskiej gospodarce}

Mówiąc o miejscu, a tym samym o roli i znaczeniu, przemysłu spożywczego w gospodarce narodowej wyróżnia się dwa podejścia. W pierwszym przemysł spożywczy uznawany jest za jedno z podstawowych ogniw sektora rolno-żywnościowego, inaczej agrobiznesu. Natomiast w drugim przemysł spożywczy, zgodnie z Polską Klasyfikacją Działalności (PKD) traktowany jest jako jeden z wielu działów przetwórstwa przemysłowego w Polsce.

$\mathrm{W}$ teorii ekonomii pojęcie agrobiznesu pojawiło się w czasie, gdy malało znaczenie rolnictwa w gospodarce narodowej, spadało tempo popytu na produkty rolnictwa, wzrastały nadwyżki żywności, opłacalność produkcji rolniczej była coraz niższa, a nowe technologie wytwarzania żywności wymagały nowych struktur rynkowych i organizacyjnych tego obszaru gospodarki. Agrobiznes jest definiowany jako system obejmujący wiele ogniw, zaczynając od pozyskania surowców pierwotnych, a kończąc na wytwarzaniu finalnych produktów żywnościowych. Swoim zasięgiem obejmuje: przemysł wytwarzający środki produkcji dla rolnictwa i przemysłu spożywczego, rolnictwo - pojmowane jako wytwórczość surowców żywnościowych i gotowej żywności, rybołówstwo i leśnictwo, skup surowców rolnych, ich przechowywanie 
i transport, przemysł spożywczy, hurtowy i detaliczny handel żywnością oraz usługi związane z funkcjonowaniem tych dziedzin. Syntetycznie ujmując, agrobiznes to całokształt działań wykonywanych przez przedsiębiorstwa działające na rynku rolnym lub z nim związane i funkcjonujące w celu wytworzenia produktów pochodzenia rolniczego, ich przetworzenia oraz sprzedania [Firlej 2008, s. 11].

W polskiej literaturze przedmiotu pojęcie agrobiznesu w interesujący i szeroki sposób wyjaśnia uznany autor, A. Woś:

- definiując go jako wyodrębniony system gospodarki narodowej występujący w postaci struktury złożonej, zespalającej ze sobą te działalności człowieka, które bezpośrednio lub pośrednio uczestniczą w wytwarzaniu finalnych produktów żywnościowych, począwszy od pozyskania surowców pierwotnych aż do zakupu żywności przez konsumenta,

- uznając za dziedzinę aktywności podmiotów gospodarczych,

- określając jako dziedzinę wiedzy i badań naukowych, która została rozwinięta $\mathrm{w}$ większości renomowanych uniwersytetów ekonomicznych i rolniczych w krajach wysoko rozwiniętych [Woś 1998, s. 14].

Głównym ogniwem w agrobiznesie, obok rolnictwa, jest przemysł spożywczy. Jest on podstawowym odbiorcą produktów gospodarstw rolniczych. Wraz z rozwojem gospodarczym i rosnącymi wymaganiami konsumentów zmieniają się relacje między wartością wytworzoną w rolnictwie a wartością dodaną w przemyśle na korzyść przemysłu. Przemysł spożywczy zespala ogniwa agrobiznesu, gdyż kontraktuje, skupuje od rolników i innych dostawców produkty rolne $\mathrm{i}$, w procesie produkcji, przetwarza je na uszlachetnione produkty żywnościowe, co powoduje dodawanie do wartości wytworzonej w rolnictwie nowych wartości tzw. przetwórczych. Ogromne znaczenie przemysłu spożywczego wynika również $z$ tego, że przetwarza on nietrwałe surowce roślinne i zwierzęce na bardziej trwałe, spełniające określone normy pod względem jakościowym, odżywczym, sanitarnym i handlowym. Współcześnie od przemysłu spożywczego oczekuje się produktów o długim terminie przydatności, wysokiej jakości i produktów atrakcyjnie opakowanych. Już w raporcie przygotowany przez Komisję Europejską w 1992 r. zwracano uwagę na ciągły proces przekształceń przemysłu spożywczego, tradycyjnie postrzeganego jako sektor niskiej technologii, w przemysł coraz bardziej zaawansowany technologicznie, gdzie występuje silna konkurencja implikująca modyfikacje towarów [Commission of the European Communities 1992].

Rośnie udział „świadomych” konsumentów żywności, którzy są zainteresowani możliwością zakupu produktów bezpiecznych, odpowiedniej jakości i z właściwego miejsca pochodzenia. W procesie produkcji żywności coraz silniej akcentuje się konieczność zwiększenia oszczędności zasobów środowiskowych i poprawy efektywności procesów produkcyjnych, czego następstwem będą pozytywne przemiany społeczno-ekonomiczne na wsi i obszarach pozamiejskich. 
Osiąganie wymaganych międzynarodowych standardów jakości wymusza stosowania w procesie wytwarzania żywności innowacyjnych produktów, metod produkcji, organizacji oraz marketingu.

Miejsce i powiązania przemysłu spożywczego w łańcuchu żywnościowy agrobiznesu prezentuje rys. 3.1.

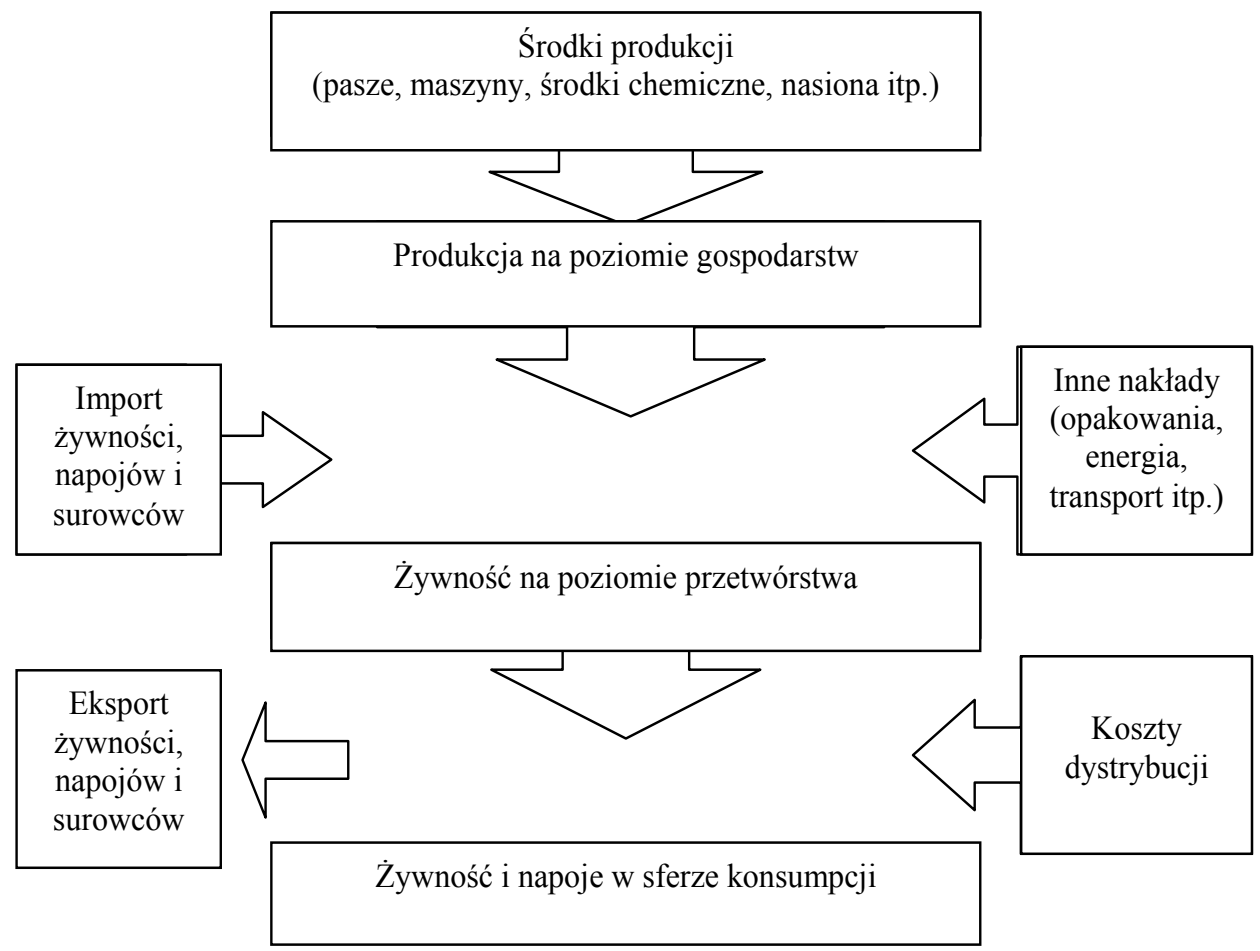

Rysunek 3.1. Schemat łańcucha agrobiznesu

Źródło: K. Firlej, Rozwój przemysłu rolno-spożywczego w sektorze agrobiznesu i jego determinanty, Wyd. Uniwersytetu Ekonomicznego, Kraków 2008, s. 50.

Powyższy schemat uwzględnia powiązania podstawowych sfer oddziaływania występujących w procesie powstawania produktu końcowego, czyli żywności przeznaczonej do spożycia. Przemysł spożywczy w sektorze agrobiznesu to zespół procesów tworzących jedno z najważniejszych ogniw i zajmujący trzy podstawowe pod względem oddziaływania obszary [Brodziński, Chyłek 1999, s. 133]:

- zakres najwęższy obejmuje tylko przetwórstwo płodów rolniczych, co stanowi treść jego branż, 
- zakres średni, który zaczyna się u „wrót farmy”, a kończy na „talerzu konsumenta", obejmuje, oprócz samego przetwórstwa, zagadnienia przechowalnictwa, skupu surowców, obrotu żywności oraz technologii i higieny przyrządzania potraw,

- zakres najszerszy obejmuje wiele aspektów produkcyjno-rolniczych (np. rodzaje i jakość nasion, odmiany, środki ochrony roślin, co powinno skutkować wysoką jakością płodów rolnych wykorzystywanych w przetwórstwie) oraz problematykę żywieniową.

Oceniając stan i perspektywy rozwoju produkcji żywności w Polsce należy zwrócić uwagę na problem wpływu globalizacji i integracji na krajowy agrobiznes. W ostatnim czasie obserwujemy intensywny rozwój gospodarki rolno-żywnościowej, szczególnie w trzech wysoko rozwiniętych regionach świata - Ameryka Północna, Europa Zachodnia, Japonia. Polska jako kraj członkowski UE uczestniczy w unijnym łańcuchu żywnościowym, co dla polskich przedsiębiorstw przemysłu spożywczego stwarza zarówno szanse, jak i zagrożenia.

W rozprawie, celem zapewnienia porównywalności danych dotyczących przemysłu spożywczego w latach 1999-2008, posłużono się Polską Klasyfikacją Działalności z 2004 r.. Polska Klasyfikacja Działalności (dokładniej PKD 2004) ${ }^{12}$ wyróżnia trzy sekcje przemysłu: „górnictwo” (sekcja C), „przetwórstwo przemysłowe” (sekcja D) oraz „wytwarzanie i zaopatrywanie w energię elektryczną, gaz i wodę" (sekcja E).

Przemysł spożywczy obejmuje produkcję artykułów spożywczych, napojów i wyrobów tytoniowych, czyli 15 i 16 dział sekcji D (,przetwórstwo przemysłowe”). Z kolei w obrębie działu 15 produkcja artykułów spożywczych i napojów wyodrębnia się grupy (trzycyfrowy poziom agregacji) oraz klasy (czterocyfrowy poziom agregacji).

W pracy analizie poddano przemysł spożywczy ogółem oraz klasy lub grupy klas, zwane często w literaturze przedmiotu branżami lub kierunkami przetwórstwa spożywczego [por. np. Drożdż 2008]. Poniżej przedstawiono podział przemysł spożywczego na klasy lub grupy klas (branże):

przetwórstwo produktów pochodzenia zwierzęcego:

- przemysł mięsny $(1511,1513)$

- przemysł drobiarski (1512)

- przetwórstwo ryb (1520)

- przemysł mleczarski $(1551,1552)$

${ }^{12}$ Od 1.01.2008 r., zgodnie z rozporządzeniem Rady Ministrów z dnia 24.12.2007 r. w sprawie Polskiej Klasyfikacji Działalności (Dz. U. Nr 251, poz. 1885), wprowadzono do stosowania w statystce, ewidencji i dokumentacji oraz rachunkowości, a także w urzędowych rejestrach i systemach informacyjnych administracji publicznej nową Polską Klasyfikację Działalności 2007 (PKD 2007). Jej przyjęcie było związane z wprowadzeniem we Wspólnocie w 2006 r. przez Parlament Europejski i Radę nowej wspólnej statystycznej klasyfikacji działalności gospodarczej NACE Rev. 2. Więcej informacji znajduje się na stronie: http://www.stat.gov.pl/klasyfikacje/pkd_07/pkd_07.htm. 
przetwórstwo produktów pochodzenia roślinnego:

- przemysł ziemniaczany $(1531,1562)$

- przemysł owocowo-warzywny $(1532,1533)$

- przemysł olejarski $(1541,1542,1543)$

- przemysł zbożowo-młynarski $(1561,1585)$

- przemysł cukrowniczy (1583)

przetwórstwo wtórne:

- przemysł paszowy $(1571,1572)$

- przemysł piekarski (1581)

- przemysł cukierniczy $(1582,1584)$

- przemysł koncentratów spożywczych $(1586,1587,1588,1589)$

- przemysł napojów bezalkoholowych (1598)

produkcja używek:

- przemysł spirytusowy (1591 i 1592)

- przemysł winiarski $(1593,1594,1595)$

- przemysł piwowarski (1596 i 1597)

- przemysł tytoniowy (1600).

W tabeli 3.1 zaprezentowano przedmiot działalności przedsiębiorstw funkcjonujących w poszczególnych branżach przemysłu spożywczego.

Warto nadmienić, że według nowej klasyfikacji działalności PKD 2007 do sekcji ,przetwórstwo przemysłowe” zalicza się m.in. przedsiębiorstwa produkujące artykuły spożywcze (dział 10), przedsiębiorstwa produkujące napoje (dział 11) i przedsiębiorstwa produkujące wyroby tytoniowe (dział 12). W PKD 2004 produkcja artykułów spożywczych i napojów stanowiła jeden dział (dział 15). Różnice występują nie tylko w klasyfikacji działów, ale również grup i klas przetwórstwa żywności ${ }^{13}$.

Przemysł spożywczy jest jednym z największych działów polskiej gospodarki, co potwierdzają poniższe dane statystyczne. Udział przemysłu spożywczego w wartości sprzedaży całego przemysłu wyniósł w 2009 r. 17,6\% (w 2008 r. 16\%), a w wartości sprzedaży przetwórstwa przemysłowego 21\% (19\%) [Rocznik statystyczny przemystu 2009, s. 111-112; Rocznik statystyczny RP 2010, s. 541] i jest wyższy niż w UE-15, gdzie wynosi średnio ok. 15\%. Wśród krajów UE wyższy udział niż w Polsce mają tylko Dania i Grecja.

Wytworzona przez przemysł spożywczy w Polsce wartość dodana brutto w 2009 r. wyniosła 37,5 mld zł (w 2008 r. ok. 35 mld zł) i stanowiła 3,1\% (3,0\%) wartości dodanej brutto wytworzonej w całej gospodarce narodowej. Zatrudnienie w przemyśle spożywczym ukształtowało się w 2009 r. na poziomie 424,6 tys. osób (w 2008 r. 433,3 tys. osób), co stanowiło 4,3\% (4,4\%) ogółu zatrudnionych w gospodarce i około 16\% (15\%) zatrudnionych ogółem w przemyśle [Rocznik statystyczny RP 2010, s. 263 i 759].

\footnotetext{
${ }^{13}$ Szerzej na ten temat: http://www.stat.gov.pl/klasyfikacje/pkd_07/pdf/2_PKD-2007-schemat_2.pdf
} 
Tabela 3.1. Przedmiot działalności branż przemysłu spożywczego według PKD 2004

\begin{tabular}{|c|c|}
\hline Klasa przemysłu (branża) & Przedmiot działalności według PKD 2004 \\
\hline Przemysł mięsny & $\begin{array}{l}\text { Produkcja mięsa z wyjątkiem drobiowego i króliczego (PKD 1511) } \\
\text { oraz wyrobów z mięsa, w tym drobiowego i króliczego (PKD 1513) }\end{array}$ \\
\hline Przemysł drobiarski & Produkcja mięsa z drobiu i królików (PKD 1512) \\
\hline Przetwórstwo ryb & Przetwarzanie ryb oraz pozostałych produktów rybactwa (PKD 1520) \\
\hline Przemysł mleczarski & Przerób mleka (PKD1551) oraz produkcja lodów (PKD 1552) \\
\hline Przemysł ziemniaczany & $\begin{array}{l}\text { Przetwarzanie i konserwowanie ziemniaków (PKD 1531) oraz } \\
\text { wytwarzanie skrobi i produktów skrobiowych (PKD 1562) }\end{array}$ \\
\hline $\begin{array}{l}\text { Przemysł owocowo- } \\
\text { warzywny }\end{array}$ & $\begin{array}{l}\text { Produkcja soków z owoców i warzyw (PKD 1532) oraz przetwórstwo } \\
\text { i konserwowanie owoców i warzyw (PKD 1533) }\end{array}$ \\
\hline Przemysł olejarski & $\begin{array}{l}\text { Produkcja olejów (PKD 1541), thuszczów nieczyszczonych } \\
\text { i rafinowanych (PKD 1542) oraz margaryny (PKD 1543) }\end{array}$ \\
\hline $\begin{array}{l}\text { Przemysł zbożowo- } \\
\text { młynarski }\end{array}$ & $\begin{array}{l}\text { Przemiał zbóż (PKD 1561) oraz produkcja makaronów i klusek (PKD } \\
1585 \text { ) }\end{array}$ \\
\hline Przemysł cukrowniczy & Produkcja cukru (PKD 1583) \\
\hline Przemysł paszowy & $\begin{array}{l}\text { Produkcja pasz dla zwierząt hodowlanych (PKD 1571) oraz zwierząt } \\
\text { domowych (PKD 1572) }\end{array}$ \\
\hline Przemysł piekarski & $\begin{array}{l}\text { Produkcja pieczywa świeżego, wyrobów piekarskich i ciastkarskich } \\
\text { (PKD 1581) }\end{array}$ \\
\hline Przemysł cukierniczy & $\begin{array}{l}\text { Produkcja pieczywa cukierniczego trwałego (PKD 1582) oraz kakao, } \\
\text { czekolady i wyrobów cukierniczych (PKD 1584) }\end{array}$ \\
\hline $\begin{array}{l}\text { Przemysł koncentratów } \\
\text { spożywczych }\end{array}$ & $\begin{array}{l}\text { Przetwórstwo herbaty i kawy (PKD 1586), produkcja przypraw (PKD } \\
\text { 1587), produkcja odżywek i żywności dietetycznej (PKD 1588) oraz } \\
\text { produkcja pozostałych artykułów spożywczych (PKD 1589) }\end{array}$ \\
\hline $\begin{array}{l}\text { Przemysł napojów } \\
\text { bezalkoholowych }\end{array}$ & $\begin{array}{l}\text { Produkcja napojów owocowych, warzywnych i owocowo- } \\
\text { warzywnych oraz wód mineralnych (PKD 1598) }\end{array}$ \\
\hline Przemysł spirytusowy & $\begin{array}{l}\text { Produkcja napojów alkoholowych (PKD1591) } \\
\text { oraz alkoholu etylowego (PKD 1592) }\end{array}$ \\
\hline Przemysł winiarski & $\begin{array}{l}\text { Wytwarza wina gronowe (PKD 1593), jabłecznik i wina owocowe } \\
\text { (PKD 1594) oraz napoje fermentowane (PKD 1595) }\end{array}$ \\
\hline Przemysł piwowarski & Produkcja piwa (PKD 1596) i słodu (PKD 1597) \\
\hline Przemysł tytoniowy & Produkcja papierosów i innych wyrobów tytoniowych (PKD 1600) \\
\hline
\end{tabular}

Źródło: opracowanie własne na podstawie: http://www.technopark.lodz.pl/docs/schemat klasyfikacji.pdf; J. D ro żd ż, Analiza ekonomiczno-finansowa przemystu spożywczego $w$ latach 2003-2007, IERiGŻ-PIB, Warszawa 2008, s. 9-111. 


\subsection{Tendencje rozwojowe przemysłu spożywczego w latach 1999-2008}

Coraz większe zapotrzebowanie na żywność wysoko przetworzoną powoduje wzrost znaczenia przemysłu spożywczego w produkcji żywności i sprawia, iż przemysł spożywczy należy do najszybciej rozwijających się ogniw agrobiznesu.

Stan i przemiany przemysłu spożywczego, podobnie jak każdego innego rodzaju działalności gospodarczej, zależą od poziomu rozwoju kraju, tempa tego rozwoju i przekształceń strukturalnych. Przekształcenia w całej gospodarce sprzyjają na ogół podobnym zmianom w przemyśle spożywczym. Równocześnie przemysł spożywczy jest działem przemysłu uznawanym za szczególnie wrażliwy w procesach integracji europejskiej, gdyż Unia Europejska wyjątkowo dokładnie określa jakość żywności oraz warunki jej produkcji i obrotu, stosuje różne formy bezpośredniej lub pośredniej interwencji na rynku rolno-żywnościowym, ustanawiając administracyjne procedury ograniczające mechanizmy rynkowe.

Dla przemysłu spożywczego najważniejsze są następujące cechy rozwoju gospodarczego kraju [por. Urban 2004, s. 11-12]:

- tempo wzrostu PKB, kształtujące zarówno popyt konsumpcyjny, jak i inwestycyjny,

- przemiany strukturalne, a w tym dynamika rozwoju działów oferujących inne produkty i usługi,

- mechanizmy i parametry regulacji procesów gospodarczych,

- sytuacja dochodowa ludności oraz stan rozwarstwienia społeczeństwa i zmiany w tych dziedzinach.

We wszystkich wymienionych obszarach w latach 1999-2008 dokonały się istotne zmiany. Transformacja systemowa, a przede wszystkim integracja europejska spowodowały przebudowę całej gospodarki, w tym przemysłu spożywczego, dostosowując je do zasad funkcjonowania wypracowanych przez kraje wysoko rozwinięte.

\subsubsection{Rozwój i przemiany struktury produkcji przemysłu spożywczego}

Analizując rozwój przemysłu spożywczego w dziesięcioleciu 1999-2008 wyodrębnimy pięcioletni okres poprzedzający integrację z UE (1999-2003) oraz drugi pięcioletni okres pełnego członkostwa Polski w Unii (2004-2008).

W latach 1999-2008 produkcja sprzedana przemysłu spożywczego rosła średniorocznie o 4,4\%, a w całym analizowanym okresie wzrosła o 47\%. Tempo wzrostu produkcji sprzedanej było wyższe w okresie członkostwa Polski w UE niż w latach bezpośrednio poprzedzających akcesję do UE i wynosiło odpowiednio 
5,6\% i 3,4\%. Jednak warto jeszcze zwrócić uwagę na fakt, że w latach wcześniejszych, tj. 1993-1998, produkcja sprzedana przemysłu spożywczego rosła średniorocznie o 9\%. Porównanie średniorocznych temp wzrostu w trzech podokresach 1993-1998 (9\%), 1999-2003 (3,4\%) i 2004-2008 (5,6\%) upoważnia do stwierdzenia, że efekt integracji w badanej dziedzinie jest słabszy od efektów wywołanych procesami transformacji, zachodzącymi w poprzedniej dekadzie (tab. 3.2).

W latach 1999-2008 najsilniejsze tempo wzrostu miało miejsce w roku 2003, osiągając 7,9\%. Przyjmuje się, że w 2003 r. rozpoczęło się kolejne ożywienie gospodarcze w przemyśle spożywczym, po kilkuletnim zastoju w latach 1998-2002. Ożywienie to ma trwałe podstawy. Wraz z wejściem do UE nastąpił wzrost popytu krajowego, który jest efektem rosnących dochodów polskiego społeczeństwa. W latach 2004-2008 nastąpił wzrost realnych wynagrodzeń o około 18\%, średniorocznie wynagrodzenia rosły w tym czasie o 4,3\% [Rocznik statystyczny $R P$, 2010, s. 44-45].

Analizując informacje zawarte w tab. 3.2 zauważamy, że w latach 1999-2008 produkcja sprzedana przemysłu spożywczego wzrastała w tempie bardzo podobnym do tempa wzrostu PKB. Średnioroczne tempo wzrostu produkcji sprzedanej przemysłu spożywczego wyniosło bowiem $4,4 \%$ wobec $4,2 \%$ wzrostu PKB. Natomiast w latach 1993-1998, tj. w okresie bardzo szybkiego rozwoju polskiej gospodarki, utrwalania zasad gospodarki rynkowej, intensywnych przekształceń własnościowych i restrukturyzacji przedsiębiorstw tempo wzrostu produkcji przemysłu spożywczego było zdecydowanie wyższe od tempa rozwoju PKB. Dynamika produkcji sprzedanej przemysłu spożywczego jest skorelowana z tempem rozwoju polskiej gospodarki. Okazuje się bowiem, że w latach dużego ożywienia gospodarczego (1993-1998) tempo wzrostu produkcji sprzedanej przemysłu spożywczego było blisko dwukrotnie większe od tempa wzrostu PKB.

W okresie 1993-1998 przemysłowa produkcja żywności i napojów zwiększyła się aż o $54 \%$, tj. o 9\% rocznie, a wyrobów tytoniowych o $14 \%$. W tym samym czasie produkcja przemysłu spożywczego rosła szybciej niż popyt krajowy i popyt całkowity (łącznie z eksportem). Rozpoczyna się zatem proces uprzemysławiania produkcji żywności kosztem ograniczania przetwórstwa lokalnego i samozaopatrzenia.

W latach 1999-2003 nastąpiło jednak spowolnienie rozwoju gospodarczego kraju i duże obniżenia się tempa wzrostu produkcji przemysłu spożywczego. Średnioroczne tempo wzrostu PKB spadło z 5,6\% w latach 1993-1998 do 2,6\% w latach 1999-2003, co przełożyło się na spadek tempa wzrostu produkcji przemysłu spożywczego, odpowiednio z 9\% do 3,4\%. Na szczęście w kolejnym pięcioleciu, 2004-2008, a więc już w warunkach integracji europejskiej nastąpiło ożywienie gospodarcze i średnioroczny wzrost PKB ukształtował się na poziomie $5,4 \%$, natomiast produkcja sprzedana przemysłu spożywczego wzrastała średniorocznie o 5,6\%, ale nie osiągnęła już tempa wzrostu z lat 1993-1998. 
Tabela 3.2. Zestawienie dynamiki rozwoju wybranych kategorii ekonomicznych w \% (ceny stałe)

\begin{tabular}{|c|c|c|c|c|c|}
\hline \multirow{2}{*}{ Kategoria ekonomiczna } & \multicolumn{4}{|c|}{$\begin{array}{l}\text { Średnioroczne tempo zmian } \\
\text { w latach }\end{array}$} & \multirow{2}{*}{$\begin{array}{c}\text { Przyrost } \\
\text { w latach } \\
1999-2008\end{array}$} \\
\hline & $\begin{array}{c}1993- \\
1998\end{array}$ & $\begin{array}{c}1999- \\
2003\end{array}$ & $\begin{array}{c}2004- \\
2008\end{array}$ & $\begin{array}{l}1999- \\
2008\end{array}$ & \\
\hline $\begin{array}{l}\text { Produkcja sprzedana przemysłu } \\
\text { spożywczego }\end{array}$ & 9,0 & 3,4 & 5,6 & 4,4 & 47,4 \\
\hline PKB & 5,6 & 2,6 & 5,4 & 4,2 & 44,2 \\
\hline Spożycie żywności & 3,2 & 1,4 & 2,3 & 1,9 & 18,4 \\
\hline Produkcja rolnictwa globalna & 1,3 & $-0,7$ & 0,8 & 0,8 & 7,7 \\
\hline Produkcja towarowa rolnictwa & 2,1 & 2,0 & 1,6 & 2,0 & 19,2 \\
\hline $\begin{array}{l}\text { Eksport artykułów spożywczych, } \\
\text { napojów i wyrobów tytoniowych }\end{array}$ & 15,1 & 12,2 & 14,4 & 14,4 & 235,9 \\
\hline $\begin{array}{l}\text { Import artykułów spożywczych, } \\
\text { napojów i wyrobów tytoniowych }\end{array}$ & 11,8 & 4,2 & 16,4 & 11,3 & 162,5 \\
\hline Produkcja sprzedana przemysłu & 7,2 & 4,1 & 7,6 & 6,6 & 77,2 \\
\hline
\end{tabular}

Źr ó d ło : obliczenia własne na podstawie danych GUS.

Po wejściu Polski do UE rośnie zarówno produkcja sprzedana przemysłu spożywczego, jak i globalna i towarowa produkcja rolnicza. Jednak tempo wzrostu produkcji sprzedanej przemysłu spożywczego jest kilkakrotnie wyższe od analogicznego miernika produkcji rolnictwa, co oznacza rosnące w społeczeństwie zapotrzebowanie na żywność przetworzoną, ułatwiającą i skracającą czas przygotowania posiłków. Świadczy to również o słabnącej w polskiej gospodarce relacji przemysłu spożywczego z jego bazą surowcową - rolnictwem.

W latach 2004-2008 tempo wzrostu produkcji sprzedanej przemysłu spożywczego było prawie takie samo jak tempo rozwoju gospodarczego Polski (5,6\% i 5,4\%), i ponad dwukrotnie szybsze od tempa wzrostu spożycia żywności oraz prawie o jedną trzecią wolniejsze niż produkcja przemysłu ogółem (rys. 3.2). Rośnie znaczenie przemysłu spożywczego w agrobiznesie, ale spada jego znaczenie w produkcji całego polskiego przemysłu.

W analizie rozwoju przemysłu spożywczego w Polsce należy zwrócić uwagę na zmiany, jakie dokonały się w eksporcie produktów tego kierunku działalności wytwórczej. Dynamika eksportu była imponująca, bowiem jego wartość w cenach bieżących wzrosła z $8565 \mathrm{mln}$ zł w roku 1999 do $35104 \mathrm{mln}$ zł w roku 2008, co oznacza ponad czterokrotny wzrost. W strukturze geograficznej eksportu produktów przemysłu spożywczego dominują rynki krajów UE, a ich znaczenie, zwłaszcza od 2004 r., systematycznie wzrasta. W roku 2008 na rynki UE trafiło $81 \%$ wartości eksportu polskiej żywności, napojów i wyrobów tytoniowych. 
Szybki wzrost eksportu jest zapewne jednym z głównych czynników rozwoju analizowanego przemysłu. O znaczeniu eksportu w rozwoju przemysłu spożywczego świadczy ponad dwukrotny wzrost jego udziału w wartości przemysłu spożywczego. Wskaźnik ten z poziomu około 10\% w latach 1999-2001 zwiększył się do $23 \%$ w roku 2008 (por. tab. 3.3).

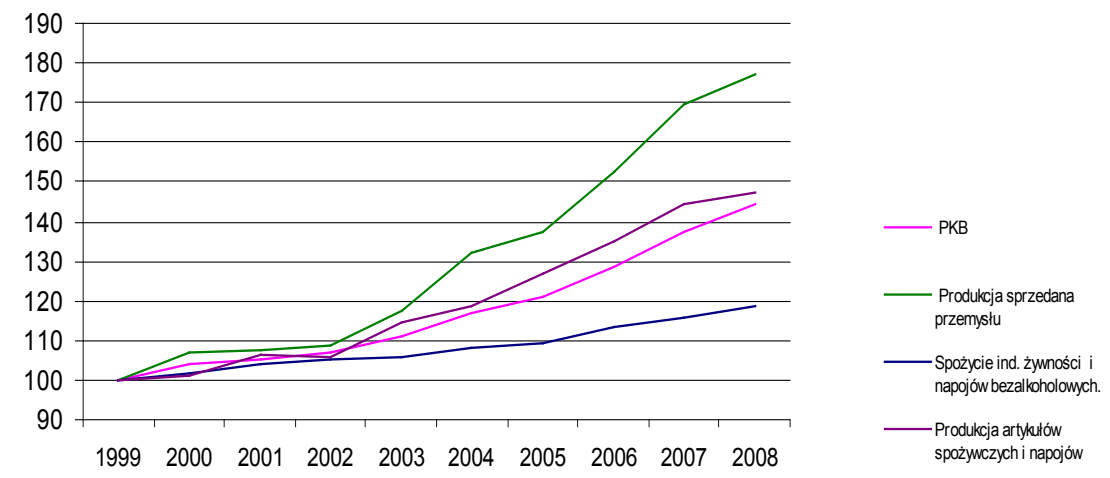

Rysunek 3.2. Dynamika produkcji sprzedanej przemysłu spożywczego na tle dynamiki PKB, spożycia żywności i produkcji przemysłowej (w cenach stałych, rok $1999=100$ )

Źr ódło: dane GUS i obliczenia własne.

Tabela 3.3. Wartość sprzedaży i eksportu przemysłu spożywczego w latach 1999-2008

\begin{tabular}{|c|c|c|c|}
\hline Lata & $\begin{array}{c}\text { Wartość sprzedaży art. } \\
\text { spożywczych, napojów } \\
\text { i wyrobów tytoniowych } \\
\text { (w mln zł) }\end{array}$ & $\begin{array}{c}\text { Wartość eksportu art. } \\
\text { spożywczych, napojów } \\
\text { i wyrobów tytoniowych } \\
\text { (w mln zł) }\end{array}$ & $\begin{array}{c}\text { Udział eksportu } \\
\text { w sprzedaży przemysłu } \\
\text { spożywczego (w \%) }\end{array}$ \\
\hline 1999 & 84413,3 & 8546,8 & 10,1 \\
\hline 2000 & 92891,5 & 9919,4 & 10,7 \\
\hline 2001 & 100036,8 & 10758,1 & 10,8 \\
\hline 2002 & 98480,4 & 11287,7 & 11,5 \\
\hline 2003 & 105006,9 & 14749,8 & 14,0 \\
\hline 2004 & 116755,2 & 19720,1 & 16,9 \\
\hline 2005 & 123537,6 & 24114,9 & 19,5 \\
\hline 2006 & 129544,0 & 28567,0 & 22,1 \\
\hline 2007 & 146005,6 & 32358,2 & 22,2 \\
\hline 2008 & 149889,9 & 35103,7 & 23,4 \\
\hline
\end{tabular}

Źródło: opracowanie własne na podstawie danych GUS. 
Od 1999 r. połowa przyrostu produkcji przemysłu spożywczego jest lokowana na zagranicznych rynkach, zatem bez rozwoju eksportu, będącego przede wszystkim efektem akcesji do UE, przyrost produkcji przemysłu spożywczego w cenach stałych (por. tab. 3.2) wynosiłby nie 47\%, a tylko ok. 23\%. Szczególnie duży jest udział eksportu w przemyśle owocowo-warzywnym, mięsnym mleczarskim oraz w innych kierunkach, wykorzystujących surowce importowane. Należą do nich: przetwórstwo ryb, kawy herbaty, wyrobów czekoladowych, produkcja wyrobów tytoniowych [Analiza produkcyjno-ekonomicznej ..., 2008, s. 122-123]. Dynamiczny rozwój tych dziedzin świadczy o uzyskanych na międzynarodowym rynku przewagach konkurencyjnych.

Ważnym czynnikiem rozwoju przemysłu spożywczego jest rosnący popyt na żywność wysoko przetworzoną. Najbardziej dynamiczną dziedziną przemysłu spożywczego w analizowanym okresie było wtórne przetwórstwo żywności, a zwłaszcza produkcja konserw, potraw, dań gotowych i innych wyrobów wieloskładnikowych oraz przekąsek, deserów i napojów bezalkoholowych. Produkcja tych wyrobów po wejściu do UE rozwijała się w tempie $6,6 \%$ rocznie co oznacza, że wskaźnik ten był zbliżony do analogicznego z pięciolecia poprzedzającego integrację z UE. Zatem po wejściu do UE wcześniejsza tendencja nie uległa zmianie.

Kolejną cechą rozwoju polskiego przemysłu spożywczego jest zróżnicowanie poziomu i struktury produkcji głównych kierunków przetwórstwa tego przemysłu. W wartości produkcji sprzedanej przemysłu spożywczego dominuje i rośnie udział przetwórstwa produktów pochodzenia zwierzęcego, z 32,1\% w 2003 r. do 36,7\% w 2008 r. Wzrasta również znaczenie przetwórstwa wtórnego, np. w roku 2008 udział ten wyniósł 23,1\% i był taki sam jak odsetek produkcji używek, najniższy udział w wartości produkcji sprzedanej ma przetwórstwo produktów pochodzenia roślinnego z poziomem 17,1\% w 2008 r. wobec 18,4\% w 2003 r.

Tabela 3.4. Struktura produkcji sprzedanej przemysłu spożywczego w 2003 i 2008 r. według głównych kierunków przetwórstwa (w \%, ceny stałe)

\begin{tabular}{|l|r|r|}
\hline \multicolumn{1}{|c|}{ Wyszczególnienie* } & 2003 & 2008 \\
\hline Przemysł spożywczy & 100,0 & 100,0 \\
\hline Przetwórstwo produktów pochodzenia zwierzęcego & 32,1 & 36,7 \\
\hline Przetwórstwo produktów pochodzenia roślinnego & 18,4 & 17,1 \\
\hline Przetwórstwo wtórne & 20,3 & 23,1 \\
\hline Produkcja używek & 29,2 & 23,1 \\
\hline
\end{tabular}

* Dane dotyczą podmiotów zatrudniających powyżej 49 osób.

Źr ódło: obliczenia własne na podstawie niepublikowanych danych GUS. 


\subsubsection{Bezpośrednie inwestycje zagraniczne}

Przemysł spożywczy należał w latach 90. do tych działów przetwórstwa przemysłowego, które były przedmiotem dużego zainteresowania kapitału zagranicznego. Ze względu na niski poziom kapitału krajowego w tym obszarze działalności gospodarczej ważny był i jest napływ inwestycji zagranicznych. Szczególnie pożądany wydaje się napływ kapitału zagranicznego w postaci bezpośrednich inwestycji zagranicznych (BIZ), które są istotnym źródłem finansowania procesów modernizacyjnych i rozwojowych. Bezpośrednie inwestycje zagraniczne w przemyśle spożywczym w Polsce rozpoczynały się w latach dziewięćdziesiątych od: (1) zakupu całości, części przedsiębiorstwa lub akcji od Skarbu Państwa, lub (2) od innego właściciela albo też (3) od budowy od podstaw nowego zakładu. W dalszej fazie następowało zwykle zwiększenie majątku przedsiębiorstwa [Urban, Rowiński i inni 2004, s. 109].

Wielkość inwestycji zagranicznych $\mathrm{w}$ danym kraju świadczy o integracji z gospodarką światową oraz wskazuje na jego atrakcyjność dla inwestorów zagranicznych.

Z analizy napływu kapitału zagranicznego do Polski wynika, że do $2000 \mathrm{r}$. obserwowano szybką tendencję wzrostową tego zjawiska. W latach następnych wystąpiło znaczące załamanie, ale w roku poprzedzającym integrację Polski z UE nastąpił wzrost poziomu BIZ (por. rys. 3.3). Polska była postrzegana przez inwestorów zagranicznych jako kraj atrakcyjny, a większość kapitału zagranicznego napływającego do naszego kraju pochodzi z wysoko rozwiniętych krajów UE.

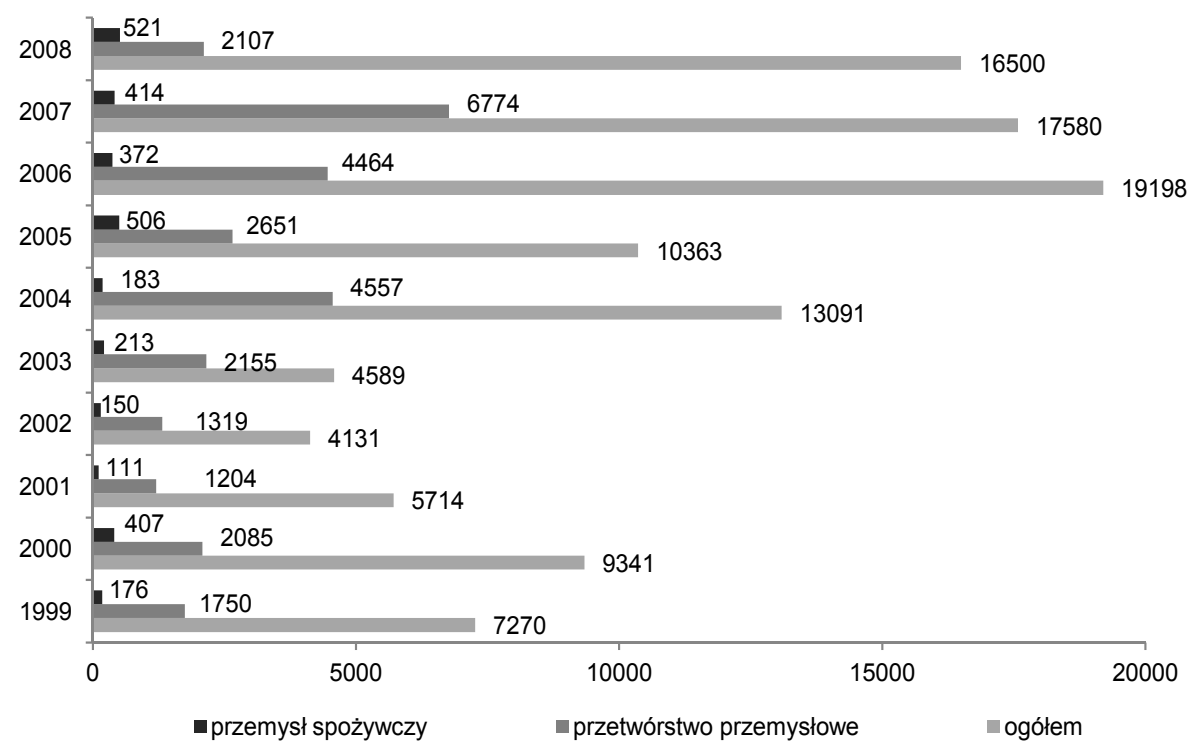

Rysunek 3.3. Napływ BIZ do Polski w latach 1999-2008 (mln USD)

Źr ód ło : Narodowy Bank Polski. 
Do końca 2008 r. odnotowano w Polsce łączny napływ BIZ w wysokości $163956 \mathrm{mln}$ USD. Bezpośrednio do przetwórstwa przemysłowego trafiło 50617 mln USD, co stanowiło ok. 31\% skumulowanej wartości bezpośrednich inwestycji zagranicznych w Polsce, a na przemysł spożywczy przypadło 7806 mln USD, tj. ok. 5\% tej wartości.

Przemysł spożywczy to drugi dział przetwórstwa przemysłowego, po przemyśle motoryzacyjnym, pod względem wielkości napływu bezpośrednich inwestycji zagranicznych w Polsce (na koniec 2008 r.).

Skumulowane inwestycje zagraniczne w przemyśle spożywczym do $2008 \mathrm{r}$. wynosiły 7806 mln USD, co stanowi 15,4\% kapitału zagranicznego zainwestowanego w przetwórstwie przemysłowym w Polsce (wykres 3.4). W latach 1999-2008, pomimo rosnącej wartości inwestowanego kapitału w przemyśle spożywczym, jego znaczenie w inwestycjach zagranicznych w Polsce stopniowo się zmniejszało, z ponad 9\% w 1999 r. do $5 \% \mathrm{w} 2008 \mathrm{r}$. W połowie lat 90. XX w. było ono dwukrotnie wyższe niż w 1999 r. Silny strumień inwestycji zagranicznych napływających w latach dziewięćdziesiątych do przemysłu spożywczego wiązał się ściśle z procesem prywatyzacji. Kapitał zagraniczny wybrał najbardziej dynamiczne oraz generujące największe zyski branże. Były to dobrze funkcjonujące branże przemysłu spożywczego, takie jak: przemysł tytoniowy, cukierniczy, koncentratów spożywczych, piwowarski i olejarski. Prywatyzacja, przy wykorzystaniu kapitału zagranicznego i z jego udziałem, stanowiła szansę dla zaistnienia tych firm na rynku krajowym i zagranicznym. Należy wspomnieć, że istniały przypadki prywatyzowania przedsiębiorstw branży drobiarskiej, mięsnej, młynarskiej, owocowo-warzywnej, paszowej, rybnej, ziemniaczanej, nie miały one jednak większego znaczenia w ogólnym procesie prywatyzacji. Dostarczanie przez zagranicznych inwestorów nowych technologii, know-how oraz kapitału finansowego umożliwiło przeprowadzenie modernizacji i restrukturyzacji. Przekształcone z udziałem kapitału zagranicznego przedsiębiorstwa charakteryzowały się szybką dynamiką rozwojową, upatrując swych szans w eksporcie towarów i wykorzystaniu doświadczenia zagranicznych inwestorów. Na rynku funkcjonuje wiele przedsiębiorstw, które podlegały zarówno przekształceniom własnościowym, jak i restrukturyzacyjnym. Zajmują one wiodącą pozycję w gospodarce żywnościowej i posiadają znaną markę.

Analizując napływ BIZ do przemysłu spożywczego w Polsce warto zwrócić uwagę na lokalizację branżową tych inwestycji. W tabeli 3.5. zaprezentowano udział poszczególnych branż i kierunków przetwórstwa spożywczego w skumulowanej wartości BIZ na koniec 2008 r. 


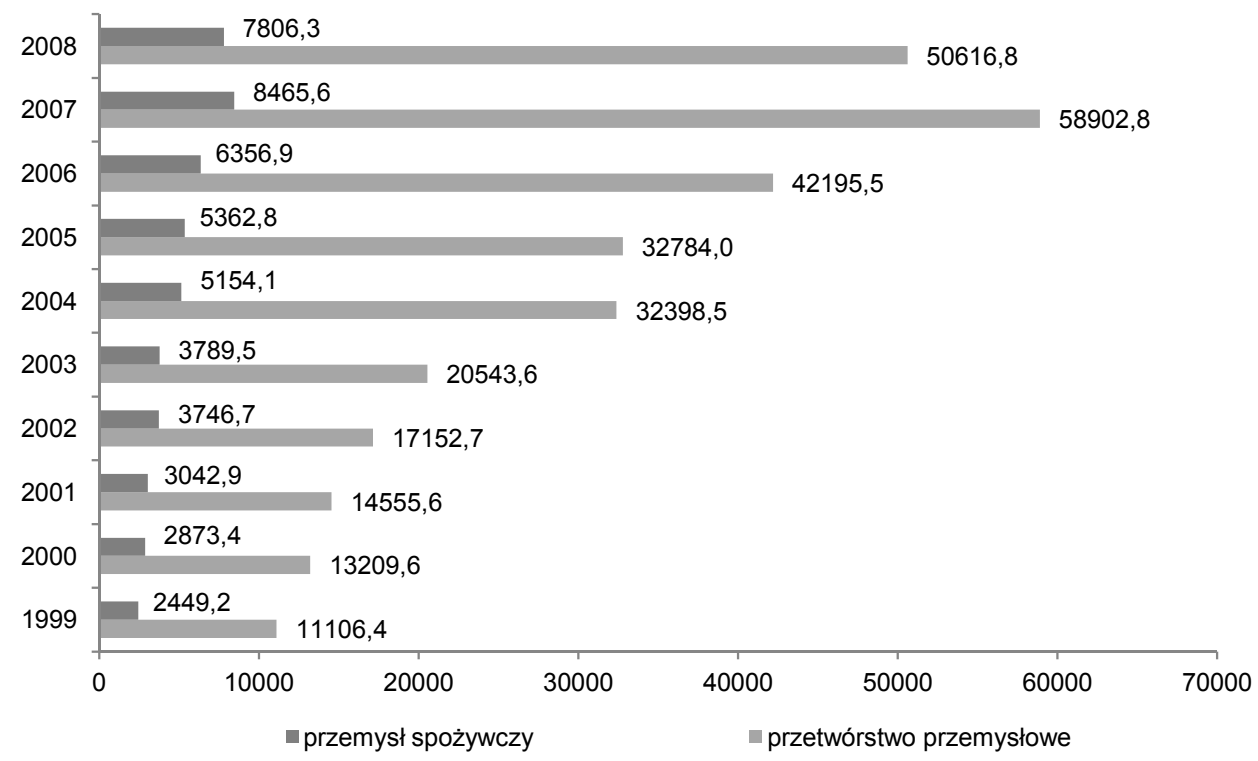

Rysunek 3.4. Skumulowana wartość kapitału zagranicznego w przetwórstwie przemysłowym oraz przemyśle spożywczym w Polsce w latach 1999-2008 (w mln USD)

Źr ó d ło : Narodowy Bank Polski

Tabela 3.5. Struktura branżowa skumulowanej wartości inwestycji zagranicznych w przemyśle spożywczym (stan na 31.12.2008)

\begin{tabular}{|l|c|}
\hline \multicolumn{1}{|c|}{ Wyszczególnienie } & Udział (\%) \\
\hline \multicolumn{1}{|c|}{$[\mathrm{A}]$} & {$[\mathrm{B}]$} \\
\hline Przetwórstwo produktów pochodzenia zwierzęcego & $\mathbf{1 2 , 7 3}$ \\
\hline Przemysł mięsny & 4,47 \\
\hline Przemysł drobiowy & 0,75 \\
\hline Przemysł rybny & 1,70 \\
\hline Przemysł mleczarski & 5,81 \\
\hline Przetwórstwo produktów pochodzenia roślinnego & $\mathbf{2 3 , 2 4}$ \\
\hline Przemysł ziemniaczany & 4,98 \\
\hline Przemysł owocowo-warzywny & 6,71 \\
\hline Przemysł olejarski & 3,41 \\
\hline Przemysł zbożowo-młynarski & 1,17 \\
\hline Przemysł cukrowniczy & 6,97 \\
\hline
\end{tabular}




\begin{tabular}{|l|c|}
\hline \multicolumn{1}{|c|}{$[\mathrm{A}]$} & {$[\mathrm{B}]$} \\
\hline Przetwórstwo wtórne & $\mathbf{4 0 , 0 0}$ \\
\hline Przemysł paszowy & 7,85 \\
\hline Przemysł piekarski & 0,78 \\
\hline Przemysł cukierniczy & 8,24 \\
\hline Produkcja koncentratów spożywczych & 10,07 \\
\hline Produkcja napojów bezalkoholowych & 13,06 \\
\hline Produkcja używek & $\mathbf{2 4 , 0 3}$ \\
\hline Przemysł spirytusowy & 4,03 \\
\hline Przemysł winiarski & 0,67 \\
\hline Przemysł piwowarski & 11,46 \\
\hline Przemysł tytoniowy & 7,87 \\
\hline Razem & $\mathbf{1 0 0 , 0 0}$ \\
\hline
\end{tabular}

Źr ódło: opracowanie własne na podstawie niepublikowanych danych NBP.

Z powyższych danych, dotyczących lokalizacji kapitału zagranicznego w polskim przemyśle spożywczym do końca 2008 r. wynika, że zdecydowanie najwięcej tego kapitału ulokowano w przetwórstwie wtórnym (40\%), najmniej w przetwórstwie produktów pochodzenia zwierzęcego (12,73\%). Podobny udział w BIZ odnotowano dla produkcji używek $(24,03 \%)$ i przetwórstwa produktów pochodzenia roślinnego $(23,24 \%)$.

Największą popularnością wśród inwestorów zagranicznych cieszyła się branża napojów bezalkoholowych, drugie miejsce zajęła branża piwowarska, a trzecie produkcja koncentratów spożywczych. Śladowe ilości kapitału zagranicznego zaangażowano w branży winiarskiej $(0,67 \%)$, drobiowej $(0,75 \%)$ oraz piekarskiej (0,78\%).

Ważnymi zagranicznymi inwestorami w przemyśle spożywczym, którzy weszli na polski rynek byli: Coca Cola Hellenic Bottling Company, niemiecka Reemtsma Cigarettenfabrik GmbH, amerykański Philips Morris, szwajcarskie Nestle, amerykańskie Pepsico, holenderskie Harbin BV i Heineken. Czas pokazał, że inwestycje były trafne, firmy z udziałem kapitału zagranicznego przynoszą spodziewane dochody [Firlej 2008, s.101-102].

\subsubsection{Produktywność przemysłu spożywczego}

Pozytywną cechą przekształceń w polskim przemyśle spożywczym jest wzrost wydajności pracy. Analizując zmiany wydajności pracy mierzonej 
produkcją sprzedaną przemysłu spożywczego w cenach stałych na 1 zatrudnionego widzimy, że w latach 1999-2008 wydajność ta wzrosła z 197,8 tys. zł do 329,8 tys. zł (zwiększenie o 67\%) W całym badanym okresie, zarówno w pięcioleciu poprzedzającym integrację, jak i w latach członkostwa Polski w UE, badana wydajność pracy systematycznie wzrastała, przeciętnie z r. na rok prawie o $6 \%$. Wzrost ten osiągnięto, w przeciwieństwie do lat wcześniejszych (1993-1998), w warunkach stabilizacji zatrudnienia na poziomie około 430 tys. osób rocznie.

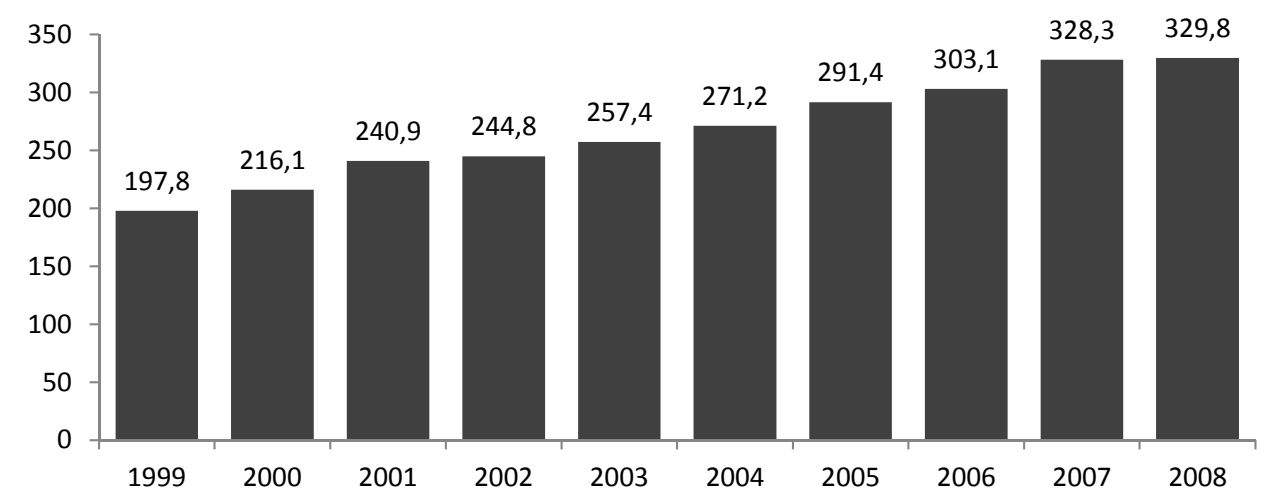

Rysunek 3.5. Wydajność pracy w przemyśle spożywczym (produkcja sprzedana na 1 zatrudnionego w tys. zł) w latach 1999-2008 (ceny stałe)

Źród ło : opracowanie własne na podstawie Roczników statystycznych przemystu GUS.

Osiągnięto również dużą poprawę wydajności pracy mierzonej wartością dodaną brutto na 1 zatrudnionego (rys. 3.6). W latach 1999-2008 średnioroczny wzrost wydajności pracy w przemyśle spożywczym wyniósł $3,9 \%$, a w całym badanym okresie 1999-2008 wydajność pracy wzrosła prawie o $42 \%$. Jednak to imponujące tempo wzrostu wydajności pracy (mierzone wartością dodaną brutto) zostało zahamowane w 2008, kiedy to po raz pierwszy w ciągu badanego dziesięciolecia wydajność spadła o 1,6\% w stosunku do roku 2007. Na razie trudno powiedzieć czy jest to początek nowej tendencji będącej efektem kryzysu gospodarczego. 


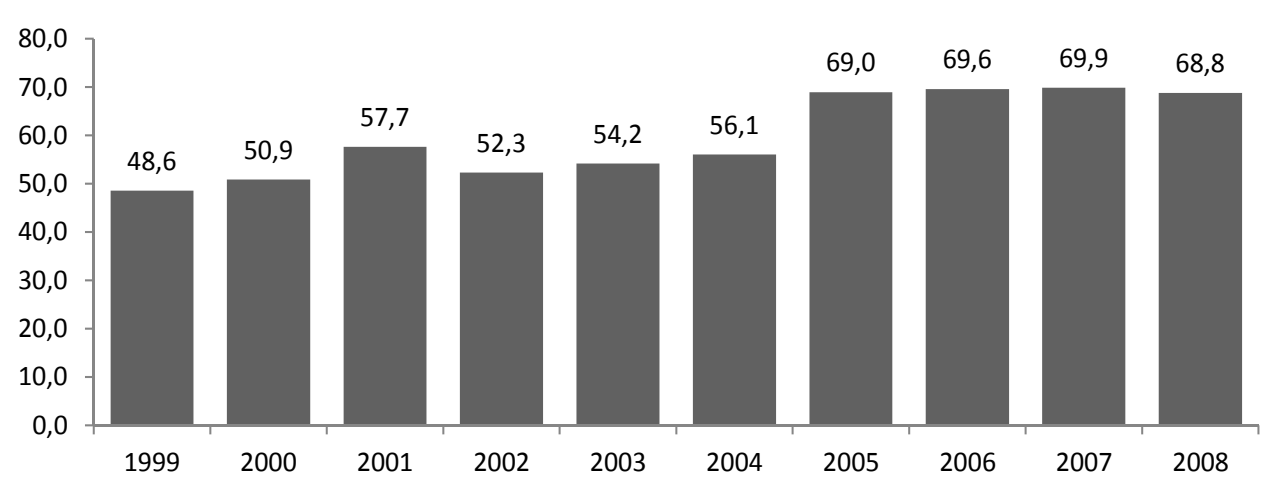

Rysunek 3.6. Wydajność w przemyśle spożywczym mierzona wartością dodaną brutto (ceny stałe) na 1 zatrudnionego w tys. zł

Źródło: opracowanie własne na podstawie Roczników statystycznych przemysłu GUS dla lat 1999-2008.

Warto przeanalizować również poziom wydajności pracy w produkcji artykułów spożywczych, napojów i wyrobów tytoniowych na tle wydajności pracy obserwowanej w przemyśle ogółem oraz $\mathrm{w}$ innych działach przetwórstwa przemysłowego (por. tab. 3.6).

W roku 2008 wydajność pracy w przemyśle spożywczym mierzona produkcją sprzedaną na jednego zatrudnionego wyniosła 343 tys. zł i była wyższa zarówno od wydajności osiągniętej w przemyśle ogółem (320 tys. zł), jak i w całej sekcji przetwórstwa przemysłowego (317 tys. zł). Należy również podkreślić, że wydajność pracy w przemyśle spożywczym w 2008 r. była kilkakrotnie wyższa od wydajności pracy występującej w polskim rolnictwie (40 tys. zł). Zdecydowanie gorzej przedstawia się sytuacja przemysłu spożywczego pod względem wydajności pracy wyrażonej wartością dodaną brutto na jednego zatrudnionego. Obliczona w ten sposób wydajność pracy w przemyśle spożywczym wyniosła tylko 71 tys. zł na jednego zatrudnionego i była niższa od wydajności w przemyśle ogółem (93 tys. zł) i przetwórstwie przemysłowym (82 tys. zł), ale kilkakrotnie wyższa niż w rolnictwie (18 tys. zł). 
Tabela 3.6. Wydajność pracy w przemyśle spożywczym na tle innych działów przetwórstwa przemysłowego i przemysłu ogółem w Polsce w 2008 r. (ceny bieżące)

\begin{tabular}{|c|c|c|}
\hline \multirow[t]{2}{*}{ Wyszczególnienie } & $\begin{array}{l}\text { Wydajność } \\
\text { pracy } \\
\text { mierzona } \\
\text { produkcją } \\
\text { sprzedaną }\end{array}$ & $\begin{array}{c}\text { Wydajność } \\
\text { pracy } \\
\text { mierzona } \\
\text { wartością } \\
\text { dodaną brutto }\end{array}$ \\
\hline & \multicolumn{2}{|c|}{ w tys. zl na 1 zatrudnionego } \\
\hline Przemysł ogółem & 320 & 93 \\
\hline Przetwórstwo przemysłowe & 317 & 82 \\
\hline $\begin{array}{l}\text { Produkcja artykułów spożywczych, napojów i wyrobów } \\
\text { tytoniowych }\end{array}$ & 343 & 71 \\
\hline Włókiennictwo & 137 & 54 \\
\hline $\begin{array}{l}\text { Produkcja koksu, produktów rafinacji ropy naftowej i paliw } \\
\text { jądrowych }\end{array}$ & 3624 & 552 \\
\hline Produkcja wyrobów chemicznych & 474 & 126 \\
\hline Produkcja wyrobów gumowych i z tworzyw sztucznych & 272 & 77 \\
\hline Produkcja metali & 591 & 141 \\
\hline $\begin{array}{l}\text { Produkcja wyrobów z metali (metalowych wyrobów gotowych, } \\
\text { z wyłączeniem maszyn i urządzeń) }\end{array}$ & 239 & 74 \\
\hline Produkcja maszyn i urządzeń, gdzie indziej niesklasyfikowana & 280 & 80 \\
\hline Produkcja maszyn biurowych i komputerów & 307 & 101 \\
\hline $\begin{array}{l}\text { Produkcja sprzętu i urządzeń radiowych, telewizyjnych } \\
\text { i telekomunikacyjnych }\end{array}$ & 511 & 72 \\
\hline $\begin{array}{l}\text { Produkcja instrumentów medycznych, precyzyjnych } \\
\text { i optycznych, zegarów i zegarków }\end{array}$ & 243 & 97 \\
\hline Produkcja pojazdów samochodowych, przyczep i naczep & 596 & 95 \\
\hline Produkcja mebli; pozostała działalność produkcyjna & 173 & 55 \\
\hline Produkcja odzieży i wyrobów futrzarskich & 64 & 38 \\
\hline Produkcja skór wyprawionych i wyrobów ze skór wyprawionych & 113 & 36 \\
\hline $\begin{array}{l}\text { Produkcja drewna i wyrobów z drewna oraz z korka (z wyłączeniem } \\
\text { mebli), wyrobów ze słomy i materiałów używanych do wyplatania }\end{array}$ & 206 & 59 \\
\hline Produkcja masy włóknistej, papieru oraz wyrobów z papieru & 405 & 101 \\
\hline $\begin{array}{l}\text { Działalność wydawnicza; poligrafia i reprodukcja zapisanych } \\
\text { nośników informacji }\end{array}$ & 296 & 135 \\
\hline Przetwarzanie odpadów & 443 & 106 \\
\hline Produkcja wyrobów z pozostałych surowców niemetalicznych & 302 & 109 \\
\hline $\begin{array}{l}\text { Produkcja maszyn i aparatury elektrycznej, gdzie indziej } \\
\text { niesklasyfikowana }\end{array}$ & 264 & 83 \\
\hline Produkcja pozostałego sprzętu transportowego & 213 & 65 \\
\hline
\end{tabular}

Źr ó dł o : opracowanie własne na podstawie Rocznika statystycznego przemysłu 2009, GUS. 
Lepsze wyniki w zakresie wydajności pracy, mierzonej produkcją sprzedaną oraz wartością dodaną brutto, osiągnęły działy przetwórstwa przemysłowego zaliczane do wyższych niż przemysł spożywczy poziomów techniki - produkcja koksu, produktów rafinacji ropy naftowej i paliw jądrowych; produkcja wyrobów chemicznych; produkcja metali; produkcja sprzętu i urządzeń radiowych, telewizyjnych i komunikacyjnych; produkcja pojazdów samochodowych, przyczep i naczep. Spośród działów przetwórstwa przemysłowego należących, podobnie jak przemysł spożywczy, do grupy niskiej techniki wyższą wydajność pracy zaobserwowano tylko w dwóch działach - przetwarzanie odpadów oraz w dziale produkcja masy włóknistej, papieru oraz wyrobów z papieru.

Jednak, mimo obserwowanej w ostatnich latach rosnącej tendencji wydajności pracy w polskim przemyśle spożywczym, jest ona nadal niższa niż w ,starej” UE. Szacuje się, że różnica ta wynosi około $35 \%$, ale charakteryzuje się trendem malejącym [Urban, Szczepaniak, Mroczek 2010, s. 34-35].

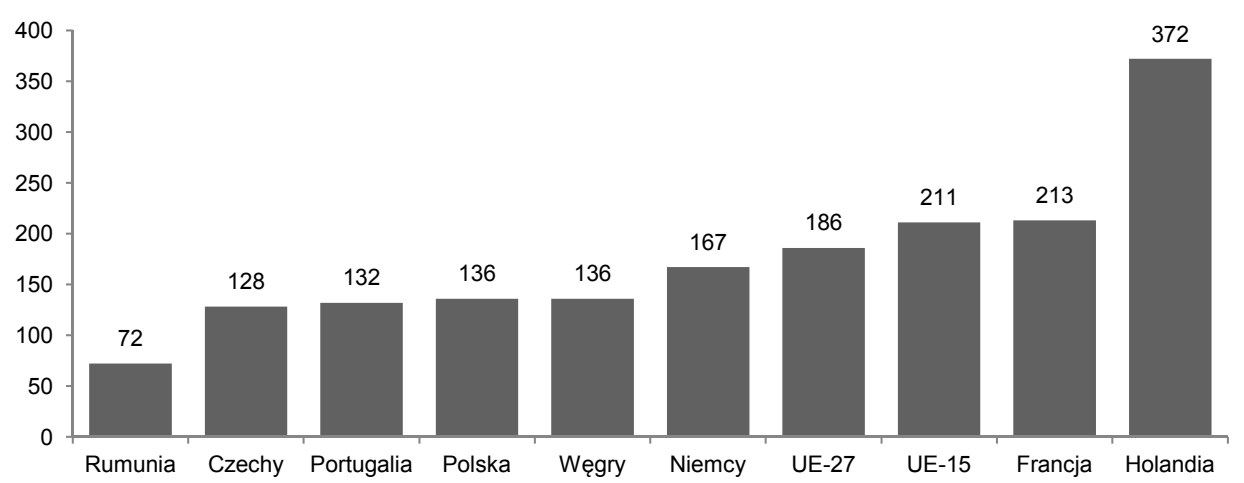

Uwaga: bez przemysłu tytoniowego.

Rysunek 3.7. Wydajność pracy w polskim przemyśle spożywczym na tle wybranych krajów UE w 2007 r. (w tys. euro)

Źródło: R. Urban., Wptyw integracji z Unia Europejska na polski przemyst spożywczy, [w:] R. U rb an (red.), Wplyw integracji z Unia Europejska na polska gospodarke żywnościowa, raport nr 90, IERiGŻ-PIB, Warszawa 2008, s. 114.

Wśród nowych krajów członkowskich UE wydajność pracy w polskim przemyśle spożywczym jest wyższa od przeciętnej i kształtuje się na podobnym poziomie jak na Węgrzech, w Słowenii, Słowacji i Czechach, przy czym jest znacznie wyższa niż w krajach bałtyckich oraz Bułgarii i Rumunii.

Oceniając produktywność przemysłu spożywczego nie można pominąć bardzo ważnego aspektu produktywności, a mianowicie zużycia energii i wody w procesie produkcji (por. tab. 3.7) 
Tabela 3.7. Zużycie energii i wody w przemyśle spożywczym w latach 1999-2008*

\begin{tabular}{|l|c|c|c|c|c|c|c|c|}
\hline \multicolumn{1}{|c|}{ Wyszczególnienie } & 1999 & 2000 & 2002 & 2003 & 2004 & 2005 & 2007 & 2008 \\
\hline $\begin{array}{l}\text { Zużycie na 1 mld produkcji } \\
\text { sprzedanej energii w tys. TJ }\end{array}$ & 1,00 & 0,95 & 0,89 & 0,86 & 0,81 & 0,75 & 0,64 & 0,62 \\
\hline $\begin{array}{l}\text { Zużycie na 1 mld produkcji } \\
\text { sprzedanej wody w } \mathrm{hm}^{3}\end{array}$ & 1,21 & 1,13 & 0,95 & 0,92 & 0,90 & 0,85 & 0,73 & 0,68 \\
\hline
\end{tabular}

*W cenach stałych z 2005 r.

Źr ó d ł o : obliczenia własne na podstawie Roczników statystycznych przemystu dla lat 2000-2009.

W latach 1999-2008 nastąpiła wyraźna poprawa w zakresie jednostkowego zużycia energii i wody. Jednostkowe zużycie energii zmniejszyło się w badanym okresie o $38 \%$, a wody o 44\%. Średnioroczne tempo obniżania się energochłonności i wodochłonności było wysokie i wynosiło około 4\%. Poprawa efektywności wykorzystania energii i wody wpływa nie tylko na wyniki ekonomiczne przedsiębiorstw przemysłu spożywczego, ale również przyczynia się do osiągania standardów i spełniania wymagań, stawianych krajom członkowskim przez UE, w zakresie produkcji i ochrony środowiska.

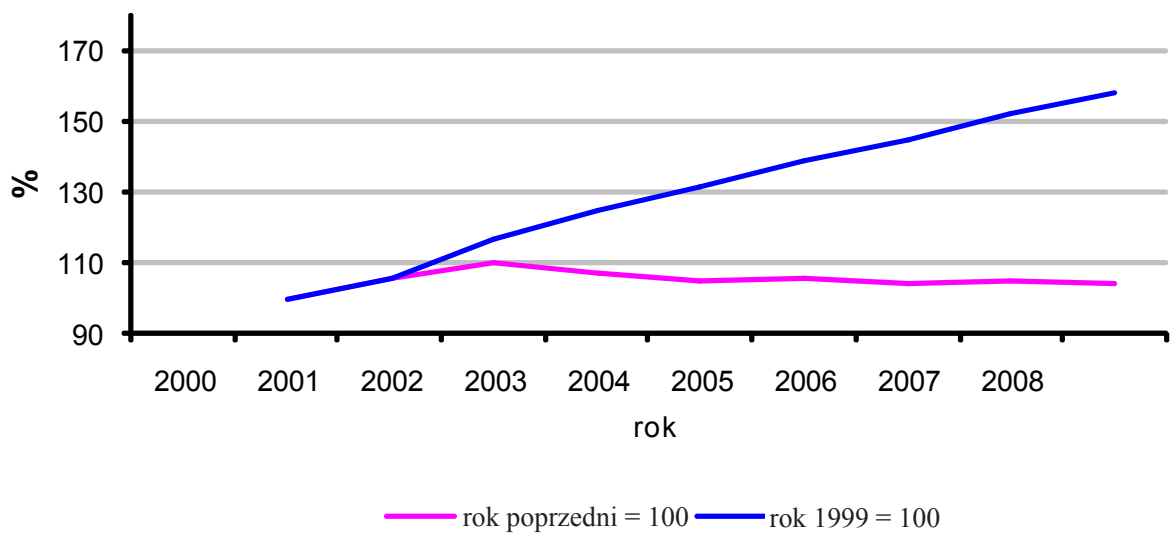

Rysunek 3.8. Dynamika majątku trwałego w produkcji artykułów spożywczych, napojów i wyrobów tytoniowych w latach 1999-2008 (ceny stałe)

Źródło: opracowanie własne na podstawie danych z Roczników statystycznych przemysłu GUS dla lat 2000-2009. 
Wzrost efektywności wykorzystania ludzkiej pracy, energii i wody został osiągnięty m.in. poprzez wzrost technicznego uzbrojenia pracy i majątkochłonności produkcji. W badanym przedziale czasowym wartość majątku trwałego (wartości brutto środków trwałych) systematycznie wzrastała i tak w roku 2008, w porównaniu z rokiem 1999, wartość tego majątku (w cenach stałych) wzrosła o 58\%, a średnioroczne tempo wzrostu przekroczyło 5\% (rys. 3.8). Najbardziej dynamiczny wzrost majątku trwałego odnotowano w okresach bezpośrednio poprzedzających integrację europejską. W latach 2002 i 2003 tempo wzrostu majątku trwałego wyniosło odpowiednio $10 \%$ i $7 \%$.

$\mathrm{Z}$ informacji zawartych $\mathrm{w}$ tab. 3.8 wynika, że już po wejściu Polski do UE zmiany w zakresie majątkochłonności produkcji (wartość brutto środków trwałych na 1 zł produkcji sprzedanej) były niewielkie. Obserwuje się natomiast stałą tendencję wzrostową technicznego uzbrojenia pracy, które wyrażono wartością majątku trwałego przypadającą na 1 osobę zatrudnioną w przemyśle spożywczym.

Tabela 3.8. Majątek trwały w produkcji artykułów spożywczych, napojów i wyrobów tytoniowych*

\begin{tabular}{|l|c|c|c|c|c|c|c|c|c|c|}
\hline $\begin{array}{l}\text { Wyszcze- } \\
\text { gólnienie }\end{array}$ & 1999 & 2000 & 2001 & 2002 & 2003 & 2004 & 2005 & 2006 & 2007 & 2008 \\
\hline $\begin{array}{l}\text { Wartość } \\
\text { brutto śr. } \\
\text { trwałych } \\
\text { w mln zł }\end{array}$ & 43282,66 & 43326,43 & 45844,91 & 50523,85 & 53988,00 & 56859,54 & 60055,50 & 62669,76 & 65889,64 & 68486,36 \\
\hline $\begin{array}{l}\text { Wartość } \\
\text { brutto środ- } \\
\text { ków trwa- } \\
\text { łych na 1 zł } \\
\text { produkcji } \\
\text { sprzedanej } \\
\text { w zł }\end{array}$ & 0,44 & 0,43 & 0,42 & 0,47 & 0,48 & 0,49 & 0,49 & 0,49 & 0,46 & 0,47 \\
\hline $\begin{array}{l}\text { Wartość } \\
\text { brutto } \\
\text { śodków } \\
\text { trwałych na } \\
\begin{array}{l}\text { zatrud- } \\
\text { nionego } \\
\text { w tys. zł }\end{array}\end{array}$ & 86,81 & 92,82 & 101,45 & 115,30 & 124,40 & 132,45 & 141,67 & 147,67 & 151,99 & 156,58 \\
\hline
\end{tabular}

* W cenach stałych z 2005 r.

Źródło: obliczenia własne na podstawie Roczników statystycznych przemysłu GUS dla lat 2000-2009.

Zmiana, a przede wszystkim poprawa, relacji między zasobami pracy żywej i majątku trwałego w polskim przemyśle spożywczym były efektem wysokiego poziomu inwestowania. Trwające $\mathrm{w}$ polskim przemyśle spożywczym ożywienie 
inwestycyjne zostało wywołane przede wszystkim procesami integracyjnymi i koniecznością dostosowania zakładów do standardów unijnych. W 2008 r. wartość inwestycji w przemyśle spożywczym (ceny stałe) wyniosła 7,6 mld zł i była najwyższa w całym analizowanym okresie. Jest to poziom o 9\% wyższy niż w $2007 \mathrm{r}$. i o ponad 15\% niż w 1999 r. Największe tempo wzrostu nakładów inwestycyjnych odnotowano w latach 2003 i 2004, kiedy to inwestycje wzrosły (w stosunku do roku poprzedniego) odpowiednio o $18,8 \%$ i $15,5 \%$ (rys. 3.9).

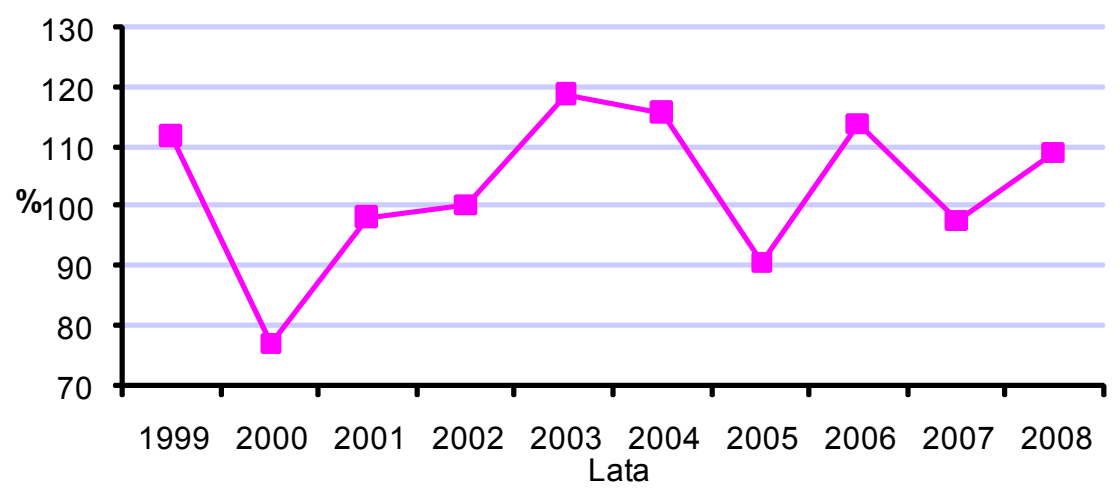

Rysunek 3.9. Dynamika nakładów inwestycyjnych przemysłu spożywczego (ceny stałe, rok poprzedni $=100)$ w latach $1999-2008$

Źródło: obliczenia własne na podstawie Roczników statystycznych przemysłu GUS dla lat 2000-2009.

Utrzymujący się wysoki poziom inwestowania w przedsiębiorstwach przemysłu spożywczego przyczynił się do kilkakrotnego wzrostu liczby zakładów uprawnionych do handlu na rynkach UE oraz do dalszej poprawy stanu technicznego i unowocześnienia sposobów wytwarzania żywności w tych podmiotach. W okresie integrowania z UE wzrost liczby zakładów spełniających warunki handlu na rynkach Wspólnoty był imponujący [Urban 2009, s. 225]:

- 15-krotny w przemyśle mięsnym (do ponad 900 zakładów),

- 6-krotny w przemyśle mleczarskim i drobiarskim (odpowiednio do 235 i 211 zakładów),

- 4-krotny w przemyśle rybnym (do 242 zakładów).

Ogromne środki zainwestowane w przemysł spożywczy poprawiły stan techniczny i technologiczny przetwórstwa żywności, co w efekcie spowodowało poprawę konkurencyjności tego przemysłu i sprawiło, że pod względem nowoczesności polski przemysł spożywczy, a szczególnie liderzy tego przemysłu, należą do ścisłej czołówki europejskiej. Wiele polskich zakładów przetwórstwa żywności uznawanych jest za najnowocześniejsze w Europie. 


\subsubsection{Wyniki ekonomiczno-finansowe przemysłu spożywczego}

W okresie integrowania się z UE nastąpiło ożywienie produkcyjne $\mathrm{i}$ inwestycyjne oraz efektywniejsze wykorzystanie czynników wytwórczych i wzrost eksportu. Wszystkie te pozytywne zmiany, zachodzące w omawianym dziale przetwórstwa przemysłowego, przyczyniły się do poprawy jego wyników ekonomicznych i finansowych. Odwrócona została wcześniejsza tendencja spadku realnej wartości dodanej. Od 2003 r. wartość dodana brutto w przemyśle spożywczym systematycznie wzrasta (rys. 3.10). Wyjątek stanowi jedynie rok 2008, kiedy ta wzrostowa tendencja została zahamowana, poprzez nieznaczny spadek wartości dodanej (w cenach stałych). W latach 2003-2008 ta sama wielkość wzrosła o $28 \%$, z 23,5 do 30,1 mld zł.

\section{$m \ln z \nmid$}

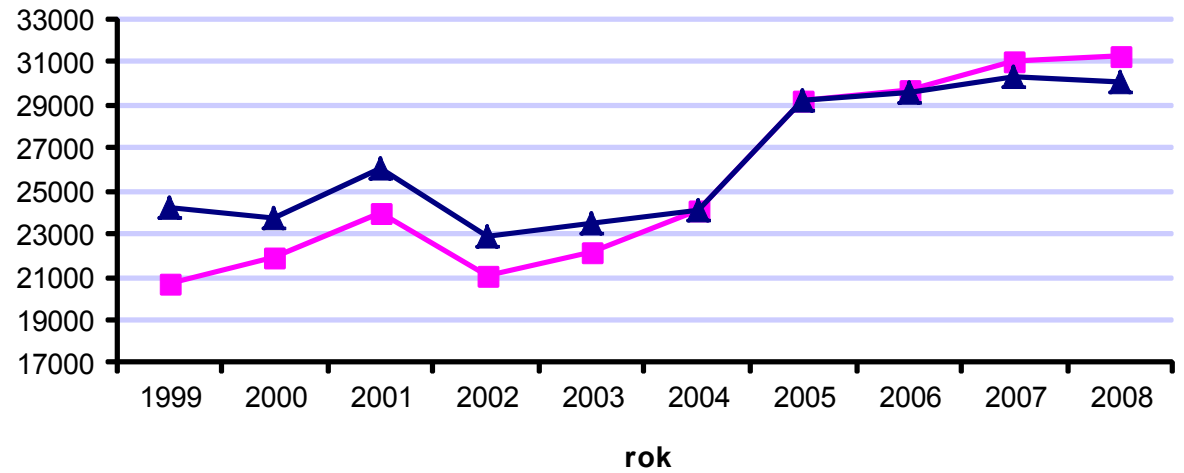

—Wartość dod. brutto art.spoż., napojów i wyr. tyton. (c. bieżące) w mln zł

—Wartość dod. brutto art.spoż., napojów i wyr. tyton. (c. stałe z 2005 roku) w mln zł

Rysunek 3.10 Wartość dodana przemysłu spożywczego (w mln zł) w latach 1999-2008

Źródło: opracowanie własne na podstawie: Roczników statystycznych GUS 2000-2009 oraz Roczników statystycznych przemystu GUS dla lat 2000-2009.

Kolejnym sygnałem poprawy wyników przemysłu spożywczego jest zwiększająca się kwota zysku, zarówno netto, jak i brutto. W dalszych rozważaniach skoncentrowano się jedynie na analizie zysku netto, czyli wyniku finansowego, który pozostaje po pomniejszeniu zysku brutto o obowiązkowe obciążenia, tj. podatek dochodowy od osób prawnych i fizycznych oraz inne płatności wynikające z odrębnych przepisów [Rocznik statystyczny przemystu, 2009, s.146]. Zysk netto w cenach stałych wzrósł z poziomu 119,7 mln zł w r. 2000 do prawie 3,9 mld zł w 2008 r. W okresie 1999-2008 rekordową kwotę zysku netto przemysł spożywczy wypracował w 2007 r., kiedy wyniosła ona aż 5,9 mld zł (por. tab. 3.9). 
Tabela 3.9. Wyniki finansowe przemysłu spożywczego w Polsce

\begin{tabular}{|l|c|c|c|c|c|c|c|c|c|c|}
\hline \multicolumn{1}{|c|}{ Wyszczególnienie } & 1999 & 2000 & 2001 & 2002 & 2003 & 2004 & 2005 & 2006 & 2007 & 2008 \\
\hline $\begin{array}{l}\text { Wynik finansowy netto } \\
\text { prod. art. spoż., napojów, } \\
\text { wyr. tyt.w mln zł* }\end{array}$ & $-486,6$ & 119,7 & 977,3 & 2012,2 & 1546,6 & 4559,9 & 4255,0 & 5031,1 & 5912,4 & 3865,5 \\
\hline $\begin{array}{l}\text { Wskaźnik rentowności } \\
\text { obrotu netto } \\
\text { przedsiębiorstw przemysłu } \\
\text { spożywczego w \% }\end{array}$ & $-0,41$ & 0,10 & 0,74 & 1,66 & 1,19 & 3,28 & 3,00 & 3,40 & 3,61 & 2,41 \\
\hline $\begin{array}{l}\text { Wskaźnik płynności } \\
\text { bieżącej }\end{array}$ & 1,12 & 1,14 & 1,20 & 1,17 & 1,15 & 1,18 & 1,27 & 1,27 & 1,25 & 1,20 \\
\hline $\begin{array}{l}\text { Wskaźnik rentowności } \\
\text { kapitału własnego (ROE) } \\
\text { w \% }\end{array}$ & $-1,85$ & 0,44 & 3,43 & 6,53 & 4,90 & 13,71 & 11,81 & 13,18 & 14,20 & 9,66 \\
\hline
\end{tabular}

* W cenach stałych z $2005 \mathrm{r}$.

Źródło: obliczenia własne na podstawie Roczników statystycznych przemystu GUS dla lat 2000-2009.

Wyraźnie poprawiła się również rentowność przychodów, co obrazuje wskaźnik rentowności obrotu netto (tab. 3.9). Wskaźnik ten określa zdolność generowania zysków netto przez przedsiębiorstwa przemysłu spożywczego. W badanych latach miernik ten charakteryzował się wysoką dynamiką wzrostu, bowiem jego wartość wzrosła z 0,10\% w 2000 r. do 2,41\% w roku 2008. Najlepsze wyniki jednak w tym zakresie, jak i w przypadku zysku netto, przemysł spożywczy osiągnął w roku 2007 ze wskaźnikiem rentowności obrotu netto na poziomie 3,61\%. W latach załamania gospodarczego (1999-2000) rentowność obrotu wynosiła średnio $-0,15 \%$, natomiast w latach bezpośrednio poprzedzających integrację 2001-2003 zwiększyła się średnio do 1,2\%. Po wejściu Polski do UE wskaźniki rentowności obrotu w przemyśle spożywczym wynosiły co najmniej 3\% i dopiero w roku 2008 wartość tego miernika spadła poniżej 3\%, co jest prawdopodobnie związane ze skutkami światowego kryzysu.

W przedsiębiorstwach przemysłu spożywczego zaobserwowano także poprawę bieżącej płynności finansowej, która określa zdolność firm produkujących artykuły spożywcze, napoje i wyroby tytoniowe do terminowej realizacji zobowiązań bieżących. Wskaźnik płynności finansowej w latach 2004-2008, czyli w okresie członkostwa Polski w UE, wynosił średnio 1,23 wobec wartości 1,16 w latach bezpośrednio poprzedzających integrację.

Warto również podkreślić, że mimo ogromnego wysiłku związanego z procesami dostosowania firm spożywczych do standardów europejskich, zadłużenie długoterminowe (pożyczki i kredyty) utrzymywało się na stosunkowo niskim poziomie i w badanych latach 1999-2008 wynosiło średnio 15\% wartości kapitału własnego. 
Niezwykle istotnym efektem poprawy wyników finansowych jest wzrost zarówno wartości kapitału własnego, jak i jego rentowności (wskaźnik ROE), z 0,44 w 2000 r. do 9,66\% w 2008 r., przy czym wyjątkiem jest rok 2007 z najwyższą wartością wynoszącą aż 14,20\%. Wskaźnik ROE wyraża stopę zysku z kapitału własnego zaangażowanego w dany przemysł. Od 2004 r. stopa zysku w przemyśle spożywczym jest dwukrotnie wyższa od oprocentowania lokat bankowych i obligacji państwowych, a więc konkurencyjna w stosunku do innych zastosowań kapitału i zapewniająca premię za ryzyko inwestowania w przetwórstwo żywności. Ten dział może również konkurować o alokację inwestycji z innymi rodzajami działalności produkcyjnej. Kolejny raz okazało się, że w 2008 r. została zahamowana tendencja pozytywnych zmian wskaźników finansowych firm przemysłu spożywczego. Światowy kryzys finansowy i gospodarczy skutkował w Polsce spowolnieniem wzrostu gospodarczego, co przełożyło się na wyraźny spadek tempa wzrostu popytu konsumpcyjnego, ale na szczęście nie było w tej dziedzinie dramatycznego spadku. Nasilenie zjawisk kryzysowych w polskim przemyśle spożywczym było mniejsze niż w przemyśle ogółem, wyniki osiągnięte przez przemysł spożywczy w 2009 r. pozwalają przypuszczać, iż kryzys wywołał tylko przejściową stagnację produkcji przemysłu spożywczego i również przejściowe pogorszenie wyników finansowych. W 2009 r., w porównaniu z rokiem poprzednim, produkcja sprzedana przemysłu spożywczego (ceny stałe) wzrosła o $4,5 \%$, wyrobów tytoniowych o $11,3 \%$, a niewielki spadek produkcji miał miejsce jedynie w przypadku produkcji napojów i wyniósł $0,8 \%$. Warto nadmienić, że w tym samym czasie produkcja sprzedana przemysłu i przetwórstwa przemysłowego spadła o 4\% [Rocznik statystyczny RP, 2010, s. 543]. Wypracowany przez przemysł spożywczy w 2009 r. zysk finansowy netto był imponujący, bowiem wyniósł 6,8 mld zł (ceny stałe) wobec 3,9 mld zł w 2008 r. i 5,9 mld zł w 2007 r.

Kolejnym istotnym elementem sprzyjającym rozwojowi jest koncentracja produkcji przemysłu spożywczego, co wyraża się zmniejszeniem liczby małych przedsiębiorstw i mikrofirm oraz wzmocnieniem pozycji rynkowej dużych firm (tab. 3.10).

Tabela 3.10. Liczba przedsiębiorstw produkujących artykuły spożywcze i napoje w wybranych latach okresu 2000-2008

\begin{tabular}{|l|r|r|r|r|}
\hline \multicolumn{1}{|c|}{ Wyszczególnienie } & \multicolumn{1}{c|}{2000} & \multicolumn{1}{c|}{2003} & \multicolumn{1}{c|}{2007} & \multicolumn{1}{c|}{2008} \\
\hline Mikrofirmy (do 9 pracowników) & 14960 & 12638 & 10469 & 10807 \\
\hline Firmy małe (10-49 pracowników) & 5269 & 5353 & 4738 & 5149 \\
\hline Firmy średnie (50-249 pracowników) & 1399 & 1255 & 1232 & 1286 \\
\hline Firmy duże (250 i więcej pracowników) & 349 & 270 & 288 & 285 \\
\hline Ogółem & 21977 & 19516 & 16727 & 17527 \\
\hline
\end{tabular}

Źródło: Roczniki statystyczne przemystu GUS dla lat 2001, 2004, 2008 i 2009. 
W Polsce od lat 90., czyli od początku transformacji gospodarczej, maleje liczba przedsiębiorstw działających w przetwórstwie spożywczym. Jednak najbardziej zmniejszyła się liczba firm zatrudniających do 9 osób, czyli mikrofirm. Zmniejsza się również udział tych podmiotów gospodarczych w obrotach przemysłu spożywczego. W 1998 r. odsetek mikroprzedsiębiorstw w produkcji sprzedanej artykułów spożywczych i napojów wyniósł 10,5\%, spadając do 8,99\% w 2003 r., a w roku 2008 już było to tylko 6,03\% (rys. 3.11). Zakłady zatrudniające do 9 osób dominują w piekarnictwie i w przetwórstwie mięsa czerwonego. W tych dwóch obszarach przetwórstwa spożywczego funkcjonuje około 5 tys. mikrofirm, co stanowi prawie połowę wszystkich mikroprzedsiębiorstw przemysłu spożywczego. Znacznym odsetkiem najmniejszych podmiotów gospodarczych charakteryzują się przetwórstwo owocowo-warzywne, młynarstwo i cukiernictwo.

Wzrost udziału w produkcji i zatrudnieniu firm dużych powoduje zwiększenie siły ekonomicznej tej grupy podmiotów i tym samym wzrost ich konkurencyjności. Po pięciu latach członkostwa Polski w Unii Europejskiej struktura podmiotowa przemysłu spożywczego w Polsce jest podobna do tejże struktury w UE (rys. 3.11).

Według R. Urbana ta struktura jest zróżnicowana, płynna i sprzyjająca konkurencji. Brak w przemyśle spożywczym monopoli, a oligopole występują tylko w takich branżach, jak piwna, tytoniowa, spirytusowa, olejarska i cukrownicza [Urban, Szczepaniak, Mroczek 2010, s. 43].

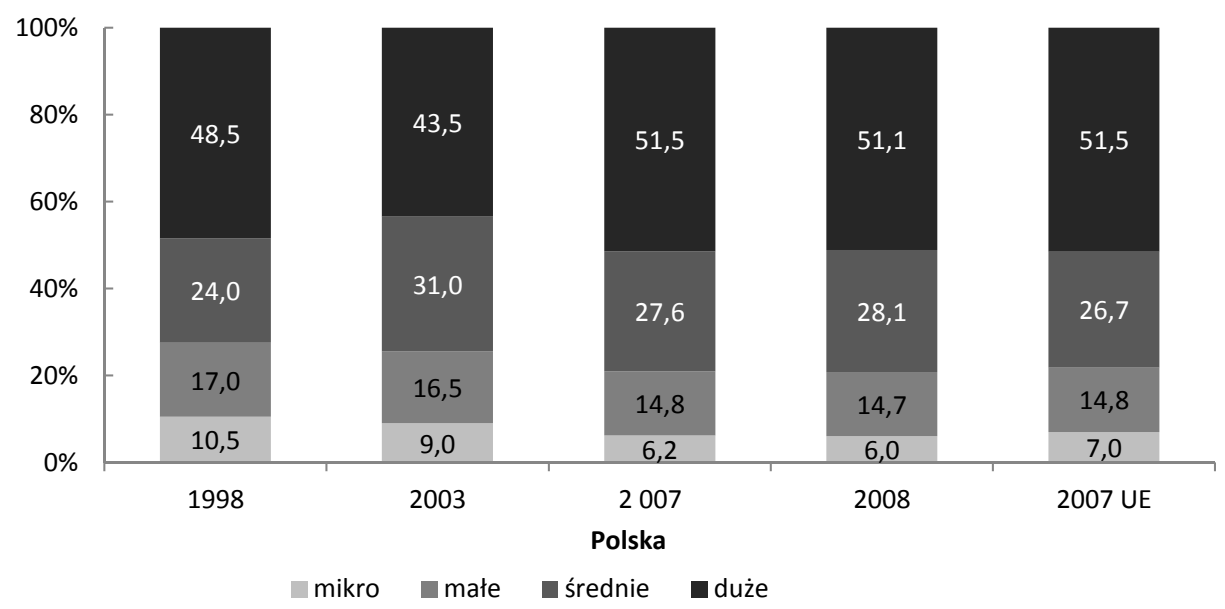

Rysunek 3.11. Struktura podmiotowa produkcji sprzedanej przemysłu spożywczego w Polsce i UE w wybranych latach okresu 1998-2008 (w \%)

Źródło: opracowanie własne na podstawie Roczników statystycznych przemystu GUS dla lat 1999, 2004, 2008 i 2009. 
Analiza sytuacji ekonomiczno-finansowej przemysłu spożywczego dowodzi, iż przetwórstwo żywności w Polsce radzi sobie całkiem nieźle z kryzysem i posiada zdolności dostosowawcze do zmieniającego się otoczenia zewnętrznego. Akcesja Polski do UE pokazała, że polskie produkty żywnościowe są konkurencyjne i cenione na rynku europejskim. Popularność zyskały przede wszystkim owoce, warzywa, produkty mleczne oraz mięso. Jest to zapewne efektem wysokiej jakości tych produktów i ich niższych cen. Jednak główną cechą polskiego przemysłu spożywczego, decydującą o odporności tego przemysłu na zjawiska kryzysowe, jest silna orientacja na rozwijający się i ogromny rynek krajowy i dostosowania struktury produkcji do zmieniającego się modelu wyżywienia. Ważnym czynnikiem rozwoju przemysłu spożywczego w Polsce jest również stale rosnącą liczba klientów ceniących polskie produkty żywnościowe.

\subsection{Ocena konkurencyjności branż przemysłu spożywczego w latach 2002-2008}

Transformacja gospodarcza, integracja europejska oraz globalizacja przyniosły zmianę warunków funkcjonowania polskiej gospodarki. Na polskim rynku pojawiło się zjawisko konkurencji, zarówno między firmami krajowymi, jak i krajowymi i zagranicznymi. Możliwość funkcjonowania polskiej gospodarki w przestrzeni międzynarodowej jest niewątpliwie zjawiskiem pozytywnym, ale należy pamiętać, że obok szans na rozwój pojawiają się również realne zagrożenia. O tym, czy polska gospodarka będzie korzystać z umiędzynarodowienia, decyduje jej konkurencyjność.

W dobie globalizacji gospodarki i liberalizacji międzynarodowego handlu trudno oceniać sytuację przemysłu spożywczego w Polsce bez uwzględnienia w tej ocenie jego konkurencyjności, a w szczególności konkurencyjności branż tego przemysłu, które utożsamia się z grupą firm konkurujących ze sobą i oferujących identyczne bądź podobne do siebie produkty.

Przeprowadzenie oceny konkurencyjności branż przemysłu spożywczego wiąże się z koniecznością zastosowania pewnych miar. W literaturze przedmiotu można spotkać wiele propozycji. W sposób syntetyczny zostały one przedstawione przez W. Jakóbika [2000, s. 35-40], który w zestawie mezoekonomicznych mierników konkurencyjności wyróżnia kilka wskaźników:

- wskaźnik penetracji produkcji krajowej przez import,

- wskaźnik kosztu krajowych czynników produkcji,

- wskaźnik ujawnionej przewagi komparatywnej,

- wskaźnik intensywności handlu wewnątrzgałęziowego (intra-industry trade IIT). 
Inne zestawienie wskaźników konkurencyjności stosowanych w analizach poziomu mezoekonomicznego opracowała A. Zielińska-Głębocka [2000, s. 12-13]:

- wskaźnik konkurencyjności eksportowej,

- wskaźnik konkurencyjności technologicznej i innowacyjnej,

- wskaźnik konkurencyjności regionalnej.

W dalszej części opracowania przedstawione zostaną tylko te mierniki, które będą wykorzystane w empirycznej ocenie konkurencyjności branż polskiego przemysłu spożywczego. Ocena konkurencyjności została dokonana w oparciu o sześć mierników. Pierwsze trzy mierniki dotyczą sytuacji handlu zagranicznego.

Wskaźnik określający atrakcyjność badanej branży to stopa eksportu. Jest to relacja eksportu $i$-tej branży do wielkości produkcji w $i$-tej branży [Zielińska-

-Głębocka 2000, s.12-13]:

$$
W_{i}=\frac{X_{i t}}{P_{i t}},
$$

gdzie:

$P_{i}$ - produkcja sprzedana $i$-tej branży,

$X_{i}$ - eksport w $i$-tej branży,

$t$ - czas analizy.

Kolejnym miernikiem, który zostanie wykorzystany do oceny konkurencyjności branży jest wskaźnik relacji eksport/import [Zielińska-Głębocka 2000, s.12-13]:

$$
R_{i}=\frac{X_{i t}}{M_{i t}},
$$

gdzie:

$X_{i}$ - eksport w $i$-tej branży,

$M_{i}$ - import $i$-tej branży,

$t-$ czas analizy.

O konkurencyjności danej branży nie może świadczyć tylko i wyłącznie dodatnie saldo bilansu handlowego w odniesieniu do danych towarów. Konieczne jest określenie intensywności równoczesnego eksportu i importu danej branży. Jeśli wielkość eksportu i importu jest do siebie zbliżona, to dopiero wówczas można mówić o tzw. ,partnerskiej konkurencyjności”. Tak rozumianą konkurencyjność mierzy kolejny miernik. Jest nim wskaźnik specjalizacji, wskaźnik intensywności handlu wewnątrzgałęziowego $i$-tej branży - równoczesny eksport i import wyrobów $i$-tej branży (intra-industry trade IIT). Wskaźnik ten zwany jest również indeksem Grubela-Lloyda i wyznaczany jest według następującej formuły [Jankowska 2005, s. 83-84]: 


$$
I I T_{i t}=1-\frac{\left|X_{i t}-M_{i t}\right|}{X_{i t}+M_{i t}},
$$

gdzie:

$X_{i}$ - eksport w $i$-tej branży,

$M_{i}$ - import $i$-tej branży,

$t-$ czas analizy.

Zaprezentowane dotychczas wskaźniki konkurencyjności odnoszą się do rynku międzynarodowego, można więc stwierdzić, że za ich pomocą próbuje się ocenić międzynarodową konkurencyjność branż przemysłu spożywczego. Jednak w badaniu konkurencyjności branży nie można poprzestać na relacjach w handlu zagranicznym. Ważną rolę w ocenie konkurencyjności spełniają miary charakteryzujące sprawność i efektywność działania. Według M. Portera [1998] branże rozwijają się dzięki wprowadzaniu innowacji w przedsiębiorstwach, co pozwala firmom na uzyskanie przewag konkurencyjnych nad krajowymi i zagranicznymi rywalami. Zatem poprawa konkurencyjności branży znajduje, w krótkim czasie, odzwierciedlenie we wzroście produkcji sprzedanej, zaś w długim okresie we wzroście wydajności czynników produkcji.. Popularnymi miarami wykorzystywanymi do tego typu ocen konkurencyjności są [Zielińska-Głębocka 2000, s. 14-16]:

- dynamika wzrostu zatrudnienia,

- produkcja sprzedana i/lub jej dynamika

- wydajność pracy i/lub jej dynamika,

- wydajność/produktywność zasobów użytych do wytworzenia produkcji sprzedanej,

- współczynnik całkowitej produkcyjności czynników produkcji (TFP Total Factor Productivity).

Wskaźnik mierzący wydajność (produktywność) zasobów zużytych do wytworzenia produkcji sprzedanej można zapisać [Jankowska 2005, s. 83-84]:

$$
W_{i}=\frac{P_{i t}}{Z_{i t}},
$$

gdzie:

$P_{i}$ - produkcja sprzedana $i$-tej branży,

$Z_{i}$-zasoby zużyte do wytworzenia produkcji w $i$-tej branży,

$t$ - czas analizy.

W celu zbadania łącznie wydajności pracy oraz produktywności zasobów wykorzystanych do produkcji można posłużyć się współczynnikiem całkowitej produkcyjności czynników produkcji (TFP - Total Factor Productivity), a jego sposób wyznaczania przedstawia formuła [por. Englander, Gurney 1994, s. 169]: 


$$
T F P_{i t}=\frac{P_{i t}}{P_{i t-1}}-\left[\left(\frac{L P_{i t}}{L P_{i t-1}} * 1-\alpha\right)+\left(\frac{C P_{i t}}{C P_{i t-1}} * \alpha\right)\right],
$$

gdzie:

$$
1-\alpha_{i t}=\frac{W_{i t}+N_{i t}}{W_{i t}+N_{i t}+C_{i t}}, \quad L P_{i t}=\frac{P_{i t}}{L_{i t}}, \quad C P_{i t}=\frac{P_{i t}}{C_{i t}},
$$

$P_{i}$ - produkcja sprzedana $i$-tej branży, $L P_{i t}$ - wydajność pracy $i$-tej branży,

$C P_{i t}$ - produkcyjność majątku trwałego $i$-tej branży,

$W_{i}$-wynagrodzenia $i$-tej branży,

$N_{i}$ - narzuty na płace $i$-tej branży,

$C_{i}$ - majątek trwały $i$-tej branży,

$L_{i}-$ zatrudnienie i-tej branży,

$1-\alpha$ - współczynnik informujący, jaki jest udział pracy w przychodach czynników produkcji,

$t$ - czas analizy.

Zaprezentowane powyżej mierniki można uznać za tzw. syntetyczne mierniki - służące do oceny konkurencyjności branży. Bazują one bowiem na zagregowanych danych dotyczących eksportu, importu oraz rozmiarach produkcji analizowanych branż przemysłu spożywczego. W procedurze oceny konkurencyjności branży można jeszcze posłużyć się tzw. miernikami cząstkowymi, które szacuje się na podstawie danych pochodzących od pojedynczych przedsiębiorstw funkcjonujących w branży [Jankowska 2005, s. 86-91].

W tej części rozprawy podjęto próbę oceny konkurencyjności 18 branż przemysłu spożywczego w Polsce za pomocą opisanych powyżej mierników konkurencyjności oraz miar dynamiki. W tym celu posłużono się niepublikowanymi danymi statystycznymi charakteryzującymi eksport, import, wynagrodzenia brutto, ubezpieczenia społeczne i inne świadczenia w poszczególnych branżach przetwórstwa spożywczego oraz danymi publikowanymi przez GUS w zakresie produkcji sprzedanej, wielkości zatrudnienia i wartości brutto środków trwałych. Wszystkie informacje, zarówno publikowane, jak i niepublikowane, dotyczą przedsiębiorstw zatrudniających powyżej 49 osób, a analiza obejmuje lata 2002-2008.

W pierwszej kolejności skoncentrowano się na ocenie konkurencyjności produkcji odnoszącej się do rynku międzynarodowego. Obliczono stopy eksportu $W_{i}$ (3.1), wskaźniki relacji eksport/import $R_{i}$ (3.2) oraz wskaźniki handlu wewnątrz gałęziowego $I I T_{i}(3.3)$. Ze względu na występujące znaczne zróżnicowanie wartości tych wskaźników w poszczególnych latach oraz w celu uzyskania efektu przejrzystości prowadzonych analiz, postanowiono uśrednić wartości tych mierników. W tab. 3.11 zestawiono średnie roczne wartości omawianych trzech wskaźników konkurencyjności obliczonych dla lat 2002-2008 i poszczególnych branż przetwórstwa spożywczego. 
Tabela 3.11. Średni roczny poziom stopy eksportu, relacji eksport/import oraz wskaźnika IIT w branżach przemysłu spożywczego w latach 2002-2008

\begin{tabular}{|l|c|c|c|}
\hline \multirow{2}{*}{ Branże przetwórstwa spożywczego } & \multicolumn{3}{|c|}{ Średnia roczna } \\
\cline { 2 - 4 } & $\begin{array}{c}\text { stopa eksportu } \\
W_{i}\end{array}$ & $\begin{array}{c}\text { relacja } \\
\text { eksport/import } \\
R_{i}\end{array}$ & $\begin{array}{c}\text { wartość } \\
\text { wskaźnika } \\
I I T_{i}\end{array}$ \\
\hline Przemysł mięsny (1) & 0,077 & 2,002 & 0,680 \\
\hline Przemysł drobiarski (2) & 0,177 & $\mathbf{1 2 , 4 9 2}$ & 0,178 \\
\hline Przetwórstwo ryb (3) & $\mathbf{0 , 4 6 2}$ & 1,128 & $\mathbf{0 , 9 4 1}$ \\
\hline Przemysł mleczarski (4) & 0,093 & 1,589 & 0,769 \\
\hline Przemysł ziemniaczany (5) & 0,279 & 2,086 & 0,678 \\
\hline Przemysł owocowo-warzywny (6) & 0,340 & 2,236 & 0,620 \\
\hline Przemysł olejarski (7) & 0,168 & 1,446 & 0,805 \\
\hline Przemysł zbożowo-młynarski (8) & 0,087 & 0,999 & $\mathbf{0 , 9 2 4}$ \\
\hline Przemysł cukrowniczy (9) & 0,120 & $\mathbf{1 3 , 2 8 5}$ & 0,165 \\
\hline Przemysł paszowy (10) & 0,139 & 0,514 & 0,676 \\
\hline Przemysł piekarski (11) & 0,084 & 1,080 & $\mathbf{0 , 9 4 6}$ \\
\hline Przemysł cukierniczy (12) & 0,327 & 1,231 & 0,898 \\
\hline Przemysł koncentratów spożywczych (13) & 0,195 & 0,589 & 0,728 \\
\hline Przemysł napojów bezalkoholowych (14) & 0,045 & 0,303 & 0,454 \\
\hline Przemysł spirytusowy (15) & 0,125 & 1,558 & 0,711 \\
\hline Przemysł winiarski (16) & 0,132 & 0,481 & 0,642 \\
\hline Przemysł piwowarski (17) & 0,021 & 0,259 & 0,407 \\
\hline Przemysł tytoniowy (18) & 0,262 & 0,499 & 0,634 \\
\hline
\end{tabular}

Źródło: obliczenia własne na podstawie niepublikowanych danych GUS.

Obliczona dla lat 2002-2008 wartość średniej rocznej stopy eksportu wahała się od 0,021 (przemysł piwowarski) do 0,462 (przetwórstwo ryb). Warto nadmienić, że kapitał zagraniczny ulokowany w przemyśle piwowarskim nastawiony jest przede wszystkim na zaspokojenie potrzeb ogromnego rynku krajowego i m.in. $z$ tego wynika niewielkie znaczenie eksportu w tej branży (zaledwie 2,1\%). Połowa branż przemysłu spożywczego osiągnęła wynik wynoszący co najmniej 0,139 , co oznacza, że właśnie w tych branżach eksport stanowi co najmniej $14 \%$ produkcji sprzedanej (rys. 3.12).

Wysoki udział eksportu osiągają nie tylko przemysł owocowo-warzywny (34\%), ziemniaczany $(27,9 \%)$, czy drobiarski $(17,7 \%)$, które bazują na polskich surowcach, lecz także wiele innych działów produkcji żywności. Obserwujemy zatem duży udział eksportu w takich specjalnościach polskiego sektora żywnościowego jak przetwórstwo owoców i warzyw, rzepaku czy też produkcja pieczywa cukierniczego $(32,7 \%)$ oraz $\mathrm{w}$ wielu kierunkach przetwórstwa wykorzystujących 
surowce importowane. Wśród nich wymienić należy produkcję wyrobów tytoniowych, produkcję koncentratów spożywczych (zwłaszcza produkcja kawy, herbaty, przypraw), a przede wszystkim przetwórstwo ryb, które zajmuje pierwsze miejsce pod względem udziału eksportu w produkcji sprzedanej $(46,2 \%)$. Rozwój tych branż świadczy o przewagach konkurencyjnych, na poziomie przetwórstwa i wskazuje na niezależność tych branż od polskiego zaplecza surowcowego. W branżach charakteryzujących się dużym udziałem eksportu w produkcji sprzedanej odnotowano znaczący wzrost dynamiki eksportu począwszy od roku 2004.

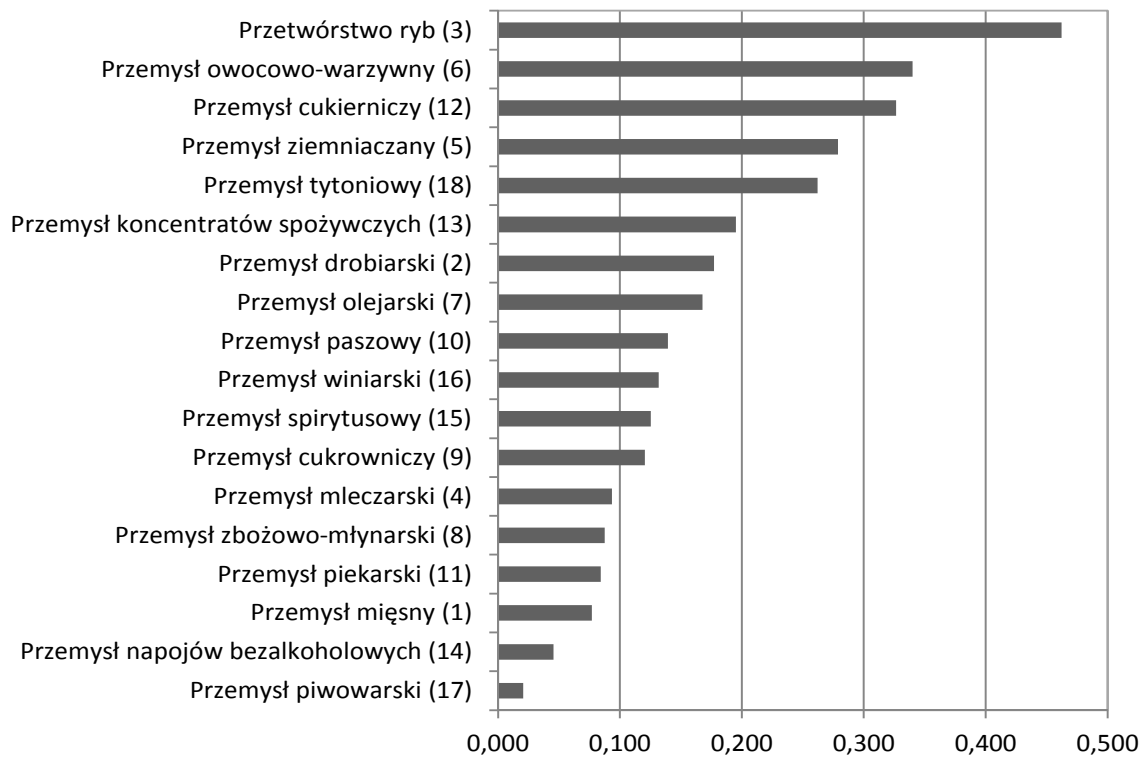

Rysunek 3.12. Średnia roczna stopa eksportu w przemyśle spożywczym w latach 2002-2008

Źr ódło: opracowanie własne na podstawie danych z tab. 3.11.

Eksport, uwzględniając niewykorzystany potencjał produkcyjny przemysłu spożywczego oraz zaplecze surowcowe, jest ważnym czynnikiem determinującym rozwój produkcji żywności w Polsce. O znaczeniu eksportu w rozwoju całego przemysłu spożywczego świadczy jego rosnący udział w wartości produkcji sprzedanej, który w 2008 r. wyniósł $23,4 \%$, wynika z tego, że prawie 1/4 produkcji przemysłu spożywczego jest eksportowana.

Kolejnym miernikiem użytym do oceny konkurencyjności branż przemysłu spożywczego w kontekście rynku międzynarodowego jest wskaźnik relacji eksport-import. Średnia roczna wartość tego wskaźnika w latach 2002-2008 dla poszczególnych branż przemysłu spożywczego (por. rys. 3.13) charakteryzowała się dużą zmiennością, bowiem jego wartość kształtowała się na poziomie od 0,259 (przemysł piwowarski) do 13,285 (przemysł cukrowniczy). 


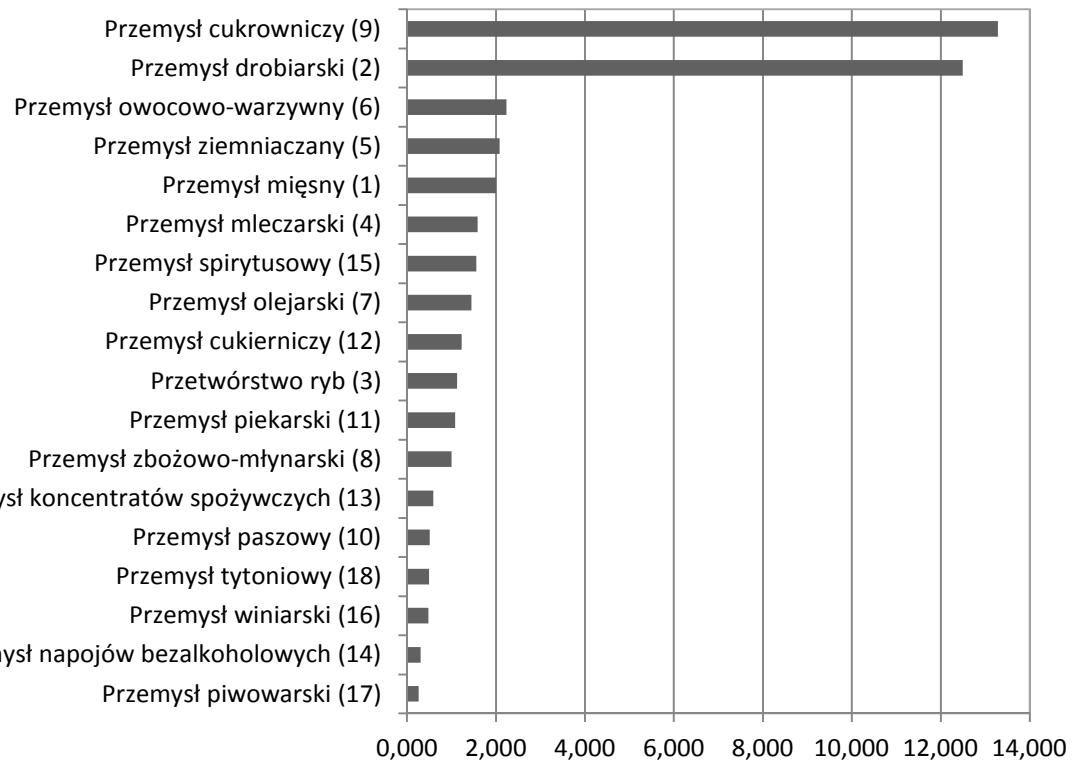

Rysunek 3.13. Średnia roczna relacja eksport/import w branżach przemysłu spożywczego w latach 2002-2008

Źródło: opracowanie własne na podstawie danych z tab. 3.11.

W jedenastu branżach przemysłu spożywczego wartość wskaźnika relacji eksport- import była większa od jedności, co oznacza, że eksport przewyższał tutaj import. Należą do nich: przemysł cukrowniczy, drobiarski, owocowo-warzywny, ziemniaczany, mięsny, mleczarski, spirytusowy, olejarski, cukierniczy, rybny i piekarski. W przemyśle mięsnym $(2,002)$, ziemniaczanym $(2,086)$ i owocowo-warzywnym $(2,236)$ eksport był ponad dwukrotnie większy od importu. W dwóch branżach, cukrowniczej $(13,285)$ i drobiarskiej $(12,492)$, a więc w branżach, które zajęły dwa pierwsze miejsca eksport kilkunastokrotnie przekraczał import. Porównując obecnie prowadzoną ocenę konkurencyjności z poprzednią, przeprowadzoną według stopy eksportu, zauważamy, że w jednym i drugim przypadku najniższą konkurencyjnością charakteryzowały się produkcja piwa i produkcja napojów bezalkoholowych, a najwyższą - przemysł drobiarski, owocowo-warzywny i ziemniaczany. Przemysł cukrowniczy, który według relacji eksport/import jest najbardziej konkurencyjny, w poprzedniej klasyfikacji zajął dopiero dwunaste miejsce. Warto w tym miejscu przypomnieć, na co wcześniej zwracano uwagę, że konkurencyjność jest zjawiskiem złożonym, wielowymiarowym i nie można wyciągać zbyt daleko idących wniosków na podstawie pojedynczych mierników.

Wskaźnik handlu wewnątrzgałęziowego (indeks Grubela-Lloyda) to trzeci miernik wykorzystany do oceny konkurencyjności branż przemysłu spożywczego w ramach rynku międzynarodowego. Rysunek 3.14 prezentuje branże przemysłu spożywczego uszeregowane według rosnących wartości wskaźnika $I I T_{i}$. 


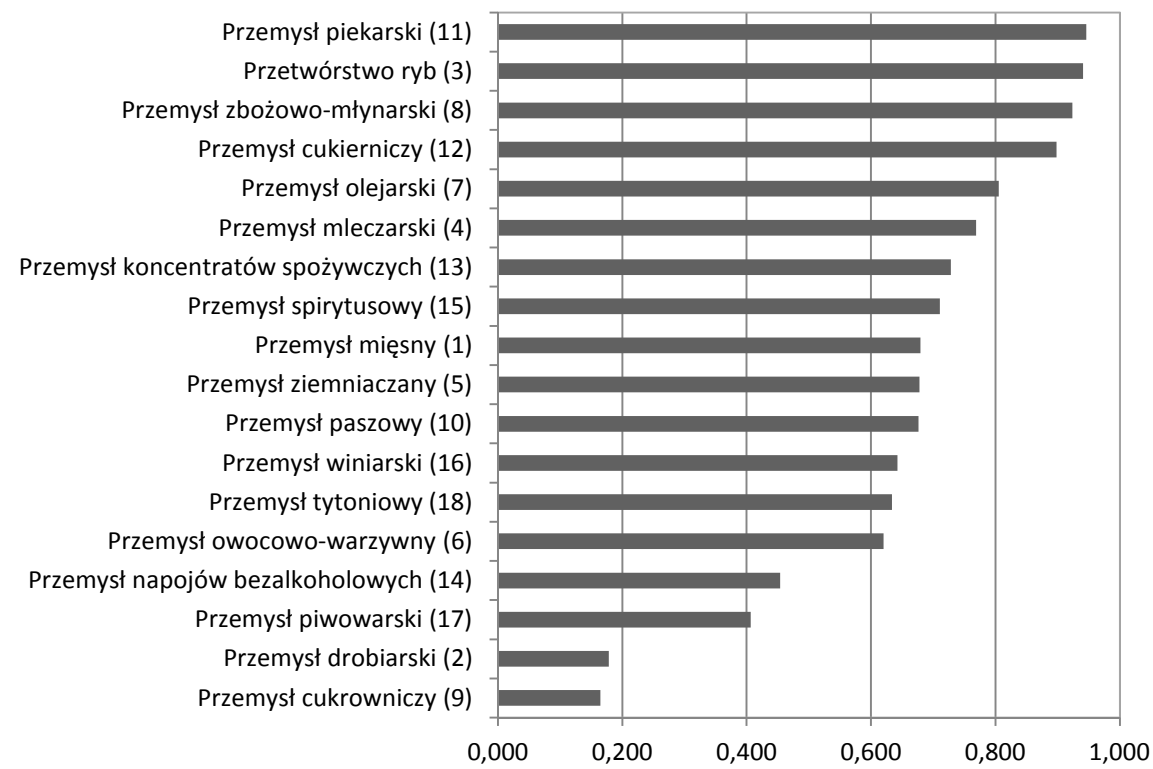

Rysunek 3.14 Średnia roczna wartość wskaźnika IIT w branżach przemysłu spożywczego w latach 2002-2008

Źr ódło: opracowanie własne na podstawie danych z tab. 3.11.

Wyraźnie najniższe poziomy wskaźnika IIT odnotowano dla przemysłu cukrowniczego $(0,165)$ oraz drobiarskiego $(0,178)$. W tych dwóch branżach eksport kilkakrotnie przewyższa import. Natomiast w trzech branżach przemysłu spożywczego wskaźnik IIT jest bardzo wysoki i przekracza wartość 0,9 , a osiągnęły go przemysły: zbożowo-młynarski $(0,924)$, rybny $(0,941)$ oraz piekarski $(0,946)$. W tych trzech sektorach mamy bez wątpienia do czynienia z partnerską konkurencyjnością, czyli zarówno skala eksportu, jak i importu są do siebie zbliżone, co świadczy o rozwiniętym handlu wewnątrzgałęziowym. Do branż charakteryzujących się partnerską konkurencyjnością możemy jeszcze zaliczyć przemysł olejarski i cukierniczy, gdzie wskaźniki IIT wynoszą odpowiednio 0,805 i 0,898.

Badanie konkurencyjności branż przemysłu spożywczego wymaga uwzględnienia jeszcze innych, poza relacjami w handlu międzynarodowym, aspektów konkurencyjności. Konkurencyjność branży jest efektem przede wszystkim konkurencyjności przedsiębiorstw funkcjonujących w danej branży. Rywalizacja między firmami przemysłu spożywczego na krajowym i zagranicznym rynku zmusza do poprawy efektywności, którą można osiągnąć poprzez innowacje produktowe, procesowe, organizacyjne oraz marketingowe. Aktywność innowacyjna przedsiębiorstw może się objawiać wzrostem produkcji sprzedanej, wydajności pracy i produktywności czynników produkcji, a więc wzrostem konkurencyjności przedsiębiorstw. 
Dla pełniejszego zobrazowania konkurencyjności branż przemysłu spożywczego w tab. 3.12 zestawiono średnioroczne tempa zmian produkcji sprzedanej, wydajności pracy i łącznej produktywności czynników produkcji (w cenach stałych z 2005 r.) obliczone na podstawie danych z lat 2002-2008.

Tabela 3.12. Średnioroczne tempa zmian produkcji sprzedanej, wydajności pracy i łącznej produktywności czynników produkcji w latach 2002-2008 (ceny stałe, rok $2005=100$ )

\begin{tabular}{|l|r|r|r|}
\hline \multirow{2}{*}{ Branże przetwórstwa spożywczego } & \multicolumn{3}{|c|}{ Średnioroczne tempo zmian w latach 2002-2008 } \\
\cline { 2 - 4 } & Pt/Pt-1 & LPt/LPt-1 & \multicolumn{1}{c|}{ TFP } \\
\cline { 2 - 4 } & $\begin{array}{c}\text { Produkcja } \\
\text { sprzedana }\end{array}$ & $\begin{array}{c}\text { Wydajność } \\
\text { pracy }\end{array}$ & $\begin{array}{c}\text { Łączna produktywność } \\
\text { czynników produkcji }\end{array}$ \\
\hline Przemysł mięsny (1) & 7,6 & 3,5 & 7,9 \\
\hline Przemysł drobiarski (2) & 12,2 & 7,5 & 11,5 \\
\hline Przetwórstwo ryb (3) & 15,8 & 7,3 & 16,0 \\
\hline Przemysł mleczarski (4) & 6,4 & 9,5 & 4,3 \\
\hline Przemysł ziemniaczany (5) & $-9,7$ & 4,3 & $-3,4$ \\
\hline Przemysł owocowo-warzywny (6) & 8,3 & 5,4 & 9,1 \\
\hline Przemysł olejarski (7) & 9,5 & 10,6 & $-2,4$ \\
\hline Przemysł zbożowo-młynarski (8) & 7,1 & 5,9 & 4,7 \\
\hline Przemysł cukrowniczy (9) & $-0,2$ & 19,6 & $-6,5$ \\
\hline Przemysł paszowy (10) & 5,2 & 6,7 & 4,2 \\
\hline Przemysł piekarski (11) & 9,7 & 4,5 & 8,9 \\
\hline Przemysł cukierniczy (12) & 9,5 & 8,0 & 9,7 \\
\hline Przemysł koncentratów spożywczych (13) & 4,8 & 0,5 & 8,7 \\
\hline Przemysł napojów bezalkoholowych (14) & 4,2 & 7,5 & 2,5 \\
\hline Przemysł spirytusowy (15) & 7,0 & 11,2 & 0,2 \\
\hline Przemysł winiarski (16) & $-12,5$ & 3,9 & $-24,8$ \\
\hline Przemysł piwowarski (17) & 4,3 & 9,4 & 1,9 \\
\hline Przemysł tytoniowy (18) & $-6,7$ & $-4,6$ & 3,5 \\
\hline & & & \\
\hline
\end{tabular}

Źródło: obliczenia własne na podstawie publikowanych i niepublikowanych danych GUS.

Analiza dynamiki produkcji sprzedanej dowodzi, że tylko w czterech branżach, a mianowicie w branży cukrowniczej, ziemniaczanej, winiarskiej i tytoniowej miało miejsce pogorszenie się tej wielkości. Średnioroczne tempo wzrostu produkcji sprzedanej w pozostałych branżach przemysłu spożywczego było zróżnicowane i wyniosło od 4,2 \% w przemyśle napojów bezalkoholowych do 15,8\% w przetwórstwie ryb (por. rys. 3.15).

Kolejny raz branża rybna okazała się najbardziej konkurencyjna. Rynek ryb jest od wielu lat stabilnym rynkiem rolno-żywnościowym w Polsce. Warto jednak zauważyć, że systematycznie traci na znaczeniu rybołówstwo krajowe, jako 
źródło surowca dla przetwórstwa ryb. Ograniczenia połowów wynikające z przyznawanych kwot połowowych oraz mała różnorodność biologiczna poławianych ryb powodują coraz większe uzależnienie od importu. Udział importu w podaży ryb wykorzystywany przez krajowe przetwórstwo wynosi ok. 70\%, natomiast eksport stanowi prawie 50\% produkcji sprzedanej (por. tab. 3.11).

Drugie miejsce pod względem tempa wzrostu produkcji sprzedanej zajęła produkcja drobiarska $12,2 \%$. Impulsem dla wzrostu produkcji w branży drobiarskiej był przede wszystkim wzrost eksportu wywołany zwiększonym popytem na polski drób w krajach UE.

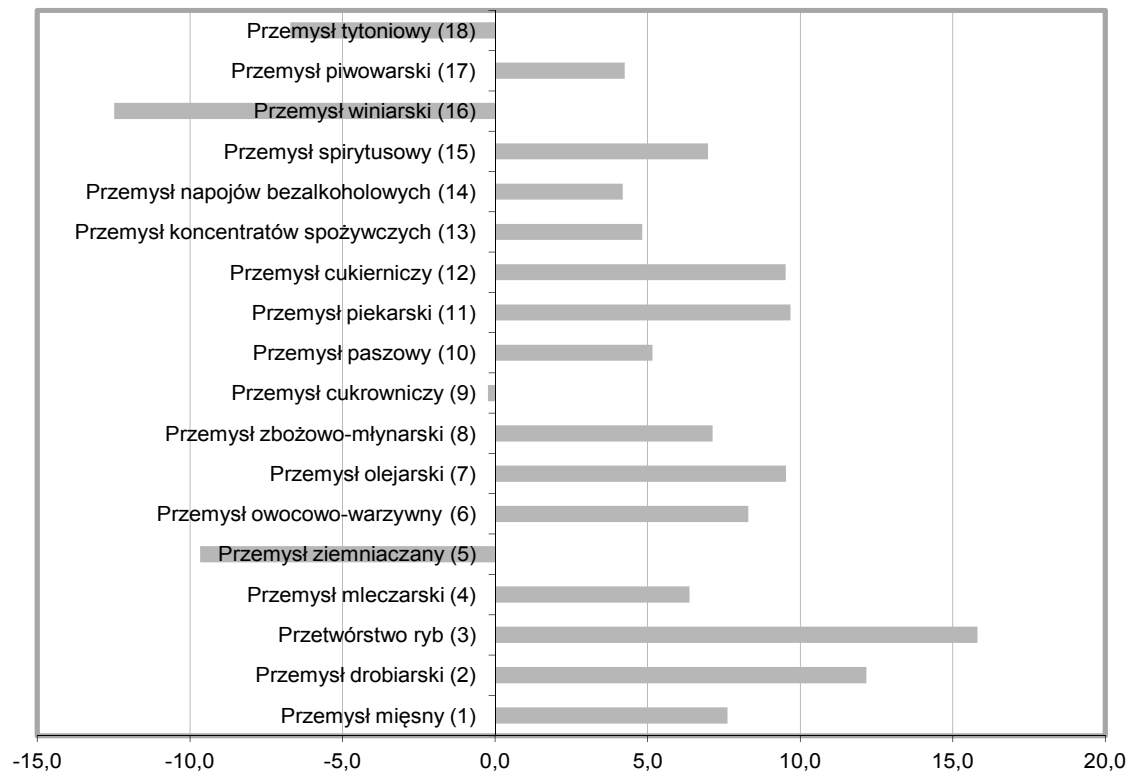

Rysunek 3.15 Średnie tempo zmian produkcji sprzedanej w branżach przemysłu spożywczego w latach $2002-2008$ (ceny stałe, rok $2005=100$ )

Źródło : opracowanie własne na podstawie danych z tab. 3.12.

Imponujący wzrost produkcji sprzedanej wystąpił również w branży piekarskiej $(9,7 \%)$, cukierniczej $(9,5 \%)$, olejarskiej (9,5\%), owocowo-warzywnej $(8,3 \%)$ oraz mięsnej $(7,6 \%)$.

Oceniając konkurencyjność branż za pomocą zmian poziomu produkcji sprzedanej warto odnotować jeszcze jedno pozytywne zjawisko. We wszystkich branżach wzrostowi produkcji sprzedanej towarzyszył wzrost wydajności pracy oraz wzrost łącznej produktywności czynników produkcji, co świadczy o coraz lepszym wykorzystaniu czynników produkcji i postępie technicznym w badanych obszarach działalności gospodarczej. 
Średnioroczny spadek wydajności pracy, mierzonej produkcją sprzedaną na 1 zatrudnionego, nastąpił tylko w przemyśle tytoniowym $-4,6 \%$. W pozostałych branżach wydajność pracy w latach 2002-2008 wzrastała przeciętnie z roku na rok, od 0,5\% (przemysł koncentratów spożywczych) do 19,6\% (przemysł cukrowniczy). Jednak w przemyśle cukrowniczym wzrostowi wydajności pracy towarzyszył silny spadek produktywność czynników produkcji $(-6,5 \%)$ oraz spadek produkcji sprzedanej $(-0,2 \%)$. Wzrost wydajności pracy w przemyśle cukrowniczym wynika przede wszystkim z ogromnego spadku zatrudnienia, będącego efektem wyłączania z produkcji wielu cukrowni. Zjawisko to uległo wyraźnemu nasileniu od 2004 r. W badanym okresie w branży cukrowniczej, spośród wszystkich branż przemysłu spożywczego, odnotowano największy spadek zatrudnienia. W 2008 r. w porównaniu z rokiem 2002 zatrudnienie w tej branży zmniejszyło się aż o $66 \%$.

Podejmując próbę oceny konkurencyjności branż przemysłu spożywczego poprzez analizę dynamiki produktywności czynników produkcji (TFP) chcemy wskazać, na ile wzrost produkcji sprzedanej wynika ze zmian produkcyjności czynników produkcji.

Rysunek 3.16 ilustruje sytuację poszczególnych branży przemysłu spożywczego ze względu na dynamikę TFP w latach 2002-2008.

W czterech branżach tempo zmian łącznej produktywności czynników produkcji było ujemne. Największy spadek TFP wystąpił w branży winiarskiej $(-24,8 \%)$, następnie w branży cukrowniczej $(-6,5 \%)$, ziemniaczanej $(-3,4 \%)$ i olejarskiej (-2,4\%). Warto przypomnieć, że w latach 2002-2008 branża winiarska odnotowała największy spadek produkcji sprzedanej (12,5\% średniorocznie). Niekorzystny wynik TFP w branży winiarskiej wynika z szybszego spadku przychodów ze sprzedaży aniżeli zatrudnienia i z malejącej wartości majątku.

$\mathrm{Z}$ kolei sytuacja w przemyśle cukrowniczym w ostatnich latach jest pod wpływem trwającej w UE reformy regulacji rynku cukru, której celem jest poprawa międzynarodowej konkurencyjności i konieczność wywiązania się ze zobowiązań wobec WTO. Postępująca reforma Wspólnej Polityki Rolnej na rynku cukru powoduje zmniejszanie przyznawanych Polsce kwot produkcyjnych oraz spadek cen buraków, co pogarsza opłacalność produkcji i przetwórstwa buraków. W konsekwencji maleje obszar upraw buraków i liczba cukrowni. Uprawa i przetwórstwo buraków są coraz mniej opłacalne.

Spośród 14 branż z dodatnim średniorocznym tempem TFP najszybszym tempem wzrostu charakteryzowały się przemysły: rybny $(16 \%)$, drobiarski $(11,5 \%)$, cukierniczy $(9,7 \%)$, owocowo-warzywny $(9,1 \%)$, piekarski $(8,9 \%)$, koncentratów spożywczych $(8,7 \%)$ oraz mięsny $(7,9 \%)$.W pozostałych branżach produkcyjność zwiększała się w wolniejszym tempie, od 0,2 do 4,7\% średniorocznie.

Zmiany produktywności odegrały znaczącą rolę we wzroście produkcji sprzedanej przemysłu spożywczego. W większości branż wzrost TFP był ważnym źródłem wzrostu produkcji sprzedanej. Wyjątkiem w tym zakresie jest przemysł 
tytoniowy, gdzie, mimo wzrostu TFP średniorocznie o 3,5\%, pojawił się spadek produkcji sprzedanej o $6,7 \%$.

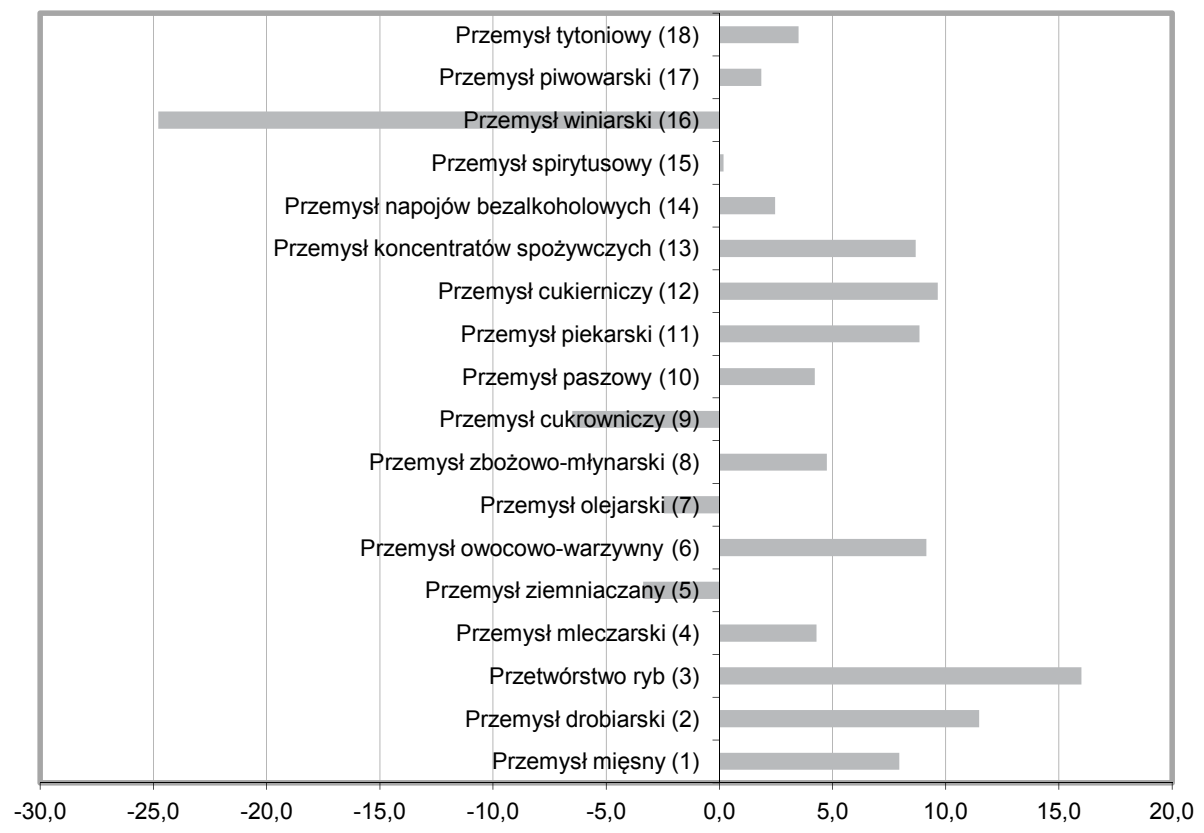

Rysunek 3.16. Średnie roczne tempo zmian $T F P$ w branżach przemysłu spożywczego w latach 2002-2008 (ceny stałe, rok $2005=100$ )

Źródło: opracowanie własne na podstawie danych z tab. 3.12.

Poprawa produktywności była następstwem ożywienia inwestycyjnego w przemyśle spożywczym w okresie integrowania z UE, które było związane z koniecznością dostosowania zakładów do standardów unijnych. Szczególnie wysoki był poziom nakładów inwestycyjnych w branżach wrażliwych, tj. w przetwórstwie produktów pochodzenia zwierzęcego (branża drobiarska, rybna, mięsna i mleczarska). Obecna aktywność inwestycyjna wynika zarówno z konieczności ciągłej modernizacji potencjału wytwórczego w celu poprawy konkurencyjności firm, jak również z potrzeby budowania trwałych podstaw dla zwiększenia produkcji.

\section{Podsumowanie}

Z przeprowadzonych analiz wynika, iż rośnie znaczenie przemysłu spożywczego w polskim agrobiznesie. Wzrost zapotrzebowania na żywność wysoko przetworzoną i dobrą jakościowo sprawia, iż przemysł spożywczy należy do 
najszybciej rozwijających się ogniw sektora żywnościowego. Maleje jednak znaczenie tego kierunku przetwórstwa przemysłowego w przemyśle ogółem.

W badanym dziesięcioleciu, w przemyśle spożywczym w Polsce wystąpiło wiele pozytywnych zjawisk. Na skutek przyspieszonego rozwoju i wzrostu produkcji oraz poprawy produktywności i rosnącego udziału eksportu w produkcji sprzedanej nastąpiła wyraźna poprawa stanu ekonomiczno-finansowego przedsiębiorstw.

Rozwój produkcji i poprawa wyników ekonomiczno-finansowych były zjawiskiem powszechnym, obejmującym większość branż przemysłu spożywczego. Wzrost udziału w produkcji i zatrudnieniu firm dużych powoduje zwiększenie siły ekonomicznej tej grupy podmiotów i tym samym wzrost ich konkurencyjności.

$\mathrm{Na}$ dobre wyniki w handlu zagranicznym wpływają przewagi komparatywne i wysoka jakość oferowanej żywności.

Ogromne nakłady inwestycyjne poprawiły stan techniczny zakładów, dostosowując je do standardów unijnych oraz przyczyniły się do wzrostu konkurencyjności na międzynarodowych rynkach. Pod względem nowoczesności polski przemysł spożywczy, a szczególnie liderzy tego przemysłu należą do ścisłej czołówki europejskiej. Wiele polskich przedsiębiorstw przetwórstwa żywności uznawanych jest za najnowocześniejsze w Europie.

Przed przedsiębiorstwami przemysłu spożywczego stają ciągle nowe wyzwania. Maleją przewagi kosztowo-cenowe, a silna konkurencja na rynku żywności wymaga poszukiwania nowych źródeł konkurencyjności, takich jak jakość, unikatowość produktów, kreowanie wizerunku firmy opartego na zaufaniu, innowacyjność, przedsiębiorczość oraz wiedza i kapitał ludzki. 



\section{Analiza innowacyjności przedsiębiorstw przemysłu spożywczego w Polsce}

\section{Wprowadzenie}

Zmieniające się nieustannie warunki rynkowe, silna konkurencja, ciągle rosnące wymagania nabywców żywności, którzy oczekują produktów bezpiecznych, o określonej jakości i z właściwego miejsca pochodzenia, powodują, że przedsiębiorstwa przemysłu spożywczego zmuszone są do podejmowania działań innowacyjnych.

Już w 1992 r. raport opracowany przez Komisję Wspólnoty Europejskiej wskazał na ciągły proces przekształceń przemysłu spożywczego, tradycyjnie postrzeganego jako dział niskiej techniki, w przemysł coraz bardziej zaawansowany technologicznie [Commission ..., 1992], gdzie występuje silna konkurencja implikująca modyfikacje technologiczne, organizacyjne i marketingowe. W tej sytuacji ważna i potrzebna staje się diagnoza działalności innowacyjnej przedsiębiorstw produkujących żywność w Polsce.

Przedmiotem niniejszego rozdziału jest analiza działalności innowacyjnej przedsiębiorstw przemysłu spożywczego w kontekście działalności innowacyjnej przedsiębiorstw całego przetwórstwa przemysłowego i przemysłu ogółem. Analiza została przeprowadzona na postawie wyników badań działalności innowacyjnej przedsiębiorstw zrealizowanych przez GUS zgodnie z międzynarodową metodologią Oslo.

W końcowej części tego rozdziału wskazano miejsce, jakie zajmuje przemysł produkujący artykuły spożywcze i napoje w rankingu innowacyjności działów przetwórstwa przemysłowego w Polsce.

\subsection{Działalność innowacyjna przedsiębiorstw przemysłu spożywczego w Polsce w latach 1999-2008}

Działalność innowacyjna, czyli działalność ukierunkowana na wzrost skłonności do wprowadzania innowacji, jest dzisiaj koniecznością i nie można nie doceniać jej roli, gdyż jest uznawana za główny czynnik determinujący rozwój przedsiębiorstw.

Powstaje więc pytanie, jaki jest poziom innowacyjności przedsiębiorstw przemysłu spożywczego w Polsce. W tym rozdziale podjęto próbę odpowiedzi na to pytanie, analizując dane $\mathrm{z}$ lat 1999-2008, a więc obejmujące dziesięć lat, w tym pięć lat poprzedzających integrację i pięć lat członkostwa Polski w UE. Jednak 
sprawozdawczość GUS nie objęła swym zakresem wszystkich wskaźników charakteryzujących działalność innowacyjną przedsiębiorstw w poprzednim badaniu. GUS, doskonaląc metodologię badań w kolejnych edycjach, zwiększał stopień szczegółowości badań i tym samym liczbę wskaźników.

Analiza działalności innowacyjnej przedsiębiorstw została przeprowadzona w oparciu o roczne informacje (wskaźniki) statystyczne publikowane przez GUS w: Działalności innowacyjnej przedsiębiorstw, Nauce i technice oraz w Rocznikach statystycznych przemystu. Niestety, w momencie zamykania opracowania (grudzień 2010 r.) nie ukazała się jeszcze publikacja Działalność innowacyjna przedsiębiorstw w latach 2006-2008. Na stronach internetowych GUS dostępna była jedynie notatka informacyjna prezentująca, w sposób syntetyczny, wyniki badań działalności innowacyjnej przedsiębiorstw w latach 2006-2008.

W wymienionych publikacjach prezentowane są wyniki dwóch rodzajów badań statystycznych dotyczących innowacji, o których pisano wcześniej. W skali rocznej skróconych badań przedsiębiorstw przemysłowych obejmujących jednostki liczące powyżej 49 pracujących oraz cyklicznych badań dotyczących różnorodnych aspektów działalności innowacyjnej przedsiębiorstw w przemyśle, biorąc pod uwagę również jednostki mniejsze, liczące od 10 do 49 pracujących.

Celem zapewnienia porównywalności danych w czasie i na różnych poziomach agregacji przemysłu spożywczego analizie poddano głównie przedsiębiorstwa zatrudniające powyżej 49 osób.

Ta część analizy obejmuje swym zakresem podmioty gospodarcze w sekcjach C, D i E według Polskiej Klasyfikacji Działalności 2004, w których liczba pracujących przekroczyła 49 osób. Jest to zbiorowość, która w 2008 r. obejmowała łącznie 9319 przedsiębiorstw, z których 92,9\% należało do sekcji przetwórstwo przemysłowe (D), a 16,9\% to przedsiębiorstwa przemysłu spożywczego (15 i 16 dział sekcji D). W strukturze według wielkości dominują przedsiębiorstwa liczące od 50 do 249 pracujących, których udział w 2008 r. wyniósł 80,4\% (przedsiębiorstwa liczące od 250 do 499 pracujących stanowiły $11,5 \%$, a przedsiębiorstwa liczące powyżej 499 pracujących $8,1 \%$.

Analizie poddano:

- poziom i strukturę nakładów na działalność innowacyjną,

- źródła innowacji,

- rodzaje innowacji,

- sprzedaż produktów nowych lub istotnie ulepszonych,

- ochronę własności intelektualnej,

- współpracę z innymi przedsiębiorstwami i instytucjami w zakresie działalności innowacyjnej,

- przeszkody utrudniające wprowadzanie innowacji.

Mierniki wykorzystane do oceny działalności innowacyjnej przedsiębiorstw przetwórstwa przemysłowego, a w szczególności przemysłu spożywczego, zostały 
podzielone na dwie zasadnicze grupy( zob. tab. 4.1). Oprócz wskaźników charakteryzujących nakłady i efekty działalności innowacyjnej zwrócono jeszcze uwagę na współpracę w działalności innowacyjnej i bariery wprowadzania innowacji.

Tabela 4.1. Wybrane mierniki charakteryzujące działalność innowacyjną przedsiębiorstw

\begin{tabular}{|c|c|}
\hline $\begin{array}{l}\text { Wskaźniki nakładów } \\
\text { Input statistics }\end{array}$ & $\begin{array}{l}\text { Wskaźniki efektów } \\
\text { Output statistics }\end{array}$ \\
\hline $\begin{array}{l}\text { - Poziom i struktura nakładów na działalność } \\
\text { innowacyjną } \\
\text { • Źródła innowacyjności }\end{array}$ & $\begin{array}{l}\text { - Udział przedsiębiorstw innowacyjnych } \\
\text { w ogólnej liczbie przedsiębiorstw } \\
\text { - Udział sprzedaży wyrobów nowych i zmoder- } \\
\text { nizowanych w sprzedaży wyrobów ogółem } \\
\text { - Innowacje organizacyjne i marketingowe } \\
\text { - Innowacje przynoszące korzyści dla środo- } \\
\text { wiska } \\
\text { - Intensywność innowacji } \\
\text { - Wynalazki i wzory użytkowe }\end{array}$ \\
\hline
\end{tabular}

Źr ó d ł o : opracowanie własne na podstawie: Nauka i technika w 2007 roku, GUS, Warszawa 2009, s. 27-28.

\subsubsection{Nakłady na działalność innowacyjną}

Działalność innowacyjna przedsiębiorstw w przemyśle stanowi podstawowy, obok działalności $B+R$, element społeczeństwa i gospodarki opartych na wiedzy. Dążenie do zaspokojenia potrzeb klientów wymaga od przedsiębiorców nieustannego usprawniania funkcjonowania firm oraz wprowadzania na rynek nowych produktów, co stwarza im szanse na osiągnięcie sukcesów rynkowych. Zatem od innowacyjności działań przedsiębiorstw i od innowacyjności oferty rynkowej zależy ich konkurencyjność. Jest to szczególnie ważne w dobie integracji i globalizacji. W praktyce gospodarczej ważnym czynnikiem określającym innowacyjność przedsiębiorstw jest poziom nakładów na działalność innowacyjną. W ocenie ograniczono się do przedsiębiorstw zatrudniających powyżej 49 osób.

Według metodologii GUS (metodologia Oslo) nakłady na działalność innowacyjną obejmują nakłady na: prace badawcze i rozwojowe $(B+R)$ wykonane przez własne zaplecze badawcze przedsiębiorstw, jak również nabyte od innych jednostek, zakup wiedzy ze źródeł zewnętrznych (gotowej technologii w postaci dokumentacji i praw - patenty, wynalazki nieopatentowane, licencje, ujawnienia know-how, znaki towarowe itp.), zakup oprogramowania, nakłady inwestycyjne na środki trwałe niezbędne do wprowadzenia innowacji (maszyny, urządzenia techniczne, narzędzia, środki transportu, budynki, budowle oraz grunty), szkolenie 
personelu związane z działalnością innowacyjną, marketing dotyczący nowych lub istotnie ulepszonych produktów oraz pozostałe przygotowania do wprowadzenia innowacji produktowych i procesowych [Rocznik statystyczny przemystu, 2010, s. 447].

W latach 1999-2008 nakłady na działalność innowacyjną w przedsiębiorstwach produkujących artykuły spożywcze i napoje zmniejszyły się w ujęciu nominalnym o $35 \%$ (z 3152,4 mln zł w 1999 r. do 2034,5 mln zł w 2008 r.), natomiast realnie spadek wyniósł około 49\% (rys. 4.1.). Rekordowy poziom nakładów na działalność innowacyjną w przetwórstwie żywności, wynoszący 3152,4 mln zł, wystąpił w 1999 r., co oznaczało, w porównaniu z rokiem poprzednim, ponad dwukrotny wzrost nakładów. Niestety była to sytuacja wyjątkowa i w kolejnych latach nakłady kształtowały się na zdecydowanie niższym poziomie. Ze względu na nietypowy, wyjątkowo wysoki poziom nakładów na działalność innowacyjną w przedsiębiorstwach przemysłu spożywczego w 1999 r., do obliczeń średniorocznego tempa zmian nakładów włączono jeszcze rok 1998. W okresie 1998-2008 odnotowano średnioroczne tempo wzrostu nakładów na działalność innowacyjną (ceny stałe) wynoszące niespełna $1 \%$. W badanym okresie dynamika nakładów na działalność innowacyjną w przedsiębiorstwach przetwórstwa przemysłowego (sekcja $\mathrm{D}$ według PKD) pokrywała się z dynamiką nakładów w przedsiębiorstwach przemysłowych ogółem (rys. 4.1). W latach 1999-2003, a więc w okresie poprzedzającym integrację Polski z UE, nakłady na działalność innowacyjną w przedsiębiorstwach przemysłu spożywczego oraz w przedsiębiorstwach przemysłowych charakteryzowały się tym samym kierunkiem zmian i podobnym, wyłączając rok 1999, tempem tych przeobrażeń. W pierwszych czterech latach członkostwa Polski w UE (2004-2007) dynamika nakładów na innowacje w przedsiębiorstwach produkujących żywność była korzystniejsza niż w przedsiębiorstwach przemysłowych. Nakłady na działalność innowacyjną w przemyśle spożywczym w latach 2004-2007 były wyraźnie wyższe niż w 1998 r., i tak w roku 2004 o 38\%, 2005 o 17\%, 2006 o 50\% i 2007 o $24 \%$, podczas gdy w przemyśle odnotowano nawet spadek nakładów (w 2005 r.) w stosunku do roku 1998 o około 5\%. Jednak w 2008 r. powyższa tendencja została zahamowana, nakłady na działalność innowacyjną w przemyśle spożywczym były wyższe w porównaniu z $1998 \mathrm{r}$. zaledwie o $10 \%$, podczas gdy w przemyśle ogółem aż o prawie $44 \%$. Trudno powiedzieć, czy jest to początek nowej tendencji, czy może następstwo faktu, że procesy dostosowawcze w ogromnej liczbie przedsiębiorstw przemysłu spożywczego, zwłaszcza w tzw. sektorach wrażliwych, tj. w przetwórstwie produktów pochodzenia zwierzęcego, kończyły się w 2007 r., co może skutkować w kolejnych latach osłabieniem aktywności innowacyjnej. 


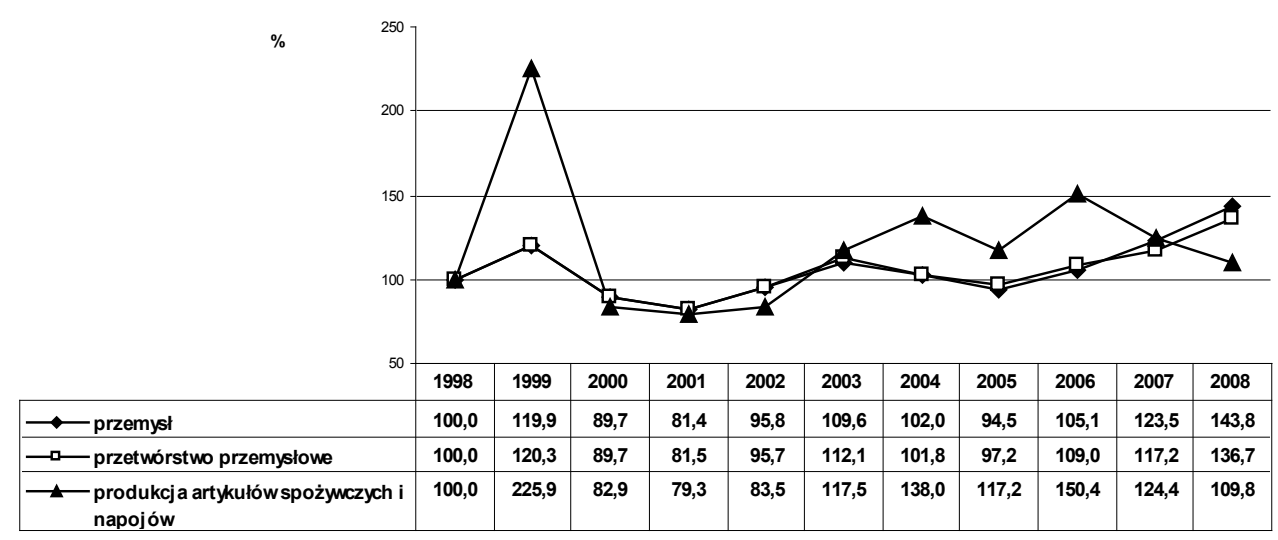

Rysunek 4.1. Dynamika nakładów na działalność innowacyjną w przedsiębiorstwach produkujących artykuły spożywcze i napoje, przedsiębiorstwach przemysłowych i przedsiębiorstwach przetwórstwa przemysłowego w latach 1998-2008 (ceny stałe)

Źr ó d ł o : opracowanie własne na podstawie Roczników statystycznych przemystu GUS dla lat 1999-2009 (dotyczy wszystkich rysunków w rozdz. 4).

Zaprezentowane dane wskazują, że nakłady na działalność innowacyjną, zarówno w przedsiębiorstwach przemysłu spożywczego, jak i w przedsiębiorstwach przetwórstwa przemysłowego czy przemysłu ogółem, charakteryzowały się dużą zmiennością w badanym okresie. Oceniając dynamikę tych nakładów warto, W celu lepszego jej zobrazowania, porównać średniookresowe tempo zmian. W analizowanych latach, 1998-2008, najwyższe średnioroczne tempo wzrostu nakładów na działalność innowacyjną na poziomie 3,8\% wystąpiło w przemyśle ogółem, w przetwórstwie przemysłowym wyniosło $3,2 \%$, a w przemyśle spożywczym było najniższe zaledwie na poziomie $1 \%$.

Poziom nakładów na działalność innowacyjną należy rozpatrywać w połączeniu z ich przeznaczeniem (tab. 4.2). W strukturze nakładów na działalność innowacyjną według rodzajów działalności innowacyjnej dominują w 2008 r., podobnie jak w latach wcześniejszych, nakłady inwestycyjne na zakup maszyn i urządzeń technicznych oraz środki transportu. Ich udział w 2008 r. w przemyśle spożywczym wyniósł $58,2 \%$, w przemyśle ogółem $57,1 \%$ i na podobnym poziomie 57,3\% - w przetwórstwie przemysłowym. Ten odsetek w badanym okresie wahał się w przedsiębiorstwach przemysłu spożywczego od 50,0\% w 1999 r. do $69,7 \%$ w 2003 r. Z przytoczonych liczb wynika, że w roku poprzedzającym integrację z UE nakłady na zakup maszyn i urządzeń technicznych oraz środków transportu pochłonęły największą część ogólnych nakładów na działalność innowacyjną. 
Tabela 4.2. Struktura nakładów finansowych na działalność innowacyjną w przedsiębiorstwach przemysłu spożywczego, przetwórstwa przemysłowego i przemysłu ogółem w Polsce w latach 1999-2008 (w \%)

\begin{tabular}{|c|c|c|c|c|c|c|c|c|c|c|c|}
\hline Wys & & 1999 & 2000 & 2001 & 2002 & 2003 & 2004 & 2005 & 2006 & 2007 & 2008 \\
\hline \multirow{3}{*}{$\begin{array}{l}\text { Nakłady na działalność } \\
\text { badawczo-rozwojową } \\
(\mathrm{B}+\mathrm{R})\end{array}$} & $\mathrm{a}$ & 34,0 & 2,5 & 2 & 3,7 & 2,3 & 2,0 & 2,0 & 2,7 & 2,6 & 3,7 \\
\hline & $\mathrm{b}$ & 20,5 & 13,3 & 10,8 & 10,1 & 12,9 & 8,0 & 9,5 & 9,5 & 9,4 & 9,5 \\
\hline & $\mathrm{c}$ & 18,5 & 12,8 & 10,2 & 9,3 & 12,0 & 7,5 & 9,6 & 9,2 & 8,1 & 8,2 \\
\hline \multirow{3}{*}{$\begin{array}{l}\text { Nakłady na zakup gotowej } \\
\text { technologii w postaci } \\
\text { dokumentacji i praw }\end{array}$} & $\mathrm{a}$ & 0,8 & 0,8 & 2,0 & 3,4 & 0,9 & 3,1 & 1,7 & 1,6 & 1,7 & 0,4 \\
\hline & $\mathrm{b}$ & 2,3 & 2,6 & 2,1 & 3,1 & 5,0 & 3,0 & 2,4 & 2,0 & 1,8 & 1,2 \\
\hline & $\mathrm{c}$ & 2,3 & 2,4 & 1,9 & 3,0 & 4,7 & 2,8 & 2,4 & 2,0 & 1,7 & 1,1 \\
\hline \multirow{3}{*}{$\begin{array}{l}\text { Nakłady inwestycyjne } \\
\text { na maszyny, urządzenia } \\
\text { techniczne i narzędzia oraz } \\
\text { środki transportu }\end{array}$} & $\mathrm{a}$ & 50,0 & 62,0 & 65,9 & 63,5 & 69,7 & 62,6 & 64,7 & 62,2 & 64,7 & 58,2 \\
\hline & $\mathrm{b}$ & 47,7 & 53,5 & 55,6 & 63,3 & 61,7 & 59,2 & 59,1 & 58,9 & 58,4 & 57,3 \\
\hline & $\mathrm{c}$ & 50,2 & 54,0 & 54,8 & 62,8 & 62,9 & 59,8 & 58,6 & 58,8 & 58,8 & 57,1 \\
\hline \multirow{3}{*}{$\begin{array}{l}\text { Nakłady inwestycyjne na } \\
\text { budynki i budowle }\end{array}$} & $\mathrm{a}$ & 5,6 & 25,8 & 16,9 & 18,9 & 21,7 & 23,5 & 25,3 & 23,3 & 18,4 & 21,1 \\
\hline & $\mathrm{b}$ & 11,8 & 21,8 & 24,5 & 18,4 & 15,1 & 23,6 & 24,0 & 22,9 & 22,8 & 26,2 \\
\hline & $\mathrm{c}$ & 12,6 & 22,4 & 26,1 & 20,1 & 15,2 & 23,2 & 24,1 & 22,8 & 24,2 & 27,4 \\
\hline \multirow{3}{*}{$\begin{array}{l}\text { Nakłady na szkolenie } \\
\text { personelu związane } \\
\text { z działalnością } \\
\text { innowacyjną }\end{array}$} & $\mathrm{a}$ & 0,5 & 0,1 & 0,3 & 0,1 & 0,1 & 0,1 & 0,1 & 0,1 & 0,1 & 0,5 \\
\hline & $\mathrm{b}$ & 08 & 1,2 & 0,8 & 0,2 & 0,2 & 0,2 & 0,3 & 0,2 & 0,4 & 0,4 \\
\hline & c & 1,0 & 1,1 & 0,7 & 0,2 & 0,2 & 0,3 & 0,3 & 0,3 & 0,3 & 0,9 \\
\hline \multirow{3}{*}{$\begin{array}{l}\text { Nakłady na marketing } \\
\text { dotyczący nowych } \\
\text { i zmodernizowanych } \\
\text { wyrobów }\end{array}$} & $\mathrm{a}$ & 8,3 & 6,1 & 10,2 & 4,2 & 3,2 & 5,5 & 4,1 & 7,3 & 10,1 & 12,0 \\
\hline & $\mathrm{b}$ & 3,6 & 3,6 & 3,1 & 1,7 & 1,5 & 3,0 & 2,2 & 3,1 & 3,7 & 2,9 \\
\hline & $\mathrm{c}$ & 3,2 & 3,2 & 2,8 & 1,5 & 1,3 & 2,6 & 2,0 & 2,8 & 3,1 & 2,5 \\
\hline \multirow{3}{*}{ Pozostałe nakłady } & $\mathrm{a}$ & 0,9 & 2,7 & 2,4 & 6,4 & 2,0 & 3,1 & 2,1 & 2,8 & 2,5 & 4,1 \\
\hline & $\mathrm{b}$ & 13,3 & 4,1 & 3,2 & 3,2 & 3,6 & 3,1 & 2,6 & 3,4 & 3,6 & 2,4 \\
\hline & $\mathrm{c}$ & 12,1 & 4,1 & 3,5 & 3,2 & 3,7 & 3,8 & 2,9 & 4,0 & 3,8 & 2,7 \\
\hline \multirow{3}{*}{$\begin{array}{l}\text { Ogółem nakłady na } \\
\text { działalność innowacyjną }\end{array}$} & $\mathrm{a}$ & 100 & 100 & 100 & 100 & 100 & 100 & 100 & 100 & 100 & 100 \\
\hline & $\mathrm{b}$ & 100 & 100 & 100 & 100 & 100 & 100 & 100 & 100 & 100 & 100 \\
\hline & $\mathrm{c}$ & 100 & 100 & 100 & 100 & 100 & 100 & 100 & 100 & 100 & 100 \\
\hline
\end{tabular}

Objaśnienia: a - przedsiębiorstwa przemysłu spożywczego; b - przedsiębiorstwa przetwórstwa przemysłowego; $\mathrm{c}$ - przedsiębiorstwa przemysłowe ogółem

Źródło: opracowanie własne na podstawie Roczników statystycznych przemysłu GUS, dla lat 1999-2009.

W strukturze nakładów na działalność innowacyjną drugie miejsce, zarówno wśród przedsiębiorstw przemysłu spożywczego, jak i przedsiębiorstw przetwórstwa przemysłowego oraz przemysłu ogółem, zajmują nakłady inwestycyjne na budynki i budowle (tab. 4.2). W całym przemyśle łącznie na maszyny i urządzenia oraz budynki i budowle w 2008 r. przeznaczono 84,5\%, w przetwórstwie przemysłowym 
83,5\% oraz w przemyśle spożywczym 79,3\% całości nakładów na działalność innowacyjną. W strukturze nakładów na działalność innowacyjną utrzymuje się więc dominacja nakładów inwestycyjnych (na maszyny i urządzenia oraz budynki i budowle), których łączny udział w analizowanych latach wyniósł średnio ponad 80\%.

Najwyższy, nietypowy, udział nakładów na B+R wystąpił w 1999 r., zarówno w przedsiębiorstwach przemysłu spożywczego (34\%), jak i w przetwórstwie przemysłowym $(20,5 \%)$ oraz przemyśle $(18,5 \%)$. Niestety w pozostałych latach udział ten ukształtował się na zdecydowanie niższym poziomie. Ważne dla działalności innowacyjnej nakłady na B+R stanowiły w latach 2000-2008 tylko od 2,0 do 3,7 \% nakładów w przemyśle spożywczy, 8,0 -13,3\% w przetwórstwie przemysłowym oraz 7,5-12,8 \% w całym przemyśle. Znaczenie nakładów na $\mathrm{B}+\mathrm{R}$ w przedsiębiorstwach przemysłu spożywczego było słabsze niż w przedsiębiorstwach przetwórstwa przemysłowego i przemysłu ogółem.

Stosunkowo niewielki udział nakładów na $\mathrm{B}+\mathrm{R}$ i wysoki odsetek nakładów inwestycyjnych (na maszyny i urządzenia oraz budynki i budowle) w nakładach ogółem na działalność innowacyjną to cechy charakterystyczne działalności innowacyjnej w przedsiębiorstwach krajów słabo rozwiniętych, tzw. doganiających. W takich podmiotach dąży się do jak najszybszego zmniejszenia luki technologicznej poprzez absorpcję z zewnątrz technologii materialnej.

Analizując strukturę nakładów na działalność innowacyjną warto jeszcze zwrócić uwagę na nakłady przeznaczone na marketing dotyczący nowych i zmodernizowanych wyrobów. W przedsiębiorstwach przemysłu spożywczego udział tych nakładów $(3,2-12,0 \%)$ jest zdecydowanie wyższy niż w przedsiębiorstwach przetwórstwa przemysłowego $(1,5-3,6 \%)$ i przedsiębiorstwach przemysłu ogółem (1,3-3,2 \%). Znaczenie pozostałych nakładów jest mniej ważące.

Przedsiębiorstwa wprowadzające innowacje korzystają z wielu źródeł informacji, które im ten proces ułatwiają. W literaturze przedmiotu wyróżnia się dwa podstawowe rodzaje źródeł [Działalność innowacyjna przedsiębiorstw $w$ latach 2004-2006, s. 6-7] :

- źródła wewnętrzne,

- źródła zewnętrzne.

GUS w przeprowadzanych badaniach do źródeł wewnętrznych zalicza:

- źródła wewnątrz przedsiębiorstwa: własne zaplecze badawczo-rozwojowe, kadra kierownicza, służby marketingowe, działy produkcji i sprzedaży itp.,

- inne przedsiębiorstwa należące do tej samej grupy przedsiębiorstw.

Z kolei w grupie źródeł zewnętrznych uwzględniono: źródła rynkowe:

- dostawcy wyposażenia, materiałów, komponentów i oprogramowania,

- klienci,

- konkurenci i inne przedsiębiorstwa z tej samej dziedziny działalności,

- firmy konsultingowe, laboratoria komercyjne i prywatne instytucje B+R; 
źródła instytucjonalne:

- placówki naukowe PAN,

- jednostki badawczo-rozwojowe (JBR-y),

- zagraniczne publiczne instytucje badawcze,

- szkoły wyższe (krajowe i zagraniczne);

pozostałe źródła:

- konferencje, targi, wystawy,

- czasopisma i publikacje (naukowe, techniczne, handlowe),

- towarzystwa i stowarzyszenia naukowo-techniczne, specjalistyczne i zawodowe.

Z badań przeprowadzonych przez GUS wynika, że w działalności innowacyjnej przedsiębiorstw w Polsce w latach 2004-2006, podobnie jak w poprzednich edycjach badań nad innowacjami, największe znaczenie miały następujące źródła informacji:

- źródła wewnątrz przedsiębiorstwa - 43,9\% przedsiębiorstw produkujących artykuły spożywcze i napoje, $45,7 \%$ przedsiębiorstw przetwórstwa przemysłowego i $45,3 \%$ przedsiębiorstw przemysłu ogółem, aktywnych innowacyjnie w latach 2004-2006, oceniło znaczenie tego źródła jako „wysokie”;

- klienci - 23,4\% aktywnych innowacyjnie przedsiębiorstw produkujących żywność, 28,8\% przedsiębiorstw przetwórstwa przemysłowego i 27,7\% przedsiębiorstw przemysłu ogółem uznało znaczenie tego źródła jako „wysokie”.

Najmniejsze znaczenie jako źródło informacji miały źródła instytucjonalne, tj. placówki naukowe PAN, JBR-y, zagraniczne publiczne instytucje badawcze oraz szkoły wyższe.

Wyniki w zakresie źródeł innowacyjności przedsiębiorstw przemysłowych w Polsce są zgodne z wynikami innych krajów uczestniczących w badaniu innowacji według metodologii Oslo.

\subsubsection{Efekty działalności innowacyjnej}

Zgodnie z międzynarodową metodologią przyjętą przez GUS dotyczącą badania działalności innowacyjnej przedsiębiorstwo innowacyjne to takie, które w danym okresie, najczęściej trzyletnim, wprowadziło przynajmniej jedną innowację produktową lub procesową. W tabeli 4.3 umieszczono udziały przedsiębiorstw innowacyjnych w wybranych okresach badawczych.

W produkcji artykułów spożywczych i napojów udział przedsiębiorstw innowacyjnych w latach 1998-2000 nie był wysoki, wynosił 26,8\%, w następnych okresach badawczych nastąpiła wyraźna poprawa. Największy udział przedsiębiorstw innowacyjnych, wynoszący 42,1\% odnotowano w latach 2004-2006 i niestety po tym okresie miał miejsce stopniowy spadek odsetka przedsiębiorstw innowacyjnych aż do 29,6\% w latach 2006-2008. Wynika to zapewne ze znacznego zmniejszenia nakładów na działalność innowacyjną 
w przedsiębiorstwach produkujących żywność (por. rys. 4.1). Znaczenie przedsiębiorstw innowacyjnych w przemyśle ogółem był nieco wyższe, zwłaszcza w ostatnim okresie badawczym 2006-2008, kiedy to różnica wynosiła ponad 8 punktów procentowych. W tej części analizy, celem uzyskania większej czytelności informacji zawartych $\mathrm{w}$ tab. 4.3, pominięto innowacyjność przedsiębiorstw przetwórstwa przemysłowego, których innowacyjność była zbliżona do innowacyjności przedsiębiorstw przemysłu ogółem ( różnice wynosiły od 0,1 do 0,3 pkt. proc.).

Tabela 4.3. Działalność innowacyjna przedsiębiorstw produkujących artykuły spożywcze i napoje oraz przedsiębiorstw przemysłowych w latach 1998-2008

\begin{tabular}{|c|c|c|c|c|c|c|c|c|c|c|}
\hline \multirow[b]{3}{*}{ Wyszczególnienie } & \multicolumn{10}{|c|}{$\begin{array}{c}\text { Przedsiębiorstwa, które wprowadziły innowacje jako odsetek ogółu } \\
\text { przedsiębiorstw w latach }\end{array}$} \\
\hline & \multicolumn{2}{|c|}{ 1998-2000 } & \multicolumn{2}{|c|}{ 2003-2005 } & \multicolumn{2}{|c|}{ 2004-2006 } & \multicolumn{2}{|c|}{$2005-2007$} & \multicolumn{2}{|c|}{$2006-2008$} \\
\hline & 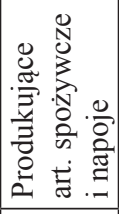 & 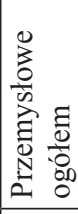 & 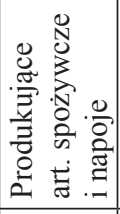 & 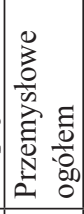 & 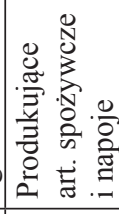 & 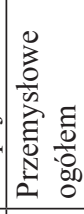 & 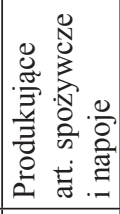 & 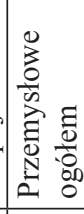 & 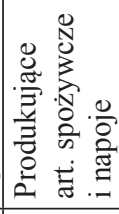 & 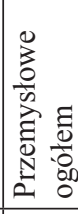 \\
\hline $\begin{array}{l}\text { Przedsiębiorstwa, } \\
\text { które wprowadziły } \\
\text { innowacje ogółem }\end{array}$ & 26,8 & 30,2 & 40,3 & 41,5 & 42,1 & 42,5 & 32,1 & 36,7 & 29,6 & 37,7 \\
\hline $\begin{array}{l}\text { Przedsiębiorstwa, } \\
\text { które wprowadzily } \\
\text { innowacje } \\
\text { produktowe }\end{array}$ & 22,5 & 25 & 28,1 & 28,1 & 29,8 & 29,3 & 25,2 & 28 & 23,2 & 28,4 \\
\hline $\begin{array}{l}\text { Przedsiębiorstwa, } \\
\text { które wprowadziły } \\
\text { innowacje } \\
\text { procesowe }\end{array}$ & 18,6 & 21,1 & 32,1 & 32,5 & 36 & 35,9 & 20,9 & 25,2 & 22,9 & 30,1 \\
\hline
\end{tabular}

Źródło: opracowanie własne na podstawie Roczników statystycznych przemystu, dla lat 1999-2009, GUS.

Poziom aktywności innowacyjnej przedsiębiorstw w przemyśle w Polsce był niższy niż w większości krajów UE oraz Norwegii i Islandii uczestniczących w IV rundzie programu CIS (2002-2004). Ogółem dla przemysłu i usług dla państw UE-27 wskaźnik przedsiębiorstw aktywnych innowacyjnie wyniósł 39,5\%. Najwyższy stopień aktywności innowacyjnej w przemyśle w latach 2002-2004 zanotowano w Niemczech (72,8\%), Irlandii (60,9\%) oraz Belgii $(58,1 \%)$. 
Analizując rodzaj wprowadzonych innowacji w przedsiębiorstwach produkujących żywność zauważamy, że w poszczególnych podokresach: 1998-2000, 2005-2007 oraz 2006-2008 dominowały takie innowacje, które wprowadziły nowe lub istotnie ulepszone produkty (wyroby i usługi). Największa różnica $(6,2$ pkt. proc.) między udziałem przedsiębiorstw wprowadzających innowacje produktowe i procesowe (na korzyść procesowych) wystąpiła w okresie największej aktywności innowacyjnej, tj. w latach 2004-2006. Podobne tendencje zmian zaobserwowano w przypadku przedsiębiorstw przemysłu ogółem.

Poziom innowacyjności gospodarki danego kraju, jej sekcji i działów zależy przede wszystkim od aktywności innowacyjnej przedsiębiorstw, od ich zdolności do szybkiego i aktywnego przyswajania nowej wiedzy i technologii. Innowacyjność gospodarki kojarzy się ze stopniem nowoczesności wyrobów oferowanych na coraz bardziej konkurencyjnych rynkach. Cechą nowej gospodarki jest istotne skrócenie cyklu życia produktów. W przemyśle przetwórczym krajów wysoko rozwiniętych wymiana asortymentów wytwarzanych produktów dokonuje się w okresie 2-5 lat w zależności od branży. Zgodnie z metodologią Oslo ważnym wskaźnikiem służącym do oceny efektów działalności innowacyjnej przedsiębiorstw jest tzw. współczynnik odnowienia produkcji, który określa udział sprzedaży produktów nowych i istotnie ulepszonych w wartości sprzedaży ogółem.

Udział wyrobów nowych i istotnie ulepszonych w produkcji sprzedanej, zarówno przedsiębiorstw produkujących żywność, jak i przedsiębiorstw przetwórstwa przemysłowego oraz przemysłu ogółem, był niski. W przedsiębiorstwach produkujących artykuły spożywcze i napoje wartość tego wskaźnika w całym badanym okresie była wyraźnie niższa niż w pozostałych grupach przedsiębiorstw. $\mathrm{W}$ roku przedakcesyjnym oraz $\mathrm{w}$ dwóch pierwszych latach członkostwa Polski w UE nastąpił wzrost udziału sprzedaży wyrobów nowych i zmodernizowanych w sprzedaży wyrobów ogólem. Jednak w kolejnych okresach, zwłaszcza w latach 2007 i 2008, ta pozytywna tendencja została zahamowana. W roku 2008 udział sprzedaży wyrobów nowych i istotnie ulepszonych w sprzedaży wyrobów ogółem w przedsiębiorstwach produkujących żywność wyniósł zaledwie $8,4 \%$, podczas gdy w przetwórstwie przemysłowym stanowił 18\% i przemyśle ogółem 15,8\%.

Mimo pewnych pozytywnych zmian przeciętny poziom nowoczesności polskich produktów nadal odbiega in minus od przeciętnego wskaźnika nowoczesności w krajach wysoko rozwiniętych.

Sprzedaż produktów nowych i istotnie ulepszonych bada się ponadto w podziale na sprzedaż:

- produktów nowych lub istotnie ulepszonych dla rynku, na którym działa przedsiębiorstwo, wprowadzonych na rynek w ciągu ostatnich trzech lat,

- produktów nowych lub istotnie ulepszonych tylko dla przedsiębiorstwa, wprowadzonych na rynek w ciągu ostatnich trzech lat. 
Tabela 4.4. Produkcja sprzedana wyrobów nowych i istotnie ulepszonych w latach 1999-2008

\begin{tabular}{|c|c|c|c|c|c|c|c|c|c|c|}
\hline \multirow{4}{*}{ Wyszczególnienie } & 1999 & 2000 & 2001 & 2002 & 2003 & 2004 & 2005 & 2006 & 2007 & 2008 \\
\hline & \multicolumn{10}{|c|}{ Wyroby, których produkcję uruchomiono w latach: } \\
\hline & $\begin{array}{c}1997- \\
1999\end{array}$ & $\begin{array}{c}1998- \\
2000\end{array}$ & $\begin{array}{c}1999- \\
2001\end{array}$ & $\begin{array}{c}2000- \\
2002\end{array}$ & $\begin{array}{c}2001- \\
2003\end{array}$ & $\begin{array}{c}2002- \\
2004\end{array}$ & $\begin{array}{c}2003- \\
2005\end{array}$ & $\begin{array}{c}2004- \\
2006\end{array}$ & $\begin{array}{c}2005- \\
2007\end{array}$ & $\begin{array}{c}2006- \\
2008\end{array}$ \\
\hline & \multicolumn{10}{|c|}{$\mathrm{w} \%$ produkcji sprzedanej } \\
\hline $\begin{array}{l}\text { Przedsiębiorstwa } \\
\text { produkujące } \\
\text { artykuły } \\
\text { spożywcze i napoje }\end{array}$ & 12,5 & 9,6 & 10,3 & 7,3 & 13,4 & 12,5 & 11,1 & 11,5 & 10,2 & 8,4 \\
\hline $\begin{array}{l}\text { Przedsiębiorstwa } \\
\text { przetwórstwa } \\
\text { przemysłowego }\end{array}$ & 24,7 & 18,5 & 20,8 & 19,1 & 23,8 & 23,8 & 25,1 & 20,2 & 16,3 & 18 \\
\hline $\begin{array}{l}\text { Przedsiębiorstwa } \\
\text { przemysłowe } \\
\text { ogółem }\end{array}$ & 21,3 & 16,4 & 18 & 16,7 & 20,7 & 20,9 & 21,8 & 18 & 14,7 & 15,8 \\
\hline
\end{tabular}

Ź ró dło : Roczniki statystyczne przemysłu oraz Nauka i technika dla odpowiednich lat, GUS.

W strukturze sprzedaży produktów innowacyjnych w przedsiębiorstwach produkujących artykuły spożywcze i napoje produkty nowe lub istotnie ulepszone dla rynku stanowiły w 2007 r. ok. 53\% sprzedaży produktów innowacyjnych, natomiast w przedsiębiorstwach przemysłu ogółem $46 \%$.

W badaniach działalności innowacyjnej pytano również przedsiębiorstwa o innowacje nietechnologiczne, tzn. o innowacje inne niż wprowadzanie nowych lub istotnie ulepszonych produktów i/lub procesów, czyli pytano o innowacje organizacyjne i marketingowe. Jednak pytania dotyczące konkretnych innowacji organizacyjnych i marketingowych w kolejnych okresach badawczych były przez GUS modyfikowane, co uniemożliwia bardziej dogłębną analizę tego zjawiska w czasie.

W ostatnim z wyodrębnionych okresów badawczych pytania dotyczyły innowacji organizacyjnych, wprowadzonych w latach 2006-2008, takich jak:

- nowe metody w zasadach działania,

- nowe zasady podziału zadań i uprawnień decyzyjnych,

- nowe metody w zakresie stosunków z otoczeniem.

W zakresie innowacji marketingowych, wprowadzonych w latach 2006-2008, zapytano o wprowadzenie takich innowacji jak:

- znaczące zmiany w projekcie/konstrukcji lub opakowaniu produktów,

- nowe media lub techniki promocji produktów,

- nowe metody w zakresie dystrybucji produktów lub kanałów sprzedaży,

- nowe metody kształtowania cen wyrobów i usług. 
Odsetek przedsiębiorstw, które wprowadziły w latach 2006-2008 przynajmniej jedną z wyżej wymienionych innowacji organizacyjnych lub marketingowych wyniósł $22,1 \% \mathrm{w}$ przedsiębiorstwach produkujących artykuły spożywcze i napoje, natomiast w przemyśle ogółem odsetek ten wyniósł 26,9\% (zob. tab. 4.5). W latach 2006-2008 w porównaniu z poprzednim okresem 2004-2006 nastąpił spadek zarówno w zakresie innowacji organizacyjnych, jak i marketingowych we wszystkich badanych grupach przedsiębiorstw. Przedstawione informacje dotyczą przedsiębiorstw zatrudniających powyżej 9 osób.

GUS w badaniach działalności innowacyjnej przedsiębiorstw wprowadził w latach 2006-2008 po raz pierwszy moduł badania dotyczący innowacji przynoszących korzyści dla środowiska (ekoinnowacji). Innowacja przynosząca korzyści dla środowiska (ekoinnowacja) to nowy lub istotnie ulepszony produkt (wyrób lub usługa), proces, metoda organizacyjna lub marketingowa, które przynoszą korzyści dla środowiska w porównaniu z rozwiązaniami alternatywnymi. Innowacje te były badane w podziale na innowacje przynoszące korzyści w okresie wytwarzania produktu oraz w okresie użytkowania zakupionego produktu.

Tabela 4.5. Przedsiębiorstwa, które wprowadziły innowacje organizacyjne i/lub marketingowe jako odsetek ogółu przedsiębiorstw

\begin{tabular}{|l|c|c|c|c|}
\hline \multirow{2}{*}{ Wyszczególnienie } & \multicolumn{3}{|c|}{$\begin{array}{c}\text { Przedsiębiorstwa, które wprowadziły innowacje organizacyjne i/ } \\
\text { lub marketingowe w \% ogółu przedsiębiorstw w latach }\end{array}$} \\
\cline { 2 - 5 } & \multicolumn{2}{|c|}{ 2004-2006 } & \multicolumn{2}{c|}{ 2006-2008 } \\
\cline { 2 - 5 } & $\begin{array}{c}\text { produkujące } \\
\text { art. spożywcze } \\
\text { inapoje }\end{array}$ & $\begin{array}{c}\text { przemysłowe } \\
\text { ogółem }\end{array}$ & $\begin{array}{c}\text { produkujące } \\
\text { art. spożywcze } \\
\text { i napoje }\end{array}$ & $\begin{array}{c}\text { przemysłowe } \\
\text { ogółem }\end{array}$ \\
\hline $\begin{array}{l}\text { Przedsiębiorstwa, które } \\
\text { wprowadziły przynajmniej } \\
\text { jedną innowację } \\
\text { organizacyjną lub } \\
\text { marketingową }\end{array}$ & 29,6 & 29,8 & 22,1 & 26,9 \\
\hline $\begin{array}{l}\text { Przedsiębiorstwa, które } \\
\text { wprowadziły innowacje } \\
\text { organizacyjne }\end{array}$ & 19,5 & 23,4 & 10,7 & 13,3 \\
\hline $\begin{array}{l}\text { Przedsiębiorstwa, które } \\
\text { wprowadziły innowacje } \\
\text { marketingowe }\end{array}$ & 24,2 & 18,4 & 13,7 & 13,5 \\
\hline
\end{tabular}

Źr ó d ło: Działalność innowacyjna przedsiębiorstw w latach 2004-2006, GUS, Warszawa 2008; Nauka i technika w 2008 roku, GUS, Warszawa 2010.

Do korzyści w zakresie wytwarzania wyrobu lub usługi zaliczono:

- obniżkę materiałochłonności na jednostkę produktu,

- obniżkę energochłonności na jednostkę produktu, 
- obniżkę emisji dwutlenku węgla przez przedsiębiorstwo,

- użycie materiałów mniej zanieczyszczających środowisko,

- zmniejszenie zanieczyszczenia gleby, wody lub powietrza,

- powtórne wykorzystanie (recykling) odpadów, wody lub materiałów.

Natomiast do korzyści w okresie użytkowania zakupionego wyrobu lub korzystania z usługi przez użytkowników końcowych zaliczono:

- zmniejszenie zużycia energii,

- zmniejszenie zanieczyszczenia powietrza, wody, gleby lub poziomu hałasu,

- poprawę możliwości powtórnego wykorzystania (recyklingu) produktu po okresie użytkowania.

Z przeprowadzonego badania wynika, że innowacje przynoszące korzyści dla środowiska wprowadziło $23,3 \%$ przedsiębiorstw produkujących artykuły spożywcze i napoje i $26,2 \%$ przedsiębiorstw przemysłowych ogółem. Odsetek innowacji przynoszących korzyści w okresie wytwarzania produktu w produkcji żywności kształtował się na poziomie 20,3\%, a w przemyśle ogółem wyniósł 24,1\%. Z kolei wskaźniki innowacji przynoszących korzyści dla środowiska w okresie użytkowania zakupionego produktu wyniosły odpowiednio 16,2\% i $17,5 \%$.

Szczegółową strukturę ekoinnowacji przynoszących korzyści w okresie wytwarzania i użytkowania produktu prezentują odpowiednio rysunki 4.2. i 4.3 .

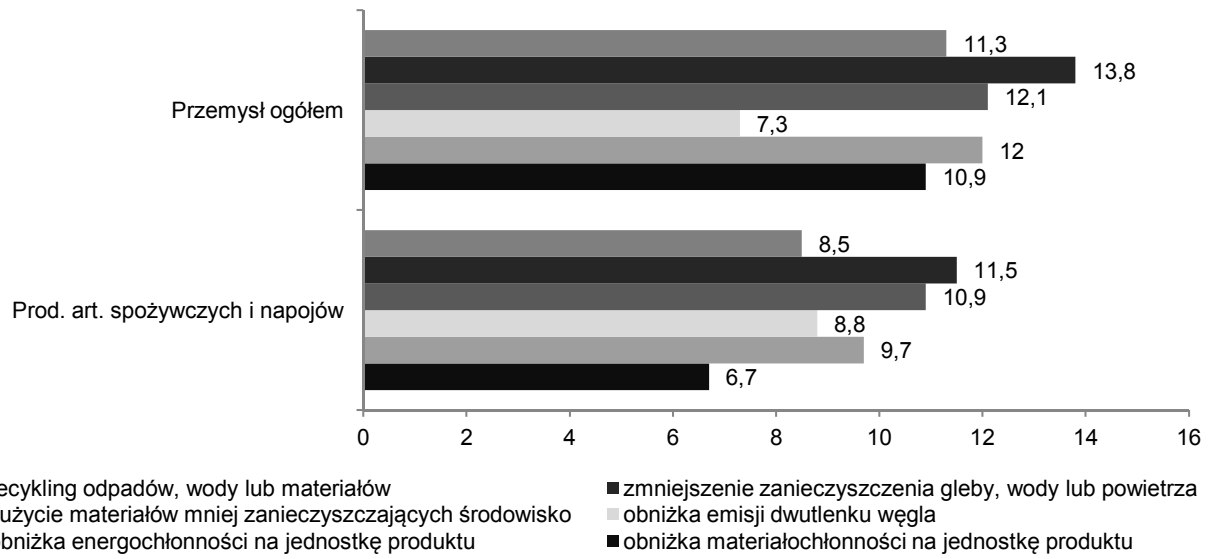

Rysunek 4.2. Struktura innowacji przynoszących korzyści dla środowiska w okresie wytwarzania produktu (wprowadzonych w latach 2006-2008)

Źró dło: Nauka i technika w 2008 roku, GUS, Warszawa 2010. 


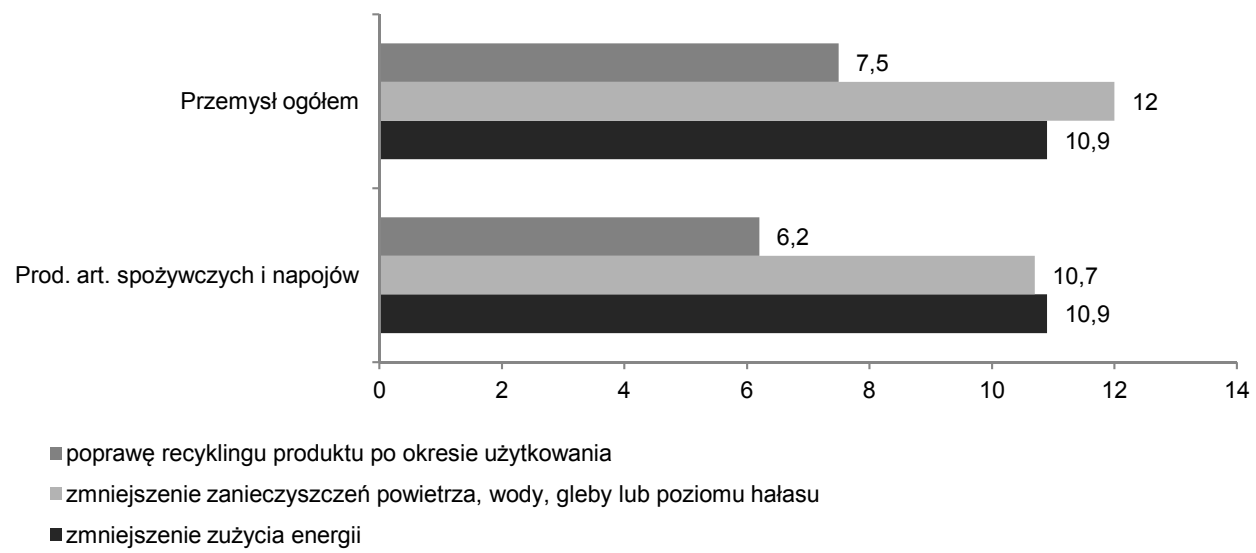

Rysunek 4.3. Struktura innowacji przynoszących korzyści dla środowiska w okresie użytkowania produktu (wprowadzonych w latach 2006-2008)

Źr ód ło : jak w rys. 4.2.

Najczęściej wprowadzaną innowacją przynoszącą korzyści w okresie wytwarzania wyrobu lub usługi było zmniejszenie zanieczyszczania gleby, wody lub powietrza. Podobna sytuacja wystąpiła w przypadku innowacji przynoszących korzyści dla środowiska w okresie użytkowania produktu. Były to bowiem innowacje zmniejszające również zanieczyszczenie powietrza, wody, gleby lub poziomu hałasu. Wprowadzanie innowacji przynoszących korzyści dla środowiska wiąże się z koniecznością wypełniania wielu norm i przepisów w zakresie ochrony środowiska wymaganych na terenie UE.

$\mathrm{W}$ analizie aktywności innowacyjnej gospodarki, jej sekcji i działów wykorzystuje się również wskaźnik intensywności innowacji, który jest relacją nakładów na działalność innowacyjną przedsiębiorstw przemysłowych do wartości produkcji sprzedanej przemysłu. Na rysuneku 4.4 przedstawiono kształtowanie się tego wskaźnika w przedsiębiorstwach przemysłu spożywczego, przetwórstwa przemysłowego i przemysłu ogółem w latach 1999-2008.

We wszystkich badanych grupach przedsiębiorstw działalność innowacyjna była najbardziej intensywna w 1999 r. W latach 2000-2006 kierunek zmian w analizowanych grupach przedsiębiorstw był podobny, jednak dynamika była różna. Po spadku intensywności innowacji w latach 2000-2001, w kolejnych dwóch okresach bezpośrednio poprzedzających integrację Polski z UE odsetek nakładów na działalność innowacyjną w produkcji sprzedanej wzrastał. Niestety, w roku 2004 tendencja wzrostowa została zahamowana, ale poziom intensywności innowacji w przemyśle spożywczym w latach 2004-2006 zbliżał się do poziomu intensywności innowacji w przetwórstwie przemysłowym i przemyśle ogółem. Jednak w ostatnich dwóch latach badanego okresu intensywność innowacji 
w przemyśle spożywczym wyraźnie malała, podczas gdy w przedsiębiorstwach przetwórstwa przemysłowego i przemysłu ogółem wzrastała. Generalnie w całym badanym okresie, za wyjątkiem 1999 r., intensywność innowacji w przedsiębiorstwach przemysłu spożywczego była najniższa.

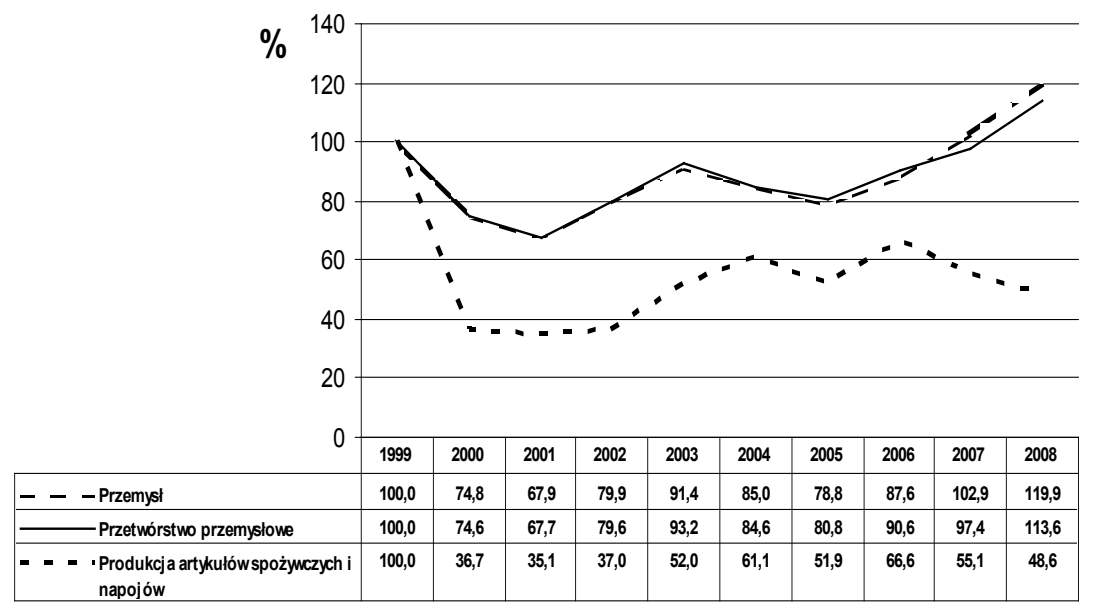

Rysunek 4.4. Dynamika intensywności innowacji w przedsiębiorstwach przemysłu ogółem, przetwórstwie przemysłowym i produkcji artykułów spożywczych i napojów w latach 1999-2008 (ceny stałe)

Ważnym aspektem działalności innowacyjnej przedsiębiorstw jest ochrona własności intelektualnej. W badaniach GUS wyróżniono pięć metod ochrony własności intelektualnej:

- zgłoszenie wynalazku do opatentowania,

- rejestracja wzoru użytkowego,

- rejestracja wzoru przemysłowego,

- rejestracja znaku towarowego,

- zastrzeżenie praw autorskich.

Wyniki badania wskazują, że tylko $8,8 \%$ przedsiębiorstw produkujących artykuły spożywcze i napoje, $10,1 \%$ przedsiębiorstw przetwórstwa przemysłowego i 9,9\% przedsiębiorstw przemysłu ogółem stosowało przynajmniej jedną z wyżej wymienionych form ochrony. Dla porównania w produkcji wyrobów tytoniowych udział przedsiębiorstw stosujących ochronę własności intelektualnej wyniósł aż $73 \%$. Najczęściej stosowaną metodą ochrony własności intelektualnej była rejestracja znaku towarowego $-7,6 \%$ przedsiębiorstw produkujących artykuły spożywcze i napoje, 7,0\% przedsiębiorstw przetwórstwa przemysłowego i $6,8 \%$ przedsiębiorstw przemysłu ogółem. Własność intelektualna częściej była chroniona przez duże przedsiębiorstwa.

Efekty działań innowacyjnych przedsiębiorstw powinny być zgodne z osiąganiem celów, istotnych z punktu widzenia realizowanych przez nie strategii 
rozwoju. W badaniach GUS (2004-2006) wyróżniono następujące efekty działalności innowacyjnej:

a) dotyczące produktów:

- zwiększenie asortymentu produktów,

- wejście na nowe rynki lub zwiększenie udziału na dotychczasowych rynkach,

- poprawa jakości produktów;

b) dotyczące procesów:

- zwiększenie (poprawa) elastyczności produkcji,

- zwiększenie zdolności produkcyjnych,

- obniżka kosztów pracy na jednostkę produktu,

- obniżka materiałochłonności i energochłonności na jednostkę produktu;

c) inne:

- zmniejszenie szkodliwości dla środowiska oraz poprawa bezpieczeństwa i higieny pracy,

- wypełnienie przepisów, norm lub standardów.

Wyniki przeprowadzonego badania wskazują, że hierarchia celów działalności innowacyjnej przedsiębiorstw produkujących artykuły spożywcze i napoje oraz przedsiębiorstw przetwórstwa przemysłowego i przemysłu ogółem jest zbieżna. Najważniejszym okazały się efekty dotyczące produktów, a wśród nich:

- poprawa jakości produktów - 38,9\% przedsiębiorstw aktywnych innowacyjnie produkujących artykuły spożywcze i napoje, $42 \%$ przedsiębiorstw przetwórstwa przemysłowego i 40,9\% przedsiębiorstw przemysłu ogółem uznało wpływ tego efektu jako, ,wysoki” oraz

- zwiększenie asortymentu produktów - 36,4\% przedsiębiorstw aktywnych innowacyjnie produkujących artykuły spożywcze i napoje, $39,6 \%$ przedsiębiorstw przetwórstwa przemysłowego i 38,0\% przedsiębiorstw przemysłu ogółem uznało wpływ tego efektu jako ,wysoki”.

Najmniej istotnymi efektami we wszystkich trzech analizowanych grupach przedsiębiorstw okazały się efekty związane z obniżką materiałochłonności i obniżką kosztów pracy. Ocena znaczenia efektów działalności innowacyjnej przedsiębiorstw w Polsce w latach 2004-2006 była bardzo podobna do oceny efektów działalności innowacyjnej przedsiębiorstw w krajach UE.

\subsubsection{Współpraca w zakresie działalności innowacyjnej}

Uważa się, że do sukcesu wprowadzanych w przedsiębiorstwie innowacji przyczynia się w dużym stopniu współpraca między różnymi jednostkami w procesie opracowywania i wprowadzania innowacji. Współpraca z innymi jednostkami w zakresie działalności innowacyjnej pozwala przedsiębiorstwom na obniżenie kosztów i ryzyka tej działalności, jak również na wymianę wiedzy i doświadczeń. W wielu krajach wysoko rozwiniętych w wyniku takiej współpracy powstają tzw. 
klastry innowacyjne. GUS, dostrzegając wagę problemu zwrócił uwagę, w ostatnich edycjach badań działalności innowacyjnej przedsiębiorstw, na ten element procesu innowacyjnego.

W badaniach GUS zapytano aktywne innowacyjnie firmy, czy w badanym okresie, najczęściej trzyletnim, posiadały jakieś porozumienia (umowy) o współpracy w zakresie działalności innowacyjnej z innymi jednostkami, takimi jak:

- inne przedsiębiorstwa należące do tej samej grupy przedsiębiorstw,

- dostawcy wyposażenia, materiałów, komponentów i oprogramowania,

- klienci,

- konkurenci i inne przedsiębiorstwa z tej samej dziedziny działalności,

- firmy konsultingowe (konsultanci), laboratoria komercyjne, prywatne instytucje $\mathrm{B}+\mathrm{R}$,

- placówki naukowe PAN,

- jednostki badawczo-rozwojowe,

- zagraniczne publiczne instytucje $\mathrm{B}+\mathrm{R}$,

- szkoły wyższe (krajowe i zagraniczne).

Badanie dotyczyło tylko współpracy polegającej na aktywnym udziale badanych przedsiębiorstw we wspólnych $\mathrm{z}$ innymi jednostkami projektach z zakresu działalności B+R i innych rodzajów działalności innowacyjnej. Prezentowane poniżej informacje $\mathrm{w}$ zakresie współpracy w działalności innowacyjnej przedsiębiorstw produkujących żywność, przedsiębiorstw przetwórstwa przemysłowego i przemysłu ogółem dotyczą jednostek zatrudniających powyżej 9 osób. Wynika to ze zmiany sposobu publikowania przez GUS danych w Nauce i technice w 2008 roku.

W latach 2004-2006 współpracowało w zakresie działalności innowacyjnej $8 \%$ przedsiębiorstw produkujących artykuły spożywcze i napoje, $10,7 \%$ przedsiębiorstw przetwórstwa przemysłowego i $11,1 \%$ przedsiębiorstw przemysłowych ogółem. W grupie przedsiębiorstw aktywnych innowacyjnie udział podmiotów aktywnie uczestniczących we wspólnej z innymi jednostkami realizacji projektów innowacyjnych był znacznie wyższy i wynosił w produkcji żywności 39,3\%, w przetwórstwie przemysłowym $45,1 \%$ i w przemyśle ogółem $46,2 \%$. Na pytanie dotyczące współpracy w zakresie działalności innowacyjnej w latach 2006-2008 twierdząco odpowiedziało 4,4\% przedsiębiorstw produkujących artykuły spożywcze i napoje, $8,1 \%$ przedsiębiorstw przetwórstwa przemysłowego oraz $8,3 \%$ przedsiębiorstw $\mathrm{w}$ przemyśle, co oznacza spadek w porównaniu z poprzednim okresem badawczym (2004-2006). Spadek udziału przedsiębiorstw współpracujących z innymi jednostkami w procesie innowacyjnym w latach 2006-2008 miał również miejsce $\mathrm{w}$ grupie przedsiębiorstw aktywnych innowacyjnie. W produkcji żywności odsetek ten wyniósł 24,1\%, w przetwórstwie przemysłowym 37,2\% i przemyśle ogółem $38,1 \%$.

Skłonność do współpracy rosła wraz z wielkością przedsiębiorstwa, podobnie jak to miało miejsce w przypadku innych wskaźników charakteryzujących innowacyjność. 
Dla przedsiębiorstw przemysłowych głównym partnerem we współpracy w zakresie działalności innowacyjnej, zarówno w okresie 2004-2006 jak i 2006-2008, byli dostawcy wyposażenia, materiałów, komponentów i oprogramowania. Współpracowało z nimi w badanych okresach odpowiednio $6,9 \%$ i $6,6 \%$ badanych przedsiębiorstw w przemyśle. Na kolejnym miejscu pod względem częstotliwości podejmowanej współpracy znaleźli się klienci 4.5\% i 4,3\% przedsiębiorstw przemysłowych współpracowało z tym partnerem.

\subsubsection{Bariery rozwoju innowacji}

GUS w badaniach działalności innowacyjnej przedsiębiorstw uwzględnia również przyczyny niepowodzeń projektów innowacyjnych. W badaniu obejmującym lata 2004-2006 zapytano przedsiębiorstwa jakie przeszkody utrudniały czy uniemożliwiały pomyślną realizację rozpoczętych lub planowanych projektów innowacyjnych. Zgodnie z międzynarodową metodologią Oslo wyróżniono następujące przeszkody dla innowacji:

czynniki ekonomiczne:

- brak środków finansowych w przedsiębiorstwie lub w grupie przedsiębiorstw,

- brak środków finansowych ze źródeł zewnętrznych,

- zbyt wysokie koszty innowacji;

czynniki związane z wiedzą:

- brak wykwalifikowanego personelu,

- brak informacji na temat technologii,

- brak informacji na temat rynków;

czynniki rynkowe:

- rynek opanowany przez dominujące przedsiębiorstwa,

- niepewny popyt na innowacyjne (nowe) produkty;

czynniki pozostałe:

- brak potrzeby prowadzenia działalności innowacyjnej ze względu na wprowadzenie innowacji w latach poprzednich,

- brak popytu na innowacje.

Z przeprowadzonych badań wynika, że główną przeszkodą w działalności innowacyjnej były czynniki ekonomiczne, a mianowicie:

- brak środków finansowych w przedsiębiorstwie lub grupie przedsiębiorstw - stopień ważności tego czynnika jako przeszkody w procesie innowacyjnym jako „wysoki” uznało 33,1\% przedsiębiorstw produkujących artykuły spożywcze i napoje, 34,9\% przedsiębiorstw przetwórstwa przemysłowego i 34,7\% przedsiębiorstw przemysłu ogółem,

- zbyt wysokie koszty innowacji - 32,6\% przedsiębiorstw produkujących artykuły spożywcze i napoje, $34,7 \%$ przedsiębiorstw przetwórstwa przemysłowego i $34,5 \%$ przedsiębiorstw przemysłu ogółem. 
Warto podkreślić, że we wszystkich dotychczasowych badaniach czynniki ekonomiczne były najczęściej wymieniane przez przedsiębiorstwa w krajach europejskich jako przeszkody w procesie powstawania i wdrażania innowacji. Drugie miejsce zajęły przeszkody rynkowe - od 19,6 do 23,8\% przedsiębiorstw uznało je za istotne przeszkody w działalności innowacyjnej.

Czynniki związane $\mathrm{z}$ wiedzą przedsiębiorcy uznali za najmniej znaczące przeszkody.

Wyniki badań wskazują, że przedsiębiorstwa mniejsze częściej niż duże napotykają na poważne trudności w realizacji projektów innowacyjnych.

Z powyższej analizy wskaźnikowej działalności innowacyjnej przedsiębiorstw wynika, że przedsiębiorstwa produkujące żywność cechuje niższa innowacyjność niż przedsiębiorstwa przetwórstwa przemysłowego i przemysłu ogółem. W tym miejscu należy jednak przestrzec przed wyciąganiem zbyt daleko idących wniosków, porównanie bowiem dotyczyło różnych poziomów agregacji przedsiębiorstw. Przemysł spożywczy obejmuje dwa działy przetwórstwa przemysłowego (sekcja D), a mianowicie dział produkujący artykuły spożywcze i napoje (dział 15) oraz przemysły tytoniowy (dział 16). Celem właściwego zobrazowania innowacyjności i wskazania miejsca przedsiębiorstw przemysłu spożywczego na tle pozostałych przedsiębiorstw przemysłowych należy dokonać porównania na podobnym poziomie agregacji, $\mathrm{tj}$. na poziomie działów przetwórstwa przemysłowego. Porównanie na takim poziomie agregacji zostanie zrealizowane w następnym podrozdziale.

\subsection{Miejsce przemysłu spożywczego w przetwórstwie przemysłowym - analiza innowacyjności według głównych składowych}

Z przeprowadzonej w poprzednim podrozdziale analizy wynika, że innowacyjność jest zjawiskiem wielowymiarowym, opisywanym przez wiele wskaźników. Definicje działalności innowacyjnej, innowacji i innowacyjności wskazują na różne aspekty tego zagadnienia. Wydaje się, że w analizach porównawczych nie można poprzestać na ocenie kształtowania się poszczególnych wskaźników i konieczne jest takie ujęcie, które pozwoli spojrzeć na innowacje, jednocześnie zarówno od strony determinant, jak i uzyskiwanych rezultatów. Akceptując pogląd Z. J. Acsa i D. B. Audretscha o niższej efektywności pojedynczych miar innowacyjności, w badaniu zastosowano syntetyczną miarę aktywności innowacyjnej - wskaźnik (indeks) innowacyjności [Acs, Audretsch 1987, s. 567].

W niniejszym badaniu, uwzględniając Polską Klasyfikację Działalności (PKD), podjęto próbę pomiaru innowacyjności przetwórstwa przemysłowego (sekcja D) na dwucyfrowym poziomie agregacji, czyli na poziomie działów tej 
sekcji. Celem prezentowanego w niniejszym podrozdziale badania jest wyznaczenie wskaźnika innowacyjności i określenie w oparciu o ten syntetyczny miernik pozycji poszczególnych działów przetwórstwa przemysłowego, w tym działu produkującego żywność. Wskaźnik syntetyczny (indeks), który jest miarą całkowitej innowacyjności danego działu, obliczono przy użyciu metody głównych składowych (Principal Components Analysis - PCA) i programu SPSS.

Warto przypomnieć, że nie zawsze dostępne informacje umożliwiają łączną analizę działów 15 i 16 i tym samym rozpatrywanie przemysłu spożywczego jako całości. Zatem w dalszej części pracy oceniano oddzielnie produkcję artykułów spożywczych i napojów (dział 15) oraz przemysł tytoniowy (dział 16).

\subsubsection{Metodologia glównych składowych}

Indeks jest narzędziem statystycznym, które jest często używane w analizie złożonych zjawisk. Umożliwia porównanie wielowymiarowych obiektów badania, czyli obiektów opisywanych przez wiele zmiennych, co prowadzi do ustalenia ich zasadniczych właściwości.

Innowacyjność na szczeblu makro-, mezo- i mikroekonomicznym jest efektem oddziaływania dużej liczby czynników (zmiennych), które wpływają na poziom i intensywność działalności innowacyjnej. Brak jest modeli teoretycznych wyjaśniających, które zmienne są bardziej, a które mniej istotne. Nie ma wiedzy o tym, które ze zmiennych można na początku badania odrzucić jako mało ważne.

Indeks jest pewną funkcją wszystkich dostępnych danych, dostarczając prostej, łatwej w interpretacji i porównaniach liczby, która mierzy intensywność lub poziom rozwoju badanego zjawiska. Indeks osiąga te cele agregując szereg zmiennych do jednego wymiaru. Zakłada się, że wszystkie zmienne są stymulantami, to znaczy że ich wyższa wartość jest objawem większej aktywności innowacyjnej. Zatem taki indeks powinien być interpretowany jako miara całkowitej działalności innowacyjnej danego działu [Gomułka 2006, s.296]. Stosowanie indeksu pozwala wykorzystać wszystkie dostępne informacje na temat zjawiska, które w przypadku koncentrowania się na jednej wybranej zmiennej zostałyby utracone.

W wielu przypadkach wszystkim zmiennym składającym się na indeks nadaje się tę samą wagę. W innych sytuacjach wagi są arbitralnie nadawane przez ekspertów. W niniejszym badaniu starano się uwzględnić wagi dla poszczególnych zmiennych. W tym celu zastosowano metodę głównych składowych (Principal Components Analysis - PCA), która została wykorzystana do wyboru wag dla zmiennych składających się na indeks oraz do wyboru samych zmiennych.

Metoda głównych składowych polega na ortogonalnym przekształceniu nelementowego zbioru zmiennych pierwotnych (opisujących m obiektów) na nowy układ nieskorelowanych zmiennych zwanych głównymi składowymi. Każda 
z głównych składowych jest liniową funkcją standaryzowanych zmiennych wejściowych postaci [Malarska 2005, s. 214]:

$$
F_{j}=a_{j 1} Z_{1}+a_{j 2} Z_{2}+\ldots+a_{j n} Z_{n}, \quad j=1,2, \ldots, n .
$$

Model analizy głównych składowych w zapisie macierzowym ma postać:

$$
F=A^{T} Z
$$

gdzie:

$A=\left[a_{j i}\right]_{n \times m}-$ poszukiwana macierz przekształcenia ortogonalnego zmiennych $Z_{j} \quad \mathrm{w} \quad F_{j}(j=1,2, \ldots, n)$;

$F_{j}-j$-ta składowa główna.

$\mathrm{Z}$ zapisu (4.2) wynika, że:

$Z=A F$.

W modelu $P C A$ ładunki czynnikowe $a_{j i}$ (współczynniki macierzy A), zwane również wagami składowych określają siłę skorelowania zmiennej $Z_{j}$ z czynnikami $F_{j}(j=1,2, \ldots, n)$, przy których ładunki te stoją.

Wyznaczanie głównych składowych jest efektem wielowymiarowej rotacji przestrzeni zmiennych, która maksymalizuje wariancje kluczowych wymiarów. Tworzy ona nową przestrzeń, w której pierwszy wymiar zwany główną składową reprezentuje oś w pierwotnej przestrzeni, wzdłuż której dane mają największą wariancję. Druga główna składowa reprezentuje drugi rząd wariancji danych, po wykluczeniu wariancji tłumaczonej przez pierwszą składową. Zatem główne składowe są tak wyznaczane, aby wariancje (V) kolejnych składowych, będące miarą ich zasobów informacyjnych o badanym zjawisku, były coraz mniejsze [Malarska 2005, s. 220]:

$$
V\left(F_{1}\right)>V\left(F_{2}\right)>\ldots>V\left(F_{n}\right) .
$$

Jednocześnie suma wariancji wszystkich zmiennych wejściowych jest równa sumie wariancji głównych składowych, co oznacza, że przekształcanie zmiennych wejściowych w główne składowe nie prowadzi do żadnych strat informacji o badanym zjawisku:

$$
\sum_{j=1}^{n} V\left(F_{j}\right)=\sum_{j=1}^{n} V\left(Z_{j}\right)=n \text {. }
$$

W zasadzie możemy wyznaczyć tyle głównych składowych, ile mamy zmiennych pierwotnych. Jednakże tylko kilka pierwszych składowych zawiera zdecydowaną większość informacji o badanym zjawisku (wyjaśnia większość wariancji w zbiorze danych) i tym samym ma znaczenie interpretacyjne. Taka sytuacja pozwala na redukcję głównych składowych i tym samym redukcję zmiennych przy 
możliwie małej stracie informacji wejściowych. Główne składowe są uznawane za reprezentacje sił wpływających na badane zjawisko. Decyzja co do liczby głównych składowych (czynników), które ostatecznie zostaną wykorzystane w analizie, jest decyzją o charakterze subiektywnym. Jednak w praktyce korzysta się z pewnych technik (kryteriów), które ułatwiają taką decyzję, a są to [Panek 2009, s.181-182]:

- kryterium stopnia wyjaśnianej wariancji,

- kryterium wartości własnej Kaisera,

- kryterium osypiska,

- kryterium istotności głównych składowych.

Dla uzyskania głównych składowych łatwych do zinterpretowania zachodzi potrzeba rotowania osi - czynników układu współrzędnych z wartościami ładunków czynnikowych.

Popularnymi metodami rotacji są: quartimax, varimax i equamax. Obrót osi sprawia, że każda zmienna skojarzona zostaje z możliwie najmniejszą liczbą czynników. Zmienne silnie powiązane z określoną składową powodują klarowny i łatwy w interpretacji obraz jednorodnych, grupowych powiązań.

W przypadku danych o innowacyjności przyjęto założenie, iż pierwsza główna składowa reprezentuje zjawisko generalnej aktywności innowacyjnej. Założenie to jest zasadne metodologicznie, gdyż wszystkie zmienne uwzględnione w badaniu są objawami innowacyjności.

Zastosowana w badaniu procedura wyznaczania indeksu jest dwuetapowa:

I. Etap pierwszy - oparty na modelu bezpośrednim składa się z następujących czynności:

1. ustalenie wstępnej listy zmiennych (zmiennych wejściowych) opisujących innowacyjność działów przetwórstwa przemysłowego,

2. standaryzacja danych,

3. analiza macierzy współczynników korelacji między zmiennymi wejściowymi,

4. obliczenie ładunków czynnikowych modelu i określenie liczby głównych składowych (czynników);

II. Etap drugi - oparty na modelu derywowanym (pochodnym względem wyjściowego) składa się z kolejnych czynności:

1. rotacja osi - czynników (osi stanowionych przez czynniki zmiennych),

2. analiza wyznaczonych głównych składowych na podstawie wartości ładunków czynnikowych,

3. ustalenie wag dla zmiennych składających się na indeks innowacyjności,

4. unormowanie pierwszej głównej składowej (wymiaru innowacyjności) na przedział $[0,100]$,

5. interpretacja uzyskanych wyników.

W niniejszym opracowaniu wykorzystano dane statystyczne przeprowadzonego przez GUS skróconego badania działalności innowacyjnej przedsiębiorstw w przetwórstwie przemysłowym (sekcja D według PKD 2004) w latach 2005-2007. 
Z publikowanych przez GUS informacji dotyczących działalności innowacyjnej przedsiębiorstw przetwórstwa przemysłowego wybrano 22 zmienne (wejściowe). Ważnym kryterium wyboru zmiennych, obok merytorycznego, była kompletność danych dla poszczególnych obiektów. Analizowane obiekty to działy przemysłu przetwórczego na dwucyfrowym poziomie agregacji według PKD. Do zbioru obiektów dodano tzw. dział bazowy „0”, który jest opisywany przez same zera $i$ jest punktem referencyjnym dla hipotetycznego całkiem nieinnowacyjnego działu. Ma on wpływ na wynik i zwiększa wariancję danych [Gomułka 2006, s. 185]. Ponieważ przedmiotem tego badania jest porównanie działalności innowacyjnej poszczególnych działów, wybrano dane relatywne lub dane absolutne przeliczono na wielkości stosunkowe. Wykaz zmiennych wejściowych opisujących innowacyjność, które uwzględniono w badaniu przedstawia tab. 4.6:

Tabela 4.6. Wykaz zmiennych uwzględnionych w badaniu innowacyjności działów przetwórstwa przemysłowego

\begin{tabular}{|c|c|c|c|}
\hline $\begin{array}{c}\text { Kod } \\
\text { zmiennej }\end{array}$ & Nazwa zmiennej & $\begin{array}{l}\text { Przedział } \\
\text { czasowy }\end{array}$ & $\begin{array}{l}\text { Powód } \\
\text { odrzucenia }\end{array}$ \\
\hline$[\mathrm{A}]$ & [B] & {$[\mathrm{C}]$} & [D] \\
\hline $\mathrm{X} 1$ & $\begin{array}{l}\text { Przedsiębiorstwa innowacyjne (wprowadziły innowacje) w } \\
\text { \% ogółu przedsiębiorstw }\end{array}$ & 2005-2007 & \\
\hline $\mathrm{X} 2$ & $\begin{array}{l}\text { Przedsiębiorstwa, które wprowadziły nowe lub istotnie } \\
\text { ulepszone produkty w \% ogółu przedsiębiorstw }\end{array}$ & 2005-2007 & \\
\hline $\mathrm{X} 3$ & $\begin{array}{l}\text { Przedsiębiorstwa, które wprowadziły nowe lub istotnie } \\
\text { ulepszone produkty w tym nowe dla rynku } \mathrm{w} \% \text { ogółu }\end{array}$ & 2005-2007 & \\
\hline $\mathrm{X} 4$ & $\begin{array}{l}\text { Przedsiębiorstwa, które wprowadziły nowe lub istotnie } \\
\text { ulepszone procesy w \% ogółu przedsiębiorstw }\end{array}$ & 2005-2007 & \\
\hline X5 & $\begin{array}{l}\text { Udział przedsiębiorstw, które poniosły nakłady na działalność } \\
\text { innowacyjną w \% }\end{array}$ & 2007 & \\
\hline X6 & $\begin{array}{l}\text { Nakłady przypadające na } 1 \text { przedsiębiorstwo prowadzące } \\
\text { działalność innowacyjną w tys. zł }\end{array}$ & 2007 & $\begin{array}{c}\text { Ujemna } \\
\text { korelacja }\end{array}$ \\
\hline $\mathrm{X} 7$ & $\begin{array}{l}\text { Udział nakładów na B+R w \% nakładów na działalność } \\
\text { innowacyjną }\end{array}$ & 2007 & \\
\hline $\mathrm{X} 8$ & $\begin{array}{l}\text { Udział nakładów na zakup gotowej technologii w } \% \\
\text { nakładów na działalność innowacyjną }\end{array}$ & 2007 & $\begin{array}{l}\text { Ujemna } \\
\text { korelacja }\end{array}$ \\
\hline X9 & $\begin{array}{l}\text { Udział nakładów na oprogramowanie w \% nakładów na } \\
\text { działalność innowacyjną }\end{array}$ & 2007 & $\begin{array}{l}\text { Ujemna } \\
\text { korelacja }\end{array}$ \\
\hline $\mathrm{X} 10$ & $\begin{array}{l}\text { Udział nakładów inwestycyjnych na budynki i budowle oraz } \\
\text { grunty w \% nakładów na działalność innowacyjną }\end{array}$ & 2007 & $\begin{array}{l}\text { Ujemna } \\
\text { korelacja }\end{array}$ \\
\hline X11 & $\begin{array}{l}\text { Udział nakładów inwestycyjnych na maszyny i urządzenia } \\
\text { techniczne w \% nakładów na działalność innowacyjną }\end{array}$ & 2007 & $\begin{array}{l}\text { Ujemna } \\
\text { korelacja }\end{array}$ \\
\hline $\mathrm{X} 12$ & $\begin{array}{l}\text { Udział nakładów inwestycyjnych na maszyny i urządzenia } \\
\text { techniczne w tym z importu w \% nakładów na działalność } \\
\text { innowacyjną }\end{array}$ & 2007 & $\begin{array}{l}\text { Ujemna } \\
\text { korelacja }\end{array}$ \\
\hline
\end{tabular}




\begin{tabular}{|c|c|c|c|}
\hline$[\mathrm{A}]$ & [B] & {$[\mathrm{C}]$} & [D] \\
\hline X13 & $\begin{array}{l}\text { Udział nakładów na szkolenie personelu związane } \\
\text { z działalnością innowacyjną w \% nakładów na działalność } \\
\text { innowacyjną }\end{array}$ & 2007 & \\
\hline X14 & $\begin{array}{l}\text { Udział nakładów na marketing dotyczący nowych i istotnie } \\
\text { ulepszonych produktów w \% nakładów na działalność } \\
\text { innowacyjną }\end{array}$ & 2007 & \\
\hline X15 & $\begin{array}{l}\text { Przychody ze sprzedaży w 2007r. produktów innowacyjnych, } \\
\text { które wprowadzono na rynek w 1. 2005-2007 w \% sprzedaży } \\
\text { ogółem }\end{array}$ & 2007 & \\
\hline X16 & $\begin{array}{l}\text { Przychody ze sprzedaży w 2007r. produktów innowacyjnych } \\
\text { - nowych dla rynku, które wprowadzono na rynek w 1. 2005- } \\
2007 \text { w \% sprzedaży ogółem }\end{array}$ & 2007 & \\
\hline X17 & $\begin{array}{l}\text { Przychody ze sprzedaży w 2007r. produktów innowacyjnych } \\
\text { - nowych tylko dla przedsiębiorstwa, które wprowadzono na } \\
\text { rynek w 1. 2005-2007 w \% sprzedaży ogółem }\end{array}$ & 2007 & \\
\hline X18 & $\begin{array}{l}\text { Produkcja sprzedana wyrobów nowych lub istotnie } \\
\text { ulepszonych } \mathrm{w} \% \text { produkcji sprzedanej wyrobów }\end{array}$ & 2005-2007 & \\
\hline X19 & $\begin{array}{l}\text { Przedsiębiorstwa przemysłowe, które posiadały } \\
\text { porozumienia o współpracy z innymi jednostkami dotyczące } \\
\text { działalności innowacyjnej w \% ogółu przedsiębiorstw }\end{array}$ & 2005-2007 & \\
\hline X20 & $\begin{array}{l}\text { Przedsiębiorstwa przemysłowe, które posiadały } \\
\text { porozumienia o współpracy z innymi jednostkami dotyczące } \\
\text { działalności innowacyjnej w \% ogółu przedsiębiorstw } \\
\text { aktywnych innowacyjnie }\end{array}$ & 2005-2007 & \\
\hline $\mathrm{X} 21$ & $\begin{array}{l}\text { Linie produkcyjne automatyczne przypadające na } 1 \\
\text { przedsiębiorstwo }\end{array}$ & 2007 & $\begin{array}{c}\text { Ujemna } \\
\text { korelacja }\end{array}$ \\
\hline $\mathrm{X} 22$ & $\begin{array}{l}\text { Udział nakładów na środki trwałe służące ochronie } \\
\text { środowiska } \mathrm{w} \% \text { nakładów inwestycyjnych }\end{array}$ & 2007 & $\begin{array}{l}\text { Ujemna } \\
\text { korelacja }\end{array}$ \\
\hline
\end{tabular}

Źródło: opracowanie własne.

Uwzględnione w badaniu zmienne można podzielić na kilka grup. Pierwsza grupa zawiera zmienne (X1-X4 oraz X19 i X20) opisujące procentowy odsetek przedsiębiorstw, które $\mathrm{w}$ danej branży wykazały się działalnością innowacyjną. Druga grupa zmiennych (X5-X14 i X22) dotyczy nakładów na działalność innowacyjną, charakteryzuje poziom i strukturę tych nakładów w przedsiębiorstwach przemysłowych. Zmienna X6 informuje o nakładach innowacyjnych przypadających na 1 przedsiębiorstwo prowadzące działalność innowacyjną w danej branży, a zmienna X5 określa udział przedsiębiorstw, które poniosły nakłady na działalność innowacyjną. Zmienne X7-X14 opisują strukturę nakładów na działalność innowacyjną jako udział procentowy poszczególnych rodzajów nakładów 
inwestycyjnych w nakładach na działalność innowacyjną ogółem danej branży. Do tej grupy należy jeszcze zaliczyć zmienną X22, która informuje jaka jest relacja nakładów na środki trwałe służące ochronie środowiska do nakładów inwestycyjnych ogółem.

Automatyzacja produkcji przemysłowej jest opisana przez zmienną X21, która wyraża liczbę automatycznych linii produkcyjnych przypadających na 1 przedsiębiorstwo w danej branży.

W ostatniej grupie znajdują się zmienne X15-X18, które opisują efekty podjętych przez przedsiębiorstwa działań innowacyjnych w postaci przychodów ze sprzedaży produktów innowacyjnych jako odsetek sprzedaży ogółem oraz udziału produkcji sprzedanej tychże wyrobów w produkcji sprzedanej ogółem.

\subsubsection{Ranking działów przetwórstwa przemysłowego według innowacyjności}

Wstępna analiza metodą głównych składowych wykazała, że zmienne X8X12 oraz X6, X21 i X22 są bardzo słabo, a nawet ujemnie skorelowane z pozostałymi zmiennymi. Stanowi to istotny powód do odrzucenia tych zmiennych $z$ dalszej analizy. Zmienne te dotyczą przede wszystkim udziału nakładów inwestycyjnych w nakładach na działalność innowacyjną oraz środków automatyzacji produkcji. Niska i ujemna korelację tych zmiennych może oznaczać, że pewien rodzaj nakładów inwestycyjnych nie czyni przedsiębiorstw innowacyjnych w innych wymiarach.

Pierwotnie metodą głównych składowych wyodrębniono 14 składowych, które tłumaczą coraz mniej wariancji. Rozkład całkowitej wariancji wyjaśnianej przez poszczególne składowe przedstawia rys. 4.5.

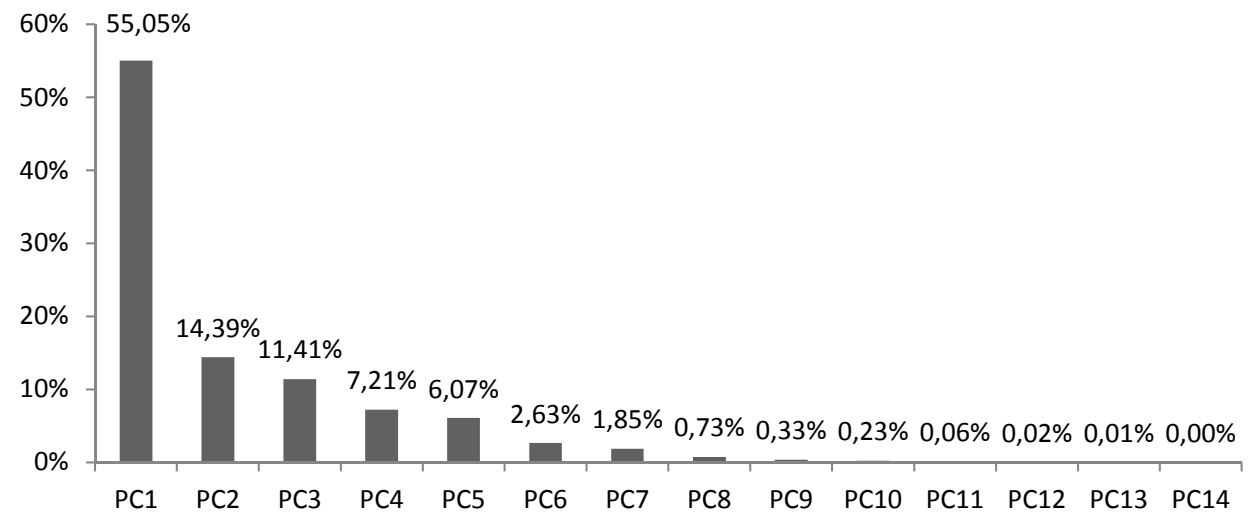

Rysunek 4.5. Stopień wyjaśnienia wariancji przez składowe 
Pierwsza i druga składowa wyjaśniają ponad 69\% wariancji, w tym PC1 aż $55 \%$.

Pojawia się pytanie ile głównych składowych należy uwzględnić w dalszej analizie. Cztery pierwsze składowe mają wartości własne większe od 1, co oznacza, że kryterium wartości własnej Kaisera, towarzyszące tym charakterystykom, wskazuje na wyodrębnienie czterech głównych składowych. Ostatecznie, uwzględniając dodatkowo stopień wyjaśnienia wariancji (zasobów zmienności wspólnej), pozostawiamy cztery główne składowe. W ocenie statystycznej taki model wypada najlepiej, wyjaśnia ponad 88\% zmienności danych.

Interpretacja otrzymanych głównych składowych dokonywana jest na podstawie wartości rotowanych ich współczynników, które stanowią jednocześnie współczynniki korelacji liniowej pomiędzy zmiennymi wejściowymi i głównymi składowymi. W badaniu rotowano metodą varimax, quartimax i equamax. Najlepsze efekty, które umożliwiają i ułatwiają formalno-merytoryczną ocenę działalności innowacyjnej dała metoda quartimax.

Pierwsza główna składowa reprezentuje przede wszystkim zmienne: X1udział przedsiębiorstw innowacyjnych, X5 - udział przedsiębiorstw, które poniosły nakłady na działalność innowacyjną, X19 - przedsiębiorstwa przemysłowe, które posiadały porozumienia o współpracy z innymi jednostkami dotyczące działalności innowacyjnej w odsetku ogółu przedsiębiorstw, X2 - przedsiębiorstwa, które wprowadziły nowe lub istotnie ulepszone produkty w odsetku ogółu przedsiębiorstw, X4 - przedsiębiorstwa, które wprowadziły nowe lub istotnie ulepszone procesy w odsetku ogółu przedsiębiorstw, X3 - przedsiębiorstwa, które wprowadziły nowe lub istotnie ulepszone produkty, w tym nowe dla rynku w odsetku ogółu przedsiębiorstw oraz X20 - przedsiębiorstwa przemysłowe, które posiadały porozumienia o współpracy z innymi jednostkami dotyczące działalności innowacyjnej w odsetku ogółu przedsiębiorstw aktywnych innowacyjnie. Zmienne te są silnie skorelowane z główną składową (współczynnik korelacji sięga 0,874-0,983).

Natomiast druga z głównych składowych przenosi przede wszystkim informacje zawarte w zmiennych: X16 - przychody ze sprzedaży produktów innowacyjnych - nowych dla rynku w odsetku sprzedaży ogółem, X15 - przychody ze sprzedaży produktów innowacyjnych w odsetku sprzedaży ogółem i X18 - produkcja sprzedana wyrobów nowych lub istotnie ulepszonych w odsetku produkcji sprzedanej wyrobów.

Główne składowe trzecia i czwarta reprezentują tylko po dwie zmienne. Trzecia zmienną X13 - nakłady na szkolenie personelu związane z działalnością innowacyjną w odsetku nakładów na działalność innowacyjną i X7 - nakłady na $\mathrm{B}+\mathrm{R}$ w odsetku nakładów na działalność innowacyjną. Natomiast czwarta obejmuje zmienną X14 - udział nakładów na marketing dotyczący nowych $i$ istotnie ulepszonych produktów w odsetku nakładów na działalność innowacyjną i X17 - przychody ze sprzedaży produktów innowacyjnych - nowych tylko 
dla przedsiębiorstwa w odsetku sprzedaży ogółem. Jednak stopień skorelowania ostatniej zmiennej z główną składową jest niewielki, zmiany zmienności X17 zaledwie w 35,8\% wyjaśniają zmienność składowej i odwrotnie.

Tabela 4.7. Macierz rotowanych składowych*

\begin{tabular}{|c|c|c|c|c|}
\hline \multirow{2}{*}{ Zmienne } & \multicolumn{4}{|c|}{ Składowa } \\
\hline & 1 & 2 & 3 & 4 \\
\hline X1 & 0,983 & & & \\
\hline X5 & 0,983 & & & \\
\hline X19 & 0,963 & & & \\
\hline X2 & 0,940 & & & \\
\hline X4 & 0,917 & & & \\
\hline X3 & 0,908 & & & \\
\hline X20 & 0,874 & & & \\
\hline X16 & & 0,915 & & \\
\hline X15 & 0,427 & 0,898 & & \\
\hline X18 & 0,495 & 0,838 & & \\
\hline X13 & & & 0,940 & \\
\hline X7 & & & 0,838 & \\
\hline X14 & & & & 0,598 \\
\hline X17 & 0,451 & & & \\
\hline
\end{tabular}

Metoda rotacji - quartimax z normalizacją Kaisera.

* - rotacja osiągnęła zbieżność w 5 iteracjach.

Powyższe uwarunkowania oraz założenie przyjęte w badaniu, że PC1 reprezentuje zjawisko generalnej aktywności innowacyjnej, skłania nas do skoncentrowania się (w ocenie aktywności innowacyjnej działów przetwórstwa przemysłowego) na dwóch pierwszych składowych, które tłumaczą 69\% zmienności danych.

Rysunek 4.6 prezentuje współczynniki dla dwóch pierwszych składowych, które są parametrami liniowej funkcji transformacji, tworzącej te ładunki czynnikowe. Pierwsza główna składowa zawiera siedem istotnych zmiennych: X1 - X5 oraz X19 i X20. Ładunki przyjmują wartości od 0,14 do 0,19. Zmienne te są ujemnie skorelowane z PC2. Każda z tych siedmiu zmiennych (np. X1 - udział przedsiębiorstw innowacyjnych) jest często używana jako samodzielna miara innowacyjności, zatem ich udział w PC1 potwierdza oczekiwania. Zmienne: X7, X13, X14 i X17 można przyjąć, że w zasadzie nie wykazują zależności zarówno $\mathrm{z}$ pierwszą, jak i drugą składową. Drugi wymiar innowacyjności (PC2) jest silnie reprezentowany przez zmienne X15, X16 i X18. Dokładniej ten rezultat obrazuje rys. 4. 6. 


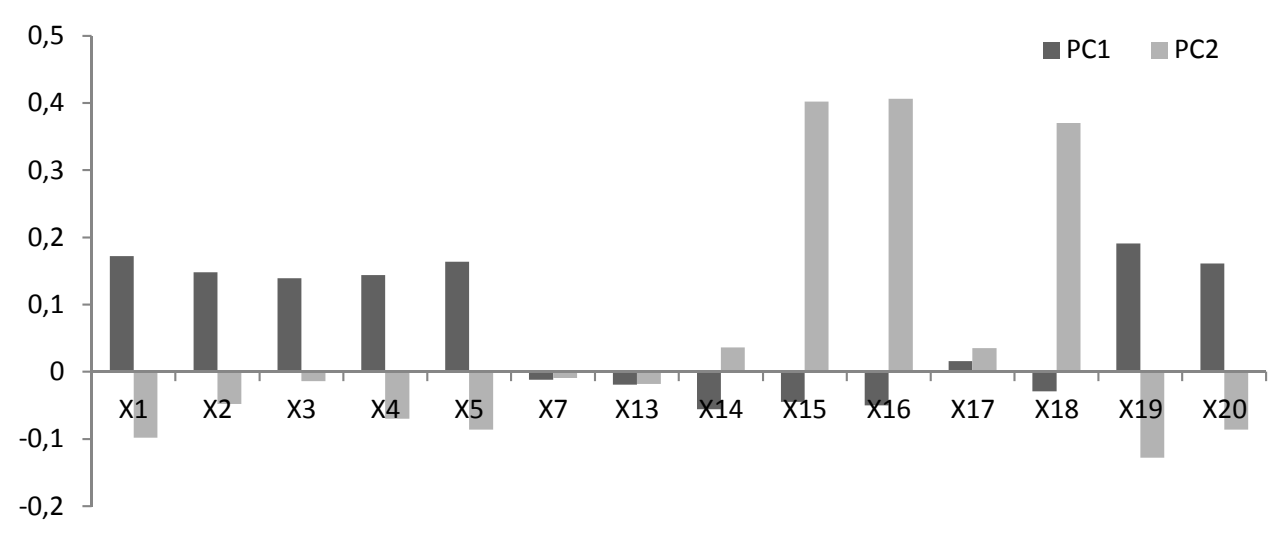

Rysunek 4.6. Ładunki między głównymi składowymi a zmiennymi

Na rysunku 4.7 umieszczono wszystkie analizowane działy według ich pozycji na płaszczyźnie wyznaczonej przez pierwszą i drugą składową. Wyższa innowacyjność jest związana z wyższą dodatnią wartością składowej PC1. Badane działy przetwórstwa przemysłowego dzielą się na trzy zasadnicze grupy. Pierwsza grupa zawiera najbardziej innowacyjne działy: 23 - Wytwarzanie koksu, produktów rafinacji ropy naftowej i paliw jądrowych, 16 - Produkcja wyrobów tytoniowych oraz 24 - Produkcja wyrobów chemicznych. Grupa główna, najbardziej liczna, skupia działy o bardzo różnym stopniu aktywności innowacyjnej - zaczyna się bowiem od działu zerowego i kończy na dziale 30 (Produkcja maszyn biurowych i komputerów), którego innowacyjność jest wysoka. W grupie tej znajduje się dział 15 - Produkcja artykułów spożywczych i napojów. Osobno występuje dział 32 (Produkcja sprzętu i urządzeń radiowych, telewizyjnych i telekomunikacyjnych), który charakteryzuje się innowacyjnością nieco wyższą od przeciętnej i wyróżnia się przede wszystkim pod względem drugiej głównej składowej. Dział ten jest silnie związany ze zmiennymi X15, X16 i X17. Zależność ta wynika ze specyfiki działu 32, którego innowacyjność jest opisana przez wysokie wartości tych zmiennych. Metoda głównych składowych wyodrębniła wariancję tych zmiennych jako drugą główną składową.

Zmienne reprezentowane przez PC2 można interpretować jako inny, drugi wymiar aktywności innowacyjnej, a mianowicie jako efekt podjętych działań i nakładów innowacyjnych w postaci udziału produkcji sprzedanej i przychodów ze sprzedaży wyrobów innowacyjnych. Kolejne miejsca pod względem drugiego wymiaru innowacyjności zajmują działy - 36 (Produkcja mebli; działalność produkcyjna, gdzie indziej niesklasyfikowana), 21 (Produkcja masy włóknistej, papieru oraz wyrobów z papieru), 30 (Produkcja maszyn biurowych i komputerów). Jednak drugi wymiar innowacyjności w przypadku tych działów jest wyraźnie 
niższy niż przedsiębiorstw produkujących sprzęt i urządzenia radiowe, telewizyjne i telekomunikacyjne.

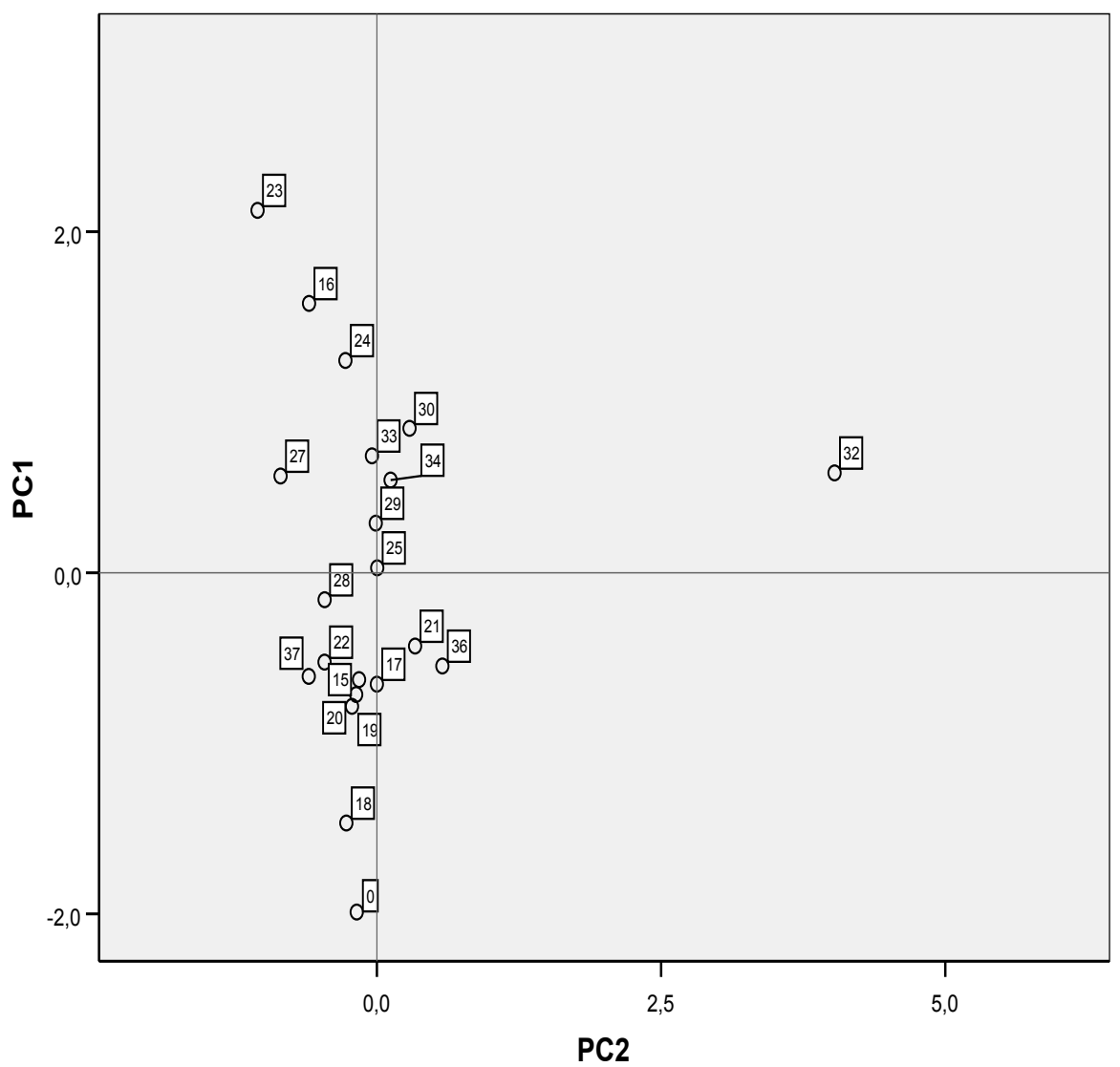

Rysunek 4.7. Działy przetwórstwa przemysłowego na płaszczyźnie PC1 i PC2

Ostatecznie do obliczenia indeksu innowacyjności działów przetwórstwa przemysłowego użyto 14 zmiennych, co reprezentuje PC1. Analizie poddano 20 działów przetwórstwa przemysłowego (sekcja D) oraz dział bazowy. Indeks opiera się bezpośrednio na lokalizacji działów (obiektów) w wymiarze pierwszej głównej składowej. Wyniki zostały unormowane w taki sposób, aby dział o najwyższym zmierzonym poziomie innowacyjności osiągała wynik „100”, a wszystkie pozostałe działy proporcjonalnie mniejszy.

Wyniki obliczeń indeksu innowacyjności i miejsce danego działu w rankingu innowacyjności prezentuje tab. 4.8. 
Tabela 4.8. Działy przetwórstwa przemysłowego wg indeksu innowacyjności

\begin{tabular}{|c|c|c|c|}
\hline PKD & Nazwa działu & $\begin{array}{l}\text { Wartość } \\
\text { indeksu }\end{array}$ & $\begin{array}{l}\text { Pozycja } \\
\text { w rankingu }\end{array}$ \\
\hline 15 & Produkcja artykułów spożywczych i napojów & 33,1 & 16 \\
\hline 16 & Produkcja wyrobów tytoniowych & 86,7 & 2 \\
\hline 17 & Włókiennictwo & 32,5 & 17 \\
\hline 18 & Produkcja odzieży i wyrobów futrzarskich & 12,7 & 20 \\
\hline 19 & Produkcja skór wyprawionych i wyrobów ze skór wyprawionych & 29,3 & 19 \\
\hline 20 & $\begin{array}{l}\text { Produkcja drewna i wyrobów z drewna oraz z korka } \\
\text { (z wyłączeniem mebli), wyrobów ze słomy i materiałów } \\
\text { używanych do wyplatania }\end{array}$ & 31,0 & 18 \\
\hline 21 & Produkcja masy włóknistej, papieru oraz wyrobów z papieru & 37,9 & 12 \\
\hline 22 & $\begin{array}{l}\text { Działalność wydawnicza, poligrafia i reprodukcja zapisanych } \\
\text { nośników informacji }\end{array}$ & 35,6 & 13 \\
\hline 23 & $\begin{array}{l}\text { Wytwarzanie koksu, produktów rafinacji ropy naftowej i paliw } \\
\text { jądrowych }\end{array}$ & 100,0 & 1 \\
\hline 24 & Produkcja wyrobów chemicznych & 78,6 & 3 \\
\hline 25 & Produkcja wyrobów gumowych i z tworzyw sztucznych & 49,1 & 10 \\
\hline 27 & Produkcja metali & 62,1 & 7 \\
\hline 28 & $\begin{array}{l}\text { Produkcja metalowych wyrobów gotowych, z wyłączeniem } \\
\text { maszyn i urządzeń }\end{array}$ & 44,5 & 11 \\
\hline 29 & Produkcja maszyn i urządzeń, gdzie indziej niesklasyfikowana & 55,4 & 9 \\
\hline 30 & Produkcja maszyn biurowych i komputerów & 68,9 & 4 \\
\hline 32 & $\begin{array}{l}\text { Produkcja sprzętu i urządzeń radiowych, telewizyjnych } \\
\text { i telekomunikacyjnych }\end{array}$ & 62,5 & 6 \\
\hline 33 & $\begin{array}{l}\text { Produkcja instrumentów medycznych, precyzyjnych } \\
\text { i optycznych, zegarów i zegarków }\end{array}$ & 65,0 & 5 \\
\hline 34 & Produkcja pojazdów samochodowych, przyczep i naczep & 61,6 & 8 \\
\hline 36 & $\begin{array}{l}\text { Produkcja mebli; działalność produkcyjna, gdzie indziej } \\
\text { niesklasyfikowana }\end{array}$ & 35,1 & 14 \\
\hline 37 & Przetwarzanie odpadów & 33,6 & 15 \\
\hline 00 & Dział bazowy & 0 & 21 \\
\hline
\end{tabular}

Źródło: opracowanie własne.

$\mathrm{Na}$ rysunku 4.8. przedstawiono działy przetwórstwa przemysłowego uporządkowane według ich aktywności innowacyjnej. Najbardziej innowacyjny jest dział 23 - Wytwarzanie koksu, produktów rafinacji ropy naftowej i paliw jądrowych. W dziale tym wszystkie zmienne tworzące pierwszą składową są znacznie wyższe od średniej dla działów. Szczególnie wysoki jest w tym przypadku udział 
przedsiębiorstw, które posiadały porozumienia o współpracy z innymi jednostkami dotyczące działalności innowacyjnej oraz udział nakładów na środki trwałe służące ochronie środowiska. Innowacyjność działu 16 (Produkcja wyrobów tytoniowych), zajmującego drugie miejsce w rankingu, jest o 13 punktów niższa niż pierwszego. O wysokiej pozycji tego działu przesądziły zmienne, których wartości znacznie odbiegały od średniej. W strukturze nakładów na działalność innowacyjną wysoki był udział przede wszystkim nakładów na maszyny i urządzenia. Dział ten wyróżniał się także pod względem udziału przedsiębiorstw, które wprowadziły na rynek nowe produkty oraz bardzo wysokim odsetkiem przedsiębiorstw innowacyjnych. Dział 24 - Produkcja wyrobów chemicznych zajmuje trzecie miejsce. Przedsiębiorstwa tego działu poniosły wysokie nakłady na inwestycje związane z ochroną środowiska, wysoki był również udział przedsiębiorstw, które wprowadziły nowe lub istotnie ulepszone procesy oraz produkty. Pozycja działów znajdujących się na samym szczycie rankingu jest zapewne efektem ogromnej konkurencji na rynku, transferu technologii poprzez napływ kapitału zagranicznego, konieczności dostosowań metod produkcji do przepisów unijnych. Obliczony indeks wskazuje na duże zróżnicowanie aktywności innowacyjnej przedsiębiorstw przetwórstwa przemysłowego. Innowacyjnością poniżej 50 punktów charakteryzuje się ponad połowa uwzględnionych w badaniu działów.

Innowacyjność przedsiębiorstw produkujących artykuły spożywcze i napoje została oceniona na 33,1 punktu, co skutkuje dopiero 16. miejscem w rankingu.

Ostatnie trzy działy w rankingu to: 20 - Produkcja drewna i wyrobów z drewna oraz z korka (z wyłączeniem mebli), wyrobów ze słomy i materiałów używanych do wyplatania, 19 - Produkcja skór wyprawionych i wyrobów ze skór wyprawionych oraz 18 - Produkcja odzieży i wyrobów futrzarskich. Są to działy bardzo pracochłonne, w których pracę rąk ludzkich trudno zastąpić maszynami. Wdrażanie innowacji ma zatem mniejszy wymiar niż w działach z czołówki rankingu. Inwestowaniem w przedsiębiorstwa o takich profilach produkcji nie był ponadto zainteresowany kapitał zagraniczny.

$\mathrm{W}$ analizach działalności innowacyjnej sekcji przetwórstwo przemysłowe warto zwrócić uwagę na klasyfikację działów według poziomów techniki opublikowaną przez OECD w 1997 r. [por. Nauka i technika w 2009 roku, s. 200]. Wyróżnia się cztery poziomy techniki: wysoką, średniowysoką, średnioniską i niską. Wśród dziesięciu najbardziej innowacyjnych działów przetwórstwa przemysłowego tylko trzy działy należą do dziedzin wysokiej techniki: Produkcja maszyn biurowych i komputerów (4 miejsce w rankingu); Produkcja instrumentów medycznych, precyzyjnych i optycznych, zegarów i zegarków (5) oraz Produkcja sprzętu i urządzeń radiowych, telewizyjnych i telekomunikacyjnych. Lider innowacyjności, dział zajmujący pierwsze miejsce w rankingu - Wytwarzanie koksu, produktów rafinacji ropy naftowej i paliw jądrowych reprezentuje średnioniską technikę. Dział zajmujący drugie miejsce, Produkcja wyrobów tytoniowych należy do dziedzin niskiej techniki. Natomiast dział trzeci na liści - Produkcja 
wyrobów chemicznych to średniowysoka technika. Sukces innowacyjny działów zajmujących trzy pierwsze miejsca jest efektem przynajmniej jednego z trzech czynników: pomyślnej restrukturyzacji branży; transferu technologii poprzez napływ zagranicznych inwestycji bezpośrednich; dostępu do wykwalifikowanej kadry. Działy zajmujące dziewięć ostatnich miejsc (w tym produkcja artykułów spożywczych i napojów) w rankingu innowacyjności charakteryzują się niską techniką.

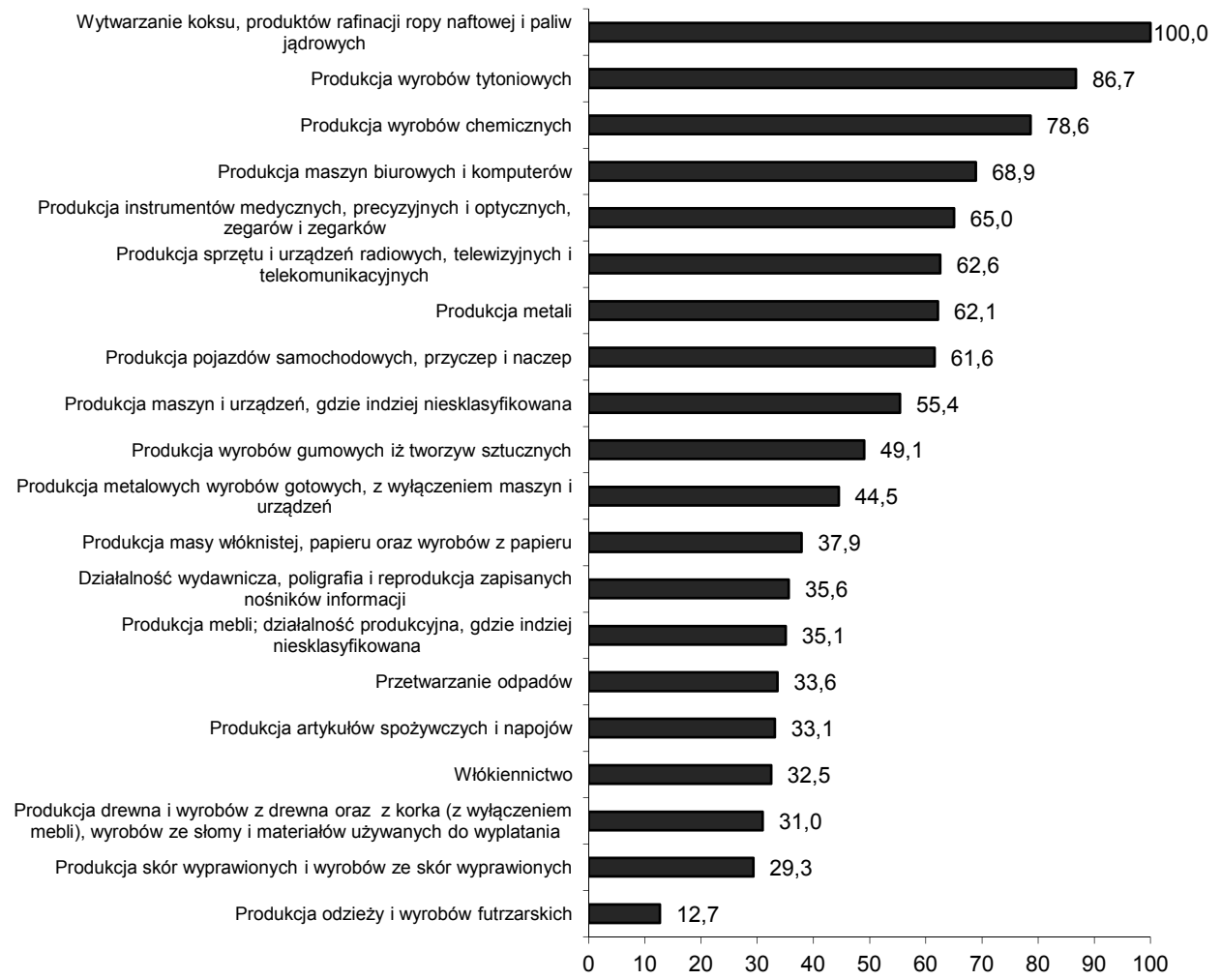

Rysunek 4. 8. Ranking działów przetwórstwa przemysłowego według indeksu innowacyjności Źr ódło: opracowanie własne na podst. tab. 4.8.

\section{Podsumowanie}

Budowa i rozwój społeczeństwa i gospodarki opartych na wiedzy powoduje, że statystyka działalności innowacyjnej ma coraz większe znaczenie i tym samym staje się jednym z najistotniejszych działów statystyki gospodarczej. Badania statystyczne innowacji, które dostarczają wiarygodnych informacji, są uznawane za ważny czynnik wspierający działalność innowacyjną kraju. 
Przeprowadzona, w oparciu o wskaźniki statystyczne publikowane przez GUS, analiza działalności innowacyjnej przedsiębiorstw dowodzi, że przedsiębiorstwa przemysłu spożywczego charakteryzują się niższą innowacyjnością niż przedsiębiorstwa przetwórstwa przemysłowego i przemysłu ogółem.

W badanym okresie 1999-2008 nakłady na działalność innowacyjną (ceny stałe) podlegały dużym wahaniom. Najwyższy poziom nakładów w trzech analizowanych grupach przedsiębiorstw odnotowano w 1999 roku. W pierwszych czterech latach członkostwa Polski w UE dynamika nakładów na innowacje w przedsiębiorstwach produkujących żywność była większa niż w przedsiębiorstwach przemysłowych. Jednak w roku 2008 powyższa tendencja uległa odwróceniu.

W strukturze nakładów na działalność innowacyjną dominowały nakłady na zakup maszyn, urządzeń technicznych i narzędzi oraz środków transportu. Niestety niewielki był udział wydatków na działalność badawczą i rozwojową. Poziom aktywności innowacyjnej przedsiębiorstw w przemyśle w Polsce był niższy niż w większości krajów UE. Wprowadzanie innowacji przynoszących korzyści dla środowiska wiąże się z koniecznością wypełniania wielu norm i przepisów w zakresie ochrony środowiska wymaganych na terenie UE.

Wyniki przeprowadzonego badania wskazują także, że hierarchia celów działalności innowacyjnej przedsiębiorstw produkujących artykuły spożywcze i napoje oraz przedsiębiorstw przetwórstwa przemysłowego i przemysłu ogółem jest podobna. Najważniejsze okazały się cele dotyczące produktów, a wśród nich: poprawa jakości produktów oraz zwiększenie asortymentu produktów. Najmniej istotnymi efektami we wszystkich trzech analizowanych grupach przedsiębiorstw były efekty związane z obniżką materiałochłonności i redukcją kosztów pracy.

Dla badanych przedsiębiorstw głównym partnerem we współpracy w zakresie działalności innowacyjnej byli dostawcy wyposażenia, materiałów, komponentów i oprogramowania. Na kolejnym miejscu pod względem częstotliwości podejmowanej współpracy znaleźli się klienci. Skłonność do współpracy rosła, podobnie jak w przypadku innych wskaźników charakteryzujących innowacyjność, wraz z wielkością przedsiębiorstwa.

Z przeprowadzonych badań wynika, że główną przeszkodą w działalności innowacyjnej były czynniki ekonomiczne, a mianowicie: brak środków finansowych w przedsiębiorstwie i zbyt wysokie koszty innowacji.

Warto podkreślić, że we wszystkich dotychczasowych badaniach innowacyjności przedsiębiorstw, czynniki ekonomiczne były najczęściej wymieniane, również przez przedsiębiorców w innych krajach europejskich, jako przeszkody w procesie powstawania i wdrażania innowacji. Czynniki związane z wiedzą przedsiębiorcy uznali za najmniej znaczące przeszkody.

Wyniki badań potwierdzają, że przedsiębiorstwa mniejsze częściej niż duże napotykają na trudności w realizacji projektów innowacyjnych.

Aktywność innowacyjna działu produkującego artykuły spożywcze i napoje na tle pozostałych działów przetwórstwa przemysłowego została oceniona za 
pomocą syntetycznego miernika innowacyjności. Zbudowany dla potrzeb analizy indeks innowacyjności pozwala na ocenę, że najbardziej innowacyjne są działy: 23- Wytwarzanie koksu, produktów rafinacji ropy naftowej i paliw jądrowych (średnio-niska technika), 16 - Produkcja wyrobów tytoniowych (niska technika), 24 - Produkcja wyrobów chemicznych (średnio-wysoka technika), 30 - Produkcja maszyn biurowych i komputerów (wysoka technika). Dział 15 - Produkcja artykułów spożywczych i napojów (niska technika) znalazł się na 16 miejscu i wyprzedził pod względem innowacyjności tylko cztery działy (Włókiennictwo, Produkcję drewna, Produkcję skór wyprawionych i Produkcję odzieży futrzarskiej).

Przeprowadzone badanie może być pewną przesłanką dla potrzeb opracowania przyszłej polityki wspierania działalności innowacyjnej przedsiębiorstw przetwórstwa przemysłowego. Zaproponowany indeksu innowacyjności stanowić może narzędzie do podejmowania decyzji, które działy powinny zostać uznane za priorytetowe w zakresie polityki wspierania innowacyjności. 


\section{Ocena innowacyjności przedsiębiorstw w poszczególnych branżach przemysłu spożywczego - próba budowy i empirycznej weryfikacji syntetycznego miernika}

\section{Wprowadzenie}

Innowacyjność przedsiębiorstw przemysłowych jest ważnym czynnikiem determinującym rozwój przedsiębiorstw i choć metodologa badań innowacyjności przedsiębiorstw wciąż jest rozwijana i udoskonalana ${ }^{14}$, to już obecnie wskaźniki innowacyjności stanowić mogą cenne źródło informacji w ocenie ich innowacyjności.

W rozdziale omówiono podstawowe wskaźniki dotyczące innowacyjności przedsiębiorstw przemysłowych, przedstawiono wybrane zagadnienia z zakresu metod porządkowania liniowego obiektów i analizy skupień, zaprezentowano wyniki wstępnej analizy danych oraz wyniki wielowymiarowej analizy statystycznej poświęconej ocenie innowacyjności branż (klas) przemysłu spożywczego w Polsce w latach 2004-2008.

\subsection{Wskaźniki innowacyjności przedsiębiorstw przemysłowych}

Ogólny zarys metodologii statystycznych badań innowacji przedstawiony został $\mathrm{w}$ podrozdziale 2.2 .

Na podstawie wyników badania PNT-02 Sprawozdanie o innowacjach $w$ przemyśle realizowanego przez GUS w ramach programu CIS zbudowano zestaw potencjalnych wskaźników diagnostycznych innowacyjności przedsiębiorstw przemysłu spożywczego w Polsce w latach 2004-2008, których wartości stanowiły punkt wyjścia do analizy innowacyjności tego sektora przemysłu. Są to:

1) udział przedsiębiorstw innowacyjnych w ogólnej liczbie przedsiębiorstw,

2) udział przedsiębiorstw, które wprowadziły nowe lub istotnie ulepszone produkty w ogólnej liczbie przedsiębiorstw,

3) udział przedsiębiorstw, które wprowadziły nowe lub istotnie ulepszone produkty dla rynku w ogólnej liczbie przedsiębiorstw,

${ }^{14}$ Prace w zakresie statystycznych badań innowacji zainicjowane zostały przez Komisję Europejską na początku lat 90 . O znaczeniu, jakie przypisywane jest w UE badaniom statystycznym innowacji świadczy stwierdzenie, jakie padło na konferencji Innovation measurement and policies w Luksemburgu w 1996 r.: „Badania statystyczne innowacji i inne sposoby pomiaru innowacji powinny być rozwijane tak, by w przyszłości osiągnęły status podobny do tego, jaki obecnie mają rachunki narodowe" oraz akty legislacyjne stanowiące aktualną podstawę prawną badań statystycznych innowacji w krajach członkowskich UE i EFTA [GUS 2006, s. 17]. 
4) udział przedsiębiorstw, które wprowadziły nowe lub istotnie ulepszone procesy (aktywnych innowacyjnie) w ogólnej liczbie przedsiębiorstw,

5) udział przedsiębiorstw, które poniosły nakłady na działalność innowacyjną (prowadzących działalność innowacyjną) jako odsetek przedsiębiorstw,

6) wartość nakładów na działalność innowacyjna ogółem (B+R, zakup technologii, oprogramowania, nakłady inwestycyjne na środki trwałe, szkolenie personelu, marketing, pozostałe nakłady) przypadająca na 1 przedsiębiorstwo,

7) udział nakładów na działalność badawczo-rozwojową ogółem w wartości nakładów ogółem na działalność innowacyjną,

8) udział nakładów na działalność badawczo-rozwojową wewnętrzną (w przedsiębiorstwie) w wartości nakładów ogółem na działalność innowacyjną,

9) udział nakładów na zakup gotowej technologii w wartości nakładów ogółem na działalność innowacyjną,

10) udział nakładów na oprogramowanie w wartości nakładów ogółem na działalność innowacyjną,

11) udział nakładów na budynki i budowle oraz grunty w wartości nakładów ogółem na działalność innowacyjną,

12) udział nakładów na maszyny i urządzenia techniczne w wartości nakładów ogółem na działalność innowacyjną,

13) udział nakładów na maszyny i urządzenia techniczne z importu w wartości nakładów ogółem na działalność innowacyjną,

14) udział nakładów na szkolenie personelu w wartości nakładów ogółem na działalność innowacyjną,

15) udział nakładów na marketing w wartości nakładów ogółem na działalność innowacyjną,

16) udział przychodów ze sprzedaży produktów innowacyjnych w wartości sprzedaży ogółem,

17) udział przychodów ze sprzedaży produktów innowacyjnych nowych dla rynku w wartości sprzedaży ogółem,

18) udział przychodów ze sprzedaży produktów innowacyjnych nowych tylko dla przedsiębiorstwa w wartości sprzedaży ogółem,

19) udział przedsiębiorstw przemysłowych posiadających porozumienia o współpracy dotyczące działalności innowacyjnej z innymi jednostkami w ogólnej liczbie przedsiębiorstw,

20) udział przedsiębiorstw przemysłowych posiadających porozumienia o współpracy dotyczące działalności innowacyjnej z innymi jednostkami w ogólnej liczbie przedsiębiorstw aktywnych innowacyjnie,

21) liczba linii produkcyjnych automatycznych przypadających na 1 przedsiębiorstwo,

22) udział wartości produkcji sprzedanej wyrobów nowych lub istotnie ulepszonych w wartości ogółem produkcji sprzedanej wyrobów. 
W literaturze przedmiotu z reguły mówi się o poszczególnych branżach przemysłu spożywczego [por. Drożdż 2008, s. 9], podczas gdy według Polskiej Klasyfikacji Działalności (PKD 2004) w ramach przemysłu spożywczego wyróżnia się następujące klasy przemysłu:

1) mięsny $(1511,1513)$

2) drobiarski (1512)

3) przetwórstwo ryb (1520)

4) mleczarski $(1551,1552)$

5) ziemniaczany $(1531,1562)$

6) owocowo-warzywny $(1532,1533)$

7) olejarski $(1541,1542,1543)$

8) zbożowo-młynarski $(1561,1585)$

9) cukrowniczy (1583)

10) paszowy $(1571,1572)$

11) piekarski (1581)

12) cukierniczy $(1582,1584)$

13) koncentratów spożywczych $(1586,1587,1588,1589)$

14) napojów bezalkoholowych (1598)

15) spirytusowy (1591 i 1592)

16) winiarski $(1593,1594,1595)$

17) piwowarski (1596 i 1597)

18) tytoniowy (1600).

Warto zauważyć, że de facto podmiotami (obiektami) analizy są przedsiębiorstwa, tj. podmioty prowadzące działalność gospodarczą, należące do ww. klas przemysłu.

\subsection{Procedura porządkowania liniowego}

Metody porządkowania liniowego obiektów opisanych zestawem wielu cech diagnostycznych zalicza się do metod Wielowymiarowej Analizy Statystycznej (WAS). Ich idea polega na porządkowaniu elementów badanego zbioru obiektów według wartości wybranych cech (lub wskaźników) diagnostycznych w oparciu o zdefiniowane nadrzędne kryterium ich oceny [Grabiński i in. 1989, s. 53-54]. Czynność porządkowania polega z reguły na konstrukcji wskaźnika syntetycznego dla obiektów, będącego w rezultacie przeprowadzonych analiz miernikiem badanego zjawiska. Uniwersalność metod porządkowania liniowego sprawia, że są często wykorzystywane do różnego rodzaju porównań o charakterze społeczno-ekonomicznym.

Zagadnienie porządkowania liniowego obiektów można rozpatrywać w ujęciu statycznym lub dynamicznym. Należy jednak zwrócić uwagę, że 
samo wykorzystanie szeregu czasowego i analiza prowadzona w pewnym okresie nie wskazuje jeszcze, że analiza ma charakter dynamiczny, Decyduje o tym cel oraz szczegółowy sposób prowadzenia analizy ${ }^{15}$. Rankingi publikowane w literaturze mają z reguły charakter statyczny, gdyż są budowane oddzielnie dla każdego z momentów (krótkich przedziałów czasowych) badanego okresu.

Ogólny schemat porządkowania liniowego obiektów w ujęciu statycznym można opisać za pomocą sześciu następujących po sobie etapów ${ }^{16}$ :

1. Sformułowanie celu analizy oraz wstępnych hipotez badawczych.

2. Określenie zakresu merytorycznego (obiekty, wskaźniki) i czasowego badania.

3. Budowa bazy danych zawierającej wartości dopuszczalnych wskaźników diagnostycznych.

4. Wstępna analiza danych:

- analiza opisowa wskaźników diagnostycznych (miary położenia, rozstępu, zmienności),

- analiza korelacji, redukcja i dobór wskaźników diagnostycznych,

- określenie charakteru wskaźników diagnostycznych i ich ewentualna stymulacja,

- ustalenie wag dla wskaźników diagnostycznych.

5. Porządkowanie liniowe obiektów:

- normalizacja wskaźników diagnostycznych,

- wybór formuły agregacji wskaźników diagnostycznych (metoda wzorcowa, metoda bezwzorcowa, metoda rzutowanie ortogonalne obiektów na prostą),

- ocena jakości uzyskanych wyników i wybór rozwiązania optymalnego.

6. Interpretacja wyników porządkowania liniowego obiektów:

- analiza korelacji wskaźników diagnostycznych ze zmienną syntetyczną,

- hierarchizacja obiektów, prezentacja graficzna i interpretacja uzyskanych wyników.

Pierwsze trzy etapy schematu porządkowania liniowego obiektów w ujęciu statycznym nie wymagają komentarza, gdyż są typowe dla różnego rodzaju analiz. Głównym celem etapu czwartego, wstępnej analizy danych, jest ocena własności poszczególnych wskaźników diagnostycznych oraz ich dobór do analizy. Na tym etapie następuje przejście od zestawu wskaźników dopuszczalnych, ustalonych

\footnotetext{
${ }^{15} \mathrm{~W}$ literaturze metody porządkowania liniowego w ujęciu dynamicznym to: analiza tempa zmian rozwoju (wzrostu) obiektów w czasie oraz analiza zróżnicowania dynamiki badanych obiektów w czasie z punktu widzenia struktury indywidualnych mierników cząstkowych [Grabiński i in. 1989, s. 201-208].

${ }^{16}$ Opracowanie własne na podstawie [Grabiński i in. 1989, s. 87-89] oraz [Kolenda 2006, s. 139-140].
} 
na podstawie przesłanek merytoryczno-formalnych, do zestawu wskaźników diagnostycznych. Jest to ważny etap, gdyż zbyt duża liczba zmiennych diagnostycznych, mało istotnych lub nadmiernie ze sobą skorelowanych, może utrudnić uzyskanie właściwego - najlepszego pod względem jakości - wyniku porządkowania liniowego obiektów (klas przedsiębiorstw).

Dokonując wyboru cech diagnostycznych należy kierować się następującymi kryteriami informacyjnymi [Ostasiewicz 1999, s. 110]: uniwersalność - cechy powinny mieć powszechnie uznaną wagę i znaczenie w temacie analizy; zmienność - cechy nie powinny być podobne do siebie w sensie informacji o badanych obiektach, natomiast powinny mieć dużą zdolność różnicowania obiektów (wysoką zmienność); ważność - wskaźniki pod względem których badane obiekty trudno osiągają wysokie wartości (istotne); skorelowanie - wybrane wskaźniki powinny być słabo skorelowane między sobą, natomiast silnie skorelowane ze wskaźnikami wyłączonymi z analizy w drodze redukcji.

Do oceny zmienności potencjalnych wskaźników diagnostycznych można w analizie wykorzystać względną miarę ich rozproszenia, tj. klasyczny współczynnik zmienności $v_{j}$ podany wzorem:

$$
v_{j}=\frac{s_{j}}{\bar{x}_{j}},
$$

gdzie:

$$
\begin{aligned}
& \bar{x}_{j}=\frac{1}{n} \sum_{i=1}^{n} x_{i j} \text { oznacza średnią arytmetyczną wskaźnika } X_{j}, \\
& s_{j}=\sqrt{\frac{1}{n} \sum_{i=1}^{n}\left(x_{i j}-\bar{x}_{j}\right)^{2}} \text { jest odchyleniem standardowym wskaźnika } X_{j}(j=1, \ldots, m) .
\end{aligned}
$$

Ze zbioru potencjalnych wskaźników diagnostycznych eliminuje się te, dla których $\left|v_{j}\right|<0,1$.

Inną miarą zmienności jest współczynnik względnej amplitudy wahań $A\left(X_{j}\right)$ danego wskaźnika. Jeżeli $X_{j}$ jest stymulantą to $A\left(X_{j}\right)$ informuje, ile razy najwyższa wartość danego wskaźnika dla obiektu pierwszego w rankingu przewyższa najniższą wartość tego wskaźnika dla obiektu ostatniego w rankingu (dla destymulanty interpretacja jest odwrotna) [Kukuła 2000, s. 47-52]:

$$
A\left(X_{j}\right)=\frac{\max _{i} x_{i j}}{\min _{i} x_{i j}},(i=1, \ldots, n ; j=1, \ldots, m),
$$

przy czym $\min x_{j} \neq 0$. Przyjęcie dodatkowego warunku, że współczynnik $A\left(X_{j}\right) \geq c$, gdzie $c=1,2$ pozwala na eliminacją zmiennych o niskiej amplitudzie wahań. 
W kolejnym kroku wstępnej analizy danych do oceny siły skorelowania wskaźników diagnostycznych można wykorzystać metodę odwróconej macierzy korelacji, która przebiega następująco [Malina, Zeliaś 1998, s. 529-530]:

- wyznacza się macierz odwrotną $R^{-1}$ do macierzy korelacji $R$ postaci:

$$
R^{-1}=\left[\begin{array}{cccc}
\widetilde{r}_{11} & \widetilde{r}_{12} & \ldots & \widetilde{r}_{1 m} \\
\widetilde{r}_{21} & \widetilde{r}_{22} & \ldots & \widetilde{r}_{2 m} \\
\ldots & \ldots & \ldots & \ldots \\
\widetilde{r}_{m 1} & \widetilde{r}_{m 2} & \ldots & \widetilde{r}_{m m}
\end{array}\right] \text {, dla } R=\left[\begin{array}{cccc}
1 & r_{12} & \ldots & r_{1 m} \\
r_{21} & 1 & \ldots & r_{2 m} \\
\ldots & \ldots & \ldots & \ldots \\
r_{m 1} & r_{m 2} & \ldots & 1
\end{array}\right] \text {, }
$$

o wartościach:

$$
\widetilde{r}_{j p}=\frac{(-1)^{j+p} \operatorname{det}\left(R_{j p}\right)}{\operatorname{det}(R)},
$$

przy czym det $(R)$ to wyznacznik macierzy korelacji, a det $\left(R_{j p}\right)$ to wyznacznik macierzy powstałej przez usunięcie $j$-tego wiersza i $p$-tej kolumny, dla $j=p$ $(j, p=1, \ldots, m)$,

- wyróżnia się elementy $\widetilde{r}_{j p}$ dla $j=p$, czyli elementy $\widetilde{r}_{j j}$ na przekątnej głównej odwróconej macierzy korelacji spełniające nierówność $\left|\widetilde{r}_{j j}\right|>r_{0}-\mathrm{z}$ reguły przyjmuje się, że $r_{0}=10$. Są to elementy o wartości większej od zadanej wartości progowej, które krokowo eliminuje się ze zbioru wskaźników przyjętych do analizy.

Kolejny krok analizy, określenie charakteru wskaźników diagnostycznych i ich ewentualna stymulacja, polega na przekształceniu wartości destymulant i nominant na stymulanty. Przekształcenie to jest wymagane w przypadku metod bezwzorcowego porządkowania liniowego obiektów i ma na celu ujednolicenie charakteru (preferencji) wskaźników wykorzystywanych do budowy wskaźnika (miernika) syntetycznego, poprzedza etap ich normalizacji. Postulat jednolitej preferencji oraz nieujemności zmiennych, czyli zamiana destymulant $X_{j}^{D}=\left(x_{j 1}^{D}, x_{j 2}^{D}, \ldots, x_{j n}^{D}\right)^{T}$ na stymulanty $X_{j}^{S}=\left(x_{j 1}^{S}, x_{j 2}^{S}, \ldots, x_{j n}^{S}\right)^{T}$, można uzyskać [Walesiak 1990, s. 37-46]:

- za pomocą przekształcania ilorazowego przy założeniu, że wszystkie wartości cechy są niezerowe:

$$
x_{i j}^{S}=\frac{b}{x_{i j}^{D}},(i=1, \ldots, n),
$$

gdzie stała $b>0$. W szczególnych przypadkach np. $b=1$ lub $b=\min _{i} x_{i j}^{D}$,

- za pomocą formuły różnicowej:

$$
x_{i j}^{S}=c-b x_{i j}^{D},(i=1, \ldots, n) \text {, }
$$


gdzie stała $b>0$. W szczególności można przyjąć $c=0$ i $b=1$, a więc przeciwieństwo wartości cechy diagnostycznej lub $c=1$ i $b=1$, czyli odwrotność zmiennej $\operatorname{lub} c \geq \max _{i} x_{i j}^{D}$ i $b=1$ dla zmiennej o wartościach ujemnych.

W badaniach empirycznych może również wystąpić potrzeba zamiany nominant na stymulanty przy zastosowaniu przekształcenia ilorazowego lub różnicowego, lecz z reguły unika się wykorzystywania wskaźników o tym charakterze w budowie wskaźników (mierników) syntetycznych.

Zagadnienie ważenia zmiennych, czyli przypisywania im określonych wag w celu zróżnicowania znaczenia poszczególnych cech diagnostycznych w analizie jest zagadnieniem kontrowersyjnym. $Z$ reguły przyjmuje się założenie o jednakowej ważności poszczególnych zmiennych, argumentując to brakiem nietrywialnych sposobów ich ważenia z wykorzystaniem dodatkowych informacji, wówczas:

$$
\alpha_{j}=1 / m,(j=1, \ldots, m) .
$$

$\mathrm{Z}$ drugiej strony w literaturze znane są sposoby określania wag na podstawie informacji zawartych w danych statystycznych wykorzystywanych do analizy, m.in. w oparciu o zmienność (5.8), skorelowanie cech (5.9) czy na podstawie elementów pierwszej głównej składowej, tj. analizy czynnikowej macierzy korelacji cech diagnostycznych [Grabiński i in. 1989, s. 25-27]:

$$
\alpha_{j}=\frac{v_{j}}{\sum_{j=1}^{m} v_{j}},(j=1, \ldots, m),
$$

gdzie $v_{j}$ - współczynnik zmienności wskaźnika $X_{j}$ przed jego normalizacją̨ ${ }^{17}$,

$$
\alpha_{j}=\frac{r_{j p}}{\sum_{j=1}^{m} \sum_{p=1}^{m} r_{j p}},(j, p=1, \ldots, m),
$$

gdzie $r_{j p}$ - elementy macierzy korelacji $R_{m \times m}$ przed normalizacją wskaźników.

Wiadomo, że wykorzystując wzory (5.8) i (5.9) wyższe wagi przypisane zostaną wskaźnikom o relatywnie dużym stopniu zmienności lub ich wysokim skorelowaniu w stosunku do pozostałych wskaźników diagnostycznych. Należy również pamiętać, że ewentualnego obliczania wag dokonuje się na podstawie oryginalnych wartości zmiennych diagnostycznych, a procedurę ich ważenia stosuje po etapie normalizacji zmiennych, na etapie agregacji wartości cech diagnostycznych.

${ }^{17}$ Wagi wyznaczone w oparciu o współczynniki zmienności cech z punktu widzenia ich własności nie są właściwe do analizy, gdyż nie biorą pod uwagę powiązań między zmiennymi i mogą doprowadzić do marginalizacji niektórych zmiennych, wybranych na wcześniejszym etapie doboru i redukcji zmiennych. 
Piąty etap analizy jest właściwym etapem porządkowania liniowego obiektów, związanym z wyborem formuły agregacji danych, a poprzedzony jest normalizacją i ważeniem wskaźników diagnostycznych. Procedury dotyczące normalizacji i agregacji zmiennych stanowią najbardziej obszerną część literatury przedmiotu z zakresu metod porządkowania liniowego obiektów. Różnorodność znanych metod sprawia, że ten najistotniejszy etap analizy jest zarazem najtrudniejszy.

Zasadniczym celem normalizacji cech diagnostycznych przyjętych do analizy jest uzyskanie niemianowanych wartości zmiennych oraz ujednolicenie rzędu ich wielkości. Podstawowym wymogiem stawianym procedurom normalizacji jest, aby przekształcenie zachowywało współzależność (korelację) między cechami oraz podstawowe wskaźniki dotyczące kształtu ich rozkładów (skośność, kurtozę). Wspomniane własności spełnia przekształcenie liniowe zmiennej $X_{j}=\left(x_{1 j}, x_{2 j}, \ldots, x_{n j}\right)^{T} \mathrm{w}$ zmienną $Z_{j}=\left(z_{1 j}, z_{2 j}, \ldots, z_{n j}\right)^{T}$ postaci [Zeliaś 2000, s. 792]:

$$
\begin{gathered}
z_{i j}=\frac{x_{i j}-a_{j}}{b_{j}},(j=1, \ldots, m), \\
z_{i j}=\frac{a_{j}-x_{i j}}{b_{j}},(j=1, \ldots, m),
\end{gathered}
$$

odpowiednio dla stymulant (5.10) i destymulant (5.11) przy czym, jeżeli: $a_{j}$ jest miarą położenia danej cechy, np. średnią arytmetyczną $a_{j}=\bar{x}_{j}$, a $b_{j}$ miarą jej zmienności, np. odchyleniem standardowym $\left(b_{j}=s_{j}\right)$, to jest to przekształcenie standaryzacyjne; jeżeli $b_{j}$ jest miarą zmienności - rozstępu $b_{j}=\max _{i} x_{i j}-\min _{i} x_{i j}$, to jest to przekształcenie unitaryzacyjne; gdy $a_{j}=0\left(b_{j}>0\right)$ otrzymuje się przekształcenie ilorazowe.

$\mathrm{W}$ literaturze przedmiotu występuje wiele przekształceń normalizacyjnych, gdyż dopuszczalne jest podstawienie za parametry $a_{j}$ i $b_{j}$ także innych charakterystyk badanych zmiennych ${ }^{18}$, odpowiednio: wartość minimalną, maksymalną, medianę oraz medianowe odchylenie bezwzględne, sumę wartości $x_{i j}$ czy sumę kwadratów wartości $x_{i j}$. Dopiero analiza teoretycznych własności poszczególnych metod normalizacji [Kukuła 2000, s. 77-100] pozwala na ocenę ich przydatności, wybór i zastosowanie na potrzeby porządkowania liniowego obiektów przekształceń o najlepszych własnościach.

Okazuje się, że tylko metoda unitaryzacji zerowanej z parametrami, odpowiednio $a_{j}=\min _{i} x_{i j}$ i $b_{j}=\max _{i} x_{i j}-\min _{i} x_{i j}$ dla stymulant oraz $a_{j}=\max _{i} x_{i j}$

${ }^{18}$ W zakresie procedur normalizacyjnych: Grabiński i in. [1989, s. 27-28] wskazują na 3 najczęściej wykorzystywane w praktyce przekształcenia; Domański i in. [1998, s. 49-48] prezentują 5 przekształceń standaryzujących oraz 10 ilorazowych; Kukuła [2000, s. 106-110] przyjmuje inny podział metod normalizacjii omawia 10 przekształceń normalizacyjnych; Zeliaś [2002, s. 792-794] prezentuje 2 metodystandaryzacji, 4 unitaryzacji i 6 sposobów przekształcenia ilorazowego; Walesiak [2006, s. 16-22] analizuje łącznie 11 przekształceń; a Młodak [2006, s. 39-42], odpowiednio 4 metody standaryzacji, 7 metod unitaryzacji i 8 typu ilorazowego, wśród których znajdują się również propozycje autora z wykorzystaniem statystyk pozycyjnych. 
i $b_{j}=\max _{i} x_{i j}-\min _{i} x_{i j}$ dla destymulant, dająca znormalizowane wartości wskaźników diagnostycznych $\mathrm{z}$ przedziału $\langle 0 ; 1\rangle$, spełnia wszystkie teoretyczne postulaty formuły normalizacyjnej i zapewnia uniwersalne unormowanie wszystkich cech. W dalszej kolejności znalazły się: klasyczna formuła standaryzacji z parametrami $a_{j}=\bar{x}_{j}$ i $b_{j}=s_{j}$ oraz przekształcenie ilorazowe z parametrami $a_{j}=0$ i $b_{j}=\sum_{i=1}^{n} x_{i j}$, przy czym to właśnie dwa ostatnie wymienione przekształcenia - standaryzacyjne i ilorazowe - są najczęściej wykorzystywane w praktyce. Ponadto, aby możliwe było porównywanie wartości mierników syntetycznych w czasie, należy zestandaryzować wartości wskaźników diagnostycznych $X$ w całym badanym okresie względem czasu $T(t=1, \ldots, T)$ [Zeliaś 2000, s. 98-101]:

$$
z_{i j t}=\frac{x_{i j t}-\frac{1}{T n} \sum_{i=1}^{n} \sum_{t=1}^{T} x_{i j t}}{\sqrt{\frac{1}{T n} \sum_{i=1}^{n} \sum_{t=1}^{T}\left(x_{i j t}-\frac{1}{T n} \sum_{i=1}^{n} \sum_{t=1}^{T} x_{i j t}\right)^{2}}},(j=1, \ldots, m) .
$$

Właściwym krokiem etapu porządkowania liniowego obiektów jest wybór formuły agregacji zmiennych diagnostycznych. Najczęściej wykorzystywane są dwa rodzaje metod porządkowania liniowego [Grabiński i in. 1989, s, 31-32]: wzorcowe polegające na konstrukcji hipotetycznego obiektu wzorcowego, stanowiącego punkt odniesienia dla prowadzonej analizy (zapoczątkowane przez Hellwiga) oraz bezwzorcowe, polegające na konstrukcji miernika syntetycznego - w literaturze znana jest jeszcze trzecia grupa metod porządkowania liniowego obiektów - rzutowania ortogonalnego punktów na prostą. Miernik syntetyczny $M$ o wartościach $\mu_{i}$ dla $i$ - tego obiektu $(i=1, \ldots, n)$ obliczonych na podstawie unormowanych wartości zmiennych $z_{i j}$ oraz wag $\alpha_{j}(j=1, \ldots, m)$ przypisanych zmiennym $\alpha_{j} \in(0 ; m)$, dla których w szczególności $\sum_{j=1}^{m} \alpha_{j}=1$, wyrazić można w postaci średniej arytmetycznej, harmonicznej i geometrycznej wskaźników diagnostycznych. W badaniach porównawczych najczęściej wykorzystywana jest formuła oparta na wartości średniej znormalizowanych wskaźników diagnostycznych [Gatnar, Walesiak 2004, s. 355]:

$$
\mu_{i}=\frac{1}{m} \sum_{j=1}^{m}\left(z_{i j} \alpha_{j}\right)
$$

która może być stosowana, gdy wszystkie zmienne (stymulanty, destymulanty, nominanty) były pierwotnie mierzone na skali przedziałowej lub ilorazowej; przy stymulacji zastosowano przekształcenie ilorazowe lub różnicowe; natomiast normalizację przeprowadzono za pomocą standaryzacji, unitaryzacji bądź unitaryzacji zerowanej. 
Stosunkowo od niedawna, gdyż dopiero od 2006 r., zwraca się w literaturze uwagę na potrzebę dokonania oceny jakości wyników rankingów i wybór rozwiązania optymalnego, aby uniknąć formułowania wniosków na podstawie rankingów zbudowanych z wykorzystaniem „przypadkowo” wybranych procedur cząstkowych. W tym celu należy dokonać kilku wariantów analizy porządkowania liniowego obiektów z wykorzystaniem „najlepszych” cząstkowych procedur obliczeniowych, biorąc pod uwagę ich teoretyczne własności, a następnie dokonać oceny jakości uzyskanych wyników (porządkowania).

Dokonując oceny jakości wyniku rankingu w ujęciu statycznym, np. według różnych metod porządkowania, dla tego samego zbioru obiektów z wykorzystaniem tych samych unormowanych wartości cech, można posłużyć się metodą wariancji kierunkowej zmiennej syntetycznej $M^{*}$, opisaną wzorem [Kolenda 2006, s. 137-140]:

$$
s^{2}\left(M^{*}\right)=\frac{\sum_{i=1}^{n}\left(\mu_{i}^{*}-\bar{\mu}^{*}\right)^{2}}{n},(i=1, \ldots, n),
$$

gdzie: $\mu_{i}^{*}$ to wartości zmiennej syntetycznej $M^{*}, n$ - liczba obiektów, a $\bar{\mu}^{*}$ to średnia arytmetyczna zmiennej syntetycznej $M^{*}\left(\bar{\mu}^{*}=0\right) \mu_{i}^{*}$ wyznaczonej następująco:

$$
\begin{aligned}
& \mu_{i}^{*}=\sum_{j=1}^{m}\left(z_{i j} w_{j}\right),(i=1, \ldots, n), \\
& \sum_{j=1}^{m} w_{j}^{2}=1, w_{j}>0,
\end{aligned}
$$

przy czym $w_{j}$ to wagi będące współrzędnymi wektora jednostkowego.

Aby wykorzystać metodę wariancji kierunkowej do oceny jakości uporządkowania obiektów rankingu należy dysponować wynikiem porządkowania obiektów uzyskanym na podstawie metody rzutowania ortogonalnego obiektów na prostą lub odpowiednim wynikiem przekształconym. Okazuje się bowiem, że każdy inny wynik porządkowania obiektów, uzyskany w oparciu o wartości, np. miernika syntetycznego $M$ z dowolnymi wagami $\alpha_{j}$ sumującymi się do jedności, można przekształcić na wynik porządkowania obiektów o wartościach miernika $M^{*}$ (rzutowanie ortogonalne) z wagami $w_{j}$ określonymi według wzoru (5.17), spełniającymi warunek (5.18):

$$
w_{j}=\frac{\alpha_{j}}{\sqrt{\sum_{j=1}^{m} \alpha_{j}^{2}}},
$$




$$
\sum_{j=1}^{m} w_{j}^{2}=\frac{\alpha_{1}^{2}+\alpha_{2}^{2}+\ldots+\alpha_{m}^{2}}{\sum_{i=1}^{m} \alpha_{j}^{2}} \Rightarrow \sum_{j=1}^{m} w_{j}^{2}=1 .
$$

Zamiana wag nie ma znaczenia dla samego wyniku porządkowania, gdyż zachowane zostają wszelkie proporcje między wagami, a kolejność obiektów w rankingu nie ulega zmianie.

Idę̨ metody oceny poprawności wyniku porządkowania obiektów za pomocą wariancji kierunkowej można wyjaśnić następująco [Kolenda 2006, s. 137-140; Mikulec 2008, s. 35]:

- Poprzez wyznaczenie wektora jednostkowego wag $w_{j}$ (5.17), określającego nachylenie prostej, metoda sprowadza się do wyboru prostej rzutowania obiektów, dla której suma odległości rzutów ortogonalnych $o_{i}^{\prime}$ wszystkich obiektów $o_{i}$ na tę prostą będzie najmniejsza. Przypadek ten pozwala wyjaśnić największą część wariancji wspólnej pomiędzy cechami opisującymi porządkowane obiekty.

- Wraz ze wzrostem dopasowania szukanej prostej do obiektów $o_{i}$, suma odległości rzutów $o_{i}^{\prime}$ obiektów $o_{i}$ od początku układu współrzędnych (suma $\left.\mu_{i}^{*}\right)$ będzie dążyła do sumy odległości wszystkich badanych obiektów $o_{i}$ od początku układu współrzędnych, która jest odległością maksymalną tych obiektów i stanowi jednoznaczną charakterystykę danego zbioru uporządkowanych obiektów.

- Jeśli zatem suma wartości $\mu_{i}^{*}$ obliczona na podstawie unormowanych wartości poszczególnych zmiennych $z_{i j}$ dąży do maksimum, to również uśredniona suma kwadratów $s^{2}\left(M^{*}\right)$, tj. wariancja kierunkowa zmiennej syntetycznej zapisana wzorem (5.14) przy warunku $\bar{\mu}^{*}=0$ dąży do maksimum i stanowi jednoznaczne kryterium wyboru najlepszego uporządkowania obiektów. Powyższe rozważania pozostają zasadne także w przypadku porządkowania liniowego obiektów opisanych $m$ wielowymiarowym zestawem cech diagnostycznych $(m>2)$.

Finalnym krokiem analizy jest wyznaczenie korelacji wskaźników diagnostycznych ze zmienną syntetyczną, interpretacja wyników porządkowania liniowego obiektów oraz ich prezentacja graficzna.

\subsection{Wybrane zagadnienia metod analizy skupień}

Analiza skupień w intuicyjnym rozumieniu oznacza zarówno czynność grupowania, jak i metody analizy zbioru obiektów. Z reguły ma na celu określenie rozłącznych podzbiorów zbioru obiektów, wewnątrz których są one w jakimś sensie bliskie, natomiast różne podzbiory są od siebie, w porównaniu z obiektami wewnątrz każdego z nich, odległe [Koronacki, Ćwik 2005, s. 263]. Zagadnienie grupowania obiektów można rozpatrywać w ujęciu statycznym, tj. w jednym punkcie 
czasowym (krótkim przedziale czasowym) lub w ujęciu dynamicznym w kilku punktach czasowych, tj. porównywać zmiany przynależności obiektów do grup.

Ogólny schemat metody analizy skupień w ujęciu statycznym i dynamicznym można opisać za pomocą ośmiu następujących po sobie etapów ${ }^{19}$ :

1. Wybór jednostek do analizy skupień - podejście opisowe lub stochastyczne (próba losowa pobrana z populacji); selekcja - wybór istotnych wskaźników diagnostycznych, pozwalających na grupowanie obiektów, ważenie wskaźników diagnostycznych przyjętych do analizy. Budowa bazy danych.

2. Wizualizacja obiektów (lub wskaźników diagnostycznych) oraz macierzy odległości.

3. Nadanie wag i normalizacja wskaźników diagnostycznych - wybór procedur ich ważenia i normalizacji lub podjęcie decyzji o braku niniejszego etapu analizy.

4. Wybór miary niepodobieństwa, odległości między obiektami lub miary podobieństwa obiektów - miar sąsiedztwa.

5. Wybór metod analizy skupień właściwych dla danego zagadnienia, zdefiniowanie skupienia - poszczególne metody mają zdolność wyszukiwania skupień o właściwej dla danej metody strukturze.

6. Wstępne ustalenie liczby poszukiwanych klas.

7. Klasyfikacja obiektów - właściwy etap analizy skupień:

- ocena wyniku pod względem liczby wyodrębnionych klas,

- porównywanie parami wyników uzyskanych różnymi metodami analizy,

- testowanie, replikacja (powtórzenie analizy),

- ocena jakości wyniku grupowania,

- interpretacja, opis wyniku grupowania (skupień).

8. Analiza zgodności wyników grupowania w czasie.

Tematyka analizy skupień, ze względu na jej wieloetapowość, jest bardzo obszerna, dlatego też w niniejszym rozdziale dokonano krótkiego przeglądu metod w ramach powyższego schematu sygnalizując jedynie niektóre zagadnienia i dokonując wyboru metod, które będą stosowane w dalszej części pracy, poświęconej empirycznej analizie innowacyjności przedsiębiorstw przemysłu spożywczego w Polsce.

Zagadnienie wyboru jednostek do analizy nie stanowi w prowadzonej analizie - innowacyjności przedsiębiorstw przemysłu spożywczego - problemu, gdyż ma ona charakter opisowy. „Wybór” klas analizowanych przedsiębiorstw wynika z Polskiej Klasyfikacji Działalności (PKD 2004), a wybór okresu przyjętego do analizy z dostępności porównywalnych danych statystycznych z tego zakresu.

Tak jak w przypadku metod porządkowania liniowego obiektów, tak i w przypadku metody analizy skupień trudno jest wskazać „najlepsze” metody doboru wskaźników diagnostycznych (lub zmiennych). Warto jednak zwrócić uwagę, że obydwie wspomniane metody analizy wielowymiarowej wymagają takiego

\footnotetext{
s. 6-10].

${ }^{19}$ Opracowanie własne na podstawie: [Milligan, Cooper 1987, s. 329-331]; [Gordon 1999,
} 
doboru wskaźników (zmiennych), aby były one między sobą jak najsłabiej skorelowane, przy czym brak jest $\mathrm{w}$ tego typu analizie zmiennej zależnej. Na podstawie literatury przedmiotu można stwierdzić, iż raczej nie zaleca się stosowania metody głównych składowych $(P C A)$, gdyż może powodować utratę struktury klas lub hierarchicznej struktury drzewa. $\mathrm{Z}$ definicji wynika, że powinna ona być stosowana do transformacji, a nie redukcji wymiaru przestrzeni (analizy) w przestrzeń o mniejszym wymiarze. Proponowane są natomiast metody bazujące na ocenie zdolności cech do różnicowania zbioru obiektów lub na bezpośrednim doborze zmiennych do analizy w oparciu o ich skorelowanie [Milligan 1996, s. 347-348]. Jedną z najnowszych metod doboru wskaźników (lub zmiennych) opracowaną typowo na potrzeby analizy skupień jest heurystyczna procedura doboru zmiennych HINoV (Heuristic Identification of Noisy Variables) powiązana $\mathrm{z}$ metodą $k$-średnich i skorygowanym indeksem Randa [Steinley, Brusco 2008, s. 846-850], przy czym można ją zaadoptować na potrzeby innych metod analizy skupień, np. aglomeracyjnych. Podstawową jej wadą jest konieczność, już na wstępie, określenia (przyjęcia) liczby poszukiwanych skupień, co nie zawsze jest zadaniem prostym. Przyjmijmy zatem, że na potrzeby analizy skupień innowacyjności przedsiębiorstw przemysłowych wykorzystana zostanie ta sama metoda doboru zmiennych, co w przypadku porządkowania liniowego obiektów, a więc zmodyfikowana metoda odwróconej macierzy korelacji (zob. rozdz. 5.2).

Etap graficznej prezentacji danych ma za zadanie określić (przyjąć) liczbę poszukiwanych skupień, odkryć ich strukturę, a w szczególności pomóc w wyborze właściwych algorytmów grupowania biorąc pod uwagę ich własności. Metody graficzne mogą być także wykorzystywane we wcześniejszym, wstępnym etapie analizy, tzn. doboru i redukcji zmiennych do analizy skupień, np. wykres pudełkowy (ramka-wąsy).

Kolejny krok w schemacie analizy skupień - wybór procedur ważenia i normalizacji wskaźników diagnostycznych lub podjęcie decyzji o braku ważenia i normalizacji budzi kontrowersje zarówno w kontekście samego ważenia i normalizacji zmiennych, jak i w kontekście ich zasadności w analizie skupień.

W zakresie ważenia wskaźników diagnostycznych obiektywne wydaje się podejście równego traktowania wszystkich wskaźników (zmiennych) przyjętych do analizy skupień w szczególności, gdy nie są znane nietrywialnie sposoby ważenia zmiennych, lub brak mocnych argumentów za stosowaniem prostych, powszechnie znanych metod. Mocnego argumentu przemawiającego za niestosowaniem ważenia wskaźników diagnostycznych na potrzeby analizy skupień dostarczyli Gnanadesikan i in. (1995), którzy przeanalizowali dziewięć różnych procedur ważenia zmiennych i wykazali, że: po pierwsze, najlepsze, tj. dające najmniejszy błąd niezgodnych klasyfikacji, są metody oparte na wewnętrznej zmienności wskaźników diagnostycznych (lub zmiennych) w wyodrębnionych skupieniach. W praktyce jednak zastosowanie tych procedur ważenia jest niemożliwe, gdyż $\mathrm{z}$ reguły nie jest znana struktura skupień, a jej wykrycie jest celem samej analizy 
skupień. Ponadto, tego rodzaju system ważenia wymagałby skonstruowania skomplikowanego iteracyjnego schematu analizy [Gnanadesikan i in. 1995, s. 116-125].

Jeśli zaś chodzi o normalizację wskaźników diagnostycznych to już w pracy Cormacka z 1971 r. [Cormack 1971, s. 325] podjęto ten problem i wyjaśniono, że: $\mathrm{z}$ reguły nie jest zasadna standaryzacja zmiennych $\mathrm{w}$ analizie skupień, celem wyeliminowania różnic $\mathrm{w}$ skalach pomiaru cech, gdyż różnice pomiędzy cechami mogą wynikać $\mathrm{z}$ ich naturalnych własności; ponadto dowiedziono, że system wag odwrotnie proporcjonalnych do całkowitej zmienności cech - standaryzacja zmiennych przez ich całkowite odchylenie - jest nieefektywny, a wręcz niewskazany, gdyż utrudnia rozróżnianie grup obiektów podobnych. Także Milligan [Milligan 1996, s. 352-354] wskazuje na błędne przekonanie wielu badaczy, iż: fakt występowania znacznej różnicy zmienności cech w analizie skupień jest podstawą do przeprowadzenia standaryzacji zmiennych; cechy o dużej zmienności będą miały nadmierny (przesadny) wpływ na wyniki prowadzonej analizy skupień. Autor podkreśla, że normalizacja zmiennych jest sprawą indywidualną, a nie rutynowym przekształceniem jak również, że nieuzasadnione jest twierdzenie, że standaryzacja może utrudnić lub ukryć strukturę skupień występujących w danych, jeśli taka istnieje.

Przechodząc do właściwych zagadnień samej analizy skupień podstawową sprawą jest wybór miary sąsiedztwa, wśród których wyróżnia się miary niepodobieństwa - odległości między obiektami i podobieństwa - bliskości obiektów. $\mathrm{Z}$ reguły miary odległości wykorzystuje się w analizie skupień dotyczącej obiektów, a miary bliskości w analizie skupień dotyczącej wskaźników diagnostycznych (w charakterze metody doboru wskaźników diagnostycznych). I chociaż w literaturze znanych jest wiele miar odległości ${ }^{20}$ to ze względu na fakt, iż zastosowanie określonej miary odległości zależy m.in.: od skal pomiaru wskaźników diagnostycznych (zmiennych) przyjętych do analizy i ewentualnej ich normalizacji oraz od własności miary odległości, interpretacji, wybór miary sąsiedztwa jest stosunkowo prosty. W praktyce, ze względu na najlepiej rozpoznane własności i użyteczną interpretację geometryczną, powszechnie wykorzystywaną w analizie skupień miarą odległości $d(i, s)$ jest odległość euklidesowa (metryka) lub kwadrat odległości euklidesowej:

$$
\begin{aligned}
& d(i, s)=\sqrt{\sum_{j=1}^{m}\left(x_{i j}-x_{s j}\right)^{2}}, \\
& d(i, s)=\sum_{j=1}^{m}\left(x_{i j}-x_{s j}\right)^{2},
\end{aligned}
$$

\footnotetext{
${ }^{20}$ Minkowskiego (miejska, euklidesowa), Czebyszewa, Canberra, Braya-Curtisa, uogólniona miara odległości GDM, Mahalanobisa [Everitt i in. 2001, s. 40]; [Walesiak 2006, s. 36-41]; [Kolenda 2006, 48, 53-55].
} 
gdzie:

$n$ - liczba obiektów $(i, s=1, \ldots, n)$,

$m-\operatorname{liczba} \operatorname{cech}(j=1, \ldots, m)$,

$x_{i j}, x_{s j}-$ wartości cechy $x_{j}$ dla obiektów $i, s$.

Kolejny krok to wybór metody analizy skupień właściwej dla danego zagadnienia oraz zdefiniowanie skupienia w przedmiotowej analizie - poszczególne grupy metod mają zdolność wyszukiwania skupień o właściwej dla tych metod strukturze. Wybór ten ma duże znaczenie, gdyż warunkuje stosowanie procedur obliczeniowych na innych (dalszych) etapach analizy. Na potrzeby analiz społeczno-ekonomicznych wykorzystuje się metody aglomeracyjne bądź podziałowe. O ile wybór jednej z tych grup metod można uzasadnić merytoryczne, o tyle wybór konkretnego algorytmu metody w ramach danej grupy metod jest trudniejszy. Powszechność stosowania tych metod wynika z ich uniwersalności oraz stopnia poznania. Metody aglomeracyjne to metody hierarchiczne, działające według jednej centralnej procedury aglomeracyjnej, w których w wyniku wielu pojedynczych kroków analizy macierzy odległości między obiektami otrzymuje się zagnieżdżoną, hierarchiczną strukturę obiektów lub skupień obiektów podobnych. Uzyskany w ten sposób wynik jest najczęściej przedstawiany w postaci drzewa zwanego także dendrogramem. Do najbardziej popularnych należą algorytmy: pojedynczego wiązania, pełnego wiązania, średniej grupowej, ważonej średniej grupowej, średniego niepodobieństwa, Warda, czy mediany.

Metody podziałowe, optymalizując wstępny podział obiektów, dają w wyniku analizy różne, niezachodzące na siebie skupienia. Często są określane jako procedury niehierarchicznego grupowania obiektów, gdyż na wyjściu dają tylko jeden końcowy wynik podziału zbioru analizowanych obiektów. Najbardziej znane algorytmy podziałowe to $k$-średnich oraz PAM.

Ze względu na nieduży zbiór obiektów będących przedmiotem niniejszej analizy oraz trudności, jakie z reguły pojawiają się przy ustaleniu liczby poszukiwanych klas (kolejny krok analizy) powodujące konieczność przeanalizowania większej liczby potencjalnych rozwiązań, na potrzeby analizy skupień innowacyjności przedsiębiorstw przemysłu spożywczego w Polsce wykorzystane zostaną metody aglomeracyjne. Analiza własności metod aglomeracyjnych pod względem ich zdolności do tworzenia spójnych i izolowanych klas oraz fakt uwzględniania, bądź nieuwzględniania liczby obiektów przy wyznaczaniu odległości międzygrupowych, pozwoliły na wybór spośród nich algorytmów charakteryzujących się „pożądanymi własnościami”, tj. metody średniej grupowej oraz metody Warda [Gordon 1987, s. 123; Gordon 1996, s. 74-76].

Schemat analizy dla metod aglomeracyjnych działających według centralnej procedury aglomeracyjnej można przedstawić w następujących krokach [Johnson 1967, s. 245; Everitt i in. 2001, s. 61]: 
1. W macierzy odległości między obiektami wyszukuje się pary obiektów (w dalszych krokach skupień) najmniej do siebie niepodobnych, tj. o najmniejszej, niezerowej odległości między nimi - załóżmy, że są to podzbiory $K_{q}$ i $K_{r}$.

2. Redukuje się liczbę wszystkich występujących na danym etapie klas o jedną, łącząc zbiory $K_{q}, K_{r}$ i nadając im nazwę $K_{q}\left(K_{q} \Leftarrow K_{q} \cup K_{r}\right)$ - jednocześnie usuwa się zbiór $K_{r}$.

3. Wyznacza się nową macierz odległości pomiędzy połączonym zbiorem $K_{q}$ i wszystkimi innymi obiektami (skupieniami) według wzoru Lance'a i Williama:

$$
\begin{aligned}
& d\left(K_{q} \cup K_{r}, K_{s}\right)= \\
& =\alpha_{q} d\left(K_{q}, K_{s}\right)+\alpha_{r} d\left(K_{r}, K_{s}\right)+\beta d\left(K_{q}, K_{r}\right)+\gamma\left|d\left(K_{q}, K_{s}\right)-d\left(K_{r}, K_{s}\right)\right| .
\end{aligned}
$$

Tabela 5.1. Parametry metod aglomeracyjnych (hierarchicznych) analizy skupień *

\begin{tabular}{|l|c|c|c|c|}
\hline \multicolumn{1}{|c|}{ Metoda } & $\alpha_{q}$ & $\alpha_{r}$ & $\beta$ & $\gamma$ \\
\hline Pojedynczego wiązania & $\frac{1}{2}$ & $\frac{1}{2}$ & 0 & $-\frac{1}{2}$ \\
\hline Pełnego wiązania & $\frac{1}{2}$ & $\frac{1}{2}$ & 0 & $\frac{1}{2}$ \\
\hline Średniej grupowej & $\frac{n_{q}}{n_{q}+n_{r}}$ & $\frac{n_{r}}{n_{q}+n_{r}}$ & 0 & 0 \\
\hline Ważonej średniej grupowej & $\frac{1}{2}$ & $\frac{1}{2}$ & 0 & 0 \\
\hline $\begin{array}{l}\text { Średniego niepodobieństwa } \\
\text { (odległości) }\end{array}$ & $\frac{\left(\begin{array}{c}n_{q}+n_{s} \\
2\end{array}\right)}{\left(\begin{array}{c}n_{+} \\
2\end{array}\right)}$ & $\frac{\left(\begin{array}{c}n_{r}+n_{s} \\
2\end{array}\right)}{\left(\begin{array}{c}n_{+} \\
2\end{array}\right)}$ & $\frac{\left(\begin{array}{c}n_{q}+n_{r} \\
2\end{array}\right)}{\left(\begin{array}{c}n_{+} \\
2\end{array}\right)}$ & 0 \\
\hline Wewnątrzklasowej sumy kwadratów & $\frac{n_{q}+n_{s}}{n_{+}}$ & $\frac{n_{r}+n_{s}}{n_{+}}$ & $\frac{n_{q}+n_{r}}{n_{+}}$ & 0 \\
\hline Powiększonej sumy kwadratów (Warda) & $\frac{n_{q}+n_{s}}{n_{+}}$ & $\frac{n_{r}+n_{s}}{n_{+}}$ & $\frac{-n_{s}}{n_{+}}$ & 0 \\
\hline Środka ciężkości & $\frac{n_{q}}{n_{q}+n_{r}}$ & $\frac{n_{r}}{n_{q}+n_{r}}$ & $\frac{-n_{q} n_{r}}{\left(n_{q}+n_{r}\right)^{2}}$ & 0 \\
\hline Mediany & $\frac{1}{2}$ & $\frac{1}{2}$ & $-\frac{1}{4}$ & 0 \\
\hline Giętka & $\frac{1}{2}(1-\beta)$ & $\frac{1}{2}(1-\beta)$ & $\beta(\beta<1)$ & 0 \\
\hline
\end{tabular}

${ }^{*}$ Łączna liczba obiektów w skupieniach q, r, s: $n_{+}=n_{q}+n_{r}+n_{s}$.

Ź ró dło : opracowanie własne (dotyczy wszystkich tabel w rozdz. 5). 
4. Powtarza się kroki od 1 do 3, dopóki wszystkie obiekty nie zostaną przypisane do jednego skupienia.

Różnice pomiędzy metodami aglomeracyjnymi wynikają z odmienności sposobu definiowania odległości międzygrupowej wyznaczanej w etapie 3) powyższej procedury poprzez odpowiednie parametry wzoru (5.21) - zob. tab. 5.1.

Zaletą metod aglomeracyjnych jest to, że nie wymagają określania liczby poszukiwanych skupień obiektów podobnych przed przystąpieniem do analizy. Wybór wyniku, tj. podziału zbioru obiektów i tym samym liczby skupień jest dokonywany na podstawie wykresu drzewa, poprzez zastosowanie właściwych metod oceny wyników grupowania - a więc niejako post factum z wykorzystaniem uzyskanego wyniku grupowania, co nie komplikuje całego schematu analizy. Warto bowiem pamiętać, że liczba możliwych podziałów $n$ analizowanych obiektów na $u$ skupień (klas) jest bardzo duża i wynosi:

$$
K(n, u)=\frac{1}{u !} \sum_{q=1}^{u}(-1)^{u-q}\left(\begin{array}{l}
u \\
q
\end{array}\right) q^{n}
$$

przykładowo dla $K(5,3)=25, K(10,3)=9330$, a dla $K(50,4) \approx 5,3 \times 10^{28}$.

Nietrywialne wyniki podziału analizowanego zbioru danych, połączone z oceną wyników grupowania, uzyskuje się wykorzystując zaawansowane „reguły zatrzymania" zaproponowane przez Mojenę [Mojena 1977, s. 359-363], badane przez Mojenę i Wisharta i zaimplementowane w programie Clustangraphics 8 [Wishart 2006].

Reguła górnego obszaru odrzucenia (Upper Tail Rule) polega na analizie istotności różnic odległości wiązania kolejnych obiektów na wykresie drzewa poczynając od wyniku podziału obiektów na $n, n-1, \ldots, 1$ skupień i przesuwając się zgodnie z kierunkiem łączenia obiektów na wykresie drzewa. Każdy dendrogram dla $n$ obiektów można traktować jak zbiór wyników analizy skupień, tj. podziałów $K_{0}, K_{1}, \ldots, K_{n-1}$ oraz związanych z nimi kolejnych odległości łączenia obiektów na wykresie drzewa $h_{0}, h_{1}, \ldots, h_{n-1}$, przy czym (subskrypt) $0,1, \ldots, n-1$ odnosi się do wyniku podziału obiektów na $n, n-1, \ldots, 1$ skupień. Na podstawie $n-1$ wartości $h_{1}, \ldots, h_{n-1}$ połączeń wszystkich $n$ analizowanych obiektów w skupienia wyznacza się ich wartość średnią $\bar{h}(e)$ i odchylenie standardowe $S_{h(e)}$. Do oceny istotności każdego e-tego kroku w hierarchicznej procedurze grupowania oraz związanego z nim poziomu $h$ łączenia kolejnego obiektu w dendrogramie wykorzystuje się statystykę t-Studenta. Poszukuje się pierwszego poziomu wiązania obiektów na wykresie drzewa (krok), w którym nastąpi odrzucenie hipotezy $H_{0}$ o nieistotności różnic pomiędzy kolejnymi wiązaniami, na rzecz hipotezy alternatywnej $H_{1}$ stwierdzającej ich istotność. $Z$ ciągu klasyfikacji wybiera się podział (krok $e=1, \ldots, n-2)$, który pierwszy spełnia nierówność: 
$U T R: h(e+1)>\bar{h}+a S_{h}$,

przy czym: $h(e+1)$ to poziom łączenia obiektów w skupienia w kroku $e+1$ ustalony na podstawie analizowanego zbioru danych; parametr $a \in\langle 2,75-3,5\rangle$ stanowi regułę „błędu” i umożliwia uzyskanie nietrywialnego wyniku podziału obiektów.

W przypadku metod aglomeracyjnych tracą na znaczeniu: porównywanie parami wyników uzyskanych różnymi metodami analizy; testowanie, replikacja analizy, które można zastąpić samą oceną jakości wyniku grupowania i wyborem właściwego wyniku grupowania. Ze względu na uniwersalność z reguły do tego celu wykorzystywany jest indeks sylwetkowy $S I(u)$, nazywany całkowitym indeksem sylwetkowym GSI (Global Silhouette Index), który można stosować zarówno w przypadku metod aglomeracyjnych i podziałowych. Wartości indeksu sylwetkowego wyznacza się na podstawie, kolejno: cząstkowych ocen $s(i)$ przynależności każdego obiektu do skupienia, agregowanych w kolejnym kroku dla poszczególnych skupień wartości $S(q)$ (5.24), wartości $S I(u)$ (5.25) będącej łączną oceną całego grupowania:

$$
\begin{aligned}
& S(q)=\frac{1}{n_{q}} \sum_{i=1}^{n_{q}} s(i), \text { gdzie } s(i)=\frac{b(i)-a(i)}{\max \{a(i) ; b(i)\}}, \\
& G S I=S I(u)=\frac{1}{u} \sum_{q=1}^{u} S(q),
\end{aligned}
$$

gdzie:

$a(i)$ - średnia odległość $i$ - tego obiektu od wszystkich pozostałych obiektów w skupieniu $K_{q}$,

$b(i)$ - minimalna przeciętna odległość $i$ - tego obiektu w skupieniu $K_{q}$.

Z konstrukcji indeksu cząstkowego $s(i)$ wynika, że $s(i) \in\langle-1,1\rangle$, przy czym: jeżeli obiekt $i$ jest niepoprawnie zaklasyfikowany to $s(i) \in\langle-1,0)$; w przypadku obiektu $i$ tworzącego skupienie jednoelementowe $s(i)=0$; a wraz ze wzrostem stopnia przynależności obiektu $i$ do skupienia $s(i) \in(0,1\rangle$, dlatego też ostatecznie wartość $G S I \in\langle 0,1\rangle$. Wartość $G S I>0,71$ wskazuje na silną strukturę uzyskanych grup; $G S I \in\langle 0,51 ; 0,70\rangle$ potwierdza sensowną strukturę grupowania; $G S I \in\langle 0,26$; $0,50\rangle$ mówi, że wyodrębniona struktura jest słaba, a wynik analizy skupień może być sztuczny (być może należy zastosować inną metodę analizy); natomiast wynik $G S I \leq 0,25$ nakazuje odrzucić uzyskane rozwiązania - wskazując na brak skupień w zbiorze danych [Kaufman, Rousseeuw 1990, s. 88].

Końcowym etapem analizy skupień jest interpretacja i opis wyniku grupowania (uzyskanych skupień) oraz ocena zgodności grupowania obiektów w czasie. 


\subsection{Wstępna analiza danych - dobór wskaźników diagnostycznych}

W pierwszym kroku wstępnej analizy danych ze zbioru potencjalnych wskaźników diagnostycznych przyjętych do oceny innowacyjności branż przemysłu spożywczego w Polsce wyeliminowano zmienne o numerach 16, 17, 18 z brakami danych, które wynikały głównie ze zmian metodologii badania PNT-02.

W kolejnym kroku na podstawie miar statystyki opisowej (położenia, rozstępu, zmienności) dokonano oceny przydatności pozostałych wskaźników do analizy. Pozostałe 19 wskaźników charakteryzowało się dostateczną zmiennością $\left|v_{j}\right|>10 \%$ oraz dostateczną amplitudą wahań.

W ostatnim kroku wstępnej analizy danych oceniono skorelowanie potencjalnych wskaźników diagnostycznych, celem redukcji i doboru finalnego zestawu wskaźników diagnostycznych. Metodę odwróconej macierzy korelacji zaproponowaną przez Zeliasia i Malinę w 1998 r. rozszerzono tak, aby uzyskać ten sam zestaw wskaźników diagnostycznych dla każdego roku analizy, tzn.:

- Celem dalszej redukcji zbioru potencjalnych cech diagnostycznych dla poszczególnych lat analizy $t(t=2004, \ldots, 2008)$, usunięto wskaźniki diagnostyczne (wiersze $j$ ), dla których suma wartości bezwzględnych współczynników korelacji w wierszu macierzy korelacji $R$ była największa. Przy sumowaniu współczynników w wierszu $j$ macierzy korelacji $R$ brano pod uwagę tylko zmienne silnie skorelowane $\left(r_{j \bullet}>0,5\right)$. Tym samym z analizy usunięto wskaźniki diagnostyczne najsilniej (łącznie) skorelowane z pozostałymi analizowanymi wskaźnikami. Dla każdego roku uzyskano nieco inny, mniej liczny, zestaw wskaźników diagnostycznych, przy czym wyeliminowano te same wskaźniki, zbyt mocno skorelowane w całym okresie analizy, w latach 2004-2008.

- W trzecim kroku analizy korelacji, w wyniku dalszej redukcji zbioru potencjalnych wskaźników diagnostycznych, celem uzyskania jednakowego zbioru cech w całym badanym okresie dla poszczególnych lat analizy $t(t=2004, \ldots$, 2008) usunięto wskaźniki (wiersze $j$ ), dla których suma wartości bezwzględnych współczynników korelacji w wierszu macierzy korelacji była największa. Brano pod uwagę wskaźniki $j$ o najwyższych wartościach bezwzględnych współczynników korelacji $\left(\max _{j, p} r_{j p}\right)$. Tym samym z analizy usunięto pojedyncze zmienne, najsilniej skorelowane z pozostałymi analizowanymi cechami.

Podsumowując, w wyniku analizy korelacji usunięto $\mathrm{z}$ dalszej analizy wskaźniki o numerach: 2, 5, 19 (pozostało 16 wskaźników); 3 i 8 (pozostało 14 wskaźników) oraz 4, 12, 15, 20, 21, 22 i 14 (pozostało 7 wskaźników). Ostatecznie do budowy rankingów innowacyjności przedsiębiorstw klas przemysłu spożywczego wykorzystano zestaw 7 wskaźników diagnostycznych zamieszczonych $\mathrm{w}$ tab. 5.2, które potraktowano jako stymulanty oceny innowacyjności przedsiębiorstw. 
Pod względem pierwszego z wymienionych wskaźników diagnostycznych, tj. liczby przedsiębiorstw innowacyjnych jako odsetek ogółu przedsiębiorstw, w 2004 r. na tle wszystkich analizowanych klas przemysłu spożywczego wyróżniały się klasy - przemysłu tytoniowego (100\%), spirytusowego $(90,2 \%)$ i olejarskiego $(85,6 \%)$, w których odsetek przedsiębiorstw innowacyjnych był największy. Także w 2008 r. w wymienionych klasach przemysłu spożywczego odnotowano najwyższe wartości omawianego wskaźnika, z tym, że uległy one zmniejszeniu i wyrównaniu, powodując zmianę kolejności klas przemysłu w rankingu - olejarski $(69,7 \%)$, spirytusowy $(69,0 \%)$ i tytoniowy $(64,4 \%)$. Wspomniane klasy przedsiębiorstw przemysłu spożywczego w całym badanym okresie zajmowały naprzemiennie pierwsze trzy miejsca w rankingach. Najsłabiej prezentowały się przedsiębiorstwa przetwórstwa rybnego (2004 r., 33,4\%) i przemysłu piekarskiego (2008 r., 17,4\%), w których odnotowano najniższy odsetek przedsiębiorstw innowacyjnych - zob. rys. 5.1.

Tabela 5.2. Wskaźniki diagnostyczne innowacyjności klas przemysłu spożywczego

\begin{tabular}{|c|c|l|}
\hline Symbol * & Preferencje** & \multicolumn{1}{c|}{ Wyszczególnienie } \\
\hline$Z 1$ & $\mathrm{~S}$ & Przedsiębiorstwa innowacyjne w \% ogółu przedsiębiorstw \\
\hline$Z 6$ & $\mathrm{~S}$ & $\begin{array}{l}\text { Nakłady przypadające na 1 przedsiębiorstwo prowadzące } \\
\text { działalność innowacyjną (w tys. zł) }\end{array}$ \\
\hline$Z 7$ & $\mathrm{~S}$ & Nakłady na B+R w \% nakładów na działalność innowacyjną \\
\hline$Z 9$ & $\mathrm{~S}$ & $\begin{array}{l}\text { Nakłady na zakup gotowej technologii w \% nakładów na } \\
\text { działalność innowacyjną }\end{array}$ \\
\hline$Z 10$ & $\mathrm{~S}$ & $\begin{array}{l}\text { Nakłady na oprogramowanie w \% nakładów na działalność } \\
\text { innowacyjną }\end{array}$ \\
\hline$Z 13$ & $\mathrm{~S}$ & $\begin{array}{l}\text { Nakłady inwestycyjne na budynki i budowle oraz grunty w \% } \\
\text { nakładów na działalność innowacyjną }\end{array}$ \\
\hline
\end{tabular}

*Symbol wskaźnika odpowiada ich numeracji w rozdz. 5.1.

${ }^{* *} \mathrm{~S}-$ stymulanta.

Z punktu widzenia nakładów przypadających na 1 przedsiębiorstwo prowadzące działalność innowacyjną (w tys. zł) w pierwszych trzech latach badanego okresu (2004-2006) wyróżniała się branża tytoniowa, w której odnotowano najwyższe nakłady przypadające na 1 przedsiębiorstwo. W 2007 r. najwyższą wartość omawianego wskaźnika odnotowano wśród przedsiębiorstw przemysłu paszowego, a w 2008 r. wśród przedsiębiorstw przemysłu olejarskiego. 
Najniższe nakłady przypadające na 1 przedsiębiorstwo prowadzące działalność innowacyjną (w tys. zł) występowały: w 2004 r. w przemyśle spirytusowym, w 2005 r. w przemyśle piekarskim, a od 2006 r. w przemyśle winiarskim - zob. rys. 5.2.

Kolejny wskaźnik diagnostyczny przyjęty do analizy odnosi się do najważniejszej kategorii nakładów innowacyjnych, tzn. nakładów na $\mathrm{B}+\mathrm{R}$, związanych z opracowywaniem nowych i ulepszonych produktów (innowacji produktowych) i procesów (innowacji procesowych) w odsetku nakładów na działalność innowacyjną. $Z$ danych zamieszczonych na rysunku 5.3 wynika, że w większości klas przedsiębiorstw przemysłu spożywczego nie przekraczał on $4 \%$. Charakterystyczne jest, że wśród przedsiębiorstw przemysłu olejarskiego, cukrowniczego i winiarskiego tego rodzaju nakłady na przestrzeni badanego okresu w ogóle nie wystąpiły. Natomiast klasy przedsiębiorstw przemysły spożywczego, w których odnotowano najwyższy udział nakładów na B+R w wartości nakładów na działalność innowacyjną, to: przemysł piwowarski (20,2\%, 2004 r.), paszowy $(12,7 \%$ w 2005 r., $17,7 \%$ w 2006 r. i 30,9\% w 2008 r.) oraz przemysł ziemniaczany $(11,5 \%$ w 2007 r.).

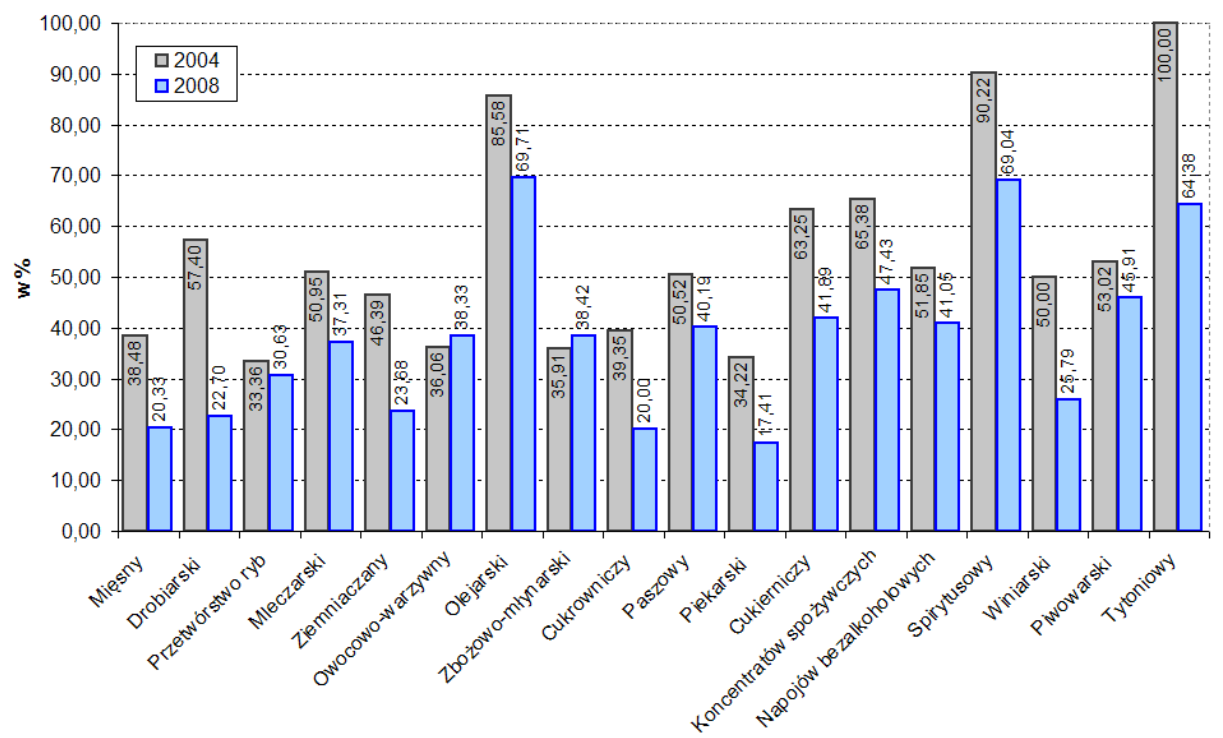

Rysunek 5.1. Przedsiębiorstwa innowacyjne jako odsetek ogółu przedsiębiorstw w klasach przemysłu spożywczego w latach 2004 i 2008

Źródło: opracowanie własne (dotyczy wszystkich rysunków w rozdz. 5). 


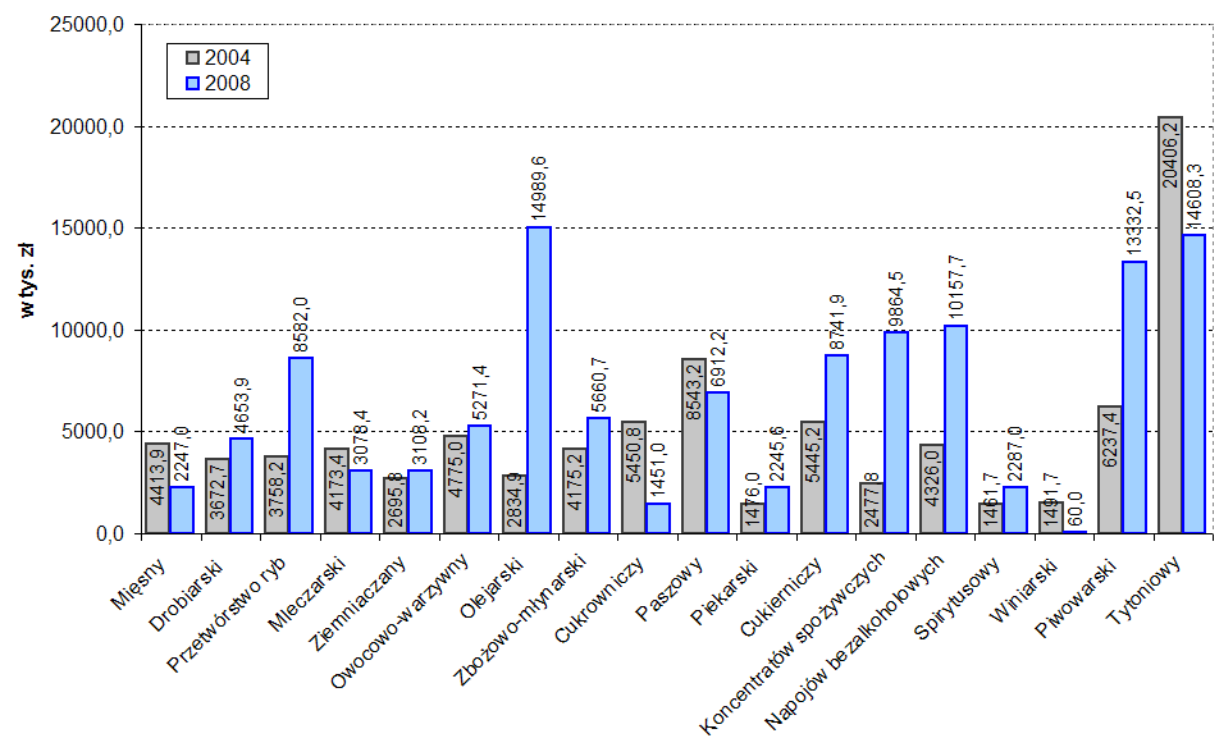

Rysunek 5.2. Nakłady przypadające na 1 przedsiębiorstwo prowadzące działalność innowacyjną w klasach przemysłu spożywczego w latach 2004 i 2008

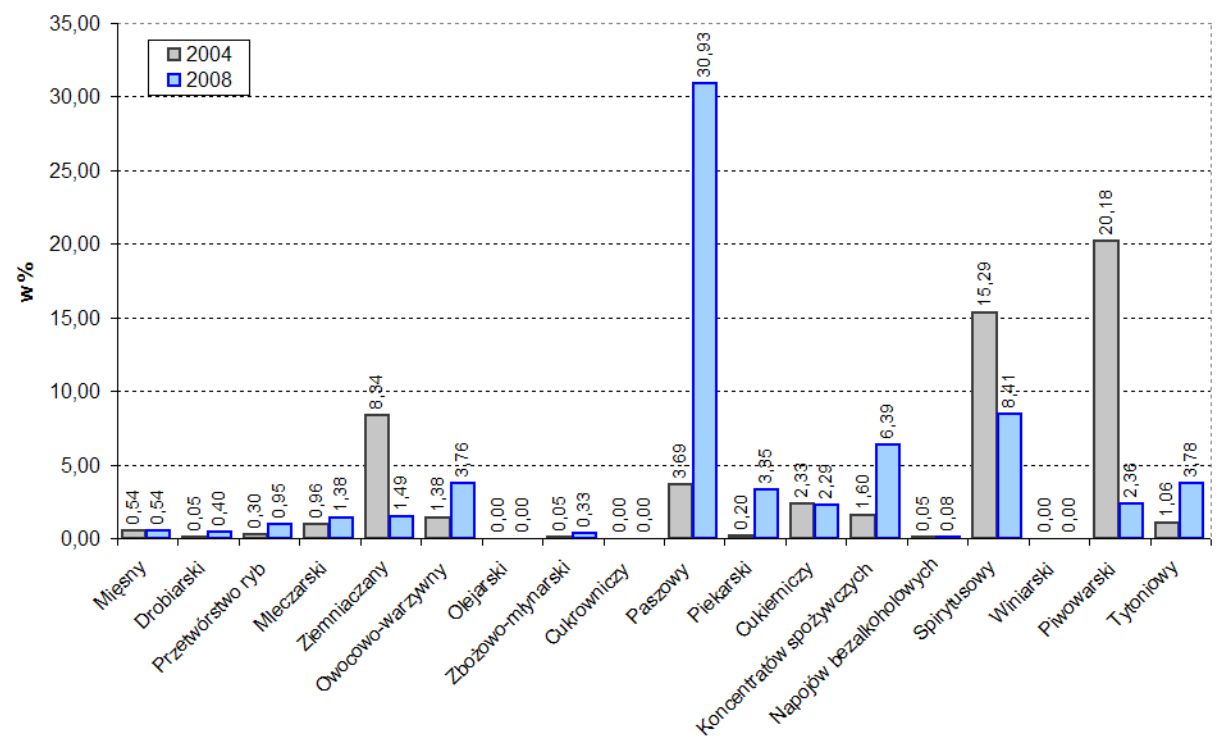

Rysunek 5.3. Nakłady na B+R jako odsetek nakładów na działalność innowacyjną w klasach przemysłu spożywczego w latach 2004 i 2008 


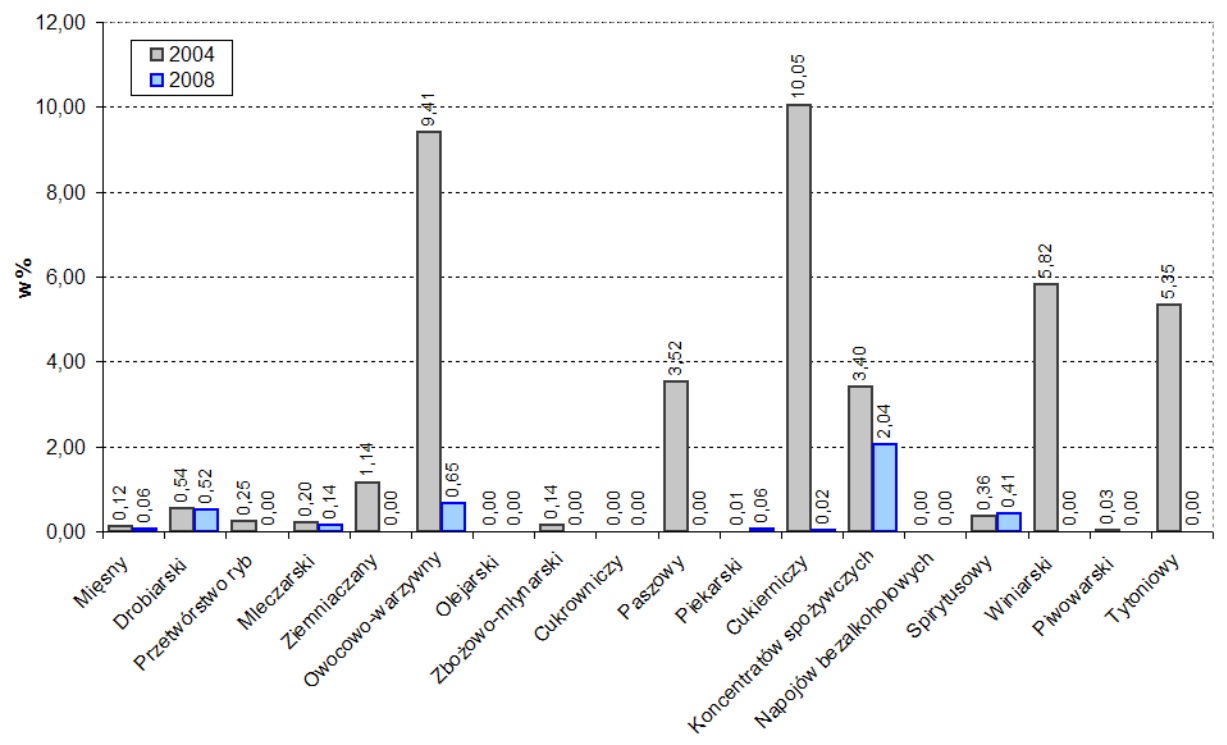

Rysunek 5.4. Nakłady na zakup gotowej technologii jako odsetek nakładów na działalność innowacyjną w klasach przemysłu spożywczego w latach 2004 i 2008

Podobną sytuację zaobserwować można pod względem wskaźnika nakładów na zakup gotowej technologii, tj. dokumentacji, praw (licencji, praw patentowych, know-how itp.) jako odsetka nakładów na działalność innowacyjną. Na przestrzeni badanego okresu jedynie w nielicznych klasach przedsiębiorstw przemysłu spożywczego wystąpiły tego rodzaju nakłady i wówczas stanowiły znaczną cześć nakładów na działalność innowacyjną. W 2004 r. i pod względem omawianego wskaźnika wyróżniły się przedsiębiorstwa przemysłu cukierniczego $(10,0 \%)$ i owocowo-warzywnego $(9,4 \%)$, a w 2008 r. przedsiębiorstwa przemysłu koncentratów spożywczych (2,0\%). Na rys. 5.4 można zauważyć, że udział tego rodzaju nakładów w 2008 r., w stosunku do 2004 r. uległ wyraźnemu zmniejszeniu.

Kolejny wskaźnik przyjęty do analizy to wskaźnik nakładów na oprogramowanie, tj. kosztów zakupu, opracowania (doskonalenia) i adaptacji (aktualizacji) oprogramowania, jako odsetek nakładów na działalność innowacyjną - zob. rys. 5.5. Najwyższy udział tego rodzaju nakładów odnotowano wśród przedsiębiorstw przemysłu piwowarskiego (14,9\% w 2004 r. i 11,8\% w 2006 r.), a także w przedsiębiorstwach przemysłu spirytusowego (5,7\% w 2005 r.), przemysłu koncentratów spożywczych $(3,3 \%$ w 2007 r.) oraz przemysłu owocowo-warzywnego $(9,1 \%$ w 2008 r.). Najniższy odsetek nakładów na oprogramowanie wystąpił wśród przedsiębiorstw przemysłu ziemniaczanego (2004 r., 2006 r.), paszowego (2005 r.), winiarskiego (2007-2008) i cukrowniczego (2008 r.), ich udział nie przekraczał $0,28 \%$. 


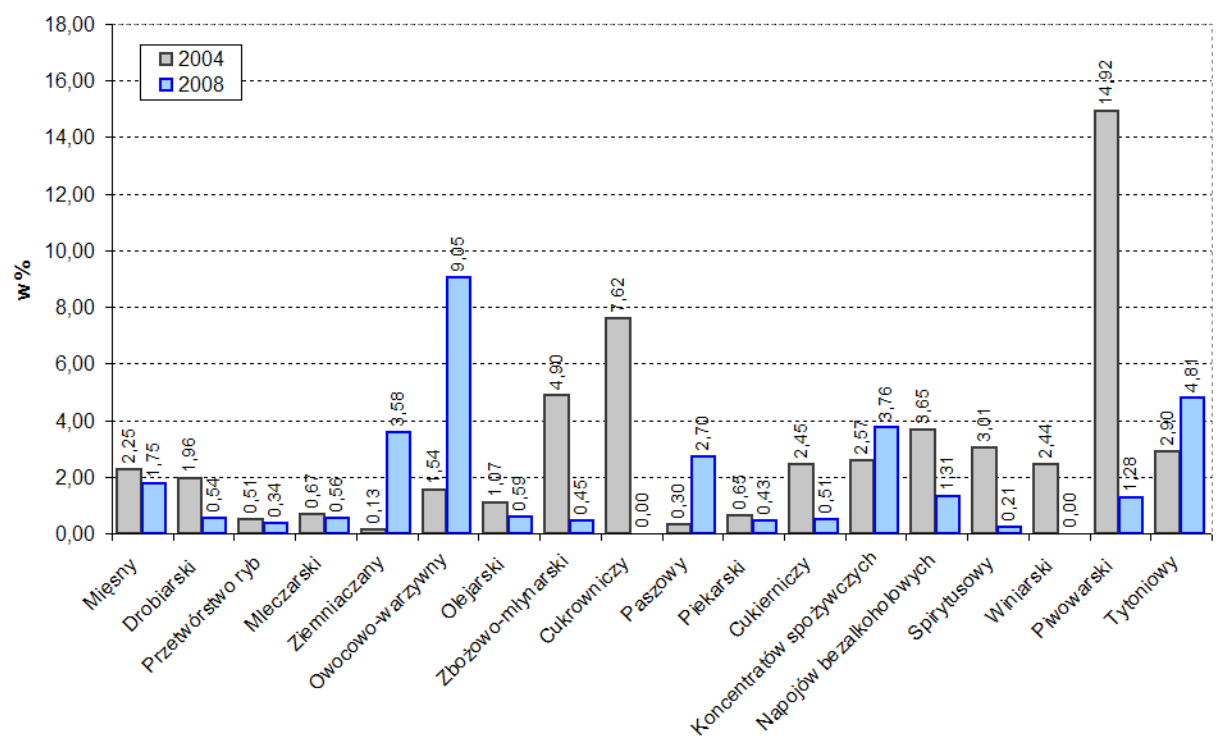

Rysunek 5. 5. Nakłady na oprogramowanie jako odsetek nakładów na działalność innowacyjną w klasach przemysłu spożywczego w latach 2004 i 2008

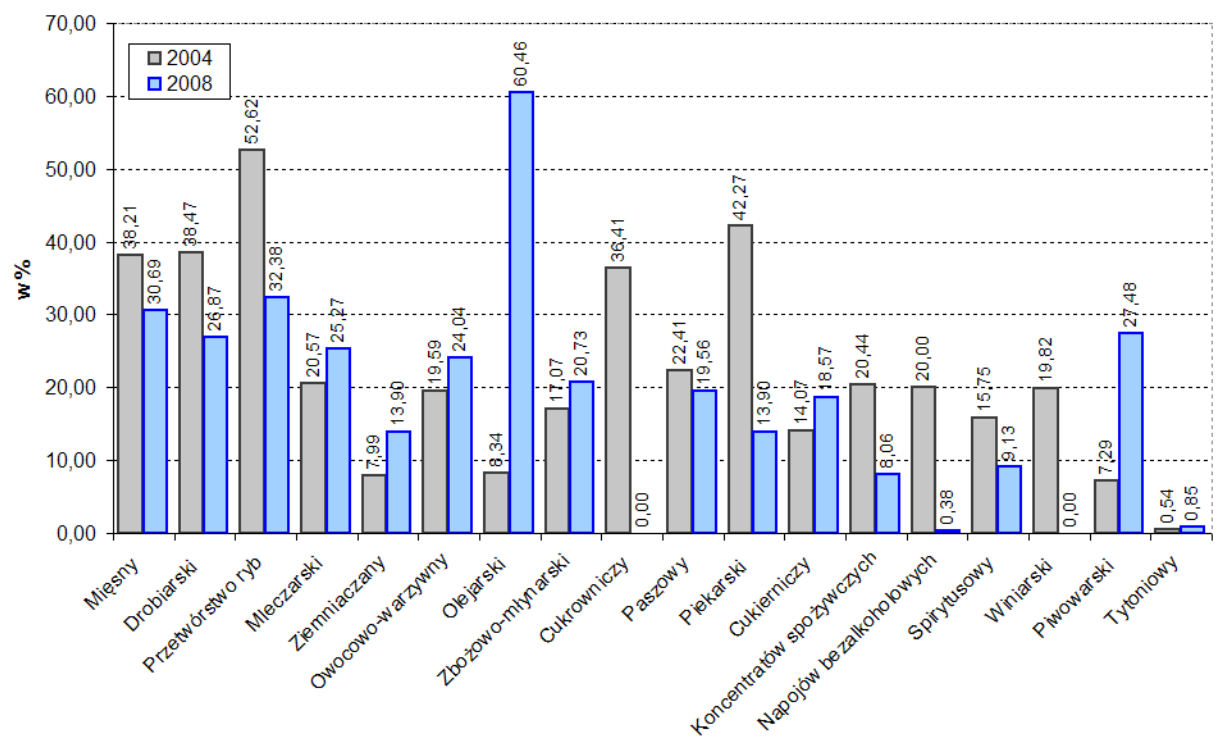

Rysunek 5. 6. Nakłady inwestycyjne na budynki i budowle oraz grunty jako odsetek nakładów na działalność innowacyjną w klasach spożywczego w latach 2004-2008 
Wartości dwóch ostatnich wskaźników innowacyjności przedsiębiorstw przemysłowych przyjętych do analizy, dotyczących udziału nakładów inwestycyjnych na budynki, budowle oraz grunty jako odsetek nakładów innowacyjnych ogółem (rys. 5.6) oraz udziału nakładów na maszyny i urządzenia techniczne z importu jako odsetek nakładów innowacyjnych ogółem (rys. 5.7) wskazują, że to właśnie tego rodzaju nakłady mają z reguły „duży udział” w nakładach innowacyjnych przedsiębiorstw przemysłowych. W 2004 r. najwyższy udział nakładów na budynki, budowle oraz grunty wystąpił w przedsiębiorstwach przetwórstwa rybnego $52,6 \%$, a w 2008 r. w przedsiębiorstwach przemysłu olejarskiego $60,5 \%$, podczas gdy najniższe nakłady odnotowano w 2004 r. w przedsiębiorstwach przemysłu tytoniowego $(0,5 \%)$, a w $2008 \mathrm{r}$. w przedsiębiorstwach przemysłu cukrowniczego i winiarskiego (brak nakładów).

Pod względem wskaźnika nakładów innowacyjnych przedsiębiorstw przemysłowych na maszyny i urządzenia techniczne z importu jako odsetek nakładów ogółem na tle wszystkich analizowanych klas przedsiębiorstw przemysłowych „pozytywnie" wyróżniły się przedsiębiorstwa: przemysłu tytoniowego (lata 2004-2006), piwowarskiego (2007 r.) i napojów bezalkoholowych, w których w odnotowano najwyższe wartości omawianego wskaźnika. Tymczasem w przedsiębiorstwach przemysłu paszowego (2004 r.), cukrowniczego (2005 r., 2008 r.) i winiarskiego (2006-2008) udział tego rodzaju nakładów był najmniejszy lub w ogóle one nie występowały.

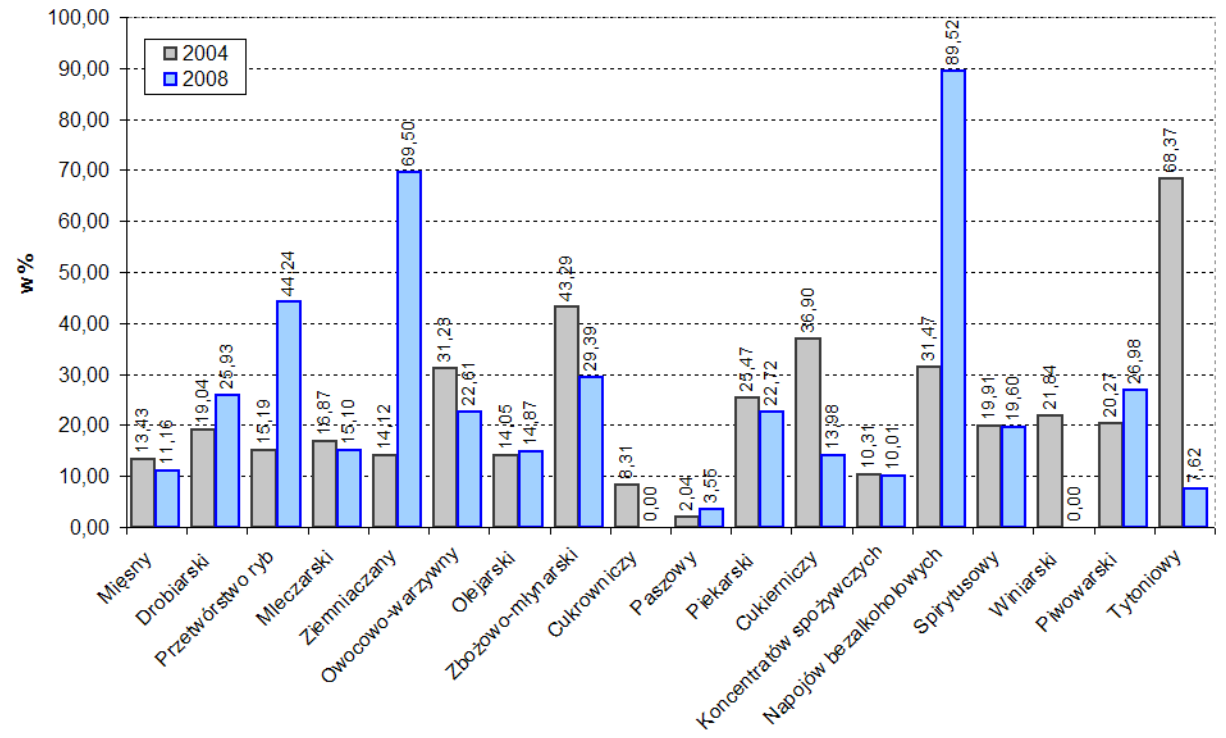

Rysunek 5.7. Nakłady inwestycyjne na maszyny i urządzenia techniczne z importu jako odsetek nakładów na działalność innowacyjną w klasach przemysłu spożywczego w latach 2004 i 2008 


\subsection{Syntetyczna ocena innowacyjności branż przemysłu spożywczego w latach 2004-2008}

Wyznaczając mierniki syntetyczne innowacyjności przedsiębiorstw przemysłu spożywczego w Polsce w latach 2004-2008 przyjęto system wag równych (zob. wzór 5.7), a obliczenia przeprowadzono w dwóch wariantach, z zastosowaniem: unitaryzacji wskaźników diagnostycznych (wariant I) i klasycznej standaryzacji wskaźników diagnostycznych (wariant II) - zob. tab. 5.3 i 5.4. W obliczeniach dokonano agregacji wskaźników diagnostycznych poprzez sumowanie ich znormalizowanych wartości. Daje ona dokładnie taki sam wynik porządkowania liniowego obiektów co agregacja według średniej arytmetycznej znormalizowanych wartości wskaźników diagnostycznych (zob. wzór 5.13).

Tabela 5.3. Charakterystyki liczbowe porządkowania liniowego przedsiębiorstw przemysłu spożywczego wraz z oceną jakości porządkowania dla wariantu I - unitaryzacja wskaźników diagnostycznych

\begin{tabular}{|l|c|c|c|c|c|c|c|c|c|c|}
\hline \multirow{2}{*}{\multicolumn{1}{|c|}{ Przemysł }} & \multicolumn{5}{|c|}{ Miernik syntetyczny $M$} & \multicolumn{5}{c|}{ Wartości $\left(\mu_{i}^{*}-\bar{\mu}^{*}\right)^{2}$} \\
\cline { 2 - 12 } & 2004 & 2005 & 2006 & 2007 & 2008 & 2004 & 2005 & 2006 & 2007 & 2008 \\
\hline Mięsny & 1,310 & 1,126 & 1,323 & 1,652 & 1,075 & 0,0007 & 0,0026 & 0,0008 & 0,0001 & 0,0017 \\
\hline Drobiarski & 1,642 & 1,464 & 1,437 & 1,780 & 1,470 & 0,0001 & 0,0011 & 0,0005 & 0 & 0,0004 \\
\hline Przetwórstwo ryb & 1,385 & 1,352 & 1,374 & 1,491 & 1,922 & 0,0005 & 0,0015 & 0,0006 & 0,0003 & 0 \\
\hline Mleczarski & 1,119 & 1,248 & 1,142 & 1,707 & 1,344 & 0,0014 & 0,0020 & 0,0014 & 0 & 0,0007 \\
\hline Ziemniaczany & 1,113 & 1,953 & 1,433 & 2,200 & 1,774 & 0,0014 & 0 & 0,0005 & 0,0004 & 0 \\
\hline $\begin{array}{l}\text { Owocowo- } \\
\text {-warzywny }\end{array}$ & 2,121 & 1,636 & 1,288 & 1,891 & 2,839 & 0,0003 & 0,0006 & 0,0009 & 0 & 0,0030 \\
\hline Olejarski & 1,250 & 1,850 & 3,337 & 2,511 & 3,231 & 0,0009 & 0,0001 & 0,0065 & 0,0014 & 0,0057 \\
\hline $\begin{array}{l}\text { Zbożowo- } \\
\text {-młynarski }\end{array}$ & 1,460 & 1,463 & 1,224 & 1,393 & 1,508 & 0,0003 & 0,0011 & 0,0011 & 0,0006 & 0,0003 \\
\hline Cukrowniczy & 1,590 & 1,990 & 1,731 & 1,048 & 0,143 & 0,0001 & 0 & 0 & 0,0018 & 0,0083 \\
\hline Paszowy & 1,596 & 3,418 & 2,875 & 1,826 & 2,556 & 0,0001 & 0,0053 & 0,0031 & 0 & 0,0015 \\
\hline Piekarski & 1,214 & 1,705 & 1,051 & 0,931 & 0,815 & 0,0010 & 0,0004 & 0,0018 & 0,0024 & 0,0030 \\
\hline Cukierniczy & 2,716 & 3,335 & 2,152 & 3,243 & 1,653 & 0,0024 & 0,0046 & 0,0003 & 0,0058 & 0,0001 \\
\hline $\begin{array}{l}\text { Koncentratów } \\
\text { spożywczych }\end{array}$ & 1,623 & 2,242 & 2,227 & 3,124 & 3,098 & 0,0001 & 0,0001 & 0,0004 & 0,0049 & 0,0047 \\
\hline $\begin{array}{l}\text { Napojów } \\
\text { bezalkoholowych }\end{array}$ & 1,486 & 1,650 & 1,460 & 1,368 & 2,282 & 0,0003 & 0,0005 & 0,0004 & 0,0006 & 0,0006 \\
\hline Spirytusowy & 2,403 & 2,786 & 2,670 & 2,199 & 2,002 & 0,0011 & 0,0015 & 0,0020 & 0,0004 & 0,0001 \\
\hline Winiarski & 1,655 & 2,335 & 0,737 & 0 & 0,160 & 0,0001 & 0,0002 & 0,0035 & 0,0098 & 0,0081 \\
\hline Piwowarski & 2,955 & 2,035 & 2,288 & 1,977 & 2,408 & 0,0039 & 0 & 0,0006 & 0,0001 & 0,0010 \\
\hline Tytoniowy & 3,772 & 3,751 & 3,344 & 2,595 & 2,625 & 0,0113 & 0,0082 & 0,0066 & 0,0017 & 0,0019 \\
\hline$s^{2}\left(M^{*}\right)$ & $\mathbf{x}$ & $\mathbf{x}$ & $\mathbf{x}$ & $\mathbf{x}$ & $\mathbf{x}$ & $\mathbf{0 , 0 0 1 4}$ & $\mathbf{0 , 0 0 1 7}$ & $\mathbf{0 , 0 0 1 7}$ & $\mathbf{0 , 0 0 1 7}$ & $\mathbf{0 , 0 0 2 3}$ \\
\hline
\end{tabular}


W kolejnej tabeli zaprezentowano wyniki porządkowania liniowego przedsiębiorstw przemysłu spożywczego dla II wariantu (klasyczna standaryzacja wskaźników diagnostycznych).

Tabela 5.4. Charakterystyki liczbowe porządkowania liniowego przedsiębiorstw przemysłu spożywczego wraz z oceną jakości porządkowania dla wariantu II - klasyczna standaryzacja wskaźników diagnostycznych

\begin{tabular}{|l|c|c|c|c|c|c|c|c|c|c|}
\hline \multirow{2}{*}{\multicolumn{1}{|c|}{ Przemysł }} & \multicolumn{4}{|c|}{ Miernik syntetyczny $M$} & \multicolumn{5}{c|}{ Wartości $\left(\mu_{i}^{*}-\bar{\mu}^{*}\right)^{2}$} \\
\cline { 2 - 11 } & 2004 & 2005 & 2006 & 2007 & 2008 & 2004 & 2005 & 2006 & 2007 & 2008 \\
\hline Mięsny &, 737 & $-3,609$ & $-1,979$ & $-0,849$ & $-1-2,596$ & 0,0088 & 0,0380 & 0,0114 & 0,0021 & 0,0197 \\
\hline Drobiarski & $-0,580$ & $-2,316$ & $-1,462$ & $-0,396$ & $-1,131$ & 0,0010 & 0,0156 & 0,0062 & 0,0005 & 0,0037 \\
\hline Przetwórstwo ryb & $-1,492$ & $-2,816$ & $-1,713$ & $-1,282$ & 0,330 & 0,0065 & 0,0231 & 0,0086 & 0,0048 & 0,0003 \\
\hline Mleczarski & $-2,585$ & $-2,883$ & $-2,744$ & $-0,577$ & $-1,782$ & 0,0195 & 0,0242 & 0,0220 & 0,0010 & 0,0093 \\
\hline Ziemniaczany & $-2,839$ & $-0,352$ & $-1,557$ & 1,144 & 0,056 & 0,0235 & 0,0004 & 0,0071 & 0,0038 & 0,0000 \\
\hline $\begin{array}{l}\text { Owocowo- } \\
\text {-warzywny }\end{array}$ & 0,861 & $-1,551$ & $-2,071$ & 0,249 & 4,185 & 0,0022 & 0,0070 & 0,0125 & 0,0002 & 0,0511 \\
\hline Olejarski & $-2,318$ & $-0,699$ & 5,504 & 2,622 & 4,797 & 0,0157 & 0,0014 & 0,0883 & 0,0200 & 0,0671 \\
\hline $\begin{array}{l}\text { Zbożowo- } \\
\text {-młynarski }\end{array}$ & 0,793 & $-2,189$ & $-2,490$ & $-1,829$ & $-1,310$ & 0,0018 & 0,0140 & 0,0181 & 0,0098 & 0,0050 \\
\hline Cukrowniczy & $-0,474$ & $-0,650$ & $-0,434$ & $-3,237$ & $-6,349$ & 0,0007 & 0,0012 & 0,0006 & 0,0306 & 0,1175 \\
\hline Paszowy & $-1,005$ & 4,731 & 4,553 & 0,145 & 3,241 & 0,0029 & 0,0653 & 0,0604 & 0,0001 & 0,0306 \\
\hline Piekarski & $-2,124$ & $-1,293$ & $-3,025$ & $-3,610$ & $-3,598$ & 0,0132 & 0,0049 & 0,0267 & 0,0380 & 0,0377 \\
\hline Cukierniczy & 3,042 & 4,575 & 1,296 & 5,929 & $-0,887$ & 0,0270 & 0,0610 & 0,0049 & 0,1025 & 0,0023 \\
\hline $\begin{array}{l}\text { Koncentratów } \\
\text { spożywczych }\end{array}$ & $-1,028$ & 0,716 & 1,479 & 5,116 & 5,032 & 0,0031 & 0,0015 & 0,0064 & 0,0763 & 0,0738 \\
\hline $\begin{array}{l}\text { Napojów } \\
\text { bezalkoholowych }\end{array}$ & $-0,915$ & $-1,317$ & $-1,470$ & $-1,764$ & 1,459 & 0,0024 & 0,0051 & 0,0063 & 0,0091 & 0,0062 \\
\hline Spirytusowy & 1,951 & 2,706 & 3,046 & 1,389 & 0,550 & 0,0111 & 0,0213 & 0,0271 & 0,0056 & 0,0009 \\
\hline Winiarski & $-0,913$ & 0,652 & $-4,334$ & $-7,325$ & $-6,292$ & 0,0024 & 0,0012 & 0,0548 & 0,1564 & 0,1154 \\
\hline Piwowarski & 4,839 & $-0,210$ & 1,702 & 1,093 & 1,869 & 0,0683 & 0,0001 & 0,0084 & 0,0035 & 0,0102 \\
\hline Tytoniowy & 8,110 & 6,504 & 5,698 & 3,182 & 2,425 & 0,1917 & 0,1233 & 0,0947 & 0,0295 & 0,0171 \\
\hline$s^{2}\left(M^{*}\right)$ & $\mathbf{x}$ & $\mathbf{x}$ & $\mathbf{x}$ & $\mathbf{x}$ & $\mathbf{x}$ & $\mathbf{0 , 0 2 2 3}$ & $\mathbf{0 , 0 2 2 7}$ & $\mathbf{0 , 0 2 5 8}$ & $\mathbf{0 , 0 2 7 4}$ & $\mathbf{0 , 0 3 1 6}$ \\
\hline
\end{tabular}

Opierając się na kryterium maksymalizacji wariancji kierunkowej miernika syntetycznego, która w tym przypadku wymagała przekształcenia wartości miernika syntetycznego $M$ na wynik rzutowania ortogonalnego obiektów na prostą $M^{*}$ (zob. rozdz. 5.2), za „lepszy” ranking innowacyjności przedsiębiorstw przemysłu spożywczego uznano wyniki uzyskane w wariancie II analizy - zob. tab. 5.3. i 5.4. 
Aby możliwe było pełne porównywanie wartości mierników syntetycznych innowacyjności przedsiębiorstw przemysłu spożywczego w czasie, a nie tylko w ramach klas przemysłu spożywczego w danym okresie, dokonano przeliczenia mierników syntetycznych z wykorzystaniem standaryzacji wskaźników diagnostycznych względem czasu $T$ w całym badanym okresie 2004-2008 (zob. wzór 5.12). Uzyskane wyniki przedstawiono na rysunkach 5.8-5.12.

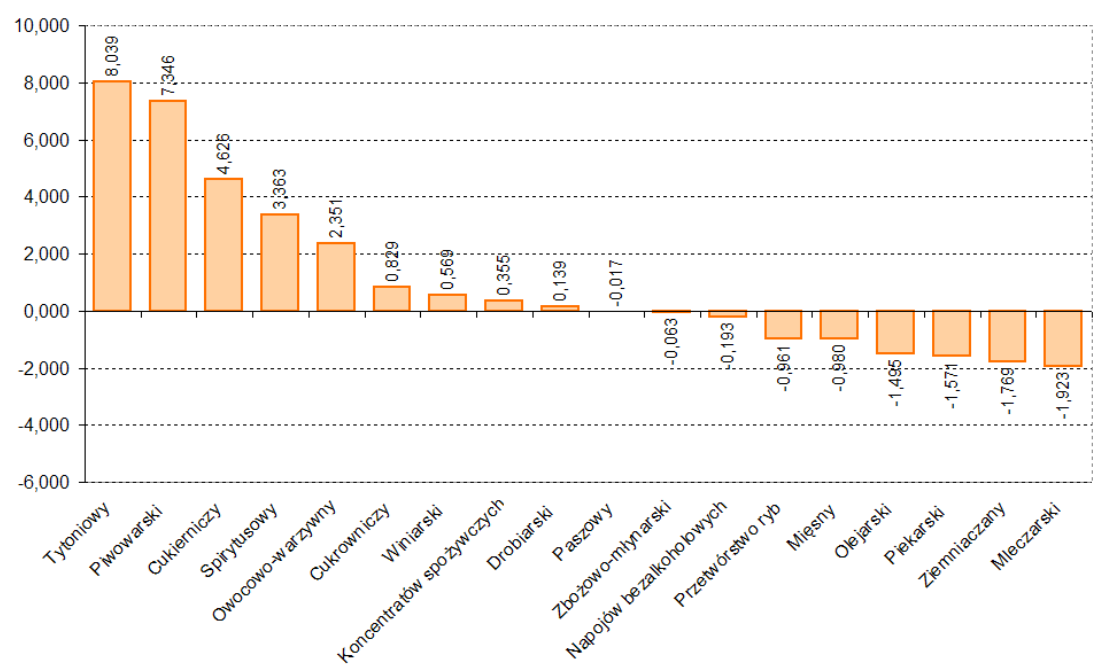

Rysunek 5. 8. Ranking innowacyjności przedsiębiorstw przemysłu spożywczego w Polsce w 2004 r. (standaryzacja wskaźników w czasie)

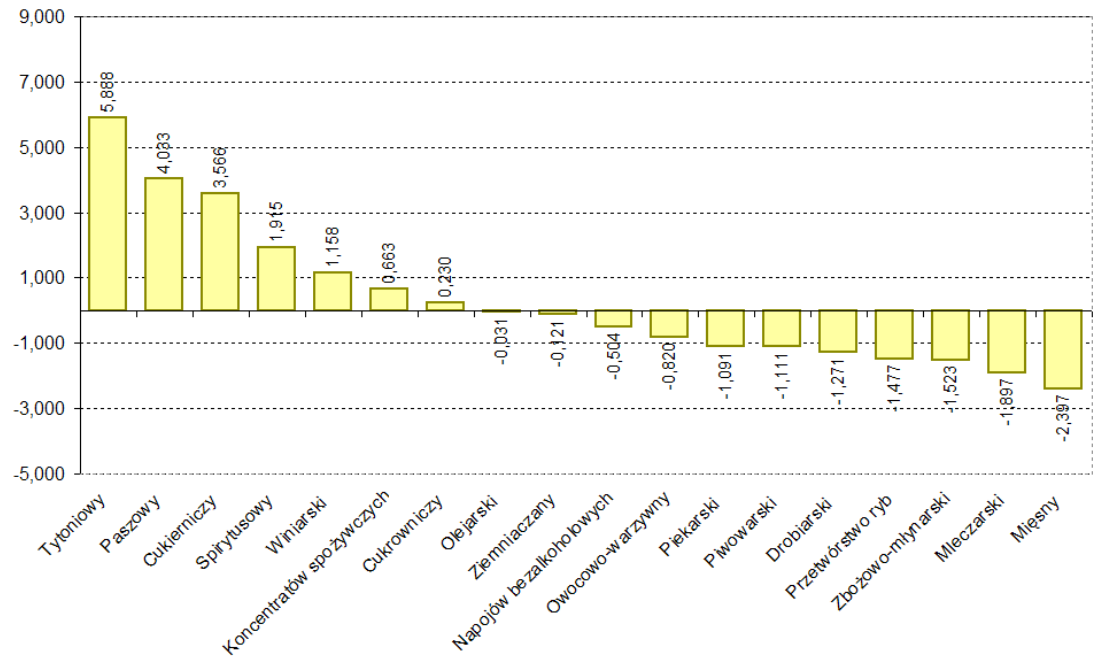

Rysunek 5. 9. Ranking innowacyjności przedsiębiorstw przemysłu spożywczego w Polsce w 2005 r. (standaryzacja wskaźników w czasie) 


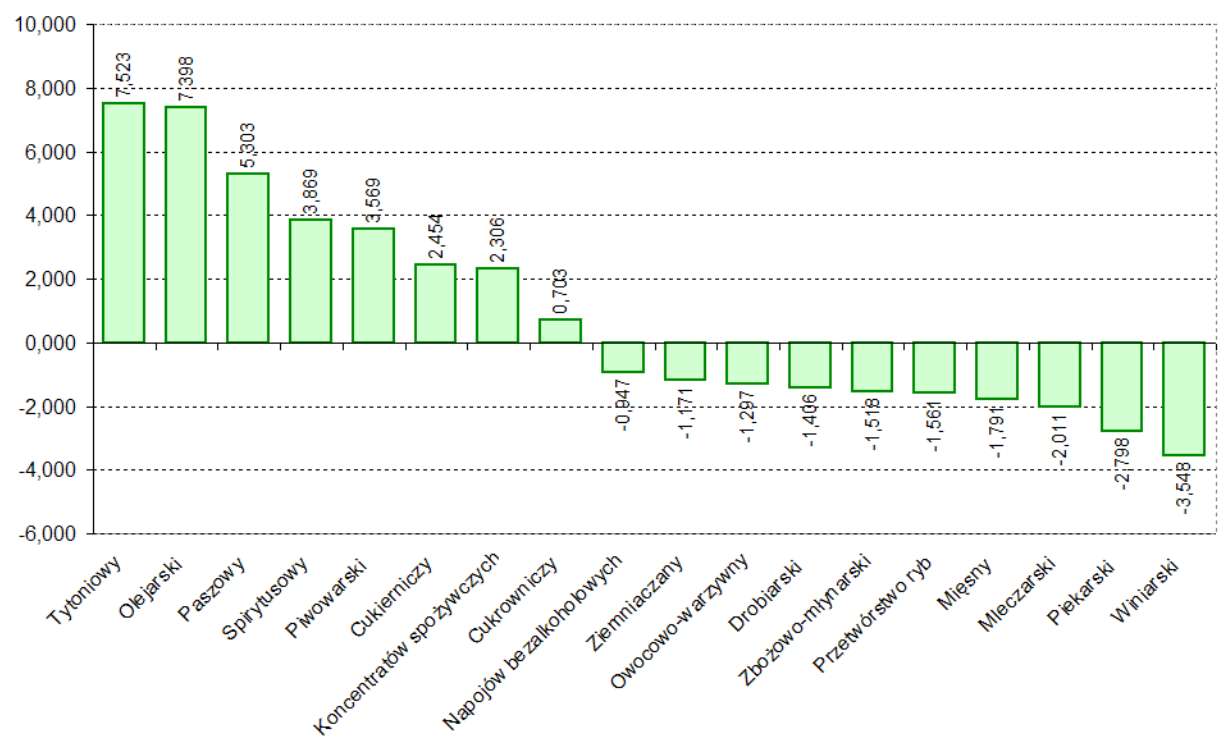

Rysunek 5.10. Ranking innowacyjności przedsiębiorstw przemysłu spożywczego w Polsce w 2006 r. (standaryzacja wskaźników w czasie)

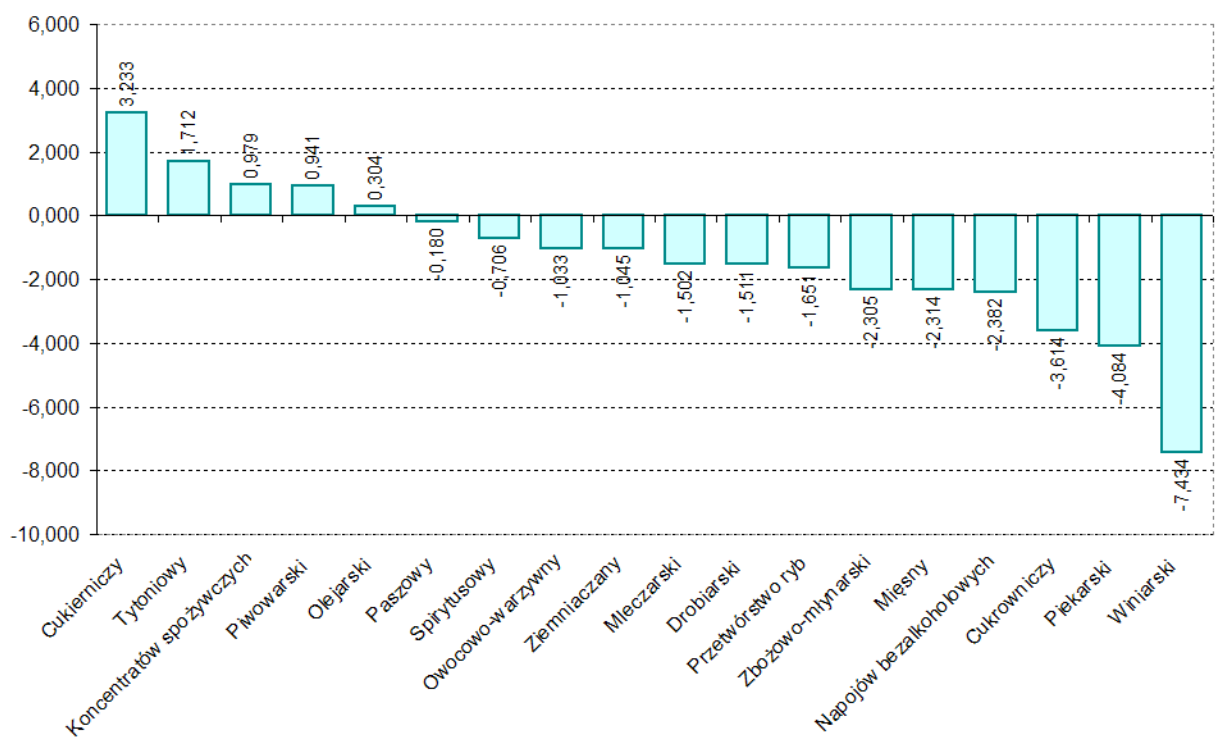

Rysunek 5.11. Ranking innowacyjności przedsiębiorstw przemysłu spożywczego w Polsce w 2007 r. (standaryzacja wskaźników w czasie) 
Jeśli porównać wyniki rankingów uzyskane w wariancie II analizy (klasyczna standaryzacja) oraz wyniki z wykorzystaniem standaryzacji wskaźników diagnostycznych względem czasu $T$ (w całym badanym okresie 2004-2008) to okazuje się, że z reguły klasy przedsiębiorstw przemysły spożywczego znajdujące się na pierwszych i ostatnich miejscach w rankingach dla danego roku pokrywają się, niemniej jednak są też między nimi różnice. Dla pełnej zgodności analizy w czasie należy porównywać wyniki analiz zamieszczone na wykresach (standaryzacja wskaźników diagnostycznych względem czasu $T$ ) oraz traktować je jako ostateczny wynik oceny innowacyjności przedsiębiorstw przemysłu spożywczego w Polsce, w latach 2004-2008.

Analiza korelacji wskaźników diagnostycznych z wartościami miernika syntetycznego dla poszczególnych okresów analizy (lata 2004-2008) wykazała zgodność kierunku skorelowania (korelacja dodatnia) i siły oddziaływania wskaźników na wartość miernika, co wskazuje na poprawny dobór zmiennych do analizy. Spośród wskaźników diagnostycznych najsłabiej skorelowane ze zmienną syntetyczną były wartości wskaźnika Z11 - nakłady inwestycyjne na budynki i budowle oraz grunty w odsetku nakładów na działalność innowacyjną.

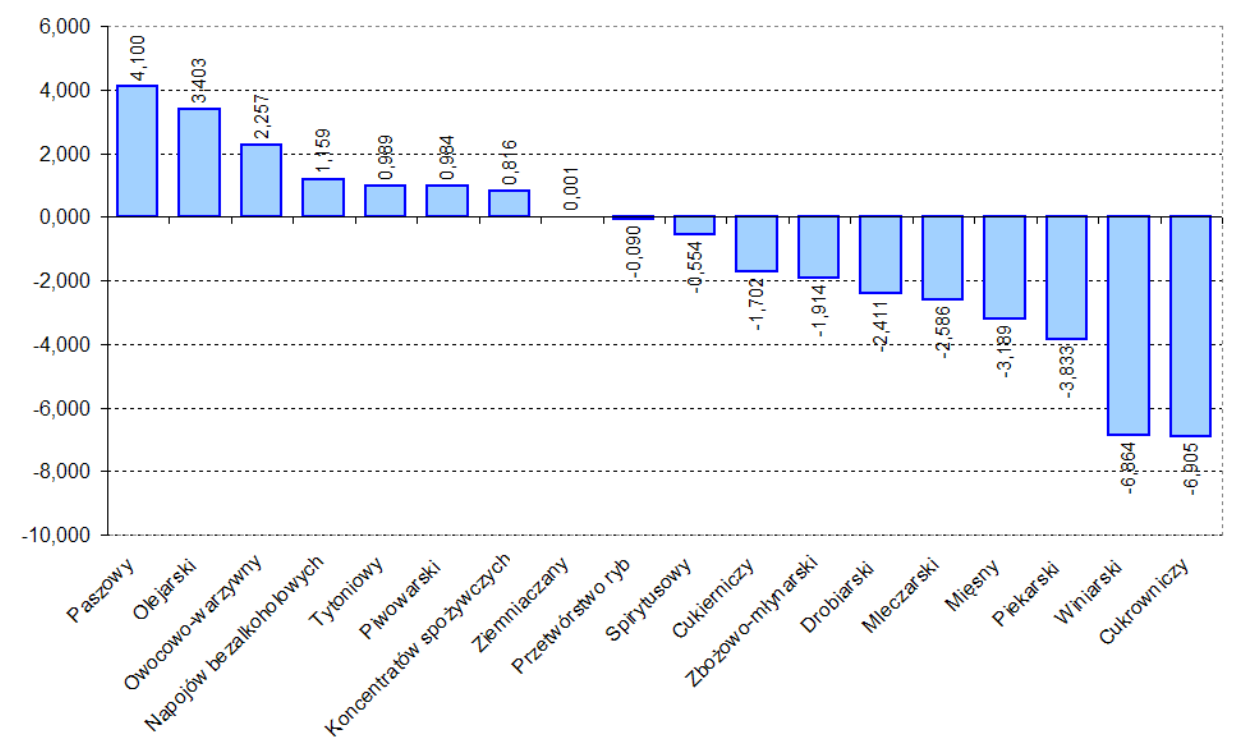

Rysunek 5. 12. Ranking innowacyjności przedsiębiorstw przemysłu spożywczego w Polsce w 2008 r. (standaryzacja wskaźników w czasie)

Porównując dla każdego kolejnego roku analizy przedsiębiorstwa klas przemysłu spożywczego znajdujące się na pierwszych trzech miejscach w rankingu można wskazać na pewną zawężoną grupę najbardziej innowacyjnych przedsiębiorstw przemysłu spożywczego (zob. rys. 5.8-5.12). 
W 2004 r. najwyższe miejsca w rankingu innowacyjności zajęły przedsiębiorstwa przemysłu: tytoniowego $(8,039)$, piwowarskiego $(7,346)$ i cukierniczego $(4,626)$.

W 2005 r. spośród nich w czołówce rankingu (na tych samych miejscach) pozostały dwie klasy przedsiębiorstw - przemysłu tytoniowego $(5,888)$ i cukierniczego $(3,566)$. Przedsiębiorstwa przemysłu piwowarskiego spadły pod względem oceny innowacyjności dokonanej na podstawie przyjętych do analizy wskaźników diagnostycznych, z 2 na 13 miejsce, a na miejscu 2 uplasowały się przedsiębiorstwa przemysłu paszowego $(4,033)$, które rok wcześniej, tj. w $2004 \mathrm{r}$. znajdowały się na miejscu $10 \mathrm{w}$ rankingu.

W 2006 r. ponownie, jako najbardziej innowacyjne ocenione zostały przedsiębiorstwa przemysłu tytoniowego $(7,523)$. Miejsce $2 \mathrm{w}$ rankingu ,zajęły przedsiębiorstwa przemysłu olejarskiego $(7,398)$, które w latach poprzednich 2004-2005 znajdowały się, odpowiednio na 15 i 8 miejscu w rankingu. Zmiana ta spowodowała spadek z 2 na 3 miejsce w rankingu innowacyjności w 2006 r. przedsiębiorstw przemysłu paszowego (5.303) oraz spadek z 3 na 6 miejsce $w$ rankingu innowacyjności przedsiębiorstw przemysłu cukierniczego. Należy także zwrócić uwagę, że w latach 2004-2006 na 4 pozycji niezmiennie plasowały się przedsiębiorstwa przemysłu spirytusowego.

Znaczne zmiany wystąpiły w 2007 r. Wyniki uzyskanych analiz wskazują, że jedynie przedsiębiorstwa przemysłu tytoniowego $(1,712)$ pozostały w ścisłej czołówce przedsiębiorstw najbardziej innowacyjnych, choć spadły z 1 na 2 miejsce w rankingu. Wśród najbardziej innowacyjnych na miejscu 1 ponownie pojawiły się przedsiębiorstwa przemysłu cukierniczego $(3,233)$. W 2007 r. z miejsca 3 na 6 w rankingu innowacyjności spadły przedsiębiorstwa przemysłu paszowego, a na ich miejscu po raz pierwszy pojawiły się przedsiębiorstwa przemysłu koncentratów spożywczych $(0,979)$, które w latach 2004-2006 zajmowały, odpowiednio 8, 6 i 7 miejsce $w$ rankingu.

W 2008 r. na pierwsze miejsca w rankingu pod względem innowacyjności powróciły przedsiębiorstwa klas przemysły spożywczego, które już we wcześniejszych latach plasowały się w czołówce rankingu. Na miejscu 1 znalazły się przedsiębiorstwa przemysłu paszowego $(4,100)$, które w 2005 r. zajmowały miejsce 2, a w 2006 r. miejsce $3 \mathrm{w}$ rankingu. Z kolei na miejscu 2 w 2008 r. powróciły przedsiębiorstwa przemysłu olejarskiego $(3,403)$, które dokładnie to samo (2 miejsce) w rankingu zajmowały w 2006 r. W 2008 r. po raz pierwszy wśród przedsiębiorstw najbardziej innowacyjne pojawiły się przedsiębiorstwa przemysłu owocowo-warzywnego $(2,257)$, które w poprzednich latach zajmowały w rankingu pozycje: 5 w 2004 r., 11 w 2005 r. i 2006 r. oraz 8 w 2007 r.

Podsumowując wyniki uzyskanych na tym etapie analiz należy stwierdzić, że o ile w latach 2004-2007 najbardziej innowacyjnymi, w świetle wskaźników diagnostycznych przyjętych do analizy, były przedsiębiorstwa przemysłu tytoniowego oraz cukierniczego i paszowego, które z pewnymi „,przerwami w czasie”, znajdowały 
się w ścisłej czołówce w rankingu. W latach 2004-2006 na miejscu 4 znajdowały się przedsiębiorstwa przemysłu spirytusowego. Natomiast w latach 2007-2008 należy odnotować zmiany w innowacyjności przedsiębiorstw przemysły spożywczego w Polsce na korzyść przedsiębiorstw przemysłu koncentratów spożywczych, przemysłu olejarskiego i owocowo-warzywnego - z tym, że zaobserwowane zmiany nie mają jeszcze tak trwałego charakteru jak sytuacja w latach 2004-2006.

Klasy przemysłu spożywczego, które w poszczególnych latach badanego okresu ocenione zostały jako najmniej innowacyjne (choć w jakimś stopniu były innowacyjne):

- w 2004 r. przedsiębiorstwa przemysłu piekarskiego (miejsce 16), ziemniaczanego (miejsce 17) i mleczarskiego (miejsce 18),

- w 2005 r. przedsiębiorstwa przemysłu zbożowo-młynarskiego (miejsce 16), mleczarskiego (miejsce 17) i mięsnego (miejsce 18),

- w 2006 r. przedsiębiorstwa przemysłu mleczarskiego (miejsce 16), piekarskiego (miejsce 17) i winiarskiego (miejsce 18),

- w 2007 r. przedsiębiorstwa przemysłu cukrowniczego (miejsce 16), piekarskiego (miejsce 17) i winiarskiego (miejsce 18),

- w 2008 r. przedsiębiorstwa przemysłu piekarskiego (miejsce 16), winiarskiego (miejsce 17) i cukrowniczego (miejsce 18).

Z powyższego wyszczególnienia wynika, że przedsiębiorstwa o najmniejszym stopniu innowacyjności w latach 2004-2008 reprezentowały klasy przemysłu spożywczego zajmujące się przetwórstwem ,podstawowych produktów spożywczych”.

W dalszej części badań podjęto próbę określenia branż przemysłu spożywczego podobnych do siebie $\mathrm{z}$ punktu widzenia poziomu innowacyjności. Wykorzystano w tym celu aglomeracyjne metody analiz skupień, które są metodami hierarchicznymi. Postępowanie badawcze oparto na tym samym, co poprzednio, zestawie zmiennych diagnostycznych (zob. tablica 5.2).

Uwzględniając poszczególne etapy i kroki analizy skupień, wstępne ustalenia oraz praktyczne wskazówki zamieszczone w rozdziale 5.3, na potrzeby grupowania przedsiębiorstw przemysłu spożywczego (z punktu widzenia innowacyjności) przyjęto następujące założenia:

- w charakterze miary odległości między obiektami przyjęto odległość euklidesową lub kwadrat odległości euklidesowej,

- spośród metod aglomeracyjnych zastosowano algorytm metody średniej grupowej lub algorytm metody Warda,

- oceny wyniku grupowania, tj. przycięcia wykresu drzewa i wyboru wyniku grupowania dokonano na podstawie reguły prawostronnego górnego obszaru odrzucenia (upper tail rule) zaproponowanej przez Mojenę,

- oceny jakości wyniku grupowania oraz wyboru ostatecznego wyniku grupowania dokonano z wykorzystaniem indeksu sylwetkowego Rousseeuwa.

Wykorzystując 7 wskaźników diagnostycznych z zakresu innowacji dla każdego roku analizy (lata 2004-2008) przeanalizowano 4 warianty grupowania 
uzyskane za pomocą kombinacji 2 wskazanych metod i 2 miar odległości, a każdy z wyników oceniono pod względem jakości grupowania, tj. poprawności przynależności obiektów do poszczególnych skupień. Ostatecznie dla każdego roku analizy innowacyjności przedsiębiorstw przemysłowych wskazano „najlepszy” w sensie jakości grupowania wynik podziału przedsiębiorstw. Wyniki zamieszczone w tab. 5.5-5.9 otrzymano dzięki zastosowaniu metody górnego obszaru odrzucenia (UTR) dla każdego wariantu grupowania oraz metody oceny jakości grupowania - indeksu sylwetkowego $(G S I)$, a obliczeń dokonano w programie Clustangraphics 8 [Wishart 2006] oraz w środowisku R (pakiet ClusterSim) [Walesiak, Dudek 2010].

Tabela 5.5. Charakterystyki liczbowe grupowania przedsiębiorstw przemysłu spożywczego wraz z oceną jakości wyników grupowania dla 2004 r.

\begin{tabular}{|l|l|c|c|}
\hline $\begin{array}{c}\text { Metoda } \\
\text { aglomeracyjna }\end{array}$ & \multicolumn{1}{|c|}{$\begin{array}{c}\text { Miara odległości } \\
d(i, s)\end{array}$} & $\begin{array}{c}\text { Liczba skupień } \\
(U T R)\end{array}$ & $\begin{array}{c}\text { Indeks sylwetkowy } \\
(G S I)\end{array}$ \\
\hline Średniej grupowej & euklidesowa & 3 & 0,5322 \\
\hline Średniej grupowej & kwadrat euklidesowej & 2 & 0,9161 \\
\hline Warda & euklidesowa & 3 & 0,5247 \\
\hline Warda & kwadrat euklidesowej & 2 & 0,9161 \\
\hline
\end{tabular}

W tabeli 5.5. zamieszczone zostały wyniki analizy skupień innowacyjności przedsiębiorstw przemysłu spożywczego uzyskane dla 2004 r. Zgodnie z kryterium maksymalizacji indeksu sylwetkowego $(G S I)$ za ostateczny wynik analizy dla tego roku przyjmuje się podział przedsiębiorstw na 2 skupienia, przy czym może on wydawać się zbyt trywialny - szczegółowe porównanie przynależności obiektów (przedsiębiorstw) do skupień wykazało, że zarówno metodą średniej grupowej, jak i Warda, uzyskano dokładnie ten sam podział. Dla 2004 r. można wskazać również na wynik podziału przedsiębiorstw na 3 skupienia metodą średniej grupowej z odleglością euklidesową z wartością $G S I=0,5322$, który zgodnie z interpretacją indeksu sylwetkowego należy ocenić jako „sensowną strukturę grupowania" - zob. rys. 5.13.

Wynikiem analizy skupień innowacyjności branż przemysłu spożywczego dla 2004 r. są następujące klasy(zob. rys. 5.13):

- skupienie 1: mięsny, napojów bezalkoholowych, mleczarski, zbożowomłynarski, owocowo-warzywny, drobiarski, przetwórstwo ryb, cukrowniczy, cukierniczy, piwowarski, ziemniaczany, olejarski, koncentratów spożywczych, piekarski, winiarski oraz spirytusowy,

- skupienie 2: paszowy,

- skupienie 3: tytoniowy, 


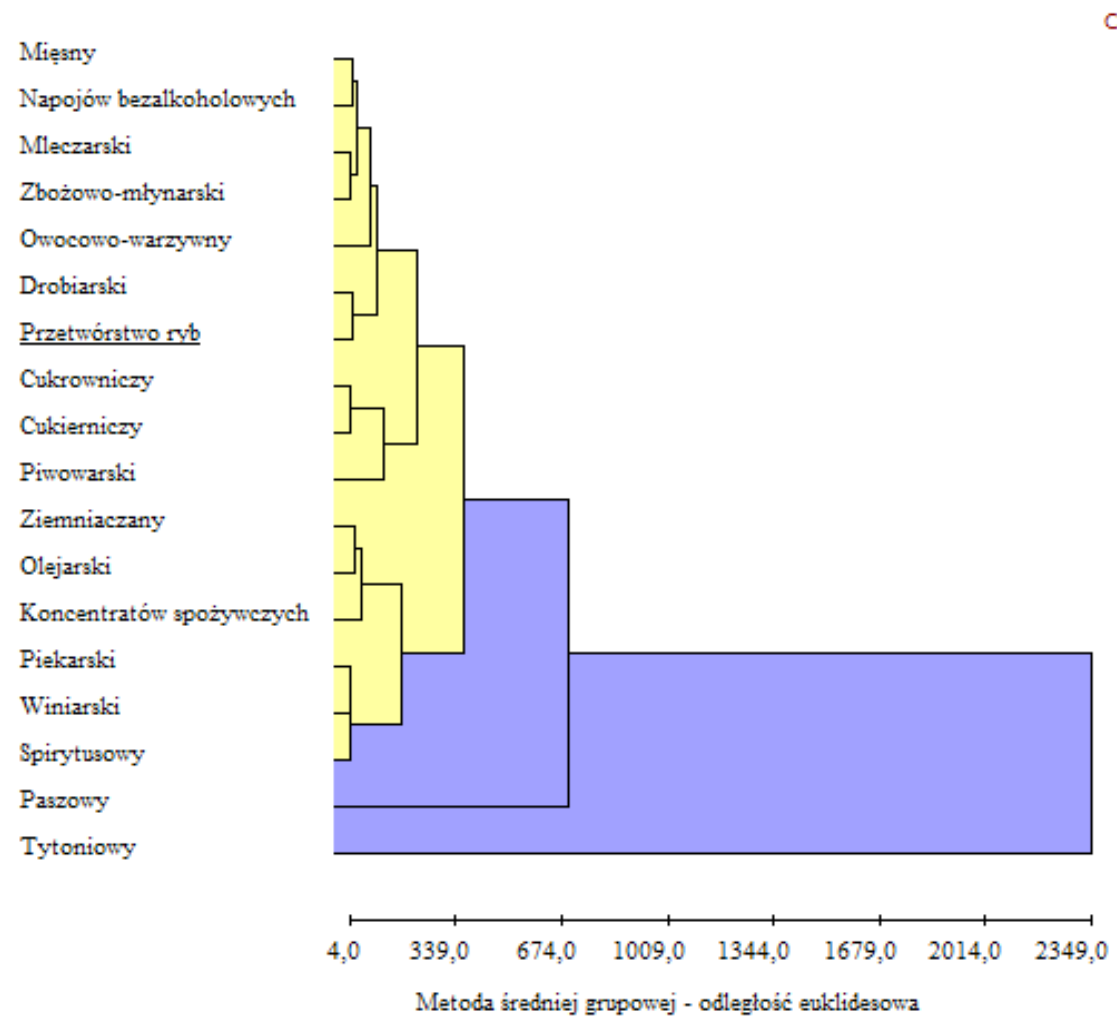

Uwaga: podkreślenie oznacza obiekt o średnich wartościach wskaźników diagnostycznych w skupieniu.

Rysunek 5. 13. Dendrogram skupień branż przemysłu spożywczego dla 2004 r.

Odnosząc się do wyników analizy skupień innowacyjności przedsiębiorstw przemysłu spożywczego uzyskanych dla 2005 r. (zob. tablica 5.6) również podział na 2 skupienia należy uznać za „niewystarczający”, wobec czego kolejnym z najwyższą wartością indeksu GSI jest podział na 3 skupienia uzyskany metodą średniej grupowej z kwadratem odległości euklidesowej $(G S I=0,7355)$ - zob. rys.5.14.

Wyniki analizy skupień innowacyjności branż przemysłu spożywczego dla 2005 r. przedstawiają się następująco (zob. rys. 5.14):

- skupienie 1: mięsny, drobiarski, spirytusowy, zbożowo-młynarski, winiarski, ziemniaczany, koncentratów spożywczych, piekarski, przetwórstwo ryb, mleczarski, napojów bezalkoholowych, owocowo-warzywny oraz olejarski,

- skupienie 2: cukrowniczy, piwowarski,

- skupienie 3: paszowy, cukierniczy oraz tytoniowy. 
Tabela 5.6. Charakterystyki liczbowe grupowania przedsiębiorstw przemysłu spożywczego wraz z oceną jakości wyników grupowania dla 2005 r.

\begin{tabular}{|l|l|c|c|}
\hline $\begin{array}{c}\text { Metoda } \\
\text { aglomeracyjna }\end{array}$ & \multicolumn{1}{c|}{$\begin{array}{c}\text { Miara odległości } \\
d(i, s)\end{array}$} & $\begin{array}{c}\text { Liczba skupień } \\
(U T R)\end{array}$ & $\begin{array}{c}\text { Indeks sylwetkowy } \\
(G S I)\end{array}$ \\
\hline Średniej grupowej & euklidesowa & 4 & 0,6278 \\
\hline Średniej grupowej & kwadrat euklidesowej & 3 & 0,7355 \\
\hline Warda & euklidesowa & 3 & 0,5792 \\
\hline Warda & kwadrat euklidesowej & 2 & 0,8683 \\
\hline
\end{tabular}

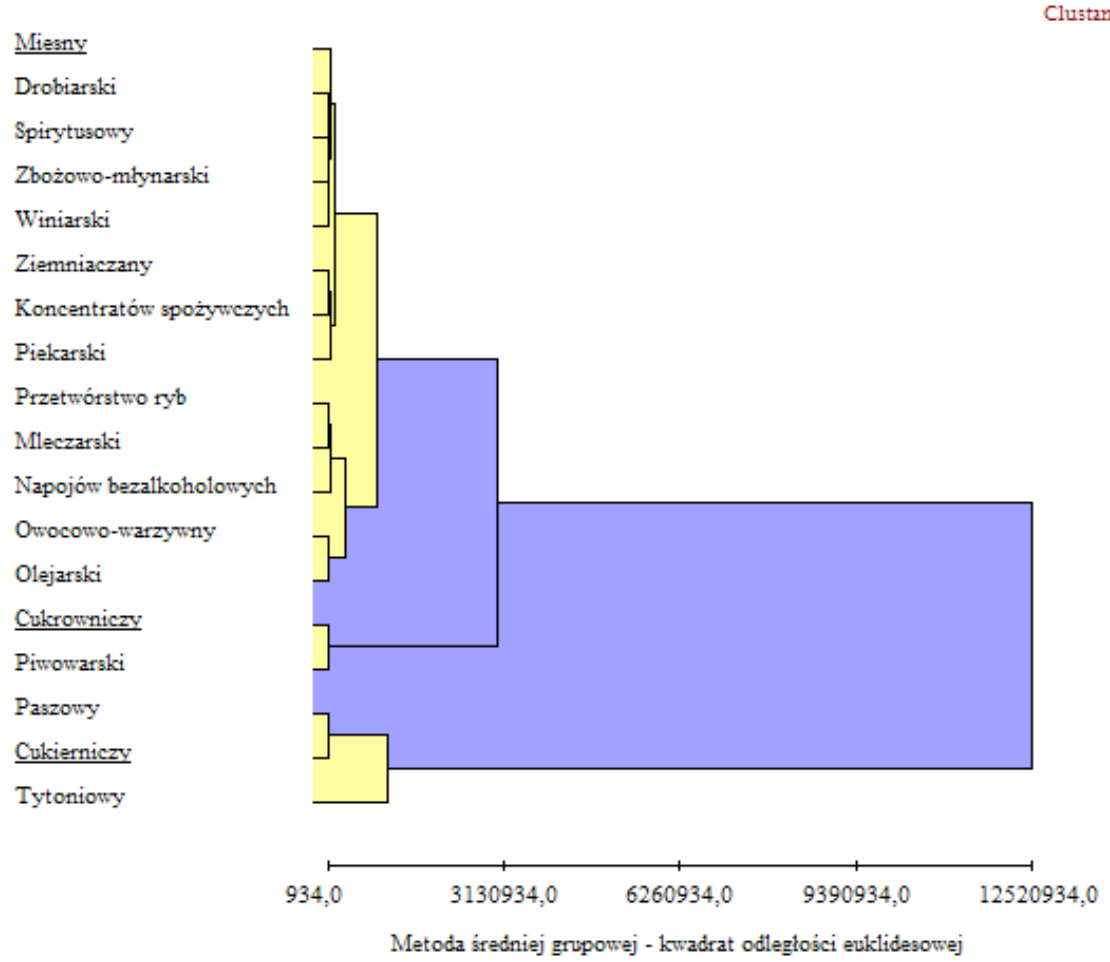

Uwaga: podkreślenie oznacza obiekt o średnich wartościach wskaźników diagnostycznych w skupieniu.

Rysunek 5. 14. Dendrogram skupień branż przemysłu spożywczego dla 2005 r.

Również podział na 4 skupienia przedsiębiorstw podobnych metodą średniej grupowej z odległością euklidesową dla 2005 r. z wartością indeksu sylwetkowego $G S I=0,6278$ jest do zaakceptowania, gdyż ma ,sensowną strukturę” grupowania. W stosunku do podziału na 3 skupienia przedstawionego powyżej w tym grupowaniu nastąpiło wyłącznie w postaci odrębnego skupienia przedsiębiorstw przemysłu tytoniowego (skupienie 4) - zob. rys. 5.15. 


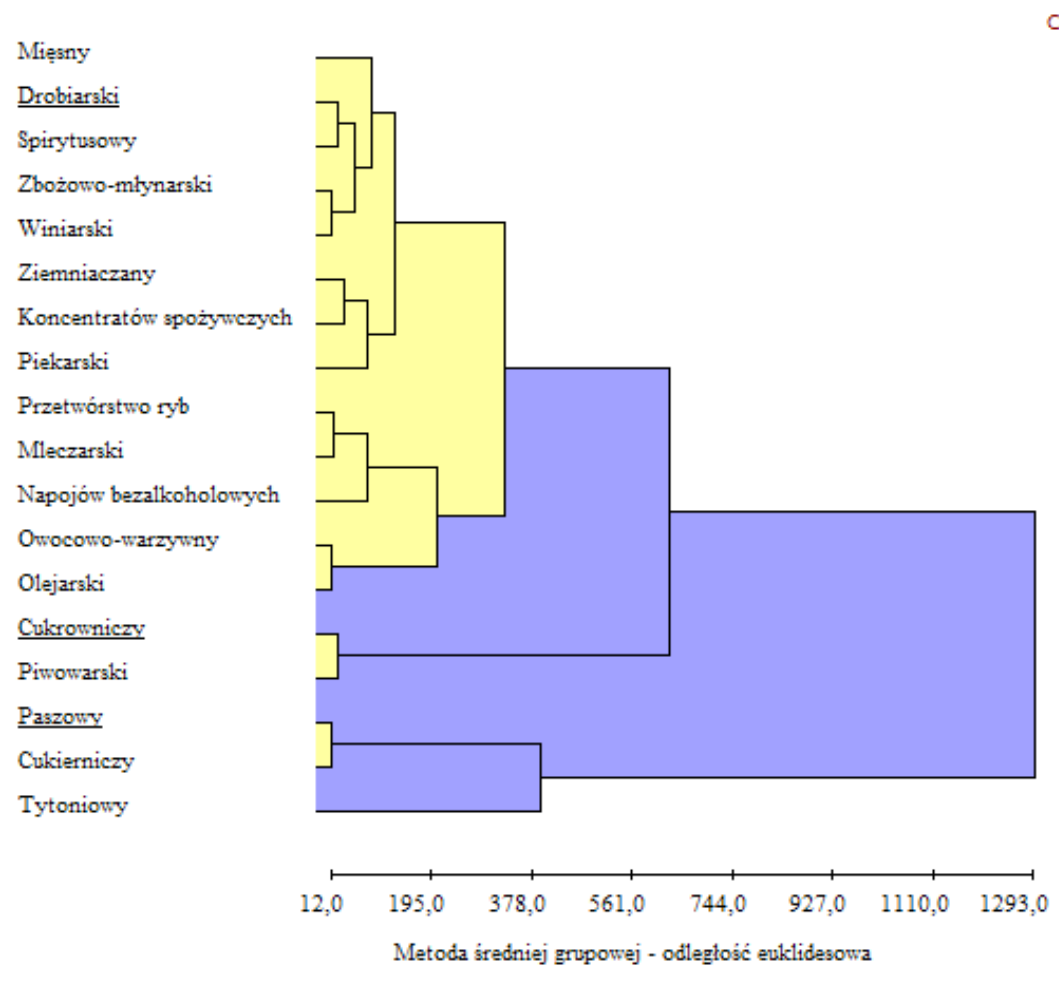

Uwaga: podkreślenie oznacza obiekt o średnich wartościach wskaźników diagnostycznych w skupieniu.

Rysunek 5.15. Dendrogram skupień branż przemysłu spożywczego dla 2005 r. (4 skupienia)

Skupienia innowacyjności branż przemysłu spożywczego dla 2005 r. są następujące (zob. rys. 5.15):

- skupienie 1: mięsny, drobiarski, spirytusowy, zbożowo-młynarski, winiarski, ziemniaczany, koncentratów spożywczych, piekarski, przetwórstwo ryb, mleczarski, napojów bezalkoholowych, owocowo-warzywny oraz olejarski,

- skupienie 2: cukrowniczy, piwowarski,

- skupienie 3: paszowy, cukierniczy,

- skupienie 4: tytoniowy.

Ocena wyników analizy skupień innowacyjności przedsiębiorstw przemysłu spożywczego uzyskanych dla 2006 r. (zob. tab. 5.7) wygląda podobnie. Maksymalizując wartość indeksu oceniającego jakość grupowania za ostateczny wynik klasyfikacji należy przyjąć podział przedsiębiorstw klas przemysłu spożywczego (z punktu widzenia innowacyjności) na 3 skupienia, uzyskany metodą średniej grupowej $\mathbf{z}$ kwadratem odległości euklidesowej $(G S I=0,8176)$. 
Tak wysoka wartość indeksu sylwetkowego świadczy o silnej strukturze grup. Niemniej jednak również podział metodą średniej grupowej z odległością euklidesową można uznać za poprawny $(G S I=0,5992)$ - zob. rys. 5.16.

Tabela 5.7. Charakterystyki liczbowe grupowania przedsiębiorstw przemysłu spożywczego wraz z oceną jakości grupowania dla 2006 r.

\begin{tabular}{|l|l|c|c|}
\hline $\begin{array}{c}\text { Metoda } \\
\text { aglomeracyjna }\end{array}$ & \multicolumn{1}{|c|}{$\begin{array}{c}\text { Miara odległości } \\
d(i, s)\end{array}$} & $\begin{array}{c}\text { Liczba skupień } \\
(U T R)\end{array}$ & $\begin{array}{c}\text { Indeks sylwetkowy } \\
(G S I)\end{array}$ \\
\hline Średniej grupowej & euklidesowa & 4 & 0,5992 \\
\hline Średniej grupowej & kwadrat euklidesowej & 3 & 0,8176 \\
\hline Warda & euklidesowa & 3 & 0,6235 \\
\hline Warda & kwadrat euklidesowej & 3 & 0,7518 \\
\hline
\end{tabular}

Wynik analizy skupień dla 2006 r. na 3 skupienia (zob. rys. 5.16):

- skupienie 1: mięsny, przetwórstwo ryb, piekarski, napojów bezalkoholowych, spirytusowy, winiarski, drobiarski, mleczarski, ziemniaczany, zbożowomłynarski, owocowo-warzywny, olejarski, koncentratów spożywczych, cukierniczy oraz piwowarski,

- skupienie 2: cukrowniczy, paszowy,

- skupienie 3: tytoniowy.

Drugim poprawnym wynikiem analizy skupień branż przemysłu spożywczego dla 2006 r. są 4 skupienia (zob. rys. 5.16.):

- skupienie 1: mięsny, przetwórstwo ryb, piekarski, napojów bezalkoholowych, spirytusowy, winiarski, drobiarski, mleczarski, ziemniaczany, zbożowomłynarski, owocowo-warzywny, olejarski oraz koncentratów spożywczych,

- skupienie 2: cukierniczy, piwowarski,

- skupienie 3: cukrowniczy, paszowy,

- skupienie 4: tytoniowy.

Wyniki grupowania przedsiębiorstw przemysłu spożywczego pod względem ich innowacyjności w 2007 r. (zob. tab. 5.8.) po raz kolejny wskazują na występowanie 3 skupień przedsiębiorstw podobnych - metoda średniej grupowej z kwadratem odległości euklidesowej $(G S I=0,7942)$, przy czym drugi podział na 3 skupienia metodą średniej grupowej jest dokładnie taki sam. Należy zauważyć, że również podział na 4 skupienia metodą Warda z odległością euklidesową też jest dopuszczalny - zob. rys. 5.18. 


Miẹsny
Przetwórstwo ryb
Piekarski
Napojów bezalkoholowych
Spirytusowy
Winiarski
Drobiarski
Mleczarski
Ziemniaczany
Zbożowo-mitynarski
Owocowo-warzywny
Olejarski
Koncentratów spożywczych
Cukierniczy
Piwowarski
Cukrowniczy
Paszowy
Tytoniowy

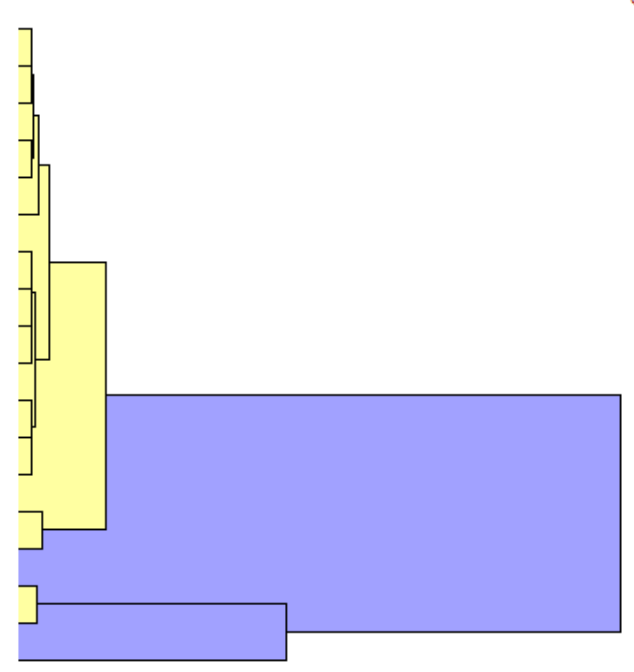

Clustan $^{\mathrm{TM}}$

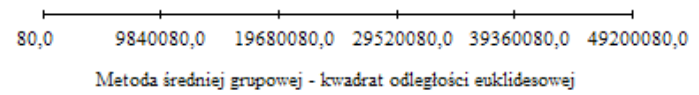

Mięsny

Przetwórstwo ryb

Piekarski

Napojów bezalkoholowych

Spirytusowy

Winiarski

Drobiarski

Mleczarski

Ziemniaczany

Zbożowo-mlynarski

Owocowo-warzywny

Olejarski

Koncentratów spożywczych

Cukierniczy

Piwowarski

Cukrowniczy

Paszowy

Tytoniowy
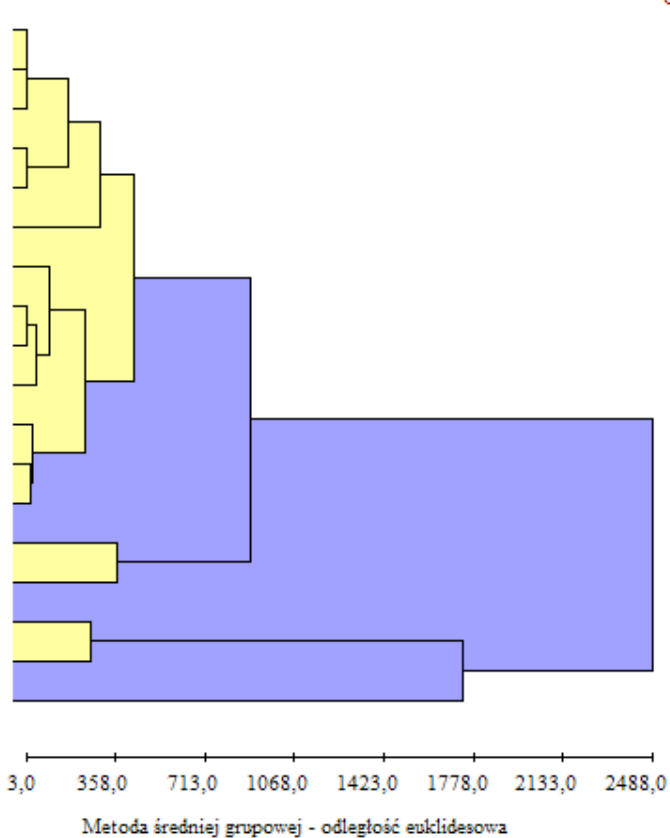

Uwaga: podkreślenie oznacza obiekt o średnich wartościach wskaźników diagnostycznych w skupieniu.

Rysunek 5. 16. Dendrogram skupień branż przemysłu spożywczego dla 2006 r. (3 i 4 skupienia) 


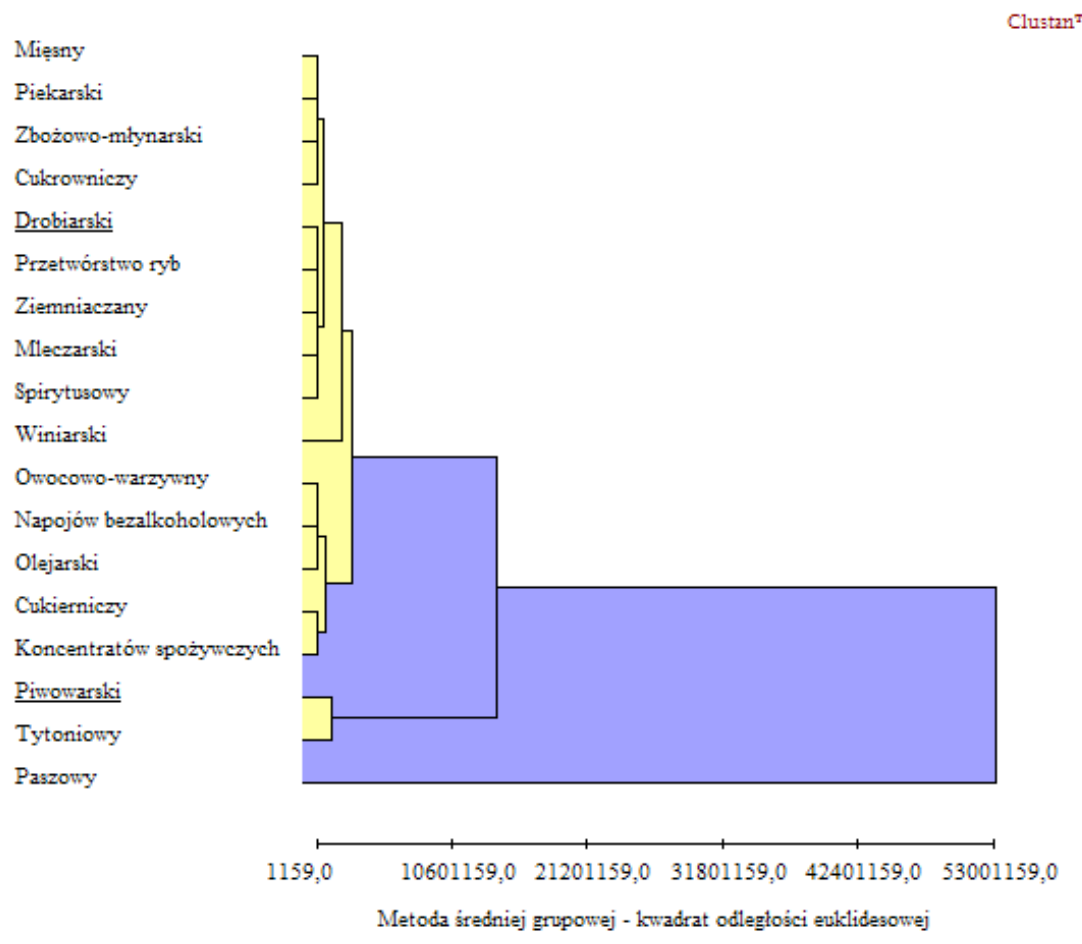

Uwaga: podkreślenie oznacza obiekt o średnich wartościach wskaźników diagnostycznych w skupieniu.

Rysunek 5.17. Dendrogram skupień branż przemysłu spożywczego dla 2007 r. (3 skupienia)

Tabela 5.8. Charakterystyki liczbowe grupowania przedsiębiorstw przemysłu spożywczego wraz z oceną jakości grupowania dla $2007 \mathrm{r}$.

\begin{tabular}{|l|l|c|c|}
\hline $\begin{array}{c}\text { Metoda } \\
\text { aglomeracyjna }\end{array}$ & \multicolumn{1}{c|}{$\begin{array}{c}\text { Miara odległości } \\
d(i, s)\end{array}$} & $\begin{array}{c}\text { Liczba skupień } \\
(U T R)\end{array}$ & $\begin{array}{c}\text { Indeks sylwetkowy } \\
(G S I)\end{array}$ \\
\hline Średniej grupowej & euklidesowa & 3 & 0,6434 \\
\hline Średniej grupowej & kwadrat euklidesowej & 3 & 0,7942 \\
\hline Warda & euklidesowa & 4 & 0,5352 \\
\hline Warda & kwadrat euklidesowej & 2 & 0,8533 \\
\hline
\end{tabular}

Wyniki analizy skupień dla 2007 r. przedstawiają się następująco (zob. rys. 5.17):

- skupienie 1: mięsny, piekarski, zbożowo-młynarski, cukrowniczy, drobiarski, przetwórstwo ryb, ziemniaczany, mleczarski, spirytusowy, 
owocowo-warzywny, napojów bezalkoholowych, olejarski, cukierniczy, koncentratów spożywczych oraz winiarski,

- skupienie 2: piwowarski, tytoniowy,

- skupienie 3: paszowy.

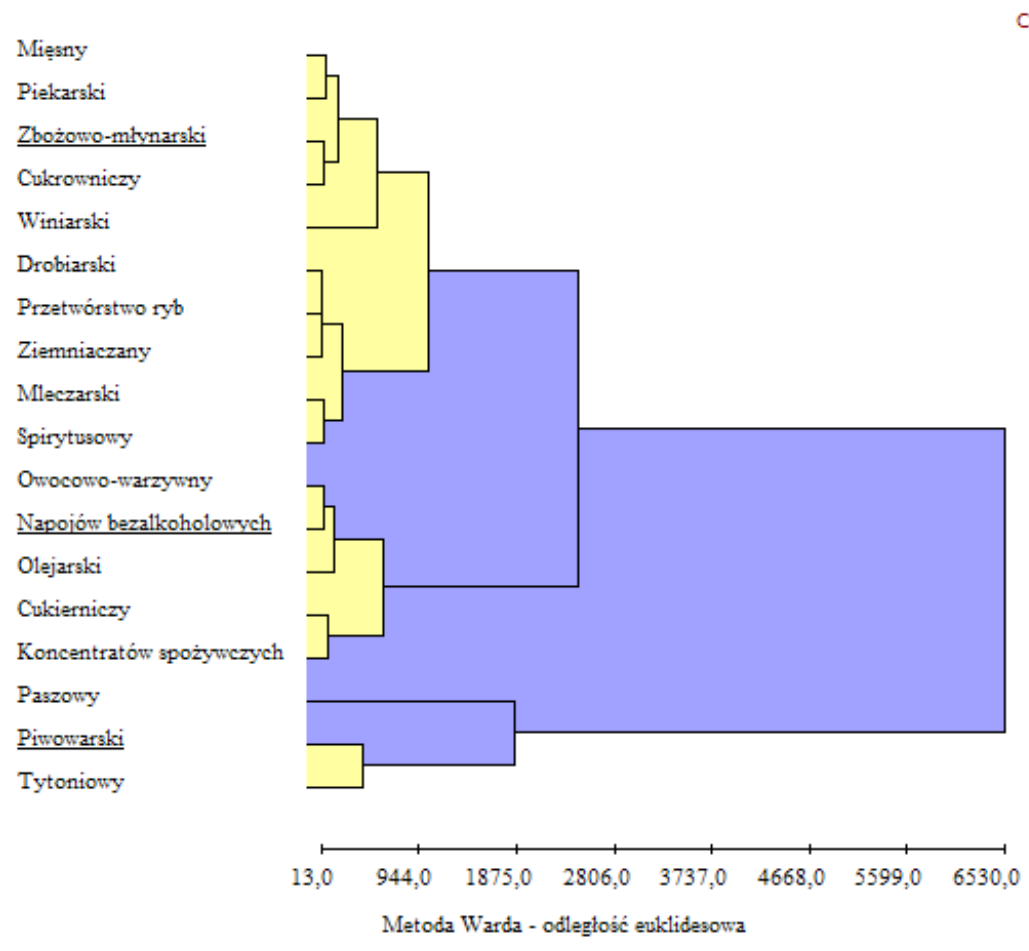

Uwaga: podkreślenie oznacza obiekt o średnich wartościach wskaźników diagnostycznych w skupieniu.

Rysunek 5. 18. Dendrogram skupień branż przemysłu spożywczego dla 2007 r. (4 skupienia)

Wniki analizy skupień dla 2007 r. z podziałem na 4 skupienia są następujące (zob. rys. 5.18):

- skupienie 1: mięsny, piekarski, zbożowo-młynarski, cukrowniczy, winiarski, drobiarski, przetwórstwo ryb, ziemniaczany, mleczarski oraz spirytusowy,

- skupienie 2: owocowo-warzywny, napojów bezalkoholowych, olejarski, cukierniczy oraz koncentratów spożywczych,

- skupienie 3: paszowy,

- skupienie 4: piwowarski, tytoniowy. 
Wynik analizy skupień uzyskany dla 2008 r. wyraźnie różni się od wcześniej prezentowanych. Maksymalizując wartość indeksu sylwetkowego należałoby z punktu widzenia analizowanej innowacyjności wybrać wynik grupowania przedsiębiorstw na 3 skupienia jednostek podobnych $(G S I=0,7561)$ - metoda średniej grupowej $\mathbf{z}$ kwadratem odległości euklidesowej. Okazuje się jednak, że pozostałe dwa podziały przedsiębiorstw na 4 skupienia są równie „dobre” i są to dokładnie te same rozwiązania, a różnią się tym, że największe skupienie przedsiębiorstw podobnych zostało podzielone na dwa mnisze skupienia - zob. rys. 5.19 .

Tabela 5.9. Charakterystyki liczbowe grupowania przedsiębiorstw przemysłu spożywczego wraz z oceną jakości grupowania dla $2008 \mathrm{r}$.

\begin{tabular}{|l|l|c|c|}
\hline $\begin{array}{c}\text { Metoda } \\
\text { aglomeracyjna }\end{array}$ & \multicolumn{1}{|c|}{$\begin{array}{c}\text { Miara odległości } \\
d(i, s)\end{array}$} & $\begin{array}{c}\text { Liczba skupień } \\
(U T R)\end{array}$ & $\begin{array}{c}\text { Indeks sylwetkowy } \\
(G S I)\end{array}$ \\
\hline Średniej grupowej & euklidesowa & $\mathrm{s} 4$ & 0,6715 \\
\hline Średniej grupowej & kwadrat euklidesowej & 3 & 0,7561 \\
\hline Warda & euklidesowa & 4 & 0,6715 \\
\hline Warda & kwadrat euklidesowej & 3 & 0,7025 \\
\hline
\end{tabular}

Wyniki analizy skupień dla 2008 r. z podziałem na 3 skupienia są następujące (zob. rys. 5.19):

- skupienie 1: mięsny, piekarski, spirytusowy, cukrowniczy, mleczarski, ziemniaczany, winiarski, drobiarski, owocowo-warzywny, zbożowo-młynarski oraz paszowy,

- skupienie 2: przetwórstwo ryb, cukierniczy, koncentratów spożywczych oraz napojów bezalkoholowych,

- skupienie 3: olejarski, tytoniowy, piwowarski.

Wyniki analizy skupień dla $2008 \mathrm{r}$. z podziałem na 4 skupienia przedstawiają się następująco (zob. rys. 5.19):

- skupienie 1: mięsny, piekarski, spirytusowy, cukrowniczy, mleczarski, ziemniaczany oraz winiarski,

- skupienie 2: drobiarski, owocowo-warzywny, zbożowo-młynarski oraz paszowy,

- skupienie 3: przetwórstwo ryb, cukierniczy, koncentratów spożywczych oraz napojów bezalkoholowych,

- skupienie 4: olejarski, tytoniowy, piwowarski. 

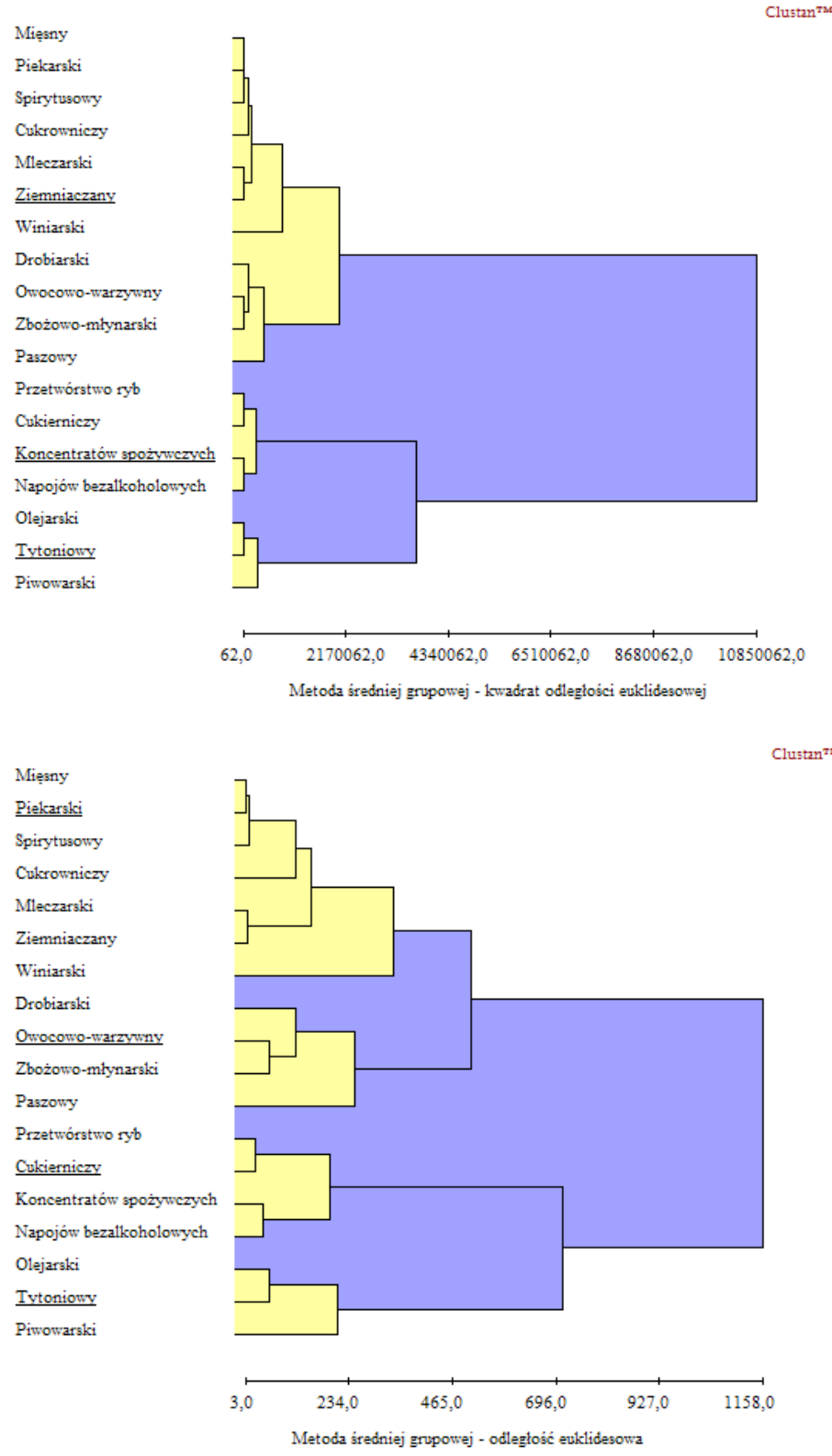

Uwaga: podkreślenie oznacza obiekt o średnich wartościach wskaźników diagnostycznych w skupieniu.

Rysunek 5. 19. Dendrogram skupień branż przemysłu spożywczego dla 2008 r. ( podział na 3 i 4 skupienia) 
Należy zauważyć, że wszystkie zaprezentowane powyżej wyniki grupowania przedsiębiorstw przemysłu spożywczego z punktu widzenia innowacji na 4 skupienia są równie dobre, co odpowiadające im wyniki podziału przedsiębiorstw na 3 skupienia (z wyjątkiem 2004 r.). Dostarczają przy tym bardziej „szczegółowych" informacji, wobec czego to one stanowią końcowe podsumowanie analizy.

Dane zamieszczone w tab. 5.10 pozwalają na szczegółową charakterystykę skupień z punktu widzenia wartości wskaźników diagnostycznych przyjętych do analizy.

W przypadku wyniku grupowania na 3 skupienia uzyskanego dla $2004 \mathrm{r}$. (zob. rys. 5.13) w najliczniejszym skupieniu 16 klas przedsiębiorstw przemysłu spożywczego wystąpiły maksymalne wartości pod względem wskaźników Z10 i $Z 11$, tj. na „nakładów na oprogramowanie” i „nakładów inwestycyjnych na budynki i budowle oraz grunty", oraz minimalne wartości wskaźników Z6 i Z9, tj. „nakładów przypadających nal przedsiębiorstwo innowacyjne” i „nakładów na zakup gotowej technologii". Skupienie 2, przedsiębiorstw przemysłu paszowego, wyróżniło się maksymalną wartością wskaźnika „udziału nakładów na B+R”. Skupienie 3, przedsiębiorstw przemysłu tytoniowego, za wyjątkiem wskaźnika Z10 (,nakładów na oprogramowanie”) wyróżniało się maksymalnymi, bądź minimalnymi wartościami wszystkich pozostałych wskaźników, w tym najwyższą wartością nakładów przypadających na 1 przedsiębiorstwo prowadzące działalność innowacyjną (Z6).

Wynik grupowania przedsiębiorstw przemysłu spożywczego dla 2005 r. na 4 skupienia (zob. rys. 5.15) przedstawia się nieco inaczej. W najbardziej licznym skupieniu, 13 klas przemysłu odnotowano najniższą wartość wskaźnika Z6, tj. nakłady przypadających na 1 przedsiębiorstwo prowadzące działalność innowacyjną - poza tym przedsiębiorstwa $\mathrm{z}$ tych klas nie wyróżniały się pod względem innych wskaźników innowacyjności. Skupienie 2, przedsiębiorstw z klas przemysłu cukrowniczego i piwowarskiego, charakteryzowało się wysokimi wskaźnikami Z9 i Z10, tj. „nakładów na zakup gotowej technologii” i „oprogramowanie”. Natomiast skrajne wartości pozostałych wskaźników diagnostycznych skumulowały się w 3 i 4 skupieniu, odpowiednio przedsiębiorstw przemysłu \{paszowego, cukierniczego\}, \{tytoniowego\}, które można uznać za najbardziej innowacyjne. Warto zwrócić uwagę, że struktura 4 skupień przedsiębiorstw przemysłu spożywczego ocenianych z punktu widzenia uzyskana dla 2006 r. jest dokładnie taka sama jak dla 2005 r. (zob. rys. 5.15, 5.16) - ponownie w najliczniejszym skupieniu przedsiębiorstw odnotowano najniższe nakłady przypadające na 1 przedsiębiorstwo prowadzące działalność innowacyjną. Przewaga pozostałych skrajnych wartości wskaźników diagnostycznych wystąpiła w skupieniu 3 i 4 \{paszowy, cukierniczy\}, \{tytoniowy\}, które można uznać za najbardziej innowacyjne. 
Tablela 5. 10. Charakterystyka skupień wyników grupowania w latach 2004-2008

\begin{tabular}{|c|c|c|c|c|c|c|c|c|}
\hline \multirow{2}{*}{ Skupienie } & \multirow{2}{*}{ Obiekty } & \multicolumn{7}{|c|}{ Wskaźniki diagnostyczne } \\
\hline & & $\mathrm{Z1}$ & Z6 & $\mathrm{Z7}$ & Z9 & $\mathrm{Z10}$ & Z11 & Z13 \\
\hline \multicolumn{9}{|c|}{ Rok 2004, metoda średniej grupowej, odległość euklidesowa (rys. 5.13) } \\
\hline 1 & 16 & 51,96 & 3679,10 & 3,20 & 1,97 & 3,15 & 23,68 & 21,36 \\
\hline 2 & 1 & $\mathbf{5 0 , 5 2}$ & 8543,15 & 3,69 & 3,52 & $\mathbf{0 , 3 0}$ & 22,41 & 2,04 \\
\hline 3 & 1 & 100,00 & 20406,23 & 1,06 & 5,35 & 2,90 & $\mathbf{0 , 5 4}$ & 68,37 \\
\hline \multicolumn{2}{|c|}{$\max$} & 100,00 & 20406,23 & 3,69 & 5,35 & 3,15 & 23,68 & 68,37 \\
\hline \multicolumn{2}{|c|}{$\min$} & 50,52 & 3679,10 & 1,06 & 1,97 & 0,30 & 0,54 & 2,04 \\
\hline \multicolumn{9}{|c|}{ Rok 2005, metoda średniej grupowej, odległość euklidesowa (rys. 5.15) } \\
\hline 1 & 13 & 46,61 & 2963,31 & 1,69 & 0,77 & 2,03 & 26,79 & 25,25 \\
\hline 2 & 2 & 44,58 & 7374,23 & 1,54 & 0,61 & 3,41 & 29,80 & 2,00 \\
\hline 3 & 2 & 47,79 & 11708,12 & 6,77 & 4,27 & 1,18 & 37,17 & 21,86 \\
\hline 4 & 1 & 100,00 & 14453,84 & 1,39 & 1,50 & 1,65 & 9,63 & 74,81 \\
\hline \multicolumn{2}{|c|}{$\max$} & 100,00 & 14453,84 & 6,77 & 4,27 & 3,41 & 37,17 & 74,81 \\
\hline \multicolumn{2}{|c|}{$\min$} & 44,58 & 2963,31 & 1,39 & 0,61 & 1,18 & 9,63 & 2,00 \\
\hline \multicolumn{9}{|c|}{ Rok 2006, metoda średniej grupowej, odległość euklidesowa (rys. 5.16) } \\
\hline 1 & 13 & 48,75 & 3856,05 & 1,47 & 1,28 & 2,65 & 25,01 & 18,92 \\
\hline 2 & 2 & 51,10 & 10099,6 & 2,49 & 3,26 & 6,29 & 14,38 & 25,28 \\
\hline 3 & 2 & 43,10 & 18059,61 & 8,86 & 1,04 & 2,37 & 31,02 & $\mathbf{5 , 5 7}$ \\
\hline 4 & 1 & 100,00 & 30228,85 & 0,64 & $\mathbf{0 , 0 4}$ & $\mathbf{0 , 4 0}$ & 14,14 & 68,12 \\
\hline \multicolumn{2}{|c|}{$\max$} & 100,00 & 30228,85 & 8,86 & 3,26 & 6,29 & 31,02 & 68,12 \\
\hline \multicolumn{2}{|c|}{$\min$} & 43,00 & 3856,05 & 0,64 & 0,04 & 0,40 & 14,14 & 5,57 \\
\hline \multicolumn{9}{|c|}{ Rok 2007, metoda Warda, odległość euklidesowa (rys. 5.18) } \\
\hline 1 & 10 & 33,24 & 3636,57 & 2,28 & 0,18 & 0,48 & 21,29 & 18,48 \\
\hline 2 & 5 & 45,33 & 7592,14 & 2,44 & 2,36 & 1,65 & 18,00 & 24,25 \\
\hline 3 & 1 & 38,73 & 25010,61 & 0,97 & 0 & 0,12 & 14,50 & 2,33 \\
\hline 4 & 2 & 50,23 & 14529,71 & 0,88 & $\mathbf{0}$ & 0,61 & 3,49 & 66,67 \\
\hline \multicolumn{2}{|c|}{$\max$} & 50,23 & 25010,61 & 2,44 & 2,36 & 1,65 & 21,29 & 66,67 \\
\hline \multicolumn{2}{|c|}{$\min$} & 33,24 & 3636,57 & 0,88 & 0 & 0,12 & 3,49 & 2,33 \\
\hline \multicolumn{9}{|c|}{ Rok 2008, metoda średniej grupowej, odległość euklidesowa (rys. 5.19) } \\
\hline 1 & 7 & 30,51 & 2068,16 & 2,17 & 0,1 & 0,93 & 13,27 & 19,73 \\
\hline 2 & 4 & 34,91 & 5624,54 & 8,85 & 0,29 & 3,18 & 22,80 & 20,37 \\
\hline 3 & 4 & 40,25 & 9336,54 & 2,43 & 0,51 & 1,48 & 14,85 & 39,44 \\
\hline 4 & 3 & 60,00 & 14310,14 & 2,05 & $\mathbf{0}$ & 2,23 & 29,60 & 16,49 \\
\hline \multicolumn{2}{|c|}{$\max$} & 60,00 & 14310,14 & 8,85 & 0,51 & 3,18 & 29,60 & 39,44 \\
\hline \multicolumn{2}{|c|}{$\min$} & 30,51 & 2068,16 & 2,05 & 0 & 0,93 & 13,27 & 16,49 \\
\hline
\end{tabular}


W 2007 r. wynik klasyfikacji przedsiębiorstw przemysłu spożywczego wyraźnie się zmienił, nastąpiło rozbicie występującego dotychczas najbardziej licznego skupienia klas przedsiębiorstw (połączenie z innymi klasami przedsiębiorstw), co wpłynęło na wewnętrzną spójność obiektów w tych grupach (zob. rys. 5.18). Skupienie 10 klas przedsiębiorstw przemysłu spożywczego charakteryzowało się najniższą wartością wskaźników Z1 i Z6, dotyczących „udziału przedsiębiorstw innowacyjnych” oraz „nakładów przypadających na 1 przedsiębiorstwo”, wyróżniało się jednak najwyższą wartością wskaźnika Z11, tj. nakładów na „budynki budowle orz grunty". Na tle dotychczas omawianych skupień przedsiębiorstw podobnych w 2007 r. na szczególną uwagę zasługuje drugie skupienie 5 klas przedsiębiorstw przemysłu spożywczego \{owocowo-warzywny, napojów bezalkoholowych, olejarski, cukierniczy, koncentratów spożywczych\}, które można uznać za najbardziej innowacyjnie rozwijające się. Wyróżniało się ono maksymalnymi wartościami aż 3 wskaźników diagnostycznych $(Z 7, Z 9, Z 10)$, związanych z ,nakładami na B+R”, ,nakładami na zakup gotowej technologii” i „,nakładami na oprogramowanie". Przedsiębiorstwami przemysłu o najwyższych nakładach przypadających na 1 przedsiębiorstwo prowadzące działalność innowacyjną okazały się przedsiębiorstwa przemysłu paszowego (3 skupienie). Natomiast w skupieniu 4, w przedsiębiorstwach przemysłu piwowarskiego i tytoniowego odnotowano najwyższy, na tle pozostałych skupień, „odsetek przedsiębiorstw innowacyjnych” (Z1) oraz najwyższą wartość wskaźnika (Z13), tj. „nakładów inwestycyjnych na maszyny i urządzenia techniczne z importu".

Ostatnia klasyfikacja innowacyjności przedsiębiorstw przemysłu spożywczego uzyskana dla 2008 r. przedstawiona została na rys. 5.19. Nastąpiła w niej jeszcze większa konsolidacja skupień. W pierwszym z nich odnotowano najniższe wartości 4 spośród 7 wskaźników diagnostycznych - „udziału przedsiębiorstw innowacyjnych” (Z1), ,nakładów przypadających na 1 przedsiębiorstwo innowacyjne” (Z2), ,nakładów na oprogramowanie" $(Z 10)$ i ,nakładów inwestycyjnych na budynki i budowle oraz grunty" (Z11). Na szczególną uwagę zasługują skupienia 2 i 3, do których zaliczono przedsiębiorstwa z następujących branż przemysłu spożywczego: \{drobiarski, owocowo-warzywny, zbożowo-młynarski, paszowy\} oraz \{przetwórstwo ryb, cukierniczy, koncentratów spożywczych, napojów bezalkoholowych\}. Skupienie 2 charakteryzowało się maksymalną wartością wskaźników $Z 7$ i $Z 10$ z zakresu: „nakładów na B+R” i „nakładów na oprogramowanie” wśród określonych klas przemysłu. W skupieniu 3 odnotowano maksymalne wartości wskaźników Z9 i Z13 z zakresu: „nakładów na zakup gotowej technologii”, ,nakładów inwestycyjnych na maszyny i urządzenia techniczne $\mathrm{z}$ importu". Z tego punktu widzenia omawiane skupienia można określić, jako klasy przedsiębiorstw innowacyjnie rozwijających się. Wciąż jednak najwyższą wartość wskaźników Z1 i Z2, tj. „udziału przedsiębiorstw innowacyjnych” i „nakładów przypadających na 1 przedsiębiorstwo innowacyjne” i Z11, czyli „nakładów na budynki i budowle oraz grunty" odnotowano w przemyśle \{olejarskim, tytoniowymi piwowarskim \} (skupienie 4) - w pewnym stopniu jest to związane ze specyfiką tego rodzaju przemysłu, który wymaga wysokich nakładów kapitałowych. 



\section{Ekonometryczna analiza efektów innowacyjności w przemyśle spożywczym}

\section{Wprowadzenie}

Badanie innowacyjności na poziomie całego agregatu, jakim jest przemysł spożywczy i jego klas (branż), skłania do postawienia pytania: czy i w jakim stopniu innowacyjność wpływa na pozycję konkurencyjną przedsiębiorstw w analizowanym obszarze gospodarki. Celem tego rozdziału jest próba odpowiedzi na powyższe pytanie, najpierw poprzez przybliżenie teoretycznych podstaw budowy modeli wzrostu gospodarczego czy postępu technicznego (efektu innowacji), a następnie, poprzez empiryczną weryfikację modeli uwzględniających wpływ innowacji na konkurencyjność przedsiębiorstw na różnych poziomach agregacji, badanego przemysłu.

\subsection{Przegląd ekonomicznych modeli wzrostu gospodarczego}

Przed naukami ekonomicznymi stoją ogromne wyzwania związane z identyfikacją, pomiarem i skalą innowacyjności gospodarki, postępu technicznego, czy tzw. gospodarki opartej na wiedzy. Istnieje potrzeba konstrukcji metod i miar, które oceniałyby nie tylko stopień zaawansowania gospodarki opartej na wiedzy i jej innowacyjności, ale również określały wpływ tych kategorii na wzrost gospodarczy, na wzrost konkurencyjności poszczególnych sektorów gospodarki i funkcjonujących w nich podmiotów gospodarczych.

We współczesnych badaniach ekonomicznych dużo miejsca poświęca się zagadnieniom dotyczącym powiązań między wzrostem gospodarczym a postępem technicznym czy innowacjami. W tego typu analizach zwraca się uwagę na wykorzystanie nowoczesnych procedur badawczych, w tym metod współczesnej ekonometrii. Modele ekonometryczne są ważnym narzędziem służącym do ilościowego opisu mechanizmów gospodarki opartej na wiedzy. Punktem wyjścia do ich budowy jest endogeniczna teoria wzrostu gospodarczego ${ }^{21}$.

Za prekursorów teorii wzrostu gospodarczego uznaje się, znane w historii myśli ekonomicznej, postacie: A. Smitha, D. Ricarda, T. Malthusa, A. Marshalla oraz J. Schumpetera [za: Domar 1962, s. 52-53; Solow 1988, s. 307]. Pierwsze sformalizowane modele wzrostu gospodarczego powstały pod koniec lat 20 . $\mathrm{XX}$ w. Do najpopularniejszych, pochodzących z tego okresu, modeli wzrostu go-

${ }^{21}$ Obszerny przegląd empirycznych modeli wzrostu z endogenicznym postępem technicznym można znaleźć w pracy: W. Welfe 2000. 
spodarczego zalicza się: model F. Ramseya z 1928 r. i G. A. Feldmana z lat 1927 i 1928 [Tokarski 2001, s. 11]. Przyjmuje się, że początek ekonometrii, zainicjowanej badaniami Frisha dotyczącymi funkcji produkcji, przypada również na koniec lat 20. ubiegłego wieku [Sztaudynger 2005, s. 7].

Pierwszymi ekonomistami, którzy sformułowali koncepcję wzrostu gospodarczego, która na trwałe weszła do współczesnej makroekonomii, byli R. F. Harrod i E. D. Domar. Ich modele wywodzą się z keynesowskiego nurtu teorii makroekonomii, do którego wpisują się modele wzrostu gospodarki socjalistycznej proponowane przez M. Kaleckiego [por. M. Kalecki 1970, s. 125-133]. W teorii makroekonomii, po keynesistowskich modelach wzrostu gospodarczego, pojawiły się modele neoklasyczne, a wśród nich na szczególną uwagę zasługuje model Solowa-Swana, w którym do klasycznej funkcji produkcji (typu Cobba-Douglasa) wprowadzono zmienną czasową, która odzwierciedla egzogeniczność postępu technicznego [Cichy 2008, s. 9].

W drugiej połowie XX w. podejmowane były liczne próby wyjaśnienia źródeł postępu technicznego. W modelu N. Kaldora z 1957 r. i modelu Arrowa z 1962 r. postęp techniczny łączono z inwestycjami w kapitał rzeczowy [Tokarski 2001, s. 18-19]. K. Shell, w swoim modelu z 1966 r., wskazywał na związki postępu technicznego $\mathrm{z}$ inwestycjami w wiedzę naukowo-techniczną, a H. Uzawa (1965) z inwestycjami w kapitał ludzki [por. Shell 1966]. Od drugiej połowy lat 80. XX w. pojawiają się modele wzrostu endogenicznego, które rozszerzają neoklasyczny model Solowa, gdzie endogenizuje się postęp techniczny oraz stopy oszczędności/inwestycji w ujęciu makroekonomicznym.

Do najczęściej weryfikowanych na gruncie empirycznym modeli wzrostu endogenicznego zaliczyć można modele R. E. Lucasa (1988) i P. M. Romera (1986 i 1990). Punktem wyjścia jest tutaj krytyczna analiza modelu Solowa i postawienie tezy, iż postęp techniczny (rozumiany jako akumulacja wiedzy naukowo-technicznej lub kapitału ludzkiego) jest efektem celowych decyzji inwestycyjnych podmiotów w ww. sferach. Z kolei odrzucenie tezy o stałych efektach skali funkcji produkcji wynika stąd, że akumulacja wiedzy naukowo-technicznej i kapitału ludzkiego prowadzi do efektów zewnętrznych, będących skutkiem tego, iż ze zgromadzonej wiedzy i kapitału ludzkiego mogą korzystać nie tylko podmioty bezpośrednio ponoszące koszty owej akumulacji, lecz również ich otoczenie mikro- i/lub makroekonomiczne [Liberda 1996, s. 328-333]. Główną tezą wynikającą z teorii wzrostu endogenicznego jest stwierdzenie, iż na skutek istnienia efektów zewnętrznych, związanych z postępem technicznym, możliwe jest podniesienie długookresowej stopy wzrostu gospodarczego w sposób skuteczny i trwały [Tokarski 2001, s.35-44].

Współcześnie zauważa się, że istotną rolę w generowaniu wzrostu gospodarczego odgrywa zarówno aktywność sektora $\mathrm{B}+\mathrm{R}$, jak i pozostałych sekcji i działów gospodarki, które prowadzą badania naukowe i wdrażają innowacje. Przejawy tej działalności materializują się w nakładach na innowacje, w nakładach na $\mathrm{B}+\mathrm{R}$, edukację 
oraz w wynikach badań w postaci patentów i licencji. W endogenicznej teorii wzrostu przyjmuje się bowiem, że postęp techniczny wynika przede wszystkim z innowacji powstających w wyniku krajowej i zagranicznej działalności badawczo-rozwojowej oraz z akumulacji kapitału ludzkiego [Świeczewska 2007, s. 81].

Postęp techniczny „stanowi istotny, jeśli nie najistotniejszy, czynnik wzrostu gospodarczego" [Tokarski 2001a, s.13]. Postęp techniczny, czyli wprowadzanie nowych, udoskonalonych metod produkcji i doskonalszych narzędzi, pozwalających na osiągnięcie większych efektów produkcyjnych, przy zastosowaniu tej samej liczby czynników produkcji lub na uzyskiwanie dotychczasowych efektów przy zastosowaniu mniejszej ilości środków, powoduje wzrost efektywności przedsiębiorstw, sektorów gospodarki i wreszcie wzrost PKB. Każdy więc wzrost strumienia produkcji, który nie wynika ze wzrostu zasobów czynników produkcji, czyli nie jest związany z procesem akumulacji kapitału rzeczowego i wzrostem nakładów pracy, jest efektem działania postępu technicznego. Postęp techniczny może być generowany przez innowacje produktowe, procesowe i organizacyjne. W skali mikro ocenę efektów postępu technicznego sprowadza się na ogół do oceny pojedynczych przedsięwzięć innowacyjnych [Juszczak-Szumacher 1996, s. 58]. Natomiast w ujęciu makroekonomicznym efekty postępu technicznego są oceniane poprzez zmiany efektywności analizowanych struktur gospodarczych. Zmiany te wyrażają się na ogół przemianami w strukturze czynników produkcji, zmianami w strukturze produkcji oraz zmianami produktywności pojedynczych czynników produkcji, jak również całej grupy czynników. W tym ostatnim przypadku mamy do czynienia ze zmianami łącznej produktywności czynników produkcji $(T F P)$. W procesie wzrostu gospodarczego efekty absorpcji wiedzy w postaci innowacji są zazwyczaj opisywane przez łączną produktywność czynników produkcji, która określa wielkość produkcji przypadającą na jednostkę kombinacji czynników produkcji. Zatem TFP jest syntetycznym miernikiem oceny zmian efektywności procesów produkcyjnych będących efektem postępu technicznego.

Jako jeden z pierwszych, postęp techniczny do funkcji produkcji wprowadził R. Solow [1957]. Zaproponowana przez niego funkcja produkcji rozszerzała klasyczną funkcję Cobba-Douglasa o łączną produktywność czynników produkcji [Świeczewska 2007, s.74]:

$$
Y_{t}=A_{t} K_{t}^{\alpha} L_{t}^{1-\alpha}
$$

gdzie:

$Y_{t}$ - wartość produkcji (w cenach stałych),

$A_{t}$ - łączna produktywność czynników produkcji $A_{t}=T F P_{t}$,

$K_{t}$ - wartość kapitału (w cenach stałych),

$L_{t}$ - nakłady pracy,

$\alpha, 1-\alpha$ - elastyczności produkcji względem odpowiednio nakładów kapitału i pracy. 
Przy stałej podaży jednego z podstawowych czynników produkcji możliwy jest trwały wzrost gospodarczy, wynikający z akumulacji pozostałych czynników (w tym postępu technicznego).

Metodologia Solowa pomiaru łącznej produktywności czynników produkcji w kolejnych latach była dalej rozwijana (por. np. Denison 1962; Hal 1990; Röger 1995; Barro 1999; Mohnen 2002; Jorgenson, Ho i Stiroh 2008; Burda i Severgnini 2008, 2009).

W badaniach empirycznych korzysta się z różnych metod wyznaczania łącznej produktywności czynników produkcji. Najczęściej jest nią metoda oparta na koncepcji funkcji produkcji. Jeśli założymy, że kapitał (K) i praca (L) są jedynymi czynnikami produkcji, wówczas poziom $T F P$, który określa wielkość produkcji (Y) na jednostkę kombinacji czynników produkcji w okresie $t$, można zapisać jako:

$$
T F P_{t}=\frac{Y_{t}}{F\left(K_{t}, L_{t}\right)} .
$$

Powyższe wyrażenie możemy sprowadzić do postaci:

$$
Y_{t}=T F P_{t} \cdot F\left(K_{t}, L_{t}\right) \text {. }
$$

Pierwsze szacunki stopy postępu technicznego, utożsamianego ze stopą wzrostu łącznej produktywności czynników produkcji, przeprowadził cytowany wcześniej Solow [1957]. W swoich badaniach wykorzystał marginalną teorię podziału J. B. Clarka, która zakłada, że każdy czynnik produkcji opłacany jest według jego produktu krańcowego, korzyści skali są niezmienne. Funkcja produkcji jest więc jednorodna stopnia pierwszego, tzn. $p$-krotny wzrost nakładów wszystkich czynników produkcji powoduje również $p$-krotny wzrost produkcji [por. W Welfe, A. Welfe 1996, s. 43]. Uwzględniając stopy wzrostu formuła (6.3) przyjmuje postać [Świeczewska 2007, s.72-73]:

$$
\frac{\stackrel{\circ}{T F P_{t}}}{T F P_{t}}=\frac{\stackrel{\circ}{Y}_{t}}{Y_{t}}-\alpha_{t}^{K} \frac{\stackrel{\circ}{K_{t}}}{K_{t}}-\left(1-\alpha_{t}^{K}\right) \frac{\stackrel{\circ}{L}_{t}}{L_{t}},
$$

gdzie:

$$
\frac{d Y_{t}}{d t}=\stackrel{\circ}{Y}, \frac{d T F P_{t}}{d t}={\stackrel{\circ}{F} P_{t}}, \frac{d K_{t}}{d t}=\stackrel{\circ}{K}_{t}, \frac{d L_{t}}{d t}=\stackrel{\circ}{L}_{t},
$$

$\alpha,(1-\alpha)$ są udziałami nakładów kapitału i pracy w produkcie.

Tempo wzrostu łącznej produktywności czynników produkcji, utożsamiane często ze stopą postępu technicznego, jest zatem różnicą między stopą wzrostu produktu a ważoną sumą stóp wzrostu podstawowych czynników produkcji, z wagami określającymi udział każdego z tych czynników w produkcie. W przypadku większej liczby czynników, stopa wzrostu łącznej produktywności czynników 
produkcji jest różnicą między stopą wzrostu produkcji a ważoną sumą stóp wzrostu nakładów $n$ czynników produkcji z wagami określającymi elastyczność produkcji względem danego czynnika.

Rozliczając wzrost produkcji w postaci różnicy w równaniu (6.4) występuje tzw. reszta Solowa [Tokarski 2001, s. 24-25; Sztaudynger 2003, s.15].

Oszacowanie tempa wzrostu TFP sprowadza się w zasadzie do wyznaczenia elastyczności produkcji względem każdego z czynników produkcji i w związku $\mathrm{z}$ tym pojawia się problem wyboru postaci funkcji produkcji. W badaniach empirycznych funkcja ta najczęściej przyjmuje postać dwuczynnikowej funkcji produkcji typu Cobba-Douglasa [Świeczewska 2007, s.74]. Zatem formułę (6.1) dla stóp wzrostu można również zapisać jako:

$$
\frac{\stackrel{\circ}{A}_{t}}{A_{t}}=\frac{\stackrel{\circ}{Y}_{t}}{Y_{t}}-\alpha \frac{\stackrel{\circ}{K}_{t}}{K_{t}}-(1-\alpha) \frac{\stackrel{\circ}{L}_{t}}{L_{t}}
$$

co jest równoważne z zapisem (6.4).

Określenie dynamiki łącznej produktywności czynników produkcji wymaga wyznaczenia parametrów funkcji (6.1), które określają elastyczność produkcji względem każdego z czynników produkcji. Ocenę tych parametrów można otrzymać przez bezpośrednią estymację parametrów funkcji produkcji lub w wyniku kalibracji. W przypadku kalibracji korzysta się z wyników neoklasycznej teorii produkcji, w myśl której parametr $\alpha$ może być aproksymowany przez udział nadwyżki operacyjnej w wartości dodanej, a więc przez odjęcie od jedności udziału kosztów pracy w wartości dodanej [Barro 1999, s. 118-137]. Zatem, w dhugim okresie elastyczności względem czynników produkcji są równe udziałowi poszczególnych czynników produkcji w wartości dodanej. W przypadku kapitału parametr $\alpha$ jest równy udziałowi nadwyżki operacyjnej brutto w wartości dodanej, a $1-\alpha$-udziałowi kosztów pracy w wartości dodanej [Świeczewska 2007, s. 74]. Jednak sposób ten, szeroko wykorzystywany w badaniach empirycznych, budzi wiele wątpliwości. Po pierwsze, w długich okresach zmienia się udział kosztów pracy w wartości dodanej, a po drugie, koszty pracy są różnie definiowane [W. Welfe 2007, s. 14].

W analizach funkcji produkcji dla potrzeb obliczenia poziomu i dynamiki łącznej produktywności czynników produkcji należy zwrócić uwagę na kilka kwestii, które wpływają na jakość przeprowadzonych badań. Dotyczy to przede wszystkim postaci funkcji produkcji, a także problemów związanych z doborem odpowiednich mierników produkcji i jej czynników. Kolejnym problemem jest występowanie różnicy między produkcją efektywną (obserwowaną) a produkcją potencjalną, wynikającą z funkcji produkcji, przy założeniu pełnego wykorzystania zdolności produkcyjnych. Zatem wielkość produkcji obserwowanej powinna być skorygowana stopniem wykorzystania potencjału produkcyjnego [W.Welfe 2003, s. 107]. Obok wymienionych ograniczeń pojawiają się jeszcze problemy dostępności danych statystycznych. 
Liczne badania empiryczne mające na celu wskazanie źródeł postępu technicznego opierają się na funkcji produkcji, poszerzonej o nowy czynnik produkcji charakteryzujący potencjał naukowo-badawczy danej gospodarki, mierzony przede wszystkim skumulowanymi nakładami na $\mathrm{B}+\mathrm{R}$ lub nakładami na działalność innowacyjną. Tego typu badania prowadzono od połowy XX w., a w ich obszarze znalazły się prace m. in. takich badaczy, jak Z. Griliches $(1957,1979)$, J. Schmookler (1966), E. Mansfield (1968). Wyniki analiz, realizowanych głównie na szczeblu przedsiębiorstw i gałęzi gospodarki, dowodziły istnienia dodatniej zależności między wielkością nakładów na działalność innowacyjną a rozwojem gospodarczym. W latach osiemdziesiątych poprzedniego wieku taka hipoteza była weryfikowana przede wszystkim na poziomie gospodarek narodowych, a wykorzystywana do tego celu funkcja produkcji przyjęła postać [Griliches 1995, s.55]:

$$
Y_{t}=A_{t} F\left(B R K_{t}, K_{t}, L_{t}\right),
$$

gdzie:

$Y_{t}$ - wielkość produkcji (w cenach stałych),

$A_{t}$ - czynnik odzwierciedlający nieucieleśniony, egzogeniczny postęp techniczny, łych),

$B R K_{t}$ - skumulowana wielkość nakładów na działalność $\mathrm{B}+\mathrm{R}$ (w cenach sta-

$K_{t}$ - zasób kapitału (w cenach stałych),

$L_{t}-$ zasoby pracy.

Wielkość skumulowana nakładów na $B+R$ jest równa sumie przeszłych nakładów na $\mathrm{B}+\mathrm{R}$ uwzględniających stopę deprecjacji, którą przyjmuje się zwykle na poziomie 0,05-0,2 [Coe, Helpman 1995, s. 883; W. Welfe 2001, s.141]. W literaturze przedmiotu wskazano ponadto, że stopa wzrostu łącznej produktywności czynników produkcji zależy od stopy wzrostu skumulowanych nakładów na działalność $\mathrm{B}+\mathrm{R}$.

Jeżeli stopa deprecjacji skumulowanych nakładów na działalność badawczorozwojową jest bliska zeru, to wówczas przyrost skumulowanych nakładów na $\mathrm{B}+\mathrm{R}$ może być opisywany przez wielkość bieżących nakładów na $\mathrm{B}+\mathrm{R}$ poniesionych w okresie t, czyli przez BR. Wobec powyższego założenia funkcję produkcji opisaną zależnością (6.6) można przekształcić do postaci [por. np. Świeszewska 2007, s. 84] :

$$
\frac{d T F P_{t}}{d t} \cdot \frac{1}{T F P_{t}}=\lambda+\mu \frac{B R_{t}}{Y_{t}} .
$$

Stopa wzrostu łącznej produktywności czynników produkcji jest zatem funkcją intensywności nakładów na działalność badawczo-rozwojową, określoną przez udział bieżących nakładów na $\mathrm{B}+\mathrm{R}$ w produkcji. Parametr $\mu$ określa 
stopę zwrotu z inwestycji w sferę B+R [Griliches 1980, s. 344; Nadiri 1993, s. 9]. Natomiast $\lambda$ to stopa egzogenicznego nieucieleśnionego postępu technicznego $\left(\frac{d A_{t}}{d t} \cdot \frac{1}{A_{t}}=\lambda\right)$.

Początek badań nad zależnością między tempem wzrostu łącznej produktywności czynników produkcji a nakładami na działalność badawczo-rozwojową (skumulowanymi lub bieżącymi) miał miejsce w latach 80. ubiegłego wieku. Badania prowadzono na szczeblu przedsiębiorstw i na poziomie gałęzi przemysłu [Griliches 1980, 1981, 1986]. Zwracano uwagę na transfer nakładów na B+R ( $R \& D$ spillovers) między poszczególnymi przedsiębiorstwami czy gałęziami przemysłu, bowiem produktywność danego podmiotu zależy również od innowacyjności związanych i kooperujących z nim podmiotów. Wyróżnia się dwa rodzaje transferu technologii [Griliches 1979]: transfer technologii ucieleśnionej, który ma charakter bezpośredni przez transakcje związane z zakupem dóbr pośrednich, inwestycyjnych, licencji itp. lub transfer ogólnodostępnej wiedzy i technologii (knowledge spillovers), który ma charakter pośredni. Ten ostatni jest efektem obserwacji i kopiowania istniejącej w otoczeniu wiedzy [Meister, Verspagen 2004].

Jednak uwzględnienie $\mathrm{w}$ badaniach empirycznych korzyści wynikających $\mathrm{z}$ transferu wiedzy zewnętrznej nie jest zadaniem łatwym, gdyż wymaga skonstruowania miernika tych korzyści, który uwzględniałby zarówno różne nośniki innowacji, jak i potencjału innowacyjnego podmiotów, z których następuje transfer. W tym miejscu pojawiają się problemy z dostępnością danych statystycznych. Potrzebne są informacje o transakcjach dóbr pośrednich, jak i inwestycyjnych oraz patentów. W analizach sektorowych przydatne mogą się okazać współczynniki input-output, które charakteryzują przepływy produktów. Ważną zmienną opisującą korzyści z transferu wiedzy jest wielkość importu, w tym inwestycyjnego, oraz wielkość bezpośrednich inwestycji zagranicznych czy przepływ patentów między poszczególnymi krajami. Przykłady mierników korzyści zewnętrznych wynikających z transferu wiedzy i technologii można spotkać w pracy I. Świeczewskiej [2007], Ł. Tomaszewicz (red.) [2010].

\subsection{Ocena wpływu innowacyjności na konkurencyjność przedsiębiorstw funkcjonujących w przemyśle spożywczym}

Punktem wyjścia w formułowaniu oceny relacji między innowacyjnością a konkurencyjnością przemysłu produkującego żywność są wspomniane wyżej modele ekonomiczne.

Na gruncie teorii uwzględniającej wpływ innowacji na poziom i tempo wzrostu gospodarczego udowodniono, że osiągnięcie przewagi konkurencyjnej jest 
możliwe poprzez działania innowacyjne, a zdolność przemysłu do innowacji i do podnoszenia poziomu technologicznego decyduje o konkurencyjności gospodarki [Porter 1990]. Zatem pozycja konkurencyjna firm przetwórstwa przemysłowego oraz całej gospodarki jest w znacznym stopniu rezultatem wdrażania do procesu gospodarczego osiągnięć nauki w postaci nowych, lepszych rozwiązań dotyczących środków produkcji i metod wytwarzania. Według M. Portera wpływ działalności innowacyjnej działów przetwórstwa przemysłowego na ich konkurencyjność odzwierciedlają zmiany w wydajności pracy i kapitału. Trwały wzrost efektywności, definiowany przez Portera jako wytworzona wartość przypadająca na jednostkę pracy lub kapitału, wymaga ciągłego postępu w gospodarce, a więc wprowadzania innowacji. Zwiększenie efektywności działów jest możliwe przez podwyższanie jakości produktów, ich modyfikowanie oraz doskonalenie technologii ich wytwarzania. Oznacza to, że innowacje prowadzą do zmian przewag konkurencyjnych, co ostatecznie znajduje odzwierciedlenie w zmianach wydajności czynników wytwórczych. Wydaje się zatem, że w krótkim okresie poprawa konkurencyjności działów przetwórstwa przemysłowego znajduje odzwierciedlenie we wzroście wartości produkcji sprzedanej, zaś w długim okresie we wzroście produktywności, w tym wydajności pracy czy łącznej produktywności czynników produkcji.

Warto przy tym zauważyć, że główne przyczyny znacznego zróżnicowania poziomu innowacyjności działów przetwórstwa przemysłowego to niejednakowe nakłady na działalność innowacyjną, w tym przede wszystkim na $\mathrm{B}+\mathrm{R}$, poziom i struktura zatrudnienia oraz organizacja i kooperacja w zakresie działalności innowacyjnej.

W ocenie wpływu innowacji na konkurencyjność działów przetwórstwa przemysłowego w Polsce należy brać pod uwagę, z jednej strony, poziom wydatków przedsiębiorstw z danej branży na działalność innowacyjną (w tym wydatki na $B+R$ ) jako nakład na tworzenie i wprowadzanie nowych rozwiązań, zaś z drugiej strony osiągnięte wyniki, mierzone zmianami wartości dodanej, dynamiką produkcji sprzedanej oraz zmianami wydajności pracy czy łącznej produktywności czynników produkcji [Witkowski, Weresa, 2006, s. 2002-2003]. Mówiąc o nakładach na działalność innowacyjną należy pamiętać o transferze wiedzy z zagranicy. W niniejszym badaniu przyjęto, że zmiennymi opisującymi ten przepływ są import i BIZ.

Ocena wpływu innowacji na konkurencyjność przedsiębiorstw przemysłu spożywczego została przeprowadzona na dwóch poziomach agregacji działalności według PKD 2004. Pierwszy z nich obejmuje przedsiębiorstwa przemysłu spożywczego ogółem, czyli 15. i 16. dział przetwórstwa przemysłowego (dwucyfrowy poziom agregacji według PKD). Drugi poziom, bardziej szczegółowy, dotyczy klas lub grup klas, które stanowią 18 branż przemysłu spożywczego (czterocyfrowy poziom agregacji według PKD). 


\subsubsection{Przemysł spożywczy ogółem}

W niniejszym punkcie przedstawione zostały wyniki badań mających na celu ilościową ocenę wpływu innowacji na konkurencyjność przedsiębiorstw całego agregatu jakim jest przemysł spożywczy. Jako mierniki konkurencyjności przyjęto - w zależności od wersji modelu - produkcję sprzedaną, wartość dodaną brutto, wydajność pracy oraz TFP. Badanie opiera się na analizie funkcji produkcji Cobba-Douglasa poszerzonej o zmienne opisujące innowacje (nakłady na działalność innowacyjną, import i BIZ). Import i inwestycje zagraniczne są kanałami transferu wiedzy i technologii z zagranicy.

Analiza przeprowadzona została $\mathrm{z}$ wykorzystaniem próby czasowej obejmującej 13 obserwacji (dane za lata 1996-2008) opisujących działalność przedsiębiorstw przemysłu spożywczego. Dane te pochodziły z publikowanych baz Głównego Urzędu Statystycznego i dotyczyły przedsiębiorstw zatrudniających powyżej 49 pracowników. Informacje o poziomie BIZ w tym dziale gospodarki uzyskano z NBP.

Zbiór danych obejmował takie informacje na temat przemysłu spożywczego, jak: produkcja globalna, produkcja sprzedana, wartość dodana brutto, koszty związane z zatrudnieniem, nadwyżka operacyjna brutto, wartość brutto środków trwałych, nakłady inwestycyjne, pracujący, zatrudnieni w B+R. Nakłady na działalność innowacyjną obejmowały nakłady na: B+R; zakup gotowej technologii w postaci praw i dokumentacji; maszyny, urządzenia techniczne i narzędzia oraz środki transportu; budynki i budowle; szkolenie personelu związane z działalnością innowacyjną; marketing dotyczący nowych i zmodernizowanych wyrobów oraz napływ zagranicznych inwestycji bezpośrednich, eksport $i$ import. Wszystkie zmienne mierzące „wartość pieniężną” zostały urealnione i wyrażone w cenach stałych z $2000 \mathrm{r}$.

Oszacowania parametrów modeli przeprowadzono w pakiecie GRETL.

\subsubsection{Model produkcji sprzedanej}

W celu zweryfikowania, jaki wpływ na zmiany produkcji sprzedanej w przemyśle spożywczym mają poszczególne czynniki związane z szeroko rozumianą innowacyjnością tego przemysłu oszacowano model, będący poszerzoną funkcją produkcji Cobba-Douglasa. W funkcji tej, poza pierwotnymi czynnikami produkcji (pracą, mierzoną liczbą pracujących oraz kapitałem, mierzonym wartością brutto środków trwałych w cenach stałych), uwzględniono także czynniki związane z innowacyjnością przedsiębiorstw przemysłu spożywczego. Uznano również, że w przypadku gospodarek słabo rozwiniętych istotny wpływ na konkurencyjność (mierzoną np. produkcją sprzedaną) ma transfer wiedzy i technologii z zagranicy, a korzyści wynikające z tego transferu zależą m.in. od stopnia otwartości danej gospodarki [Coe, Helpman, Hoffmaister 1997, s. 137]. Zatem efekty 
absorpcji wiedzy wyrażone zostały zarówno przez krajowe, jak i zagraniczne nakłady na innowacje lub $\mathrm{B}+\mathrm{R}$, a mówiąc o absorpcji wiedzy z zewnątrz w opisie innowacji uwzględniono napływ zagranicznych inwestycji bezpośrednich oraz eksport i import.

Funkcję produkcji sprzedanej przemysłu spożywczego, w której, poza klasycznymi czynnikami produkcji (pracą i kapitałem), uwzględniono także czynnik związany z innowacyjnością tej sfery gospodarki można zapisać w postaci zlinearyzowanej następująco:

$$
\ln Y_{t}=\alpha_{0}+\alpha_{1} \ln K_{t}+\alpha_{2} \ln L_{t}+\alpha_{k} \ln I N N T R_{t}+\varepsilon_{t},
$$

gdzie:

$Y_{t}$ - produkcja sprzedana (w cenach stałych),

$K_{t}$ - wartość brutto środków trwałych (w cenach stałych),

$L_{t}-$ liczba zatrudnionych,

$I N N T R_{t}$ - zmienna opisująca innowacyjność (nakłady na działalność innowacyjną i/lub transfer wiedzy z zagranicy) w cenach stałych,

$\alpha_{1}, \ldots, \alpha_{k}$ - parametry modelu,

$\varepsilon_{t}-$ składnik losowy, przy czym zakłada się, że $\varepsilon_{t} \sim \mathrm{N}\left(0, \sigma^{2}\right)$.

W pracy testowano różne warianty modelu (6.8), w których innowacje wyrażano za pomocą różnych zmiennych. Wyniki estymacji najlepszych, w opinii autorki, modeli przedstawia tab. 6.1.

Wszystkie analizowane modele są poprawne pod względem statystycznym. Świadczą o tym wysokie wartości współczynników determinacji (wskazujące na dobre własności prognostyczne) i wartości statystyki Durbina-Watsona (świadczące o braku autokorelacji składnika losowego). Analizując model produkcji sprzedanej w klasycznej, potęgowej postaci, uzyskujemy elastyczności zmiennych zgodne z założeniami (mniejsze od 1). Na ich podstawie wnioskujemy, że istotny i stosunkowo silny wpływ na poziom produkcji sprzedanej ma wartość środków trwałych $(K)$. Natomiast wpływ zatrudnienia $(L)$, drugiego klasycznego czynnika produkcji, nie jest istotny statystycznie. W kolejnych wariantach modelu produkcji sprzedanej uwzględniano również nakłady wewnętrzne na $\mathrm{B}+\mathrm{R}(\mathrm{BRW})$, import (IMP) i eksport (EKSP) przemysłu spożywczego, a także bezpośrednie inwestycje zagraniczne - zarówno bieżące (BIZ), jak i opóźnione (BIZ_2). Zestawiając wpływ kapitału (K), eksportu, innowacji (mierzonych nakładami wewnętrznymi na działalność badawczo-rozwojową - BRW) i BIZ wykazano istotne (w sensie statystycznym) oddziaływanie wszystkich tych czynników. Podobne wyniki uzyskano uwzględniając - zamiast eksportu - import lub bezpośrednie inwestycje zagraniczne. Efekty innowacji są już widoczne w tym samym okresie, w którym zostały poniesione nakłady. 
Tabela 6. 1. Wyniki estymacji parametrów modelu produkcji sprzedanej (logarytmy)

\begin{tabular}{|c|c|c|c|c|c|c|}
\hline \multirow[b]{2}{*}{ Zmienna } & \multicolumn{6}{|c|}{ Oszacowanie parametrów } \\
\hline & Wariant I & Wariant II & Wariant III & Wariant IV & Wariant V & $\begin{array}{l}\text { Wariant VI } \\
\text { przyrosty } \\
\text { zmiennych }\end{array}$ \\
\hline Stała & $\begin{array}{c}7,599 \\
(96,41)\end{array}$ & $\begin{array}{c}6,736 \\
(40,33)\end{array}$ & $\begin{array}{c}7,899 \\
(69,03)\end{array}$ & $\begin{array}{c}7,269 \\
(38,48)\end{array}$ & $\begin{array}{c}7,803 \\
(72,91)\end{array}$ & $\begin{array}{l}0,013 \\
(2,20)\end{array}$ \\
\hline $\ln \mathrm{K}$ & $\begin{array}{c}0,273 \\
(22,05)\end{array}$ & $\begin{array}{c}0,255 \\
(12,83)\end{array}$ & $\begin{array}{c}0,276 \\
(19,02)\end{array}$ & $\begin{array}{c}0,348 \\
(10,59)\end{array}$ & $\begin{array}{c}0,296 \\
(19,25)\end{array}$ & $\begin{array}{l}0,162 \\
(3,06)\end{array}$ \\
\hline $\ln$ EKSP & $\begin{array}{c}0,194 \\
(17,85) \\
\end{array}$ & & $\begin{array}{l}0,148 \\
(9,99) \\
\end{array}$ & $\begin{array}{l}0,155 \\
(9,74) \\
\end{array}$ & $\begin{array}{l}0,134 \\
(9,49)\end{array}$ & \\
\hline $\ln$ IMP & & $\begin{array}{c}0,300 \\
(12,07)\end{array}$ & & & & \\
\hline ln BRW & & & $\begin{array}{l}0,030 \\
(2,94)\end{array}$ & & $\begin{array}{l}0,026 \\
(2,93)\end{array}$ & $\begin{array}{l}0,040 \\
(4,47)\end{array}$ \\
\hline $\ln \mathrm{BIZ} \_2$ & & & & $\begin{array}{l}0,018 \\
(2,37)\end{array}$ & & \\
\hline Ln BIZ & & & & & $\begin{array}{l}0,015 \\
(2,13)\end{array}$ & $\begin{array}{l}0,013 \\
(3,07)\end{array}$ \\
\hline $\begin{array}{l}\text { Zmienna zero- } \\
\text { jedynkowa }\end{array}$ & \begin{tabular}{cc}
\multicolumn{2}{c}{ Tak } \\
u & 00 \\
u & 04
\end{tabular} & Nie & Nie & Nie & Nie & Nie \\
\hline$R^{2}$ & 0,997 & 0,990 & 0,995 & 0,993 & 0,997 & 0,934 \\
\hline$R^{2}$ skorygowany & 0,996 & 0,989 & 0,993 & 0,990 & 0,995 & 0,896 \\
\hline DW & 1,513 & 2,607 & 2,369 & 2,953 & 1,68 & 2,057 \\
\hline
\end{tabular}

Oznaczenia: $K$ - wartość brutto środków trwałych (w mln zł), EKSP- eksport (w mln zł), IMP- import (w mln zł), $B R W$ - nakłady wewnętrzne na B+R (w mln zł), BIZ_2 - napływ zagranicznych inwestycji bezpośrednich opóźnionych o dwa lata (w mln USD), BIZ - napływ zagranicznych inwestycji bezpośrednich w mln USD, ln - logarytm naturalny.

$R^{2}$ - współczynnik determinacji, DW - statystyka Durbina -Watsona.

Źródło: opracowanie własne (dotyczy wszystkich tabel w rozdz. 6).

Z wariantu I, gdzie czynnikami konkurencyjności są kapitał i eksport, wynika, że wraz ze wzrostem środków trwałych o $1 \%$ produkcja sprzedana rośnie średnio o $0,273 \%$, natomiast wzrost eksportu o $1 \%$ skutkuje wzrostem tej produkcji o $0,194 \%$. Z wariantu II wnioskujemy, iż silniejsze efekty w postaci wzrostu produkcji sprzedanej daje import niż eksport, bowiem 1-procentowy 
wzrost importu powoduje wzrost produkcji sprzedanej w przemyśle spożywczym przeciętnie o $0,3 \%$. W równaniu III jedną ze zmiennych objaśniających, obok kapitału i eksportu, są nakłady wewnętrzne na działalność $B+R$, a ich wzrost o $1 \%$ skutkuje wzrostem produkcji sprzedanej średnio o $0,03 \%$. BIZ ulokowane w przedsiębiorstwach przemysłu spożywczego w Polsce zwiększają konkurencyjność tego działu gospodarki. Wzrost BIZ o 1\% w roku badanym przyczynia się do wzrostu produkcji sprzedanej w tym samym okresie średnio o $0,015 \%$, natomiast nieco silniejszy jest efekt BIZ poniesionych dwa lata wcześniej (wariant IV). W ostatnim wariancie (por. tab. 6.1) do objaśnienia relacji, zachodzących między produkcją sprzedaną a jej czynnikami, stosuje się nie poziom tych zmiennych, ale ich dynamikę. Zatem model zbudowany jest na podstawie przyrostów (tempa zmian). Okazuje się, że wzrostowi każdego z czynników produkcji (kapitału, nakładów na $\mathrm{B}+\mathrm{R}$ oraz BIZ) o 1 punkt procentowy towarzyszy wzrost produkcji sprzedanej odpowiednio o $0,162,0,040$ oraz 0,013 punktów procentowych.

\subsubsection{Model wydajności pracy}

Funkcja produkcji opisana modelem (6.8), omówiona w punkcie 6.2.1.1, została przekształcona do postaci funkcji wydajności pracy. Przekształcenie to jest możliwe przy założeniu, że funkcja produkcji charakteryzuje się stałymi efektami skali (suma parametrów przy zmiennych objaśniających równa się 1). Wówczas funkcję tę można zapisać w postaci:

$$
\ln \left(\frac{Y_{t}}{L_{t}}\right)=\alpha_{0}+\alpha_{1} \ln \left(\frac{K_{t}}{L_{t}}\right)+\alpha_{k} \ln \left(\frac{I N N T R_{t}}{L_{t}}\right)+\varepsilon_{t} .
$$

Funkcja ta określa zależności między wydajnością pracy a technicznym uzbrojeniem pracy $\left(\frac{K_{t}}{L_{t}}\right)$ oraz intensywnością czynników opisujących innowacje przemysłu spożywczego.

Wyniki estymacji wybranych (zdaniem autorki najlepszych zarówno od strony merytorycznej, jak i statystycznej) wariantów modelu wydajności pracy (6.9) przedstawiono $\mathrm{w}$ tab. 6.2. Oszacowane modele posiadają dobre własności prognostyczne.

Jak już wcześniej podkreślono, jedną z charakterystyk pozwalających ocenić kondycję (konkurencyjność) przedsiębiorstw przemysłu spożywczego, a w szczególności jej reakcję na działalność innowacyjną prowadzoną w przedsiębiorstwach, jest wydajność pracy. 
Tabela 6.2. Wyniki estymacji parametrów modelu wydajność pracy (logarytmy)

\begin{tabular}{|c|c|c|c|c|}
\hline \multirow{2}{*}{ Zmienna } & \multicolumn{4}{|c|}{ Oszacowanie parametrów } \\
\hline & Wariant I & Wariant II & Wariant III & Wariant IV \\
\hline Stała & $\begin{array}{c}4,224 \\
(158,29) \\
\end{array}$ & $\begin{array}{c}3,901 \\
(61,95) \\
\end{array}$ & $\begin{array}{c}4,613 \\
(177,41) \\
\end{array}$ & $\begin{array}{c}4,860 \\
(54,12)\end{array}$ \\
\hline $\ln \mathrm{K} / \mathrm{L}$ & $\begin{array}{c}0,364 \\
(26,87) \\
\end{array}$ & $\begin{array}{c}0,324 \\
(15,12)\end{array}$ & $\begin{array}{c}0,506 \\
(33,81)\end{array}$ & $\begin{array}{c}0,452 \\
(15,98)\end{array}$ \\
\hline $\ln \mathrm{EKSP} / \mathrm{L}$ & $\begin{array}{c}0,174 \\
(15,48) \\
\end{array}$ & & & \\
\hline $\ln \mathrm{IMP} / \mathrm{L}$ & & $\begin{array}{c}0,294 \\
(11,07) \\
\end{array}$ & & \\
\hline $\ln \mathrm{BIZ} / \mathrm{L}$ & & & $\begin{array}{l}0,098 \\
(9,01) \\
\end{array}$ & \\
\hline $\ln \mathrm{BRW} / \mathrm{L}$ & & & & $\begin{array}{l}0,072 \\
(3,65) \\
\end{array}$ \\
\hline $\begin{array}{l}\text { Zmienna zero- } \\
\text { jedynkowa }\end{array}$ & $\begin{array}{c}\text { Tak } \\
\text { u9899 }\end{array}$ & $\begin{array}{c}\text { Tak } \\
\text { u9899 }\end{array}$ & $\begin{array}{l}\text { Tak } \\
\text { u98 } \\
\text { u00 }\end{array}$ & $\begin{array}{c}\text { Tak } \\
\text { u9901 }\end{array}$ \\
\hline$R^{2}$ & 0,998 & 0,995 & 0,995 & 0,985 \\
\hline$R^{2}$ skorygowany & 0,997 & 0,994 & 0,992 & 0,980 \\
\hline DW & 2,346 & 1,936 & 2,596 & 1,545 \\
\hline
\end{tabular}

Oznaczenia: $K / L$ - wartość brutto środków trwałych na zatrudnionego (w tys. zł), EKSP/L eksport na zatrudnionego (w tys. zł), IMP/L - import na zatrudnionego (w tys. zł), BIZ - napływ zagranicznych inwestycji bezpośrednich na zatrudnionego (w tys. USD), BRW/L - nakłady wewnętrzne na B+R na zatrudnionego (w tys. zl), pozostałe oznaczenia jak w tab. 6.1.

Estymacja modeli wydajności pracy wykazała, że poza technicznym uzbrojeniem pracy (środki trwałe na jednego zatrudnionego - K/L) istotnie, a przy tym dodatnio wpływają na konkurencyjność przemysłu spożywczego również intensywność: eksportu (EKSP/L), importu (IMP/L), nakładów na działalność B+R $(\mathrm{B}+\mathrm{R} / \mathrm{L})$ oraz napływu BIZ (BIZ/L). Zatrudnienie, podobnie jak w przypadku produkcji sprzedanej, nie ma istotnego wpływu na konkurencyjność przedsiębiorstw przemysłu spożywczego mierzoną wydajnością pracy. Warto przy tym podkreślić, że zmiany wydajności pracy w największym stopniu determinuje techniczne uzbrojenie pracy, następnie intensywność importu (wraz ze wzrostem wskaźnika o 1\% produkcja sprzedana na zatrudnionego rośnie średnio o 0,294\%), intensywność eksportu (0,174\%), intensywność BIZ (0,098\%), a w najmniejszym stopniu intensywność nakładów wewnętrznych na B+R (0,072\%).

Elastyczności dla tych zmiennych są - zgodnie z oczekiwaniami - mniejsze od 1 . 


\subsubsection{Model wartości dodanej brutto}

Alternatywą dla modelu (6.9) jest model, w którym wydajność pracy jest wyrażona nie wartością produkcji sprzedanej na zatrudnionego a wartością dodaną na zatrudnionego.

Istotny wpływ na wartość dodaną brutto, podobnie jak na wydajność pracy, mają: techniczne uzbrojenie pracy (K/L), intensywność importu (IMP/L), eksportu (EKSP/L), BIZ (BIZ/L) oraz intensywność wewnętrznych nakładów na działalność badawczo-rozwojową (BRW/L) (por. tab. 6.3).

Tabela 6.3. Wyniki estymacji parametrów modelu wartości dodanej brutto na zatrudnionego (logarytmy)

\begin{tabular}{|c|c|c|c|c|}
\hline \multirow{2}{*}{ Zmienna } & \multicolumn{4}{|c|}{ Oszacowanie parametrów } \\
\hline & Wariant I & Wariant II & Wariant III & Wariant IV \\
\hline Stała & $\begin{array}{c}1,879 \\
(12,19)\end{array}$ & $\begin{array}{l}1,355 \\
(7,30)\end{array}$ & $\begin{array}{c}3,589 \\
(15,10)\end{array}$ & $\begin{array}{c}2,754 \\
(29,65)\end{array}$ \\
\hline $\ln \mathrm{K} / \mathrm{L}$ & $\begin{array}{l}0,434 \\
(6,36)\end{array}$ & $\begin{array}{l}0,301 \\
(5,48)\end{array}$ & $\begin{array}{l}0,544 \\
(7,14)\end{array}$ & $\begin{array}{c}0,786 \\
(13,76)\end{array}$ \\
\hline $\ln \mathrm{EKSP} / \mathrm{L}$ & $\begin{array}{l}0,416 \\
(6,44)\end{array}$ & & & \\
\hline $\ln \mathrm{IMP} / \mathrm{L}$ & & $\begin{array}{l}0,632 \\
(8,32)\end{array}$ & & \\
\hline $\ln \mathrm{BIZ} / \mathrm{L}$ & & & & $\begin{array}{l}0,227 \\
(5,36)\end{array}$ \\
\hline $\ln \mathrm{BRW} / \mathrm{L}$ & & & $\begin{array}{l}0,194 \\
(3,71)\end{array}$ & \\
\hline $\begin{array}{l}\text { Zmienna zero- } \\
\text { jedynkowa }\end{array}$ & $\begin{array}{c}\text { Tak } \\
\text { u9900 } \\
\text { u04 }\end{array}$ & $\begin{array}{c}\text { Tak } \\
\text { u05 } \\
\text { u9900 } \\
\text { u06 }\end{array}$ & $\begin{array}{l}\text { Tak } \\
\text { u01 } \\
\text { u05 }\end{array}$ & $\begin{array}{l}\text { Tak } \\
\text { u99 }\end{array}$ \\
\hline$R^{2}$ & 0,975 & 0,989 & 0,958 & 0,958 \\
\hline$R^{2}$ skorygowany & 0,963 & 0,982 & 0,937 & 0,944 \\
\hline DW & 1,844 & 2,574 & 1,952 & 1,905 \\
\hline
\end{tabular}

Oznaczenia jak w tab. 6.2.

Elastyczność technicznego uzbrojenia pracy względem wartości dodanej brutto jest dość wysoka. Warto też zauważyć, że wartość dodana brutto reaguje silniej na wzrost eksportu, importu, BIZ i nakładów na B+R, niż wydajność pracy, 
co jest zgodne z oczekiwaniami i teorią ekonomii. Według M. Portera (1998), w krótkim okresie poprawa konkurencyjności branży, będąca efektem wprowadzonych innowacji (własnych i transferowanych z zewnątrz), znajduje odzwierciedlenie we wzroście produkcji sprzedanej i wartości dodanej brutto, zaś w długim okresie we wzroście wydajności pracy.

Model wartości dodanej brutto jest poprawny pod względem statystycznym (wysokie wartości skorygowanego $R^{2}$ oraz statystyki $D W$ ).

\subsubsection{Model lącznej produktywności czynników produkcji (TFP)}

Kolejną zmienną, wyrażającą konkurencyjność przemysłu spożywczego, jest łączna produktywność czynników produkcji. Oszacowanie TFP oparte zostało na analizie funkcji produkcji typu Cobba-Douglasa, charakteryzującej się stałymi efektami skali:

$$
Y_{t}=A_{t} K_{t}^{\alpha} L_{t}^{1-\alpha} e^{\varepsilon_{t}},
$$

gdzie:

$Y_{t}$ - wartość produkcji (w cenach stałych),

$A_{t}$ - łączna produktywność czynników produkcji $A_{t}=T F P_{t}$,

$K_{t}$ - wartość kapitału (w cenach stałych),

$L_{t}$ - nakłady pracy,

$\alpha, 1-\alpha$ - elastyczność produkcji względem odpowiednio nakładów kapitału i pracy.

Funkcję (6.10) można przekształcić do funkcji wydajności pracy:

$$
\frac{Y_{t}}{L_{t}}=A\left(\frac{K_{t}}{L_{t}}\right)^{\alpha} e^{\varepsilon_{t}} .
$$

Na podstawie powyższej funkcji oszacowano elastyczność wydajności pracy względem technicznego uzbrojenia pracy (parametr $\alpha$ ), który następnie posłużył do obliczenia poziomu TFP dla przemysłu spożywczego według formuły:

$$
T F P_{t}=\frac{Y_{t}}{K_{t}^{\alpha} L_{t}^{1-\alpha}} .
$$

W dalszym kroku podjęto próbę wyjaśnienia zmian TFP za pomocą omawianych wcześniej czynników, określających innowacyjność przemysłu spożywczego. W tym celu oszacowano parametry równania opisującego zmiany TFP, uwzględniając postać liniową i potęgową: 
$T F P=\mathrm{f}\left(I N N T R, \varepsilon_{t}\right)$

W tabeli 6.4 przedstawiono oszacowania najlepszych wariantów modelu (6.13) w jego postaci liniowej i potęgowej. Wyszczególnione w tabeli zmienne objaśniające to te, które okazały się statystycznie istotne. Pod względem statystycznym najsłabsze wyniki uzyskano w przypadku modelowania TFP pod wpływem nakładów na działalność innowacyjną poniesionych w przedsiębiorstwach przemysłu spożywczego (współczynnik determinacji jest stosunkowo niski poniżej 0,8), niska jest także wartość statystyki Durbina-Watsona, co wskazuje na występowanie dodatniej autokorelacji składnika losowego. Pozostałe modele są satysfakcjonujące z punktu widzenia dopasowania, jak i autokorelacji reszt. Dodatkowo należy zauważyć, że wpływ nakładów na innowacje lub ich import, o ile istnieje, na ogół ujawnia się po pewnym czasie. Dlatego też w kolejnych wariantach modelu TFP testowano nakłady na działalność innowacyjną i import przemysłu spożywczego z okresu bieżącego, jak i też z uwzględnieniem opóźnienia wynoszącego 1 lub 2 lata. Najlepsze efekty dały opóźnienia nakładów na działalność innowacyjną o 2 lata, a w przypadku importu - zarówno o 2 lata, jak i o 1 rok (por. tab. 6.4).

Analizując modele TFP w klasycznej, potęgowej postaci, uzyskujemy elastyczności zmiennych zgodne z założeniami (mniejsze od 1). Na ich postawie wnioskujemy, że:

- wraz ze wzrostem nakładów na działalność innowacyjną (ogółem) w przemyśle spożywczym o $1 \%$, TFP rośnie średnio o $0,749 \%$,

- wraz ze wzrostem nakładów innowacyjnych na maszyny i urządzenia w przemyśle spożywczym o $1 \%$ TFP rośnie średnio o $0,768 \%$,

- wraz ze wzrostem importu przemysłu spożywczego o 1\% TFP rośnie średnio o $0,260 \%$,

- jeśli weźmiemy pod uwagę jednoczesne oddziaływanie importu i nakładów innowacyjnych na maszyny i urządzenia, to warto podkreślić, że 1-procentowy wzrost importu pociąga za sobą wzrost TFP średnio o $0,478 \%$, podczas gdy 1-procentowy wzrost nakładów innowacyjnych na maszyny i urządzenia powoduje wzrost TFP średnio o $0,187 \%$.

Wyniki te są poprawne ekonomicznie. Na łączną produktywność czynników produkcji w przemyśle spożywczym najsilniej oddziałują nakłady innowacyjne na maszyny i urządzenia.

Dodajmy, że równolegle dokonano estymacji modeli liniowych, jednak wyniki były mniej satysfakcjonujące niż w przypadku modeli potęgowych. 
Tabela 6.4. Wyniki estymacji parametrów modelu TFP

\begin{tabular}{|c|c|c|c|c|c|c|c|}
\hline \multirow[b]{2}{*}{ Zmienna } & \multicolumn{7}{|c|}{ Oszacowanie parametrów } \\
\hline & $\begin{array}{c}\text { Wariant } \\
\text { I }\end{array}$ & $\begin{array}{c}\text { Wariant } \\
\text { II }\end{array}$ & $\begin{array}{c}\text { Wariant } \\
\text { III }\end{array}$ & $\begin{array}{c}\text { Wariant } \\
\text { IV }\end{array}$ & $\begin{array}{c}\text { Wariant } \\
\mathrm{V}\end{array}$ & $\begin{array}{c}\text { Wariant } \\
\text { VI }\end{array}$ & $\begin{array}{c}\text { Wariant } \\
\text { VII }\end{array}$ \\
\hline Stała & $\begin{array}{c}3,684 \\
(0,942)\end{array}$ & $\begin{array}{l}-2,061 \\
(-2,53)\end{array}$ & $\begin{array}{l}-2,280 \\
(-1,90)\end{array}$ & $\begin{array}{l}5,812 \\
(1,45)\end{array}$ & $\begin{array}{l}7,522 \\
(2,85)\end{array}$ & $\begin{array}{c}0,805 \\
(0,842)\end{array}$ & $\begin{array}{l}-2,511 \\
(-3,87)\end{array}$ \\
\hline MASZ_2 & $\begin{array}{l}0,022 \\
(6,28)\end{array}$ & & & & & & \\
\hline ln MASZ_2 & & $\begin{array}{l}0,768 \\
(6,54)\end{array}$ & & & & & $\begin{array}{l}0,187 \\
(3,01)\end{array}$ \\
\hline INNOW_2 & & & & $\begin{array}{l}0,012 \\
(5,32)\end{array}$ & & & \\
\hline ln INNOW_2 & & & $\begin{array}{l}0,749 \\
(4,62)\end{array}$ & & & & \\
\hline IMP_2 & & & & & $\begin{array}{c}0,0017 \\
(7,10)\end{array}$ & & \\
\hline ln IMP_2 & & & & & & $\begin{array}{l}0,260 \\
(2,50)\end{array}$ & \\
\hline ln IMP_1 & & & & & & & $\begin{array}{l}0,478 \\
(6,73)\end{array}$ \\
\hline $\begin{array}{l}\text { Zmienne } \\
\text { zero-jedynkowe }\end{array}$ & $\begin{array}{c}\text { Tak } \\
\text { u2001 }\end{array}$ & $\begin{array}{c}\text { Tak } \\
\text { u2001 } \\
\text { u2007 }\end{array}$ & $\begin{array}{c}\text { Tak } \\
\text { u2001 } \\
\text { u2007 }\end{array}$ & $\begin{array}{c}\text { Tak } \\
\text { u2001 } \\
\text { u2007 }\end{array}$ & $\begin{array}{c}\text { Tak } \\
\text { u0507 }\end{array}$ & $\begin{array}{c}\text { Tak } \\
\text { u0508 }\end{array}$ & $\begin{array}{c}\text { Tak } \\
\text { u0507 }\end{array}$ \\
\hline$R^{2}$ & 0,853 & 0,922 & 0,860 & 0,893 & 0,940 & 0,968 & 0,965 \\
\hline$R^{2}$ skorygowany & 0,812 & 0,882 & 0,790 & 0,839 & 0,925 & 0,960 & 0,950 \\
\hline DW & 1,923 & 2,735 & 1,490 & 1,500 & 2,389 & 2,718 & 2,158 \\
\hline
\end{tabular}

Oznaczenia: MASZ_2 - nakłady na maszyny, urządzenia techniczne i narzędzia oraz środki transportu, opóźnione o dwa lata (w mln zł), INNOW_2 - nakłady na działalność innowacyjną opóźnione o dwa lata (w mln zł), IMP_2 - import opóźniony o dwa lata (w mln zł), IMP_1-import opóźniony o rok (w mln zł), pozostałe oznaczenia jak w tab. 6.1.

Podsumowując rozważania niniejszego podrozdziału należy podkreślić, że analiza łącznej produktywności czynników produkcji wskazuje na największe znaczenie nakładów na działalność innowacyjną, w tym nakładów na maszyny i urządzenia oraz środki transportu. Nakłady poniesione na działalność innowacyjną ogółem w przedsiębiorstwach przemysłu spożywczego przynoszą istotne efekty w postaci wzrostu TFP $\mathrm{w}$ ciągu dwóch lat od chwili inwestycji. $\mathrm{Z}$ kolei oceniając konkurencyjność przemysłu spożywczego (mierzoną produkcją sprzedaną, wydajnością pracy oraz wartością dodaną brutto) warto zauważyć tutaj istotny wpływ intensywności importu, wydatków na B+R oraz BIZ. 


\subsubsection{Branże przemysłu spożywczego}

Analiza ekonometryczna wpływu innowacji na konkurencyjność przedsiębiorstw funkcjonujących w poszczególnych branżach przemysłu spożywczego jest przedmiotem rozważań tej części rozprawy. Przeprowadzona została z wykorzystaniem regresji panelowej, przy zastosowaniu dwóch podejść, które różnią się między sobą przede wszystkim czynnikiem opisującym innowacyjność branż przemysłu spożywczego oraz okresem analizy.

$\mathrm{W}$ podejściu pierwszym, podobnie jak w przypadku analiz prowadzonych na poziomie całego przemysłu spożywczego, innowacyjność wyrażają rożne rodzaje nakładów na działalność innowacyjną, ich struktura oraz import. Badanie obejmuje lata 2002-2008.

W podejściu drugim innowacyjność jest opisana za pomocą syntetycznego wskaźnika innowacyjności branż. Wskaźnik ten został wyznaczony dla poszczególnych branż przemysłu spożywczego i okresu 2004-2008 (por. rozdz. 5).

Modele panelowe mogą mieć postać: modeli z dekompozycją wyrazu wolnego (FEM - Fixed Effects Model) lub modeli z dekompozycją składnika losowego (REM - Random Effects Model), przy czym dekompozycja może uwzględniać tylko jeden czynnik (modele jednoczynnikowe) lub dwa czynniki równocześnie (modele dwuczynnikowe).

Modele FEM i REM można ogólnie zapisać następująco ${ }^{22}$ :

$$
y_{i t}=m_{i}+b x_{i t}+e_{i t}
$$

gdzie:

$m_{i}$ - ogólny wyraz wolny,

$b$ - parametr strukturalny wyrażający wpływ zmiennej objaśniającej $X$,

$x_{i t}$ - realizacja zmiennej objaśniającej dla $i$-tego obiektu $\mathrm{w} t$-tym okresie,

$e_{i t}$-reszty, spełniające klasyczne założenia: $\mathrm{E}\left(\mathrm{e}_{\mathrm{it}}\right)=0 \mathrm{i} \operatorname{Var}\left(\mathrm{e}_{\mathrm{it}}\right)=S_{e}^{2}$.

W modelu FEM $m_{i}$ jest dekomponowany w wyrazy wolne (stałe) dla poszczególnych grup oddzielnie. Model ma zatem postać [Suchecki 2000]:

$$
y_{i t}=a_{1} d_{1 i t}+a_{2} d_{2 i t}+\ldots+a_{k} d_{k i t}+b x_{i t}+e_{i t}=a_{i}+b x_{i t}+e_{i t},
$$

gdzie:

$a_{i}$ - specyficzne wyrazy wolne, zaś $d_{i}$ zmienne zero-jedynkowe, przyjmujące wartość 1 , gdy $j=i$.

W modelu REM $m_{i}$ wyraża specyficzne składniki losowe. Model ten można zapisać następująco [Green 2008]:

${ }^{22}$ Dla uproszczenia zapisano modele z jedną zmienną objaśniającą, niemniej jednak modele te mogą mieć oczywiście postać wielozmiennowych. 


$$
y_{i t}=a+b x_{i t}+e_{i t}+u_{i},
$$

gdzie:

$$
\mathrm{E}\left(\mathrm{u}_{\mathrm{i}}\right)=0, \operatorname{Var}\left(\mathrm{u}_{\mathrm{i}}\right)=S_{e}^{2}, \operatorname{Cov}\left(\mathrm{e}_{\mathrm{it}}, \mathrm{u}_{\mathrm{i}}\right)=0 .
$$

Ocena modelu opiera się na statystyce chi-kwadrat, która bazuje na funkcji wiarygodności (statystyce $L R T$ - Likelihood Ratio Test) oraz statystyce $F$ (liczonej tradycyjnie w oparciu o sumy kwadratów odchyleń). Dla modelu REM przeprowadzany jest odpowiednio test mnożnika Lagrange'a, którego statystyką testową jest $L M T$ (Lagrange Multiplier Test Statistics). Przy niskim $p$ - mniejszym niż przyjęty poziom istotności $\alpha$ (standardowo przyjmuje się $\alpha=0,05$ ), uznaje się zasadność dekompozycji wyrazu wolnego lub składnika losowego. Wybór między modelem FEM i REM dokonywany jest z wykorzystaniem testu Hausmana (przy $p<0,05$ model FEM uznawany jest za bardziej wiarygodny niż REM) [Hausman 1978; Hausman, Taylor 1981].

Zastosowanie modeli panelowych pozwoliło, po pierwsze, na scharakteryzowanie związków przyczynowo-skutkowych między konkurencyjnością przemysłu spożywczego a jego innowacyjnością z uwzględnieniem zróżnicowania branżowego. Po drugie, estymacja modeli z dekompozycją wyrazu wolnego dla branż umożliwia wyodrębnienie efektów grupowych. Dokonano przy tym estymacji zarówno modeli z dekompozycją wyrazu wolnego, jak i składnika losowego, jedno- (z uwzględnieniem efektów grupowych), jak i dwuczynnikowych (z uwzględnieniem efektów grupowych i czasowych) ${ }^{23}$. Z uwagi na cel analizy (zwrócenie uwagi na zróżnicowanie branżowe omawianych prawidłowości), a także kryterium statystyczne (wyniki testu Hausmana), prezentowane wyniki ograniczone zostały do modeli jednoczynnikowych z dekompozycją wyrazu wolnego.

I) $\mathrm{W}$ podejściu I analiza przeprowadzona została $\mathrm{z}$ wykorzystaniem próby przekrojowo-czasowej obejmującej 126 obserwacji (dane dla 18 branż przemysłu spożywczego za lata 2002-2008), dotyczących działalności przedsiębiorstw poszczególnych branż przemysłu spożywczego. Informacje te pochodziły z publikowanych i niepublikowanych baz Głównego Urzędu Statystycznego i dotyczyły przedsiębiorstw zatrudniających powyżej 49 pracowników.

Niestety, sposób agregacji danych nie pozwolił na wyodrębnienie analogicznych jak w modelach (6.8), (6.9) i (6.13) zmiennych, a tym samym na proste przełożenie analiz prowadzonych na poziomie całego przemysłu spożywczego na poziom branż. Z uwagi na ograniczoną dostępność danych statystycznych, konkurencyjność przedsiębiorstw badana była za pomocą produkcji sprzedanej, wartości dodanej i wydajności pracy (mierzonej tradycyjnie, jako stosunek produkcji sprzedanej i zatrudnienia). $Z$ kolei innowacyjność przedsiębiorstw wyrażona była, podobnie jak w przypadku przemysłu spożywczego ogółem (por. podrozdział 6.2.1), za pomocą nakładów na działalność innowacyjną, które obejmują nakłady na: (i) $B+R$,

\footnotetext{
${ }^{23}$ Metodologia konstrukcji modeli panelowych oraz ich oceny została szeroko omówiona np. w: B. Dańska, I. Laskowska [1996].
} 
(ii) zakup gotowej technologii w postaci praw i dokumentacji, (iii) maszyny, urządzenia techniczne i narzędzia oraz środki transportu, (iv) budynki i budowle, (v) szkolenie personelu związane z działalnością innowacyjną, (vi) marketing dotyczący nowych i zmodernizowanych wyrobów oraz (vii) import. Niestety, w przypadku branż przemysłu spożywczego nie dysponowano informacjami o napływie bezpośrednich inwestycji zagranicznych w poszczególnych latach okresu 2002-2008.

Wszystkie zmienne zostały wyrażone: (1) w ujęciu bezwzględnym w cenach stałych $(2005=100)$ oraz $(2)$ w ujęciu względnym - jako odsetek łącznych nakładów na innowacje.

Oszacowania parametrów modeli przeprowadzono w LIMDEP 7.0.

Analiza uzyskanych wyników ograniczona zostanie do prezentacji i omówienia wniosków płynących dla tych relacji, które okazały się poprawne w sensie statystycznym i ekonomicznym. Pominięcie analiz dla konkretnej zmiennej wyrażającej innowacyjność oznacza brak satysfakcjonujących wyników w tym zakresie.

\section{Model produkcji sprzedanej - ujęcie branżowe}

W estymacji modelu produkcji sprzedanej punkt wyjścia stanowiła funkcja produkcji Cobba-Douglasa, w której każdorazowo uwzględniono kapitał (K) i pracę $(\mathrm{L})$ oraz alternatywne zmienne wyrażające innowacyjność. W każdym z wyestymowanych modeli wpływ zmiennej $K$ okazał się istotny statystycznie, zaś zmiennej $L$ - nieistotny statystycznie. Otrzymane wartości estymatora elastyczności majątku trwałego względem produkcji są zgodne z oczekiwaniami i oscylują wokół 0,7 . Oznacza to, że wraz ze wzrostem majątku trwałego o $1 \%$ można się spodziewać wzrostu produkcji sprzedanej średnio o $0,7 \%$. W wariantach I - III uwzględniono (oprócz majątku trwałego) różne zmienne opisujące innowacyjność branż przemysłu spożywczego:

$$
\begin{array}{ll}
\text { - wariant I: } & \text { PROD }=\mathrm{f}(\mathrm{K}, \mathrm{INN}) \\
\text { - wariant II: } & \text { PROD }=\mathrm{f}(\mathrm{K}, \mathrm{UBRW}) \\
\text { - wariant III: } & \text { PROD }=\mathrm{f}(\mathrm{K}, \mathrm{BRW})
\end{array}
$$

Wyniki estymacji zaprezentowano w tab. 6.5.

Wykazano istotny i zgodny z oczekiwaniami, tzn. pozytywny wpływ innowacji - mierzonej w przeliczeniu na przedsiębiorstwo, wydatków wewnętrznych na $\mathrm{B}+\mathrm{R}$ (w tym udziału tych wydatków w łącznych nakładach na innowacje). Wzrost o $1 \%$ nakładów innowacyjnych (na przedsiębiorstwo) powoduje wzrost produkcji sprzedanej średnio o $0,038 \%$. Z kolei analogiczny wzrost nakładów wewnętrznych na działalność badawczo-rozwojową skutkuje wzrostem produkcji sprzedanej średnio o $0,012 \%$. Zwiększenie udział nakładów na $\mathrm{B}+\mathrm{R}$ w nakładach na działalność innowacyjną ogółem o 1 punkt procentowy przyczynia się do wzrostu 
produkcji sprzedanej o 0,011\%. Uzyskane elastyczności są zatem niskie (rzędu $0,01-0,04)$. Wpływ innowacji na produkcję sprzedaną jest zauważalny, jednak na tle pozostałych czynników jeszcze niewielki.

Tabela 6.5. Wyniki estymacji parametrów modelu produkcji sprzedanej w branżach przemysłu spożywczego (logarytmy)

\begin{tabular}{|l|c|c|c|}
\hline \multirow{2}{*}{ Zmienne } & \multicolumn{3}{|c|}{ Oszacowanie parametrów } \\
\cline { 2 - 4 } & Wariant I & Wariant II & Wariant III \\
\hline \multirow{2}{*}{$\ln \mathrm{K}$} & $\begin{array}{c}0,667 \\
(10,93)\end{array}$ & $\begin{array}{c}0,716 \\
(14,20)\end{array}$ & $\begin{array}{c}0,709 \\
(13,99)\end{array}$ \\
\hline \multirow{2}{*}{$\ln$ INN } & 0,038 & & \\
& $(1,66)$ & & 0,012 \\
\multirow{2}{*}{$\ln$ BRW } & & & $(2,10)$ \\
\hline \multirow{2}{*}{$\ln$ UBRW } & & 0,011 & \\
& & $(2,08)$ & 0,987 \\
\hline$R^{2}$ & 0,987 & 0,987 & 0,985 \\
\hline$R^{2}$ skorygowany & 0,985 & 0,985 & 307,202 \\
\hline LRT & 314,219 & 311,395 & $(0,000)$ \\
(p) & $(0,000)$ & $(0,000)$ & 65,167 \\
\hline$F$ & 69,257 & 67,583 & $(0,000)$ \\
(p) & $(0,000)$ & $(0,000)$ & \\
\hline
\end{tabular}

Oznaczenia: $\mathrm{K}$ - wartość brutto środków trwałych (w mln zł), BRW - nakłady na B+R wewnętrzne w mln zł, INN - nakłady innowacyjne przypadające na 1 przedsiębiorstwo prowadzące działalność innowacyjną (w tys. zł), UBRW - nakłady na B+R wewnętrzne jako odsetek nakładów na działalność innowacyjną,

LRT - statystyka testu LRT (Likelihood Ratio Test), F - statystyka testu Fishera Snedecora, p- prawdopodobieństwo testowe.

Oszacowane równania charakteryzują się dobrymi własnościami prognostycznymi ( $\mathrm{R}^{2}$ bliskie 1$)$. Efekty grupowe okazały się istotne statystycznie, o czym świadczy niskie prawdopodobieństwo testowe $p$ dla $L R T$ i $F^{24}$. Znajomość oszacowań wyrazów wolnych umożliwia analizę zróżnicowania wartości produkcji sprzedanej przez branże. Porównując poszczególne branże, największe różnice odnotowano między przemysłem mięsnym (1), drobiarskim (2), mleczarskim (4) oraz paszowym (10) a ziemniaczanym (5), winiarskim (14) oraz tytoniowym (18). Można zatem powiedzieć, iż efekty zaangażowania majątku i aktywności innowacyjnej są najsilniejsze w tych branżach, które podlegały większym przeobrażeniom w związku z otwarciem rynków unijnych (branż: mięsna, drobiarska, mleczarska).

${ }^{24}$ Zarówno w teście $L R T$, jak i $F$ w hipotezie zerowej zakłada się brak efektów grupowych [por. Dańska 2000, s. 40-42]. 
Potwierdza to wcześniejsze wnioski o głębokiej restrukturyzacji i modernizacji tych branż przemysłu spożywczego, co związane było przede wszystkim z koniecznością dostosowania parku maszynowego do wymogów jakościowych UE. Branże te, jak wykazano wcześniej, w największym stopniu modernizowały swoją bazę technologiczną w związku z wymogami norm ISO czy HCCAP. Nakłady innowacyjne w przeliczeniu na przedsiębiorstwo innowacyjne przyniosły w tych branżach największe efekty. Szersze otwarcie na rynki europejskie skutkowało nasileniem się działań marketingowych w wymienionych branżach, co znalazło również odzwierciedlenie w poziomie sprzedaży i tym samym w wartościach wyrazów wolnych.

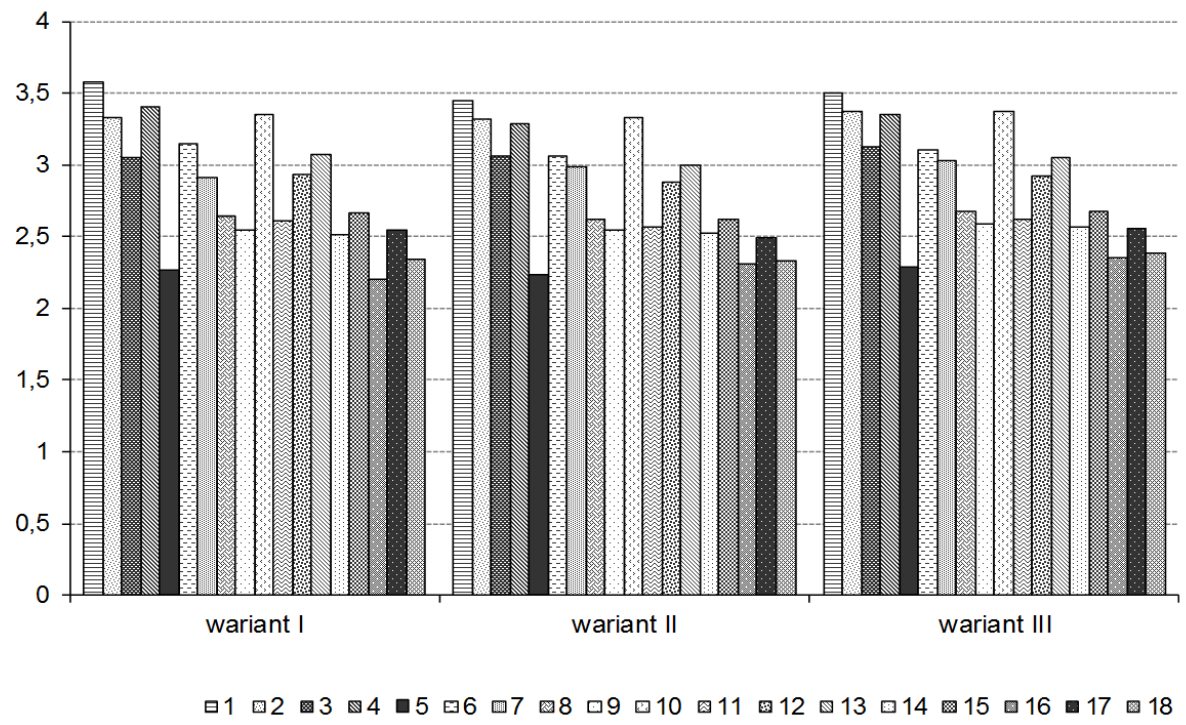

Na rysunku przedstawiono efekty grupowe w następujących branżach: 1 - mięsna, 2 - drobiarska, 3- rybna, 4 - mleczarska, 5- ziemniaczana, 6- owocowo-warzywna, 7 - olejarska, 8 - zbożowo-młynarska, 9 - cukrownicza, 10 - paszowa, 11- piekarska, 12 - cukiernicza, 13 - koncentratów spożywczych, 14 - napojów bezalkoholowych, 15 - spirytusowa 16 - winiarska, 17 - piwowarska, 18 - tytoniowa. Oznaczenie branż dotyczy rys. 6.1 - 6.3.

\section{Rysunek 6.1. Wartości wyrazów wolnych dla poszczególnych branż przemysłu spożywczego} w modelu produkcji sprzedanej

Źr ódło: opracowanie własne (dotyczy wszystkich rysunków w rozdz. 6).

\section{Model wydajności pracy - ujęcie branżowe}

Kolejnym miernikiem konkurencyjności branż przemysłu spożywczego jest wydajność pracy mierzona produkcją sprzedaną na zatrudnionego. W modelu tym zmienne objaśniające przeliczono na zatrudnionego, co oznacza, że model określa 
relacje między wydajnością pracy a technicznym uzbrojeniem pracy $(\mathrm{K} / \mathrm{L})$ oraz intensywnością czynników opisujących innowacje. Estymacji podlegały następujące funkcje:

$$
\begin{array}{ll}
\text { - wariant I: } & \text { WYD_PR }=\mathrm{f}(\mathrm{K} / \mathrm{L}, \mathrm{BRW} / \mathrm{L}) \\
\text { - wariant II: } & \text { WYD_PR }=\mathrm{f}(\mathrm{K} / \mathrm{L}, \mathrm{BB} / \mathrm{L}) \\
\text { - wariant III: } & \text { WYD_PR }=\mathrm{f}(\mathrm{K} / \mathrm{L}, \mathrm{MASZ} / \mathrm{L}) \\
\text { - wariant IV: } & \text { WYD_PR }=\mathrm{f}(\mathrm{K} / \mathrm{L}, \mathrm{MASZ} / \mathrm{L}) \\
\text { - wariant V: } & \text { WYD_PR }=\mathrm{f}(\mathrm{K} / \mathrm{L}, \mathrm{MARK} / \mathrm{L}) \\
\text { - wariant VI: } & \text { WYD_PR }=\mathrm{f}\left(\mathrm{K} / \mathrm{L}, \mathrm{MASZ} / \mathrm{L} \_2\right)
\end{array}
$$

\begin{tabular}{|c|c|c|c|c|c|c|}
\hline \multirow{2}{*}{ Zmienna } & \multicolumn{6}{|c|}{ Oszacowanie parametrów } \\
\hline & Wariant I & Wariant II & Wariant III & Wariant IV & Wariant V & Wariant VI \\
\hline $\ln \mathrm{K} / \mathrm{L}$ & $\begin{array}{l}0,477 \\
(4,96) \\
\end{array}$ & $\begin{array}{l}0,491 \\
(5,35) \\
\end{array}$ & $\begin{array}{l}0,415 \\
(4,29) \\
\end{array}$ & $\begin{array}{l}0,488 \\
(5,16) \\
\end{array}$ & $\begin{array}{l}0,399 \\
(4,19) \\
\end{array}$ & $\begin{array}{l}0,425 \\
(4,53) \\
\end{array}$ \\
\hline $\ln \mathrm{BRW} / \mathrm{L}$ & $\begin{array}{l}0,015 \\
(0,09)\end{array}$ & & & & & \\
\hline $\ln \mathrm{BB} / \mathrm{L}$ & & $\begin{array}{l}0,043 \\
(3,58)\end{array}$ & & & & \\
\hline $\ln \mathrm{MASZ} / \mathrm{L}$ & & & $\begin{array}{l}0,062 \\
(2,99)\end{array}$ & & & \\
\hline $\ln \mathrm{MASZI} / \mathrm{L}$ & & & & $\begin{array}{l}0,027 \\
(2,49)\end{array}$ & & \\
\hline $\ln$ MARK/L & & & & & $\begin{array}{l}0,070 \\
(3,55)\end{array}$ & \\
\hline $\ln \mathrm{MASZ} / \mathrm{L} \_2$ & & & & & & $\begin{array}{l}0,101 \\
(1,96)\end{array}$ \\
\hline$R^{2}$ & 0,970 & 0,973 & 0,972 & 0,971 & 0,973 & 0,964 \\
\hline$R^{2}$ skorygowany & 0,965 & 0,968 & 0,967 & 0,966 & 0,954 & 0,960 \\
\hline $\begin{array}{l}\text { LRT } \\
(\mathrm{p}) \\
\end{array}$ & $\begin{array}{l}431,48 \\
(0,000) \\
\end{array}$ & $\begin{array}{c}442,318 \\
(0,000) \\
\end{array}$ & $\begin{array}{c}436,712 \\
(0,000) \\
\end{array}$ & $\begin{array}{c}435,636 \\
(0,000) \\
\end{array}$ & $\begin{array}{c}440,100 \\
(0,000) \\
\end{array}$ & $\begin{array}{c}198,614 \\
(0,000) \\
\end{array}$ \\
\hline $\begin{array}{l}\text { F } \\
(p)\end{array}$ & $\begin{array}{l}185,23 \\
(0,000)\end{array}$ & $\begin{array}{c}202,420 \\
(0,000)\end{array}$ & $\begin{array}{l}193,341 \\
(0,000)\end{array}$ & $\begin{array}{c}191,644 \\
(0,000)\end{array}$ & $\begin{array}{c}198,780 \\
(0,000)\end{array}$ & $\begin{array}{l}33,299 \\
(0,000)\end{array}$ \\
\hline
\end{tabular}

Wyniki estymacji wybranych, zdaniem autorki najlepszych od strony statystycznej i merytorycznej, wariantów modelu wydajności pracy przedstawiono w tab. 6.6.

Tabela 6. 6. Wyniki estymacji parametrów modelu wydajności pracy w branżach przemysłu spożywczego (logarytmy)

Oznaczenia: K/L - techniczne uzbrojenie pracy (w tys. zł), BRW/L - nakłady na B+R wewnętrzne na zatrudnionego (w tys. zł), BB/L - nakłady inwestycyjne na budynki i budowle oraz grunty na zatrudnionego (w tys. zł), MASZ/L - nakłady inwestycyjne na maszyny i urządzenia techniczne na zatrudnionego (w tys. zł), MASZI/L - nakłady inwestycyjne na maszyny i urządzenia techniczne z importu na zatrudnionego (w tys. zł), MARK/L - nakłady na marketing dotyczący nowych lub istotnie ulepszonych produktów na zatrudnionego (w tys. zł), MASZ/L_2- nakłady na maszyny, urządzenia techniczne oraz środki transportu na zatrudnionego, opóźnione o dwa lata (w tys. zł) 
Biorąc pod uwagę nakłady per capita, istotny wpływ na wyniki osiągane przez poszczególne branże przemysłu spożywczego wywierają - oprócz technicznego uzbrojenia pracy $(K / L)$ - nakłady wewnętrzne na B+R (BRW/L), nakłady na budynki i budowle (BB/L), na maszyny i urządzenia - MASZ/L (w tym z importu - MASZI/L) oraz nakłady na marketing związany z innowacyjnymi produktami (MARK/L). Porównując elastyczności dla poszczególnych zmiennych wyrażających innowacje, stosunkowo najsilniejsze zmiany wydajności pracy mają miejsce pod wpływem zmian nakładów na maszyny i urządzenia oraz marketing związany $\mathrm{z}$ innowacjami. Są to jednak i tak nieznaczne wzrosty rzędu $0,06-0,07 \%$, podczas gdy wzrost technicznego uzbrojenia pracy o $1 \%$ powoduje wzrost wartości produkcji sprzedanej średnio o ok. 0,40\%.

Warto zwrócić uwagę, że istotny wpływ na wydajność pracy wykazano również w przypadku opóźnionej o dwa okresy zmiennej określającej intensywności nakładów na maszyny i urządzenia - MASZ/L_2 (por. wariant VI). Kierunek tego wpływu jest zgodny z oczekiwaniami - wzrost intensywności nakładów na maszyny i urządzenia (związanych z działalnością innowacyjną) o 1\% powoduje wzrost wydajności pracy w branżach przemysłu spożywczego rzędu średnio o $0,1 \%$.

Porównanie wyrazów wolnych wskazuje na wyraźnie niższe efekty „branżowe" w przemyśle winiarskim (14) i ziemniaczanym (5), zaś zdecydowanie najwyższe - w przemyśle mięsnym (1) i mleczarskim (4) i owocowo-warzywnym (6).

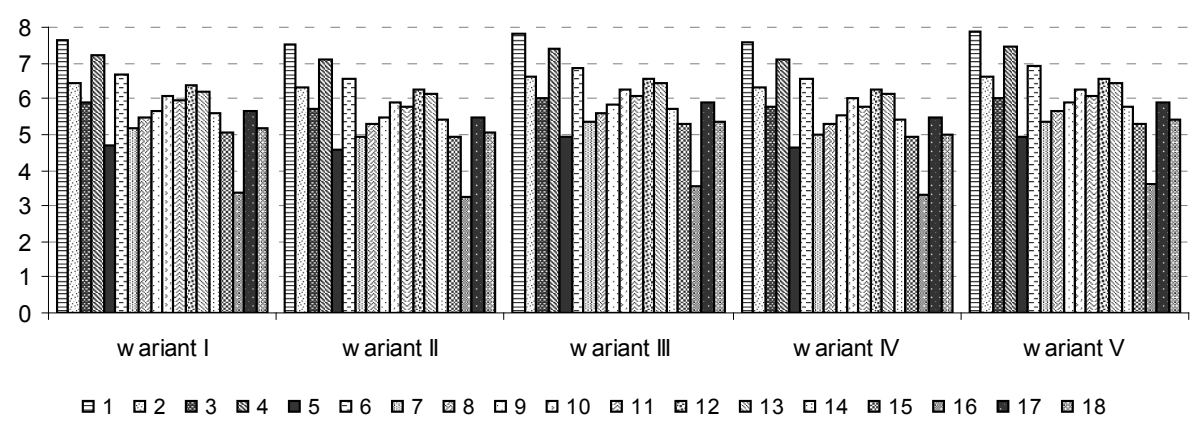

Rysunek 6. 2. Wartości wyrazów wolnych dla poszczególnych branż przemysłu spożywczego w modelu wydajności pracy

\section{Model wartości dodanej brutto}

Testowano różne wersje modelu wartości dodanej brutto, uwzględniając m.in. opóźnienia. Jednak na podstawie danych przekrojowo-czasowych, na których oparte są analizy, nie udało się skonstruować modelu, który w satysfakcjonujący 
sposób wyjaśniał zmienność wartości dodanej pod wpływem innowacji. Trudno jest wskazać jednoznaczną przyczynę stwierdzonego braku zależności. Badania natomiast wykazały istnienie istotnej statystycznie zależności między wartością produkcji sprzedanej a innowacjami (por. tab. 6.5). Wynika to prawdopodobnie $\mathrm{z}$ faktu, że w krótkim okresie efektem poniesionych nakładów na działalność innowacyjną są nowe lub ulepszone produkty, nowe technologie, co pozwala zwiększyć wartość produkcji sprzedanej, ale stanowi to koszt, który musi być uwzględniony przy określaniu wartości dodanej. Zwiększona wartość sprzedaży jest więc krótkoterminowym efektem poniesionych nakładów na innowacje, a wysokie koszty poniesionych nakładów powodują, że wartość dodana nie od razu ulega zwiększeniu. Kolejną przyczyną stwierdzonego braku zależności może być zbyt niski poziom nakładów na innowacje, by móc stwierdzić istnienie zależności dopiero przy wyższych nakładach i większej ich wariancji możliwe byłoby jej określenie.

II) Analizę wpływu innowacyjności na wyniki poszczególnych branż przemysłu spożywczego wieńczy ocena jej zmienności z wykorzystaniem skonstruowanego w pracy omówionego w rozdz. 5 wskaźnika syntetycznego. Z uwagi na fakt, iż wskaźnik syntetyczny został obliczony dla lat 2004-2008, modele skonstruowano opierając się na zawężonej do tego okresu próbie, a badaniem objęto, podobnie jak poprzednio, 18 branż. Zbadano relacje między syntetycznie rozumianą innowacyjnością a konkurencyjnością branż przemysłu spożywczego mierzoną jak uprzednio wartością produkcji sprzedanej, wydajnością pracy oraz wartością dodaną. W funkcji produkcji Cobba-Douglasa, poza pierwotnymi czynnikami produkcji (pracą mierzoną liczbą zatrudnionych oraz kapitałem mierzonym wartością brutto środków trwałych), uwzględniono miernik syntetyczny innowacyjności.

\section{Model produkcji sprzedanej - podejście II}

Dokonując oceny implikacji innowacyjności dla produkcji sprzedanej przemysłu spożywczego estymowano dwie wersje modelu: liniową i potęgową, stosując dla każdej z nich te same zmienne objaśniające. Zadowalające wyniki uzyskano dla funkcji liniowej, zaprezentowano je w tab. 6.7.

Statystyczna jakość modelu produkcji sprzedanej jest dobra, na co wskazuje wysoka zgodność wyników teoretycznych z empirycznymi $\left(R^{2}=0,99\right)$. Wszystkie trzy zmienne objaśniające są istotne statystycznie i co ważne, oszacowane parametry modelu wskazują na relacje zgodne z oczekiwaniami. Wzrost wartości brutto środków trwałych o $1 \mathrm{mln}$ zł powoduje wzrost produkcji sprzedanej średnio o ok. 1,5 mln zł, zaś wzrost zatrudnienia o tysiąc osób zwiększa wartość produkcji sprzedanej przeciętnie o $80 \mathrm{mln}$ zł. Model potwierdza, że innowacyjność jest czynnikiem determinującym wzrost konkurencyjności przedsiębiorstw. Wpływ 
innowacyjności na produkcję sprzedaną przemysłu spożywczego jest istotny statystycznie i dodatni. Produkcja sprzedana zwiększa się średnio o 59,9 mln zł na skutek wzrostu wskaźnika innowacyjności o 1 punkt procentowy.

Tabela 6.7. Wyniki estymacji parametrów modelu produkcji sprzedanej w branżach przemysłu spożywczego (funkcja liniowa)

\begin{tabular}{|l|c|}
\hline \multicolumn{1}{|c|}{ Zmienna } & Oszacowanie parametrów \\
\hline $\mathrm{K}$ & $\begin{array}{l}1,477 \\
(8,30)\end{array}$ \\
\hline $\mathrm{L}$ & 80,011 \\
& $(1,99)$ \\
\hline \multirow{2}{*}{$\mathrm{Ws}$} & 59,924 \\
& $(2,338)$ \\
\hline$R^{2}$ & 0,993 \\
\hline$R^{2}$ skorygowany & 0,991 \\
\hline LRT & 242,077 \\
$(\mathrm{p})$ & $(0,000)$ \\
\hline $\mathrm{F}$ & 55,719 \\
$(\mathrm{p})$ & $(0,000)$ \\
\hline
\end{tabular}

Oznaczenia: K - wartość brutto środków trwałych (w mln zł), L - zatrudnienie (w tys. osób), Ws - syntetyczny wskaźnik innowacyjności branż przemysłu spożywczego, wyznaczony w podrozdz. 5.5.

Porównanie wyrazów wolnych wskazuje na wyraźne zróżnicowanie grupowe. Wysokie wartości odnotowano, podobnie jak w przypadku modelu produkcji sprzedanej w okresie 2002-2008 dla przemysłu mięsnego i mleczarskiego. Zdecydowanie najniższe wartości zaobserwowano dla przemysłu winiarskiego (por. rys. 6.3).

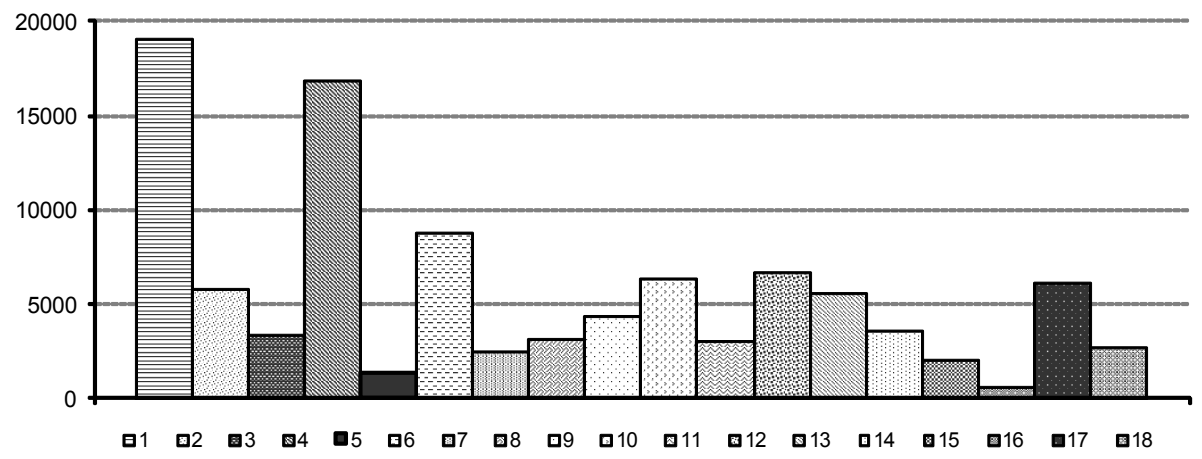

Rysunek 6.3. Wartości wyrazów wolnych dla poszczególnych branż przemysłu spożywczego (model produkcji sprzedanej) 
Podjęte w badaniu próby zbudowania modelu wydajności pracy nie powiodły się. Otrzymano wprawdzie dodatnie wartości parametrów, które wskazują, iż zarówno kapitał, jak i innowacje wpływają pozytywnie na wydajność pracy, ale wpływ ten nie jest istotny statystycznie. Prawdopodobne jest istnienie dodatniego związku między wydajnością pracy a innowacjami w dłuższym horyzoncie czasowym, jednak niedostateczna długość dostępnych szeregów czasowych ogranicza przeprowadzenie tego rodzaju analiz.

\section{Model wartości dodanej - podejście II}

W ostatnim kroku budowano model wartości dodanej brutto. Ze względu na fakt, iż wartość dodana brutto w niektórych obiektach (branżach przemysłu spożywczego w okresie 2004-2008) osiąga wartości ujemne, budowę modelu oparto na analizie liniowej funkcji produkcji Cobba-Douglasa. Logarytmowanie wartości ujemnych, potrzebne dla estymacji parametrów zlinearyzowanego modelu potęgowego, nie jest możliwe.

Również estymacja modelu dla wartości dodanej, nie przyniosła oczekiwanych rezultatów. Relacja między wartością dodaną a innowacyjnością może mieć dużo bardziej skomplikowany charakter w poszczególnych branżach niż ma to miejsce w przypadku wcześniej analizowanych mierników konkurencyjności, np. produkcji sprzedanej. Wskazane byłoby odrębne modelowanie zależności w poszczególnych branżach, co jednak nie jest możliwe z uwagi na zbyt krótkie szeregi czasowe dla pojedynczych branż.

Dlatego wnioski dotyczące oddziaływania innowacyjności (w ujęciu wielowymiarowym) muszą zostać ograniczone do omówionego modelu produkcji sprzedanej (tab. 6.7).

\section{Podsumowanie}

Biorąc pod uwagę dynamicznie zmieniające się warunki otoczenia, innowacyjność stanowić powinna jeden z najważniejszych motorów gospodarki, zaś w skali mikro- i mezoekonomicznej powinna determinować konkurencyjność podmiotów gospodarczych, branż i działów przemysłu. Przeprowadzona analiza ekonometryczna wykazała słuszność stawianej tezy. Konkurencyjność przemysłu spożywczego ogółem, jak i na poziomie branż, w istotnym stopniu determinowana jest przez innowacje.

W pierwszym etapie skonstruowane zostały modele konkurencyjności przemysłu spożywczego ogółem, mierzonej wartością produkcji sprzedanej, 
wydajnością pracy, a także wartością dodaną brutto i łączną produktywnością czynników produkcji (TFP). Podstawą konstrukcji tych modeli była funkcja produkcji Cobba-Douglasa, w której czynnikami produkcji, oprócz kapitału i pracy, były zmienne charakteryzujące innowacyjność przedsiębiorstw przemysłu spożywczego.

Uzyskane wyniki potwierdzają istnienie statystycznie istotnego wpływu wewnętrznych nakładów na działalność $\mathrm{B}+\mathrm{R}$, importu oraz BIZ na produkcję sprzedaną. Zgodnie z oczekiwaniami, konkurencyjność przemysłu spożywczego jest tym większa, im wyższe są wewnętrzne nakłady na $\mathrm{B}+\mathrm{R}$, podobne prawidłowości odnotowano w odniesieniu do importu i BIZ. Estymacja modeli wydajności pracy i wartości dodanej brutto wykazała, że, poza technicznym uzbrojeniem pracy, istotnie, a przy tym dodatnio, wpływają na konkurencyjność przemysłu spożywczego również intensywność eksportu, importu, BIZ oraz intensywność nakładów na działalność B+R. Wartość dodana brutto reaguje silniej na bieżące zmiany innowacyjności niż wydajność pracy. Na łączną produktywność czynników produkcji wpływają pozytywnie nakłady innowacyjne na maszyny i urządzenia, nakłady innowacyjne ogółem oraz import. Przeprowadzona analiza potwierdza zatem hipotezę o wpływie innowacji na wzrost konkurencyjności przemysłu spożywczego.

Estymacja modeli panelowych wskazuje na istotną rolę innowacyjności w osiąganych wynikach branż przemysłu spożywczego. Zbudowane modele, w których postęp techniczny wyrażany był za pomocą różnych zmiennych opisujących innowacyjność branż przemysłu spożywczego, pozwalają na wyciągnięcie następujących wniosków:

1) konkurencyjność przemysłu spożywczego mierzona wartością produkcji sprzedanej jest istotnie determinowana wartością zaangażowanego kapitału, mierzonego wartością majątku trwałego, a także przez ogólną wartość wydatków na innowacje (ale w przeliczeniu na przedsiębiorstwo innowacyjne w danej branży) i nakłady wewnętrzne na $\mathrm{B}+\mathrm{R}$;

2) biorąc pod uwagę wydajność pracy, istotny wpływ na wyniki osiągane przez poszczególne branże przemysłu spożywczego wywierają - oprócz technicznego uzbrojenia pracy - nakłady wewnętrzne na $\mathrm{B}+\mathrm{R}$, nakłady na budynki i budowle, na maszyny i urządzenia (w tym z importu) oraz nakłady na marketing związany $\mathrm{z}$ innowacyjnymi produktami (wszystkie zmienne w przeliczeniu na zatrudnionego), przy czym stosunkowo najsilniejsze zmiany wydajności pracy odnotowano pod wpływem zmian nakładów na maszyny i urządzenia oraz marketing związany z innowacjami.

Istotny i pozytywny wpływ innowacyjności przedsiębiorstw przemysłu spożywczego na ich konkurencyjność potwierdzają również modele, w których innowacyjność jest wyrażona za pomocą zmiennej syntetycznej. 
Należy zwrócić uwagę na niskie wartości parametrów stojących przy zmiennych wyrażających innowacyjność branż przemysłu spożywczego, co wskazuje, że na tle innych czynników (zwłaszcza technicznego uzbrojenia pracy) innowacyjność stanowi drugoplanowy czynnik zmian. Optymistyczne jest jednak to, że:

1) dla przemysłu spożywczego w Polsce wpływ ten jest na tyle wysoki, aby można było mówić o statystycznie istotnych zależnościach oraz

2) innowacyjność wywiera pozytywny wpływ na rozwój przemysłu spożywczego w Polsce. 



\section{Zakończenie}

Głównym celem autorki pracy była próba oceny skali i wpływu innowacyjności przedsiębiorstw przemysłu spożywczego w Polsce na konkurencyjność tego przemysłu.

Termin ,innowacja” stosowany jest w różnym ujęciu, autorzy tego pojęcia zwykle dokonują jego operacjonalizacji dla potrzeb dalszych badań. Rozbieżności $\mathrm{w}$ formułowaniu tego terminu wynikają $\mathrm{z}$ odmiennego pojmowania innowacji. Warto przy tym podkreślić, że w analizach ekonomicznych zwraca się coraz częściej uwagę na problem nakładów i efektów działalności innowacyjnej. Przegląd literatury wskazuje na dwa zasadnicze nurty. W pierwszym uwzględnia się rzeczowy charakter innowacji, używając tego pojęcia w odniesieniu do wyrobów lub świadczonych usług, organizacji procesów produkcji opartych na nowej bądź dotychczas niewykorzystanej wiedzy. W drugim, najszerszym ujęciu, innowacje utożsamiane są z całym procesem innowacyjnym, obejmującym działalność badawczo-rozwojową, rozwijanie idei nowego produktu lub metody, kończącym się wraz z pierwszym wdrożeniem innowacji.

Innowacje analizowane są najczęściej w trzech perspektywach: makroekonomicznej (innowacyjność gospodarki), mezoekonomicznej (innowacyjność sektora, branży) lub mikroekonomicznej (innowacyjność przedsiębiorstwa).

$\mathrm{W}$ sensie makroekonomicznym innowacyjność uwarunkowana jest przez Narodowy System Innowacji (NSI). Współcześnie polityka innowacyjna państw opiera się na tym właśnie systemie. W niniejszej pracy zwrócono uwagę na duże rozbieżności w charakterze nie tylko ogólnych zasad działania NSI w różnych krajach, ale również powiązań pomiędzy poszczególnymi jednostkami odgrywającymi istotną rolę w działalności innowacyjnej.

Jak wynika z przeprowadzonych badań, Polska pozostaje pod względem innowacyjności daleko w tyle za najlepszymi krajami UE (Szwecją, Finlandią, Niemcami). Analizowane w pracy wskaźniki rozwoju nauki, techniki i innowacji osiągają w Polsce poziom zbliżony do innych krajów Europy ŚrodkowoWschodniej, plasując Polskę na 21. pozycji wśród państw UE-27. Symptomatyczne jest to, że Polska nie prezentuje ani znaczącego postępu, ani niepokojącego pogorszenia sytuacji w tym obszarze - wskaźniki charakteryzujące trzy powiązane ze sobą sfery (nauka, technika, innowacje) są raczej stabilne i żadna istotna zmiana w okresie członkostwa Polski w UE nie nastąpiła. Jedną z ważnych przyczyn tej sytuacji wydaje się być brak przeprowadzenia w sektorze badawczym reform strukturalnych. Jak wynika z przeprowadzonej analizy, wbrew wyzwaniom strategii lizbońskiej i nowego programu rozwoju krajów UE Europa 2020. Strategia na rzecz inteligentnego i zrównoważonego rozwoju sprzyjającego włączeniu społecznemu, innowacje trudno uznać za siłę napędową polskiej gospodarki w ostatnich 
latach. Poziom rozwoju innowacyjności poszczególnych sekcji gospodarki, ale także działów i klas przemysłu, jest przy tym zróżnicowany. Dotyczy to m.in. analizowanego tu przemysłu spożywczego.

Jak pokazują wyniki badań, struktura gospodarcza i społeczna, potencjał ekonomiczny, tradycje i specyfika polskiego stołu powodują, że sektor żywnościowy (agrobiznes) stanowi ważny element równowagi makroekonomicznej polskiej gospodarki, a przemysł spożywczy staje się coraz ważniejszym ogniwem agrobiznesu.

Pogłębiona analiza produkcyjno-ekonomicznej sytuacji przemysłu spożywczego pozwala skonstatować, że polski przemysł spożywczy odniósł sukces na unijnym rynku. Co istotne, integracja Polski z UE wymusiła nasilenie procesów innowacyjnych w polskich przedsiębiorstwach. Należy przy tym podkreślić ogromne wyzwania, przed jakimi stanął przemysł spożywczy w związku z obowiązującymi w UE normami dotyczącymi nie tylko jakości produktów, ale również samych procesów produkcyjnych. Procesy dostosowawcze w przemyśle spożywczym były szczególnie intensywne na kilka lat przed integracją z Unią Europejską i bezpośrednio po akcesji. Przeobrażenia te przyczyniły się do stworzenia grupy świetnie funkcjonujących przedsiębiorstw w wielu branżach przemysłu spożywczego. W pierwszych latach członkostwa Polski w UE w przemyśle spożywczym zaobserwowano takie pozytywne zjawiska, jak:

- ożywienie produkcyjne wywołane wzrostem eksportu i popytu wewnętrznego na żywność, zwłaszcza wysoko przetworzoną,

- poprawa stanu technicznego przedsiębiorstw, będąca efektem ogromnych nakładów inwestycyjnych przeznaczonych na modernizację i restrukturyzację przedsiębiorstw,

- poprawa produktywności i efektywności przedsiębiorstw przemysłu spożywczego,

- ujawnienie przewag komparatywnych polskich producentów żywności, co przyniosło dynamiczny rozwój eksportu,

- wzrost konkurencyjności przedsiębiorstw przemysłu spożywczego na europejskim rynku oraz wyraźna poprawa stanu finansowego we wszystkich branżach.

Wyniki handlu zagranicznego przemysłu spożywczego świadczą o konkurencyjności producentów żywności również na rynku unijnym i światowym. Źródłem konkurencyjności były z jednej strony przewagi kosztowo-cenowe, z drugiej jednak była to ceniona przez zagranicznych konsumentów jakość produktów przemysłu spożywczego [Urban 2010, s. 31]. Wprawdzie przewagi kosztowo-cenowe maleją, ale wzrasta znaczenie innowacyjności jako czynnika determinującego konkurencyjność [Winek 2010, s.1-2], co, przy utrzymaniu wysokiej jakości produktów powinno determinować dalsze utrzymywanie się znaczenia polskich wyrobów spożywczych na rynkach zagranicznych. 
Z przeprowadzonych własnych badań empirycznych wynika, że stopień innowacyjności przemysłu spożywczego, w porównaniu z innymi działami przetwórstwa przemysłowego, jest niestety niski. Warto jednak przypomnieć, iż przetwórcy spożywczy zaklasyfikowani są do działów niskiej techniki, a badania wskazują, że innowacyjność przedsiębiorstw tego przemysłu wśród innych przedsiębiorstw niskiej techniki jest dość wysoka. Przedsiębiorstwa produkujące artykuły spożywcze plasują się na piątym miejscu w grupie działów niskiej techniki. Optymizmem napawać może również fakt, że firmy produkujące żywność w coraz większym stopniu doceniają znaczenie innowacyjności jako źródła konkurencyjności.

W strukturze nakładów na działalność innowacyjną dominują nakłady inwestycyjne na maszyny i urządzenia oraz budynki i budowle. Na podkreślenie zasługuje jednak fakt, że w przedsiębiorstwach przemysłu spożywczego obserwuje się zdecydowanie wyższy niż w przedsiębiorstwach innych działów przetwórstwa przemysłowego udział nakładów na marketing dotyczący nowych i zmodernizowanych wyrobów. Pozwala to na szybsze i bardziej efektywne wdrożenie innowacji na szerszą skalę.

Dokonując oceny funkcjonowania przedsiębiorstw przemysłu spożywczego z punktu widzenia ich innowacyjności warto zwrócić uwagę na źródła informacji strategicznych, zwłaszcza w kontekście planowanych i realizowanych procesów innowacyjnych. Analiza innowacyjności przedsiębiorstw, przeprowadzona na podstawie publikowanych danych GUS, wskazuje, iż w działalności innowacyjnej przedsiębiorstw w Polsce największe znaczenie odgrywały i nadal odgrywają dwa źródła informacji: znajdujące się wewnątrz przedsiębiorstwa oraz klienci. Najmniejsze znaczenie, jako źródło informacji, miały źródła instytucjonalne, tj. placówki naukowe PAN, JBR-y, zagraniczne publiczne instytucje badawcze oraz szkoły wyższe. Podobną strukturą charakteryzowały się inne kraje uczestniczące w badaniu innowacji według metodologii Oslo. Biorąc pod uwagę nikły transfer wiedzy między instytucjami naukowo-badawczymi a praktyką gospodarczą w naszym kraju, wyniki te nie dziwią, jednak nie napawają optymizmem. Przedsiębiorstwa spożywcze nie dysponują bowiem wystarczającą bazą $\mathrm{B}+\mathrm{R}$ do prowadzenia samodzielnych prac naukowo-badawczych. W konsekwencji nie sprzyja to innowacyjności tego działu przetwórstwa. Zgodnie z Narodową Strategią Innowacji tendencje te powinny ulegać zmianie.

Analizując procesy innowacyjne przemysłu spożywczego należy podkreślić, że największe natężenie zmian odnotowano tuż po integracji z UE, tj. w latach 2004-2006. Było to związane $\mathrm{z}$ koniecznością dostosowania się przedsiębiorstw do wysokich norm jakościowych obowiązujących w UE. Niestety, po tym okresie nastąpił spadek nakładów na działalność innowacyjną, jak również zmniejszył się odsetek przedsiębiorstw innowacyjnych w kolejnych trzech latach.

Wyniki przeprowadzonych badań nad innowacyjnością wskazują, że hierarchie celów działalności innowacyjnej przedsiębiorstw produkujących artykuły 
spożywcze i napoje oraz przedsiębiorstw przetwórstwa przemysłowego i przemysłu ogółem są zbieżne. Najważniejsze były efekty dotyczące produktów, a zwłaszcza poprawa jakości produktów oraz zwiększenie asortymentu produktów. Najsłabsze okazały się efekty związane z obniżką materiałochłonności i redukcją kosztów pracy. Potrzeba spełnienia wielu norm i przepisów w zakresie ochrony środowiska wymaganych na terenie UE skutkuje wdrażaniem innowacji przynoszących korzyści dla środowiska.

Dla przedsiębiorstw przemysłowych głównym partnerem we współpracy w zakresie działalności innowacyjnej, w obydwu analizowanych podokresach, byli dostawcy wyposażenia, materiałów, komponentów i oprogramowania. $\mathrm{Na}$ dalszym miejscu, pod względem częstotliwości podejmowanej współpracy, znaleźli się klienci.

Z przeprowadzonej analizy wynika ponadto, że główną przeszkodą w działalności innowacyjnej jest brak środków finansowych w przedsiębiorstwie lub grupie przedsiębiorstw oraz zbyt wysokie - w porównaniu z możliwościami finansowymi przedsiębiorstw - koszty związane z procesem badawczym.

Uwarunkowania te powodują, że innowacyjne są przede wszystkim przedsiębiorstwa większe - z punktu widzenia zatrudnienia i przychodów.

Innowacyjność w przemyśle spożywczym jest zróżnicowana branżowo. Świadczą o tym wyniki zaprezentowanych w niniejszej pracy analiz, obejmujących próbę budowy i empirycznej weryfikacji syntetycznego miernika innowacyjności (potencjału innowacyjnego) na tym poziomie agregacji. Efektem syntetycznej oceny innowacyjności branż przemysłu spożywczego jest stwierdzenie, że o ile w latach 2004-2006 najbardziej innowacyjnymi, w świetle wskaźników diagnostycznych przyjętych do analizy, były przedsiębiorstwa przemysłu tytoniowego oraz cukierniczego i paszowego, które z pewnymi ,przerwami w czasie", znajdowały się w ścisłej czołówce rankingu, to w latach 2007-2008 należy odnotować zmiany $\mathrm{w}$ innowacyjności przedsiębiorstw przemysły spożywczego w Polsce na korzyść przedsiębiorstw przemysłu koncentratów spożywczych, przemysłu olejarskiego i owocowo-warzywnego.

Wnioski te mogą stanowić wskazówkę co do przyszłej polityki wspierania działalności innowacyjnej przedsiębiorstw przemysłu spożywczego. Zaproponowany przez autorkę wskaźnik innowacyjności może być przydatnym narzędziem do podejmowania decyzji ekonomicznych o branżach, które powinny zostać uznane za priorytetowe w zakresie polityki wspierania innowacyjności.

Jednym z kluczowych obszarów analizy niniejszej pracy była ocena wpływu innowacyjności przemysłu spożywczego na jego konkurencyjność. Jak wiadomo, do najważniejszych mierników konkurencyjności przedsiębiorstw (w ujęciu mezoekonomicznym) należy wartość produkcji sprzedanej, wartość dodana oraz wydajność pracy. Badania w tym zakresie przeprowadzone zostały $\mathrm{z}$ wykorzystaniem modeli ekonometrycznych, opisujących konkurencyjność przemysłu spożywczego (w tym jego branż). W modelach - zgodnie $\mathrm{z}$ założeniami 
teoretycznymi - jako jeden z czynników konkurencyjności przyjęto innowacyjność przedsiębiorstw, mierzoną wartościowo (w cenach stałych) oraz w postaci intensywności nakładów.

Trudnym problemem metodologicznym okazał się - zwłaszcza na etapie modelowania konkurencyjności przemysłu spożywczego - problem dostępności i jakości danych statystycznych. Autorce udało się jednak skompletować porównywalne w czasie dane w odniesieniu do wszystkich klas i tym samym ocenić efekty wpływu procesu innowacyjnego na konkurencyjność przedsiębiorstw

W przeprowadzonych badaniach powiodła się próba zbudowania ekonometrycznych modeli: produkcji sprzedanej, wydajności pracy, wartości dodanej brutto oraz TFP przemysłu spożywczego (ogółem), w których zmienną objaśniającą, poza klasycznymi czynnikami produkcji, była różnie rozumiana działalność innowacyjna. Zastosowanie funkcji produkcji Cobba-Douglasa umożliwiło interpretację ocen parametrów w kategoriach elastyczności wskaźników produkcyjnych względem nakładów poszczególnych czynników wytwórczych.

Uzyskane wyniki potwierdzają istnienie statystycznie istotnego wpływu wewnętrznych nakładów na działalność $\mathrm{B}+\mathrm{R}$, importu oraz BIZ na produkcję sprzedaną. Estymacja modeli wydajności pracy i wartości dodanej brutto wykazała ponadto, że poza technicznym uzbrojeniem pracy istotnie, a przy tym dodatnio, wpływają na konkurencyjność przemysłu spożywczego: intensywność eksportu, importu, BIZ oraz intensywność nakładów na działalność B+R. Wartość dodana brutto reaguje silniej niż wydajność pracy na bieżące zmiany innowacyjności, co jest zgodne z teorią ekonomii.

Na łączną produktywność czynników produkcji wpływają pozytywnie nakłady innowacyjne na maszyny i urządzenia, nakłady innowacyjne ogółem oraz import.

Podobnych wniosków dostarcza analiza ekonometryczna konkurencyjności przemysłu spożywczego w ujęciu branżowym. Innowacyjność - obok technicznego uzbrojenia pracy bądź wartości majątku trwałego - stanowi istotną determinantę konkurencyjności przemysłu spożywczego. Zgodnie z oczekiwaniami, konkurencyjność przemysłu spożywczego jest tym większa, im wyższe są wewnętrzne nakłady na $\mathrm{B}+\mathrm{R}$, podobne prawidłowości odnotowano $\mathrm{w}$ odniesieniu do importu i BIZ. Warto również podkreślić istotność nakładów wewnętrznych (a nie nakładów ogółem) na działalność badawczo-rozwojową. Świadczy to o słabości polskiego systemu innowacji, a zwłaszcza powiązań nauki z biznesem. Implikuje to konieczność szybkich zmian w zakresie wparcia rozwoju współpracy jednostek naukowo-badawczych z polskim przemysłem spożywczym. Działania podejmowane obecnie przy współudziale środków Unii Europejskiej, w tym zwłaszcza Programu Operacyjnego Innowacyjna Gospodarka oraz - w mniejszym zakresie - Programu Operacyjnego Kapitał Ludzki, powinny w dłuższej perspektywie przynieść spodziewane efekty w postaci zwiększenia ogólnych nakładów na $B+R$, jak i współpracy w tym zakresie miedzy nauką a biznesem. 
Weryfikacja modeli panelowych pozwala na zwrócenie uwagi na jeszcze jedną istotną kwestię, że z punktu widzenia konkurencyjności przemysłu spożywczego ważna jest nie tylko ogólna wartość ponoszonych nakładów, ale również ich struktura. Spośród nakładów na innowacje szczególnie ważne okazały się nakłady na maszyny i urządzenia techniczne związane z innowacjami, nakłady na $\mathrm{B}+\mathrm{R}$ (zwłaszcza wewnętrzne) oraz nakłady na marketing innowacyjnych produktów i usług. Warto również podkreślić, że globalnie rozumiana innowacyjność (mierzona wskaźnikiem syntetycznym, którego metodologię opracowano dla potrzeb niniejszej pracy) istotnie determinuje konkurencyjność branż przemysłu spożywczego.

Zastosowanie modeli panelowych, pozwalających na ocenę omawianych relacji w ujęciu branżowym, umożliwia także sprawdzenie wniosku o istnieniu heterogeniczności branż przemysłu spożywczego. W modelach produkcji sprzedanej efekty specyficzne (najwyższe wartości wyrazów wolnych) zaznaczyły się najwyraźniej w branżach: mięsnej, mleczarskiej, drobiarskiej, paszowej i owocowo-warzywnej. Najniższe wartości wyrazów wolnych odnotowano dla branży ziemniaczanej i winiarskiej.

Zaprezentowana ocena innowacyjności i jej związku z rozwojem i konkurencyjnością przemysłu spożywczego w Polsce nie wyczerpuje złożoności zagadnienia, a stanowi jeden z jej wątków składających się na cały system ocen. Rozważane zagadnienia są szczególnie istotne w kontekście polskiej gospodarki, która stoi wobec trudnych wyzwań rozwojowych, wynikających ze zmiany układu sił konkurencyjnych w świecie i zawirowań spowodowanych kryzysem ekonomicznym. Na obecnym etapie rozwoju przemysłu spożywczego w Polsce wyczerpują się dotychczasowe źródła konkurencyjności, takie jak: relatywnie niskie koszty pracy i pozostałych czynników wytwórczych, niskie ceny płodów rolnych, czy strumienie środków unijnych zasilające procesy rozwojowe. Poszukiwać zatem należy nowych czynników modernizacji przedsiębiorstw przemysłu spożywczego i przewag konkurencyjności, wykorzystując wiedzę, innowacje i kapitał ludzki. Ważnym źródłem konkurencyjności powinna być jakość i unikalność produktów, umiejętność identyfikowania i zaspokajania indywidualnych potrzeb klientów, wszechstronne działania promocyjne oraz kreowanie wizerunku firmy opartego na zaufaniu do jakości produktów.

Przeprowadzone badania i sformułowane wnioski stanowią przyczynek do dalszych prac $\mathrm{w}$ tym zakresie, wzbogacając prezentowaną $\mathrm{w}$ polskiej literaturze przedmiotu wiedzę o przemyśle spożywczym w Polsce. 


\section{Bibliografia}

A c s Z. J., A u d r e t s c h D. B. (1987), Innovation, Market Structure, and Firm Size, ,The Review of Economics and Statistics", vol. LXIX, nr 4

A c s Z. J., A u d r e t s c h D. B. (1991), Innovation and Size at the Firm Level, „Southern Economic Journal", vol. 57 , no. 3

Aghion P. et al. (2001), Competition, Imitation and Growth with Step-by-Step Innovation, „Review of Economic Studies”, nr 68

Analiza produkcyjno-ekonomicznej sytuacji rolnictwa i gospodarki żywnościowej $w 2007$ roku (2008), IERiGŻ-PIB, Warszawa

A r c h i bug i D., M i c h i e J. (1995), Technology and Innovation: An Introduction, „Cambridge Journal of Economics", vol. 19

Archibugi D., How ells J. and J. Mich ie (2001), Innovation systems and policy in a global economy, [w:] D. A r c hibug i, J. How e 11 s, J. Mich i e (eds), Innovation Policy in a Global Economy, Cambridge University Press, Cambridge.

A r r o w K. J. (1962), The Economic Implications of Learning by Doing, „Review of Economic Studies", no. 29

B a r r o R.J. (1999), Notes on Growth Accounting, ,Journal of Economic Growth”, no. 4

B a r u k J. (1992), Innowacje czynnikiem efektywnego rozwoju przedsiębiorstwa, Wyd. Uniwersytetu M. Curie-Skłodowskiej, Lublin

Białasiewicz M. (red.), (2004), Rozwój przedsiębiorstw. Zarządzanie i diagnoza, Wyd. Naukowe Uniwersytetu Szczecińskiego, Szczecin

B 1 a u g M. (1995), Metodologia ekonomii, PWN, Warszawa

Bogdanienko J., Haffer M., Popławski W. (2004), Innowacyjność przedsiębiorstw, Wyd. UMK, Toruń

B o j e w s a B. (2009), Zarządzanie innowacjami jako źródło przedsiębiorczości małych i średnich przedsiębiorstw $w$ Polsce, Monografie i Opracowania 564, SGH, Warszawa

B rod zińs k i Z., Chyłe k E. K. (1999), Doradztwo w agrobiznesie, Wyd. ART, Olsztyn

B u d z yńs k i F. (1996), Ekonomika innowacji technicznych, Politechnika Krakowska, Kraków

Burda M.C., Severgnini B. (2008), Solow Residual without Capital Stocks, SFB 649, Discussion Paper 2008-040, Sonderforschugbereich 649, Humboldt University, Berlin

B u r d a M.C., S e v e r g n in i B. (2009), TFP Growth in Old and New Europe, SFB 649, Discussion Paper 2009-033, Humboldt University, Berlin

Che ch els ki P. (2005), Inwestycje zagraniczne w polskim przemyśle spożywczym, „Przemysł Spożywczy", nr 8

C i c h y K. (2008), Kapitat ludzki i postęp techniczny jako determinanty wzrostu gospodarczego, Instytut Wiedzy i Innowacji, Warszawa

C o e D. T., He l p m a n E. (1995), International R\&D Spillovers, "European Economic Review", vol. 39

Coe D. T., Helpman E., Hoffma ister A.W. (1997), North-South R\&D Spillovers, „The Economic Journal", vol. 107, s. 134-139

Commission of the European Communities (1992), Dable Report 1. Synospis of European Enterprises, Brussels

Competitiveness: Forging Ahead (1995), DTI, Her Majesty Stationery Office, London

Conn or T. (2003), Managing for Competitiveness: A Proposed Model for Managerial Focus, „Strategic Change”, no. 4

C o r m a c k R. (1971), A review of classification, „Journal of the Royal Statistical Society”, Series A, vol. 134(3) 
Crow M., B o ze man B. (2001), Limited by Design: R\&D Laboratories in the U.S. National Innovation System, Columbia University Press, New York 1998, [w:] P. L a r e d o, P. M u s t a r (eds), Research and Innovation Policies in the New Global Economy, An International Analysis, Edward Elgar Publishing Limited, Cheltenham (UK), Northampton MA ( USA)

Dańska B., Laskowska I. (1996) Zastosowanie modeli panelowych do badania zróżnicowania wydatków domowych na żywność oraz higienę i ochronę zdrowia, Prace Instytutu Ekonometrii i Statystyki Uniwersytetu Łódzkiego, Z. 117, Wyd. UŁ, Łódź

Dańska B., (2000) Przemystowo-czasowe modelowanie zmian $w$ działalności produkcyjnej $w$ Polsce. Zastosowanie modeli panelowych, [w:] B. S u c h e c k i (red.) Dane panelowe i modelowanie wielowymiarowe $w$ badaniach ekonomicznych, Absolwent, Łódź

D e $\mathrm{n}$ is o n E. (1962), Source of Economic Growth in the United States and the Alternative before Us, Committee for Economic Development

D o m a ń s k i Cz., P r u s k a K., W a g n e r W. (1998), Wnioskowanie statystyczne przy nieklasycznych założeniach, Wyd. UŁ, Łódź.

D o m a r E. D. (1962), Szkice z teorii wzrostu gospodarczego, PWN, Warszawa

Dossi Giovani (2000), Innovation, Organization and Economic Dynamics. Selected Essays, Edward Elgar, Cheltenham (UK), Northampton MA (USA)

D r o ż d ż J. (2008), Analiza ekonomiczno-finansowa przemysłu spożywczego w latach 2003-2007, IERiGŻ-PIB, Warszawa

D r u c k e r P. F. (1992), Innowacja i przedsiębiorczość. Praktyka i zasady, PWN, Warszawa

D r u c k e r P. F. (1995), Zarzadzanie w czasach burzliwych, Wyd. Nowoczesność, Warszawa

D r u c k e r P. F. (1999), Społeczeństwo pokapitalistyczne, PWN, Warszawa

Drucker P. F. (2004), Natchnienie i fart czyli innowacje i przedsiębiorczość, Studio Emka, Warszawa

Działania innowacyjne przedsiębiorstw w sektorze ustug w latach 2001-2003 (2005), GUS, Warszawa

Działalność innowacyjna przedsiębiorstw przemystowych w latach 2002-2004 (2006), GUS, Warszawa

Działalność innowacyjna przedsiębiorstw w latach 2004-2006 (2008), GUS, Warszawa

Działalność innowacyjna przedsiębiorstw w latach 2006-2009 (2010), GUS i US w Szczecinie, Warszawa

E d q u i s t C. (1997), Systems of Innovation; Technologies, Institutions and Organizations, Printer, London

Engl and e r S., Gurney A. (1994), Medium-Term Determinants of the OECD Productivity, OECD Economic Studies, No 22, 1994

European Innovation Scoreboard 2009. Comparative Analysis of Innovation Performance, Pro Inno Europe

European Trend Chart on Innovation, Annual Innovation Policy Trends and Appraisal Report Germany 2006 (2006), European Commission

Europa 2020. Strategia na rzecz inteligentnego i zrównoważonego rozwoju sprzyjajacego właczeniu społecznemu, Komunikat Komisji, Komisja Europejska, Bruksela 3 marca 2010

Evans M. J., Mountinho L., Ra aij W. (1996), Applied Consumer Behaviour, AddisonWesley Publishing Company, Harlow

Ever i t t B.S., L a n d a u S., L e e s e M. (2001), Cluster analysis, Hodder Arnold, London

F e n g 1 e r Z.(1991), Potencjatfirmy a innowacyjność, „Ekonomika i Organizacja Przedsiębiorstwa”, $\mathrm{nr} 10$

F e rg u s o n G., A., Tak a n Y Y. (1997), Analiza statystyczna w psychologii i pedagogice, PWN, Warszawa 
F i e d o r B. (1979), Teoria innowacji. Krytyczna analiza współczesnych koncepcji niemarksistowskich, PWN, Warszawa

F irle j K. (2008), Rozwój przemystu rolno-spożywczego w sektorze agrobiznesu i jego determinanty, Wyd. Uniwersytetu Ekonomicznego, Kraków

F1ejterski S. (1984), Istota i mierzenie konkurencyjności międzynarodowej, "Gospodarka Planowa", nr 9

Fras cati M. (2002), Proposed Standard Practice for Surveys on Research and Experimental Development, OECD

F r e e m a n Ch. (1982), The Economics of Industrial Innovation, F. Pinter, London

Fr e e m a n Ch. (1992), The Economics of Hope, Pinter Publishers, London

Gatnar E., Walesiak M. (red.) (2004), Metody statystycznej analizy wielowymiarowej w badaniach marketingowych, Wyd. AE we Wrocławiu, Wrocław.

G n a n a d e s ik a n R., Ket t e n r ing J. R., T s a o S.L. (1995), Weighting and selection of variables for cluster analysis, „Journal of Classification”, vol. 12, no 1

Goldhar J. D. (1974), Information, Idea Generation and Technological Innovation, [w:] F. D a v i d s o $\mathrm{n}$ et al., Technology Transfer, Noordhoff, Leiden

G o m ułk a M. (2006), Innowacyjność polskiego przemystu, [w:] M. A. W e r e s a (2006), Polska: Raport o konkurencyjności 2006. Rola innowacji w ksztaltowaniu przewag konkurencyjnych, Wyd. SGH, Warszawa

Go mułk a M. (2006a), Zdolność innowacyjna Polski na tle pozostałych krajów członkowskich UE, [w]: M. A. We re s a (2006), Polska: Raport o konkurencyjności 2006. Rola innowacji w kształtowaniu przewag konkurencyjnych, Wyd. SGH, Warszawa

G o m ułk a Stanisław (1998), Teoria innowacji i wzrostu gospodarczego, CASE, Warszawa

Gord o n A.D. (1987), A Review of hierarchical classification, „Journal of the Royal Statistical Society", Series A, vol. 150(2).

G o r d o n A.D. (1996), Hierarchical classification, [w:] P. A r a b i e, L.J. H u b e r t, G. De S o e t e (ed.), Clustering and classification, World Scientific, Singapore.

G o r d o n A.D. (1999), Classification, CHAPMAN \& HALL/CRC

G o r y n i a M. (2001), Międzynarodowa konkurencyjność polskich przedsiębiorstw - wyniki badań empirycznych, [w:] J. K o tow i c z-J a w or (red.), Przedsiębiorczość i konkurencyjność, Dom Wydawniczy Bellona, Warszawa

Grabińs ki T., Wy dy m u s S., Z e li á A. (1989), Metody taksonomii numerycznej w modelowaniu zjawisk społeczno-gospodarczych, PWN, Warszawa.

Gr e e n W.H. (2008), Econometric Analysis, Sixth Edition, Prentice Hall, New York

Grili ches Z. (1957), Hybrid Corn: An Exploration In the Economics of Technological Change, „Econometrica”, vol. 25

Grili ch es Z. (1979), Issues in Assessing the Contribution of R\&D to Productivity Growth, „The Bell Journal of Economics", vol. 10

Griliches Z. (1980), R\&D and Productivity Slowdown, „American Economic Review”, vol.76

Grili ch e s Z. (1981), A Market Value, R\&D and Patents, „Economic Letters”, vol. 7

Griliches Z. (1986), Productivity R\&D and Basic Research at the Firm Level in the 1970s, „American Economic Review”, vol. 76

G r i 1 i c h e s Z.(1995), Firm Productivity in Israeli Industry, 1979-1988, ,Journal of Econometrics”, vol. 65

GUS (2006), Działalność innowacyjna przedsiębiorstw przemysłowych $w$ latach 2002-2004, Informacje i opracowania statystyczne, GUS, Warszawa.

G w a r tn e y J. D., S tro u p R. L. (1987), Microeconomics. Private and Public Choice, Harcourt Brace Jovanovich Publishers/Academic Press, San Diego-New York 
H a g e J., H o 11 ing s w o r th J. R. (2000), A Srategy for the Analysis of Idea Innovation Networks and Institutions. „Organization Studies”, vol. 21, no. 5

H a 11 R. (1990), Invariance Properties and Solow's Productivity Residual, [w:] P. A. D i a m o n d (ed.), Growth/Productivity/Employment, MIT Press Cambridge, MA

H a u s m a n J. A. (1978), Specification Tests in Econometrics, „Econometrica”, vol. 46

Hausman J. A., Taylor W. E. (1981), Panel Data and Unobservable Individual Effects, „Econometrica”, vol. 49

Hunt Shelby D. (2000), A General Theory of Competition, Resources, Competence, Productivity. Economic Growth, Sage Publications Inc., Thousand Oaks-London-New Delhi

I 1 e c z k o B. (1979), Podstawy typologicznej teorii innowacyjnej, „Zagadnienia Naukoznawstwa”, nr 4, PAN, Warszawa

IMD (2009), IMD World Competitiveness Yearbook, Institute for Management Development, Lozanna

Inventory of the Polish National Innovation System (NIS) (2003), Centre for Industrial Management, Polish Academy of Sciences, European Integration Exploratorium, June 30

J a k ó b i k W. (2000), Zmiany systemowe a struktura gospodarki w Polsce, Wyd. Nauk. PWN, Warszawa

J a n a s z W. (red.), (2006), Zarys strategii rozwoju przemystu, Difin, Warszawa

J a n a s W. (red.), (2009), Innowacje w strategii rozwoju organizacji w Unii Europejskiej, Difin, Warszawa

J a n k o w s k a B. (2005), Międzynarodowa konkurencyjność branży na przykładzie polskiej branży budowlanej w latach 1994-2001, Wyd. Akademii Ekonomicznej, Poznań

Ja s ińs k i A. (1997), Innowacje i polityka innowacyjna, Wyd. Uniwersytetu w Białymstoku, Białystok

J a s iń s k i A. H. (ed.) (2002), Innovation in Transition. The Case of Poland, Wyd. Nauk. Wydziału Zarządzania Uniwersytetu Warszawskiego, Warsaw

J a s iń s k i A. (2004), Jaka polityka innowacyjna wokresie transformacji, „Sprawy Nauki”, 17.03.2004.

J a s iń s k i A. (2006), Innowacje i transfer techniki w procesie transformacji, Difin, Warszawa

J o h n s o n S.C. (1967), Hierarchical clustering schemes, „Psychometrika”, vol. 32, no 3.

Jones P., Teece D. (1988), What We Know and What We Don't Know about Competitiveness, [w:] A. F u rino (ed.), Cooperation and Competition in the Global Economy: Issues and Strategies, Ballinger, Cambridge MA

J org e n s o n D.W., H o M.S., S t i r o h K.J. (2008), A Retrospective Look at the U.S. Productivity Growth Resurgence, ,Journal of Economic Perspectives”, no. 22(1)

J u s zc zak-S z u m a cher G. (1996), Makroekonometryczna analiza procesu produkcyjnego, Wyd. Uniwersytetu Łódzkiego, Łódź

Kalecki M. (1970), Teorie wzrostu w różnych systemach społecznych, [w:] M. K ale ck i, Dzieła, t. 4: Socjalizm. Wzrost gospodarczy i efektywność inwestycji, PWE, Warszawa 1984

Kasperkiewicz W. (1989), Systemy funkcjonowania gospodarki a innowacje, Wyd. Uniwersytetu Łódzkiego, Łódź

K a s p r zy k S. (1980), Innowacje. Od koncepcji do produkcji, IWZZ, Warszawa

K a u fman L., R o u s s e u w P.J. (1990), Finding groups in data. An introduction to cluster analysis, (reprint 2005), John Wiley \& Sons, New York

K l i n c e w i c z K. (2008), Polska innowacyjność. Analiza bibliometryczna, Wyd. Nauk. Wydziału Zarządzania Uniwersytetu Warszawskiego, Warszawa

K 1 i n e S. J. (1985a), Research, invention, Innovation and Production: Models and Reality, Working Paper INN-1, Department of Mechanical Engineering, Stanford University

K 1 i n e S. J. (1985b), Innovation is not a Linear Process, „Research Management”, vol.28 
Kline S. J., Rosenberg N. (1986), An Overview of Innovation, [w:] R. Landau, N. R o s e n b e rg (eds), The Positive Sum Strategy. Harnessing Technology for Economic Growth, National Academy Press, Washington DC

Kładź K., Kowalski A. M. (2010), Rozwój klastrów przemystowych w Polsce [w:] M. A. W e r e s a (red.), Polska raport o konkurencyjności 2010. Klastry przemystowe a przewagi konkurencyjne, Instytut Gospodarki Światowej SGH w Warszawie, Warszawa

K ol e nd a M. (2006), Taksonomia numeryczna. Klasyfikacja, porządkowanie i analiza obiektów wielocechowych, Wyd. Akademii Ekonomicznej, Wrocław.

Koronacki J., Ćwik J. (2005), Statystyczne systemy uczące się, Wydawnictwo NaukowoTechniczne, Warszawa.

K o t S. M. (1993), Matematyczne modele procesów dyfuzji innowacji, PWN, Warszawa

K o t l e r Ph. (1991), Marketing Management, Prentice Hall, New Jersey

K o t 1 e r Ph. (1999), Marketing narodów, Profesjonalna Szkoła Biznesu, Kraków

Kow a lak B. (2006), Konkurencyjna gospodarka - innowacje - infrastruktura - mechanizmy rozwoju, ITeE, Warszawa-Radom

K o z i oł K. (2009), Metodologia badań innowacyjności krajów i działalności innowacyjnej przedsiębiorstw w Unii Europejskiej, [w:] W. J o n a s z (red.), Innowacje w strategii rozwoju organizacji w Unii Europejskiej, Difin, Warszawa

K o z i oł K. (2007), Innowacyjność polskich przedsiębiorstw przemystowych na tle doświadczeń Unii Europejskiej, „Rozprawy i Studia Uniwersytetu Szczecińskiego”, t. 661

Kr u g m a n P. (1994), Competitiveness, Dangerous Obsession, „Foreign Affairs” vol. 73, no. 2

K r u p o w i c z R. (2010), Polska potrzebuje nie tyle polityki innowacyjnej co polityk na rzecz innowacji, http://www.pi.gov.pl/PARP/chapter_86197...2010-08-20

K u d r y c k a I. (2003), Działalność badawczo-rozwojowa $(B+R)$ i edukacyjna-metody oceny wptywu na wzrost gospodarczy i zmiany strukturalne, Zakład Badań Statystyczno-Ekonomicznych GUS i PAN, Warszawa

Kukliński A. (red.) (2002), Gospodarka oparta na wiedzy. Wyzwania dla Polski XXI wieku, Komitet Badań Naukowych, Warszawa

Kukliński A. (red.) (2003), Gospodarka oparta na wiedzy. Perspektywy Banku Światowego, Komitet Badań Naukowych i Biuro Banku Światowego w Warszawie, Warszawa

K u k uła K. (2000), Metoda unitaryzacji zerowanej, Wyd. Nauk. PWN, Warszawa.

$\mathrm{K} u \mathrm{z} n$ e t s S. (1959), Six Lectures on Economic Growth, The Free Pres, Chicago

$\mathrm{K} \mathrm{u} \mathrm{z}$ e t s S. (1962), Invention activity problem of definition and measurements, [w:] The rate and direction of inventiveness, Random House, Princeton

K w i a t k ow s k i S. (1990), Społeczeństwo informacyjne, PWN, Warszawa

L i b e rda B. (1996), Oszczędności w teoriach konsumpcji i wzrostu, „Ekonomista”, nr 3

L i c h t a r s k i J. (red.) (1997), Podstawy nauki o przedsiębiorstwie, Wyd. Akademii Ekonomicznej, Wrocław

L i n s u K. (1997), Imitation to Innovation, Harvard Business School Press, Boston

Lucas R.E. (1988) On the Mechanism of Economics Development, „Journal of Monetary Economics", July

L u n d v a 11 B. A. (1992), National Systems of Innovation, Pinter Publishers, London

Ł o bejk o S. (2005), Systemy informacyjne $w$ zarzadzaniu wiedza i innowacja $w$ przedsiębiorstwie, Wyd. SGH, Warszawa

$Ł$ u k a s z e w i c z A. (2001), Dylematy ekonomiczne przełomu stuleci, Wyd. Key Text, Warszawa M a d e j Z. (1970), Nauka i rozwój gospodarczy, PWN, Warszawa

M a la r s k a A. (2005), Statystyczna analiza danych wspomagana programem SPSS, SPSS Polska, Kraków 
Malina A., Zeliaś A. (1998), On building taxonometric measures on living conditions, „Statistics in Transition”, vol. 3, no 3

M a n s fi e ld E. (1968), The Economics of Technological Change, W.W. Norton and Co., New York

Marciniak S. (2000), Innowacje $i$ rozwój gospodarczy, Kolegium Nauk Społecznych i Administracji Politechniki Warszawskiej, Warszawa

Meeus M., Oerlemans L. (2001), [w:] D. Archibugi, J. Howells and J. Michie (eds), Innoavtion Policy in a Global Economy, Cambridge University Press, Cambridge

M i e d zi ń s k i M. (2001), Koordynacja procesów innowacji na przykładzie polskiego województwa, [w:] Gospodarka oparta na wiedzy, Wyzwanie dla Polski XXI w., KBN, Warszawa

M e i s t e r Ch., Ve r s p a g e n B. (2004), European Productivity Gaps: Is R\&D the solution, Centre for Technology, Innovation and Culture, Working Paper, no. 01/04

Metcalfe S. (1995), The Economic Foundations of Technology Policy: Equilibrium and Evolutionary Perspectives, [w:] P. S t o n e m a n (ed.), Handbook of Economics of Innovation and Technical Change, Blackwell, London

M i k o s i k S. (1993), Teoria rozwoju gospodarczego Josepha A. Schumpetera, PWN, Warszawa

M i k u le c A. (2008), Ocena metod porządkowania liniowego w analizie starości demograficznej, „Wiadomości Statystyczne”, nr 6

Millig an G. W., Co o p er M. C. (1987), Methodology review: clustering methods, „Applied Psychological Measurement", vol. 11, no. 4, http://apm.sagepub.com/.

Milligan G. W. (1996), Clustering validation: results and implication for applied analysis, [w:] P. A rabi e, L. J. Hubert, G. D e S o e te (eds), Clustering and classification, World Scientific, Singapore.

Ministerstwo Gospodarki (2006), Departament Rozwoju Gospodarki, Kierunki zwiększenia innowacyjności gospodarki na lata 2007-2013, dokument strategiczny przyjęty przez Radę Ministrów w dniu 4 września 2006 r.

M i s a la J. (2006), Podstawowe problemy pomiaru konkurencyjności gospodarki kraju, [w:] M. A. W e r e s a (red.) (2006), Polska: Raport o konkurencyjności 2006. Rola innowacji w ksztattowaniu przewag konkurencyjnych, Wyd. SGH, Warszawa

M $\nmid$ o d a k A. (2006), Analiza taksonomiczna w statystyce regionalnej, Difin, Warszawa.

Mohnen P., Ten Ra a T. (2002), Neoclassical Growth Accounting and Frontier Analysis: A Synthesis, „Journal of Productivity Analysis”, no. 18

'M o j e n a R. (1977), Hierarchical grouping methods and stopping rules: an evaluation, „Computer Journal", vol. 20, no 4.

Molina A., Kinder T. (2000), National Systems of Innovation, Industrial Clusters and Constituency - Building in Scotland's Electronics Industry, [w:] R. E. L o p e z - M a r t i n e z, A. P i c c a $1 \mathrm{u}$ g a (eds), Knowledge Flows in National Systems of Innovation. A Comparative Analysis of Sociotechnical Constituencies in Europe and Latin America, Edward Elgar Publishing Limited, Cheltenham(UK), Northampton MA (USA)

Mujżel J. (1977), Bodźce postępu techniczno-organizacyjnego i warunki ich skuteczności w przedsiębiorstwie, PWE, Warszawa

$\mathrm{N}$ a d i r i M. I. (1993), Innovations and Technological Spillovers, NBER Working Paper, no. 4423

Nauka i technika w 2006 roku (2007), GUS , Warszawa

Nauka i technika w 2007 roku (2009), GUS, Warszawa

Nauka i technika w 2008 roku (2009) GUS, Warszawa

Nauka i technika w 2009 roku (2011) GUS, Warszawa

N els o n R. R., Winter S. G. (1977), In Search of Useful Theory of Innovation, "Research Policy", no. 6

N e l s o n R. R., R o s e n b e rg N. (1993), National Innovation System, Oxford University Press 
N e 1 s o n R. R., R o s e n b e r g N. (1993), Technical innovation and national systems, [w:] R. R. $\mathrm{N}$ e 1 s o n (ed.), National Innovation Systems, A Comparative Analysis, Oxford University Press, New York

Niedzielski P., Rychlik K. (2006), Innowacje $i$ kreatywność, Wyd. Uniwersytetu Szczecińskiego, Szczecin.

N o w a k - F a r A. (2000), Globalna konkurencja, PWN, Warszawa-Poznań

OECD (1996a), Employment and Growth in the Knowledge-based Economy, Organization for Economic Cooperation and Development, Paris

OECD (1996b), The Knowledge-based Economy, Organization for Economic Cooperation and Development, Paris

OECD (1996c), Technology and Industrial Performance, Organization for Economic Cooperation and Development, Paris

OECD (1997), Industrial Competitiveness in the Knowledge-based Economy: The New Role of Government, Organization for Economic Cooperation and Development, Paris

Okoń-Horodyńska E. (1998), Narodowy system innowacji w Polsce, Wyd. Akademii Ekonomicznej, Katowice

O k on - Ho r o d y ń s k a E. (1999), Potrzeba narodowego systemu innowacji w gospodarce polskiej, „Ekonomista”, nr 3

O k on - Ho r o d y ńs k a E. (2000), Jak budować Regionalne Systemy Innowacji, Instytut Badań nad Gospodarką Rynkową, „Polska Regionów” nr 15,

O koń-Horodyńska E. (2002), Czy Polska ma perspektywiczna politykę innowacyjna, [w:]

G. K oło d k o (red.), Rozwój polskiej gospodarki. Perspektywy i uwarunkowania, WSPiZ im

L. Koźmińskiego, Warszawa

O k o ń - H o r o d y ńk a E. (2004), Co z Narodowym Systemem Innowacji w Polsce, [w:] taż (red.), Rola polskiej nauki we wzroście innowacyjności gospodarki, Wyd.PTE, Warszawa

O k o ń - H o r o d y ń s k a E. (red.) (2000), Państwo narodowe a proces globalizacji, Wyd. Akademii Ekonomicznej im. Karola Adamieckiego, Katowice

Oslo Manual, Guidelines for Collecting and Interpreting Technological Innovation Data, (2005), OECD, Eurostat

O s t a s i e w i c z W. (red.) (1999), Statystyczne metody analizy danych, Wydawnictwo Akademii Ekonomicznej, Wrocław

P anek T. (2009), Statystyczne metody wielowymiarowej analizy porównawczej, Wyd. SGH, Warszawa

P a ng s y-K a n i a S. (2007), Polityka innowacyjna państwa a narodowa strategia konkurencyjnego rozwoju, Wyd. Uniwersytetu Gdańskiego, Gdańsk

P a t e 1 P., P a v it t K. (1994), National Innovation Systems, „Economics of Innovations and New Technology", vol. 3,

P e n c J. (1999), Innowacje i zmiany w firmie. Transformacja i sterowanie rozwojem przedsiębiorstwa, Agencja Wydawnicza Placet, Warszawa

P e r e z C. (2003), Technological Revolutions and Financial Capital. The Dynamics of Bubbles and Golden Ages, Edward Elgar, Cheltenham (UK), Northampton MA (USA)

Podręcznik Oslo. Proponowane zasady gromadzenia i interpretacji danych dotyczacych innowacji technologicznych (1999), OECD/EUROSTAT 1997, KBN, Warszawa

Polska a gospodarka oparta na wiedzy. W kierunku zwiększania konkurencyjności Polski w Unii Europejskiej, (2004), Ttzhak Goldberg, Bank Światowy, Region Europy i Azji Centralnej, Departament Rozwoju Sektora Prywatnego i Finansowego, Washington D.C.

P o m y k a $1 \mathrm{~s}$ k i A. (2001), Innowacje, Politechnika Łódzka, Łódź

P o m y k a ls k i A. (2001a), Zarządzanie innowacjami, Wyd. Nauk. PWN, Warszawa - Łódź

P o r t e r M. E. (1980), Competitive Strategy. Techniques for Analyzing Industries and Competitors, The Free Press, New York 
P o r t e r M. E. (1985), Competitive Advantage, Free Press, New York

P o r t e r M. E. (1990), The Competitive Advantage of Nations, The Free Press, New York

P o r te r M. E. (2001), Porter o konkurencji, PWE, Warszawa

P o z n án s k i K. (1979), Innowacje w gospodarce kapitalistycznej, PWN, Warszawa

P o z n a ń s k i K. (1981), Działalność innowacyjna przemystu. Elementy diagnozy, PWN, Warszawa

Procesy innowacyjne w polskiej gospodarce, (2005), raport nr 26, RSSG przy Radzie Ministrów, Warszawa

R a d o m s ki B. (2010), Konkurencyjność Polski wedtug raportów Międzynarodowego Instytutu Rozwoju Zarządzania (IMD) i Światowego Forum Ekonomicznego (WEF) w 2009 roku, [w:]

M. A. We r e s a (red.), Polska. Raport o konkurencyjności 2010. Klastry przemystowe a przewagi konkurencyjne, Instytut Gospodarki Światowej SGH w Warszawie, Warszawa

Raport „Przedsiębiorczość w Polsce”, MGPiPS, Warszawa, maj 2003 r. (wersja z dn. 4.06 .2003 r.) Revision of the high-technology sector and product classification (1997), STI Working Papers 1972/2, OECD

Rocznik statystyczny przemystu 2008, (2008), GUS, Warszawa

Rocznik statystyczny przemystu 2009, (2010), GUS, Warszawa

Rocznik Statystyczny Rzeczypospolitej Polskiej2008, (2008), GUS, Warszawa

Rocznik statystyczny Rzeczypospolitej Polskiej 2009, (2009), GUS, Warszawa

Rocznik statystyczny Rzeczypospolitej Polskiej 2010, (2010), GUS, Warszawa

Rodrigues M. J. (2003), European Policies for a Knowledge Economy, Edward Elgar, Cheltenham UK, Northampton Mass

R o m e r P. M. (1986), Increasing Returns and Long-Run Growth, „Journal of Political Economy”,

October

R o m e r P. M. (1990), Endogenous Technological Change, "Journal of Political Economy", October R o s e n b e r g N. (1974), Science, Invention and Economic Growth, "Economic Journal", no 84

R o t h w e 11 R. (1992), Successful Industrial Innovation: Critical Factors for the 1990's. „R and D Management", no 22

R o th w e 11 R. (1994), Towards the Fifth-generation Innovation Process, „International Marketing Review" no. 11(1)

Rozporządzenie Rady Ministrów z dnia 24 grudnia 2007 r. w sprawie Polskiej Klasyfikacji Działalności (Dz. U. Nr 251, poz.1885)

Rö ge r W. (1995), Can Imperfect Competition Explain the Difference between Primal and Dual Productivity Measures? Estimates for U.S. Manufacturing, „Journal of Political Economy”, no. 103(2)

S c h m o o k 1 e r J. (1966), Invention and Economic Growth, Harvard University Press, Cambridge MA $\mathrm{S} \mathrm{c}$ h u m p e t e r J. A (1928), The Instability of Capitalism, „The Economic Journal”, vol. XXXVIII Schumpeter J. A. (1934), The Theory of Economic Development: An Inquiry into Profits, Capital, Credit, Interest, and The Business Cycle, Harvard University Press, Cambridge MA

S c h u m p e t e r J. A. (1960), Teoria rozwoju gospodarczego, PWN, Warszawa

S c h u m p e t e r J. A. (1995), Kapitalizm, socjalizm, demokracja, PWN, Warszawa

She 11 K. (1966), Toward a Theory of Inventive Activity and Capital Accumulation, „American Economic Review", May

S i m on et t i R., A r c h ibug i D., E w a n g e lis t a R.(1995), Product and process innovations: how they defined? How are they quantified, „Scientometrics”, no. 32

S in g e r A. (2000), Hypercompetition, Business Press, Thompson Learning, London

$\mathrm{S} \mathrm{m}$ i t h A. (1954), Badanie nad natura i przyczyną bogactw narodów, PWN, Warszawa

Snowdon B., Vane Howard R. (2003), Rozmowy z wybitnymi ekonomistami, Dom Wydawniczy Bellona, Warszawa 
S olow R. M. (1957), Technical Change and the Aggregate Production Function, ,, Review of Economics and Statistics", no. 2 (39)

S o lo w R. M. (1988), Czy istnieja powszechnie akceptowane podstawowe zasady stosowanej makroekonomii, „Gospodarka Narodowa”, nr 4

Spielkamp A., Vopel K. (1997), National Innovation System and Mapping Innovative Clusters at the Firm Level, Center for European Economic Research, ZEW, Mannheim

S t a w a s z E. (1999), Innowacje a mała firma, Wyd. Uniwersytetu Łódzkiego, Łódź

S t e i n 1 e y D., B r u s c o M. J. (2008), Selection of variables in cluster analysis en empirical comparison of eight procedures, „Psychometrika” 2008, vol. 73, no 1.

S u che c ki B. (2000), Panel Data and Multivariate Models In the Economic Researches, Wyd. Uniwersytetu Łódzkiego, Łódź

S z a j t M. (2008), Aktywność innowacyjna a wzrost gospodarczy Polski. Analiza statystyczno-ekonometryczna, Wyd. Politechniki Częstochowskiej, Częstochowa

S z aj t M. (2009), Narodowy System innowacji $w$ Polsce na tle innych działajacych $w$ Europie, [w:] B. Kryk, K. P i e ch (red.), Innowacyjność w skali makro i mikro, Instytut Wiedzy i Innowacji, Warszawa

S z t a u d y n ge r J. J. (2003), Modyfikacje funkcji produkcji i wydajności pracy z zastosowaniami, Wyd. Uniwersytetu Łódzkiego, Łódź

S zta u dynger J. J. (2005), Wzrost gospodarczy a kapitat społeczny, prywatyzacja i inflacja, Wyd. Nauk. PWN, Warszawa

Św i e zewska I. (2007), Łaczna produktywność czynników produkcji. Ucieleśniony kapitat wiedzy, [w:] W. We $1 \mathrm{fe}$ (red.), Gospodarka oparta na wiedzy, PWE, Warszawa

Ś w i t a 1 s k i W. (2005), Innowacje i konkurencyjność, Wyd. Uniwersytetu Warszawskiego, Warszawa Ta y 1 o r P. (1969), A New Dictionary of Economics, Routledge \& Kegan Paul, London

To b i n J. (1997), An Overview of the General Theory, Cowles Foundation Paper nr 947, Washington

To kar s k i T. (2001), Modele wzrostu endogenicznego, [w:] W. W e $1 \mathrm{fe}$ (red.), Ekonometryczny model wzrostu gospodarczego, Wyd. Uniwersytetu łódzkiego, Łódź

To m a s z e w i c z Ł. (red.), (2010), Transfer technologii w procesie rozwoju polskiej gospodarki. Ujęcie sektorowe i regionalne, Wydawnictwo Uniwersytetu Łódzkiego, Łódź

To m c z a k (1996), Szanse i ograniczenia uczestnictwa polskiego rolnictwa i agrobiznesu na rynkach międzynarodowych, Roczniki Naukowe, Komitet Ekonomiki Rolnictwa, PAN, Olsztyn

Tushman M. L., Newman W. H., Rom anelli E. (1988), Convergence and Upheaval. Managing the Unsteadly Peace of Organisational evolution, „California Management Review", vol. 29, no. 1

U r b a n R. (red.), (2004), Przemiany przemystu spożywczego w latach 1988-2003, IERiGŻ, Warszawa

Urban R. (2008), Wplyw integracji z Unia Europejska na polski przemyst spożywczy,[w:] R. U rban (red.), Wpływ integracji z Unia Europejska na polska gospodarkę żywnościowa, raport nr 90, IERiGŻ-PIB, Warszawa

Urban R. (2009), Polski przemyst spożywczy po wejściu do Unii Europejskiej, [w:] K. D u c z k ow s k a - M ały s z, A. S z y m e c k a (red.), Wokót trudnych problemów globalnego rozwoju obszarów wiejskich, gospodarki żywnościowej i rolnictwa, Wyd. SGH, Warszawa

U rban R., Rowiński J., D rożdż J., S zc ze paniak I. (2004), Przemiany strukturalne przemystu spożywczego, [w:] Przemiany przemystu spożywczego $w$ latach 1988-2003, IERiGZ, Warszawa

U r b a n R., S zc ze p a n i k I., M roc z e k R. (2010), Polski sektor żywnościowy w pierwszych latach czlonkostwa, IERiGŻ-PIB, Warszawa

Utterback J. M., Abernathy W. J. (1975), A Dynamic Model of Process and Product Innovation, „Omega”, no. 6 
Ve r s p a g e n B., K l e in k n e c h t A. (1990), Demand and Innovation: Schmookler Re-examined, „Research Policy”, no. 19

Wa le si a k M. (1990), Syntetyczne badania porównawcze $w$ świetle teorii pomiaru, „Przegląd Statystyczny", nr $1-2$

Wa le s i a k M. (2006), Uogólniona miara odległości w statystycznej analizie wielowymiarowej, Wyd. Akademii Ekonomicznej, Wrocław

W a l e s i a k M., D u d e k A. (2009), The clusterSim package, (wersja 0.38-2, 10.12. 2010), http:// keii.ue.wroc.pl/clusterSim/.

Wanke-J a k u bow s k M., Wa n k - J e ri e M.(red.), (1999), Stan nauki i techniki w Polsce, Warszawa.

WEF (2009), The Global Competitiveness Report 2009-2010, Word Economic Forum, Geneva

We $1 \mathrm{fe}$ W., We $1 \mathrm{fe}$ A. (1996), Ekonometria stosowana, PWE, Warszawa

W e $1 \mathrm{fe}$ W. (2000), Empiryczne modele wzrostu, [w:] Wzrost gospodarczy, restrukturyzacja i bezrobocie w Polsce. Ujęcie teoretyczne i praktyczne, materiały pokonferencyjne, Katedra Ekonomii Uniwersytetu Łódzkiego, Łódź

Welfe W. (red.), (2001), Ekonometryczny model wzrostu gospodarczego, Wydawnictwo Uniwersytetu Łódzkiego, Łódź

Welfe W. (2003), Łączna produktywność czynników produkcji a postęp techniczny, „Studia Ekonomiczne", nr 1-2

We $1 \mathrm{fe}$ W. (2007), Przesłanki modelowania gospodarki opartej na wiedzy, [w:] W. We $1 \mathrm{fe}$ (red.), Gospodarka oparta na wiedzy, P W E, Warszawa

W e 1 f e W. (red.), (2007), Gospodarka oparta na wiedzy, PWE, Warszawa

Were sa M. A. (2002), Wpływ handlu zagranicznego i inwestycji bezpośrednich na innowacyjność polskiej gospodarki, Wyd. SGH, Warszawa

W e r e s a M. A. (2002), Wpływ handlu zagranicznego i inwestycji bezpośrednich na innowacyjność polskiej gospodarki, Wyd. SGH, Warszawa

We re s a M. A. (2003), Zdolność innowacyjna polskiej gospodarki, pozycja w świecie i regionie, [w:] H. B r d u la k, T. G oł łę b i o w s k i (red.), Wspólna Europa. Innowacyjność w działalności przedsiębiorstw, Difin, Warszawa

We r e s a M. A. (red.), (2006), Polska: Raport o konkurencyjności 2006. Rola innowacji w ksztattowaniu przewag konkurencyjnych, Wyd. SGH, Warszawa

We r e s a M. A. (red.), (2008), Polska: Raport o konkurencyjności 2008. Konkurencyjność sektora ustug, Wyd. SGH, Warszawa

We r e s a M. A., R a p a k i R. (2010), Syntetyczna ocena konkurencyjności polskiej gospodarki oraz determinanty pozycji konkurencyjnej w 2009 r., [w:] M. A. We re s a (red.), Polska raport o konkurencyjności 2010. Klastry przemysłowe a przewagi konkurencyjne, Instytut Gospodarki Światowej SGH w Warszawie, Warszawa

Wiankowski S., Okrasa Z., Boguta M., Borowicz L., Borzęcki J. (2005), Dostosowanie sfery badawczo-rozwojowej w Polsce do funkcjonowania w Europejskiej Przestrzeni Badawczej, Instytut Organizacji i Zarządzania w Przemyśle „Orgmasz”, Warszawa

W i s h a r t D. (2006), Clustangraphics primer: a guide to cluster analysis, Cluston Ltd., Edinburgh World Competitiveness Yearbook (2005), IMD, Lausanne

W o r o n i e c k i J. (2001), Nowa gospodarka: miraż czy rzeczywistość? Doktryna, praktyka, optyka OECD, [w:] Gospodarka oparta na wiedzy. Wyzwanie dla Polski XXI w., red. A Kukliński, KBN, Warszawa

W o r o n i e c k i J. (2003), Wykreowanie polskiego systemu innowacji-budowa gospodarki opartej na wiedzy, [w:] Rola polskiej nauki we wzroście innowacyjności gospodarki, materiały konferencyjne, Polskie Towarzystwo Ekonomiczne i Katedra Ekonomii Instytutu Zarządzania Uniwersytetu Jagiellońskiego, Kraków 
Wo ś A. (1998), Encyklopedia agrobiznesu, Fundacja Innowacja, Warszawa

W y s o k ińs k a Z. (2001), Konkurencyjność w międzynarodowym i globalnym handlu technologiami, Wyd. Nauk. PWN, Warszawa-Łódź

Z e li a ś A. (red.) (2000), Taksonomiczna analiza przestrzennego zróżnicowania poziomu życia $w$ Polsce w ujęciu dynamicznym, Wyd. Akademii Ekonomicznej, Kraków.

Zeliaś A. (2002), Some notes on the selection of normalisation of diagnostic variables, „Statistics in Transition”, vol. 3 , no. 5

Z i e li ńs k a-Głęb o ck a A. (red.) (2000), Konkurencyjność przemysłowa Polski w procesie integracji z Uniq Europejska, Fundacja Rozwoju Uniwersytetu Gdańskiego, Gdańsk

Z i e mi e ck i J., Ż u krowska K. (2004), Konkurencja a transformacja w Polsce. Wybrane aspekty polityki gospodarczej, Wyd. SGH, Warszawa

Z i e n k o w s k i L. (red.) (2003), Wiedza a wzrost gospodarczy, Wydawnictwo Scholar, Warszawa

Z i e n k ow s k i L. (2004), Czy polska polityka makroekonomiczna zawiera paradygmat wzrostu innowacyjności gospodarki? [w:] E. O k oń - H o r o d y ń s k a (red.), Rola polskiej nauki we wzroście innowacyjności gospodarki, Wyd. PTE, Warszawa 



\section{Spis rysunków}

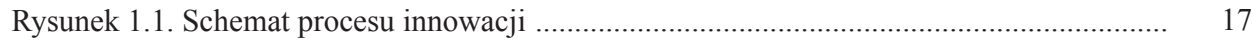

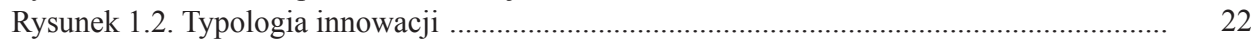

Rysunek 1.3. Podażowy liniowy model procesu innowacyjnego ............................................. 33

Rysunek 1.4. Model łańcuchowych sprzężeń zwrotnych według Kline’a i Rosenberga........... 35

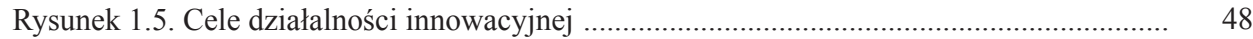

Rysunek 2.1 Schemat NSI ..........................................................................................

Rysunek 2.2. Relacja nakładów na B+R do PKB w krajach UE w 2007 r. ............................ 66

Rysunek 2.3. Liczba wniosków patentowych zgłoszonych do EPO w przeliczeniu na $1 \mathrm{mln}$

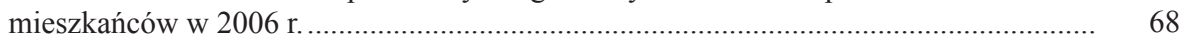

Rysunek 3.1. Schemat łańcucha agrobiznesu .................................................................... 89

Rysunek 3.2. Dynamika produkcji sprzedanej przemysłu spożywczego na tle dynamiki PKB, spoży-

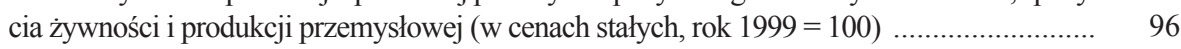

Rysunek 3.3. Napływ BIZ do Polski w latach 1999-2008 (mln USD) .................................. 98

Rysunek 3.4. Skumulowana wartość kapitału zagranicznego w przetwórstwie przemysłowym oraz przemyśle spożywczym w Polsce w latach 1999-2008 (mln USD) ..........................

Rysunek 3.5. Wydajność pracy w przemyśle spożywczym (produkcja sprzedana na 1 zatrudnionego w tys. zl) w latach 1999-2008 (ceny stałe)...

Rysunek 3.6. Wydajność w przemyśle spożywczym mierzona wartością dodaną brutto (ceny stałe) na 1 zatrudnionego w tys. zł....

Rysunek 3.7. Wydajność pracy w polskim przemyśle spożywczym na tle wybranych krajów UE w 2007 r. (w tys. euro)....

Rysunek 3.8. Dynamika majątku trwałego w produkcji artykułów spożywczych, napojów i wyrobów tytoniowych w latach 1999-2008 (c. stałe)

Rysunek 3.9. Dynamika nakładów inwestycyjnych przemysłu spożywczego (ceny stałe, rok poprzedni $=100)$ w latach $1998-2008$

Rysunek 3.10 Wartość dodana przemysłu spożywczego (w mln zł) w latach 1999-2008 .........

Rysunek 3.11. Struktura podmiotowa produkcji sprzedanej przemysłu spożywczego w Polsce i UE w wybranych latach okresu 1998-2008 (w \%) .....

Rysunek 3.12. Średnia roczna stopa eksportu w przemyśle spożywczymw latach 2002-2008

Rysunek 3.13 Średnia roczna relacja eksport/import w latach 2002-2008 w branżach przemysłu spożywczego

Rysunek 3.14 Średnia roczna wartość wskaźnika IIT w branżach przemysłu spożywczego w latach 2002-2008.

Rysunek 3.15 Średnie tempo zmian produkcji sprzedanej w branżach przemysłu spożywczego w latach 2002-2008 (ceny stałe, rok 2005 = 100)

Rysunek 3.16. Średnie roczne tempo zmian TFP w branżach przemysłu spożywczego w latach 2002-2008 (ceny stałe, rok $2005=100$ )

Rysunek 4.1. Dynamika nakładów na działalność innowacyjną w przedsiębiorstwach produkujących artykuły spożywcze i napoje, przedsiębiorstwach przemysłowych i przedsiębiorstwach przetwórstwa przemysłowego w latach 1998-2008 (ceny stałe) .....

Rysunek 4.2. Struktura innowacji przynoszących korzyści dla środowiska w okresie wytwarzania produktu (wprowadzonych w latach 2006-2008)

Rysunek 4.3. Struktura innowacji przynoszących korzyści dla środowiska w okresie użytkowania produktu (wprowadzonych w latach 2006-2008)

Rysunek 4.4. Dynamika intensywności innowacji w przedsiębiorstwach przemysłu ogółem, przetwórstwie przemysłowym i produkcji artykułów spożywczych i napojów w latach 19992008 (ceny stałe).. 
Rysunek 4.5. Stopień wyjaśnienia wariancji przez składowe

Rysunek 4.6. Ładunki między głównymi składowymi a zmiennymi ..................................... 154

Rysunek 4.7. Działy przetwórstwa przemysłowego na płaszczyźnie PC1 i PC2 ….................. 155

Rysunek 4.8. Ranking działów przetwórstwa przemysłowego według indeksu innowacyjności.. 158

Rysunek 5.1. Przedsiębiorstwa innowacyjne jako odsetek ogółu przedsiębiorstw w klasach przemysłu spożywczego w latach 2004 i 2008

Rysunek 5.2. Nakłady przypadające na 1 przedsiębiorstwo prowadzące działalność innowacyjną w klasach przemysłu spożywczego w latach 2004 i 2008

Rysunek 5.3. Nakłady na B+R jako odsetek nakładów na działalność innowacyjną w klasach przemysłu spożywczego w latach 2004 i 2008

Rysunek 5.4. Nakłady na zakup gotowej technologii jako odsetek nakładów na działalność innowacyjną w klasach przemysłu spożywczego w latach 2004 i 2008

Rysunek 5.5. Nakłady na oprogramowanie jako odsetek nakładów na działalność innowacyjną w klasach przemysłu spożywczego w latach 2004 i 2008

Rysunek 5.6. Nakłady inwestycyjne na budynki i budowle oraz grunty jako odsetek nakładów na działalność innowacyjną w klasach przemysłu spożywczego w latach 2004-2008 ....

Rysunek 5.7. Nakłady inwestycyjne na maszyny i urządzenia techniczne z importu jako odsetek nakładów na działalność innowacyjną w klasach przemysłu spożywczego w latach 2004 i 2008.

Rysunek 5.8. Ranking innowacyjności przedsiębiorstw przemysłu spożywczego w Polsce w 2004 r. (standaryzacja wskaźników w czasie)

Rysunek 5.9. Ranking innowacyjności przedsiębiorstw przemysłu spożywczego w Polsce w 2005 r. (standaryzacja wskaźników w czasie)

Rysunek 5.10. Ranking innowacyjności przedsiębiorstw przemysłu spożywczego w Polsce w 2006 r. (standaryzacja wskaźników w czasie)

Rysunek 5.11. Ranking innowacyjności przedsiębiorstw przemysłu spożywczego w Polsce w 2007 r. (standaryzacja wskaźników w czasie)

Rysunek 5.12. Ranking innowacyjności przedsiębiorstw przemysłu spożywczego w Polsce w 2008 r. (standaryzacja wskaźników w czasie)

Rysunek 5.13. Dendrogram skupień branż przemysłu spożywczego dla $2004 \mathrm{r}$.

Rysunek 5.14. Dendrogram skupień branż przemysłu spożywczego dla $2005 \mathrm{r}$.

Rysunek 5.15. Dendrogram skupień branż przemysłu spożywczego dla 2005 r. (4 skupienia) ...

Rysunek 5.16. Dendrogram skupień branż przemysłu spożywczego dla 2006 r. (3 i 4 skupienia)

Rysunek 5.17. Dendrogram skupień branż przemysłu spożywczego dla 2007 r. (3 skupienia)........ 199

Rysunek 5.18. Dendrogram skupień branż przemysłu spożywczego dla 2007 r. (4 skupienia)....... 200

Rysunek 5.19. Dendrogram skupień branż przemysłu spożywczego dla 2008 r.(podział na 3 i 4 skupienia)

Rysunek 6.1. Wartości wyrazów wolnych dla poszczególnych branż przemysłu spożywczego w modelu produkcji sprzedanej

Rysunek 6.2. Wartości wyrazów wolnych dla poszczególnych branż przemysłu spożywczego w modelu wydajności pracy.....

Rysunek 6.3. Wartości wyrazów wolnych dla poszczególnych branż przemysłu spożywczego (model produkcji sprzedanej). 


\section{Spis tabel}

Tabela 1.1 Pięć generacji modeli innowacji R. Rothwella .................................................... 32

Tabela 2.1. Wybrane instytucje NSI w Polsce ....................................................................... 62

Tabela 2.2. Liczebność jednostek prowadzących działalność badawczo-rozwojową (B+R) w wybranych latach okresu 1995-2009.

Tabela 2.3. Klasyfikacja dziedzin przemysłu według poziomów techniki opracowana przez OECD w $1997 \mathrm{r}$.

Tabela 2.4. Klasyfikacja państw członkowskich Unii Europejskiej według sumarycznego wskaźnika innowacyjności (SII) w 2009 r.

Tabela 3.1. Przedmiot działalności branż przemysłu spożywczego według PKD 2004............

Tabela 3.2. Zestawienie dynamiki rozwoju wybranych kategorii ekonomicznych w \% (ceny stałe).

Tabela 3.3. Wartość sprzedaży i eksportu przemysłu spożywczego w latach 1999-2008 ........

Tabela 3.4. Struktura produkcji sprzedanej przemysłu spożywczego w 2003 i 2008 r. według głównych kierunków przetwórstwa ( $\mathrm{w} \%$, ceny stałe).

Tabela 3.5. Struktura branżowa skumulowanej wartości inwestycji zagranicznych w przemyśle spożywczym ( $\operatorname{stan} 31.12 .2008)$

Tabela 3.6. Wydajność pracy w przemyśle spożywczym na tle innych działów przetwórstwa przemysłowego i przemysłu ogółem w 2008 roku (ceny bieżące).

Tabela 3.7. Zużycie energii i wody w przemyśle spożywczym w latach 1999-2008 ............... 106

Tabela 3.8. Majątek trwały w produkcji artykułów spożywczych, napojów i wyrobów tytoniowych

Tabela 3.9. Wyniki finansowe przemysłu spożywczego w Polsce

Tabela 3.10. Liczba przedsiębiorstw produkujących artykuły spożywcze i napoje w wybranych latach okresu 2000-2008.

Tabela 3.11. Średni roczny poziom stopy eksportu, relacji eksport/import oraz wskaźnika IIT w branżach przemysłu spożywczego w latach 2002-2008.

Tabela 3.12. Średnioroczne tempa zmian produkcji sprzedanej, wydajności pracy i łączne produktywności czynników produkcji w latach 2002-2008 (ceny stałe, rok $2005=100$ )....

Tabela 4.1. Wybrane mierniki charakteryzujące działalność innowacyjną przedsiębiorstw .....

Tabela 4.2. Struktura nakładów finansowych na działalność innowacyjną w przedsiębiorstwach przemysłu spożywczego, przetwórstwa przemysłowego i przemysłu ogółem w Polsce w latach 1999-2008 (w \%).

Tabela 4.3. Działalność innowacyjna przedsiębiorstw produkujących artykuły spożywcze i napoje oraz przedsiębiorstw przemysłowych w latach 1998-2008.

Tabela 4.4. Produkcja sprzedana wyrobów nowych i istotnie ulepszonych w latach 1999-2008....

Tabela 4.5. Przedsiębiorstwa, które wprowadziły innowacje organizacyjne i/lub marketingowe jako odsetek ogółu przedsiębiorstw.

Tabela 4.6. Wykaz zmiennych uwzględnionych w badaniu innowacyjności działów przetwórstwa przemysłowego

Tabela 4.7. Macierz rotowanych składowych.

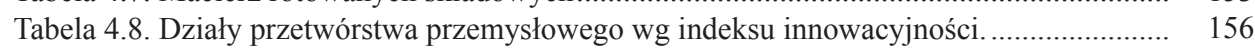

Tabela 5.1. Parametry metod aglomeracyjnych (hierarchicznych) analizy skupień.................. 176

Tabela 5.2. Wskaźniki diagnostyczne innowacyjności klas przemysłu spożywczego .............. 180

Tabela 5.3. Charakterystyki liczbowe porządkowania liniowego przedsiębiorstw przemysłu spożywczego wraz z oceną jakości porządkowania dla wariantu I - unitaryzacja wskaźników diagnostycznych. 
Tabela 5.4. Charakterystyki liczbowe porządkowania liniowego przedsiębiorstw przemysłu spożywczego wraz z oceną jakości porządkowania dla wariantu II - klasyczna standaryzacja wskaźników diagnostycznych.

Tabela 5.5. Charakterystyki liczbowe grupowania przedsiębiorstw przemysłu spożywczego wraz z oceną jakości wyników grupowania dla $2004 \mathrm{r}$.

Tabela 5.6. Charakterystyki liczbowe grupowania przedsiębiorstw przemysłu spożywczego wraz z oceną jakości wyników grupowania dla $2005 \mathrm{r}$.

Tabela 5.7. Charakterystyki liczbowe grupowania przedsiębiorstw przemysłu spożywczego wraz z oceną jakości grupowania dla $2006 \mathrm{r}$......

Tabela 5.8. Charakterystyki liczbowe grupowania przedsiębiorstw przemysłu spożywczego wraz z oceną jakości grupowania dla $2007 \mathrm{r}$

Tabela 5.9. Charakterystyki liczbowe grupowania przedsiębiorstw przemysłu spożywczego wraz z oceną jakości grupowania dla $2008 \mathrm{r}$.

Tabela 5.10. Charakterystyka skupień wyników grupowania w latach 2004-2008 .................. 204

Tabela 6. 1. Wyniki estymacji parametrów modelu produkcji sprzedanej (logarytmy) ............. 217

Tabela 6.2. Wyniki estymacji parametrów modelu wydajność pracy (logarytmy).................... 218

Tabela 6.3. Wyniki estymacji parametrów modelu wartości dodanej brutto na zatrudnionego (logarytmy).

Tabela 6.4. Wyniki estymacji parametrów modelu TFP.

Tabela 6.5. Wyniki estymacji parametrów modelu produkcji sprzedanej w branżach przemysłu spożywczego (logarytmy)

Tabela 6.6. Wyniki estymacji parametrów modelu wydajności pracy w branżach przemysłu spożywczego (logarytmy)

Tabela 6.7. Wyniki estymacji parametrów modelu produkcji sprzedanej w branżach przemysłu spożywczego (funkcja liniowa) 


\section{Innovativeness of the Food Industry in Poland (summary)}

Nowadays, in connection with the creation of the modern, knowledge-based economy, an increase in innovation, entrepreneurship and competitiveness play an important role. This view is also reflected in the strategic documents of the European Union. The EU Competitiveness and Innovation Framework Programme aims to integrate measures that support innovation activities and improved business performance, the development and compatibility of research oriented toward the modernisation of the economy taking into account the requirements of sustainable use of resources.

The growing interest in innovations results from the new perception of innovations as a factor determining the increase in economic efficiency. Innovations have become another - apart from physical capital and labour - factor of production.

The food industry is one of the most important areas of manufacturing activities in Poland. The changes occurring in the world economy increasingly affect the functioning of the food sector in Poland. The future of the food industry remains strongly connected with its efficiency and competitiveness. These aspects are important for two reasons. Firstly, the new systems of food production can be developed provided the economic efficiency of business is improved. Secondly, the issues connected with the EU standards, environmental protection and limited natural resources, particularly water access, require taking these conditions into account in production systems. Meeting these requirements is possible due to, among others, the use of innovative methods of production, management and work organisation as well as the introduction of modern forms of good distribution.

In the conditions of the modern economy, the continuous creation, absorption and adaptation of knowledge as well as the search for innovative solutions become the prerequisite for competitiveness. In order to maintain their market position, companies need to constantly develop and be innovative. Innovativeness, therefore, determines the development of the food industry in Poland, which seems to imply the obvious need to analyse the issues concerning this area.

This thesis attempts to fill the gap in the area of innovativeness analyses regarding the food industry, particularly its individual sectors (at the level of Polish Classification Activities classes) in the context of their development and competitiveness. The theses put forward in the dissertation are verified using quantitative methods, particularly multivariate statistics and panel regression, against the theoretical background of economic considerations. Importantly, this study attempts to construct and empirically verify the synthetic (summary) innovation index at the level of the food industry as well as at lower levels of aggregation. 
The main objective of the thesis is an attempt to assess the level of innovativeness of the food industry in Poland and to determine how innovation affects the development and competitiveness of the whole direction of manufacturing activities as well as its classes and groups of classes.

The systematisation of economic knowledge, which allows to understand the determinants of the complexity of processes and innovative and competitive phenomena concerning enterprises in the food industry, helps to achieve this objective.

The following specific objectives were subordinated to the achievement of the main objective:

- the presentation of the nature, multidimensionality, sources and objectives of innovative activity,

- the assessment of the quality and availability of statistical data concerning innovation in enterprises at various aggregation levels,

- the diagnosis of the production and economic standing of the food industry in Poland,

- the creation of the synthetic/summary innovation index (indexes) for the food industry at different levels of the Polish Classification Activities,

- the empirical verification of the summary innovation index of sectors (classes and groups of classes) in the food industry,

- the creation and empirical verification of competitive models of the food industry at different levels of the Polish Classification Activities.

The analysis of the food industry as $\mathrm{w}$ whole was conducted for the years of 1999-2008, therefore it encompasses the five years that preceded Poland's accession to the EU and the five years of Poland's membership in the Community structures. Where the statistical data permitted, the analysis was extended to the year 2009. A similar assessment at the level of classes and groups of classes of the food industry concerned the years 2002(4)-2008, depending on the availability of statistical information.

The structure of the thesis is determined by the main objective and the subject of the research. The analysis is of theoretical and empirical nature and the verification of the research hypotheses was conducted with the use of statistical and econometric instruments.

he thesis consists of six chapters. Chapter one is theoretical and presents the concept of innovation in its fullest possible complexity. It comprises the presentation and definitions as well as the detailed development of the concept of innovation in enterprises and the economy. It draws attention to the concept of change and innovation pointing to the problems and difficulties in defining innovation and its classification. The considerations in chapter one end with the analysis of the economic dimensions of innovation.

Chapter two aims to emphasise the importance of the National Innovation Systems (NIS) and to present the characteristics of this system in Poland as well 
as attempts to assess opportunities to increase its efficiency. This part of the thesis also presents the methodology of statistical studies of innovation used by the OECD, the European Union and the Central Statistical Office of Poland. The innovativeness rankings of the EU countries published by the European Commission in the form of the European Innovation Scoreboard (2009) were also presented.

Chapter three contains the analysis of the position of the food industry in the Polish agrobusiness, the classification of this industry according to the Polish Classification of Activities and the development trends in this industry in the years 1999-2008(9). The emphasis was placed in particular on the production sold, export, investments and foreign direct investments, workforce productivity and factor productivity. An attempt was also made to carry out quantitative assessment of the competitiveness of the food industry sectors in the analysed period.

The next chapter was devoted exclusively to the assessment of innovative activity of enterprises in the food industry in comparison with manufacturing and industry in general. The research proceedings were based on the results of the study concerning the innovative activities of enterprises conducted by the Central Statistical Office of Poland according to the international Oslo methodology. The empirical verification of the position of the food industry in the innovativeness ranking of the manufacturing industry sectors in Poland conducted with the use of the principal components method constitutes the final part of this chapter.

Chapter five contains the analysis that encompasses the lower levels of aggregation of the food industry (classes or groups of classes) with the aid of basic innovation indexes of industrial enterprises. The synthetic assessment of innovativeness of the studied sectors in the years 2004-2008, conducted on the basis of statistical methods for linear objects grouping and cluster analysis, constitutes an important contribution on part of the author.

The assessments carried out in chapter four and five point to the issue of the impact of innovation on the competitive position of the food industry enterprises. In this situation, the question how to study the relations and connections between innovations and competitiveness in the food industry remains open.

The last chapter of the thesis is an attempt to answer this question. To begin with, the emphasis was placed on the theoretical foundations for the study of the relations between technical progress and economic growth, pointing to such elements as the difficulties in identification and measurement of variables that could influence the analysed phenomena. Taking into account the above presented determinants, the empirical verification of different variants of models for competitiveness of enterprises in the food industry at different levels of its aggregation was carried out.

The published and unpublished statistical data of the Central Statistical Office of Poland are the primary source of information on innovativeness as well as production and economic performance of the food industry. The thesis was also based on the materials of the Institute of Agricultural and Food Economics concerning 
in particular foreign trade and the economic and financial situation of enterprises in individual classes of the food industry.

Other important data sources included: unpublished information of the National Bank of Poland concerning the FDI inflow and resources, information of the Polish Information and Foreign Investment Agency on foreign investments, available reports and thematic studies national as well as foreign.

The conducted research indicates that the production growth and the improvement of the economic and financial standing of the food industry was a prevalent phenomenon which encompassed all the main classes of the food industry. The in-depth analysis of the production and economic situation of the food industry allows to conclude that food industry enterprises were successful in the EU market. Difficult transformation and modernisation processes carried out in the years preceding Poland's accession to the EU had a significant impact on the state of things.

Regrettably, the degree of innovativeness of the food industry compared to other divisions of manufacturing is low. However, the fact that food-producing companies increasingly recognise the importance of innovation as the source of competitiveness can fill one with optimism. The synthetic assessment of innovativeness resulted in the conclusion that innovativeness of the food industry enterprises is sectorally and temporally varied, which confirms the rightness of the research hypothesis.

The attempt to construct the following econometric models was successful in the conducted study: production sold, workforce productivity, gross value added and TFP for the food industry (total) where the explanatory variable, apart from the classic factors of production, was the variously understood innovative activity. The obtained results confirm the existence of the statistically significant impact of innovativeness on competitiveness. Similar conclusions may be drawn from the estimation of the competitive models of the food industry with the use of the data for its sectors.

The presented assessment of innovativeness and its impact on the competitiveness of the food industry in Poland does not exhaust the complexity of the issue and constitutes one of the threads that make up the entire assessment system. The conducted study and the formulated conclusions enhance the knowledge concerning the food industry in Poland presented in the Polish subject literature. 


\section{Od Redakcji}

Maria Magdalena Grzelak ukończyła studia na Wydziale Ekonomiczno-Socjologicznym UŁ (kierunek: finanse). W Uniwersytecie Łódzkim zatrudniona jest od 1996 r., początkowo na stanowisku asystenta, a następnie adiunkta w Katedrze Statystyki Ekonomicznej i Społecznej.

Stopień doktora nauk ekonomicznych uzyskała w 1999 r., po obronie pracy doktorskiej pt. Procesy dostosowawcze rolnictwa i jego otoczenia do gospodarki rynkowej. Analiza statystyczna. Rozprawa doktorska była realizowana w ramach projektu badawczego KBN Nr 1 H02C 02113.

Przedmiotem badań naukowych Marii M. Grzelak jest przede wszystkim sektor żywnościowy. W przeszłości, wykorzystując metody statystyczne, analizowała procesy dostosowawcze rolnictwa i jego otoczenia do gospodarki rynkowej i integracji z Unią Europejską. Obecnie zainteresowania badawcze Autorki koncentrują się na zagadnieniach związanych z identyfikacją, pomiarem i skalą innowacyjności gospodarki i jej segmentów, postępem technicznym czy tzw. gospodarką opartą na wiedzy.

Efektem tego zainteresowania było opublikowanie wielu artykułów (m.in. w „Gospodarce Narodowej”, „Przeglądzie Statystycznym”, „Acta Universitatis Lodziensis” Folia Oeconomica, „Zeszytach Naukowych SGGW” i „Comparative Economic Research". Jest też autorką kilkunastu referatów na konferencje naukowe, w tym zagraniczne, zorganizowane przez International Atlantic Economic Society.

Maria M. Grzelak prowadzi zajęcia dydaktyczne z zakresu statystyki, prognozowania i symulacji oraz demografii. Jest promotorem prac licencjackich i magisterskich. 